\title{
O Holocausto como Tema nos Livros Didáticos Brasileiros Realidades e Alternativas
}

\author{
Versão Original
}

Dissertação de Mestrado apresentada ao Programa de Pós-Graduação em Estudos Judaicos e Árabes, do Departamento de Letras Orientais da Faculdade de Filosofia, Letras e Ciências Humanas da Universidade de São Paulo, como parte dos requisitos para obtenção do título de Mestre em Letras, Estudos Judaicos

Orientadora: Profa. Dra. Maria LuizaTucci Carneiro

São Paulo, 2016 
Autorizo a reprodução e divulgação total ou parcial deste trabalho, por qualquer meio convencional ou eletrônico, para fins de estudo e pesquisa, desde que citada a fonte.

Catalogação na Publicação

Serviço de Biblioteca e Documentação

Faculdade de Filosofia, Letras e Ciências Humanas da Universidade de São Paulo

Colffield Lopez, Carol

Carol Colffield Lopez ; orientadora Maria

Luiza Tucci Carneiro. - São Paulo, 2016

$270 \mathrm{f}$.

Dissertação (Mestrado) - Faculdade de Filosofia, Letras e Ciências Humanas da Universidade de São Paulo. Departamento de Letras Orientais. Área de concentração: Estudos Judaicos e Árabes.

1. Holocausto, 2, Antissemitismo, 3, Educação sobre o Holocausto. 4. Testemunhos de Sobreviventes do Holocausto. 5. Holocausto em Livros Didáticos. I. Tucci Carneiro, Maria Luiza, orient. II. Título. 
COLFFIELD LOPEZ, C. O Holocausto como Tema nos Livros Didáticos Brasileiros. Realidades e Alternativas. Dissertação apresentada à Faculdade de Filosofia, Letras e Ciências Humanas da Universidade de São Paulo para obtenção do título de Mestre em Letras, Estudos Judaicos.

Aprovado em:

\section{Banca Examinadora}

Prof. Dr.

Instituição:

Julgamento:

Assinatura:

Prof. Dr.

Instituição:

Julgamento:

Assinatura:

Prof. Dr.

Instituição:

Julgamento:

Assinatura: 
A Sofia 


\section{Agradecimentos}

Toda jornada que conduz a uma realização começa em casa, com nossa família. Portanto, gostaria de começar agradecendo a Alejandro, esposo e amigo, que sempre apoiou minhas iniciativas. Agradeço também a Sofia, a quem dedico este trabalho, meu maior tesouro, filha única em todos os sentidos, permanente companheira.

Ao meu pai, Alberto, que desde meus primeiros anos de vida instilou em mim a paixão pelos livros e o encanto de dedicar a vida à busca pelo conhecimento, assim como minha mãe, Rosita, que embora não mais esteja entre nós fisicamente, presenciando esta nova etapa, continua me acompanhando. Sua memória é a reafirmação da minha vida.

Toda jornada acadêmica, envolve a escolha de um orientador. Nesse quesito, eu não poderia ter tido melhor destino. Vai então dirigido meu infinito agradecimento à Profa. Dra. Maria Luiza Tucci Carneiro, tradução renovada do conceito de "orientação", não somente devido a seus amplos conhecimentos sobre a matéria de sua especialidade, mas também à sua profunda humanidade. Como todo grande mestre, ela consegue vislumbrar o melhor em seus alunos, alternando entre severidade e carinho. Espero ter correspondido às suas expectativas quanto ao meu trabalho.

Graças à minha orientadora tive também a oportunidade de conhecer as queridas e competentes colegas pesquisadoras do Núcleo de Estudos LEER/Arqshoah que realizam o importante trabalho de registrar a memória dos sobreviventes do Holocausto radicados no Brasil. A cada uma delas, meu profundo agradecimento.

Não poderia deixar de agradecer também a todos aqueles que são, na verdade, os protagonistas deste trabalho, os sobreviventes, que por décadas têm demonstrado uma enorme coragem de revisitar velhas - e muitas vezes não cicatrizadas - feridas, no intuito de alertar o mundo sobre as terríveis consequências da ignorância, do prejulgamento e do ódio, ingredientes básicos do antissemitismo, os quais somente poderemos continuar combatendo insistindo permanentemente na educação.

Por mais que pareça contraditório, o solitário caminho da produção acadêmica é repleto de encontros que muitas vezes, sem que os atores saibam, nos marcam em uma ou outra direção. Gostaria de deixar aqui registrados nestes agradecimentos dois nomes que, não por coincidência,

fizeram parte da banca julgadora de meu Exame de Qualificação: o Prof. Dr. Moacir Amâncio e o Prof. Dr. Nilson José Machado. 
O Prof. Amâncio, com a sensibilidade do poeta, soube orientar-me com suas observações pelos meandros das opções linguísticas naquela fase embrionária de meu trabalho.

O Prof. Machado, com a amplitude de vistas do matemático e do filósofo, conduziu-me a explorar questões e autores que hoje são parte integrante da minha própria visão de mundo e que certamente farão parte de meus trabalhos futuros.

Gostaria também de estender meus agradecimentos às instituições que durante todo este percurso me deram apoio outorgando-me bolsas de estudo: ao Instituto Samuel Klein, à União Brasileiro Israelita do Bem-Estar Social (UNIBES) e à Confederação Israelita do Brasil (CONIB). Seu incentivo aos nossos projetos é inestimável.

Finalmente, o meu muito obrigado à Universidade de São Paulo e ao seu Departamento de Letras Orientais, outra modalidade de casa. 
Não estás incumbido de completar o trabalho, porém, não estás livre para desistir dele.

Pirkei Avot 2:21 


\section{RESUMO}

\section{COLFFIELD LOPEZ, C. O Holocausto como Tema nos Livros Didáticos Brasileiros.}

Realidades e Alternativas. Dissertação (Mestrado). Faculdade de Filosofia, Letras e Ciências Humanas, Universidade de São Paulo, 2016.

O Holocausto como Tema nos Livros Didáticos Brasileiros. Realidades e alternativas, orienta-se, em sua totalidade, para dois momentos: o da análise e o da proposta. No primeiro momento, o da análise, o estudo buscou definir, em primeiro lugar, de que maneira os livros didáticos abordam o tema, principalmente no que se refere ao protagonismo dos judeus como alvo de um genocídio sem precedentes na história da humanidade. Ao mesmo tempo, a atenção concentrou-se na presença de elementos que, muitas vezes, com o intuito de "descomplicar", "facilitar" ou "popularizar" o ensino do Holocausto, resultam em sua banalização. Por último, a análise apontou a verificar a existência de elementos de instrumentalização no contexto do discurso do antissemitismo contemporâneo ou antissionismo. No segundo momento, o da proposta, apresentamos um projeto-piloto para o desenvolvimento de materiais através dos quais a história do Holocausto é contada com base no testemunho de um sobrevivente radicado no Brasil. Para tal fim, utilizamos entrevistas feitas no âmbito do Projeto Vozes do Holocausto, do Núcleo de Estudos Arqshoah/LEER/USP. Com base nos testemunhos, buscamos estabelecer a simbiose com fatos, documentos, personagens e lugares históricos. Dessa maneira, aos "dizeres" das testemunhas, enlaçaram-se os "saberes" da historiografia de modo a estabelecer um diálogo que tenta devolver às vozes dos sobreviventes ao menos parte do protagonismo que, como pudemos detectar na fase de análise, encontra-se ausente nos livros didáticos.

Palavras-chave: Holocausto, Antissemitismo, Educação sobre o Holocausto, Testemunhos 


\begin{abstract}
COLFFIELD LOPEZ, C. The Holocaust as a Theme in Brazilian Textbooks. Realities and Alternatives. Dissertação (Mestrado). Faculdade de Filosofia, Letras e Ciências Humanas, Universidade de São Paulo, 2016.
\end{abstract}

The Holocaust as a Theme in Brazilian Textbooks. Realities and Alternatives, is oriented towards two moments in the realm of Holocaust education: an analysis and a proposal. The analysis seeks to determine, first, how the theme is approached in Brazilian schoolbooks, especially in terms of the role attributed to Jews as targets of an unprecedented genocide in the history of humanity. At the same time, another aspect was taken into account. It relates to a practice, common among educators, that, although aimed at "untangling", "facilitating" or even "popularizing" the teaching of the Holocaust, holds at its core the seeds for a potential banalization. Finally, we focused on trying to detect if the texts, in some way, instrumentalize the discourse in order to fit certain ideologically-charged narratives that could be linked to the context of contemporary antisemitism or antizionism. The second moment in this dissertation the proposal - constitutes in fact a pilot project that approaches the history of the Holocaust through the voice of a survivor. For that purpose, we worked with witnesses living in Brazil interviewed by the researchers of the Projeto Vozes do Holocausto (Voices of the Holocaust Project, LEER/Arqshoah/USP). Based on those testimonies, we sought to establish a symbiosis with facts, documents, characters and historical places connecting the "saying" of the witnesses to the "knowing" of historiography in an attempt to establish a dialogue that gives back to the survivor's voice its central role.

Keywords: Holocaust, Antisemitism, Holocaust Education, Testimonies 


\section{SUMÁRIO}

INTRODUÇÃO

I. AUSCULTANDO UM VELHO ÓDIO: O PULSAR DO HOLOCAUSTO 14

1.1. Holocausto e antissemitismo como tema de estudo 14

1.2. Identificando estereótipos: a evolução da pesquisa sobre o livro didático 18

1.3. Um desafio pedagógico: o Holocausto nos livros didáticos 20

II. O PORQUÊ DE UMA EDUCAÇÃO SOBRE O HOLOCAUSTO 23

2.1. Pela formação de justos 23

2.2. Em oposição à normalização do passado 25

2.3. Pela atenção ao perigo de ideologias conspiracionistas 28

III. O HOLOCAUSTO NOS LIVROS DIDÁTICOS BRASILEIROS: PANORAMA GERAL E ESTUDOS DE CASO 36

3.1. O universo de estudo: análise teórico-qualitativa 36

3.2. Considerações sobre práticas educacionais no Brasil 52

3.3. Detalhamento da análise: dois estudos de caso 56

IV. PELAS MÃOS DE UM SOBREVIVENTE: O TESTEMUNHO COMO LAÇO 89

4.1. O Holocausto na história de uma vida narrada: proposta do projeto-piloto 89

4.2. O Holocausto através de cinco histórias de vida 94

4.2.1. Mira Wexler Gutfilen: sobrevivência nas florestas da Ucrânia 94

4.2.2. Ze'ev Litwak: os partisans judeus e a Resistência ao Nazismo 119

4.2.3. Cecília Gewertz: resiliência, resgate e... depois? 148

4.2.4. Ariella Segre: o Holocausto na Itália e a persistência do antissemitismo 176

4.2.5. Helena Blankfeld: geografia, dilemas e ideais em uma biografia 211

$\begin{array}{ll}\text { CONCLUSÃO } & 245\end{array}$ 


\section{INTRODUÇÃO}

A data de 27 de janeiro foi indicada Organização das Nações Unidas em 2005 para rememorar as vítimas do Holocausto e o significado deste genocídio considerado singular na História enquanto crime contra a humanidade.

Neste último dia 27 de janeiro de 2016, porém, foi diferente. Nesse dia, discursos de líderes internacionais - como o do Primeiro Ministro do Canadá, Justin Trudeau ${ }^{1}$ - e declarações oficiais de governos - como a expedida pelo Ministério de Relações Exteriores do Brasil ${ }^{2}$ exortaram à lembrança de um Holocausto sem judeus. Uma ausência ensurdecedora com enormes repercussões, principalmente no que se refere à educação sobre o tema e ao mesmo tempo representativa de um processo de mudança gradual em relação à maneira como o mundo lembra o evento.

No entanto, não se trata de um processo pontual nem totalmente novo. Os episódios mencionados são, antes de mais nada, simbólicos, expressando segmentos da "ideologia do apagamento" ou da "ideologia do silêncio". Sutilmente, estampam com o carimbo de estados, algo que se tem percebido e analisado ao longo dos últimos anos, enquanto estudiosos do tema. Entendemos que as motivações também não são únicas e variam de propostas bem-intencionadas que veem na universalização da história do Holocausto uma ferramenta de pedagogia da moral adaptável a todo e qualquer cenário - um antibiótico de amplo espectro. Outra possibilidade de interpretação é a de avaliarmos estes silêncios como tentativas de impor o revisionismo histórico com fins políticos procurando negar ou minimizar a dimensão da violência perpetrada pelos nazistas e colaboracionistas. Como exemplo citamos as teorias do "duplo genocídio" cada vez mais presentes principalmente em países do leste europeu ${ }^{3}$, ou as referências ao Holocausto como uma mera ocorrência durante a Segunda Guerra Mundial.

\footnotetext{
${ }^{1}$ Statement of Prime Minister of Canada on Holocaust Remembrance Day, Ottawa, Ontario, 27 January, 2016. http://pm.gc.ca/eng/news/2016/01/27/statement-prime-minister-canada-holocaust-remembrance-day Consultado em 24 de agosto de 2016.

${ }^{2}$ BRASIL. Ministério das Relações Exteriores, Brasília, 27 de janeiro de 2016. http://www.itamaraty.gov.br/index.php?option=com content\&view=article\&id=13008\&catid=42\&Itemid=280\&lan $\mathrm{g}=\mathrm{pt}-\mathrm{BR}$. Consultado em 24 de agosto de 2016.

${ }^{3}$ KATZ, Dovid. "Understanding Double Genocide". In, JHC Centre News, Jewish Holocaust Centre, Victoria, Australia, September 2011. http://defendinghistory.com/wp-content/uploads/2013/06/Dovid-Katz-on-Double-Genocide-20111.pdf Consultado em 24 de agosto de 2016.
} 
Gravitando em torno a esses percursos e, às vezes incorporando-se a eles, está um velho fenômeno que continua apresentando contundentes provas de imortalidade e de uma poderosa capacidade de regeneração, por não dizer de rejuvenescimento: o antissemitismo. Todos juntos, e principalmente este último, têm contribuído para o desenvolvimento de um fenômeno ao qual denomino a fagocitose da história do Holocausto. Fagocitose - termo emprestado da biologia - é um mecanismo pelo qual a célula engolfa objetos "estranhos" - restos de células, por exemplo seja para destruí-los, para alimentar-se deles ou até mesmo neutralizá-los de forma a torná-los inofensivos.

Desde que o mundo começou a tomar consciência - mesmo que parcialmente durante os primeiros anos após a Segunda Guerra - da dimensão do extermínio praticado contra os judeus pela Alemanha nazista, o Holocausto tem funcionado como um "objeto estranho" no corpo antissemita. No início, a reação de suas células foi lenta e localizada, afinal mais da metade da população judaica europeia havia sido exterminada, os perpetradores vencidos e não havia muito espaço, naquele momento, para a retomada imediata de teorias conspiratórias e genocidas sobre um mundo "controlado pelos judeus".

Desde a década de 1960, contudo, um grupo de intelectuais preocupados com os silêncios impostos pela história oficial ou por interesses pontuais de alguns grupos políticos começou a identificar reações mais contundentes contra a memória do Holocausto. Peter Schönbach, da Escola de Frankfurt, por exemplo, chegou a cunhar o termo antissemitismo secundário, ou seja, “a recusa ou rejeição da rememoração do crime sem precedentes cometido pelos alemães durante a Segunda Guerra Mundial"5. A materialização extrema desse fenômeno é a pseudotese de que o Holocausto nunca existiu, o qual conhecemos pelo nome de negacionismo.

A gradual reestruturação empreendida pelo povo judeu e o desenvolvimento e afirmação de seu Estado, cuja independência foi obtida em 1948, reacenderam velhos sentimentos antissemitas que tiveram repercussão a partir de 1967 com a vitória de Israel na Guerra dos Seis Dias. A versão difundida pelos antissionistas era de que os judeus estavam de volta e também

\footnotetext{
${ }^{4}$ Hoje esse argumento transparece na mentalidade coletiva e que encontra terreno fértil nas mídias digitais.

${ }^{5}$ HENI, Clemens. "Secondary Anti-Semitism: From Hard-Core to Soft-Core Denial of the Shoah", In, Jerusalem Center for Public Affairs. Jerusalem, 2 de novembro de 2008. http://jcpa.org/article/secondary-anti-semitism-fromhard-core-to-soft-core-denial-of-the-shoah/. Consultado em 25 de julho de 2016
} 
seus detratores, que passo a passo ajudariam a converter converteram o Estado de Israel no que Poliakov denominou "o judeu coletivo entre as nações"6.

Nesse processo de construção do discurso negacionista constatamos que para seus seguidores, o Holocausto representa mais uma das "artimanhas" criadas pelos Sábios de Sião e, portanto, não pertence ao universo da narrativa histórica. Para o antissionista, por sua vez, o evento também não se encaixa em sua visão de mundo. Este último, porém, não nega o evento. Em vez disso, a construção de seu discurso consiste em utilizar tropos e figuras de linguagem de forma reversa, reciclar relatos, nomear novas vítimas e novos carrascos, ou retomá-los em papeis invertidos. A partir dessa perspectiva, Israel passa a ser caracterizado como racista e - ironia das ironias - em casos mais extremos, nazista ${ }^{7}$.

Inicia-se assim uma "ginástica" materializada num processo de desconstrução e anulação da verdade histórica. Procura-se desvirtuar o Holocausto como evento histórico, processo ao qual a educação, em geral, não consegue escapar. Verificamos que sobrevive uma coletânea de imposturas ideológicas que, somadas a tentativas de "descomplicar" a história, acabam por banalizá-la e esvaziá-la de significado.

Por outro lado, fenômenos como a normalização do passado, a tendência ao fascínio pela estética fascista e a procura obsessiva pelo "politicamente correto" confluem para o que denomino de "editorialização da barbárie", ou seja, a eliminação, transformação ou adaptação de fatos documentados relacionados ao Holocausto e à Segunda Guerra Mundial na busca por uma narrativa de "fácil digestão". Tem-se, porém, como resultado, a descaracterização da História e por melhor intencionadas que possam ser essas tentativas, o preço a pagar em termos de instrumentalização e popularização - por não dizer profanação - do Holocausto é muito alto, podendo chegar a esvaziá-lo de todo e qualquer conteúdo que convide à reflexão.

Sob este viés - da anulação, do silenciamento e da deturpação dos fatos - é que propomos investigar o tratamento da questão nos livros didáticos brasileiros. Mas cabe aqui a pergunta: por

\footnotetext{
${ }^{6}$ POLIAKOV, Leon. Do Anti-sionismo ao Anti-semitismo. São Paulo: Perspectiva, 2000.

${ }^{7}$ Esta retórica direcionada a deslegitimar e demonizar o Estado de Israel tem sido disseminada, principalmente na última década, pelos seguidores do movimento BDS (Boicote, Desinvestimento e Sanções). Formalmente lançado em 2005, mas impulsionado, já em 2001, pela Conferência Mundial Contra o Racismo das Nações Unidas (Durban) o BDS é hoje apoiado por Organizações Não-Governamentais, intelectuais e artistas, e tem encontrado audiência no meio universitário e acadêmico, organizando protestos e dando publicidade a eventos como por exemplo o Israeli Apartheid Week (Semana do Apartheid Israelense), inclusive no Brasil. As distorções históricas e conceituais encontradas nos discursos do movimento que definem o árabe como o "novo judeu" e retratam Israel como a nova potência orientalista, imperialista e racista, têm contribuído para o considerável crescimento de posições antissionistas com fortes componentes antissemitas. Por outro lado, essa retórica tem servido para trivializar a realidade do conflito Árabe-Israelense, em nada contribuindo para os diálogos de paz na região.
} 
que é importante tratar o tema do Holocausto e tentar entender o fenômeno do antissemitismo em sala de aula? Afinal, não é um evento histórico como outro qualquer? E ainda, não se trata de algo que diz respeito somente aos judeus? Gostaria de apresentar a minha proposta de investigação e reflexão partindo desta última questão, ou seja, da necessidade de abordarmos na educação essa obsessão que alguns segmentos da sociedade parecem ter com os judeus e que há milênios, periodicamente, a impulsiona a escolher esse "outro" como objeto para expiar suas mazelas. $^{8}$

Curiosamente, o Holocausto, anticlímax desse processo de quase exorcismo, ocorreu em uma época em que se pensava que os ideais do Iluminismo e do Humanismo teriam dado fim aos nossos impulsos bárbaros. Foi um período em que alguns perpetraram, muitos colaboraram e a maioria observou passivamente de que maneira os judeus e toda a sua cultura se transformavam no centro de um projeto que visava apagá-los da face da Terra. Ao constatar que esse projeto havia sido em grande medida consumado, começou a perceber-se que havia algo muito sério a ser observado sobre a condição humana. O Holocausto converteu-se assim no evento emblemático - quase uma supraconsciência - da nossa mefistofélica faculdade de, quando a oportunidade se apresenta, cavarmos sem descanso em direção às profundezas.

Mas, essa consciência surgiu espontaneamente? Para alguns indivíduos sim. Eram deles as vozes que se levantavam, caindo em ouvidos surdos, enquanto o horror era perpetrado. A maioria, no entanto, precisamos de certa ajuda já que nosso histórico como espécie revela uma recorrente tendência a "varrermos a sujeira para debaixo do tapete".

Contudo, qual foi o processo que catapultou o Holocausto a essa categoria de "supraconsciência" que deu origem a todo um arcabouço linguístico, jurídico e pedagógico que utilizamos desde então para tentar prevenir os danos que, sabemos, somos capazes de infligir em nós mesmos?

Parte da resposta pode estar na mudança de paradigma que as próprias vítimas e sobreviventes do Holocausto imprimiram à abordagem de suas vivências, contribuindo extraordinariamente para construção de um verdadeiro edifício de conhecimentos sobre a catástrofe que se abateu sobre o povo judeu e que desde então tem sido entregue por eles à

\footnotetext{
8 Várias são as obras que analisam o tema. Dentre as consultadas estão: ARENDT, Hannah. The Origins of Totalitarianism. New York: Harvest, 1976, 1a. ed. 1958; CARNEIRO, Maria Luiza Tucci (org.). O Anti-Semitismo nas Américas. Memória e História. São Paulo: EDUSP, 2007; CARNEIRO, Maria Luiza Tucci. Dez Mitos Sobre os Judeus. São Paulo: Ateliê Editorial, 2014. POLIAKOV, Leon. The History of Anti-Semitism. Philadelphia: University of Pennsylvania Press, 2003 (Vols. I, II e III); WISTRICH, Robert. A Lethal Obsession: Anti-semitism from Antiquity to Global Jihad. New York: Random House, 2010.
} 
humanidade como um todo. Em seu livro The History and Sociology of Genocide, os autores Frank Chalk e Kurt Jonassohn apontam para a ausência de relatos daqueles que sofreram diretamente o impacto de eventos de caráter genocida no relato ao longo da História:

Sabemos que impérios desapareceram e que cidades foram destruídas, e suspeitamos que algumas guerras foram genocidas em seus resultados; mas não sabemos o que aconteceu com a massa de populações envolvidas nesses eventos. Seu destino era insignificante demais. Quando mencionados, eram em geral agrupados junto com os rebanhos de bois, carneiros e outros animais de criação. ${ }^{9}$

Os anos sombrios do nazismo, nesse sentido - assim como a ação persistente dos revisionistas, negacionistas e antissionistas - não conseguiram, como queriam, apagar a memória daqueles anos. Tampouco puderam contar com o esquecimento entre seus milhões de vítimas. $\mathrm{O}$ período de aproximação da catástrofe, o durante e o depois, constituem um processo inédito de produção literária e oral coerente com a milenar tradição judaica de responder às derrotas ao longo da História através da palavra.

Assim, aos milhares de diários produzidos e guardados nos lugares mais insólitos ${ }^{10}$ através dos quais seus autores procuravam que, senão seus protagonistas, ao menos os registros sobrevivessem à guerra, somaram-se projetos como o de David Boder que, ainda nos campos de deslocados coletou inúmeros testemunhos de sobreviventes. Nas décadas seguintes vieram as publicações de memórias, peças de teatro, trabalhos de ficção resgatando o tema e oferecendo o que o autor israelense Aharon Appelfeld ${ }^{11}$ denomina "a narrativa interior".

Relembrar, falar ou escrever sobre a catástrofe, no entanto, não era -e não é- uma tarefa simples. Para muitos dos sobreviventes, esse processo não ocorreu de forma imediata, nem em uma única etapa. Memórias e testemunhos expressam a companhia constante das sombras daqueles anos. A autora francesa Charlotte Delbo, chegou a referir-se a eles como uma "segunda pele", mas uma pele que não se renova e que recobre a "memória profunda" de Auschwitz que

\footnotetext{
${ }^{9}$ CHALK, F.; JONASSOHN, K. The History and Sociology of Genocide: Analyses and Case Studies. New Haven: Yale University Press, 1990, p. 8.

${ }^{10}$ Como exemplo podem citar-se, entre outros, os diários e documentos de Emmanuel Ringelblum encontrados em latas de leite nas ruínas do Gueto de Varsóvia, ou os escritos produzidos por diaristas em Birkenau e enterrados próximo a um dos crematórios.

${ }^{11}$ APPELFELD, Aharon. The Story of a Life. New York: Schocken Books, 2004.
} 
nos comunica que o que ela contém não é passado e nunca será ${ }^{12}$. Tampouco a dor e as feridas estão no passado. No entanto, as palavras continuaram fluindo e fazendo-se cada vez mais presentes.

No final da década de 1970, estudiosos como o professor e crítico literário Geoffrey Hartman, começaram a perceber o enorme potencial educativo dos testemunhos de sobreviventes do Holocausto e lançaram uma iniciativa que teve o apoio institucional da Universidade de Yale e resultando, anos mais tarde, no Arquivo Fortunoff que hoje conta com aproximadamente 4.000 histórias de vida registradas em áudio e vídeo. ${ }^{13}$

Nos anos 1990, após sua experiência como diretor do filme A Lista de Schindler, o cineasta americano Steven Spielberg deu início à USC Shoah Foundation, vinculada à Universidade do Sul da Califórnia, hoje o maior arquivo de história oral do mundo com mais de 50.000 testemunhos coletados em mais de 60 países. ${ }^{14}$

No Brasil, centenas de testemunhos de sobreviventes do Holocausto e refugiados do nazifascismo que encontraram abrigo no Brasil ou que por aqui passaram, foram coletados e estão sendo disponibilizados no Arquivo Virtual da Shoá, Arqshoah ${ }^{15}$, junto com milhares de documentos digitalizados e imagens de artefatos doados por sobreviventes e suas famílias. Coordenado pela Dra. Maria Luiza Tucci Carneiro, o arquivo é parte integrante dos projetos desenvolvidos pelo Laboratório de Estudos sobre Etnicidade, Racismo e Discriminação (LEER) na Universidade de São Paulo. Consolidado como uma importante contribuição a esse esforço coletivo, essa Base de Dados traz também, além dos testemunhos e um arquivo de documentos históricos, a uma biblioteca oral e escrita mundial e que aproxima dos pesquisadores e jovens estudantes brasileiros em geral a um evento que envolveu a humanidade como um todo.

Todas essas experiências, por outro lado, tiveram um forte impacto na própria produção historiográfica sobre o Holocausto. Autores como, por exemplo, o historiador Saul Friedländer, há décadas perceberam a necessidade de integrar as vozes das vítimas à narrativa histórica do evento sob os mais diversos aspectos, contribuindo desse modo ao questionamento da ideia de que a História é escrita pelos vencedores. Arrisco-me neste ponto a afirmar que as vítimas da violência perpetrada pelos nazistas e colaboracionistas convergiram -através de seus diários e

\footnotetext{
12 DELBO, Charlotte. Auschwitz and After. New Haven: Yale University Press, 2014 (2 ed.)

${ }^{13}$ Arquivo Fortunoff: http://web.library.yale.edu/testimonies

${ }^{14}$ USC Shoah Foundation: https://sfi.usc.edu/

${ }^{15} \mathrm{O}$ Arquivo Virtual sobre o Holocausto e o Antissemitismo pode ser acessado através do endereço: www.arqshoah.com
} 
outras formas possíveis de testemunhos- para inaugurar uma nova etapa no modo como vemos e escrevemos a História desde então.

O historiador alemão Reinhart Koselleck, ao comparar as histórias escritas ou relatadas pelos vencedores àquelas dos vencidos ensaia proposições interessantes - embora não únicas nem generalizáveis - para explicar a força intelectual destas últimas e que sem dúvida deveríamos ter em conta ao desenhar propostas para a sala de aula. Segundo o autor:

O historiador que está do lado do vencedor tende a interpretar êxitos de curto prazo da perspectiva de uma teleologia ex post facto de longo prazo, contínua.

Isso não se aplica aos vencidos. Sua experiência principal é que tudo aconteceu de forma diferente ao que era planejado ou esperado. Ao refletirem metodologicamente, eles enfrentam um maior ônus da prova ao explicar porque alguma coisa aconteceu desse modo e não daquele que havia sido previsto. A partir daí, iniciase uma busca por razões de meio e longo alcance de modo a estruturar e talvez explicar o resultado inesperado. Portanto, há algo atraente na hipótese de que precisamente a partir das experiências únicas que lhes foram impostas, resultem percepções mais duradouras e consequentemente de maior poder explanatório. Se a história, no curto prazo é feita pelos vencedores, a sabedoria histórica é, a longo prazo, enriquecida pelos vencidos. ${ }^{16}$

A inovação metodológica iniciada a partir dos escritos e testemunhos de vítimas e sobreviventes do Holocausto em sua condição de vencidos contém, segundo Koselleck, um “inesgotável potencial epistemológico”. E prossegue, “(...) uma vez que se transpõe a experiência ao conhecimento, este permanece acessível para além de qualquer mudança da experiência"17

Aqui é importante abrir parênteses para discutirmos o conceito de "vencidos" nas referências às vítimas e sobreviventes no contexto da História do Holocausto. Para muitos, a capacidade de ressurgimento do povo judeu após a Segunda Guerra, a forma de reconectar seus fragmentos e de refazer-se como nação após a barbárie é em si mesmo um feito que merece a mais profunda admiração. Desse ponto de vista, categorizar sua história como derrota, pode

${ }^{16}$ KOSELLECK, Reinhart. The Practice of Conceptual History. Timing History, Spacing Concepts. Stanford: Stanford University Press, 2002, p. 76 (tradução nossa)

${ }^{17}$ Idem, p. 83. 
parecer inadequado. Para outros - aí incluído o antissemita, o antissionista e até mesmo alguns céticos mal-intencionados - os judeus se aproveitaram dessa história para favorecimento próprio. Segundo eles, os judeus não foram vencidos, ao contrário, fizeram do Holocausto uma “indústria, um negócio". ${ }^{18}$ Há ainda os "românticos" ou "otimistas" que podem pensar que no fim das contas, o Holocausto é simplesmente uma história com final feliz.

Vejamos um brevíssimo panorama, de nenhuma forma abrangente do estado das coisas para os judeus no despertar pós-Holocausto. Enquanto o mundo comemorava o final da guerra sobre as ruinas da Alemanha nazista, para o povo judeu, a vitória dos aliados havia chegado tarde demais. Mais da metade dos membros da população judaica da Europa estavam mortos. Somente na Polônia, onde antes de 1939 viviam 3.500.000 de judeus, mais de 90\% haviam sido assassinados. As demais comunidades do leste europeu, que lá habitavam havia quase cinco séculos, não mais existiam. Os sobreviventes que emergiam das florestas onde haviam encontrado refúgio durante a guerra buscavam pontes que os conduzissem à reconstrução de suas vidas sobre as cinzas do shtetl. Perceberam, porém, que não só o shtetl, mas tampouco as pontes restavam. Aqueles que, mesmo assim, arriscavam retornar às suas casas na esperança de terem sido os únicos em suas famílias sujeitos ao périplo daqueles seis anos de inferno, descobriam que não havia mais família e o que antes era seu lar, havia sido ocupado por habitantes locais hostis aos antigos vizinhos. Na Polônia, somente no primeiro ano depois da guerra, mais de 500 judeus foram mortos em ataques isolados e pogroms organizados por "vizinhos". O mais notório é talvez o massacre perpetrado na cidade de Kielce, em julho de 1946, e que resultou na morte de pelo menos 42 judeus ${ }^{19}$.

Nos países da Europa Ocidental, o golpe também havia sido brutal. Na Alemanha, por exemplo, dos aproximadamente 500.000 judeus que havia antes da guerra, somente 60.000 ainda estavam no país, a maioria sobreviventes dos campos de concentração nazista. ${ }^{20}$ Durante anos, muitos sobreviventes permaneceriam ainda em campos de deslocados de guerra (DP Camps) na Europa, ou empreenderiam difíceis travessias para os mais diversos destinos no mundo.

A imigração para a Palestina sob o Mandato Britânico via-se também truncada pelos limites que as autoridades inglesas haviam imposto na região aos refugiados judeus. Esses

\footnotetext{
${ }^{18}$ CARNEIRO, Maria Luiza Tucci. Cidadão do Mundo. O Brasil diante do Holocausto e dos judeus refugiados do nazifascismo (1933-1948). São Paulo: Perspectiva, 2010.

19 United States Holocaust Memorial Museum: https://www.ushmm.org/wlc/en/article.php?ModuleId=10007941; para um estudo aprofundado sobre a situação dos judeus na Polônia após o Holocausto, ver GROSS, Jan T. Fear: Anti-Semitism in Poland After Auschwitz: An Essay in Historical Interpretation. New York: Random House, 2006.

${ }^{20}$ SHAPIRA, A. ; KEYNAN, I. The Survivors of the Holocaust. Jerusalem: Yad Vashem, 2016.
} 
limites manifestavam-se inclusive em bloqueios às embarcações que tentavam chegar com sobreviventes aos portos de Eretz Israel. Muitos desses navios eram desviados para a Ilha de Chipre e os refugiados - novamente - internados em campos de concentração. Outros eram enviados de volta para a Europa, como foi o caso do Exodus que transportava imigrantes ilegais ${ }^{21}$. Somente algumas embarcações conseguiram atravessar o bloqueio mediante arriscadas manobras ou violentos enfrentamentos. O mundo para os judeus continuava dividido entre "os lugares onde não podiam viver e os lugares onde não podiam entrar". ${ }^{22}$

O processo de reconstrução do povo judeu como nação depois do Holocausto em nada contradiz, deste ponto de vista, o tratamento de sua catástrofe como uma história de vencidos; tampouco impede que se reconheça a sua contribuição seminal como ponto de partida de uma historiografia criada, como forma de renascimento, por uma comunidade em luto ${ }^{23}$ e uma nova forma de ver o indivíduo dentro da História. Como povo, trata-se de uma epopeia talvez com um único paralelo encontrado no mais influente relato histórico legado pelos próprios judeus à humanidade: a Bíblia hebraica. Coincidência? Certamente não.

Não é o objetivo deste trabalho aprofundar a análise desse aspecto e muito menos estabelecer comparações entre o relato bíblico e o acervo resultante do Holocausto mas, se como afirmam Amos Oz e Fania Oz-Salzberger em seu livro Os judeus e as palavras ${ }^{24}$, "a genealogia nacional e cultural dos judeus sempre dependeu da transmissão intergeracional de conteúdo verbal" constituindo uma "linhagem não de sangue, mas de texto". Assim, podemos também afirmar que sua clareza e acessibilidade permitiram aos demais homens e mulheres sermos parte

${ }^{21}$ O Exodus 1947 -cujo nome original era President Warfield- foi um navio que entrou para a história da luta dos refugiados judeus após o Holocausto. O navio, construído em 1928, foi comprado, já bastante danificado, por uma organização militar judaica, a Haganah, cujos membros conseguiram atracar nas costas da França na tentativa de transportar judeus que buscavam imigrar ilegalmente para a Palestina controlada pelas autoridades britânicas que lhes impediam a entrada ao território. Em julho de 1947 o navio zarpou da França rumo à Palestina levando aproximadamente 4.500 homens, mulheres e crianças, todos sobreviventes do Holocausto que então habitavam em campos para deslocados de guerra (DP Camps). Antes mesmo de chegar às águas da Palestina, destroyers britânicos cercaram a embarcação desarmada, deflagrando uma luta que deixou ao menos três mortos e vários feridos. O navio foi então levado para Haifa e os passageiros foram embarcados em três navios-prisão de volta para a Europa. De regresso à França, os passageiros recusaram-se a desembarcar e iniciaram uma greve de fome. Devido à recusa das autoridades francesas de desembarcar os passageiros à força, os britânicos decidiram levar os passageiros para a zona controlada por eles na Alemanha. A repercussão internacional, parte dela graças ao trabalho da fotojornalista americana Ruth Gruber que acompanhou os exilados de porto em porto documentando seus destinos, serviu em parte para sensibilizar a opinião pública em relação aos refugiados e quanto à necessidade do reconhecimento de um Estado judeu. GRUBER, Ruth. Exodus 1947: The Ship that Launched a Nation. New York: Sterling USA, 2007.

${ }^{22}$ Discurso de Chaim Weizmann proferido em Jerusalém em 25 de abril de 1936.

23 Segundo o conceito "community in mourning" desenvolvido por Jay Winter. Ver, WINTER, Jay. Sites of Memory, Sites of Mourning: The Great War in European Cultural History. Cambridge: Cambridge University Press, 1995.

${ }^{24}$ OZ, A. ; OZ-SALZBERGER, F. Os judeus e as palavras. São Paulo: Companhia das Letras, 2015. 
dessa linhagem assim como de seu legado ético e jurídico. A produção escrita e oral do Holocausto é parte dessa linhagem. Mas se o legado que as vítimas e os sobreviventes nos transmitiram não teve como resultado a construção de catedrais ou mesquitas de pedra, por outro lado ensejou um constante pensar e repensar sobre nossa própria natureza e condição, com consequências concretas.

Talvez uma das mais eminentes seja a Declaração Universal dos Direitos Humanos, firmada em 1948 e todas suas ramificações. No campo do ensino da História, que está na base de nosso trabalho, o acervo literário e testemunhal do Holocausto rompeu de vez com o estigma de ter sido vítima de uma catástrofe e de falar sobre como é SER humano nesse contexto. Mesmo depois do Holocausto, quando as sombras tornaram a visitar-nos em Darfur, Ruanda ou BósniaHerzegovina, milhares de vozes que vivenciaram esses eventos históricos levantaram-se para registrar e alertar sobre as possibilidades, as escolhas e as limitações vividas por seres humanos em momentos de tempestade extrema. Eles também construíram suas bibliotecas, hoje disponíveis a todos, como doação para o aprofundamento dos ensinamentos que seus testemunhos ensejam. Se como Chalk e Jonnasohn afirmam em seu livro, o século XX não pode ser definido como o século do genocídio, já que é uma prática que nos caracteriza há milênios ${ }^{25}$, certamente inaugurou a era do testemunho ${ }^{26}$.

Em meio a todo esse processo e apesar das idas e vindas, pode-se dizer que temos aprendido algo com este processo de rememorações, registros de testemunhos, publicações, construção de memoriais e eventos. Em primeiro lugar, aprendemos a falar e também a ouvir, inclusive as pausas e os silêncios. Hoje a tolerância com a violência e a injustiça, ao menos para parte de alguns segmentos da humanidade, é muito menor do que era há apenas algumas décadas. O processo educativo em relação aos direitos humanos ao qual fomos expostos imediatamente após a Segunda Guerra, tem rendido frutos. Antes do Holocausto não havia sequer uma terminologia para referir-nos aos eventos que hoje conhecemos por genocídio. Temos tomado consciência, pelo menos em boa parte do mundo, de que minorias devem ser protegidas, assim como crianças, idosos, mulheres. Uma parcela dessa conscientização estendese inclusive aos esforços por proteger o ambiente e os animais.

Porém, a humanidade não caminha a passos de gigantes, nem em linha reta para um futuro de respeito mútuo. E em certos momentos, inclusive, mesmo quando caminhamos para a

${ }^{25}$ CHALK ; JONNASOHN, op. cit.

${ }^{26}$ WIEVIORKA, Annette. The Era of the Witness. Ithaca: Cornell University, 2006. 
frente acabamos fazendo-o em direção ao precipício, destruindo a nós mesmos. Na verdade, não há garantias. Nada impede que voltemos à barbárie, exceto nós mesmos. Novos cenários históricos se estabelecem, novo fantasmas aparecem, novos embates e desafios surgem. Além disso, novas gerações nascem e as lições do passado recaem também sobre elas em um exercício permanente de memória e também de esquecimento, não necessariamente de via única quanto a suas interpretações. Haverá bifurcações e encruzilhadas. Poderão surgir novos demagogos ou ideólogos puxando o coro do retrocesso. A educação, nesse sentido, é a única arma.

Freud identificou o educar como uma das três profissões impossíveis -juntamente com o governar e o curar. ${ }^{27}$ Porém, não deveríamos ler essa chamada como "o não poder fazer" e sim como a ausência de uma linha de chegada. Como acontece com qualquer utopia ou horizonte, a educação nos foge constantemente. Ao avançarmos, ela retrocede, processo que se repete $a d$ infinitum, mas que justamente por isso, obriga a que continuemos navegando.

Nesse sentido, a máxima mishnaica extraída do Pirkei Avot (a Ética dos Pais) e aqui inserida a título de epígrafe, certamente está - ou deveria estar - na mente de todo aquele que se dedica à educação; que dirá daquele cujo foco é a educação sobre o antissemitismo. Este fenômeno, em permanente transformação através dos séculos, continua presente nestas primeiras décadas do século XXI, ostentando velhos preconceitos e incorporando novos.

Em 1820 o poeta Hermann Heine em sua peça Almansor, ambientada na Espanha no século XVI, dá voz a um de seus personagens quem ao referir-se aos autos-da-fé praticados pela Inquisição professa: "Isto é só um prelúdio. Lá onde eles queimam livros, um dia acabarão queimando pessoas" 28 . Era uma frase premonitória que o mundo comprovaria pouco mais de um século depois. O Holocausto e os inúmeros episódios de perseguição ao povo judeu ao longo de sua história, provam também que - como vários autores e comentaristas da história têm afirmado - o que começa com o judeu, não para no judeu.

Portanto, voltando à questão que apresentei no início desta introdução quanto às tendências de esfacelamento da história do Holocausto e principalmente do apagamento da centralidade do povo judeu em diversas narrativas, devemos estar atentos e continuar promovendo a educação sobre o importantíssimo legado desse episódio. Mas, antes de proceder ao desenho de novas propostas para a educação sobre o tema ou de afirmar aquelas existentes, é

${ }^{27}$ A primeira menção às três profissões impossíveis encontra-se no prefácio de Sigmund Freud à obra de August Aichhorn, Verwahrloste Jugend (Juventude Determinada), Viena, 1925.

${ }^{28}$ LEWY, Guenter. Harmful and Undesirable. Book Censorship in Nazi Germany. New York: Oxford University Press, 2016. 
fundamental conhecer a essência do que existe na atualidade dentro universo sobre o qual se pretende intervir, dentro de parâmetros possíveis.

Assim, a primeira das duas etapas principais deste trabalho concentra-se na análise do tratamento do Holocausto como tema de estudo nos livros didáticos brasileiros recomendados pelo Programa Nacional do Livro Didático (PNLD), vinculado ao Ministério da Educação do Governo Federal do Brasil ${ }^{29}$. Por exigência curricular, o tema do Holocausto é tratado dentro do contexto da Segunda Guerra Mundial no $9^{\circ}$ ano do Ensino Fundamental, e no $3^{\circ}$ ano do Ensino Médio da Educação Básica. É nesse ambiente pedagógico que a análise estará concentrada em dois níveis: primeiro, uma análise geral das obras recomendadas pelo PNLD para o biênio 20152016 e segundo, uma análise pormenorizada de alguns exemplos.

A segunda etapa consiste na proposta de um projeto piloto de materiais que possam ser introduzidos na sala de aula, incorporando a visão de uma história do Holocausto tratada de maneira integrada. Pensamos em introduzir um testemunho pessoal que, por sua riqueza de detalhes, estabeleça os laços com questões gerais daquele momento/tempo histórico e concomitantemente específicas aos espaços geográficos de exclusão, irradiadores do ódio e da violência que resultaram em atos genocidas.

Do ponto de vista estrutural procurei desenvolver minha proposta teórico-metodológica antecipada nesta Introdução em três capítulos:

Capítulo I - detalhamento das questões teórico-metodológicas que orientaram tanto a escolha do objeto de estudo quanto à análise dos materiais e as propostas;

Capítulo II - avaliação de livros didáticos no que se refere ao conteúdo relacionado ao Holocausto, primeiramente de maneira geral e posteriormente através de um estudo pormenorizado de dez obras selecionadas que inclui o tratamento das linguagens verbal e nãoverbal (iconografia) além de uma abordagem da literatura e filmografia sobre o Holocausto nos livros didáticos;

Capítulo III - projeto-piloto de materiais que possam servir ao uso em sala de aula e que de algum modo aproximem experiências de vida individuais à História tratada nos livros didáticos, possibilitando a abertura do leque de narrativas sobre o período. Os protagonistas dessas histórias são sobreviventes do Holocausto radicados no Brasil que deram seus

${ }^{29} \mathrm{Na}$ apresentação do Programa Nacional do Livro Didático temos que o mesmo "tem como principal objetivo subsidiar o trabalho pedagógico dos professores por meio da distribuição de coleções de livros didáticos aos alunos da educação básica". Portal do Ministério da Educação, Governo Federal, PNLD, www.portal.mec.gov.br/pnld/apresentacao. Consultado em 08/08/2016. 
testemunhos ao Projeto Vozes do Holocausto -do qual faço parte- levado a cabo pelo Laboratório de Estudos sobre Etnicidade, Racismo e Discriminação (LEER) junto à FFLCHUniversidade de São Paulo. 


\section{AUSCULTANDO UM VELHO ÓDIO: O PULSAR DO HOLOCAUSTO}

\subsection{Holocausto e Antissemitismo como tema de estudo}

É provável que nenhum fenômeno social, cultural ou político fale tanto sobre a natureza humana como o antissemitismo. É um ódio particular baseado mais em ressentimento do que em racismo, e que acompanha as mais diversas sociedades há milênios; atravessa fronteiras, credos e etnias; gera mitos como poucos; alimenta teorias conspiratórias; desemboca em destruição. Tem o poder de transformar-se, mimetizar-se e resistir como nenhum outro ódio tem conseguido. E o mais interessante: nem precisa da presença do judeu para existir. Para muitos antissemitas, não é sequer necessário saber como é um judeu ou ter conhecido um judeu. Mesmo assim, estar ou entrar nessa categoria já acarreta perigo. É sem dúvida o ódio de mais longa duração. ${ }^{30}$ Eu o chamaria também de o ódio mais profundo. No entanto, não se nasce com ele: é ensinado.

É por isso que considero fundamental estudá-lo, analisá-lo e avaliá-lo como elemento formador de opinião no contexto da educação. Nesse sentido, o Holocausto, como exemplo máximo do antissemitismo genocida, deve ser cuidadosamente tratado nos ambientes de estudo. Se houve algo que o Holocausto mostrou foi a possibilidade de que um evento da magnitude do Holocausto tenha sido é possível. Antes dele, uma catástrofe com essas características era impensável. Daí ser oportuno retomarmos a definição de Imre Kertész, autor premiado com o Nobel de Literatura em 2002, que de certo modo traduz essa situação:

A expressão tem sido repetida com tanta frequência que se tornou quase um cliché: é necessário preservar a memória do Holocausto para que ele nunca mais aconteça. Mas desde Auschwitz, não tem acontecido nada que faça um novo Auschwitz impossível. Ao contrário. Antes de Auschwitz, Auschwitz era inimaginável. Isso não é mais assim. Porque Auschwitz de fato ocorreu, ele ficou assentado em nossa imaginação como uma firme possibilidade. O que somos capazes de imaginar, especialmente porque uma vez foi, pode ser novamente. ${ }^{31}$

\footnotetext{
${ }^{30}$ WISTRICH, Robert. Antisemitism: The Longest Hatred. London: Schocken, 1994.

${ }^{31}$ KERTÉSZ, Imre, "Über den Neuen Europäischen Antisemitismus", 2006. In, ROSENFELD, Alvin, The End of the Holocaust, Bloomington: Indiana University Press, 2011, pp. 279 (tradução nossa)

$\mathrm{O}$ texto tem alemão pode ser acessado em: https://www.perlentaucher.de/essay/imre-kertesz-ueber-den-neueneuropaeischen-antisemitismus.html,
} 
A advertência de Kertész, feita em 2006, ecoa com intensidade crescente, principalmente neste momento em que as máscaras que cobriam os rostos do velho antissemitismo - latente, mas que se acreditava de alguma forma controlado - começam a cair. Hoje, em pleno século XXI, portanto mais de cem anos depois do Caso Dreyfus ${ }^{32}$, quando uma multidão se agrupava em Paris para ver a humilhação do capitão injustamente acusado de traição aos gritos de "morte aos judeus", testemunhamos cenas semelhantes, não só na França, mas em toda a Europa e em várias partes do mundo. ${ }^{33}$

Há algo, porém, na afirmação do autor húngaro com o que talvez possamos discordar, ao menos em parte. Algo aconteceu desde Auschwitz: a educação sobre Auschwitz e toda a estrutura filosófica e jurídica advinda do evento e em grande parte construída por aqueles que o vivenciaram de perto, muito de perto. Essa estrutura tem nos servido para alavancar décadas de iniciativas em relação aos direitos humanos que, muito provavelmente, contribuíram a que novos Auschwitz tenham sido impedidos de acontecer. É certo que muitas atrocidades aconteceram desde o Holocausto, mas temos estado um pouco mais alerta.

A crise, porém, volta a assombrar-nos nesta segunda década do século XXI e, como muitas outras vezes na história da humanidade, tempos de crise materializam-se -quase invariavelmente- em tempos de antissemitismo. Nesse sentido, o Holocausto, como expressão extrema do antissemitismo genocida merece ser permanentemente revisitado pelos educadores, acadêmicos, filósofos e humanistas hoje talvez a partir de táticas e estratégias renovadas. Mas em

$32 \mathrm{O}$ caso Dreyfus, evento que dividiu a sociedade francesa no final do século XIX, eclodiu em 1894 e estendeu-se até 1906. Na superfície -e somente na superfície- esse caso poderia ser visto simplesmente como uma ocorrência em que um capitão francês, Alfred Dreyfus, foi acusado de traição por ter fornecido documentos secretos aos alemães. No entanto, seu julgamento tornou-se uma das páginas mais importantes da história judaica moderna. Desde o início, como o único judeu no Exército francês, ele havia sido alvejado e injustamente condenado. Seu julgamento foi mantido em segredo usando documentos forjados cujo objetivo era encobrir os verdadeiros autores do ato. Como resultado do julgamento, Dreyfus foi sentenciado a prisão perpétua. Antes de ser enviado ao exílio na Ilha do Diabo, foi degradado em um espetáculo público perante uma multidão enfurecida que bradava "morte aos judeus". O caso propagou-se por toda a comunidade judaica. A França, terra dos grandes ideiais da Revolução, o Estado iluminado no qual os judeus viviam e se desenvolviam, assistiam como os conhecidos estereótipos antissemitas ressurgiam. Ajudados pelos meios de comunicação, as ideias antissemitas espalharam-se rapidamente. Protestos colocavam novamente o judeu como inimigo central. A pressão de alguns intelectuais franceses, sendo um dos mais célebres o escritor Émile Zola, fez com que o caso fosse reaberto e Dreyfus fosse julgado novamente. Embora após longos anos de exílio, Dreyfus tivesse conseguido provar sua inocência e ser libertado, o caso mostrou que o mundo continuava sendo um lugar ameaçador para os judeus. Entre os que despertaram para essa realidade estava Theodor Herzl -e que anos mais tarde se tornaria pai do sionismo- quem, trabalhando como jornalista em Paris, testemunhou em primeira fila o perigo. Em um artigo escrito em 1899, Herzl afirmou: "O caso Dreyfus personifica mais do que um erro judicial; ele incorpora o desejo da vasta maioria dos franceses de condenarem um judeu e de condenar todos os judeus nesse judeu".

33 WISTRICH, Robert. A Lethal Obsession: Anti-Semitism from Antiquity to Modern Jihad. New York, 2010; MARCUS, Kenneth. The Definition of Antisemitism. New York: Oxford University Press, 2015. 
qualquer tarefa de renovação é recomendável que se tenha como ponto de partida uma análise do estado-da-arte sobre o tema de modo a tentar identificar tanto possíveis desvios quanto elementos que possam ser reaproveitados em futuras propostas. Em outras palavras, uma análise daquilo que existe pode contribuir a identificar as sementes para a continuidade ou eventuais mudanças de qualquer projeto.

No âmbito escolar, um ponto de partida interessante parece colocar-se sobre o conhecimento do conteúdo existente nos livros didáticos. Na prática escolar, o livro didático como meio de difusão de conteúdos ocupa historicamente uma importante função, em parte ainda resguardada apesar da eclosão de novas tecnologias. No caso do Brasil, sua ampla distribuição territorial, permite um alcance quase indisputável. Suas características intrínsecas no contexto de universalização da educação fazem com que esse meio tenha um valor documental privilegiado, não somente pelo que transmite a quem o utiliza - o professor e o aluno - mas também pelo que ele nos transmite sobre a sociedade e o tempo em que vivemos. Aquilo que o historiador Marc Ferro afirma a respeito da própria disciplina, poderia estender-se aos livros didáticos como meio singular de transmissão:

\section{(...) a História que é ensinada às crianças, aos adultos, também será capaz de}

dizer-nos algo sobre a identidade de uma sociedade e de seu status no tempo. ${ }^{34}$

No caso do livro didático de História, a complexidade e diversidade dos assuntos tratados, as restrições de espaço nas edições e as pressões políticas por distintas formas de tratamento dos conteúdos, transformam-no em um meio altamente seletivo do qual resultam condensações, omissões e generalizações que muitas vezes comprometem a qualidade da informação e dos saberes que se deseja transmitir.

Por outro lado, ao tempo que transpõe o conhecimento acadêmico para o âmbito da escola, o livro didático é também mercadoria e como tal, atende a processos e decisões nos moldes da indústria cultural. No entanto, é uma mercadoria diferenciada e encarregada de fazer ou desfazer impressões em um momento da vida do aluno em que as mesmas ficarão estampadas para sempre. Nesse sentido, constitui um instrumento importante para quem deseja promover

\footnotetext{
${ }^{34}$ FERRO, Marc. The Use and Abuse of History. Or How the Past is Taught to Children. London: Routledge Classics, 2003, (tradução nossa).
} 
valores relacionados à ética e ao desenvolvimento de um pensamento crítico. Nesse sentido, recorro novamente a Marc Ferro:

Nossa imagem de outros povos, como aliás de nós mesmos, reflete a história que nos ensinaram quando crianças. Essa história nos marca para o resto da vida. Sua representação, que é para cada um de nós uma descoberta do mundo, da sociedade, abarca todas as nossas opiniões temporárias ou permanentes, de tal modo que traços de nossos primeiros questionamentos, nossas primeiras emoções, permanecem indeléveis. ${ }^{35}$

Mas é em outra obra de Ferro, Os Tabus da História, que se encontra um dos principais conceitos que orientam este trabalho. O Holocausto, além de sua complexidade intrínseca como evento histórico paradigmático, guarda em seu seio inúmeros tabus que a nossa memória coletiva tem perpetuado ad infinitum. Os tabus, no sentido defendido por Ferro, diferentemente daquilo que é proibido, censurado, é “aquilo sobre o que se silencia, por medo, por pudor" 36.

No prefácio à mesma obra, Maria Luiza Tucci Carneiro desenvolve a visão de Ferro:

Equivocada pelos silêncios, a sociedade mergulha na alienação, alimentando a persistência dos interditos: acredita, sem ousar dizer, por mais absurda que seja a condição da história. (...) o tabu exerce uma função de autodefesa, assumindo a forma de "versões ilusórias". ${ }^{37}$

Autodefesa para uns, armas poderosas para outros que se servem dos tabus sobre a história do Holocausto com o mal-intencionado propósito de reduzi-la ao mínimo ou de deturpar os propósitos da perseguição, o papel dos protagonistas e as dimensões da catástrofe. Esses tabus têm o poder de diluir a corrente da história, tornando seus elementos difusos ou quase invisíveis. Com o tempo, eles se apoderam da memória, convertem fatos em dúvidas e acabam aniquilando completamente sua essência e legado.

“Quem, afinal, fala hoje da aniquilação dos armênios". Esta frase ao que parece, teria sido pronunciada por Hitler em agosto de 1939, em discurso proferido aos comandantes da Wehrmacht em sua residência de Obersalzberg. Embora não haja consenso sobre se essas

\footnotetext{
${ }^{35}$ Ibidem.

${ }^{36}$ FERRO, Os Tabus da História. Rio de Janeiro: Ediouro, 2002. Prefácio de Maria Luiza Tucci Carneiro.

${ }^{37}$ CARNEIRO, Maria Luiza Tucci. Prefácio ao livro de Marc Ferro, Os Tabus da História. Rio de Janeiro: Ediouro, 2002, p. 9
} 
palavras foram ou não pronunciadas por ele ou se estava referindo-se aos judeus ou aos poloneses, o que sim fica evidente é o que o comando nazista conhecia bem os efeitos do processo histórico sobre a memória. De fato, naquele momento ninguém mais falava da aniquilação dos armênios e, caso o projeto nazista tivesse atingido seus objetivos, ninguém provavelmente falaria da aniquilação dos judeus.

Em seu livro I sommersi e i salvati Primo Levi cita a experiência de Simon Wiesenthal e do encontro deste com o carrasco nazista no campo de concentração quem afirmava:

Qualquer que seja o modo como esta guerra vier a terminar, nós teremos vencido a guerra contra vocês; não sobrará ninguém para prestar testemunho, e mesmo se algum de vocês escapar, o mundo não irá acreditar. Talvez haja suspeitas, discussões, pesquisas de historiadores, mas não haverá certezas porque nós destruiremos as provas junto com vocês. E mesmo que reste alguma prova e que algum de vocês sobreviva, as pessoas dirão que os fatos que vocês estão contando são monstruosos demais para que alguém acredite: dirão que são exageros da propaganda aliada, e acreditarão em nós, que negaremos tudo, não em vocês. A história do Lager, será ditada por nós. ${ }^{38}$

O fenômeno negacionista parece confirmar a "profecia" do carrasco citada no trecho anterior já que, embora exista uma extensíssima historiografia sobre o Holocausto, uma riquíssima pesquisa acadêmica, os documentos herdados da própria burocracia nazista e os testemunhos dos sobreviventes, os tabus em torno ao assunto estão igualmente presentes e convenientemente incorporados ao arcabouço ideológico do antissemitismo.

\subsection{Identificando estereótipos: a evolução da pesquisa sobre o livro didático}

O período entre guerras despertou um grande interesse na pesquisa sobre o livro didático. Os horrores da até então denominada Grande Guerra (1914-1918) suscitaram uma atração particular na revisão internacional dos materiais utilizados nas escolas com o intuito de procurar maneiras de identificar estereótipos e preconceitos. As pesquisas iniciais, naquele momento, davam

\footnotetext{
${ }^{38}$ LEVI, Primo. I sommersi e i salvati. Torino: Einaudi Tascabili, 1986 (tradução nossa). Este título foi recentemente lançado em português com o título Os Afogados e os Sobreviventes. Os Delitos, os Castigos e as Penas, São Paulo, Paz \& Terra, 2016.
} 
evidências da importante função dos livros-texto na modelagem do conceito que se tinha do inimigo. Foi nesse ambiente que, na década de 1920, a Liga das Nações organizou trabalhos e publicou documentos com diretrizes de conteúdos visando o entendimento mútuo através do ensino da história. ${ }^{39}$

Mas enquanto naquele exato momento da história, na Alemanha, o Partido NacionalSocialista mal começava a organizar-se, $\mathrm{o}$ antissemitismo era bem presente:

Mesmo durante a República de Weimar, salas de aula e livrarias estavam repletas de libelos, slogans e símbolos antissemitas. Entre 1918 e 1924, ataques isolados a grupos de judeus foram registrados nos relatórios policiais. Em 1920, dois terços dos estudantes presentes na assembleia estudantil da Universidade Técnica de Hannover votaram a favor da exclusão dos estudantes de origem judaica da União dos Estudantes alemães. ${ }^{40}$

No entanto, apenas duas décadas mais tarde, a humanidade conseguiu ultrapassar ainda mais as fronteiras da barbárie. O fim da Segunda Guerra Mundial trouxe à tona os horrores das atrocidades cometidas pelo nazismo iniciando-se uma etapa de criação de todo um arcabouço jurídico e institucional visando uma política de proteção dos direitos humanos. Entre as instituições criadas no imediato pós-guerra está a UNESCO a qual posteriormente abrigaria o Programme for the Improvement of Text-Books and Teaching Materials as Aids in Developing International Understanding (Programa para a Melhoria dos Livros Didáticos e Materiais de Ensino como Ajuda no Desenvolvimento do Entendimento Internacional). ${ }^{41}$

Esse processo ocorreu ao mesmo tempo em que na Alemanha começava o esforço para "desnazificar" e democratizar o país: a sociedade alemã e suas instituições, precisavam ser “desprogramadas" de toda a propaganda nazista. No caso dos livros didáticos, os trabalhos de “descontaminação" tiveram que incluir os textos do período da República de Weimar, imbuídos de ideologia nazista e chauvinista.

Uma figura preponderante nessa tarefa foi o historiador alemão Georg Eckert, quem empreendeu uma campanha pela reforma dos livros didáticos em parceria com profissionais

\footnotetext{
${ }^{39}$ PINGEL, Falk. UNESCO Guidebook on Textbook Research and Textbook Revision. Paris/Braunschweig: UNESCO/GEI, 2010.

${ }^{40}$ CARNEIRO, Maria Luiza Tucci. "Racismo Nazista: A era nazi e o antissemitismo". In: PINSKY, Jaime ; PINKSY, Carla Bassanezi (orgs.). Faces do fanatismo. São Paulo: Contexto, 2004.

${ }^{41}$ Ibidem.
} 
oriundos de países que haviam sido inimigos durante a guerra, com o objetivo de promover o entendimento mútuo. Foi assim que em 1975 fundou-se em Braunschweig, Alemanha, o Georg Eckert Institut for International Textbook Research, referência até hoje na pesquisa sobre o livro didático no mundo. ${ }^{42}$ A partir dos anos 1980 e principalmente 1990, houve um considerável aumento internacional no interesse pela pesquisa sobre o livro didático, traduzida pela criação de diversos organismos dedicados ao assunto. ${ }^{43}$

No Brasil, a pesquisa sobre o livro didático acompanhou a tendência internacional, tendo recebido grande atenção por parte da academia, principalmente em décadas recentes, graças em parte à repercussão da tese de doutorado da Professora Circe Bittencourt que ampliou o debate sobre o tema ao abordá-lo a partir de diversos ângulos, ou seja, como suporte, como produto e como meio dentro das políticas públicas de educação. ${ }^{44}$ Quanto a estas, destaca-se no Brasil o Programa Nacional do Livro Didático (PNLD), o qual, desde 1985 e junto com outros programas de distribuição de material didático do Governo Federal, seleciona e distribui milhões de exemplares nas escolas públicas dos estados da federação, constituindo o maior do gênero no mundo. $\mathrm{O}$ aval do Ministério da Educação contribui, nesse sentido, para que estes livros também sejam adotados por diversas escolas particulares. ${ }^{45}$

\subsection{Um desafio pedagógico: o Holocausto nos livros didáticos}

Dada a importância do tema no contexto de uma educação voltada para a ética e a cidadania, a maneira como o Holocausto é apresentado nos livros didáticos já é tema de pesquisa em vários países e continua despertando considerável interesse. Como exemplo, podemos destacar o trabalho recentemente realizado pela UNESCO em parceria com o Instituto Georg

\footnotetext{
${ }^{42}$ GEI. Georg-Eckert-Institut für International Schulbuchforschung. Geschichte-Gegenwart-Zukunft. Versão em PDF disponível online: www.gei.de

${ }^{43}$ Depois do Georg Eckert Institut da Alemanha, criado em 1975, surgiram na década de 80 o Programme de Recherche Emmanuelle (França, 1980), The Textbook Colloquium (Inglaterra, 1988), International Association for Research on Textbooks and International Media (IARTEM, Noruega, 1991), Centro de Investigación MANES (Manuales Escolares, Espanha, 1992), Les Manuels Scolaires Quebécois (Canadá, 1993), Centro Internacional de Cultura Escolar (CEINCE, Espanha, 2006), Redes de Estudio en Lectura y Escritura (Argentina, 2007), In: MUNAKATA, Kazumi. "O livro didático: alguns temas de pesquisa". Revista Brasileira de História da Educação, Campinas/SP, v.12, n. 3 (30), p. 179-197, set/dez. 2012.

${ }^{44}$ BITTENCOURT, Circe. Livro Didático e Conhecimento Histórico: Uma História do Saber Escolar. Tese de Doutorado em História Social. São Paulo: FFLCH. Universidade de São Paulo, 1993.

${ }^{45}$ MIRANDA, Sonia R. ; DE LUCA, Tania R. "O livro didático de história hoje: um panorama a partir do PNLD" In, Revista Brasileira de História. Vol. 24, No. 48, São Paulo, 2004.
} 
Eckert da Alemanha, que em 2015 publicaram juntos um abrangente trabalho intitulado International Status of Education on the Holocaust. A Global Mapping of Textbooks and Curricula (Situação Internacional da Educação sobre o Holocausto. Um Mapeamento Global de Livros Escolares e Currículos). Este estudo compreende um levantamento sobre a presença do Holocausto nos currículos escolares em 125 países. A partir do estudo dos currículos, foi extraída uma amostra de 20 países para a análise de seus materiais didáticos. ${ }^{46}$

Com o intuito de aprofundar o conhecimento sobre o tema no Brasil, propus uma análise detalhada que permita um primeiro olhar na direção daquilo que professores e alunos brasileiros estão recebendo sobre o tema a partir dos materiais.

Antes de dar início à descrição sobre a metodologia de análise dos livros didáticos utilizada neste trabalho, creio que seja importante tecer certas considerações que estabeleçam algumas bases não no sentido de uma exoneração de responsabilidade dos autores dos títulos em questão, mas sim de um reconhecimento de que o projeto no qual estão envolvidos, ou seja, a produção de conteúdo para livros didáticos, não é de modo algum simples. Ao mesmo tempo, é importante estabelecer que este trabalho não visa a apontar dedos, desacreditar capacidades ou manchar reputações. O objetivo é o de tentar contribuir para a discussão sobre maneiras de abordar uma questão de grande complexidade como é o Holocausto dentro de um contexto repleto de desafios como é o de apresentar temas em um meio em si altamente complexo como é o livro didático.

Nesse sentido, dando início às considerações gerais sobre o meio que propomos analisar, é possível afirmar que em todas as decisões sobre o conteúdo do livro didático concorrem, a princípio, três aspectos fundamentais: o currículo, seu caráter de mercadoria e o autor.

O primeiro refere-se ao currículo definido pelas autoridades educacionais do país para o qual confluem, por sua vez, várias forças de cunho ideológico, político, cultural e pedagógico. Quanto ao segundo aspecto temos que, na verdade, o livro didático é um produto e como tal deve obedecer à lógica de mercado editorial, ser coerente com movimentos de oferta e demanda, e obviamente atender a fatores relacionados a custos. Portanto, decisões quanto ao conteúdo, formato, layout, quantidade de ilustrações, tipo de papel, projeto visual, entre outros, são

${ }^{46}$ UNESCO-Georg Eckert Institut. International Status of Education on the Holocaust. A Global Mapping of Textbooks and Curricula. Braunschweig/Paris: UNESCO - GEI, 2015. O documento pode ser consultado no endereço: 
direcionados a cumprir as necessidades dos potenciais compradores e, ao mesmo tempo, a atender os aspectos econômicos de sua produção.

Em meio a esses embates, encontramos o autor -terceiro e fundamental elemento desse processo- aglutinador e responsável por entregar um produto final que não só contemple as forças anteriormente citadas - o Estado e o mercado editorial - mas que ao mesmo tempo inclua os temas de maneira objetiva, voando acima ou abaixo do ar rarefeito das grandes polêmicas. Por outro lado, mediante sua proposta didático-pedagógica, exige-se que o conteúdo instigue o pensamento crítico, tudo em sintonia com uma historiografia atualizada ${ }^{47,}{ }^{48}$. Em resumo, seu desafio é enorme.

Porém, por mais desafiadora que seja a realidade, sempre há espaço para o questionamento e para o não-conformismo. Foi com a consciência desta dualidade que este trabalho foi desenvolvido procurando avançar em direção ao horizonte movediço da utopia que tanto nos atrai como historiadores e educadores.

\footnotetext{
${ }^{47}$ BRASIL. Ministério da Educação. Secretaria de Educação Básica. Diretrizes Curriculares Nacionais da Educação Básica. Brasília, 2013.

${ }^{48}$ BRASIL. Ministério da Educação. Fundo Nacional de Desenvolvimento da Educação. Secretaria de Educação Básica. Edital de Convocação para o Processos de Inscrição e Avaliação de Obras Didáticas para o Programa Nacional do Livro Didático PNLD 2017. Brasília, 2015.

http://www.fnde.gov.br/programas/livro-didatico/livro-didatico-editais/item/6228-edital-pnld-2017

Consultado em 23 de outubro de 2015.
} 


\section{O PORQUÊ DE UMA EDUCAÇÃO SOBRE O HOLOCAUSTO}

\subsection{Pela formação de justos}

Diante do atual cenário mundial muitas vezes desolador devido a manifestações crescentes de antissemitismo, cabe perguntar: vale continuar investindo em uma educação sobre o Holocausto? Há mesmo lições a serem extraídas dessa catástrofe? Alguns dos sobreviventes afirmam que não. Eles dizem: "não há nada a se aprender do Holocausto". Entre esses sobreviventes está Ruth Kluger (1931), que em uma passagem de seu livro Landscapes of Memory, publicado em 2010, escreveu:

Auschwitz não era uma instituição de ensino... Você não aprendia nada lá, menos ainda sobre humanidade e tolerância. Absolutamente nada de bom saiu dos campos de concentração. ${ }^{49}$

Tais considerações chegam a causar estranhamento ao leitor mais desinformado. No entanto, conhecendo a trajetória de Ruth Kluger sentimos que seu desabafo funciona muito mais como um sinal de alerta para as possibilidades de reprodução do ódio do que como uma negação. Apesar do gosto amargo de suas palavras, a autora nos convida a adentrar a janela de sua alma para conhecer de perto a sua experiência como austríaca e judia arrancada de seu lar em 1942 e deportada com sua mãe para o campo de Terezin ${ }^{50}$ onde permaneceu até 1944 , quando os nazistas a levaram para Auschwitz. Como sobrevivente do Holocausto, intelectual e professora de literatura, transformou seu testemunho em ensinamento, um legado para o futuro.

Como protagonista da história, as palavras de Kluger merecem cuidadosa consideração. Para quem sobreviveu a um genocídio, é possível que o trauma ofusque as possibilidades de lições a serem extraídas da sua experiência. Acompanhando seu raciocínio, procuramos alcançar a dor - se é que isso é possível - daqueles que viram seus familiares e amigos sendo conduzidos à beira de uma vala comum para serem executados, ou dos que presenciaram a seleção de seus

49 KLUGER, Ruth. Landscapes of Memory. A Holocaust Girlhood Remembered. London: Bloomsbury, 2010 (tradução nossa).

${ }^{50}$ Terezin -ou Theresienstadt, como era chamado pelos alemães- foi parte gueto, parte campo de concentração localizado a noroeste de Praga, República Tcheca. Aproximadamente 100.000 judeus morreram em Terezin, dentre eles 15.000 crianças. Jewish Virtual Library: http://www.jewishvirtuallibrary.org/jsource/Holocaust/terezin.html 
filhos para a câmara de gás. Que lições podemos tirar da história de quem teve sua dignidade, humanidade e identidade convertida em frangalhos dia após dia?

Consideramos, porém, que há sim lições importantíssimas que nos impelem a identificar os focos propagadores do ódio que culminaram com a morte de milhões de judeus, considerados por Hitler, isoladamente ou em conjunto, como o inimigo ativo ${ }^{51}$ que deveria ser exterminado onde quer que estivesse. Um desses focos era a própria educação, já que o antissemitismo foi sempre um ingrediente presente nos programas educacionais e livros didáticos na Alemanha nazista.

Assim, acredito que através da continuidade de projetos voltados ao estudo da história do Holocausto, temos a oportunidade de analisar três aspectos da pessoa humana: a face mais sinistra do mal, a face mais sinistra da passividade e também sua face mais brilhante através do exemplo daqueles que perceberam de antemão as consequências da indiferença. É desta tríade que extraio o primeiro porquê em prol de uma Educação sobre o Holocausto, a sua primeira lição.

A Avenida dos Justos entre as Nações no Memorial Yad Vashem em Jerusalém, homenageia aqueles que tiveram a coragem de enfrentar a passividade, arriscar sua integridade física, financeira ou familiar e estender algum tipo de ajuda que, para milhares de vítimas, significou a diferença entre morrer ou viver.

Ao deparar-nos com os testemunhos dos sobreviventes do Holocausto, percebemos invariavelmente que, em certo momento surgiram seres humanos que entenderam que havia algo a se fazer. Sensibilizados, buscaram possibilidades com as ferramentas de que dispunham, fosse abrigando uma família em sua própria casa, abrindo uma porta para que alguém conseguisse fugir a tempo, ou até mesmo repartindo um pedaço de pão. De pessoas simples a diplomatas de carreira, eles foram muito além dos limites na tentativa de devolver a milhares de pessoas o direito a viver.

\footnotetext{
51 Saul Friedländer desenvolveu o conceito de que para Hitler o judeu era um inimigo ativo, ou seja, quando comparado aos outros inimigos do Reich, sua ideologia se enquadrava em critérios diferentes daqueles aplicados a outros grupos (ciganos, homossexuais, Testemunhas de Jeová). Nesse sentido, o antissemitismo nazista tinha um caráter redentor; exterminar o judeu significava a salvação dos valores germânicos.

In, FRIEDLÄNDER, Saul. Nazi Germany and the Jews. The Years of Persecution, 1933-1939. Vol. 1. New York: Harper Collins, 1993; FRIEDLÄNDER, Saul. Nazi Germany and the Jews. The Years of Extermination, $1939-1945$. Vol. 2. New York: Harper Collins, 2007.
} 
Como pessoas, tendo a crer que, de maneira geral, estamos de certa forma equipados para identificar o que é certo e o que é errado. E mesmo que não estivéssemos equipados, milênios de ensinamentos filosóficos e religiosos, neles incluídos os Dez Mandamentos, deveriam ter feito seu trabalho. Não haveria porque ser necessário que nos seja dito permanentemente que matar, humilhar ou despojar alguém de sua dignidade é contra qualquer norma ética. A sacralidade da vida humana é algo que pressentimos. Todos temos afetos e a preservação da integridade física desses afetos é instintiva e comum à enorme maioria entre nós.

No entanto, o que sim nos falta muitas vezes é bagagem para agir face ao mal ou ainda, para identificar os discursos e as narrativas que constroem a imagem do "inimigo" e que por conveniência ou como fruto da propaganda resultam na paralisia dos sentidos. Essa é justamente uma das razões pelas quais creio que devemos insistir em uma educação sobre o Holocausto que através de múltiplas estratégias pedagógicas, convide o ambiente escolar e a sociedade a investir nos valores formadores da ética e da justiça.

\subsection{Em oposição à normalização do passado}

O segundo porquê em prol da continuidade e do aprofundamento de uma educação sobre o Holocausto, diz respeito a uma tendência mundial que tem tomado impulso nas últimas décadas: a "normalização" do legado do Terceiro Reich, principalmente da figura de Hitler, no contexto da cultura popular. ${ }^{52}$ Esse conceito é apresentado aqui não no sentido foucaultiano de normalização do comportamento, mas sim como forma de entender a maneira e os motivos pelos quais a percepção do passado é modificada e a maneira como isso tem se concretizado dentro da história do nazismo e do Holocausto:

Independente da forma que adquire, o conceito de normalização é definido por diversas características básicas. No nível mais abstrato, envolve a substituição de diferença por semelhança. Em relação à história e à memória, por exemplo, a normalização envolve um processo através do qual um legado histórico específico passa a ser visto como qualquer outro. Mas para que um dado passado se torne normalizado, ele

\footnotetext{
${ }^{52}$ ROSENFELD, Gavriel. Hi Hitler: How the Nazi Past is Being Normalized in Contemporary Culture. Cambridge: Cambridge University Press, 2015 (tradução nossa).
} 
deve descartar as características de outros passados. A normalização do passado pode também dar forma à identidade de grupo, permitindo a nações e a outros grupos definidos coletivamente, perceber-se como semelhantes, em vez de diferentes de outros. A normalização pode ainda liberar governos nacionais a aceitarem o mesmo tipo de políticas domésticas ou estrangeiras "normais", seguidas por outras nações. ${ }^{53}$

Este conceito é mais um dos pilares que fundamentam esta dissertação que visa analisar como o Holocausto está representado nos livros didáticos de História no Brasil. Ao diluir certos elementos, ocultar fatos, nomes, personagens e principalmente, ao emitir opiniões que distorcem os fatos, o autor/editor do livro didático passa a dar caráter editorial ao texto, muitas vezes cobrindo, como diz Marc Ferro, "a nudez da ideologia”. 54

Embora a ideia de normalidade esteja geralmente associada a características positivas -no caso de eventos históricos excepcionais e com enorme presença no imaginário coletivo- as tentativas de normalizá-lo, torná-lo típico, ou semelhante a outros eventos, pode atender a vários propósitos e produzir distintos resultados. No entanto, quaisquer que sejam esses resultados, acabam tendo como principais vítimas tanto o próprio papel didático da História quanto sua herança ética.

A normalização do Holocausto vem ocorrendo mediante vários processos: pela substituição da diferença pela semelhança, pela relativização, pela universalização, pela estetização e por último, pela negação. ${ }^{55}$ A meu ver, esses processos vêm de mãos dadas com um outro fenômeno: o fascínio pela estética fascista. ${ }^{56}$ Ambos convergem em direção a um novo olhar sobre o nazismo, seja através de humor ou do mascaramento. A história do nazismo tem sido ao longo dos anos, gradualmente reformada e repintada, tornando-a aceitável ou simplesmente apresentando-a como um mero acidente na longa História da Humanidade.

\footnotetext{
${ }^{53}$ Ibidem.

${ }^{54}$ FERRO, Marc. The Use and Abuse of History. Or how the past is taught to children. London: Routledge Classics, 2003 (tradução nossa).

${ }^{55}$ ROSENFELD, Gavriel. op. cit.

${ }^{56}$ Embora não seja adepta do pensamento contrafactual, talvez fosse interessante, apenas como exercício intelectual, considerar se o fato de conhecermos o Holocausto tão a fundo graças ao que no início denominei a "biblioteca" sobre o tema tenha tido, como efeito colateral, o fascínio que a imagem de Hitler e os símbolos nazistas exercem sobre algumas mentes. Nesse sentido poderíamos especular se, caso não se conhecessem as atrocidades por ele cometidas contra os judeus, sua imagem, sinônimo do mal absoluto, teria o mesmo impacto que tem hoje. É provável que a História o visse mais como um ditador fracassado que levou o mundo à guerra - como outros já haviam feito anteriormente - e o seu próprio país, a Alemanha, à ruína humana e material.
} 
Quando essa prática se faz presente no contexto escolar, seja na fala do professor, nos livros didáticos ou nos materiais complementares utilizados para estudar determinado período histórico - neste caso o Holocausto - ela se aproxima perigosamente da impostura, que se une a outra tendência recente que, quando usada e abusada, tende a dar à luz monstruosidades históricas. Por exemplo, o "politicamente correto", que muitas vezes, ao evitar "dar nome aos bois", acaba oferecendo interpretações deturpadas. Na atualidade, as mídias digitais, que muitas vezes substituem o professor, o livro didático e os próprios saberes escolares na formação dos alunos, aprofundam, com uma intensidade sem paralelos, essa situação.

De maneira geral, podemos afirmar que estes aspectos explicitados fazem parte da forma como o Holocausto e o Terceiro Reich são representados nos livros didáticos de História. Tratase de um processo de normalização que ocorre de maneira dupla: primeiro, pela retirada do caráter de excepcionalidade do nazismo, através da comparação de seus crimes aos de outros regimes totalitários e segundo, pela retirada do caráter de excepcionalidade do judeu como elemento fundamental no estudo das políticas e do projeto do Terceiro Reich.

Não estou afirmando aqui que essas atitudes sejam necessariamente deliberadas ou malintencionadas nem que contenham em seu cerne atitudes abertamente antissemitas. A própria dimensão das atrocidades perpetradas pelos alemães e colaboracionistas durante a Segunda Guerra, ofusca muitas vezes a abordagem do processo histórico, reduzindo o evento a uma perigosa incredulidade. O grau de crueza, somado às limitações de nossa própria percepção, tornam muitas vezes difícil a confrontação dos fatos, podendo conduzir à dúvida de que o mal alguma vez tenha atingido tamanha magnitude. Nesse sentido, vale lembrar as palavras de Hannah Arendt quando assim afirma:

... a enormidade dos crimes garante que os assassinos que proclamam sua inocência com toda sorte de mentiras, gozem de uma maior credibilidade que as vítimas que dizem a verdade. ${ }^{57}$

No caso da educação, por outro lado, considera-se muitas vezes que o aluno não se encontra emocionalmente maduro o suficiente para ser confrontado a certos aspectos da História. Projetando-se como protetores, os atores envolvidos nas políticas de educação, entre eles o professor e os autores dos livros didáticos, ao referir-se ao Holocausto, aplicam algumas

\footnotetext{
${ }^{57}$ ARENDT, Hannah. The Origins of Totalitarianism. New York: Harvest, 1976, 1a. ed. 1958.
} 
camadas de verniz a essas terríveis páginas da História do século XX. O intuito da omissão direciona-se a "alisar" asperezas, porém na maioria das vezes o resultado é o abandono da objetividade e a adoção de receitas que em certos casos se aproximam aos conteúdos encontrados nos escritos da chamada "literatura de auto-ajuda".

O educador voltado ao tema do Holocausto não tem a necessidade de debater-se com questões como as que por exemplos enfrentam os romancistas ou os poetas que de alguma forma tentam representá-lo. Não há necessidade de domesticação nem de embates entre estética ou moral da representação. Sem dúvida ele pode - e deve - lançar mão de produções cujos autores tenham já trabalhado esses dilemas. Sua função, porém, é tentar "manter o evento histórico firmemente dentro dos limites da história" ${ }^{98}$.

\subsection{Pela atenção ao perigo de ideologias conspiracionistas}

O último elemento da tríade aqui apresentada para justificar a importância do aprofundamento de uma educação sobre o Holocausto convida educadores e pesquisadores em geral a discutir sobre o perigo da proliferação do imaginário da conspiração ${ }^{59}$, tal como o do "complô judaico internacional", chamado hoje com maior frequência de "complô sionista internacional". Tais definições encontram-se presentes de maneira crescente em narrativas que tentam explicar de forma redutora um mundo percebido como cada vez mais complexo. Baseando-se em fragmentos de fatos ou em hipóteses imaginárias que optam por demonstrar a

\footnotetext{
58 Tomamos aqui emprestado o conceito de Irving Howe ao analisar a escrita do Holocausto -especificamente o papel dos testemunhos- já que parece possível transpor essa análise à educação sobre o tema: "Há, ainda, outro uso para este testemunho: manter o holocausto firmemente dentro dos limites da história, de modo que não termine como um prefácio para o Apocalipse ou escatologia ou, pior ainda, a lenda de um pequeno povo. 'Ninguém', disse o historiador Ignacy Schipper, em Maidánek, 'irá querer nos acreditar, porque nosso desastre é o desastre de todo o mundo civilizado'. A frase de Schnipper merece atenção especial. Ele não diz que o desastre foi experimentado por todo o mundo civilizado, que poderia vincular um 'universalizador' sentimental do holocausto, ao modo de escritores tais como William Styron; ele diz que o desastre dos judeus foi (ou deveria ter sido) compartilhado por todo o mundo civilizado, então o que 'nos' aconteceu poderia formar um peso sobre a consciência daquele mundo, mesmo que devamos reconhecer que, mais cedo ou mais tarde, o mundo procurará transferi-lo para algum domínio 'além' da história, um domínio ao mesmo tempo mais exaltado e menos acusativo. Ainda assim, a história é exatamente onde o holocausto deve permanecer e, para tanto, não pode nunca haver testemunhos suficientes". HOWE, Irving. "A Escrita e o Holocausto", In: Cadernos de Língua e Literatura Hebraica, Faculdade de Filosofia, Letras e Ciências Humanas/USP - n. 2 (1999) - São Paulo: Humanitas FFLCH/USP, 1998.

${ }^{59}$ Adotamos aqui as sugestões de Pierre-André Taguieff que rejeita a expressão "teoria da conspiração" ou "teoria do complô" - as quais considera enganadoras- em benefício de outras como por exemplo: "rumor de complô, medo de um complô, hipótese do complô, imaginário do complô, ideologia do complô, mito ou mitologia do complô". TAGUIEFF, Pierre-André. Court Traité de Complotologie. Paris: Mille et une nuits, 2013 (tradução nossa).
} 
"realidade" de um mundo governado por "forças ocultas", seus criadores apresentam uma narrativa alternativa para os fatos, geralmente atribuindo suas causas a grupos que supostamente se "beneficiariam" com ocultamento da "verdade". O antissemitismo hitleriano foi a manifestação mais concreta e catastrófica desse imaginário que foi levado, literalmente, às últimas consequências.

A percepção quanto a uma crescente complexidade do mundo deriva não somente dos acontecimentos, mas também da enxurrada de informações que recebemos sobre eles. O fator tecnológico permite hoje que vivenciemos guerras e conflitos virtualmente em tempo real, que tenhamos acesso direto a personalidades formadoras de opinião mediante alguns toques nas telas de nossos aparelhos, que possamos conversar com vítimas de catástrofes naturais ou de ataques terroristas, ocorridos a milhares de quilômetros de distância, sentados nas poltronas de nossas salas. Tudo isso constitui um cenário com enormes vantagens que não cabe aqui enumerar. No entanto, esse fator tem possibilitado de maneira inédita a disseminação de todo tipo de rumores e explicações de conteúdo duvidoso para os mais diversos fatos. Como aponta Rudy Reichstadt, da Fondation Jean Jaurés, França:

A internet confere a milhões de internautas anônimos um privilégio de extraterritorialidade que lhes permite assumir a função de "investigador" ou de "jornalista participativo" sem ter que, salvo raras exceções, prestar contas de nada. Age, por conseguinte, como uma formidável caixa de ressonância das teorias do complô, pondo cada um de nós em contato com teses que anteriormente teriam circulado de maneira confidencial, nos extremos mais marginais da sociedade. A internet reforça enfim o viés da confirmação (encontramos o que viemos procurar ali), oferecendo a todos a possibilidade de escolher, de maneira consumista, a versão da realidade que mais conforte as próprias representações. ${ }^{60}$

A modernidade inerente à disseminação do conspiracionismo detem-se, porém, nesse aspecto já que a produção de seu conteúdo, ainda opera através da reciclagem de velhas fórmulas. No caso do antissemitismo, isso ficam patente tanto no uso de elementos do cristianismo difundidos desde a Idade Média, quanto na retomada de acusações nos moldes dos

60 REICHSTADT, Rudy. "Conspirationnisme: un état des lieux", In: Note $n^{o}$ 11, Fondation Jean-Jaurés. Observatoire des radicalités politiques, 24 de fevereiro de 2015 (tradução nossa):

https://jean-jaures.org/sites/default/files/note-radic-pop-ndeg11.pdf Consultado em 17 de setembro de 2016. 
Protocolos dos Sábios de Sião. Esse caráter ambivalente do conspiracionismo -entre a modernidade e o arcaísmo- foi analisado por vários autores, dentre eles Karl Popper, quem em palestra proferida em 1948 no X Congresso Internacional de Filosofia em Amsterdam definia a teoria da conspiração da sociedade da seguinte maneira:

É a visão de que o que quer que aconteça na sociedade -incluindo as coisas das quais, como regra geral, as pessoas não gostam, tais como guerra, desemprego, pobreza, escassez- são o resultado de projetos diretos de alguns indivíduos ou grupos poderosos. Esta visão é muito disseminada, embora seja, não tenho dúvidas, um tipo de alguma maneira primitivo de superstição. É mais antiga do que o historicismo (o qual pode dizerse que é um derivado da teoria da conspiração); e em sua forma moderna, é o resultado típico da secularização de superstições religiosas. Foi-se crença nos deuses homéricos cujas conspirações foram responsáveis pelas vicissitudes da Guerra de Tróia. Mas o lugar dos deuses no Olimpo de Homero foi tomado agora pelos Sábios de Sião, ou pelos monopolistas, ou os capitalistas, ou os imperialistas. ${ }^{61}$

Hoje poderíamos acrescentar, como desdobramento destes últimos "agentes" citados por Popper, o "sionismo" ou o "complô americano-sionista" que, como uma "hidra fantasmagórica que estaria na origem das desgraças do mundo" 62 .

Nesse sentido, a normalização da história do Terceiro Reich e do Holocausto, à qual nos referimos no item anterior, ao eliminar em seu âmago a centralidade do judeu na visão apocalíptica do nazismo, acaba abandonando uma questão indispensável que é a de demonstrar como o mundo de Hitler era um mundo orientado por uma ideologia conspiracionista e que, como tal, não precisava ter sentido.

Assim, quando surgem narrativas que igualam o totalitarismo nazista a outros totalitarismos ou que minimizam o fato de que os nazistas estruturaram suas políticas através de uma visão inimutável, que atribuía ao judeu um caráter de ser "todo-poderoso" e "ubíquo" responsável ao mesmo tempo, por exemplo, pelo controle do capitalismo internacional e da disseminação do comunismo- distorce-se a perspectiva do processo que resultou no Holocausto, assim como a continuidade dessa visão no mundo atual, materializada em inúmeras ideologias

${ }^{61}$ POPPER, Karl R. "Prediction and Prophecy in the Social Sciences", In: GARDINER, Patrck (ed.). Theories of History. Illinois: The Free Press, 1959.

${ }^{62}$ REICHSTADT, Rudy, op. cit. 
conspiracionistas. A não atenção a esses fatores resultará fatalmente na perda do poderoso caráter de advertência da educação sobre o Holocausto quanto aos perigos de visões de mundo falsificadas.

Entendemos que cabe ao educador ou aos autores de livros didáticos insistirem que Hitler e seus seguidores eram racistas; isso não é nenhuma novidade, mas a visão de Hitler em relação aos judeus não se baseava simplesmente em um estereótipo racial ou em seus aspectos biológicos; para ele, o fundamento para o genocídio apoiava-se na crença do judeu como ator político ativo e, portanto, uma ameaça à sociedade germânica. Hitler e seus colaboradores no Ministério de Esclarecimento Público e Propaganda trabalharam para construir a imagem do judeu como raça inferior e sub-humana; a partir daí passaram a utilizar essa imagem como elemento de propaganda. A derrota do judeu, nesse universo, significava a redenção do povo alemão constituindo o que Saul Friedländer denominou de "antissemitismo redentor". ${ }^{6}$

Tratava-se de uma estratégia acionada para justificar a crise econômica, a derrota da Alemanha na Primeira Guerra Mundial, o Tratado de Versalhes, enfim, todos os males que afligiam a nação alemã. Era o meio que o nazismo encontrara para explicar porque o mundo parecia, para eles, estar fora de controle. ${ }^{64} \mathrm{~A}$ imagem física do judeu instrumentalizada a partir dos velhos elementos antissemitas reciclados, certamente, não era o único fundamento. A contribuição de Goebbels e Dietrich, como principais encarregados da propaganda, assim como de cientistas e intelectuais alemães, foi o de oferecerem justificativas ideológicas para o extermínio em massa de milhões de judeus.

Hoje o mundo parece estar também, para muitos, fora de controle. Cabe ao educador, portanto, advertir sobre o poder da imagem manipulada e de que maneira, entre 1933 e 1945, na Alemanha, essa manipulação serviu para justificar o genocídio. Exercícios que exijam pesquisa e reflexão podem complementar uma aula sobre o poder da propaganda e das teorias conspiratórias no Terceiro Reich, trazendo-as para a atualidade. Se na Alemanha nazista o antissemitismo era o elemento aglutinador de sua visão complotista, hoje seu mais novo "rebento", o antissionismo parece estar crescentemente essa função.

Governantes de alguns países parecem estar já atentos para esse fato. Um exemplo nesse sentido é a França que, através de seu Ministério da Educação tem posto em prática iniciativas

\footnotetext{
${ }^{63}$ FRIEDLÄNDER, Saul, 2007, op. cit.

${ }^{64}$ HERF, Jeffrey. Reactionary Modernism. Technology, culture, and politics in Weimar and the Third Reich. Cambridge: Cambridge University Press, 2003.
} 
no sentido de preparar os jovens estudantes a refletirem sobre questões como correlação, causalidade e busca de sentido através do conhecimento e da cultura, não de rumores. Entre os exemplos dessas iniciativas estão a organização da jornada de estudos Réagir face aux théories $d u$ complot $^{65}$ (Reagir perante as teorias do complô) ou o incentivo aos chamados "ateliês de defesa intelectual"66.

A ideia dessas iniciativas do governo francês teve como ponto de partida o próprio momento histórico do país após os atentados terroristas perpetrados em paris em janeiro de $2015^{67}$ e da subsequente onda de rumores conspiracionistas surgida a partir desses ataques. No dia 27 do mesmo mês, ou seja, aproximadamente três semanas após os acontecimentos que vitimaram fatalmente 16 pessoas na capital francesa - entre eles 4 judeus mortos em um supermercado especializado em produtos judaicos - o discurso do Presidente francês François Hollande demonstrou preocupação quanto ao crescente antissemitismo em seu país em boa parte derivado das teses complotistas e afirmava: "é pelo verbo que se prepara o extermínio"68

Em novembro de 2015, Paris sofreu um novo ataque e apenas horas após o evento conspiracionistas disseminavam suas mais diversas teses através de textos e imagens que atribuíam os atentados a um complô idealizado pelos "sionistas" -leia-se judeus.

As charges a seguir, surgidas nos dias seguintes aos ataques de novembro, são emblemáticas. A primeira delas (Figura 1), mostra em destaque uma mão "dando corda" ao que seria um "boneco" representando de forma estereotipada o francês que, por sua vez faz o mesmo com um boneco representando o terrorista suicida. Na manga do indivíduo - cujo rosto está oculto - vê-se estampada a bandeira de Israel, em clara alusão à ideia de que quem estaria "por trás” dos ataques seria “o Estado sionista”. Já a segunda charge (Figura 2), mostra a imagem do "Eterno Judeu" (der ewige Jude) usada em cartazes antissemitas pelos propagandistas do

${ }^{65}$ A primeira destas jornadas teve lugar no Museu de História Natural em Paris, em 9 de fevereiro de 2016: http://www.education.gouv.fr/cid98418/journee-d-etude-reagir-face-aux-theories-du-complot.html. Consultado em 17 de setembro de 2016.

${ }^{66}$ Os "ateliês de defesa intelectual" foram idealizados pela Professora Sophie Mazet em 2010 e têm como objetivo iniciar estudantes do Ensino Médio no espírito crítico. A iniciativa conta hoje com o aval do Ministério da Educação francês. Sua autora mantém um blog (http://www.autodefenseintellectuelle.org/) e é também autora de um livro sobre o assunto: MAZET, Sophie. Manuel d'Auto-défense Intellectuelle. Paris: Robert Laffont, 2015.

${ }^{67} \mathrm{O}$ atentado de 7 janeiro de 2015 em Paris vitimou 12 pessoas que trabalhavam no semanário Charlie Hebdo; dois dias mais tarde, 4 clientes do supermercado de produtos judaicos Hyper Cacher seriam vítimas fatais de outro ataque terrorista. Meses depois França sofreu ainda mais duas ondas de ataques: uma em novembro de 2015 em sua capital e outra em 14 de julho de 2016 na cidade de Nice.

${ }^{68}$ Discurso do Presidente francês François Hollande proferido em 27 de janeiro de 2015 no Mémorial de la Shoah, Paris, durante a cerimônia de rememoração das vítimas do Holocausto e dos 70 anos da liberação de Auschwitz. O discurso pode ser lido em: http://www.elysee.fr/declarations/article/discours-au-memorial-de-la-shoah-2/ Consultado em 17 de setembro de 2016. 
Terceiro Reich. Nesta reciclagem de claro caráter antissemita, o "judeu" aparece agradecendo ao terrorista dando a entender que este último lhe "prestou um serviço". Ambas imagens têm como objetivo "revelar" - uma das vocações dos criadores de teses conspiratórias - que os judeus, seja diretamente ou através de seu Estado, são os "verdadeiros" responsáveis por todas as tragédias que recaem sobre o mundo.

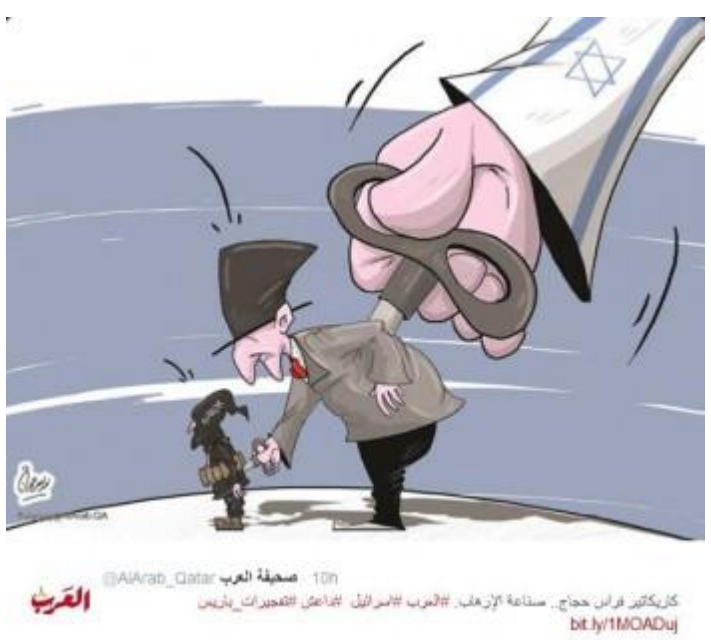

Figura 1

Feras Haggag, Jornal Al-Arab, Qatar, 17 de novembro, 2015

Fonte: Blog da ADL (Liga Anti-Difamação)

http://blog.adl.org/international/anti-semitic-conspiracy-theories-crop-up-in-wake-of-paris-attacks

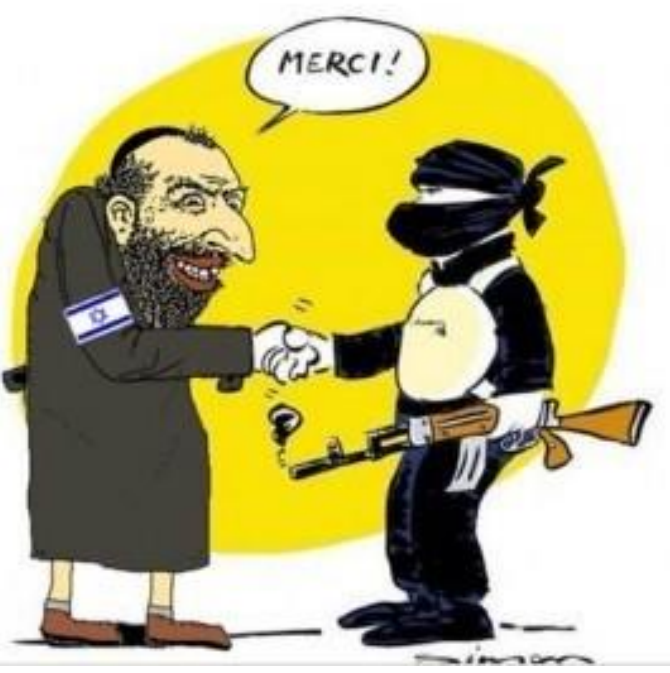

Figura 2

Autor não identificado. Divulgado por Mary Hughes Thompson, 14 de novembro, 2015 (via Twitter) Blog da ADL (Liga Anti-Difamação)

http://blog.adl.org/international/anti-semitic-conspiracy-theories-crop-up-in-wake-of-paris-attacks 
A profusão de ideias e charges de corte antissemita ligadas aos mais diversos complôs, obviamente não se limita à França e constituem modelos do próprio objetivo do conspiracionismo que é, como afirma Taguieff, funcionar "como uma incitação eficaz à mobilização e um poderoso modelo de legitimação ou de racionalização da ação, por mais criminosa ela seja. ${ }^{69}$

Na Figura 3, por exemplo, vemos o presidente americano Barack Obama tentando estender a mão a líderes muçulmanos -enquanto estes queimam a bandeira dos Estados Unidosmas impossibilitado de aproximar-se por estar com os pés amarrados pelo peso do Congresso de seu país, simbolizado pelo brasão em cujo extremo aparece uma Estrela de Davi.

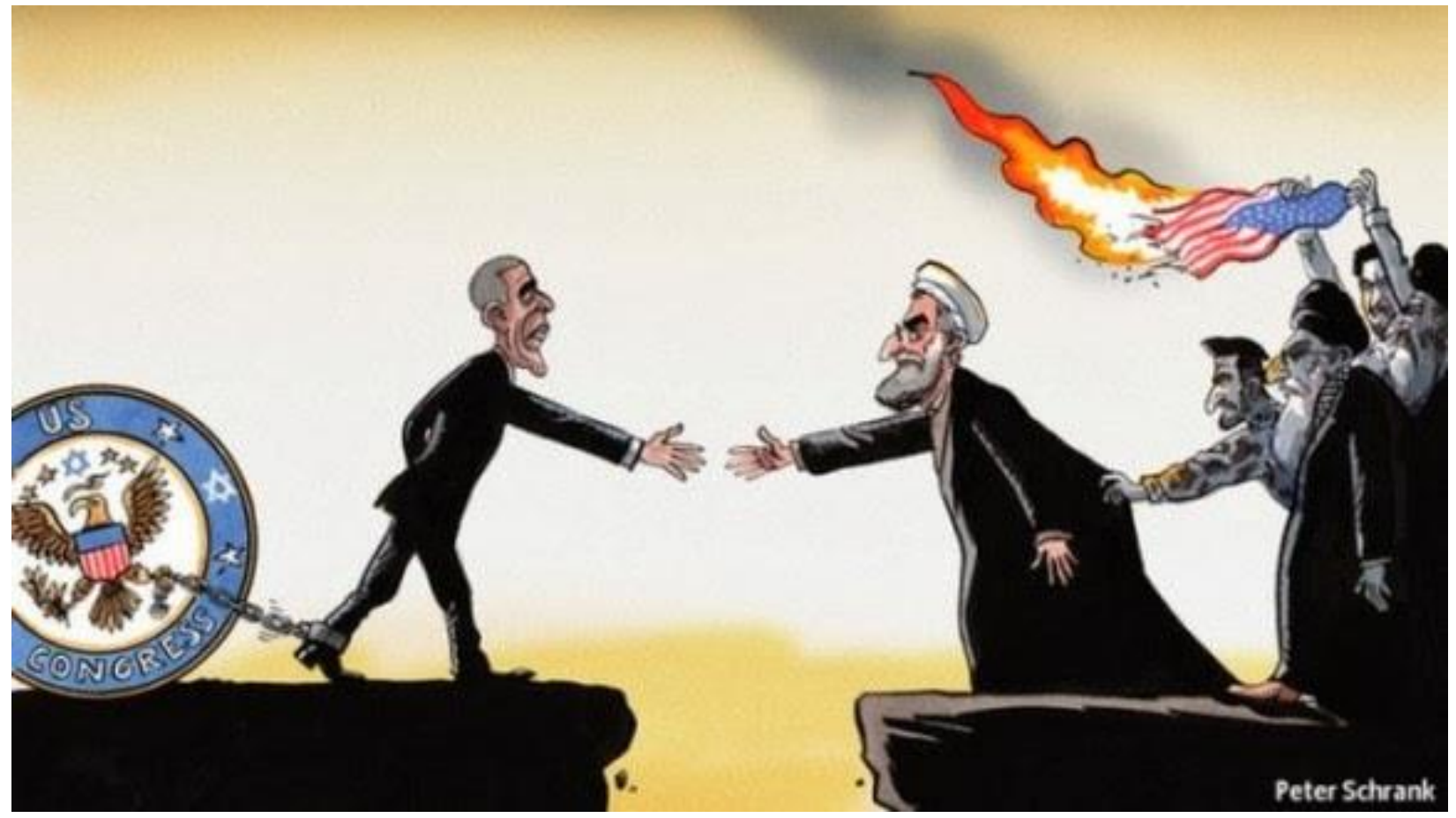

Figura 3

Charge de Peter Schrank publicada (posteriormente removida) na revista The Economist Edição Oriente Médio e África, Janeiro, 2014.

Fonte: Times of Israel, Jerusalém.

http://www.timesofisrael.com/economist-removes-anti-semitic-cartoon-after-uproar/

${ }^{69}$ TAGUIEFF, Pierre-André. L'imaginaire du complot mondial. Aspects d'un mythe moderne. Paris: Éditions Mille et une Nuits, 2006 (tradução nossa). 
As representações do Holocausto também não escapam a essas manipulações e distorções caracterizadas como formas sutis - e às vezes e não tão sutis - de incitação. Em outros casos visam também "plantar" a dúvida sobre algum fato histórico. Talvez o extremo desse fenômeno esteja no concurso de charges sobre o Holocausto patrocinado jornal iraniano Hamshahri, que periodicamente, desde 2006, faz um chamado a cartunistas de todo o mundo para uma competição de trabalhos sobre "as realidades do Holocausto". Na etapa do concurso realizada em 2016, o vencedor foi o cartunista francês Zéon, cuja charge apresentamos a seguir (Figura 4). A mesma representa o conhecido portão de entrada de Auschwitz-Birkenau como "peça de decoração" da parte superior do que seria na verdade uma caixa registradora, cheia de dinheiro, que marca o número 6.000.000 como referência ao número de judeus mortos no Holocausto. As leituras dessa charge são múltiplas e envolvem não somente elementos alusivos à conspiração judaica, através da caracterização da história do Holocausto como "indústria" à própria negação do evento tratado como "invenção".

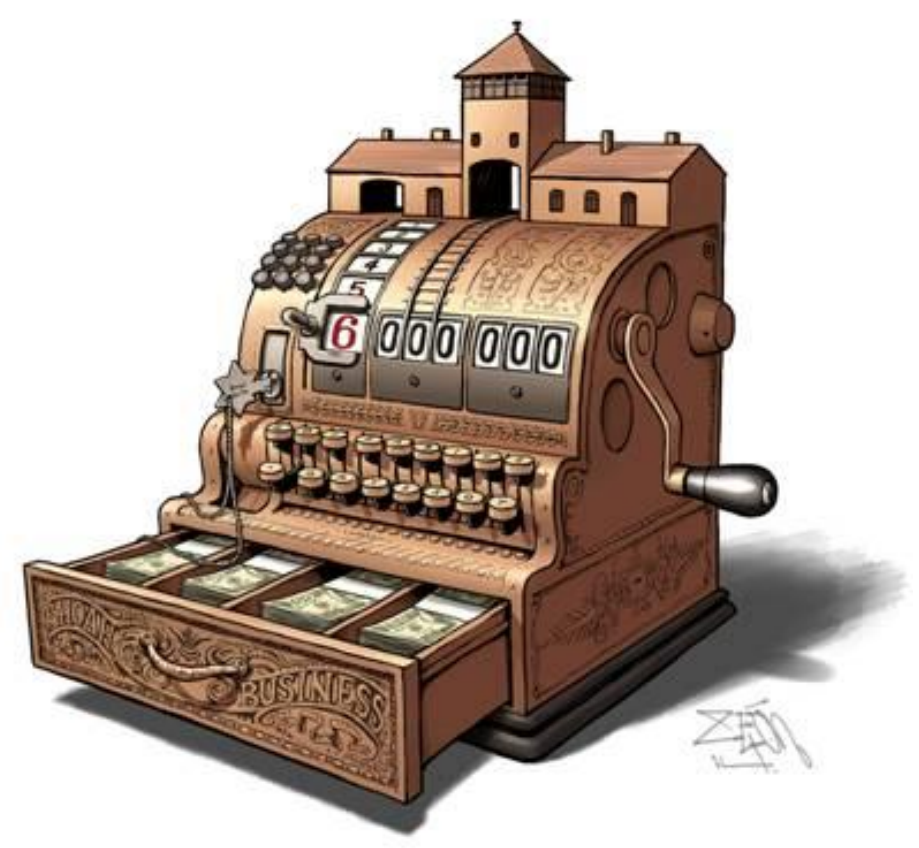

Figura 4

Charge do cartunista francês Zéon, vencedora da edição de 2016 do concurso de charges sobre o Holocausto organizado pela revista iraniana Hamshahri.

Fonte: Blog da ADL (Liga Anti-Difamação), 2016 http://blog.adl.org/international/winners-of-irans-holocaust-cartoon-contest-announced 


\section{O HOLOCAUSTO NOS LIVROS DIDÁTICOS BRASILEIROS: PANORAMA GERAL E ESTUDOS DE CASO}

\subsection{O Universo de Estudo: Análise Teórico-Qualitativa}

Nos livros didáticos de História, o Holocausto, como tema de estudo, integra o conteúdo relacionado à Segunda Guerra Mundial segundo orientações curriculares que posicionam o tema nos universos do $9^{\circ}$ ano do Ensino Fundamental e do $3^{\circ}$ ano do Ensino Médio da Educação Básica.

Para este trabalho, foi selecionado um corpus documental com base nas listas de títulos recomendados pelo PNLD para o triênio 2014-2016, no caso do $9^{\circ}$ ano do Ensino Fundamental, e para o triênio 2015-2017, no caso do $3^{\circ}$ ano do Ensino Médio.

O resultado de cada uma das escolhas em relação à maneira como o Holocausto é tratado nos livros didáticos de História no Brasil, baseou-se, para fins de análise, nos seguintes critérios:

1) Abrangência do Holocausto dentro da obra: números gerais e a relação total obra/tema;

2) Abrangência de fontes não-textuais: quantidade e tamanho de elementos que não se enquadrem na categoria texto, ou seja, fotos, desenhos, caricaturas, mapas etc.;

3) Hierarquia de apresentação: registro do destaque -ou não- do tema dentro da obra mediante sua inserção como módulo, sub-módulo, capítulo, subcapítulo, segmento ou linha;

4) Atividades complementares: relação de atividades ou sugestões propostas na obra, incluindo questionários, recomendações de livros, filmes, testes, etc.

A metodologia utilizada neste trabalho para avaliar a forma como o Holocausto é representado nos livros didáticos de História no Brasil é inseparável da perspectiva pela qual percebo o Holocausto. Estes elementos, por sua vez, imbricam-se às fontes de onde bebo e nos ombros de quem me apoio e fundamentam-se em um feixe de conceitos teóricos que se traduzem tanto no que procuro na análise quanto no modelo proposto posteriormente e que constitui a segunda parte deste trabalho.

A variedade das propostas apresentadas nos livros didáticos analisados, convidam o analista a reagir aos diversos aspectos em um regime "caso a caso". No entanto, a apreciação tem 
sem dúvida alguns pontos de partida que convém explicitar antes de proceder à exposição. Em outras palavras, passo a descrever alguns dos ângulos a partir dos quais se fundamenta este estudo.

Em primeiro lugar, tentei avaliar de que maneira a centralidade do judeu na visão de mundo e nas políticas de Hitler é evidenciado em cada texto relacionado ao Holocausto nos livros didáticos. Nesse sentido, apoiei-me para esta interpretação em alguns dos conceitos do filólogo e diarista Victor Klemperer, ele mesmo sobrevivente do Holocausto. Para isso, começo tomando emprestado de seu livro LTI. A Linguagem do Terceiro Reich, uma brevíssima passagem que resume e determina a estrutura tanto de minha análise quanto das propostas de intervenção que apresento posteriormente:

\section{O judeu é o homem mais importante no Estado de Hitler. ${ }^{70}$}

Esta é sem dúvida a mais curta das citações que incluo neste trabalho, mas constitui seu cerne. Dessa perspectiva é possível afirmar que qualquer estudo relacionado ao Holocausto que não considere esse aspecto fundamental, estará fadado a "errar o alvo". Subestimá-lo, relativizálo ou minimizá-lo gerará igual resultado.

Muitas têm sido as tentativas de entender e de explicar esta obsessão ou paranoia de Hitler, como se os elementos causais contribuíssem em algo para justificar as consequências. Considero, no entanto, que tentar uma aproximação à maneira como Hitler e o nacionalsocialismo "construíram" essa distopia de um mundo controlado por um poder internacional que tinha o judeu como protagonista, pode formar uma base sólida para desmistificar o tema e desenhar uma educação sobre o Holocausto que sirva tanto de ponto de partida quanto de alerta para os perigos dessas "construções" de fundo paranoico disfarçadas de razão. Como mostra Jeffrey Herf em sua análise sobre a propaganda nazista:

(...) Klemperer reconheceu que o antissemitismo não era somente um conjunto de preconceitos e ódios mas também um sistema explicativo para eventos históricos. ${ }^{71}$

\footnotetext{
${ }^{70}$ KLEMPERER, Victor.LTI, la langue du IIIe Reich. Paris: Éditions Albin Michel, 1996 (tradução nossa).

${ }^{71}$ HERF, Jeffrey. The Jewish Enemy. Nazi Propaganda During World War II. Cambridge, MA: The Belknap Harvard University Press, 2008.
} 
Caberia neste ponto a pergunta: haveria nazismo sem judeus?

Prosseguindo.

Um outro elemento investigado na narrativa sobre o Holocausto nos livros didáticos é o papel que Auschwitz ocupa dentro de cada título analisado. A questão origina-se no reconhecimento de que a cultura popular posiciona Auschwitz como paradigma quase absoluto do evento histórico definido como o Holocausto. Porém, o Holocausto não foi somente Auschwitz; foi também Auschwitz, assim como o foram os notórios campos de extermínio da Operação Reinhard, as massacres de Riga e Babi Yar, os partisans das florestas da Bielorússia, os milhares de guetos e campos menores espalhados pelos territórios ocupados pelos nazistas, as intermináveis jornadas nos trens que transportavam os prisioneiros aos campos, as marchas da morte, a selvageria dos Einsatzgruppen que executavam a tiros os judeus do Leste Europeu, a sistemática perseguição e desaparecimento dos judeus da Europa Ocidental. Parte dos campos do Terceiro Reich eram exclusivamente campos de extermínio nos quais os deportados nunca chegavam a pernoitar: o assassinato ocorria logo após a sua chegada, inclusive em Auschwitz. Para eles não havia tatuagens, nem pijamas listrados.

Devido a uma série de fatores dentre os quais seu caráter misto -ao mesmo tempo campo de extermínio, de trabalhos forçados e de concentração- e pela própria cronologia dos fatos, Auschwitz nos legou um importante número de sobreviventes que testemunharam sobre seu tempo nas próprias entranhas do tormento. Em parte, é graças a eles que conhecemos mais sobre esse campo do que sobre outros cenários. Mas, dos aproximadamente seis milhões de judeus mortos no Holocausto, Auschwitz responde por aproximadamente quinze por cento. Os palcos onde ocorreram os demais $85 \%$ das mortes, apesar da sólida historiografia, arquivos documentais e testemunhos, não conseguiram impregnar com a mesma força a memória sobre o evento.

Quais seriam os tabus no cerne desse fenômeno que acaba reduzindo a um único aspecto toda a complexidade de um acontecimento que é marco na história da humanidade? Poderíamos talvez explicá-lo pelo fato de que insistir em Auschwitz como símbolo exclusivo de certa forma poderia servir para expurgar culpas em termos de um "não sabíamos, não havia como saber, nada vimos, nada ouvimos"? Neste momento, são oportunas as palavras de Adorno:

É próprio do mecanismo de dominação impedir o conhecimento do sofrimento que provoca, e há um caminho direto desde o evangelho da alegria de viver até a 
instalação de matadouros humanos, embora estes estejam, como na Polônia, tão distantes que cada um de seus habitantes pode convencer-se de que não ouve os gritos de dor. ${ }^{72}$

É nesse sentido, que a geografia dos acontecimentos ocupa um papel importante tanto na etapa de análise quanto nas propostas incluídas neste trabalho. Ao tratarmos o Holocausto é importante estar atento aos lugares onde os acontecimentos ocorreram e verificar se os mesmos permitem ao estudante perceber que o Holocausto não esteve circunscrito à Alemanha ou a Auschwitz, mas que afetou toda a comunidade judaica da Europa nos cantos mais recônditos do Velho Continente. Era um projeto que, a partir da exclusão, visava a aniquilação total do povo judeu, através da proliferação do antissemitismo enquanto projeto de Estado. A forma como os livros didáticos abordam essa geografia, portanto, é também analisada.

Outra das tarefas consistiu em identificar de que maneira a terminologia sobre o tema é utilizada pelos autores dos livros didáticos. É através dela que se percebem as escolhas feitas na construção da narrativa. Vários livros didáticos incorporam pequenos glossários ou termos em destaque de modo a explicitar certos conceitos não tão familiares no dia-a-dia do aluno. No entanto, do modo como são apresentadas, muitas dessas escolhas, podem não somente gerar confusão, mas -o que é mais grave-, resultar em distorções.

Por exemplo, um dos conceitos fundamentais a se ter em conta ao analisar qualquer narrativa sobre o Holocausto é verificar como o autor define o termo antissemitismo. Vejamos um exemplo: em uma das obras destinadas a alunos do 9o ano, aparece em destaque - quadro em verde à margem da página, fonte e corpo diferenciados do restante do texto e sob o título Glossário - a definição de antissemitismo como "preconceito a povos semitas, principalmente contra judeus". ${ }^{73}$

Nesta breve definição, há vários elementos envolvidos com consequências talvez imprevistas pelo autor ou organizador da obra, que ensejam diversos problemas. O primeiro deles, talvez o menos preocupante, está no próprio sucesso da explicação, na verdade na falta de sucesso: tenta-se esclarecer um conceito complexo - antissemitismo - a partir de um conceito obscuro "povo semita". Na melhor das hipóteses, o aluno não entenderá nada. Assumo total responsabilidade pela ironia e peço desculpas por ela ao leitor já que quando falamos de

\footnotetext{
${ }^{72}$ ADORNO, Theodor W. Minimia Moralia. Lisboa: Edições 70, 1951.

${ }^{73}$ Projeto Araribá. História. 9a ano. Obra coletiva organizada pela Editora Moderna e coordenada por Maria Raquel Apolinário. São Paulo: Editora Moderna, 2013.
} 
educação sabemos que nunca se pode ter como melhor hipótese, que o aluno não entenda. Em um caso como este, no entanto, se ele entender ao pé da letra esta definição, as consequências em termos de distorção histórica serão enormes.

A primeira delas diz respeito, à denominação "povo semita”. Este já é em si um conceito problemático, artificialmente transferido do campo da filologia onde originalmente surgiu, para o da antropologia e finalmente para o da política. O termo Semitische, foi encontrado pela primeira vez nos escritos do filólogo alemão Ludwig Schlözer que propôs sua aplicação às línguas faladas na Antiguidade “do Mediterrâneo ao Eufrates e da Mesopotâmia à Arábia”. Schlözer convencionou esse nome, "inspirado pelo Capítulo X da Gênese onde são enumerados os descendentes dos três filhos de Noé: Sem, Cam e Jafé". ${ }^{74}$ Do ponto de vista das famílias linguísticas, o aramaico, o hebraico e o árabe, ficariam a partir daí "aparentadas" como línguas semíticas, conceito do qual nasceria décadas mais tarde, a ideia de uma "raça semita", oposta à "raça indo-europeia" ou "ariana". ${ }^{75}$

Dando um salto para os dias de hoje, essa confusão ainda reverbera nos discursos antissionistas que se utilizam desses conceitos para justificar a impossibilidade do fato de que existam árabes antissemitas já que eles também seriam semitas. As batalhas ideológicas são travadas fundamentalmente no campo da linguagem; a História é construída por meio da linguagem; a ferramenta da editorialização é a linguagem. Nesse sentido, a maneira como ela é manejada no contexto dos livros didáticos é de fundamental importância.

A linguagem, porém, não se limita à escolha do vocabulário ou à definição de termos ou conceitos. Seu uso como um todo é igualmente revelador. Assim, é necessário estar atento à forma, estilo, frequência de uso de termos, referências e personagens, pois esses elementos contribuem para direcionar a narrativa tal como se deseja concebê-la e transmiti-la: gramática, sintaxe, figuras de linguagem e outros elementos, todos fazem parte do "quadro" que se quer apresentar, ou seja, é em todos esses elementos combinados que a narrativa se apoia. São as linguagens (textuais e não textuais) que determinam a perspectiva desses conteúdos; e principalmente, é através delas que se constroem os mitos ${ }^{76}$ e também através dela que os mesmos se perpetuam, pondo de manifesto os significados daquilo que se deseja representar.

\footnotetext{
${ }^{74}$ HADAS-LEBEL, Mireille. L'Hébreu: 3000 ans d'histoire. Paris: Albin Michel, 1992.

${ }^{75}$ Ibidem.

${ }^{76}$ STEINER, George. "El milagro hueco", In: Lenguaje y silencio. Ensayos sobre la literatura, el lenguaje y lo inhumano. Barcelona: 2003.
} 
Nesse sentido, além de avaliar a centralidade atribuída na narrativa do livro didático tanto ao judeu quanto ao antissemitismo é importante também avaliar a maneira como o perpetrador é apresentado e estabelecer a forma como são tratados os "porque", os "como", os "quando", os "onde" e verificar como se materializam as eventuais brechas existentes. Assim, inicialmente, visando determinar como a linguagem escrita foi trabalhada na narrativa dos livros didáticos, explorei o protagonismo dos personagens dentro dela: em outras palavras, como se dá a relação sujeito/objeto; qual é o espaço que cada um ocupa. Ao mesmo tempo, verifiquei como a ação é descrita através das escolhas dos tempos verbais. Ao cruzarmos esses elementos, é possível determinar de que modo o autor apresenta o relato: quem fez o quê em relação a quem?; esses "quem" aparecem de forma explícita ou estão ocultos?; são ativos ou passivos?

Ainda dentro do contexto da linguagem escrita, vale descobrir a maneira como as vozes de vítimas e sobreviventes são apresentadas nos livros didáticos. Sabemos que todo processo histórico envolve pessoas. Ele não acontece no vácuo e afeta cada um dos envolvidos de maneira diferente. Aproximar o estudante desses protagonistas é uma das maneiras mais eficazes de provocar a reflexão. No caso da história do Holocausto, os números e o desenrolar dos acontecimentos ultrapassam em muitas vezes os limites da percepção humana. Dar um rosto, uma voz particular à narrativa, contribuem a estabelecer o laço com o testemunho, possibilitando uma melhor apreensão do impacto da catástrofe na vida de indivíduos e do mundo ao seu redor.

A sala de aula é o cenário ideal para abordar como milhões de vidas foram afetadas direta ou indiretamente, permitindo aproximar o estudante às histórias dos sobreviventes e a forma como eles vivenciaram as políticas de exclusão do poder nazista e como o antissemitismo afetava seu cotidiano. Ao mesmo tempo, permite conhecer como muitas dessas vidas foram refeitas, centenas das quais, após longas e dolorosas travessias, aqui mesmo no Brasil.

Esses registros existem e mostram claramente a singularidade de cada história de vida, tanto enquanto memória individual, como também como um todo coletivo delineado por fatos históricos comuns, como enfatizam os autores da historiografia da memória. As memórias das vítimas, que deixaram suas impressões em inúmeros escritos e diários, e o testemunho dos milhares de sobreviventes cujo registro está disponível para uso, de maneira geral, não fazem parte dos livros didáticos. Nas análises realizadas, são escassíssimas as referências a essas vozes e na maior parte dos livros, inexistentes: da voz passiva da gramática, às vozes ausentes das vítimas e sobreviventes. Como nos ensina Saul Friedländer: 
Porque são suas vozes as que revelam o que se sabia e o se conseguia saber; as deles eram as únicas vozes que expressavam tanto a clareza da percepção quanto a cegueira total de seres humanos confrontados com uma realidade completamente nova e absolutamente horripilante. ${ }^{77}$

Por último - embora lembrando que distintos temas foram surgindo em meio à análise de cada título - procuramos verificar de que maneira ou até que ponto os livros didáticos conectam os acontecimentos na Europa durante a Segunda Guerra Mundial, ao contexto histórico daquele período no Brasil no que se refere às reações do governo brasileiro ao Holocausto e à questão dos refugiados. Os currículos escolares posicionam este evento paralelamente à narrativa sobre o governo Vargas e o Estado Novo. O objetivo aqui é entender se essas linhas deixam em algum momento de ser paralelas, tocando-se em algum ponto.

A forma como a maior parte dos governos do mundo reagiu diante do flagelo, desde as primeiras políticas antissemitas de Hitler, passando pelas Conferências de Evian e Bermudas e as atitudes em relação aos refugiados durante todo o processo, espelharam em sua maioria a resposta do funcionário canadense que ao ser consultado sobre quantos judeus seu país receberia respondeu: - Nenhum já é muito ${ }^{78}$.

Posso afirmar que, de maneira geral, os textos não abordam a postura do governo Vargas e antissemitismo no Brasil na época, nem tampouco a política do governo brasileiro em relação aos judeus refugiados do nazismo, tema amplamente analisado pela historiografia brasileira. Hoje, um conjunto de estudos têm comprovado que a adoção de Circulares Secretas pelo governo brasileiro entre 1937-1948, trouxe graves consequências para milhares de judeus que tentavam deixar a Europa fugindo das perseguições do nazismo. Entre os autores que têm tratado profundamente do tema na historiografia brasileira encontram-se Maria Luiza Tucci Carneiro, Fábio Koifman, Jeffrey Lesser e Anna Rosa Bigazzi. ${ }^{79}$

\footnotetext{
${ }^{77}$ FRIEDLÄNDER, Saul, 1997, op. cit. (tradução nossa)

78 ABELLA, Irving ; TROPER, Harold. None Is Too Many. Canada and the Jews of Europe. 1933-1948. Toronto: University of Toronto Pres, 2012.

${ }^{79}$ CARNEIRO, Maria Luiza Tucci. Rompendo o Silêncio: a Historiografia sobre o Antissemitismo no Brasil. In, Cadernos de História, Belo Horizonte, v. 13, n. 18, $1^{\circ}$ sem., 2012; KOIFMAN, Fábio. O Imigrante Ideal. São Paulo: Civilização Brasileira, 2012; LESSER, Jeffrey. Immigration, Ethnicity and National Identity in Brazil. Cambridge: Cambridge UK, 2013; BIGAZZI, Anna Rosa. “In Diffesa della Razza”. Os judeus italianos refugiados do fascismo e o anti-semitismo do Governo Vargas. Tese de Doutorado. Universidade de São Paulo, São Paulo, 2008.
} 


\section{O uso das linguagens não-textuais: as imagens nos livros didáticos}

O livro didático tem-se caracterizado ao longo de sua história pela presença do texto escrito assim como de vários outros elementos tais como fotografias, mapas, caricaturas, cartazes de filmes, capas de livros e ilustrações. Sua escolha e disposição nas páginas das obras, atendem a uma narrativa, a um certo olhar sobre cada assunto, constituindo desse modo um discurso. Cabe ao autor, nesse contexto, um papel semelhante ao do curador de uma exposição, cuja tarefa reside em “(...) filtrar, organizar, confeccionar, finalmente encarregar-se de uma história composta -ou mesmo resgatada - de uma variedade infinita de contos, relíquias e vozes". ${ }^{80}$

Mas é na etimologia da palavra curador -do Latim curator ou curatorem- que encontramos sua principal função: a de guardião, no sentido de protetor e também de agente. Assim, mediante uma cuidadosa disposição dos artefatos e obedecendo a uma perspectiva previamente traçada, planejada segundo critérios pedagógicos ou catárticos, ele oferece ao visitante seja de um museu, de uma exposição ou das páginas de um livro, uma experiência singular projetada a partir de sua perspectiva.

No caso dos livros didáticos, o autor-curador depara-se com uma série de desafios intrínsecos aos mais diversos temas e que se somam àqueles relacionados às pressões próprias da produção do mesmo. Como já foi mencionado em outro tópico deste trabalho, entre elas estão por um lado, o impulso -ou a obrigação- por criar obras que "atraiam" visualmente seus consumidores alvo - professor e aluno; por outro, a inclusão de conteúdos altamente complexos em um espaço limitado. Mas o resultado dessas e outras pressões pode estar conduzindo ao processo que Marc Ferro descreve em sua obra The Use and Abuse of Memory ${ }^{81}$ :

A História não está mais sendo simplesmente narrada, em vez disso, ela é analisada através de documentos, gravuras, desenhos etc., como se a sua seleção fosse menos arbitrária do que contar uma certa história. Nos livros didáticos, o layout passou a parecer mais importante do que o texto. Cabe aos professores e às crianças reconstruírem

\footnotetext{
${ }^{80}$ BURDIN, A.; DRUCKER, J.; LUNENFELD, P.; PRESNER, T.; SCHNAPP, J. Digital_Humanities. Cambridge: The MIT Press, 2012.

${ }^{81}$ FERRO, Marc. The Use and Abuse of History. Or How the Past Is Taught to Children. London: Routledge, 2003. No Brasil, o próprio Programa Nacional do Livro Didático (PNLD) permite inclusive que sejam utilizados elementos adicionais tais como os chamados Objetos Educacionais Digitais (vídeos, animações, simuladores, imagens, jogos, textos), entre outros itens para auxiliar na aprendizagem
} 
essa história, em vez de tentar conhecer e corrigir a história da nação que, no entanto, permanece como a memória histórica da sociedade e deu a ela um significado.

O excesso dessa pedagogia tem sido amplamente demonstrado: "as crianças e os adolescentes não sabem mais nada". 82

O contorno do curador ao qual me referi anteriormente converte-se então aos poucos em outras duas figuras. A primeira delas, a do gerente de projetos, que deve trabalhar habilmente com os mais diversos fatores de pressão, buscando atender satisfatoriamente os interesses de todos os envolvidos buscando "reduzir" as complexidades o que na maioria das vezes resulta em narrativas amorfas ou incompreensíveis. A segunda figura, a do editorialista que, ao imprimir sua opinião ou seu viés político-ideológico, transforma o conteúdo histórico em peça jornalística, subvertendo o propósito do livro didático e deixando escassa margem para a reflexão. O caráter do meio como "autoridade" na transmissão do saber histórico, podem acabar estampando dessa maneira um carimbo "oficial” ao que são, na verdade, opiniões.

A fotografia como registro e sua presença nos livros didáticos, por exemplo, é um valioso documento que permite ampliar o panorama sobre o evento estudado, além de convidar à reflexão, inaugurando importantes avenidas que contribuam a estabelecer redes entre passado, presente e futuro. Quando devidamente contextualizada, constitui uma importante ferramenta para a pesquisa e a análise, podendo estabelecer inclusive uma disciplina que encoraje o aluno a “dialogar" com ela e iniciar, com o auxílio de outras fontes, um processo de questionamento que o conduza à reflexão. O professor, nesse sentido, é o mediador nessa tarefa, orientando o aluno quanto às características intrínsecas ao meio e convidando-o a empreender uma jornada em que a imagem seja uma aliada na busca, em nosso caso, pelas lições e a herança ética do Holocausto.

De qualquer maneira, a observação de Ferro constitui um poderoso alerta quando observamos o tratamento dado ao Holocausto do povo judeu nos livros didáticos de História no Brasil, já que a enorme complexidade histórica do evento, e suas implicações políticoideológicas, que se potencializam no contexto do antissemitismo contemporâneo, constituem ingredientes intrínsecos para eventuais desvios.

Outro fator "complicador" consiste no fato de que no intuito de aproximar o livro didático à era digital e aos estímulos aos quais os jovens estão permanentemente expostos, busca-se pôr em prática experiências pedagógicas que delegam ao público consumidor o papel

${ }^{82}$ Ibidem. 
de reconstrução da narrativa histórica. Para esse fim, são acrescentadas cada vez mais "distrações" às páginas do livro podendo ter como consequência, em nosso caso, o esvaziamento tanto do significado, quanto do caráter didático da história do Holocausto.

\section{O tratamento da fotografia sobre o Holocausto nos livros didáticos}

É costume dizer que quantidade não necessariamente significa qualidade e que forma não significa conteúdo, portanto, afirmar que as opções dos envolvidos na produção de livros didáticos não deveriam basear-se nesses aspectos, prescinde a necessidade de uma maior análise. No entanto, a fórmula de que "uma imagem vale mais que 1000 palavras", merece uma atenção mais afinada, principalmente quando o estudante é compelido nas atividades propostas nos livros didáticos a extrair conclusões "históricas" a partir de imagens específicas.

Sem dúvida, a presença do registro fotográfico no ensino da História é importantíssima uma vez que aporta elementos que muitas vezes escapam ao relato. Além disso, fazemos parte de uma sociedade visual e ficamos permanentemente expostos aos códigos que as imagens propiciam. Nas palavras de Susan Sontag, fotografias:

(...) alteram e alargam nossas noções sobre o que vale a pena olhar e sobre o que temos o direito de observar. Elas são uma gramática e, ainda mais importante, uma ética do ver. ${ }^{83}$

Mas quem determina qual é esse direito? Quem dita essa gramática? A quê ética estamos sendo submetidos ao entrarmos em contato com uma fotografia? A presença da fotografia como documento em sala de aula, engendra de certa forma, alguns perigos intrínsecos ao meio. Um desses perigos é que a ela pode transmitir a impressão de verdade, a ideia de que perante a imagem, somos testemunhas de um fato intocado, quase sagrado, inocente, imparcial. Essa aparente inocência ou imparcialidade pode resultar em uma falsa impressão de que através da imagem "sabemos", ou "conhecemos" a história que ela nos conta. Mas a fotografia não é um registro imparcial. Como bem define Boris Kossoy em seu livro Fotografia e História:

\footnotetext{
${ }^{83}$ SONTAG, Susan. On Photography. New York: RosettaBooks LLC, 2005 (tradução nossa).
} 
Toda fotografia tem sua origem a partir do desejo de um indivíduo que se viu motivado a congelar em imagem um aspecto dado do real, em determinado lugar e época. ${ }^{84}$

Ou seja, dado que a fotografia é produto de um desejo e ao estar ele condicionado pelo contexto em que o registro fotográfico foi obtido, a influência desse contexto sobre o resultado é patente. No entanto, o mito da autoridade da imagem ainda se impõe sobre nós de maneira quase inquestionada. Poderíamos afirmar nesse sentido, que a fotografia acaba constituindo um olhar que na prática nos cega para uma leitura mais precisa daquilo que realmente está em jogo. Levanos a acreditar que estamos perante um instante imobilizado dos fatos "tal como eles ocorreram".

Além desse aspecto que está na essência da fotografia e dos riscos da descontextualização de seu uso como documento, a escolha dos mesmos também nem sempre é “inocente". Ao folhearmos as páginas dos livros didáticos, o olhar treinado consegue perceber os indícios ${ }^{85}$ na narrativa do que o autor pretende que prevaleça. Assim, a preferência por certos atores históricos, a dimensão que cada imagem ocupa na página, as relações entre elas, são todos elementos que induzem ou conduzem a uma ou outra direção e acabam encorajando o aluno a deduzir, de forma metonímica, uma narrativa histórica cuja complexidade acaba invariavelmente sendo mutilada ou distorcida.

Como produto do meio e do contexto histórico, o acervo de fotografias sobre o Holocausto com maior circulação na atualidade, compõe-se em sua maior parte de duas fontes fundamentais: 1) fotografias profissionais para fins de propaganda; 2) registros do front produzidos por soldados e policiais alemães na "guerra contra os judeus" 86 .

A era nazista coincidiu com um momento, dentro da história da fotografia, de grande desenvolvimento tecnológico do meio e que inclui a ampla disseminação e portabilidade dos equipamentos, principalmente das câmeras, assim como uma maior facilidade nos processos de reprodução.

\footnotetext{
${ }^{84}$ KOSSOY, Boris. Fotografia e História. São Paulo: Editora Ática, 2003 (2 ${ }^{\mathrm{a}}$ ed.).

${ }^{85}$ GINZBURG, Carlo. Clues, Myths and the Historical Method. Baltimore: The Johns Hopkins University Press, 1992.

${ }^{86}$ DAWIDOWICZ, Lucy S. The War Against the Jews. 1933-1945. New York: Open Road Integrated Media, 2010. Neste livro, Dawidowicz estabelece o conceito de "guerra contra os judeus" já abordado por autores como Victor Klemperer, entre outros. Embora a autora privilegie uma visão exclusivamente "intencionalista", sua contribuição à historiografia sobre o Holocausto ", é de grande importância, principalmente no que se refere ao caráter central do judeu na visão do líder nazista e de sua política de extermínio. As imagens produzidas pelos soldados e policiais na frente de guerra, captam bem esse aspecto.
} 
Em ensaio publicado em 1998, Judith Levin e Daniel Uziel demonstraram através da análise das coleções de álbuns e fotografias do acervo do Memorial Yad Vashem, como soldados e policiais alemães registraram vários aspectos da vida dos judeus nos guetos e vilarejos do Leste europeu, mostrando as mais diversas situações de violência e crueldade, muitas vezes retratandose a si mesmos junto com suas vítimas, vivas ou mortas ${ }^{87}$. Além do registro, esses soldados e policiais tinham o costume de colecionar suas fotografias e organizá-las em álbuns, incluindo neles legendas explicativas que hoje nos permitem conhecer suas atitudes e o antissemitismo nelas contido.

A busca por confirmar os estereótipos que a propaganda antissemita disseminava através dos jornais, do cinema e de cartazes, é evidente nas fotografias feitas por soldados nazistas. Muitos desses homens, exultantes pelo sentimento de "missão cumprida", transmitiam através de inscrições no verso das imagens e em cartas, a semelhança e correspondência entre aquilo que descrevia o jornal antissemita Der Stürmer e o que haviam encontrado ${ }^{88}$. As fotografias funcionavam assim como "evidência" da "necessidade" de exterminar aqueles "elementos" -os judeus. Neste trecho da carta de um soldado alemão a seus familiares, que acompanha alguns registros fotográficos, fica patente essa afirmação:

O povo alemão tem uma profunda dívida com o Führer porque se esses animais, nossos inimigos aqui, tivessem chegado à Alemanha, assassinatos de uma natureza ainda não vista no mundo teriam ocorrido... Nenhum jornal pode descrever o que nós vimos. Beira o inacreditável e mesmo a Idade Média não se compara ao que se revelou aqui. Ler o Der Stürmer e observar suas fotos, dão-nos uma impressão limitada do que nós temos visto e dos crimes cometidos aqui pelos judeus. ${ }^{89}$

\footnotetext{
${ }^{87}$ LEVIN, Judith ; UZIEL, Daniel. “Ordinary Men, Extraordinary Photos”. Yad Vashem Studies, Vol. XXI, 1998, pp. 280-293

${ }^{88}$ Um dos álbuns analisados no ensaio de Levin e Uziel (referência anterior), mostra a obsessão dos soldados com o judeu e com o registro de sua imagem. Segundo os autores, trata-se, de um álbum luxuosamente encadernado em couro, com a dedicatória: Das Warschauer Ghetto: Ein Kulturdokument für Adolf Hitler (O Gueto de Varsóvia: um Documento Cultural para Adolf Hitler).

${ }^{89}$ BUCHBENDER, Ortwin e STERTZ, Reinhold. Das Andere Gesicht des Krieges. Munique: C. H. Beck, 1982. In, LEVIN ; UZIEL, op. cit.
} 
Por outro lado, o desenvolvimento da técnica fotográfica e sua disseminação através de manuais, proporcionavam elementos que contribuíam a produzir essas imagens de modo a corroborar a visão antissemita..$^{90}$

Em seu livro Ordinary Germans ${ }^{91}$, Daniel Goldhagen trata do aspecto quase mercantil dos registros fotográficos produzidos pelos carrascos do Batalhão de Polícia 101, sobre o qual se baseia seu estudo, mostrando que os mesmos não eram somente souvenirs para uso privado e sim compartilhados pelo grupo como atesta o seguinte depoimento:

Gostaria de fazer um comentário sobre essas fotografias. Elas eram penduradas nas paredes e qualquer um que desejasse, podia encomendar cópias delas. Eu também adquiri essas fotografias por encomenda, embora nem sempre tenha participado dos eventos que as fotografias retratavam..$^{92}$

Embora breve, este panorama serve, a meu ver, para acionar o alarme sobre a necessidade de uma contextualização criteriosa das fontes utilizadas para fins didáticos. $\mathrm{O}$ acervo do qual dispomos é valiosíssimo, mas seu uso indiscriminado pode tornar-se uma faca de dois gumes.

\section{A iconografia e a construção de narrativas sobre o Holocausto nos livros didáticos}

De maneira geral, quando analisados a partir das narrativas construídas pelas imagens, a representação do Holocausto nos livros didáticos tende a favorecer a perspectiva do perpetrador, seja pela insistência no uso da figura de Hitler repetidas vezes no mesmo capítulo, seja pelas cenas das paradas militares e dos atos de massa, ou ainda pela representação dos judeus através da lente do carrasco. Dessa forma, mesmo que inadvertidamente, direciona-se o aluno a assimilar

\footnotetext{
${ }^{90}$ Um exemplo dessa influência, são os manuais da câmera alemã Leica, lançados anualmente, e que continham os mais diversos artigos sobre como fotografar certos temas assim como sobre como obter certos efeitos. A edição de 1941 desse manual, organizado por Heinrich Stockler, contém um artigo de Bruno Kurt Schultz sobre identificação de raças. In LEVIN ; UZIEL, op. cit. Schultz era um antropólogo alemão que ocupou diversos cargos na hierarquia da SS e no partido nazista, e que nos anos 30, havia composto um conjunto de critérios raciais para candidatos à elite da SS. Ele foi o responsável pela edição de um painel, hoje no Museu Memorial do Holocausto dos Estados Unidos (USHMM), onde podem ser observados tipos étnicos de fora da Europa considerados inferiores à raça ariana. $\mathrm{O}$ painel era inclusive usado como ferramenta de ensino. Os painéis podem ser vistos online no site do Rochester Institute of Technology: http://thzici.cias.rit.edu/perilousjourneys/Race\%20Science.swf Consultado em 25/08/2016.

91 GOLDHAGEN, Daniel J. Hitler's Willing Executioners. Ordinary Germans and the Holocaust. New York: Alfred A. Knopf, 1996 (tradução nossa).

${ }^{92}$ Extraído do testemunho de H. F. Hoffman, membro da Segunda Companhia do Batalhão de Polícia 101 e citado por D. J Goldhagen no livro Hitler's Willing Executioners, op. cit.
} 
a linguagem e a perspectiva do nazismo. Esses processos poderiam ser minimizados, caso houvesse uma contextualização dessas imagens, ou através do encorajamento a pesquisas e atividades que permitam ao aluno traçar esse contexto.

Por um lado, a maioria das imagens relacionadas aos campos de concentração e guetos ou seja, a maior parte das fotografias encontradas nos livros didáticos para representar o Holocausto -, foram produzidas para fins de propaganda nazista, mostrando aspectos particulares que visavam deslegitimar e desumanizar os judeus, conforme mostrado no item anterior, e isso em parte pode acabar sendo assimilado sem filtros pelos alunos ou leitores. Por outro lado, as imagens que retratam o entusiasmo das massas pela figura do Führer demonstrando o enorme apoio que a política do Terceiro Reich obteve na Alemanha e na Áustria, podem produzir um efeito semelhante, neste caso, denotando que talvez algo de muito bom deveria haver nessas políticas para que seu líder merecesse tamanha recepção.

É ainda digno de nota que essas imagens são muitas vezes apresentadas em sequência linear com fotografias que retratam a pobreza e a crise dos anos prévios à ascensão do nazismo, através de uma narrativa encadeada, descomplicada, e justamente por isso problemática.

\section{Literatura e filmografia}

A complexidade da história do Holocausto pode parecer sem dúvida avassaladora, não somente do ponto de vista histórico, mas também filosófico e até mesmo geográfico. Sua vasta historiografia, as produções do cinema, do teatro, e principalmente da literatura assim como as coleções de testemunhos podem até mesmo intimidar. Porém avassaladora não significa de modo algum impenetrável ou inexplorável, principalmente porque muito do que foi produzido - talvez a maior parte - materializa-se como parte de um diálogo que fala diretamente ao ser humano, que levanta questões inerentes à nossa condição através das mais diversas tradições nacionais, linguísticas e culturais. São formas de resposta a uma catástrofe que ainda reverbera em nossos olhos, nossos ouvidos, no âmago de nossa espécie.

É provável que nunca, como tal, cheguemos a compreender como a humanidade saltou de forma tão calamitosa ao abismo causando uma fissura que certamente nunca irá fechar-se. Antes do Holocausto, não se cogitava que tal barbaridade em tamanha escala pudesse ser possível. Hoje, temos que conviver com a incômoda presença de que fomos, sim, capazes de visitar as 
profundezas e que a partir daí, nunca voltaremos a ser os mesmos. E é bom que assim seja. Porém, isso não nos imuniza contra a possibilidade de que essas profundezas sejam periodicamente revisitadas, mesmo porque muitos dos elementos que o tornaram a catástrofe possível, continuam presentes.

É por tudo isso que o tratamento do Holocausto do povo judeu na sala de aula requer uma abordagem que não se limite à "História pela História" ou que derive em lições moralistas. Embora certamente o Holocausto deva ser mantido no âmbito histórico, já que foi um evento histórico e, para abordá-lo acontecimentos, personagens, datas e lugares devem estar firmemente estabelecidos, o ideal seria que sua inserção na sala de aula contribua a estabelecer laços que conduzam o aluno não necessariamente a respostas certas, mas ao exercício da pergunta; que incitem a inquietação, mesmo que incômoda.

As artes sempre cumpriram um papel fundamental no sentido de iluminar ideias e promover o debate sobre as mais diversas questões inerentes à condição humana. No caso da história do Holocausto, a própria cultura popular tem desempenhado um papel importante nesse sentido.

É assim, por exemplo, que vimos como o surgimento, em meados dos anos 1970, de uma série televisiva produzida nos Estados Unidos intitulada Holocausto ${ }^{93}$, despertou o interesse de milhões de pessoas, inclusive na Alemanha, cuja população passou a discutir o tema acaloradamente. Até então, fora do âmbito das pessoas que vivenciaram de perto essa catástrofe, pouco se falava sobre o assunto. Já no início dos anos 1990, o filme A Lista de Schindler provocou reações semelhantes em escala planetária levando para as telas dos cinemas a história de um justo que acabou sendo responsável pelo resgate de mais de 1.000 judeus. Sem dúvida, artefatos da cultura popular contêm, na maioria das vezes, inúmeras imprecisões do ponto de vista histórico; fatos e personagens são tratados de modo a obter este ou aquele efeito artístico ou emotivo. Nesse sentido, quando obras como essas são transportadas para a sala de aula, podem acabar funcionando como miragens e implicando em distorções, principalmente quando são utilizadas como substitutos da História.

Por outro lado, elas contêm elementos que não devem ser de maneira nenhuma desprezados para fins pedagógicos. Em primeiro lugar, seu inquestionável poder de engajamento

\footnotetext{
93 Esta minissérie em quatro partes foi transmitida pela primeira vez nos Estados Unidos em 1978 pela rede americana NBC e conta a história de uma família de judeus alemães, a família Weiss, e da ascensão de um membro da SS. No Brasil, a série foi transmitida pela Rede Globo.
} 
cuja origem está em sua capacidade intrínseca de potencializar o diálogo "humano" com o assunto, traduzindo-se em um aporte importante de múltiplas vias aos trabalhos sobre o tema. Segundo, por serem parte da "dimensão tácita" do conhecimento transportada pelos alunos para a sala de aula. ${ }^{94}$ Quanto a este aspecto, estamos cientes de que essa dimensão tácita também pode conter em seu núcleo os germes do ceticismo, de preconceitos, até mesmo de mitos o que poderia implicar, no âmbito da Gestalt do tratamento do tema na sala de aula, em situações que, ao tentar equilibrar os aportes particulares que alunos e professores trazem à tona sobre o tema, poderiam resultar numa total descaracterização acarretando mais danos do que benefícios. Mas, se nenhum homem é uma ilha, a escola também não pode -nem deve- ser. Integrar esses elementos às aulas que tratam do Holocausto pode trazer grandes recompensas. Por isso, dentro da análise dos livros didáticos, vale a pena olharmos para o modo como a literatura e a filmografia sobre o Holocausto são abordados nos diversos materiais.

A partir de uma análise geral das obras em questão, observa-se que a postura quanto à sua inclusão é bastante diferenciada de título para título, ou seja, alguns materiais limitam-se a acrescentar uma lista de sugestões de títulos de livros e filmes para "aprofundamento" sobre o tema, porém sem nenhum "mapa" ou proposta sobre como utilizá-los. Outros acrescentam trechos de livros acompanhados de atividades pedagógicas complementares, geralmente no formato de perguntas para debate ou reflexão.

Em geral, os títulos sugeridos gravitam quase sempre em torno às mesmas obras. Isso se deve, em parte, à inércia dos encarregados de curar os livros didáticos. Existe uma oferta variada de qualidade em língua portuguesa, não somente porque muitas obras fundamentais da literatura sobre o Holocausto foram traduzidas e publicadas no Brasil, mas também porque existe uma grande biblioteca de memórias de sobreviventes residentes no Brasil que constituem não somente o relato do tempo vivido, mas também o processo de recomposição de parte daquilo que se perdeu. Suas narrativas, nesse sentido, são únicas como vínculo com um passado desaparecido.

94 POLANYI, Karl. The Tacit Dimension. Chicago: The University of Chicago Press, 2009. Para Polanyi, a "dimensão tácita" é parte crucial do conhecimento científico e contribuem para ela a tradição, práticas herdadas, valores implícitos e pré-julgamentos. Creio que no contexto em que trabalhamos, o do conhecimento histórico, essa definição pode ser aplicada acrescentando-se à lista elementos da cultura popular. 


\subsection{Considerações sobre práticas educacionais no Brasil}

Enquanto escrevo esta dissertação, mudanças nas políticas de educação no Brasil estão na ordem do dia. As discussões sobre a proposta de uma "Base Nacional Comum Curricular" no âmbito do Ministério da Educação ${ }^{95}$, têm gerado intensos e acalorados debates. Embora não pretenda aprofundar-me aqui no mérito da questão, gostaria de tecer algumas considerações gerais que fui desenvolvendo durante a trajetória que me levou à realização deste trabalho. Já que no âmbito de qualquer intervenção, é fundamental saber de onde se parte e onde se atua, ou se pretende atuar. Também é necessário equilibrar a crua análise com uma dose de otimismo, caso contrário a atividade se paralisa. No âmbito da Educação não poderia ser diferente e embora os desafios pareçam muitas vezes instransponíveis, devemos continuar andando.

Creio que seja fácil concordar com a ideia de que, ao menos em teoria, a visão do aluno como um recipiente que cabe à escola "encher" com conteúdo, há tempos deixou de ser apropriada como paradigma do que a educação deveria ser. Os discursos de hoje tendem a apontar para a criatividade, para a autonomia, para a formação de seres com pensamento crítico, enfim, queremos formar cidadãos. A ideia de recipiente, porém, parece ter sido substituída pela da "lâmpada de Aladim": através dela, a educação funcionaria como o amo que, ao esfregá-la, libertaria o gênio de seu interior. Nessa tentativa de passagem de receptáculo a lâmpada, porém, o gênio encontra-se na prática esmagado por conteúdos e tarefas que, ora libertam um Funes, $o$ memorioso de Borges ${ }^{96}$, paralisado pelo excesso de memória, ora um Bartleby de Melville ${ }^{97}$, cujo exagero de vontade própria e sua negação de realizar o que lhe é pedido, o levam à morte. Ao mesmo tempo que desejamos incentivar a liberdade intelectual do aluno, engessamos essa liberdade com temas cujo significado raramente é explicitado.

Esse "engessamento", que de certo modo resulta em sofrimento e mal-estar, parece reproduzir as observações de Freud em relação ao papel da severidade da educação na produção de neuroses e à "perda de eficiência e capacidade de prazer que tem que ser pago pela normalidade na qual o educador insiste" ${ }^{98}$. A insistência na finalidade profissional da educação, por outro lado, tem anulado ou, na melhor das hipóteses, minimizado seu papel na subjetivação

\footnotetext{
${ }^{95}$ A proposta pode ser consultada no site: http://basenacionalcomum.mec.gov.br/\#/site/inicio

${ }^{96}$ BORGES, Jorge Luis. "Funes, el memorioso". Buenos Aires, 1944.

${ }^{97}$ MELVILLE, Herman. Bartleby, the Scrivener. A story of Wall Street. Nova York, 1853.

${ }^{98}$ FREUD, S. "O interesse científico da psicanálise”, In: FREUD, S. Sigmund Freud: Obra Completa. Edição Standard. Vol. XIII, p. 169-192. Rio de Janeiro: Imago, 1996.
} 
do aluno. Temos nos dedicado muito mais ao ensino, e não necessariamente à educação, numa profusão de conteúdos fragmentária, que visa controlar os resultados, mas que tem como corolário o mais pleno desinteresse de ambos os lados. O laço deixa então de estabelecer-se.

O livro didático, de maneira geral, não escapa a esse processo. Isso não poderia ser diferente já que, além de incorporar implícita ou explicitamente o currículo "oficial”, a cultura escolar e o ambiente do qual faz parte, ele também é objeto de inúmeras pressões econômicas e políticas relativas ao seu próprio processo de produção e seleção. Dessa maneira, traduz também a hiper-fragmentação dos conteúdos, ao tempo que amplia as narrativas na tentativa de incluir a própria percepção do estudante. Como resultado dessas pressões, nem sempre se obtêm diamantes.

A partir de uma primeira abordagem das obras, é possível perceber que, embora estejam amarradas a exigências curriculares e lancem mão de recursos que parecem às vezes fundamentar-se mais em técnicas de maquiagem do que em propostas didáticas de fundo, há algumas tentativas de romper com o encadeamento cartesiano tradicional oferecendo caminhos que se o professor e o aluno souberem utilizar, poderiam resultar em modelos mais próximos a uma rede que, à medida que é tecida, pode ser percorrida sem estar necessariamente sujeita a sequências obrigatórias. ${ }^{99}$ A oferta de fontes primárias, imagens, vinhetas, sugestões de filmes, links para navegação na web, códigos QR, fragmentos literários, testemunhos, são oportunidades para superar a ideia de pré-requisito de conteúdo e conduzir o grupo a explorar suas próprias trilhas, levando ao conhecimento e à reflexão dos assuntos, através de conexões ricas em significado.

Talvez pelas características intrínsecas ao estudo da História, tanto seu currículo quanto o livro didático que dele resultam, têm a vantagem de estar, desde sua origem, inseridos em uma rede complexa que dificulta -por mais que alguns ainda tentem-, dar respostas fáceis a qualquer tema ou seguir propostas que partam do mais fácil ao mais difícil numa sucessão linear. Estudar a Antiguidade antes da Idade Média, não se faz por razões relacionadas à menor ou maior complexidade de um ou outro período, mas sim por razões cronológicas e de sucessão de eventos. Mas, até mesmo esse aspecto, a cronologia, poderia ser flexibilizado partindo de momentos cujo estudo, em vez de somente "avançar no tempo", permita retroceder ou mesmo andar para os lados, buscando elementos contemporâneos aos temas, mesmo em outras áreas do

\footnotetext{
${ }^{99}$ MACHADO, Nilson José. Epistemologia e Didática. As concepções de conhecimento e inteligência e a prática docente. São Paulo: Cortez Editora, 2002.
} 
conhecimento ou em outras partes do mundo e que demonstrem as inter-relações ideia-tempoespaço, integrando o estudo com outras disciplinas.

Todo esse processo pode chegar a gerar certo temor da parte dos professores que ora não se encontram preparados para essa abertura, ora consideram que seus alunos não estão preparados para lidar com aquilo que é sugerido nos textos e atividades. Devido a isso, muitas vezes abandonam completamente as propostas hipertextuais inseridas atualmente nos livros didáticos e retornam a uma estrutura em que o bom e velho encadeamento dá a falsa impressão de oferecer um porto seguro, ainda que resultado seja uma coleção e fatos e uma ausência de desafios.

Gostaria de salientar, no entanto, que o temor ao qual me refiro no parágrafo anterior não é necessariamente fruto de comodismo ou de falta de vontade de se pensar "fora da caixa". Em alguns casos esse pode até ser o caso, mas a estrutura das políticas educacionais no Brasil na atualidade - modelo esse também aplicado em outras partes do mundo - tem transformado paulatinamente a prática docente em um sistema de obstáculos e recompensas que em nada contribui para os resultados, muito embora nos discursos ou nas intenções, seja esse o objetivo. $^{100}$

Por um lado, replicamos um sistema que prepara alunos para passar em provas, baseado em "dicas", processo esse levado ao limite no modelo dos chamados "sistemas de ensino" particulares, que potencializam o fenômeno mediante enxurradas de testes mensais, bimestrais, simulados, provões. A "qualidade" ou o "sucesso" são então medidos através de rankings baseados em quem consegue ter mais alunos aprovados no vestibular ou melhor colocados no $\mathrm{ENEM}^{101}$. É a lógica de uma educação materializada em pura competição, não em competência.

No âmbito do ensino particular, o panorama descrito não seria um problema em si, já que pelas características intrínsecas à lógica de mercado cada família tem a liberdade de inserir ou não seus filhos nesse sistema. As escolas particulares competem no mercado para atrair seu público da maneira que melhor se adeque ao seu negócio. O problema começa quando a educação básica pública dá sinais de querer imitar essa lógica competitiva, adotando mecanismos semelhantes aos mencionados.

\footnotetext{
${ }^{100}$ CHARLOT, Bernard. La Relación con el Saber: formación de maestros y profesores, educación y globalización. Montevideo: Ediciones Trilce. 2008.

${ }^{101}$ Criado em 1998, o ENEM teve inicialmente como objetivo de avaliar os alunos ao final do Ensino Médio para, com base nos resultados, guiar as políticas públicas da educação básica. Hoje, no entanto, seu perfil aproxima-se mais de um exame destinado a servir de porta de entrada para universidades, nos moldes dos vestibulares, do que de seu propósito original.
} 
Na escola pública brasileira, o foco dessa "corrida", no entanto, está menos no aluno e mais no professor, quem se vê cada vez mais imbricado num emaranhado de avaliações, índices e pontuações que em nada têm contribuído com a melhoria da educação como um todo. Pretende-se que um aluno ao qual pouco se prepara e do qual muito pouco se exige no dia-a-dia da prática escolar, obtenha resultados comparáveis ora a alunos formados em ambientes onde o "treinamento" se assemelha mais a uma competição esportiva, ora àqueles oriundos de países cujas realidades em nada se assemelham à brasileira, para bem ou para mal.

Como corolário desse processo, é desse "desempenho" que depende o salário do professor. O binômio avaliação/bonificação tem inserido no cotidiano da escola pública, uma lógica mercantil que pouco parece ter a ver com a educação. O sistema de avaliações oficiais SARESP em São Paulo, Prova Brasil, provas diagnósticas etc.- cujo foco orienta-se somente à quantificação de resultados dos alunos e ao seu uso como meio de "responsabilizar" por falhas ou "premiar" monetariamente os professores, é mais um fator de pressão no cotidiano docente, e que concorre para a já mencionada ruptura dos laços entre professor, aluno e família, aprofundando as tendências negativas nos rumos da educação. ${ }^{102}$

Parafraseando Goya, "esse sono da razão parece estar produzindo monstros..."103

É claro que tanto avaliar quanto cobrar resultados de uma e outra parte são ambos imprescindíveis quando se almeja a excelência, uma vez que permitem visualizar a situação e modificar ou corrigir eventuais distorções. Porém, tal como está desenhada, a atual política não parece traduzir-se naquilo que queremos obter: cidadãos qualificados e autônomos que possam tomar para si a tarefa de construir uma sociedade não somente próspera, mas principalmente ética.

\footnotetext{
${ }^{102}$ PASSONE, Eric F. K. "Notas psicanalíticas: os discursos contemporâneos acerca da avaliação educacional no Brasil”, In: Revista Educação e Pesquisa. São Paulo, v. 41, n. 1, p. 185-201, jan-mar, 2015.

${ }^{103}$ A frase do pintor espanhol Francisco de Goya, "El sueño de la razón produce monstruos", pode ser lida em uma de suas gravuras (no. 43) na série Caprichos (1797-1799).
} 


\subsection{Detalhamento da análise: dois estudos de caso}

A partir deste ponto, atravessamos o limiar que nos aproxima um pouco mais do teor daquilo com que professor e o aluno convivem em seu dia a buscando entender a maneira como o Holocausto é representado nos livros didáticos de História.

Assim, conforme foi mencionado anteriormente, o corpus documental para tal finalidade baseia-se na lista de títulos recomendados pelo Programa Nacional do Livro Didático (PNLD) para a disciplina História e divide-se em dois universos por ano de escolaridade: o $9^{\circ}$ ano do Ensino Fundamental e o $3^{\circ}$ ano do Ensino Médio. Embora o estudo do Holocausto não seja uma exigência no âmbito do Programa Curricular Nacional (PCN), é nesses anos que o tema pode ser encontrado no contexto do estudo dos temas propostos nos currículos sob a denominação "Estados Totalitários" ou "Segunda Guerra Mundial".

Para este ano, escolhemos 2 (dois) títulos, um correspondendo ao $9^{\circ}$ ano do Ensino Fundamental e o outro correspondendo ao $3^{\circ}$ ano do Ensino Médio. As escolhas dos títulos foram aleatórias. A ideia de apresentá-las aqui mira o propósito de servir de amostra em relação ao estado-da-arte do tratamento do Holocausto nos títulos selecionados a partir de uma leitura próxima (close-reading) do material apresentado. O formato da análise estrutura-se a partir de três sub-temas:

1) Apresentação geral da obra;

2) O contexto do conteúdo relacionado ao Holocausto dentro da obra;

3) Tratamento do Holocausto no volume em estudo.

\subsubsection{Análise do volume correspondente ao $9^{\circ}$ ano do Ensino Fundamental}

Título da obra: $\quad$ História, Sociedade \& Cidadania

Autor: Alfredo Boulos Júnior

Editora: FTD

Ano:

2012

1) Apresentação geral da obra

Volume quarto da obra destinada aos alunos do Ensino Fundamental II, o livro contém 320 páginas divididas em 6 unidades e 19 capítulos que se organizam seguindo uma ordem 
cronológica integrando a História do Brasil à História Geral. No caso do volume em análise $\left(9^{\circ}\right.$ ano), o período tratado estende-se do século XIX com a Revolução Industrial à segunda década do século XXI.

Os textos em cada capítulo são intercalados de imagens com legendas que em diversas oportunidades colocam questões para reflexão. Há também "caixas" com os títulos "Para saber mais" - que detalha assuntos em particular ligados ao tema em estudo - e "Para refletir" - que inclui questões direcionadas ao aluno. Já a seção "Dialogando" visa a participação oral em sala de aula.

Em cada capítulo são apresentadas atividades variadas com diversos graus de complexidade que propõem, entre outros, a elaboração de legendas para imagens, a interpretação de mapas ou a redação de textos. O livro propõe ainda três seções complementares: a primeira chamada "A imagem como fonte", propõe ao aluno produzir textos a partir de uma imagem; a seção "O texto como fonte" orienta o foco na direção de documentos, relatos e textos literários visando o desenvolvimento de um olhar crítico mediado pelo professor; por último, na seção "Livros, sites e filmes" são listadas fontes adicionais para consulta, pesquisa e aprofundamento sobre cada tema.

2) O conteúdo relacionado ao Holocausto dentro da obra

Neste volume, referências ao Holocausto são encontradas na Unidade 3 intitulada “Capitalismo, Totalitarismo e Guerra” (pp. 84 a 131) que está subdividida em três capítulos, a saber: "A Grande Depressão, o fascismo e o nazismo" (pp. 84 a 101); "A Segunda Guerra Mundial” (pp. 102 a 114); “O primeiro governo Vargas” (pp. 115 a 131).

A unidade inaugura-se com uma página dupla onde são exibidas, por um lado, imagens relacionadas ao ataque à cidade de Hiroshima. Em uma delas vê-se a imagem da cidade logo após o lançamento da bomba atômica em 1945 e a outra, mais recente, mostra crianças em frente ao Parque Memorial da Paz da mesma cidade. Na página oposta, uma fotografia do corpo escultórico que homenageia os pracinhas brasileiros das Forças Armadas que lutaram na Segunda Guerra Mundial. As imagens são acompanhadas de legendas e de um texto que propõe algumas reflexões ao estudante assim como perguntas, primeiro, sobre a relação entre a ascensão do nazifascismo e a guerra; depois, sobre as consequências das bombas atômicas. Nesse sentido, percebe-se, neste primeiro momento, que o Holocausto não é tomado como um evento relevante na narrativa sobre o período. 
O primeiro capítulo da unidade (6) abre com uma discussão, também baseada em imagens, nas quais são mostradas filas de desempregados durante a depressão de 1929 e a crise em 2008. Pede-se então ao aluno que proceda a uma análise comparativa entre os dois momentos. Em seguida, a análise prossegue com os antecedentes da crise de 1929, passando posteriormente para a ascensão do fascismo na Itália.

A partir da página 93 encontram-se as primeiras referências ao tema de análise desta dissertação, a partir do relato da ascensão do nazismo ao poder, na figura de Hitler. Nesse sentido, o texto sob o título "Partido de ideologia nazista" descreve três princípios básicos do nazismo, a saber: a superioridade da raça ariana, o antissemitismo e o espaço vital.

Embora o texto não apresente uma definição de antissemitismo para o estudante, é interessante ressaltar um paradigma interpretativo que de certa forma tende na direção de uma corrente historiográfica próxima ao intencionalismo ao afirmar: "Os nazistas justificavam seu ódio aos judeus dizendo que eles haviam contaminado a 'raça ariana'. Assim, para salvar a Alemanha e purificar a 'raça ariana', os judeus deviam ser exterminados”. (p. 93).

As páginas 94 e 95 prosseguem com o desenvolvimento do tema descrevendo a ascensão do nazismo e a chegada de Hitler ao poder. Aqui é possível encontrar mais uma referência à perseguição aos judeus, embora sem mencionar explicitamente as Leis de Nuremberg de onde partiram as determinações que o livro enumera parcialmente, ou seja, a lista limita-se a citar as proibições para os judeus de "namorar, casar ou manter relações sexuais com pessoas de 'sangue alemão"” (p. 94). Na verdade, teria sido interessante se o autor tivesse enfatizado importância das referidas leis dentro do processo que conduziu ao extermínio dos judeus pois foi a partir delas que o nazismo aprofundou a construção da imagem do povo judeu como "raça" criando-se para tal finalidade um arcabouço burocrático materializado através de diversos tipos de documentos que as autoridades passaram a exigir a todos os funcionários do setor público, inclusive na educação. Estes documentos visavam basicamente a comprovação de que o indivíduo pertencia à "raça ariana". Assim, através de uma série de definições sobre quem era ou não judeu, criou-se uma situação na qual mesmo pessoas que não praticavam o judaísmo, que eram convertidos ao cristianismo, ou que em certos casos nem mesmo sabiam que tinham ascendência judaica, eram considerados judeus. A partir daí, configurou-se um cenário sem escapatória para os judeus e que, mesmo dentro da longa história do antissemitismo e das perseguições concretas anteriormente perpetradas, constituiu um método sem precedentes resumido pelo o sociólogo Raul Hilberg nos seguintes termos: 
Desde os primeiros tempos do Cristianismo, desde o século IV, século V, século VI, os missionários da cristandade haviam dito aos judeus: "Vocês não podem viver entre nós como judeus"; os governantes seculares que os seguiram a partir da Alta Idade Média haviam decidido: "Vocês não podem viver entre nós" e os nazistas finalmente decretaram: "Vocês não podem viver". ${ }^{104}$

As páginas 94 e 95 apresentam ainda duas imagens que ocupam aproximadamente metade da página, onde são exibidas duas fotografias de Hitler perante multidões de seguidores e uma pequena imagem da suástica nazista. Neste ponto, o autor convida os alunos ao "diálogo", colocando a seguinte pergunta “Por que será que milhões de alemães aderiram ao nazismo?" É uma pergunta de grande complexidade que tem encontrado na historiografia inúmeras respostas e gerado acalorados debates. Na legenda de uma das imagens ensaia-se, de certa forma, uma resposta: "Para empolgar as multidões, Hitler recorria a uma oratória demagógica, de gestos exagerados, e prometia tudo a todos, sabendo que de antemão não cumpriria”. (p. 94)

As referências à ascensão de Hitler e do nazismo ao poder finalizam com um texto dentro do quadro "Para refletir" que descreve o contexto das Olimpíadas de 1936 intitulado "As Olimpíadas de 1936: Esporte e Racismo". Nesse texto o autor mostra como Hitler utilizou os jogos como meio de propaganda, não somente do ponto de vista da organização do evento, mas também através da realização de um filme oficial para a competição produzido pela cineasta Leni Riefensthal. No livro mencionam-se também os nomes de Gretel Bergmann e Helene Meyer, duas campeãs alemãs de origem judaica que acabaram sendo incluídas na equipe da Alemanha e o impressionante desempenho do atleta negro norte-americano Jesse Owens, que ganhou quatro medalhas de ouro nos Jogos.

Este é um tema importante que pode certamente despertar o interesse dos estudantes quanto às relações entre esporte e política e seu uso para fins de propaganda, inclusive nos dias de hoje.

${ }^{104}$ Extraído da entrevista concedida por Raul Hilberg ao cineasta francês Claude Lanzmann e incluída no monumental documentário Shoah. O trecho correspondente à entrevista de Hilberg pode ser encontrado em: www.youtube.com/watch?v=pQDA4GgitCA (min. 4:44 a 5:12). Segue a transcrição: "From the earliest days, from the fourth century, fifth century, sixth century, the missionaries of Christianity had said in effect to the Jews: 'You may not live among us as Jews'; the secular rulers who followed them from the late Middle Ages had then decided: 'You may not live among us'; the Nazis finally decreed: 'You may not live"' (transcrição e tradução nossa) 
No entanto, seu tom excessivamente otimista embora possa, por um lado, contribuir ao engajamento do aluno com sua mensagem de que a vitória de Owens são "prova cabal de que as ideias xenofóbicas de Hitler não passam de ignorância e preconceito", conforme podemos ler no livro, por outro lado pode conter elementos que de certa forma acabam mascarando o real impacto dos jogos de Berlim no processo histórico dos anos posteriores.

Nesse sentido, gostaria de comentar particularmente dois aspectos tratados no texto. O primeiro deles refere-se à participação das atletas judias citadas, Gretel Bergmann e Helene Mayer. Seria importante contextualizar aqui que a inclusão de seus nomes na lista dos atletas que representariam a Alemanha nos jogos foi mais uma manobra propagandística do Reich que usou as Olimpíadas também na tentativa de dissipar rumores sobre sua política antissemita e racista. Além disso, os Estados Unidos haviam ameaçado boicotar os jogos caso não pudessem ser incluídos atletas judeus e negros. Por isso elas foram incluídas. No entanto, assim que as autoridades alemãs souberam que a delegação americana estava a caminho, Gretel foi excluída dos jogos sem protestos por parte da comunidade internacional ${ }^{105}$. No caso de Helene Mayer, sua condição de "metade" judia (sua mãe era cristã) fez com que prosseguisse nas competições.

Já o segundo aspecto relaciona-se ao fato de que, embora hoje enxerguemos as proezas de Jesse Owens como uma vitória contra o preconceito e um revés para o projeto racista do nazismo, é necessário afirmar que, no que se refere aos objetivos concretos que os propagandistas do Terceiro Reich pretendiam alcançar com a organização dos jogos, Berlim 1936 foi um grande sucesso, fundamental, naquele momento, para apaziguar os temores das potências internacionais em relação a Hitler e ao seu governo. O jornalista americano William L. Shirer que testemunhou os anos do nazismo como correspondente na Alemanha, escreveu em seu diário, no dia 16 de agosto de 1936, a respeito dos Jogos Olímpicos:

Temo que os nazistas tiveram êxito com sua propaganda. Primeiro operaram os jogos em uma escala exuberante nunca antes experimentada com apelo também aos atletas. Segundo, montaram uma vitrine muito boa para os visitantes em geral, especialmente os grandes empresários. ${ }^{106}$

\footnotetext{
${ }^{105}$ Jewish Women's Archive: http://jwa.org/encyclopedia/article/bergmann-gretel

106 SHIRER, William L. Berlin Diary. The Journal of a Foreign Correspondent, 1934-1941. New York: Alfred A. Knopf, 1942, pp. 65.
} 
O capítulo prossegue com temas relacionados à influência que o fascismo e o nazismo tiveram em outros países, incluindo o Brasil. Já o capítulo 7 (“A Segunda Guerra Mundial”, p. 102) inaugura-se com a reprodução da capa de um gibi do "Capitão América" em que o personagem luta contra uma figura que representa um nazista (identificado por uma suástica no braço) e prossegue com o passo-a-passo dos acontecimentos políticos que conduziram à guerra. Deste ponto até a página 110, o livro concentra-se me detalhes sobre táticas e estratégias relacionadas à guerra. Dois acontecimentos-chave no desenrolar do processo do Holocausto -a invasão da Polônia e da União Soviética- são apresentados sem fazer menção à guerra contra os judeus, permanecendo esta desconectada em relação ao cenário das batalhas que transcorriam em várias frentes.

3) Tratamento específico do Holocausto no volume em estudo

No final do Capítulo 7 os judeus voltam a aparecer na narrativa proposta pelo autor do livro didático mediante o relato que finaliza a parte destinada ao estudo da Segunda Guerra Mundial: "O pior crime que o Tribunal de Nuremberg comprovou ter sido cometido pelos nazistas foi o extermínio de milhões de judeus" (p. 110). Esta afirmação "dá a deixa” para o texto que segue na seção "Para refletir" e que se intitula "A 'solução final': fábricas de morte”.

Antes de proceder à análise do texto mencionado e destinado exclusivamente a tratar do Holocausto dentro da obra, é interessante notar que o termo Holocausto em si, não é utilizado em nenhum momento. Também não são utilizados os termos Shoá ou genocídio. A opção para referir-se ao evento foi mediante o uso da palavra extermínio.

Logo do início do texto, o ano de 1942 aparece como o momento -embora não haja referência ao dia ou mês- em que "os líderes nazistas decidiram matar todos os judeus em campos de extermínio especialmente construídos para essa finalidade”. Apesar de não haver um registro explícito no texto, a data provavelmente toma como base o ano de realização da chamada Conferência de Wannsee em 20 de janeiro daquele ano. Os estudos presentes na vasta historiografia sobre o Holocausto apontam que Wannsee, na verdade, não pode ser considerado como o momento em que se decidiu proceder ao assassinato em massa dos judeus.

Embora nunca tenha sido encontrado um documento especificando quando foi decidida a "Solução Final", é amplamente aceito que a decisão sobre o extermínio teria ocorrido provavelmente já durante o planejamento da chamada "Operação Barbarossa", ou seja, antes da invasão da União Soviética, sendo perpetrada inicialmente pelos Einsatzgruppen, unidades 
móveis de extermínio que avançavam "nos calcanhares" do exército alemão à medida que adentravam os territórios ocupados pela União Soviética. Esses grupos eram formados por homens da SS, Waffen SS, forças armadas alemãs e unidades da polícia alemã, totalizando aproximadamente 3.000 homens que, contando ainda com a ajuda de milhares de colaboradores locais, foram responsáveis pelo assassinato de mais de 1,5 milhão de judeus.

Os Einsatzgruppen eliminavam suas vítimas mediante fuzilamentos em massa, próximo às localidades onde habitavam. Em geral, as pessoas eram reunidas à beira de barrancos, minas ou valas cavadas por trabalhadores forçados - na maioria das vezes, as próprias vítimas. Inicialmente, o alvo eram os homens, mas por volta de agosto de 1941, passou-se a aniquilar comunidades inteiras, incluindo mulheres e crianças. A "Solução Final”, portanto, já estava em curso antes de 1942. A reunião de Wannsee foi, na verdade, um encontro que visava apenas definir métodos e políticas. ${ }^{107}$

Prosseguindo com a análise, vemos que o segundo parágrafo do capítulo (7), concentra-se em estabelecer as diferenças entre campos de concentração e campos de extermínio definindo corretamente estes últimos como uma "novidade" introduzida pela Alemanha nazista e colocando a Polônia como o lugar de escolha para a construção da maioria desses campos da morte por ser "o que tinha maior número de judeus, cerca de 3 milhões”. Certamente a questão logística teve um peso importante na decisão principalmente se levarmos em conta que a Alemanha ocupava metade da Polônia desde setembro de 1939 e, portanto, já contava com uma infraestrutura in loco.

No entanto, há outro aspecto que é importante ressaltar na abordagem do tema, e que se refere à política de dissimulação e ocultação adotada pela Alemanha nazista. Não somente nos documentos produzidos por suas autoridades quanto em discursos por eles proferidos, percebe-se uma preocupação com o apagamento de rastros ou indícios do genocídio em curso e que tem basicamente dois fundamentos: o primeiro, não alertar os judeus quanto ao destino que estava sendo traçado para eles. O pânico poderia comprometer a "eficiência" do plano e seu objetivo que era o extermínio. O texto analisado de certo modo toca na questão da dissimulação ao afirmar no terceiro parágrafo que era dito "aos prisioneiros" que "estavam indo trabalhar para a Alemanha nazista", embora não explore o propósito do engano expressamente.

107 O linguista e historiador israelense Daniel Michman tem aprofundado esse conceito em diversos artigos. Antes dele, o historiador britânico Martin Gilbert também havia explorado o assunto suas obras relacionadas ao Holocausto. 
Na verdade, uma vez decidido que a meta era a aniquilação total do povo judeu, os indivíduos que a ele pertenciam, segundo as definições estabelecidas nas Leis de Nuremberg, não podiam escapar. Somente a dissimulação permitiria que as ações fossem levadas a cabo de maneira "ordenada". Entender essa prática ajuda também a perceber que a tomada de decisões para os próprios judeus era extremamente difícil já que não era possível vislumbrar claramente qual seria o passo seguinte dos perpetradores, algo importante a ser discutido em sala de aula para compreender porque aqueles que foram alvo do processo genocida tomaram certas decisões em vez de outras.

Um segundo objetivo da política de dissimulação tinha relação com a própria “opinião pública" na Alemanha. As autoridades nazistas já haviam tido provas de que recorrer a práticas genocidas em seu próprio território poderia gerar protestos como já havia ocorrido durante a execução de milhares de deficientes físicos e mentais no chamado Programa de Eutanásia levado a cabo ainda nos anos 1930 e que fizeram com que Hitler ordenasse o fechamento dos centros de extermínio a gás dentro do território alemão e a prosseguir as execuções de forma mais descentralizada. ${ }^{108}$ Aqui temos um outro ponto de interesse para o estudo em sala de aula e que se refere ao papel dos observadores durante o genocídio e à certa debilidade do argumento de que não era possível haver reações sob o nazismo. Os protestos da população alemã contra as atrocidades cometidas no contexto do Programa de Eutanásia são prova de que a máquina nazista também podia ser desafiada. Porque não o foi no caso dos judeus é um bom tema para reflexão no âmbito dos estudos sobre o Holocausto.

O quarto parágrafo do capítulo prossegue com a descrição de alguns dos procedimentos efetuados nos campos de concentração contra os prisioneiros. Talvez por questões de espaço, o autor abandona aqui a diferenciação entre campos de concentração e de extermínio assim como entre as origens, tratamento e destino das vítimas envolvidas as quais foram relacionadas no terceiro parágrafo: “A maioria deles [os prisioneiros] era composta de judeus, mas além deles havia grande número de eslavos (russos, sérvios), ciganos, religiosos pacifistas (padres, pastores que pregavam contra a guerra e também testemunhas de Jeová, que se recusavam a prestar o serviço militar)". No texto, o processo efetuado nos distintos campos passa a ser descrito então de maneira única. Por exemplo, no início do quarto parágrafo lemos: "Logo na entrada dos

${ }^{108}$ BREITMAN, Richard. Official Secrets: What the Nazis Planned, What the British and Americans Knew. New York: Hill ; Wang, 1998. 
campos, os médicos nazistas separavam as pessoas em duas filas: uma delas era composta de velhos, doentes e crianças, mandados imediatamente para a morte nas câmaras de gás”.

Tem-se a impressão aqui de que o autor tem em mente os procedimentos praticados principalmente em Auschwitz, paradigma do sistema concentracionário nazista cujo complexo abrigava a dupla função de campo de concentração e extermínio, daí a razão das seleções. Alguns prisioneiros eram então encaminhados para trabalhos no complexo de fábricas localizadas em Birkenau e Monowitz e os não aptos eram diretamente enviados às câmaras de gás. Nos campos que se destinavam exclusivamente ao extermínio, porém, esse processo limitava-se quase que exclusivamente à escolha, dentre os prisioneiros, de alguns homens jovens para trabalharem como parte dos Sonderkommando, ou seja, os esquadrões encarregados de lidar com as tarefas diárias do campo, entre elas, transferir corpos das câmaras de gás para os crematórios. Nesses casos, a maioria absoluta dos prisioneiros conduzidos a campos de extermínio eram mortos imediatamente após a chegada, sem seleção.

No quinto parágrafo aparece finalmente o conceito utilizado no título que define os campos de extermínio como "fábricas de assassinato". Aqui há uma referência direta a Auschwitz, às precárias condições em que os prisioneiros viviam e às humilhações às quais eram submetidos. Seria importante acrescentar ainda que Auschwitz era um complexo misto com funções de concentração, trabalho e extermínio no qual grandes empresas alemãs tinham instalações que utilizavam mão de obra escrava para sua produção. Seu dia a dia foi amplamente descrito e analisado em milhares de testemunhos e memórias de sobreviventes.

Uma observação importante ainda em relação a este parágrafo diz respeito à afirmação encontrada no texto, de que "as mulheres eram constantemente violentadas pelos guardas". Afirmações como esta devem ser tratadas com muita cautela já que, embora haja registros de tais atos, a historiografia sobre o assunto ainda é escassa assim como os testemunhos a respeito. Devemos lembrar ainda que os guardas alemães, pelas determinações contidas nas próprias Leis de Nuremberg, eram expressamente proibidos de manter relações sexuais com mulheres não “arianas", principalmente judias, sob o risco de serem processados criminalmente por Rassenschande (contaminação da raça). Acredito que seja desnecessário acrescentar este aspecto pouco explorado em iniciativas que visem a educação sobre o Holocausto. A lista de maus-tratos, crimes e violações cometidas pelos nazistas é suficientemente extensa para que os livros didáticos se atenham a um aspecto que, além de pouco estudado, em nada acrescenta ao entendimento sobre o tema. 
O último parágrafo no capítulo dedicado ao Holocausto - embora, como já foi mencionado, o termo esteja completamente ausente - apresenta então alguns números relativos às vítimas: "Calcula-se que nesses campos foram mortos cerca de 6 milhões de judeus, 300 mil ciganos e centenas de milhares de soviéticos, homossexuais, deficientes físicos e religiosos". Chegamos aos números e os números, assim como as datas, são de tal importância em qualquer relato histórico que nunca é demais ressaltar o cuidado que eles merecem. No caso específico do Holocausto, essa importância potencializa-se devido à existência de tentativas revisionistas e negacionistas cujo objetivo permanente é pôr em xeque a história do evento. Eventuais erros ou confusões nesse sentido, podem facilmente tornar-se alvo de questionamentos mal-intencionados além de transmitir informações equivocadas sobre o fato histórico. Portanto, é importante que quando se decide apresentar números, estes sejam, tanto quanto possível, exatos.

Assim, no caso do texto em questão, embora o número de 6 milhões represente sim a cifra aproximada de judeus mortos no Holocausto e 300 mil seja um número dentro das estimativas de ciganos mortos pelo nazismo afirmar que todos morreram nos campos é totalmente impreciso para ambos grupos. Estatísticas baseadas em documentos, muitos deles deixados pelas próprias autoridades nazistas, revelam, em linhas gerais, que aproximadamente 2,6 milhões de judeus morreram nos principais campos de extermínio (Auschwitz, Treblinka, Belzec, Sobibor, Chelmno) e por volta de 500.000 em outros campos disseminados pela Europa. As execuções próximas às comunidades de residência no leste europeu, resultaram na morte de aproximadamente 1.5 milhão de judeus. As terríveis condições de vida e a violência nos guetos cobraram as vidas de outros aproximadamente 800.000. Outro meio milhão de vítimas morreram nas florestas como partisans ou nas marchas da morte quando da evacuação dos campos. ${ }^{109}$ Quanto aos ciganos, sabe-se também que milhares deles foram executados durante a invasão à

${ }^{109}$ Número total de judeus mortos no Holocausto: Complexo de Auschwitz (incluindo Birkenau, Monowitz e subcampos), aproximadamente 1 milhão. Treblinka, aproximadamente 925.000; Belzec, 434.508, Sobibor, pelo menos 167.000; Chelmno, entre 156.000 e 172.000; execuções em várias localidades no centro e sul da Polônia ocupada pela Alemanha (chamada de Governo Geral), pelo menos 200.000; execuções no território ocidental anexado pela Alemanha, pelo menos 20.000; execuções e assassinatos por gás (vans) em centenas de localidades na União Soviética, 1,3 milhão; execuções na União Soviética de judeus alemães, austríacos e tchecos deportados para a União Soviética), aproximadamente 55.000; execuções e assassinatos por gás (vans) na Sérbia, pelo menos 15.088; executados ou torturados até a morte na Croácia sob o regime de Ustaša, 23.000 a 25.000; mortes em guetos, ao menos 800.000; outros, pelo menos 500.000 (estes incluem pessoas executadas na Polônia entre 1939 e 1940, como partisans na Iugoslávia, Grécia, Itália, França ou Bélgica; em batalhões de trabalhos forçados na Hungria; durante ações antissemitas na Alemanha e Áustria antes da guerra, pela Guarda de Ferro na Romênia entre 1940 e 1941, em marchas de evacuação dos campos de concentração e trabalho nos últimos seis meses da guerra e pessoas que estavam escondidas e que foram mortas na Polônia, Sérbia e outras partes da Europa ocupada pela Alemanha). Fonte: United States Holocaust Memorial Museum, Washington D.C., Estados Unidos. www.ushmm.org/wlc/en/article.php?ModuleId=10008193 (Consultado em 13 de agosto de 2016). 
União Soviética no lugar em que habitavam ou onde eram encontrados, sendo que em Auschwitz, morreram pouco mais de 23.000. ${ }^{110}$

O texto analisado termina com uma menção aos "milhares de refugiados sem lar, pátria ou família", junto com uma definição do termo "refugiado" destacada ao lado do texto. Na parte inferior da página, a famosa imagem de um menino com as mãos para o alto ao deixar o Gueto de Varsóvia.

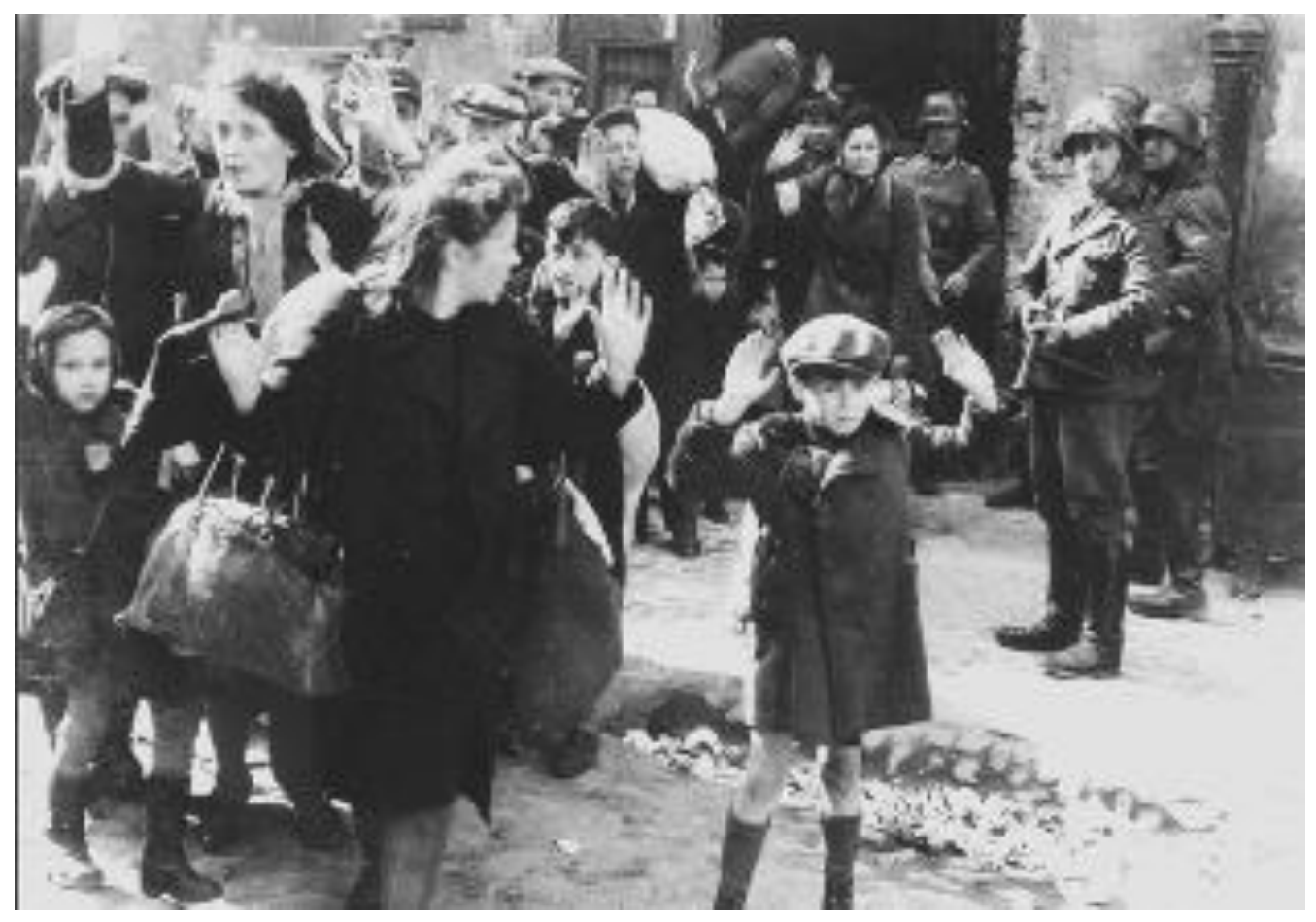

Figura A-1. Liquidação do Gueto de Varsóvia

Relatório Stroop. Fotógrafo desconhecido.

Fonte: www.yadvashem.org

O Holocausto foi um evento amplamente documentado em imagens, mas como já foi mencionado anteriormente, essas imagens estão em sua grande maioria, mediadas pela lente do perpetrador que através do uso de uma série de técnicas, escolheu sua maneira de contar a história sobre daquilo que estava testemunhando. No livro didático analisado neste momento, a imagem escolhida para acompanhar o texto (Fig. A-1), por exemplo, é parte de um álbumrelatório produzido por Jürgen Stroop, um oficial nazista que, acompanhado de um fotógrafo, 
documentou a brutal liquidação do gueto de Varsóvia após o levante em abril e maio 1943. Stroop fez três cópias desse álbum, cujo subtítulo é "Não há mais bairro judeu em Varsóvia". Duas dessas cópias foram enviadas como relatório a seus superiores e a terceira permaneceu em sua possessão. Após a guerra, o álbum e várias fotografias que não foram nele incluídas foram recuperadas por soldados aliados e posteriormente utilizadas nos julgamentos de Nuremberg ${ }^{111}$. Legendas explicativas acompanham as fotos incluídas no álbum-relatório. No caso específico da imagem aqui tratada, o texto incluído por Stroop foi: "Puxado dos bunkers à força". Legendas que acompanham outras imagens incluem referências aos judeus como "bandidos" e "traidores"

O propósito, tanto do fotógrafo quanto de Stroop, foi retratar a "necessidade" de se "puxar os bandidos para fora do bunker", sendo que os bandidos eram, na verdade, os últimos judeus sobreviventes do gueto ou que tentavam esconder-se nos arredores, fazendo-se passar como cristãos. Esse parece ter sido o caso do menino com as mãos para o alto. A imagem desse menino que hoje enxergamos como retrato da inocência de uma criança ameaçada por seu algoz, foi na verdade criada para ter, na época, um efeito contrário: o de mostrar a ameaça que os judeus, inclusive crianças, representavam dentro da ideologia construída pelo nazismo.

Nesse sentido, seria interessante incluir nos materiais didáticos, a história das próprias imagens como artefato histórico para assim resgatar, na sala de aula, esses aspectos que muitas vezes se perdem, principalmente quando tratamos de objetos que já fazem parte do imaginário sobre o Holocausto e que pela sua ubiquidade acabam sendo depurados de significado, quando poderiam ser utilizados como valiosas ferramentas pedagógicas.

No caso da legenda que acompanha a imagem em questão no livro didático analisado, acredito que cabem também algumas observações. Na mesma lê-se: "Soldados nazistas vigiam mulheres e crianças judias de mãos erguidas no Gueto de Varsóvia, na Polônia. Após uma revolta em que vinte soldados alemães foram mortos, as tropas nazistas mataram 15 mil judeus e levaram sobreviventes para campos de extermínio".

Embora a legenda mostre claramente a disparidade entre o resultado da revolta em termos do número de mortos de ambos os lados -vinte do lado alemão e 15 mil do lado dos judeus, além da deportação dos sobreviventes para campos de extermínio-, ela deixa de certa forma implícito que as mortes e a deportação foram em decorrência da revolta dos judeus, o que poderia

${ }^{111} \mathrm{Um}$ facsímile do álbum pode ser visto em: http://pamiec.pl/ftp/ilustracje/Raport_STROOPA.pdf, introduzido por uma apresentação em polonês. O documento original produzido por Stroop pode ser visto a partir da página 113 e o álbum fotográfico a partir da página 189 (ou 78, se seguirmos a numeração feita por Stroop). A foto do menino com as mãos para o alto encontra-se na página 203 (ou 91 no original). 
transmitir a ideia de que se não fosse pela revolta, a situação poderia ter sido diferente. Pode-se afirmar, no entanto, que a liquidação do Gueto de Varsóvia havia começado de fato em 22 de julho de 1942 -portanto um ano antes- na véspera do feriado judaico de Tisha B'Av (Jejum de Av) quando em apenas dois meses 265.000 pessoas foram deportadas para Treblinka onde foram assassinadas. No final de setembro de 1942, restavam no gueto menos de 60.000 pessoas. Chaim Kaplan, educador e diarista do Holocausto, registrou nas últimas páginas de seu diário que termina em agosto de 1942:

Os terríveis eventos têm me esmagado [...] não há palavras para expressar o que tem acontecido conosco desde o dia em que a expulsão foi ordenada [...]. Com um movimento de caneta o rosto de Varsóvia foi alterado. [...] Por todos os lados há um silêncio sepulcral. ${ }^{112}$

As referências a temas relacionados ao Holocausto no livro analisado, prosseguem na seção intitulada "O texto como fonte" (p. 113) na qual é inserido um trecho do Diário de Anne Frank, seguido de uma proposta de análise a partir de quatro perguntas que serão mostradas logo adiante.

O diário da jovem judia que viveu durante dois anos escondida com sua família em um anexo secreto de sua casa em Amsterdam é o símbolo do Holocausto par excellence na cultura popular. O livro figura há décadas nas listas dos mais vendidos, em muitas ocasiões perdendo somente para a Bíblia. Foi traduzido em mais de 60 línguas e circula na maioria dos países do mundo. O rosto de Anne simboliza, no imaginário coletivo, todas as vítimas do Holocausto, principalmente os mais de 1,5 milhão de crianças mortas pela barbárie nazista. Sua história foi encenada no teatro inúmeras vezes e já ganhou versões para documentários, séries e filmes. Enfim Anne Frank é provavelmente uma das crianças mais famosas do século XX.

Não há nada de negativo em tudo isso, ao contrário. O diário de Anne, principalmente nas primeiras décadas após o Holocausto, foi a obra que mais contribuiu para que o público em geral tomasse consciência de ao menos parte da guerra que a Alemanha nazista travou contra os judeus. A própria Anne Frank tinha consciência sobre a importância de seus escritos e planejava publicá-los depois do fim da guerra. Sua vida, porém, como sabemos, terminou trágica e

112 KAPLAN, Chaim A. Scroll of Agony. The Warsaw Diary of Chaim A. Kaplan. Indiana: Indiana University Press, 1999. 
prematuramente, semanas antes da derrota da Alemanha e, assim como ocorreu com todos os diários escritos pelas vítimas do Holocausto, o diário de Anne interrompe-se abruptamente. Obviamente, portanto, Anne não conseguiu concluir suas reflexões sobre os anos de guerra, sobre a violência e o horror que o nazismo infligiu sobre milhões de judeus da Europa. Não existem versões "definitivas" de sua história -como muitas vezes aparece estampado nas capas de suas inúmeras edições- uma vez que, o que ela viveu até os últimos dias, o Holocausto propriamente dito, não foi por ela registrado. O uso metonímico desse texto para fins pedagógicos, portanto, deixa muitas perguntas abertas que, para que sejam respondidas, deveriam proceder a um estudo do livro a partir da história do Holocausto e não vice-versa.

Anne era uma escritora talentosa cujo diário levanta inúmeras questões importantes para a análise da situação dos judeus durante os anos em que esteve no esconderijo com sua família e sobre a maneira como ela mesma enxergava a evolução dos acontecimentos a partir das informações com que contava. Em seu diário, a entrada do dia 11 de abril de 1944, por exemplo, é, nesse sentido, exemplar. Nessa terça-feira, Anne escrevia:

Somos constantemente lembrados do fato de que somos judeus acorrentados, amarrados a um único ponto, sem nenhum direito, mas com mil obrigações. [...] Quem infligiu isso sobre nós? Quem nos separou de todo o resto? Quem nos colocou em meio a este sofrimento? [...] Aos olhos do mundo estamos condenados, mas, se depois de todo este sofrimento ainda restarem judeus, o povo será tido como exemplo. [...] Nunca poderemos ser somente holandeses, ou somente ingleses, ou não importa o que, sempre seremos judeus também. E temos que continuar sendo judeus, mas nesse momento, todos vamos querer ser."113

No entanto, geralmente as práticas em sala de aula e os livros didáticos optam por dar uma visão mais "universal" do diário de Anne que de certo modo contribui com a tendência à desjudaização do Holocausto tratada na Introdução desta dissertação. Inúmeros são os exemplos na cultura popular dos múltiplos usos dados à imagem de Anne Frank e de seu sofrimento. Talvez o mais recente deles seja a abordagem utilizada pelo escritor de romances para jovens John Green em seu livro A Culpa é das Estrelas ${ }^{114}$, em que a protagonista, Hazel, uma adolescente doente terminal de câncer, beija pela primeira vez seu namorado Augustus -também

${ }^{113}$ FRANK, Anne. The Diary of a Young Girl. London: Penguin, 2001, p. 261-262.

${ }^{114}$ GREEN, John. A Culpa é das Estrelas. São Paulo: Intrínseca, 2012. 
doente de câncer- na escada que conduz ao anexo secreto na casa-museu de Anne Frank em Amsterdam sob os aplausos de turistas que visitam o local. A história levada ao cinema em 2014 foi um enorme sucesso de bilheteria, principalmente entre os adolescentes, ou seja, o públicoalvo das propostas aqui apresentadas. Embora o filme não faça uma comparação explícita, nas entrelinhas fica a sugestão de um nivelamento em que tanto padecer de câncer quanto ter vivenciado Holocausto podem servir igualmente como metáforas para todo o sofrimento humano. No caso de Anne Frank, acaba por transformar sua imagem em um símbolo totalmente fora do contexto histórico que a vitimou.

O livro didático analisado segue em parte a linha da descontextualização assim como da utilização da imagem de Anne Frank como símbolo dos oprimidos do mundo, mas também de esperança. $\mathrm{O}$ trecho escolhido ilustra bem este último ponto, pois dele faz parte talvez a frase mais frequentemente citada do diário, justamente aquela mais universalmente utilizada, onde Anne diz: "apesar de tudo ainda acredito que as pessoas, no fundo, são realmente boas". Caso Anne tivesse sobrevivido e, com sua capacidade de exímia escritora, tivesse podido testemunhar sobre seus dias em Auschwitz e Bergen-Belsen, teria ela mantido essas palavras?

As atividades que encerram o item intitulado "O texto como fonte" no livro analisado, baseiam-se em quatro perguntas relacionadas com o fragmento citado do diário de Anne Frank. Essas perguntas têm como objetivo, aparentemente, convidar o aluno a refletir sobre alguns pontos tocados por Anne no fragmento publicado e tentam vincular questões por ela tratadas em relação às dificuldades de ser jovem e quanto aos desafios de manter a firmeza e os ideais em tempos difíceis, finalizando com uma proposta para debate em duplas a respeito da possibilidade de manter ideais firmes em tempos de guerra.

Concluindo, ao tratar o Diário de Anne Frank no contexto da história do Holocausto, é importante convidar o aluno a perceber que o livro não é a história completa de Anne Frank nem um documento sobre o Holocausto; também não é um chamado à "beleza do espírito humano". Como aponta Cynthia Ozick no ensaio em que analisa o uso atual dado ao Diário de Anne Frank, não foi no anexo secreto em Amsterdam onde o Holocausto foi encenado ${ }^{115}$. O epílogo da vida de Anne, ou seja, sua captura e a de sua família, as humilhações às que foi submetida ao chegar a Auschwitz, a fome, o frio, seu traslado a Bergen-Belsen quando provavelmente já padecia de tifo e em condições sub-humanas são todos elementos ausentes no diário pelo simples fato de que a

115 OZICK, Cynthia. "Who Owns Anne Frank?”, In: Quarrel \& Quandary. Essays by Cynthia Ozick. New York: Alfred A. Knopf, 2000. Publicado originalmente na revista The New Yorker, edição de 6 de outubro de 1997. 
vida de sua autora e consequentemente sua escrita, foram subitamente silenciados como resultado da mais absoluta barbárie. São esses os elementos que estão no cerne da história do Holocausto. ${ }^{116}$

O capítulo no livro didático em que é tratado o Holocausto, provê ainda na seção "Livros, sites e filmes", uma lista que inclui um título relacionado ao nosso tema, A Lista de Schindler. O filme é aí descrito como a "história real de um empresário que salvava vidas de pessoas condenadas aos campos de concentração na Alemanha nazista". Talvez não intencionalmente, mas percebe-se novamente a ausência do judeu como protagonista desta história assim como de qualquer referência ao Holocausto ou a mortes nas câmaras de gás - e não somente campos de concentração - que foi realmente o destino de onde Schindler conseguiu resgatar mais de 1.000 judeus.

Assim como defendemos a contextualização no caso do uso da literatura sobre o Holocausto na sala de aula, é igualmente importante que no caso de sua filmografia a mesma também venha acompanhada de alguma discussão, mesmo que breve. No caso em questão, embora A Lista de Schindler tenha sido uma peça chave dentro do processo que levou a uma maior visibilidade do Holocausto como tema na cultura popular não podemos ter certeza quanto ao fato desse filme ter propiciado uma maior conscientização sobre o tema histórico. Nesse sentido, o caráter catártico do filme e seu final redentor em que cenas são elaboradas de modo a atingirem um clímax resolvido ao estilo hollywoodiano são elementos complicadores quando o objetivo é tratar o tema a partir tanto de uma perspectiva histórica, documental ou de testemunho no ambiente da sala de aula ou como aprofundamento dos estudos sobre o Holocausto. Por esses motivos, ao sugerir o filme deveria ficar explícito no livro didático que A Lista de Schindler constitui uma representação do Holocausto que, através de uma narrativa cinematográfica de caráter realista, cria a ilusão de relato histórico.

No entanto, quando devidamente contextualizado, o filme tem um apelo muito interessante no que se refere à voz dos sobreviventes do Holocausto, praticamente inexploradas nos livros didáticos. Além disso, ele constitui uma forte mensagem quanto ao papel desempenhado pelos chamados "justos" e "salvadores", ou seja, pessoas que, como Schindler, arriscaram suas vidas para salvar milhares de judeus das garras do nazismo e que, mesmo quando

\footnotetext{
116 Os diários das vítimas são uma valiosa fonte a ser explorada em sala de aula. O Núcleo de Estudos Arqshoah/LEER da Universidade de São Paulo está realizando um importante trabalho a partir de diários inéditos identificados nos acervos de sobreviventes do Holocausto radicados no Brasil.
} 
permaneceram no anonimato, foram fundamentais em todas e cada uma das histórias de sobrevivência. A Lista de Schindler, por outro lado, contribuiu também para aprofundar um processo que, embora já tivesse sido iniciado anteriormente, atingiu proporções planetárias com a iniciativa do diretor do filme, Steven Spielberg, de instituir a Shoah Foundation no âmbito da Universidade do Sul da Califórnia (USC) nos Estados Unidos e que hoje armazena a maior coleção de testemunhos de sobreviventes não só do Holocausto, mas também do genocídio armênio, do genocídio da etnia Tutsi, em Ruanda e do massacre de Nanjing, na China. ${ }^{117}$

\subsubsection{Análise do volume correspondente ao $3^{\circ}$ ano de Ensino Médio}

Título da obra: Conexão História

Autor: $\quad$ Roberto Catelli

Editora: $\quad$ AJS

Ano: $\quad 2013$

\section{1) Apresentação geral da obra}

Este volume destinado ao $3^{\circ}$ ano do Ensino Médio apresenta seu conteúdo ao longo de 272 páginas distribuídas em duas unidades, a saber "Conflitos e diversidade cultural no Brasil" (subdividida em 3 capítulos) e "Cidadania e Relações de Poder" (subdividida em 5 capítulos). Os temas relacionados ao Holocausto os quais serão analisados neste contexto, encontram-se na Unidade 2, Capítulo 4, intitulado "Nacionalismo, guerras mundiais e autoritarismo" (pp. 82 a 128).

Em cada capítulo são apresentados textos e imagens variados, geralmente acompanhados de atividades ou questões visando a interação com o aluno. Quanto aos textos, algumas seções apresentam fragmentos de obras de autores brasileiros ou estrangeiros (Seção "Pontos de vista" ou Seção "Releitura") e que têm como objetivo o aprofundamento ou a discussão de alguns pontos tratados no texto produzido para a própria obra. Na seção "Interdisciplinaridade" são oferecidos textos de outras áreas do conhecimento, cujo tema está relacionado com o período em estudo. Há também no capítulo uma linha do tempo com os pontos principais do tema discutido, apresentados em sequência cronológica; por último uma seção "Internet" que propõe que o aluno explore na rede além daquilo que foi tratado em sala de aula.

Por tratar-se de um volume destinado aos alunos do último ano da Educação Básica, parte de cada capítulo concentra-se na retomada dos assuntos tratados no livro com questões retiradas

\footnotetext{
${ }^{117} \mathrm{O}$ site da Fundação Shoah encontra-se no endereço www.sfi.usc.edu/vha
} 
de vestibulares e do ENEM. A última página do capítulo, apresenta ainda a seção "Para ler, assistir e navegar" com sugestões de livros, filmes e sites relacionados aos tópicos nele tratados.

2) O conteúdo relacionado ao Holocausto dentro da obra

O Capítulo 4, que abre a Unidade 2 (Cidadania e relações de poder), inicia com um texto do autor da obra que discute o conceito de cidadania num ambiente de guerra, e do lado oposto uma tela do pintor alemão George Grosz de 1937 que, como aparece na legenda, "é uma referência às marcas profundas que a Primeira Guerra Mundial deixou na sociedade europeia.” O tema da cidadania é retomado através de um texto de Maria de Lourdes Manzini-Covre (p. 85) e na sequência (p. 86) é apresentada a seção "Linha do tempo", que cobre o período de 1882 a 1955. Talvez por tratar-se de um longo e conturbado período e talvez porque muitos temas não serão tratados no corpo da obra, percebem-se nessa cronologia não só ausências importantes como também "presenças" de certa forma desconectadas do conteúdo tratado na sequência do livro. No que se refere ao Holocausto, uma presença interessante, por exemplo é a entrada referente ao ano de 1942 onde se destaca a abertura do "campo de concentração de extermínio [sic] de Treblinka, em Varsóvia". Além da sobreposição de classificações que acreditamos seja devida a um erro de digitação já que Treblinka não era um campo de concentração e sim de extermínio, é curioso que seja o único campo citado dentre tantos outros, incluindo o maior e mais conhecido, Auschwitz. Por outro lado, a escolha chama a atenção por tratar-se da única referência a eventos diretamente relacionados ao Holocausto dentro da cronologia proposta embora não seja tratado posteriormente na sequência do capítulo.

A cronologia vem acompanhada de cinco imagens fotográficas sendo duas relacionadas à Primeira Guerra, uma a Mussolini, uma ao ataque a Pearl Harbor e a última ao cogumelo da bomba atômica. A escolha das fotos, neste ponto, não posiciona o Holocausto como um dos eventos fundamentais do período em questão, curiosamente tampouco o nazismo. A seguir, na página 89 , o quadro "Contexto" dá início ao tema proposto no capítulo com um texto sob o título "Imperialismo e nacionalismo no final do século XIX" que apresenta algumas bases para o posterior estudo da Primeira Guerra Mundial e posiciona o período entre o início desta e o fim da Segunda Guerra Mundial segundo a proposta de Eric Hobsbawm -citado pelo autor- como uma "guerra de 31 anos" (p. 90) 118 .

118 Em seu livro Why Did the Heavens Not Darken? (Por que os Céus não Escureceram?), o historiador Arno J. Mayer utilizou o conceito de "Guerra dos Trinta Anos do Século XX". No entanto, após finalizar sua obra, como o 
A análise do contexto e do desenrolar da Primeira Guerra Mundial são tratados nas páginas 91 a 94, conclui com o relato do processo de estabelecimento da Liga das Nações e o início da República de Weimar (p. 96) apresentando assim o pano de fundo que levaria Hitler ao poder; inclui ainda a formação do Partido Nacional Socialista, as SA e as SS além da série de atentados e assassinatos que ocorreram no país: "Em junho de 1922, por exemplo, o ministro Rathenau foi morto por ser judeu" (p. 97). As duas imagens incluídas na mesma página, no entanto, remetem primeiramente à questão econômica da Alemanha em 1923 na qual se veem crianças brincando com blocos formados por notas de dinheiro alemão, em alusão ao período de hiperinflação vivenciado naquele país. A segunda imagem mostra Hitler em uma fotografia de 1938 -ou seja, anos depois da queda da República de Weimar, na qual segundo a legenda, o Führer passa em revista tropas da SS. As páginas 98 e 99 descrevem a crise de 1929 e iniciam o relato sobre a ascensão do nazismo ainda sob o ponto de vista da questão econômica e político partidária, embora introduza algumas considerações ideológicas do partido que "[u]tilizava um discurso francamente nacionalista [...]”, "[r] esponsabilizava o Tratado de Versalhes pela crise e culpava os judeus, especialmente os marxistas, de terem apoiado a assinatura do documento." (p. 100)

Na página 100 inicia-se o estudo do nazismo como ideologia propriamente dita, sob o título "A construção do ideário nazista" onde são descritas as bases de seu programa que "pregava o nacionalismo e estimulava o preconceito étnico, exigindo a expulsão dos judeus da Alemanha". Embora no livro o partido nacional-socialista seja definido como conservador (pp. 99), descreve-se que este "defendia a nacionalização de indústrias, a reforma agrária, a punição dos especuladores financeiros e a participação nos lucros dos trabalhadores nas empresas" (pp. 100) Nesse ponto o autor reitera a formação das forças paramilitares que "tinham como objetivo lutar contra os comunistas, promovendo também atentados contra judeus".

É provável que minha análise esteja aqui parecendo um pouco repetitiva e de certa forma tumultuada. Estou tentando seguir neste ponto a própria forma como os assuntos são apresentados no livro didático em análise e, a partir desse processo, verificar ao mesmo tempo, quais poderiam ser as perguntas que o próprio aluno poderia estar tendo a esta altura. $\mathrm{Na}$ verdade, entender o ideário nazista não é simples, mas por isso mesmo, os rótulos são sempre inadequados ao tentar abordá-lo. O fato de ser contra os comunistas não necessariamente

próprio autor confessa no "prefácio pessoal", o Judeocídio -termo que utilizou para denominar o extermínio dos judeus- "permanece tão incompreensível para mim hoje quanto há cinco anos atrás, quando decidi estuda-lo e repensá-lo". MAYER, Arno J. Why Did the Heavens not Darken? The "Final Solution" in History. New York: Pantheon Books, 1988. 
significa que era conservador; assim como o fato de querer nacionalizar empresas, não o torna socialista. Ou sim? Afinal, o termo "socialista" não faz parte do próprio nome do partido? Nesse sentido, se era socialista, porque perseguia os marxistas? Todas elas são questões complexas que, certamente, dentro do pouco espaço alocado à questão em qualquer livro didático, são difíceis de abordar.

Por outro lado, em meio a todo esse imbróglio conceitual aparece reiteradamente no relato a figura do judeu. Mas afinal, quem são os judeus? Quem é esse personagem que em apenas duas páginas deste livro didático já foi citado várias vezes como alvo de perseguição, primeiro na figura de um ministro de governo assassinado (p. 97), depois como o marxista que concordou com a assinatura do Tratado de Versalhes, mais tarde como um elemento emparelhado aos comunistas, sempre como alvo do ódio de Hitler (p. 100) e na sequência (p. 101) como um capitalista que domina os trabalhadores tal como mostra a charge no final da página onde se lê a frase em alemão: Trabalhadores! Camponeses! Se vocês preferem a dominação judia, então votem nos velhos partidos". ${ }^{119}$

Seria pertinente que nas abordagens que tratam do Holocausto e, portanto, do antissemitismo, estivessem presentes referências relacionadas à história dos judeus e do judaísmo. A ausência dessas referências, ou desse estudo, certamente resultam em "cavidades" na narrativa que o aluno acabará preenchendo por conta própria; nesse processo, corre-se o risco de que esses "enchimentos" carreguem consigo também germes de preconceito derivados de conhecimentos adquiridos nas próprias fontes propagadoras do antissemitismo, hoje acessíveis menos através dos discursos religiosos e mais nas pontas dos dedos com os quais podem-se abrir as portas para milhões e milhões de valiosos canais de informações, mas também para os centros propagadores do ódio.

No contexto da disciplina de História, que é de onde abordamos os estudos sobre o Holocausto nas escolas brasileiras, estudar a experiência judaica no tempo, sua diversidade étnica, cultural e linguística como grupo de memória das inúmeras comunidades que formaram em seus aproximadamente trinta séculos de existência, pode ser indispensável para as futuras

\footnotetext{
${ }^{119}$ No original em alemão: Arbeiter! Bauern! Gefällt euch die Judenherrschaft dann wählt eure alten Parteien. No livro didático lê-se a seguinte legenda sob a foto: "Cartaz da campanha eleitoral do Partido Nazista, de 1933, de caráter antissemita, em que se lê: "Trabalhadores! Camponeses! Se vocês preferem a dominação judia, então votem nos velhos partidos". Na verdade, pelas características da imagem, não restam dúvidas de que é uma caricatura de caráter antissemita como afirma o texto, na qual o "capitalista" é caracterizado como sendo do Partido Nazista. No entanto, a presença da estrela com a foice e o martelo ao centro, é semelhante à do Partido Comunista Alemão (KPD), embora a orientação da foice e do martelo estejam invertidas na figura em relação ao símbolo original.
} 
abordagens do Holocausto. Parece uma tarefa impossível de ser levada a cabo no pouco tempo de que dispõem professores em sala de aula e nos pequenos espaços alocados a cada tema nos materiais didáticos. Porém, se quisermos entender e compartilhar com os estudantes as lições de um fenômeno das proporções do massacre perpetrado contra os judeus na primeira metade do século XX e seu impacto na história da humanidade, é necessário fazer chegar a esse aluno as peças que compuseram o olhar unificador do nazismo sobre o judeu e que resultou na materialização de um ápice de violência em gestação havia quase dois mil anos ${ }^{120}$.

$\mathrm{O}$ antissemitismo genocida da Alemanha nazista foi o "passo além" de um processo que se apoiou nas experiências passadas não somente por todo um discurso construído contra os judeus ao longo de séculos mas também de muitas práticas já adotadas contra eles ${ }^{121}$. Esse "passo além" foi a decisão de aniquilar todos os judeus, até então sem precedentes mesmo na longa história do antijudaísmo. Mas foi também, como analisa o filósofo Vilém Flusser, um passo além na própria maneira como o nazismo definiu o judeu e na resposta que essa ideologia levou a cabo para "resolver" o abismo entre as diferentes judeidades - a do judeu integrado ao judaísmo e a do judeu assimilado - "coisificando-o" e concentrando-o na "promiscuidade de Auschwitz"122.

Porém, do ponto de vista psicológico a partir do qual opera a propaganda, o discurso nazista utilizou elementos amplamente conhecidos, fato do qual podemos derivar sua eficácia. Mas esses elementos não se apoiavam no conhecimento do judeu, do que ele fazia ou no que acreditava, muito menos do povo e de sua história; apoiava-se somente naquilo que foi construído em torno de sua imagem, tanto pelos ideólogos do cristianismo quanto por novas

\footnotetext{
${ }^{120}$ Uma interessante introdução a essa questão em sala de aula está na entrada do diário de Anne Frank citada à página 57 deste trabalho. É o olhar para dentro da questão formulada por uma jovem oriunda de uma família assimilada da Europa Ocidental e que coloca vários dos aspectos em questão.

${ }^{121}$ Para citar somente dois exemplos dessas experiências, o uso da estrela-de-davi como forma de identificar os judeus dentro das diversas áreas ocupadas pelos nazistas ou o isolamento dos judeus em guetos, já haviam sido utilizados séculos antes como forma de destacar esse grupo do resto da sociedade.

${ }^{122}$ FLUSSER, Vilém. Ser Judeu. São Paulo: Annablume Editora, 2014, p. 79. Nesta obra, Flusser interpreta como o sionismo também opera na superação desse abismo embora como olhar "alterificante, comovedoramente humano" e, ao mesmo tempo, a maneira pela qual uma outra resposta à questão judaica, a americana, tem se esboçado: "Está surgindo nos Estados Unidos toda uma civilização (literatura, arte, filosofia, técnica, ciência, maneira de viver) que tem sabor judeu". Ao ler as páginas de Flusser não pude deixar de lembrar-me de um comentário de um amigo em meio a uma conversa a respeito do judeu e do judaísmo. Reproduzo aqui a base do que ele disse: "Quando penso em catolicismo ou budismo, vem à minha mente a imagem do Papa no Vaticano ou de monges em um templo. Quando penso em judaísmo, penso em Woody Allen ou Seinfeld”.
} 
“teorias” pseudocientíficas de conteúdo racial surgidas a partir do século XIX ${ }^{123}$ em um contexto de forte emancipação e assimilação dos judeus, fundamentalmente na Europa Ocidental.

Tudo isso não seria motivo de grande preocupação se os mesmos elementos relatados não estivessem ainda presentes. Porém, sabemos que a resiliência do antissemitismo como fenômeno é inquestionável. As mercadorias em sua despensa iniciada há quase dois mil anos são permanentemente repostas ao tempo em que recebe constantemente novos "produtos", ou os mesmos produtos sob novos rótulos. Hoje, portanto, ao repertório baseado no discurso religioso anti-judeu - que ainda persiste- soma-se o pseudocientífico, as "contribuições" oriundas da propaganda nazista, as acusações de que os judeus inventaram a história do Holocausto ou de que a exploram para benefício político ou financeiro. Ultimamente, o novo refúgio do antissemitismo e seus novos consumidores que negam serem antissemitas e adotam uma nova marca, o "antissionismo", mesmo que para isso não seja para eles obrigatório entender o que é sionismo em primeiro lugar.

Mas, voltando à análise do livro didático proposto, ainda na página 101 onde é tratada a construção do ideário nazista, é apresentado o uso da propaganda e o modo como a arte no nazismo vinculava-se fortemente à política. Nos dois últimos parágrafos do texto é dado especial destaque ao cinema sob o nazismo e à figura de Joseph Goebbels. Neste ponto, vemos na página a última referência aos judeus aos quais muitos dos filmes feitos pela propaganda do nazismo se dirigiam "acusando-os de acumular fortunas explorando o povo e condenando-os por suas poucas qualidades morais, na visão segregacionista do nazismo”. Mais informações sobre um personagem que, mostrado no vácuo, terá pouca ressonância junto aos alunos, além da redação complicada dessas linhas e que acabam insinuando, de fato, que eles tinham "poucas qualidades morais" e que talvez a única atitude do nazismo era segregá-los. São justamente momentos como estes que pedem uma base histórica e conceitual mais sólida, sob risco de perpetuar e aprofundar o próprio discurso que se deseja combater.

A página 102 inclui mais duas fotografias de eventos organizados pelo nazismo, sendo a primeira dos Jogos Olímpicos de Berlim 1936 e a segunda de uma parada comemorativa do aniversário de Hitler.

${ }^{123}$ Foi uma dessas teorias que nos legou o problemático termo antissemitismo introduzido no léxico político por Wilhelm Marr a partir de seu ensaio Der Weg zum Siege des Germanenthums über das Judenthum (O Caminho para a Vitória do Germanismo sobre o Judaismo) e que passou a ser amplamente usado nas campanhas políticas visivelmente antijudaicas que se espalhavam pela Europa na virada do século XIX e primeiras décadas do século XX. 
A página 107 inicia com a descrição dos fatos que deram início ao conflito conhecido como Segunda Guerra Mundial o qual se baseia primeiramente na descrição dos movimentos do exército alemão e as sucessivas invasões e batalhas conflagradas, culminando com a rendição da Alemanha em maio de 1945, a posterior rendição do Japão em agosto e a Conferência de Potsdam que dividiu a Europa em quatro zonas de ocupação aliada (p. 113).

Antes, porém, de dar sequência ao tema seguinte tratado no livro, a Guerra Fria, as páginas 114 e 115 dedicam igual espaço a dois temas intitulados respectivamente, "A bomba atômica" (p. 114, 51 linhas) e "O Holocausto" (p. 115, 50 linhas).

Embora o objetivo desta dissertação esteja relacionado ao tratamento do Holocausto nos livros didáticos, o modo como certos temas contemporâneos ao evento são tratados e os paralelismos estabelecidos na obra, merecem também atenção. Em primeiro lugar, ambos eventos devido à forma como estão "curados" passam a mensagem de serem de alguma forma comparáveis. Ou seja, ambos transmitem a ideia de serem subprodutos de uma guerra na qual civis foram mortos em grande número e ponto final. As nuances e complexidades que levaram a um e outro desenrolar dos fatos estão postos lado a lado de tal maneira que o leitor desavisado -e há grandes chances de que o aluno alvo do livro seja um desses leitores- não consiga percebê-las.

Ainda sem adentrar na análise do texto escrito, percebem-se algumas palavras em destaque (negrito). No texto relacionado à bomba atômica, chama a atenção a presença do nome daquele que é provavelmente o judeu mais famoso da era moderna: Albert Einstein. Transcrevo aqui o fragmento em que o nome aparece, acrescentando dessa forma seu contexto: "Vários cientistas europeus expulsos de seus países por causa do nazifascismo migraram para os Estados Unidos, onde puderam pesquisar em laboratórios que tinham como fundamento as teorias do cientista alemão Albert Einstein (1879-1955) sobre a estrutura do átomo”. E prossegue: “Após um alerta de Albert Einstein sobre um suposto projeto alemão de construção de uma arma desse tipo, os americanos criaram, sob o comando do físico Robert Oppenheimer, o Projeto Manhattan.[...]". 124

Chama a atenção a simplificação da narrativa quanto ao peso atribuído ao "alerta" de Einstein e de seu papel na construção da bomba atômica o qual deixa entrever um encadeamento de fatos que podem levar o estudante a concluir que a construção da bomba atômica e, portanto, as mortes por ela causadas, poderiam ser atribuídas diretamente a Einstein. Não é o objetivo

\footnotetext{
${ }^{124}$ Em negrito na versão original do livro.
} 
deste trabalho entrar em detalhes quanto à participação do cientista no desenvolvimento da bomba atômica, mas sim chamar a atenção para o fato de que decisões políticas tomadas em tempos de guerra dificilmente são levadas a cabo da maneira como é descrito no livro analisado.

Um último aspecto que merece ser considerado encontra-se ainda no subcapítulo "A bomba atômica": "Embora ainda não tivessem concluído o processo de fabricação desse armamento, os norte-americanos esperavam conseguir o que se denominou "solução final", ${ }^{125}$ Cabe aqui chamar a atenção para o uso da expressão "solução final" como referência à decisão tomada pelo governo americano de lançar a bomba atômica em agosto de 1945. Seu uso nesse contexto é curioso já que "Solução Final" foi a expressão com que as autoridades da Alemanha nazista se referiam a seu projeto de aniquilar o povo judeu. Não é possível deduzir o porquê da opção do autor e da equipe que confeccionou este livro didático em incluir a expressão na narrativa sobre o ataque nuclear ao Japão e excluí-lo da narrativa sobre o Holocausto, mas novamente é importante considerar esses aspectos que deveriam ser criteriosamente tratados nas propostas de materiais que tenham como objetivo a educação sobre qualquer tema. A terminologia é um desses aspectos. Expressões como "Solução Final" estão totalmente imbricadas às narrativas sobre o Holocausto, mesmo porque foi criada no próprio contexto histórico pelos próprios nazistas para referir-se àquele evento em particular. Nesse sentido, qualquer referência a ela é provável que remeta o leitor - obviamente aquele que já leu algo a respeito - aos campos de extermínio nazista, nunca a Hiroshima ou Nagasaki. Não é uma questão de apropriação, mas de propriedade.

\section{3) Tratamento do Holocausto no volume em estudo}

O espaço destinado ao Holocausto no livro em questão (p. 115) começa com uma definição do evento como sendo o "genocídio em massa de judeus (e outras minorias) pelas forças nazistas". Embora não haja no texto referência a quais seriam as "outras minorias", o texto prossegue com a estimativa de que "6 milhões de judeus foram mortos entre os anos 1930 [sic] e $1945^{\prime \prime 26 . ~}$

Definições são complicadas e podem acabar deixando de lado alguns aspectos, muitas vezes importantes, e incorporando outros que nem sempre contribuem para uma ideia precisa

\footnotetext{
125 Itálico nosso.

126 O livro didático apresenta aqui uma imprecisão quanto às datas, já que em 1930 o nazismo ainda não havia chegado ao poder, fato que ocorreria somente em 1933.
} 
sobre o que tentamos definir, principalmente quando tratamos de temas de alta complexidade como o Holocausto. No entanto, mesmo que acabem sendo seletivas elas são necessárias. É através das definições que podemos desenhar alguns contornos que permitam uma abordagem mais aproximada do assunto em estudo.

Ao definir Holocausto como "genocídio em massa de judeus (e outras minorias)" tal como aparece no texto em análise - mesmo se descartarmos a redundância da colocação "genocídio em massa" - é provável que o leitor (neste caso o aluno) fique um pouco confuso já que parece haver aí algumas sobreposições que talvez devessem ser tratadas de maneira separada. Mesmo que haja conexões entre um e outro termo e entre perpetrador e alvos -no caso judeus e cada uma das outras minorias, mesmo que não especificadas- seria valioso que os textos demonstrassem uma maior preocupação com as definições. No entanto, é necessário reconhecer que mesmo na historiografia sobre o Holocausto há escolas de pensamento que orientam seu foco para um ou outro aspecto do tema principalmente quanto às motivações e métodos, o que certamente acaba influenciando as mesmas. Sem falar daquilo a que Saul Friedländer se referiu há algumas décadas como a "inquietação" (unease) do historiador perante a "opacidade [que] permanece no cerne do entendimento e interpretação histórica do ocorrido" ${ }^{127}$.

De qualquer maneira, a título de proposta, seria interessante que na sala de aula fossem discutidos alguns conceitos que apoiem o aluno e lhe permitam orientar-se dentro do tema e extrapolá-lo para outros cenários. Nesse sentido, um breve relato histórico sobre o conceito de genocídio poderia ser um bom ponto de partida.

O nascimento e desenvolvimento do termo genocídio no início dos anos 1940 por um refugiado do nazismo, primeiro na Suécia e logo depois nos Estados Unidos, ao mesmo tempo em que o extermínio dos judeus ainda se desenrolava na Europa serviria ainda, de certa maneira, para recuperar a figura de seu criador, Raphael Lemkin, assim como a importância da estrutura jurídica que ele criou -e que anos mais tarde seria em parte utilizada no Tribunal de Nuremberg para julgar os crimes do nazismo- e de sua luta pelo estabelecimento de uma Convenção sobre o Genocídio $^{128}$.

Por outro lado, é essencial determinar a quais grupos nos referimos ao tratarmos de genocídio ou Holocausto e as nuances explícitas ou implícitas na ideologia subjacente ao

127 FRIEDLÄNDER, Saul. "The 'Final Solution": On the Unease in Historical Interpretation". In, History \& Memory, Vol. 1, No. 2 (Fall-Winter, 1989), pp. 61-76.

${ }^{128}$ A Convenção para a Prevenção e a Repressão do Crime de Genocídio foi adotada pela Organização das Nações Unidas em dezembro de 1948. 
tratamento de cada um dos grupos por parte dos arquitetos das políticas de perseguição da Alemanha nazista, sem perder de vista o fato de que o Holocausto do povo judeu visava a aniquilação total, sem possibilidade de escolha ou de "mudança de lado". O nazismo classificou o judeu como "raça" e, como observa Yehuda Bauer em seu livro Rethinking the Holocaust:

Não se pode alterar a própria etnia ou nacionalidade ou "raça" -somente o perseguidor pode fazê-lo, como fizeram os alemães quando "germanizaram" adultos e crianças poloneses. Sem essa ação, não há absolutamente nenhuma outra saída para o membro de um grupo étnico ou nacional visado: aquela pessoa é polonesa ou cigano ou judeu ou sérvio. ${ }^{129}$

Com os elementos acima, parto então para o estudo do segundo parágrafo do texto em análise. Neste ponto tenta-se explicar em linhas gerais o preconceito contra os judeus, indicando inicialmente que este "existia em várias regiões do continente". De fato, o antissemitismo não era um fenômeno circunscrito à Alemanha nem tampouco recente na história europeia. E prossegue: “Os judeus não tinham uma terra natal e não partilhavam do cristianismo, o que os tornava mal vistos pela Igreja Católica”.

Apresenta-se aqui uma escolha complicada quanto à construção desta frase, a qual separo em duas partes. $\mathrm{O}$ primeiro problema refere-se ao fato de que a afirmação toca perigosamente no mito de que "os judeus não têm pátria", devendo, portanto, ser solidamente contextualizada no âmbito do livro didático, caso contrário, em vez de levar a discussão sobre os perigos do antissemitismo para a sala de aula pode-se estar, na verdade, ensinando o antissemitismo, o que certamente não é o objetivo do autor. Ao declarar que os judeus "não tinham uma terra natal" o livro parece de certo modo reafirmar a questão do desenraizamento como uma das “características" do povo judeu e não como parte do discurso antissemita.

O mapa na página seguinte poderia ser utilizado como um contundente recurso visual em sala de aula, já que reflete a longa história dos judeus na Europa -que remontava a milênios em alguns países- por volta do momento em que Hitler subiu ao poder e que constituíam comunidades ricas de elementos e cujos pensadores contribuíram integrando o judaísmo da Torá

${ }^{129}$ BAUER, Yehuda. Rethinking the Holocaust. New Haven: Yale University Press, 2001, pp. 11-12 (tradução nossa). 
e do Talmude com o melhor do pensamento contemporâneo das respectivas sociedades onde habitavam.

O segundo problema diz respeito ao não "partilhar" do cristianismo e ao fato de que os judeus eram "malvistos pela Igreja Católica" como aparece no texto analisado. Isto é certamente um eufemismo, já que o anti-judaísmo, construído ao longo dos séculos pela Igreja Católica e reafirmado pelo Protestantismo através de seu fundador Martinho Lutero, não se traduziu ao longo da história como uma simples antipatia e sim como aberta hostilidade materializada em acusações, perseguições, expulsões, ataques físicos e mortes em uma união contumaz do próprio mito do judeu desenraizado ao libelo de que os judeus mataram Cristo ${ }^{130}$.

TWO THOUSAND YEARS OF JEWISH LIFE IN EUROFE BY 1933

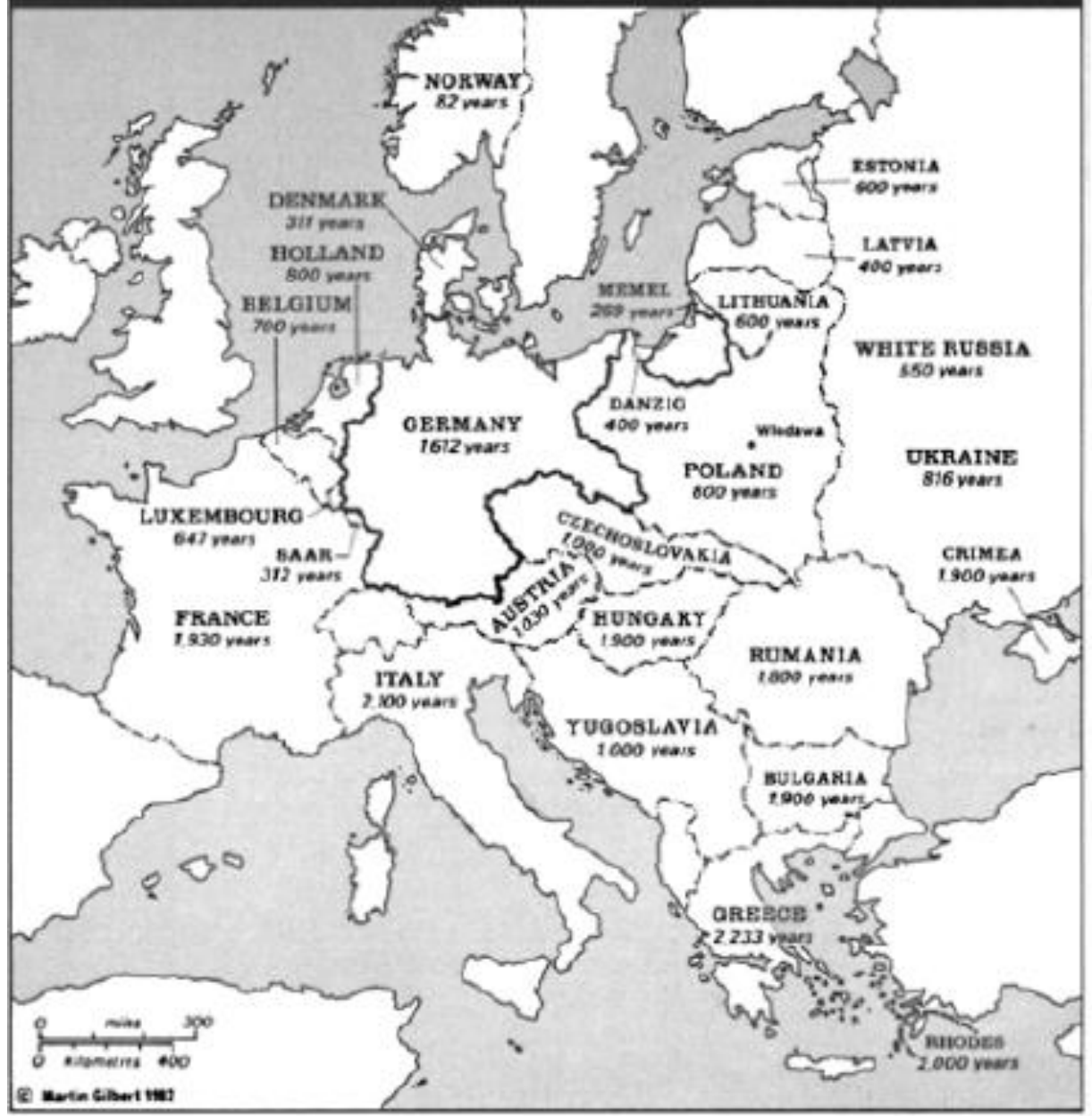

Dois mil Anos de Vida Judaica na Europa por volta de 1933.

Fonte: GILBERT, Martin. The Dent Atlas of the Holocaust. The complete history. Londres: Orion House, 1993, 2 ed., p. 8.

${ }^{130}$ CARNEIRO, Maria Luiza Tucci. Dez Mitos sobre os Judeus. São Paulo: Ateliê Editorial, 2014. 
O parágrafo analisado finaliza afirmando ter havido uma "ampliação" do antissemitismo, que define como "a rejeição dos judeus" provavelmente pelos dois motivos assinalados no início do parágrafo no livro didático. $\mathrm{O}$ antissemitismo genocida da Alemanha nazista não aparece registrado como um "salto" ou "quebra" no sentido da radicalização do anti-judaísmo religioso e do antissemitismo político, que foi efetivado através da aniquilação do povo identificado como “inimigo". Essa ausência de caracterização da singularidade do antissemitismo genocida nazista em relação a outras formas anteriormente praticadas é resolvida no parágrafo seguinte desta maneira: "Desta forma, em diferentes momentos eles [os judeus] foram perseguidos, expulsos de suas casas e cidades, responsabilizados por todo tipo de infortúnio e exterminados ${ }^{131}$. A ideia de extermínio atribuída ao anti-judaísmo e antissemitismo anteriores ao nazismo nivela ambos momentos, criando um elemento de confusão em meio à narrativa que fará com que o leitor deixe de perceber a singularidade do projeto nazista, dentro da longa história do antissemitismo.

O texto introduz ainda um breve parágrafo retirado do livro, História do Medo no Ocidente de Jean Delumeau ${ }^{132}$ no qual este autor define o que para ele são os dois componentes do antijudaísmo: por um lado "a hostilidade experimentada por uma coletividade -ou por uma parte dessa- em relação a uma minoria empreendedora, considerada inassimilável e chegando a ultrapassar um limiar tolerável no plano do número ou do êxito" (Delumeau). O objetivo da análise nesta dissertação é menos o de discutir os pontos de vista dos autores em textos inseridos nas páginas dos livros didáticos e sim examinar as escolhas feitas para serem levadas à sala de aula. Tendo sido o fragmento em questão retirado do contexto de sua obra original e recontextualizado no contexto do livro, a função é analisá-lo somente quanto ao segundo aspecto.

Nesse sentido, temos aqui colocações que, intercaladas a uma exposição sobre o Holocausto nazista traduz um quadro que não se aplica totalmente à situação dos judeus alemães à época da chegada de Hitler ao poder. Em primeiro lugar, com o fim da Primeira Guerra Mundial em 1918 e o estabelecimento da República de Weimar no mesmo ano -primeiro experimento alemão em democracia republicana- o crescimento do antissemitismo na Alemanha não pode ser explicado pelo caráter "inassimilável” do judeu. Ao contrário, deve-se provavelmente à própria integração dos judeus em todas as esferas da sociedade, ápice de um processo que começou ainda na metade do século XVIII, quando Moses Mendelssohn, um jovem

\footnotetext{
131 Grifo nosso.

132 Companhia das Letras, 1996, p. 278
} 
judeu de 14 anos, ávido por aprofundar sua educação, atravessou o portão de entrada a Berlin reservado aos judeus e aos animais tornando-se, anos mais tarde, um dos filósofos mais influentes de sua era e, junto com outros intelectuais, revolucionando a vida dos judeus da Alemanha através de suas ideias de um iluminismo judaico.

De volta ao século XX e aos anos pré-nazismo, temos que as contribuições dos judeus para as artes, as ciências, o teatro, a música e a literatura em um momento em que a Alemanha afirmava-se como um dos centros culturais mais importantes da Europa, eram extraordinárias. Dos 38 alemães premiados com o Nobel em 1938, nove (24\%) eram judeus, uma porcentagem realmente expressiva considerando que os judeus da Alemanha correspondiam a somente $0,9 \%$ da população ${ }^{133}$.

$\mathrm{Na}$ política vários judeus ocuparam cargos de destaque logo nos primeiros anos da República e estavam presentes na liderança de partidos e movimentos políticos. Faziam parte do primeiro grupo figuras como Hugo Preuss, que escreveu o primeiro esboço da Constituição de Weimar, e Walter Rathenau quem atuou primeiramente como Ministro de Assuntos Econômicos e depois como Ministro de Relações Exteriores. No segundo grupo, um dos nomes de maior destaque é o de Rosa Luxemburgo, líder revolucionária do movimento que seria o precursor do Partido Comunista Alemão. Tanto Luxemburgo quanto Rathenau foram assassinados - em 1919 e 1922, respectivamente - por membros de grupos de extrema direita, com profunda orientação antissemita que se faziam cada vez mais presentes na sociedade alemã já nos primeiros anos da República de Weimar.

Uma explicação mais próxima em relação ao caso alemão entre 1918 e 1933, e em particular ao movimento dos grupos que mais tarde se agrupariam sob a égide do nazismo, pode ser encontrada na segunda parte do parágrafo de Delumeau citado no livro didático, quanto ao "medo sentido por doutrinários que identificam o judeu com o mal absoluto e o perseguem com seu ódio implacável mesmo quando ele foi repelido para fora das fronteiras”. Esta definição, desde que contextualizada de maneira abrangente, poderia contribuir para uma maior aproximação ao tema do antissemitismo exterminacionista da Alemanha nazista já que tem como

\footnotetext{
133 Segundo o censo de 1925, a população de judeus da Alemanha era de 564.379, sendo que um terço vivia na capital, Berlim. Fonte: Weimar Republic (1918-1933). Documento produzido pelo Memorial Yad Vashem, Jerusalem, Israel. www.yadvashem.org/odot_pdf/Microsoft\%20Word\%20-\%207794.pdf. Neste documento é possível observar que o processo de assimilação não se dava somente pela participação cultural ou política dos judeus na sociedade, mas também pelo grande número de casamentos com não judeus. Segundo os dados de 1927 apresentados no estudo, $54 \%$ dos casamentos de judeus naquele ano, foram com não-judeus.
} 
foco justamente aquilo que Hitler identificava como a fonte de todos os males, além de introduzir $\mathrm{o}$ aspecto extraterritorial do projeto de aniquilação.

O penúltimo parágrafo dedicado ao tema do Holocausto, traça em linhas gerais e resumidamente o processo que levou Hitler do discurso à ação, definido no livro didático como "seu projeto de condenação do povo judeu". Talvez pela necessidade de ter que condensar em poucas linhas um processo tão complexo, o texto lista três ou quatro etapas, algumas delas em tom eufemístico e sem abordagem da questão territorial que o texto de Delumeau incluído no livro didático e citado no parágrafo anterior, de certa forma, introduzia à questão. A descrição concentra-se a partir daí exclusivamente na Alemanha resultando não só em generalizações como também em imprecisões. Transcrevo aqui a primeira parte a descrição tal como aparece no corpo do parágrafo: "Primeiro [Hitler] limitou o trânsito dos judeus, exigindo-lhes identificação. Na Alemanha, eles perderam a cidadania e foram humilhados publicamente pelas forças nazistas." (p. 115).

Não fica muito claro a que tipo de limitação do trânsito dos judeus o texto se refere nem tampouco a que tipo de exigência de identificação. Sabemos que isso de fato ocorreu em diferentes etapas e em diferentes graus em todo o território ocupado pelas forças nazistas. É provável que a referência aqui seja em relação à exigência da estrela-de-davi que os judeus foram obrigados a usar. Mas essa política somente foi posta em prática a partir de novembro de 1938, após os pogroms que tiveram lugar em várias cidades da Alemanha no evento que ficou conhecido como Kristallnacht (Noite dos Cristais); não fez parte, portanto, das primeiras medidas tomadas contra os judeus.

As primeiras medidas contra os judeus decretadas pelo nazismo, na verdade começaram imediatamente depois da chegada de Hitler ao poder em 1933 e se destinavam a limitar a participação dos judeus na vida pública. Assim, já a partir de abril do mesmo ano, por exemplo, eles foram afastados dos cargos públicos ${ }^{134}$. Ao mesmo tempo, outro conjunto de leis restringia o número de alunos judeus em escolas e universidades alemãs, assim como a atividade de judeus nas áreas médica e jurídica. Em 1934, leis proibiam atores de se apresentarem no teatro e cinema. Em 1935 seriam criadas as já mencionadas Leis de Nuremberg, que definiram o judeu como "raça" e retiraram seus direitos políticos, entre outras disposições. Tratava-se de uma

134 A "Lei para a Restauração do Serviço Civil Profissional", decretada em 7 de abril de 1933, excluía os funcionários públicos e outros empregados judeus de seus cargos no estado. 
política de perseguições e restrições profundas que em pouco tempo iria escalando e finalmente desembocaria na aniquilação física não somente do povo como de sua cultura ${ }^{135}$.

Voltando ao parágrafo em questão temos: "Em seguida, foram levados para campos de concentração $^{136}$ ou obrigados a viver em bairros isolados, chamados guetos. Nos campos de concentração, muitos eram eliminados diariamente e, a partir de 1942, foram utilizadas câmaras de gás como método de extermínio em massa". Aqui o texto implica, em voz passiva, como teria sido a sequência da política de exclusão em relação aos judeus, mas as referências parecem dizer respeito somente à Alemanha, dando a entender ao aluno que tudo esteve circunscrito a seu território, inclusive guetos e campos de concentração. Isso implicaria em desvios sérios para a compreensão sobre o tema, que podem gerar dúvidas importantes e derivar em complicados questionamentos. Por exemplo, há no fragmento em estudo, no mínimo três elementos que deveriam ser separados: campos de concentração, guetos e câmaras de gás. Em primeiro lugar, seria importante chamar a atenção para a divisão entre pelo menos dois tipos de campo: concentração e extermínio. E havia ainda os campos de trabalho. Alguns eram exclusivos para cada uma das finalidades, em outros as mesmas se sobrepunham, como ocorria em Auschwitz, que era ao mesmo tempo campo de concentração, trabalho e extermínio. Assim como Auschwitz, os campos exclusivamente de extermínio, como Chelmno, Treblinka, Sobibor, Majdanek, Belzec, estavam todos localizados em território polonês. Dentre os milhares de campos havia ainda aqueles que cumpriam o papel de campo de trabalho, mas que também contavam com câmaras de gás. Entre eles Ravensbrück, um campo destinado exclusivamente a mulheres em território alemão.

A política de reclusão em guetos, por outro lado, deu-se exclusivamente nos territórios ocupados pela Alemanha, fundamentalmente no leste europeu, após a invasão da Polônia em 1939 e da União Soviética em 1941. Alguns desses guetos duraram anos, outros alguns meses

\footnotetext{
${ }^{135} \mathrm{O}$ objetivo dos nazistas não era somente o desaparecimento físico do judeu-pessoa, mas de sua história como um todo. O nazismo idealizava um mundo desconectado de suas origens culturais e teológicas em cuja origem estava o judaísmo. Como demonstra Alon Confino em seu livro A World Without Jews, a Noite dos Cristais foi a materialização desse imaginário. No centro das piras que queimavam os objetos sagrados do judaísmo por toda a Alemanha ardiam invariavelmente os rolos da Torá das sinagogas de cada localidade, também em chamas: “(...) os judeus refletiam um passado histórico -origem histórica para ser exato- que precisava ser extirpado para que a nova Alemanha nascesse. Para criar uma civilização nazista, uma nova ordem europeia e uma nova forma de cristandade, a civilização judaica tinha que ser removida. As origens históricas da Alemanha precisavam ser purificadas até o passado compartilhado dos judeus com a cristandade, via o texto canônico". CONFINO, Alon. A World Without Jews. The Nazi Imagination from Persecution to Genocide. New Haven: Yale University Press, 2014.

136 Negrito aparece no original.
} 
sendo estes utilizados somente como transição, previamente à deportação dos judeus para os campos de extermínio.

Estas diferenciações são importantes porque somente a partir delas damos conta das dimensões geográficas e numéricas do processo de aniquilação dos judeus da Europa. Ao circunscrever a exposição ao território alemão, o estudante pode perguntar-se de que maneira se chega ao número de 6 milhões de judeus mortos na Europa, já que na Alemanha havia aproximadamente 500.000 e muitos deles inclusive sobreviveram.

Finalmente, no último parágrafo dedicado ao Holocausto, o livro faz menção aos demais grupos visados pelo nazismo, embora sem detalhamentos. O parágrafo conclui no seguinte tom: “Os horrores cometidos pelos nazistas não se limitaram apenas aos judeus. Ciganos, soviéticos, inimigos políticos, doentes mentais, homossexuais, eslavos e pacifistas também foram massacrados em campos de extermínio". Seria importante identificar no contexto do livro didáticos, as motivações que desembocaram em cada um destes genocídios perpetrados pela Alemanha nazista e comparar diferenças e semelhanças entre eles e em relação ao Holocausto do povo judeu.

O tema se encerra com uma fotografia acompanhada da legenda: "Sobreviventes do campo de concentração de Buchenwald, Alemanha, em 16 de abril de 1945". A imagem não é acompanhada de nenhuma análise ou histórico em relação ao campo. Um aspecto interessante desta fotografia a ser analisado em sala de aula é que vários dos prisioneiros aqui retratados identificaram, anos mais tarde, seus rostos. Entre eles, o célebre autor e ativista ElieWiesel (dentro do contorno branco), Prêmio Nobel da Paz em 1986. Em um de seus trabalhos mais conhecidos, Noite, Wiesel relata suas memórias como sobrevivente do Holocausto. Nas suas memórias, as próprias palavras de Wiesel nos convidam a refletir: o que é reconhecer-se para um sobrevivente do Holocausto?

Um dia, pude me levantar depois de unir todas minhas forças. Queria me ver no espelho que estava pendurado na parede em frente a mim. Eu não me via desde o tempo no gueto. Do fundo do espelho, um cadáver me contemplava. Seu olhar em meus olhos nunca mais me deixou. ${ }^{137}$

${ }^{137}$ WIESEL, Elie. La Nuit. Paris: Les Éditions du Minuit, 1958/2007. 


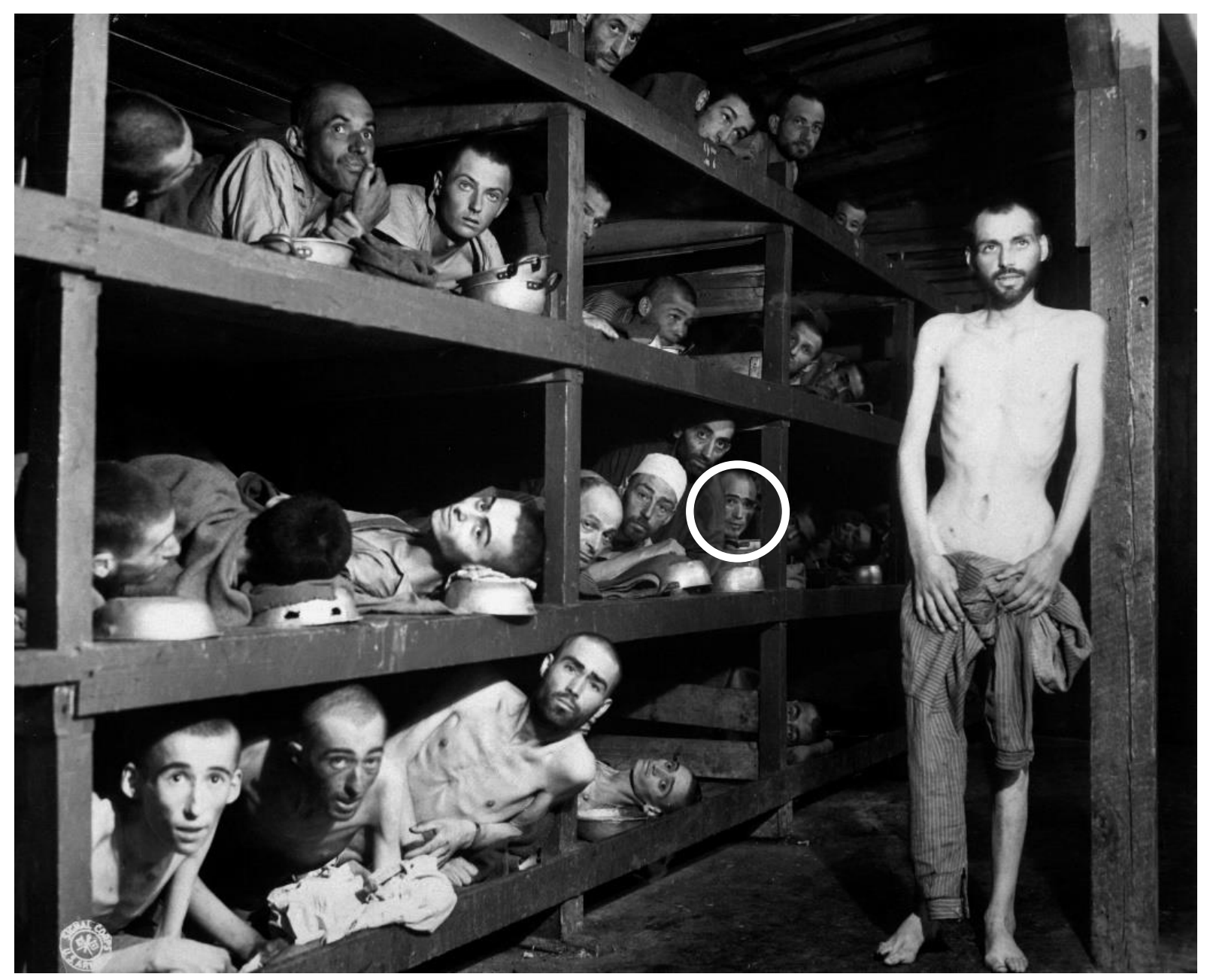

Sobreviventes do barracão 56 de Auschwitz, 16 de abril de 1945.

Indicado por um círculo branco, o rosto de Elie Wiesel

Fotógrafo: Soldado H. Miller (Exército dos Estados Unidos)

Fonte: United States Holocaust Memorial Museum (USHMM), Washington, EUA 


\section{PELAS MÃOS DE UM SOBREVIVENTE: O TESTEMUNHO COMO LAÇO}

\subsection{O Holocausto na história de uma vida narrada: projeto-piloto}

$\mathrm{O}$ trajeto percorrido durante a realização deste trabalho possibilitou-me visualizar respostas a algumas inquietações que me acompanham desde o início da jornada que levou à conclusão deste estudo, ou seja, a de como abordar a educação sobre o Holocausto. Desse modo, como consequência do diálogo resultante da análise dos livros didáticos existentes nos moldes apresentados, soma-se o desenho de propostas para materiais que permitam de certa forma aproximar o estudante das questões fundamentais que a humanidade herdou com a experiência do Holocausto e com os elementos que delas se depreendem. $\mathrm{O}$ objetivo é engajar o aluno em um processo de reflexão sobre valores e ética, mas também, despertar-lhe o interesse na análise dos fatos à sua volta.

A postura decorrente quanto à abordagem do assunto em termos pedagógicos propõe uma educação sobre o Holocausto em que as histórias de vida singulares sejam conhecidas, ouvidas e trabalhadas no próprio contexto do estudo dos fatos históricos. Decisões políticas, boas e más, afetam, em primeiro lugar, as pessoas. A barbárie do Holocausto transformou as vidas de milhões com extrema violência. $\mathrm{O}$ trauma da perseguição contra os judeus durante o nazismo ainda ecoa nas gerações subsequentes.

O tópico inicial de minha proposta para o desenvolvimento dos materiais a serem apresentados em escolas prevê assim o uso dos registros de testemunhos dos sobreviventes radicados no Brasil ${ }^{138}$ e a partir deles, estabelecer a simbiose com fatos, personagens e lugares históricos. Cada história de vida expressa suas singularidades, mas ao mesmo tempo está inserida em um contexto histórico e geográfico muito maior e que, naquele cenário de perseguição, dentro das diferentes etapas da política de exclusão e eliminação do povo judeu pelo Terceiro Reich, também permite pontos de contato e convergência.

Para o desenvolvimento desses projetos, tomo emprestados de Roland Barthes os conceitos de studium e punctum. ${ }^{139}$ Embora ambos tenham sido desenvolvidos pelo autor como categorias no âmbito da crítica fotográfica, creio que podem contribuir neste âmbito, permitindo

\footnotetext{
138 Os testemunhos que servem como base para as propostas foram realizados pela equipe do projeto Vozes do Holocausto, do Núcleo de Estudos LEER/Arqshoah da Universidade de São Paulo.

${ }^{139}$ Barthes, Roland. La Chambre Claire: Notes sur la Photographie.Paris: Gallimard Seuil, 1980.
} 
uma abordagem geral do histórico, do social e do político (o studium), ao tempo que das entrevistas, desprendem-se elementos do pessoal, da humanidade do testemunho e da testemunha (a voz, o punctum) marcando o ouvinte ou leitor com um "elemento pontiagudo" e ao mesmo tempo buscando o laço, a reciprocidade a partir da qual as vozes ou as palavras, até então soltas, ancoram-se num significado. No studium a educação como saber e cortesia, o interesse vago; no punctum a mancha, o corte da lâmina ${ }^{140}$. É ao mesmo tempo um jogo de zoom - mais uma vez a metáfora da fotografia, vem como auxílio à ideia- aproximando e afastando a imagem, partindo da singularidade de uma experiência em direção à totalidade do momento histórico e a ela voltando.

$\mathrm{Na}$ análise de testemunhos de sobreviventes do Holocausto, percebe-se claramente a possibilidade para esse contraponto. Aos seus "dizeres", os das testemunhas, podem-se enlaçar os "saberes" da historiografia e assim levá-los à sala de aula para que o diálogo se estabeleça a partir de uma abordagem coerente com as opções históricas e teóricas. A proposta é, portanto, de entrelaçar os fatos históricos, personagens e lugares elucidando as particularidades e generalidades que marcaram essas vidas, devolvendo-lhes desse modo, parte do protagonismo que os livros didáticos de certa forma lhes negam.

Assim, a partir de testemunhos em primeira pessoa coletados pela equipe do Projeto Vozes do Holocausto ${ }^{141}$, os livretos que estão sendo criados incluem trechos das entrevistas que, junto com a iconografia fornecida pelo autor do testemunho, têm como objetivo a reflexão sobre o evento histórico. Ao mesmo tempo, esses trechos serão entremeados com acontecimentos históricos relatados nos próprios testemunhos, vivenciados pelo sobrevivente diretamente, ou que são parte de cada contexto particular. Cada nova lei, cada nova decisão, cada nova política tinha um impacto na história de vida abordada e em muitas outras vidas.

Os testemunhos nos revelam desse modo não somente o que aconteceu, as decisões que essas pessoas tomaram; o que elas conseguiam e principalmente, o que não conseguiam ver, provocando assim uma reflexão baseada não no julgamento, não no que "eu teria feito de forma diferente", mas na percepção dos inimagináveis e, na maioria das vezes, instransponíveis

\footnotetext{
${ }^{140}$ Ibidem.

${ }^{141}$ Coordenado pela Profa. Dra. Maria Luiza Tucci Carneiro, este projeto, iniciado em abril de 2015, tem como objetivo registrar em áudio e vídeo as histórias de vida de sobreviventes do Holocausto refugiados no Brasil. O projeto dispõe-se igualmente, a "arquivar, identificar, digitalizar e disponibilizar estes testemunhos junto ao site do Arqshoah/LEER-USP e das instituições parceiras, com o objetivo de perpetuar a história e memória do Holocausto em detrimento da ideologia racista, do esquecimento/silêncio e do negacionismo.
}

http://leer.vitis.uspnet.usp.br/index.php/projetos/vozes-do-holocausto

Consultado em 18 de setembro de 2016. 
desafios com os quais essas pessoas se deparavam. Cada uma dessas histórias de vida provê uma infinidade de tópicos que poderiam resultar em aulas ou cursos inteiros sobre os diferentes aspectos inerentes à história do Holocausto e ao contexto histórico global.

A função delas, no entanto, não é esgotar o tema, muito pelo contrário: é aproximar o aluno, através das vozes, à história do evento e à sua herança ética. O sucesso dos materiais terá sido alcançado, se eles conseguirem despertar o interesse por explorar além do que lhes é oferecido por eles.

\section{Seleção cartográfica}

No cruzamento dos testemunhos com o processo histórico, é indispensável ainda abordar cuidadosamente a geografia dos fatos para que se conheça a extensão da perseguição implementada contra os judeus pelo Terceiro Reich. Para esse fim, o projeto aenta para a inclusão de mapas selecionados de modo a elucidar, de uma maneira mais precisa, o alcance dos eventos, tal como mostra o exemplo:

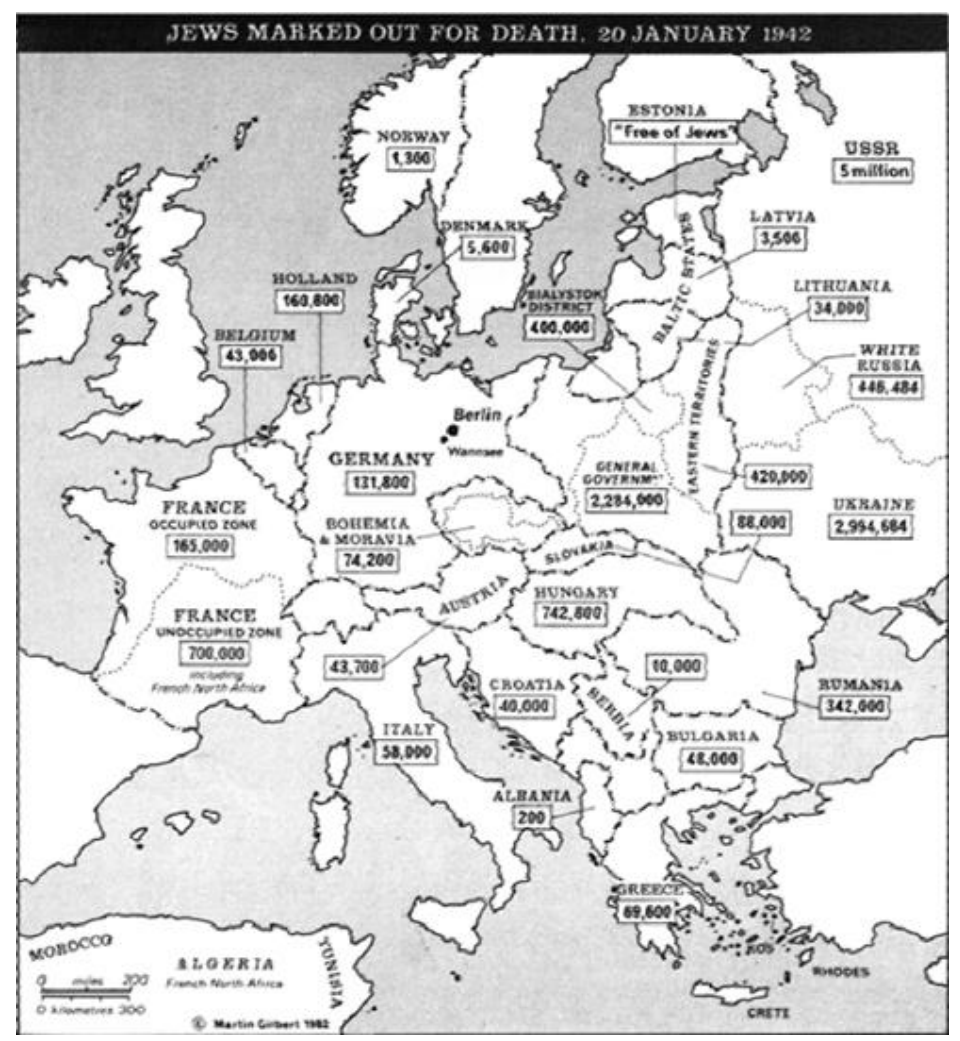

Mapa 1. Judeus marcados para a morte, 1942

Fonte: Martin Gilbert. Atlas of the Holocaust.

London, Taylor \& Francis e-Library, 2005 
O Mapa 1, por exemplo, extraído do livro de Martin Gilbert, Atlas of the Holocaust ${ }^{142}$, permite visualizar o alcance geográfico e numérico do projeto do governo alemão para o extermínio dos judeus. Ele foi produzido a partir dos documentos encontrados nos arquivos do Terceiro Reich.

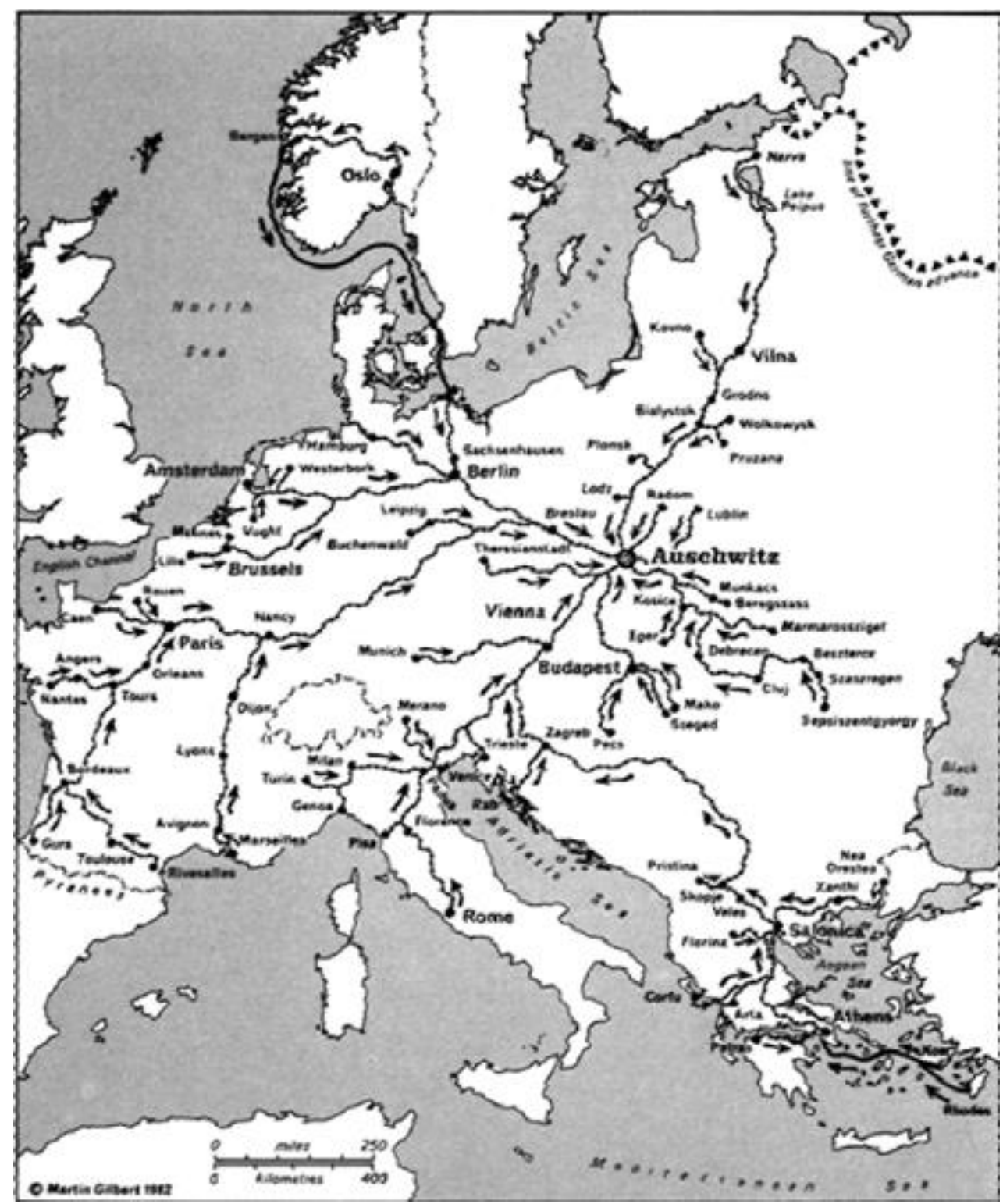

Mapa 2. Deportações para Auschwitz

Fonte: Martin Gilbert. Atlas of the Holocaust.

London: Taylor \& Francis e-Library, 2005

${ }^{142}$ GILBERT, Martin. The Dent Atlas of the Holocaust. London: Taylor \& Francis e-Library, 2005 (Electronic Edition) 
O Mapa 2, por sua vez, indica a origem e os trajetos que conduziam os deportados das mais diversas regiões da Europa, rumo ao seu extermínio, no mais conhecido campo de concentração da política de Solução Final. A extensão da perseguição é vertiginosa.

A pesquisa, no entanto, não se limita ao contexto geral, devendo ser incluídos mapas que correspondam às geografias de cada testemunho. 


\subsection{O Holocausto através de sete testemunhos}

\subsubsection{Mira Wexler Gutfilen: sobrevivência nas florestas da Ucrânia}

\section{Introduzindo a história de Mira}

"Eu não fui criança". Esta frase, pronunciada por Mira logo no início de seu testemunho, nos enfrenta de forma eloquente a uma inimaginável história de violência e injustiça extremas, mas também a um relato de resiliência, coragem e altruísmo em uma área ocupada pela Alemanha nazista onde ela vivenciou, de forma dramática, seus primeiros anos de vida. Foi em Stara Huta, cidade então localizada na Polônia (hoje pertencente à Ucrânia) que em 1941 Mira, então com apenas cinco anos de idade, viu sua família ser forçada a morar no gueto da localidade vizinha de Ludwipol. Pouco antes da liquidação do gueto no ano seguinte, Jacob Wexler, pai de Mira, conseguiu tirá-la do gueto junto com sua mãe, Chana Wexler, e abrigá-las em um bunker onde havia vários judeus.

Mas, como nos conta Mira, "todo dia tinha que ter sangue judeu, era o que dava vida a eles". Assim, durante uma Aktion (ação) dos alemães em uma casa vizinha ao bunker onde a família Wexler estava alojada, Jacob saiu para ver o que estava acontecendo e não voltou mais.

Com a morte de seu marido, Chana fugiria com a pequena Mira e o irmão de Jacob, Joseph, para a fazenda de uma família católica polonesa que os abrigou, os Weglowski. A amizade das duas famílias era conhecida, portanto o risco era enorme. Mira e sua mãe foram então esconder-se nas florestas em torno àquela localidade e quando a oportunidade surgia, iam buscavar alimentos na casa dos Weglowski, sempre dispostos a ajudar. Essa situação durou dois anos. No fim da guerra, Chana e Mira Wexler vieram para o Brasil.

Após 70 anos, em 2015, uma fundação americana (The Jewish Foundation for the Righteous), organizou nos Estados Unidos o reencontro de Mira com Helena Weglowski, sua amiga e salvadora.

A história de Mira nos remete a várias instâncias e particularidades do Holocausto na Polônia e Ucrânia, principalmente quanto à formação, manutenção e liquidação do sistema de guetos e à questão do refúgio nas florestas onde também operavam os partisans. Por outro lado, também nos oferece, como todas as demais histórias de sobrevivência, um olhar sobre os salvadores, que neste caso, foi coroado com o reencontro. 


\section{LIVRO 1 - Mira Wexler Gutfilen ${ }^{143}$}

\section{"Eu não fui criança; nem eu, nem nenhuma criança” \\ Mira Wexler, Rio de Janeiro, Julho 2015}

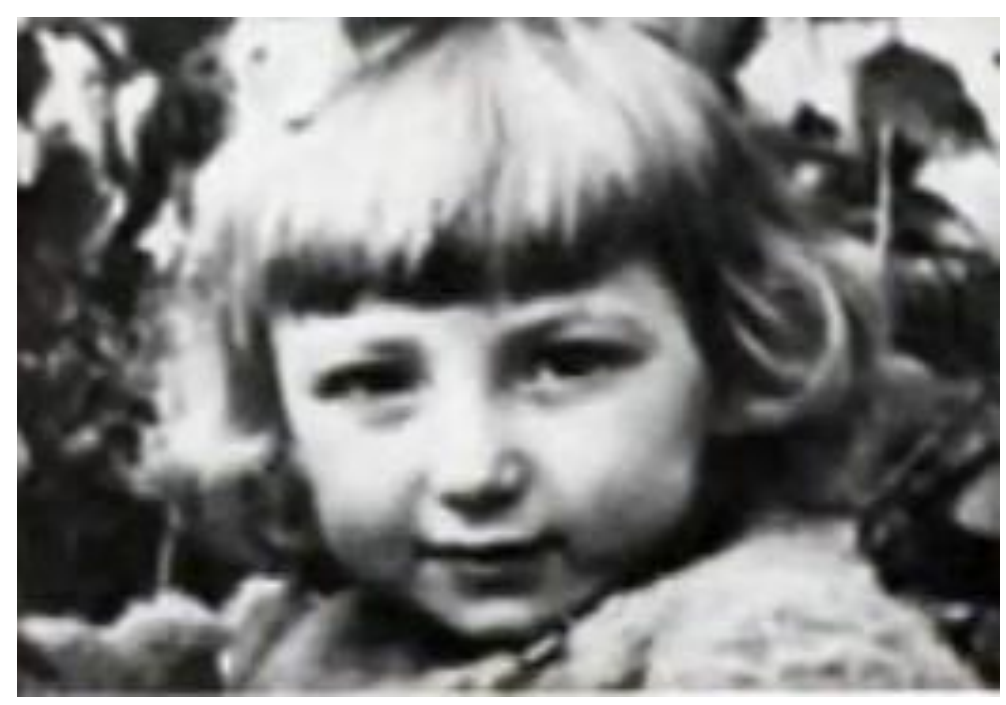

Mira Wexler aos três anos de idade

\section{Introdução}

Ao deparar-nos com toda a ternura e graça que este rostinho nos transmite, não temos como imaginar tudo o que, em pouquíssimo tempo, sua dona, a pequena Mira, iria ver e viver.

Ao ouvirmos ou lermos seu relato de vida, mais de setenta anos depois, nossos sentidos também não nos permitem apreender a dimensão da tragédia que se abateu sobre ela e sobre milhões de judeus naquela Europa que, em pleno século XX estava ensandecida de ódio e violência. Um ódio que custaria a vida de pelo menos 1,5 milhão de crianças judias.

No testemunho de Mira, cruzam-se outras histórias que adquirem um caráter indissociável. Em primeiro lugar, a história de sua mãe, Hannah, que apesar dos inimagináveis

${ }_{143}$ Testemunho de Mira Gutfilen ao Projeto Vozes do Holocausto (Arqshoah/LEER), Rio de Janeiro, 08 de julho de 2015. Ficha Técnica: Entrevistadoras, Profa. Maria Luiza Tucci Carneiro; Câmera, Laís Rigatto Cardillo; Transcrição, Samara Konno. 
obstáculos, fez tudo para tentar sobreviver e salvar a vida de sua única filha. Ao mesmo tempo, a história de uma família polonesa, os Weglowski, cujos membros arriscaram suas vidas para proteger e salvar pessoas às quais estavam unidos por fortes laços de amizade.

Mas como todas as histórias de sobreviventes daquele inferno, esta também é uma história de inúmeras perdas.

Da família de Mira, somente ela, sua mãe, um casal de tios e dois primos - cujos pais foram assassinados - sobreviveram. Os demais membros daquela família, inclusive o pai de Mira, foram fuzilados na própria cidade onde viviam, perto de suas casas.

Mira e sua mãe são parte da pequeníssima porcentagem de judeus da Volínia (então na Polônia), que sobreviveram àquela catástrofe. É uma das poucas vozes que puderam ser ouvidas após aqueles anos.

Por isso mesmo, a voz de Mira é ao mesmo tempo a voz de Ludvipol, cidade em que ela nasceu, e das centenas de pequenas comunidades de um território que se tornaria, entre junho 1941 e fevereiro de 1943, o centro de gravidade de um massacre sem precedentes, primeira etapa de uma política deliberada de extermínio de um povo e de uma cultura, que seus idealizadores, os líderes da Alemanha nazista, denominaram a "Solução Final da Questão Judaica”.

Na história de Mira não veremos campos de concentração, nem estrelas amarelas, nem braços tatuados com números. Não veremos nenhum dos símbolos que regularmente se fazem presentes em filmes, documentários, fotografias ou livros sobre o Holocausto. As câmaras de gás, os crematórios, a fúria de Auschwitz, logo estariam por vir. Seriam a mesma fúria, a mesma violência, a mesma barbárie, mas com outras "técnicas".

Ludvipol foi totalmente destruída, assim como foram totalmente destruídos os milhares de comunidades do leste europeu onde, por séculos, até o final dos anos 1930, milhões de judeus viveram e se desenvolveram. Seus nomes não fazem parte dos mapas atuais.

Hoje, o local que antes era ocupado por Ludvipol, banhado pelo rio Sluch e rodeado por frondosas florestas que testemunharam tanto a vida previamente à guerra, quanto os horrores daqueles anos, se chama Sosnova.

Porém, dessas centenas de lugares e desses milhões de judeus assassinados, restaram a memória e as palavras que nos são transmitidas por seus sobreviventes. Mais do que relatos, são retratos de localidades e vidas aniquilados por um ódio sem paralelo. 


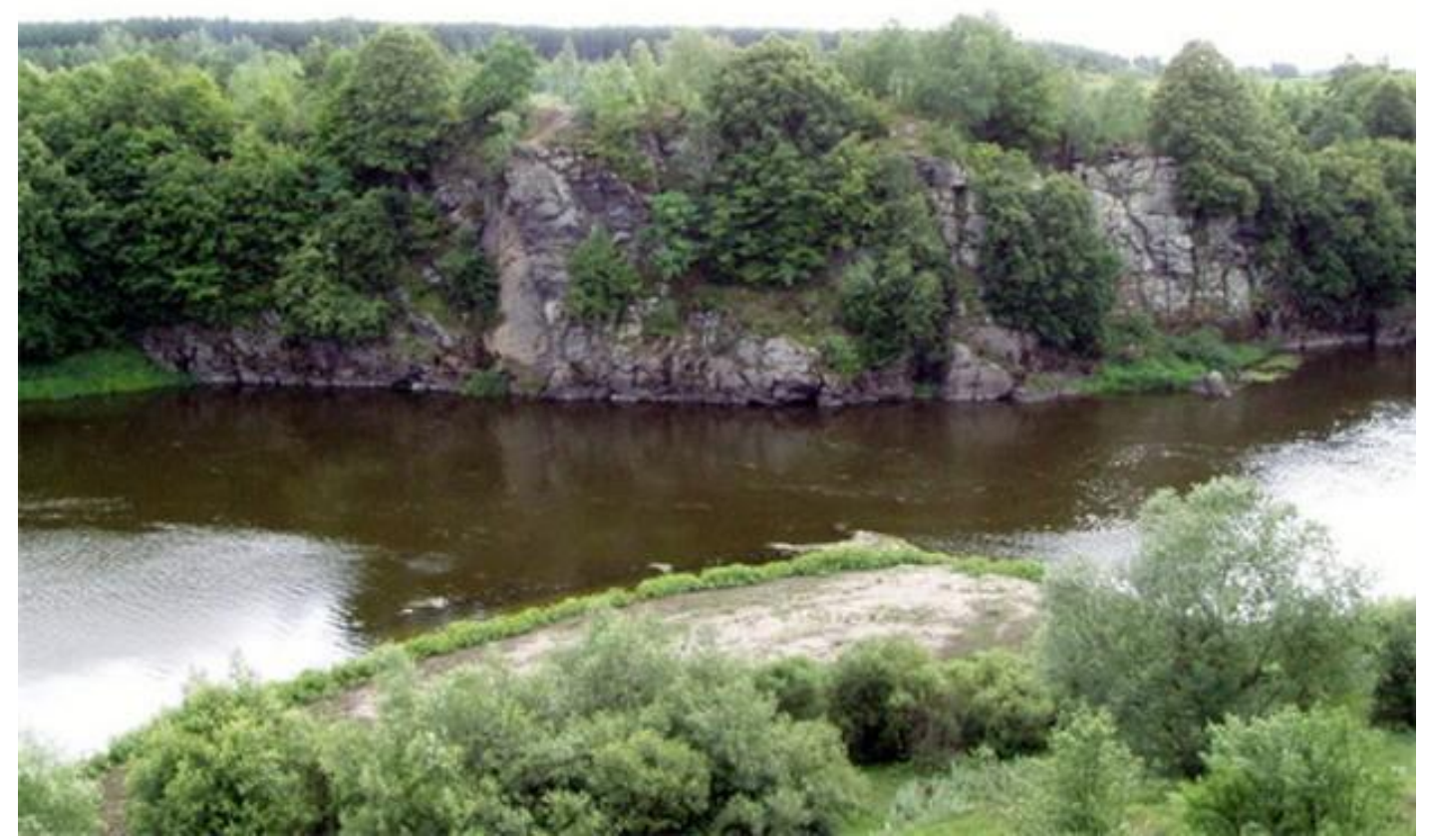

O rio Sluch hoje.

Esse rio já não banha a cidade de Ludvipol, arrasada durante a guerra No lugar que ela antes ocupava está hoje a cidade de Sosnova.

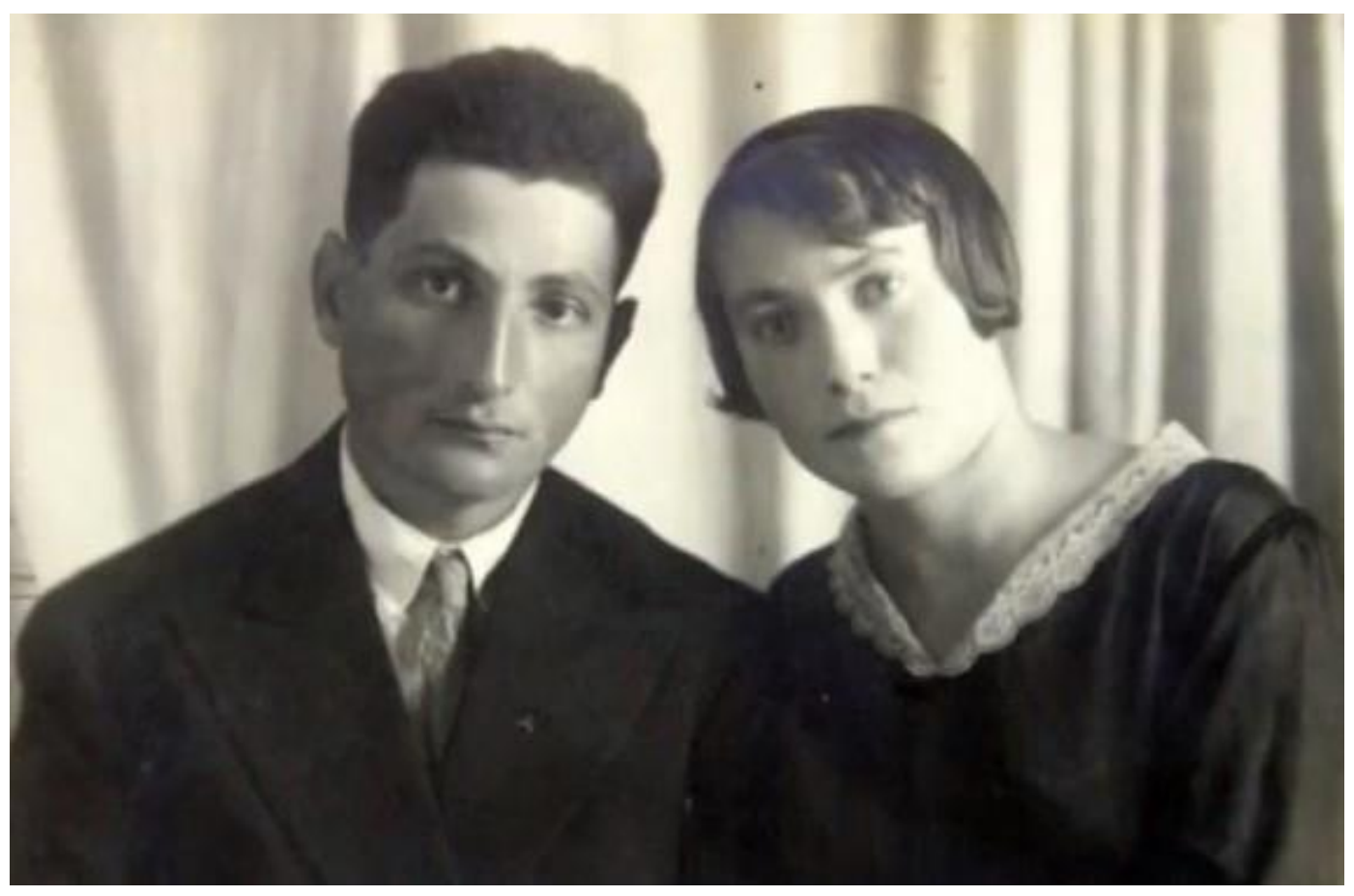

Yankiel e Hannah Wexler, os pais de Mira

Fonte: Documentário A Tale of Two Families

Jewish Foundation for the Righteous, 2015

Captura de tela 
Um conto de duas famílias ${ }^{144}$

Mira Wexler nasceu em 20 de março de 1936 na cidade de Ludvipol, localidade pertencente à região de Volínia, Polônia (hoje Noroeste da Ucrânia).

Filha única de Yankiel e Hannah Wexler, o pai de Mira era proprietário de um moinho de trigo instalado em uma grande fazenda, na localidade vizinha de Stara Huta.

Como o traslado diário de Ludvipol a Stara Huta era difícil, os donos da fazenda, Florian e Maria Weglowski, convidaram Yankiel, Hannah e a pequena Mira, a mudar-se junto com eles. Yankiel aceitou o convite e as duas famílias passaram a viver juntas, na mesma casa, como uma só família. Até aquele momento, não sabiam que seus destinos ficariam unidos para sempre.
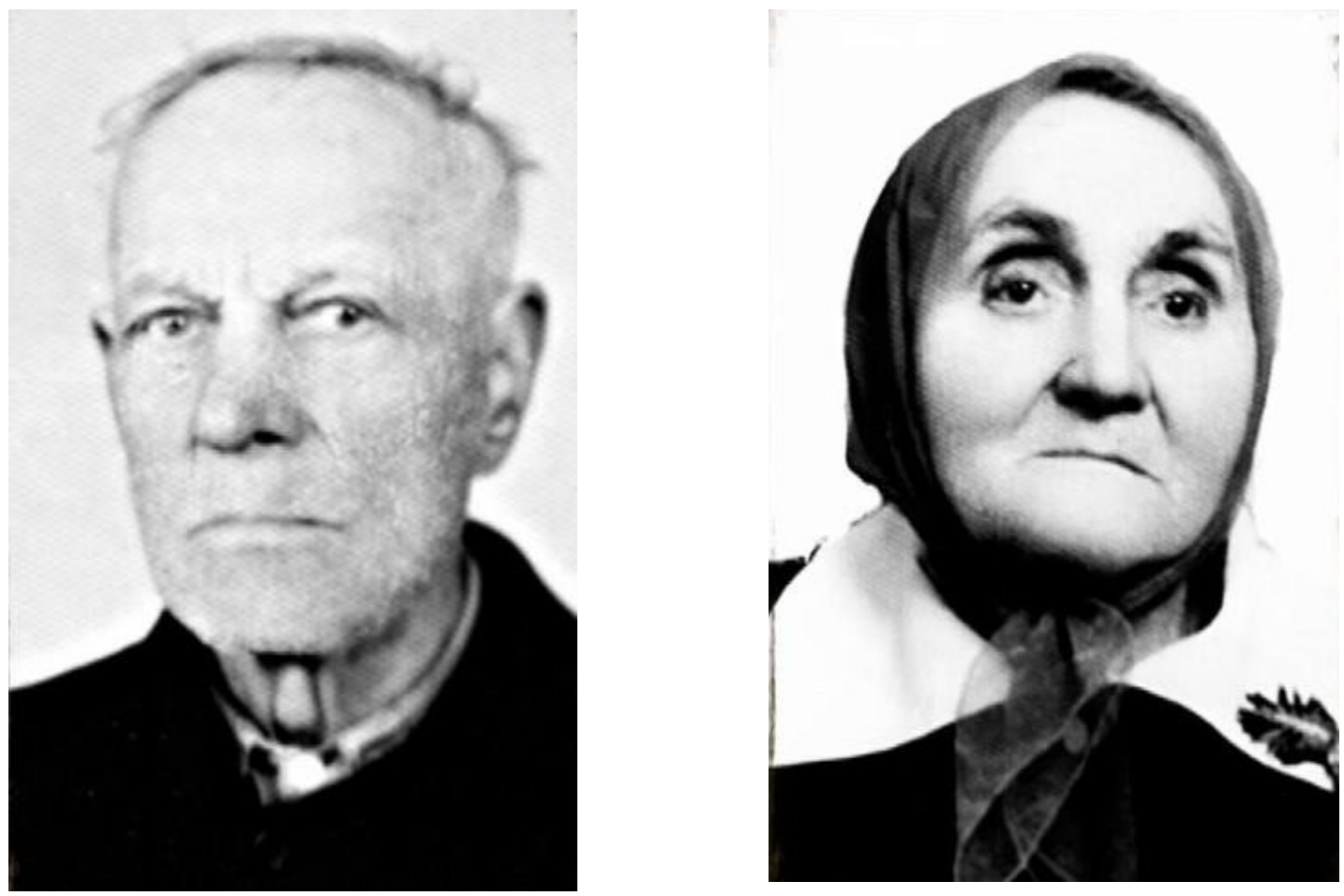

Florian e Maria Weglowski

Fonte: Documentário A Tale of Two Families

Jewish Foundation for the Righteous, 2015

Captura de tela

${ }^{144}$ Em inglês, A Tale of Two Families, é o título do documentário sobre a história de Mira Wexler e Helena Weglowski, representante da família de salvadores, realizado pela Jewish Foundation for the Righteous (Fundação Judaica para os Justos), instituição americana comprometida com o reconhecimento e o cuidado material de justos que ajudaram judeus a sobreviver o Holocausto. A JFR encarrega-se também de reunir anualmente um sobrevivente e seu salvador, em encontros anuais que acontecem nos Estados Unidos. O compromisso da Fundação é também levar às escolas a história do Holocausto. O vídeo do reencontro de Mira e Helena pode ser visto, em inglês, através deste link: https://jfr.org/video-library/reunion-2014/ 
Os Weglowski tinham quatro filhos: Leontina, Stanislaw, Witold e Helena. Mira era a menorzinha do grupo, mas todos brincavam juntos: subiam em árvores para pegar frutas frescas, passeavam nas florestas que cercavam a fazenda; no verão, assim como as outras crianças da região, banhavam-se em seus rios e lagos.

\section{Os primeiros anos da guerra}

Em 23 de agosto de 1939, Alemanha e União Soviética assinaram um acordo, conhecido como Pacto de Não Agressão (ou Molotov Ribbentrop) o qual, entre outras disposições, permitia a divisão da Polônia (localizada no meio das duas potências militares), em duas esferas de interesse: a alemã e a soviética.

Em 1 de setembro de 1939 a Alemanha invade a parte Ocidental da Polônia. Em 3 de setembro, Grã-Bretanha e França, comprometidas com a proteção das fronteiras da Polônia devido a um acordo anterior, declaram guerra à Alemanha. Começa assim a Segunda Guerra Mundial.

Em novembro do mesmo ano, a União Soviética invade a Polônia a Leste, incorporando a área onde Mira e sua família moravam. Quanto à segurança física, a anexação da região onde os Wexler moravam pela União Soviética, não repercutiu fortemente sobre a população judaica local.

Do ponto de vista cultural, no entanto, para os judeus de comunidades como Ludvipol, o abalo se fez sentir. As escolas judaicas, por exemplo, as Tarbut, envolvidas no projeto de renascimento da língua hebraica dentro do contexto do movimento sionista, foram transformadas em escolas do governo soviético. A língua não mais poderia ser o hebraico, mas o iídiche. Os livros da biblioteca das escolas seriam retirados e destruídos.

Do ponto de vista econômico, a invasão soviética implicou na desapropriação de bens e terras, afetando diretamente os Weglowski e os Wexler; eles não mais seriam proprietários nem da fazenda, nem do moinho. Porém, todos puderam permanecer naquele lugar, trabalhando as terras e moendo o trigo. Para as crianças, alheias às mazelas que já se abatiam sobre suas famílias e à catástrofe que se aproximava, aquela vida idílica continuaria ainda por mais algum tempo. 


\section{O fim da inocência}

Em 22 de junho de 1941, quando Mira tinha apenas 5 anos, a Alemanha nazista invadiu a União Soviética, rompendo assim o Pacto de Não Agressão assinado pelas duas nações. O plano de extermínio em massa dos judeus, conhecido como Solução Final, que já vinha sendo desenhado pelas autoridades nazistas, passaria então a ser implementado com força total. A primeira etapa desse plano consistia na criação dos chamados Einsatzgruppen.

\section{O que eram os Einsatzgruppen?}

Eram unidades móveis de extermínio avançando "nos calcanhares" do exército alemão que penetravam os territórios ocupados pela União Soviética. Eram formadas por homens da SS, Waffen SS, forças armadas alemãs e unidades da polícia alemã, totalizando aproximadamente 3.000 homens.

Suas necessidades logísticas - alimentação, suprimentos, habitação, transporte - eram proporcionadas pelo próprio exército alemão. Assim, contando ainda com a ajuda de milhares de colaboradores locais, foram responsáveis pelo assassinato de mais de 1.500 .000 de judeus.

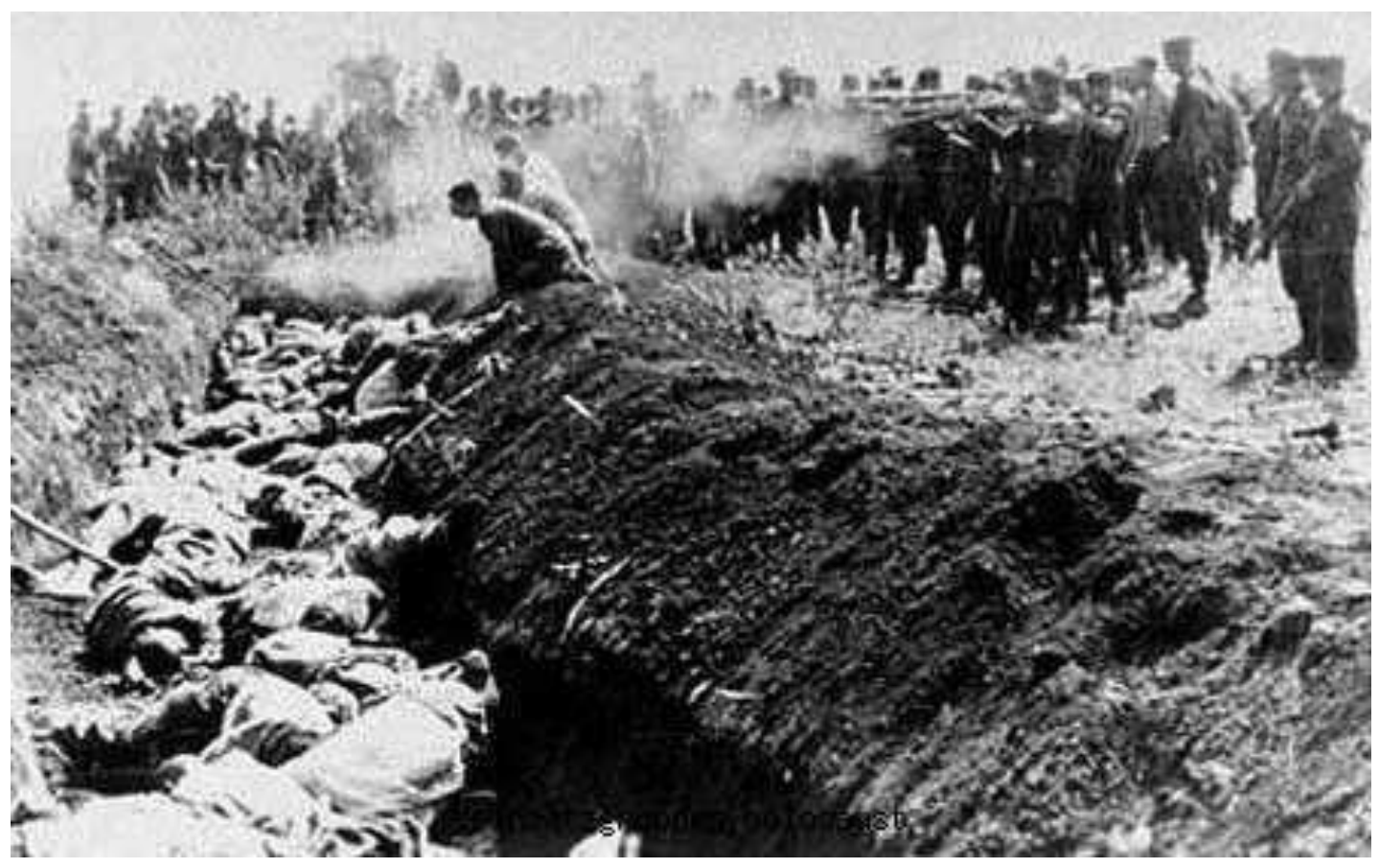

Execução de judeus por membros dos Einsatzgruppen

Fonte: Arquivo Fotográfico do United States Holocaust Memorial Museum (USHMM) Washington DC, Estados Unidos 
Os Einsatzgruppen eliminavam suas vítimas mediante fuzilamentos em massa, próximo às localidades onde habitavam. Em geral, as pessoas eram reunidas à beira de barrancos, minas ou valas cavadas por trabalhadores forçados -na maioria das vezes, as próprias vítimas.

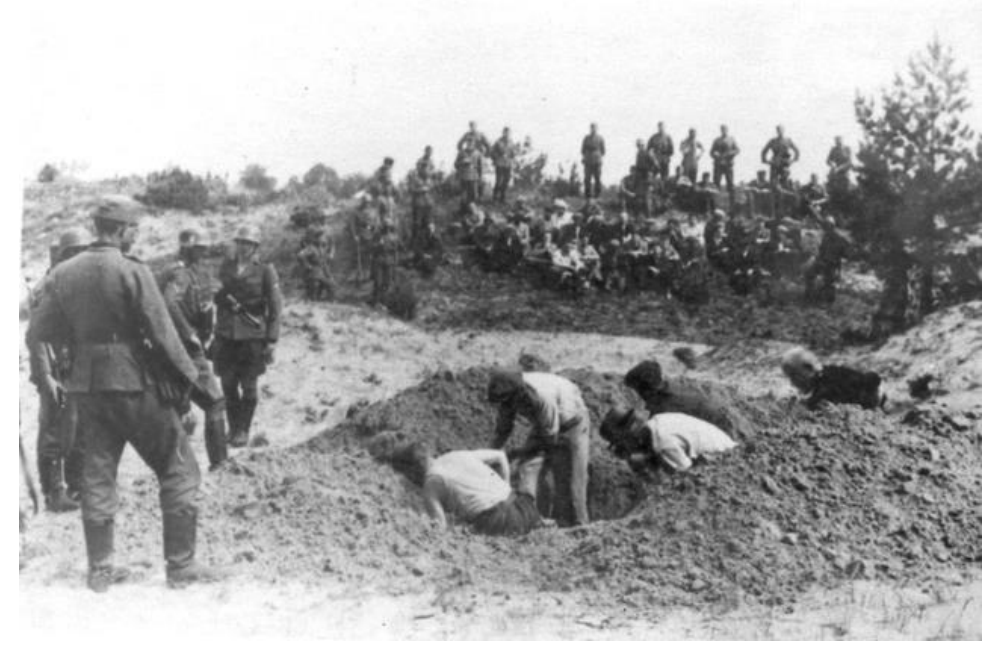

Prisioneiros judeus cavam suas valas observados por soldados alemães

Fonte: Arquivo da coleção de fotos do Memorial Yad Vashem, Jerusalém, Israel

Inicialmente, o alvo eram os homens, mas por volta de agosto de 1941, veio a decisão de aniquilar as comunidades inteiras, ou seja, o plano passava a incluir mulheres e crianças.

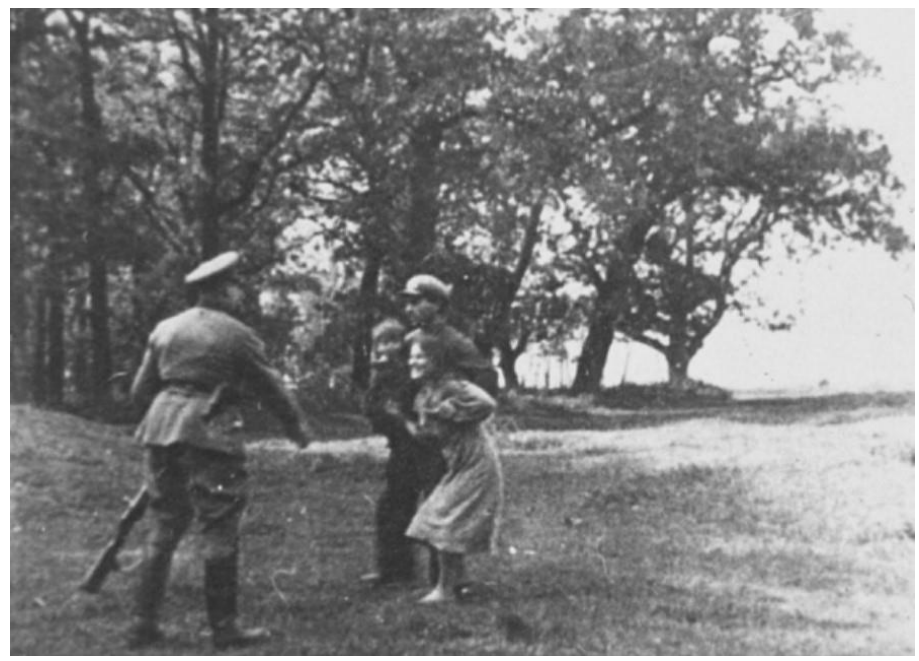

Família sendo perseguida por soldado alemão

Fonte: Arquivo Fotográfico do United States Holocaust Memorial Museum (USHMM) Washington DC, Estados Unidos 


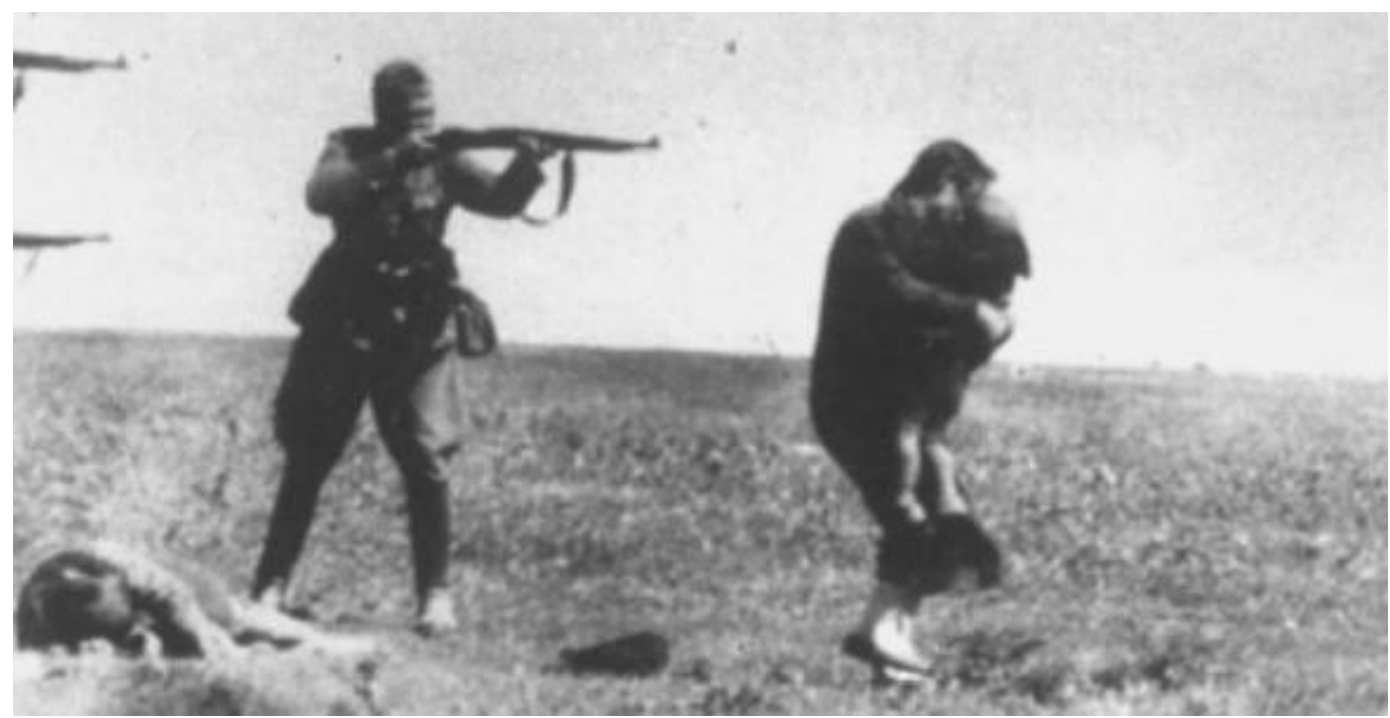

Mulher protege seu filho enquanto soldado mira para atirar.

À esquerda é possível ver também a ponta das armas de outros soldados e abaixo, um corpo no chão.

Fonte: Arquivo Fotográfico do United States Holocaust Memorial Museum (USHMM)

Washington DC, Estados Unidos

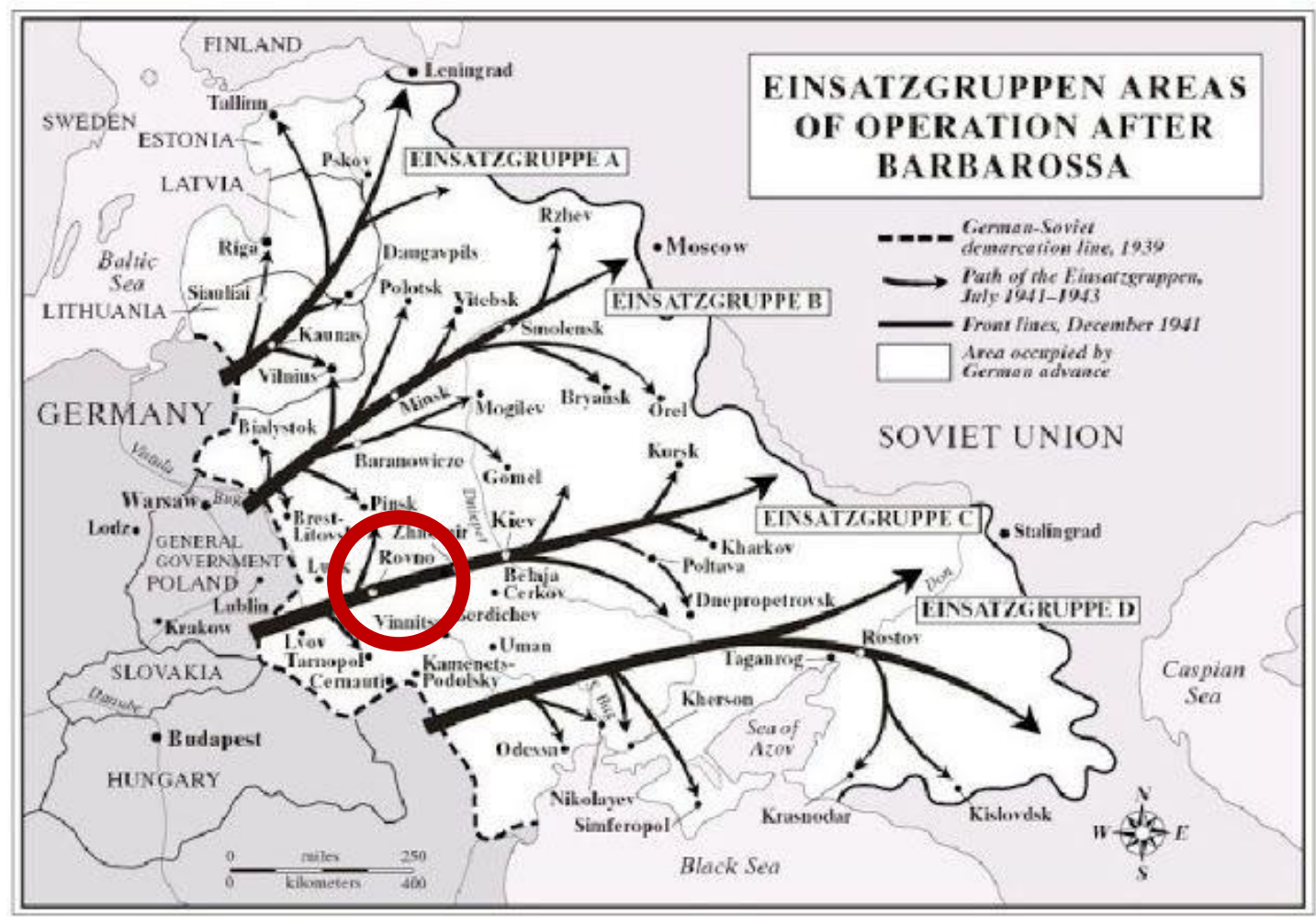

Área de operação das quatro unidades de Einzatsgruppen. Em destaque dentro do círculo (indicação aproximada), a região onde se localizavam Ludvipol e Stara Huta, onde a família Wexler vivia. O Einsatzgruppe $C$ era o encarregado de levar a cabo as tarefas de perseguição e extermínio na região. Fonte: Pinterest. 
Como mostram os mapas, o território de atuação dos Einsatzgruppen era muito extenso. Por isso, o mesmo foi dividido em quatro unidades de operação denominadas, A, B, C, D. Cada grupo era composto por 500 a 900 homens, totalizando 3.000, e subdivididos internamente -os chamados Sonderkommandos ou Einsatzkommandos - cada um deles encarregado de eliminar os judeus em sua própria região.

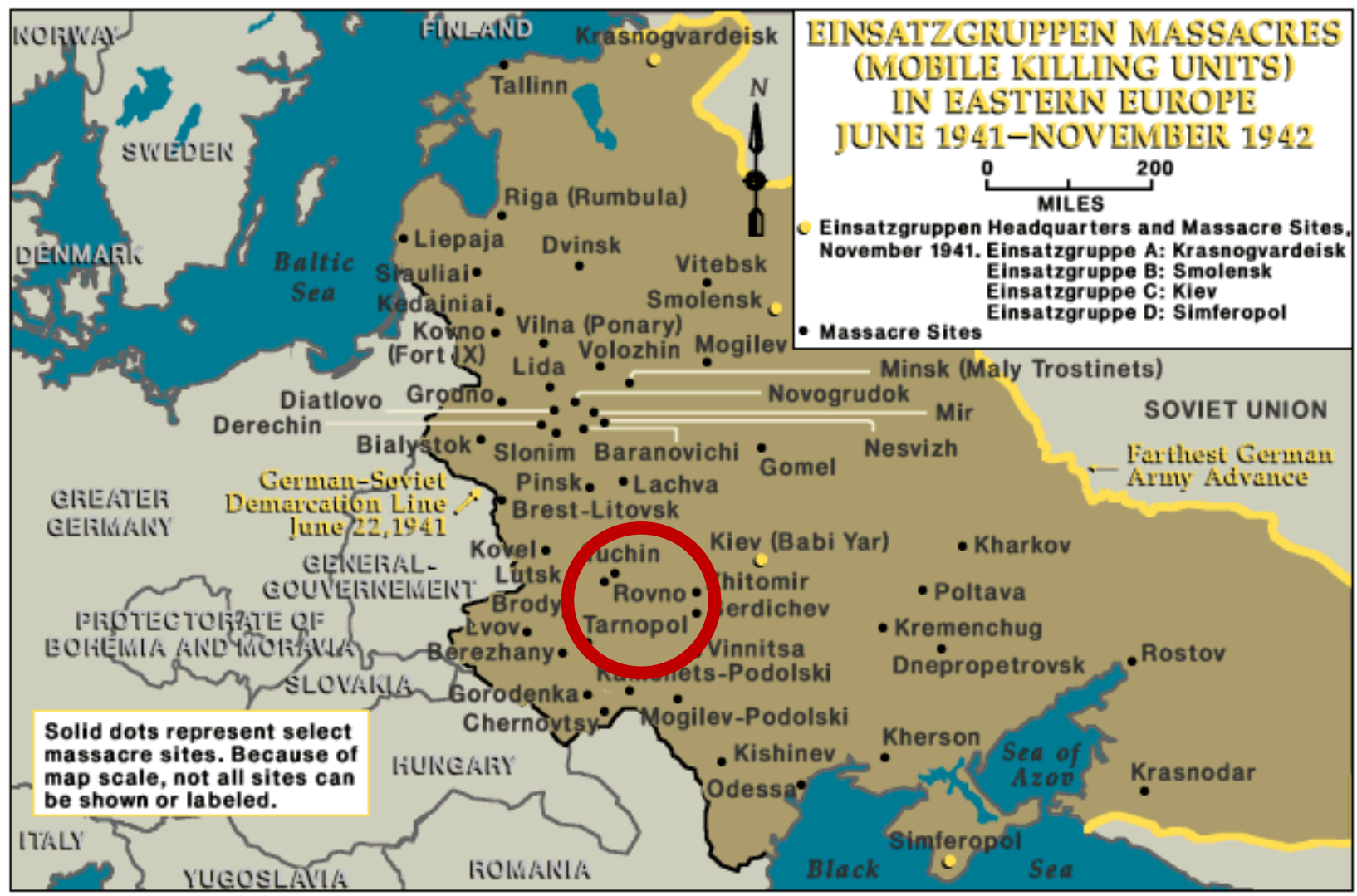

Este mapa indica alguns dos locais de massacres perpetrados pelos Einsatzgruppen. Os pontos em amarelo indicam Quarteis Generais (QGs) dos Einsatzgruppen; os pontos em preto indicam locais de massacres. A linha preta à esquerda indica a Linha de Demarcação Germano-Soviética (22 de junho de 1941); a linha amarela à direita indica o avanço do Exército alemão. Em destaque dentro do círculo (indicação aproximada), a região onde se localizavam Ludvipol e Stara Huta, localidades em que a família Wexler vivia.

Fonte: Arquivo Fotográfico do United States Holocaust Memorial Museum (USHMM), Washington DC, Estados Unidos.

O Einsatzgruppe C, que agia na região de Volínia - à qual pertenciam Ludvipol e Stara Huta - era constituído por 750 soldados e acompanhava o Corpo Sul do exército alemão. Mas eles não contavam somente com seus próprios homens para as operações: eram ajudados ostensivamente por milhares de colaboradores locais. 
Em uma de suas Aktions (ações) mais notórias, subunidades do Einsatzgruppe $C$ aniquilaram, em apenas dois dias (29 e 30 de setembro de 1941), 33.771 judeus de todas as idades e de ambos sexos, em uma ravina próxima a Kiev, hoje capital da Ucrânia, na localidade conhecida como Babi Iar. Um deles era o garotinho que aparece na foto, Velvele Pinkert, morto junto com toda sua família, pelo simples fato de ser judeu.

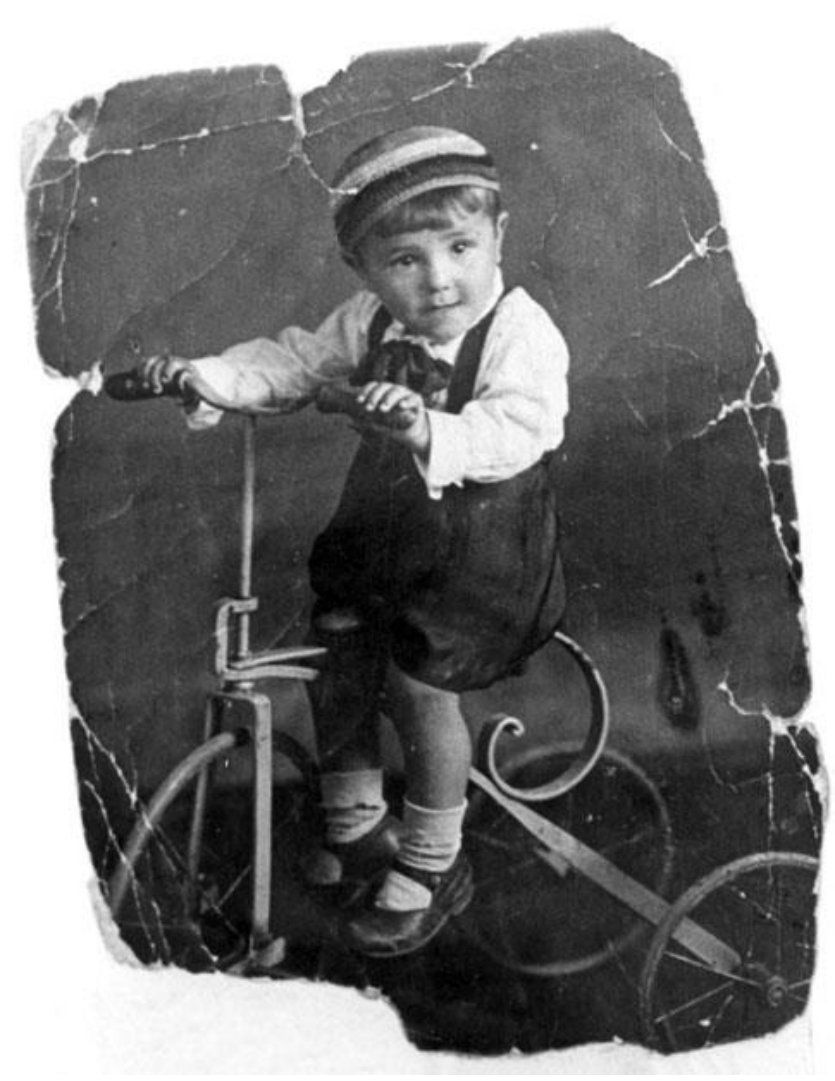

Velvele Valentine Pinkert, c. 1939

Cidade e fotógrafo não identificado.

Este menino foi um dos 33.771 judeus fuzilados por membros do Einsatzgruppe $C$ na ravina de Babi Iar entre 29 e 30 de setembro de 1941

Fonte: Arquivo da coleção de fotos do Memorial Yad Vashem Jerusalém, Israel

\section{O Einsatzgruppe C chega a Ludvipol}

Em junho de 1941, a chegada de subunidades do Einsatzgruppe $C$ a Ludvipol em busca judeus, atraiu toda sorte de assassinos ucranianos. Entre as motivações: o forte antissemitismo ou a oportunidade de apropriar-se dos bens das famílias judias que lá viviam. Em muitas 
localidades, suas ações derivavam em verdadeiros pogroms no qual morreriam muitos judeus. Em Ludvipol não seria diferente.

\section{O extermínio na prática: planejamento e trapaça}

Sempre que nos aproximamos de histórias como a de Mira e os judeus de Ludvipol, há detalhes que podem deixar o leitor inquieto. Por exemplo, você talvez pergunte: Por quê ao saber da chegada dos alemães, os judeus não fugiram? Por que eles seguiam as ordens que literalmente os levavam a "cavar suas próprias sepulturas?

Em primeiro lugar, é importante considerar que, ao olhar para o passado, nós, graças aos testemunhos, ao trabalho dos historiadores, aos documentos e diários que restaram, conseguimos ter uma visão privilegiada daquilo que aconteceu. É mais ou menos como ver um filme cujo final já conhecemos.

Porém a história, para aqueles que a estão vivendo, não funciona como um filme. Decisões são tomadas com base nas informações disponíveis naquele momento e com os meios disponíveis naquele momento. E ambos elementos eram bem escassos.

Além disso, o processo de extermínio dos judeus perpetrado pela Alemanha nazista, tinha um ingrediente adicional: havia uma política deliberada de engano.

De que maneira?

Para levar a cabo o plano de extermínio do povo judeu, os procedimentos praticados para levar à morte milhões de pessoas, tal como concebidos pela Alemanha nazista, deveriam ocorrer de maneira organizada e sistemática.

Isso não se deve ao mito da "eficiência da máquina nazista" e sim ao fato de que o objetivo era a destruição total: era necessário que as vítimas não estivessem cientes de seu verdadeiro destino, impedindo assim qualquer ato de fuga ou resistência.

Os pogroms perpetrados por antissemitas locais no vasto território em que operavam os Einsatzgruppen, embora tivessem como resultado o que os alemães desejavam - a morte dos judeus - ao mesmo tempo, alertavam as populações e semeavam o "caos". O "caos", do ponto de vista nazista, era qualquer obstáculo que dificultasse seu plano de extermínio.

Para isso, ao entrarem nas cidades, os Einsatzgruppen estabeleciam várias medidas. Uma delas era a demarcação de um gueto. 


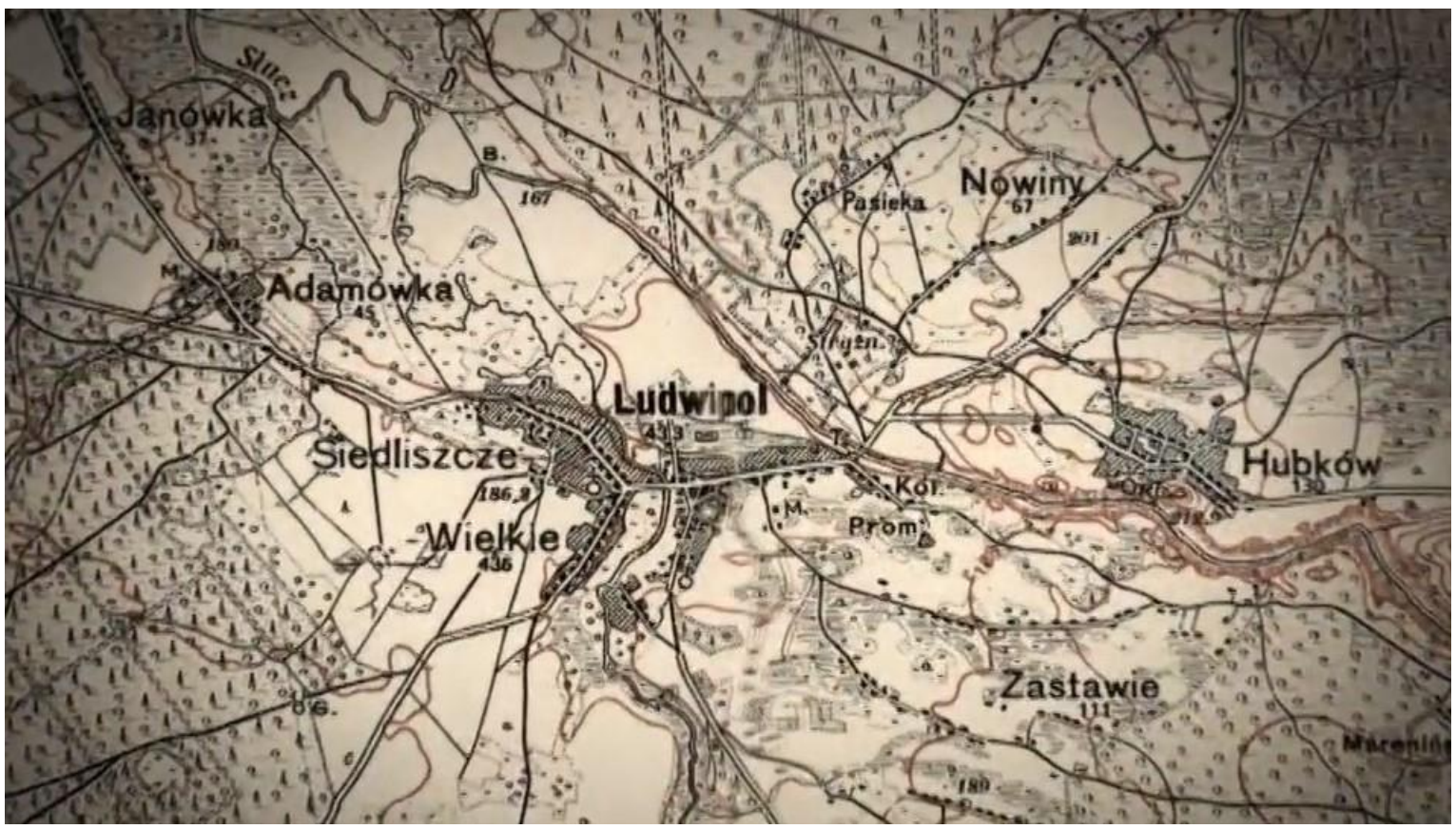

Ludvipol e região por volta de 1940.

Assim como todas as cidades habitadas por uma população superior a 1.000 judeus, em Ludvipol foi delimitado um gueto na parte antiga da cidade. Para lá foram levados, os judeus não só de Ludvipol, mas também de cidades vizinhas, os nomes de algumas das quais podemos observar no mapa.

Captura de tela do documentário A House for Two Families (Uma casa para duas famílias), Jewish Federation for the Righteous, New York, 2014.

A política de guetos foi instituída pelo governo central alemão inicialmente como forma de segregar e isolar os judeus dos poloneses nas cidades. O primeiro deles foi estabelecido na localidade de Pyotrków Trybunalsky logo após a invasão da Polônia pelo exército nazista, em setembro de 1939. Posteriormente, a prática se estendeu chegando a ultrapassar os 1.000 guetos nos territórios da Polônia anexada e União Soviética. Alguns chegaram a durar somente alguns dias, outros alguns anos.

Nos territórios controlados pelos Einsatzgruppen, determinou-se que os guetos deveriam ser estabelecidos nas cidades com mais de 1.000 habitantes judeus. Os judeus de comunidades vizinhas menores, também seriam levados para lá. 
No caso de Ludvipol, a parte velha da cidade de Ludvipol foi a escolhida para abrigar o gueto. A área foi demarcada e em seu contorno foram instaladas altas cercas de arame farpado para evitar fugas.

Assim como todos os judeus de Ludvipol e redondezas, Hannah e Yankiel Wexler, junto com a pequena Mira, foram obrigados a deixar as casas onde moravam e forçados a viver no gueto. Os avós de Mira - Michel e Miriam - foram levados para o gueto de Kostopol, localizado na mesma região.

Como o gueto era invariavelmente pequeno em relação à população que para lá era levada, várias famílias deviam compartilhar uma mesma casa.

\section{A formação do conselho judaico, o Judenrat}

Em seu testemunho, Mira nos conta que uma das primeiras ordens do comando alemão após o estabelecimento do gueto, foi a formação de um conselho, o chamado Judenrat. Sua função explícita era a de intermediação entre os oficiais alemães encarregados de levar a cabo as ações e a população judaica.

Os membros do Judenrat eram responsáveis por implementar todas as diretrizes expedidas pelos alemães, além de lidar com questões relacionadas com o dia-a-dia do gueto: alimentação, moradia, saúde, higiene e organização do trabalho. Seus membros eram rabinos ou outras autoridades influentes dentro de cada comunidade.

A situação dos membros desses conselhos era extremamente complexa. Não ram perpetradores, mas eram diretamente responsáveis por fazer cumprir as determinações dos comandantes alemães. Também não eram meros observadores. Eram vítimas, embora não claramente definidas uma vez que as complexidades morais que enfrentavam dia após dia os posicionavam em uma rede intricada de papéis que o sadismo nazista sabia explorar ao máximo.

Esses homens eram aqueles que dia após dia tinham que olhar de perto o rosto dos carrascos e negociar situações impossíveis, tendo que escolher entre miséria, fome e humilhações ou a morte da população do gueto.

A maioria dos chefes dos conselhos tentavam responder às constantes ameaças das autoridades alemãs de modo a tornar os guetos úteis tentando assim garantir a sobrevivência de seus ocupantes. Essa ideia era passada aos conselheiros pelos próprios comandantes alemães que, 
como confirma a própria Mira, constantemente garantiam aos os habitantes do gueto que eles eram bons trabalhadores, e se continuassem assim nada aconteceria com eles.

O que os conselheiros e muito menos a população em geral do gueto não sabiam era que a sorte já estava lançada. Somente quando já era tarde demais é que o verdadeiro propósito, a aniquilação total, ficaria evidente.

\section{A vida no gueto}

Assim como em todos os guetos do sistema implementado nos territórios ocupados pela Alemanha nazista, as condições de vida eram terríveis. Além das restrições de toda sorte, principalmente a escassez de comida, os toques de recolher, o isolamento, os judeus tinham que conviver com constantes perseguições. Nas palavras de Mira: "Todo dia tinha que ter sangue. Todo dia. Não passava um dia sem que matassem alguém, criança ou adulto. Era isso que dava vida a eles".

Os habitantes, homens e mulheres, eram submetidos a trabalhos forçados dos mais diversos: construção de estradas, colheita de grãos, limpeza de cavalos, corte de madeira, trabalhos nas florestas, faxina da cidade etc. Durante os trabalhos, os prisioneiros eram muitas vezes torturados. Alguns não suportavam e acabavam morrendo devido aos maus tratos.

Sem que soubessem, esses trabalhos consistiam às vezes em preparar o terreno para seu próprio extermínio...

Geograficamente, as terras onde estava implantada a cidade de Ludvipol e as florestas adjacentes, eram cortadas pelo rio Sluch. Ambas partes eram unidas por uma ponte.

Certo dia, os alemães reuniram um grupo de judeus do gueto e os conduziram pela rua principal da cidade. O grupo atravessou a ponte e, uma vez na floresta, os prisioneiros foram

forçados a cavar três grandes covas que, segundo os planos definidos pelo comando dos Einsatzgruppen e dos líderes nazistas em Berlim, receberiam os corpos da totalidade dos aproximadamente 1.500 judeus de Ludvipol. 


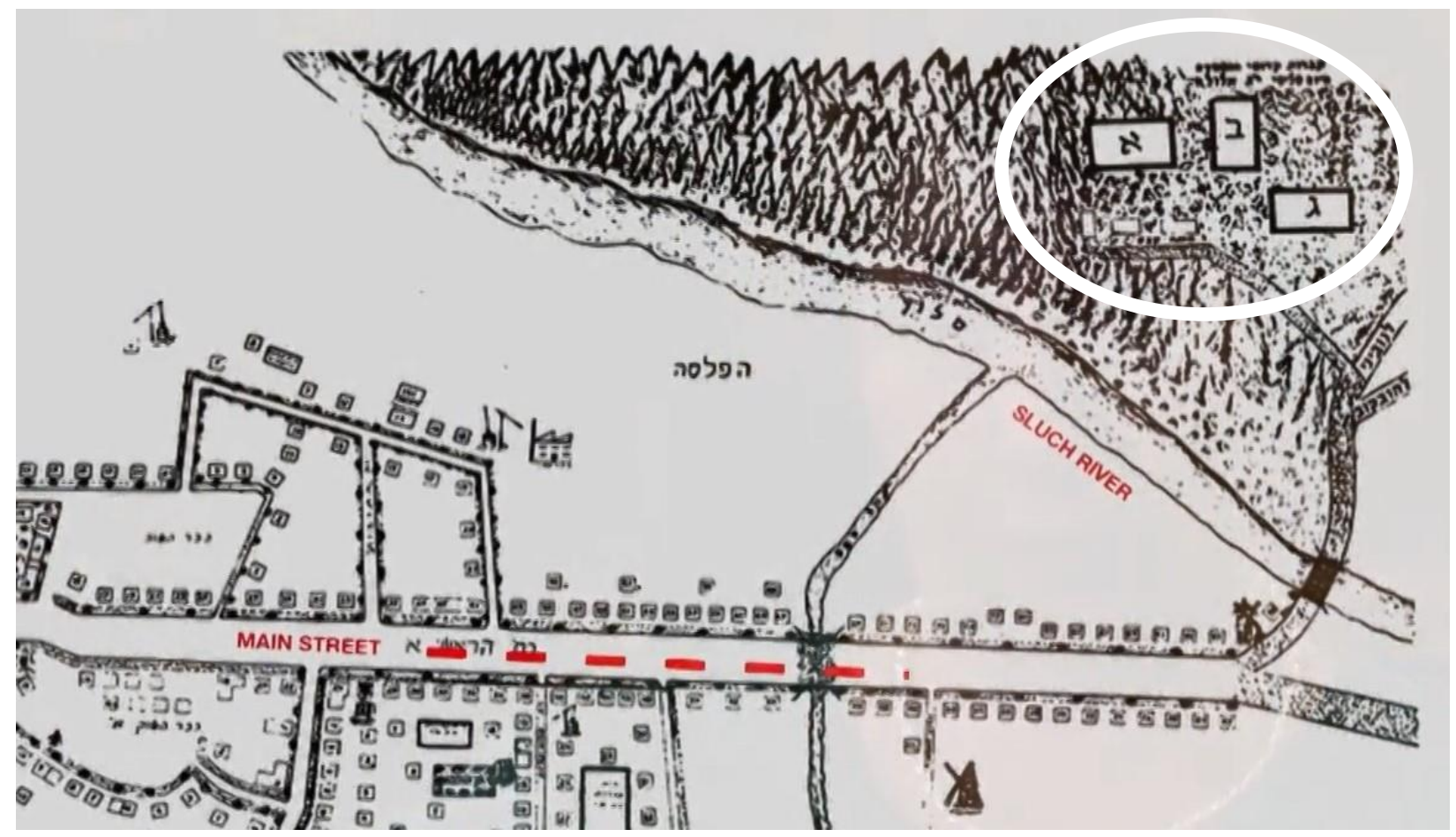

Mapa da rua principal de Ludvipol. O tracejado mostra o caminho por onde os prisioneiros foram conduzidos em direção à floresta (conforme mostrado no documentário de Mira). Na área indicada pela elipse, as covas cavadas pelos prisioneiros.

Captura de tela do documentário A House for Two Families (Uma casa para duas famílias) Jewish Federation for the Righteous, New York, 2014.

\section{A liquidação do gueto de Ludvipol}

Na noite de segunda-feira 24 de agosto de 1942, os alemães ordenaram um toque de recolher particularmente rigoroso no gueto. As pessoas não podiam sair de suas casas.

O pai de Mira, que havia acabado de chegar ao gueto depois de um dia de trabalho, refugiou-se junto com Hannah, Mira e outras pessoas, em bunkers que os moradores haviam preparado dentro das casas com a finalidade de escapar das perseguições. Na madrugada do dia 25, soldados alemães cercaram o gueto. Horas depois entraram acompanhados de colaboradores ucranianos e começaram as buscas.

De repente, na casa vizinha ao bunker onde os Wexler se encontravam, começou uma gritaria. Yankiel saiu para ver o que estava acontecendo. Foi naquele momento que Mira viu seu pai pela última vez. 
Todo morador do gueto que os soldados encontrassem for a de casa, era assassinado no local. Foi provavelmente assim que Yankiel morreu.

Vendo que seu marido não voltava, Hannah tentou sair do esconderijo para encontra-lo. Hannah pediu a uma senhora que estava no bunker chamada Blima, que ficasse com Mira enquanto ela saía. Blima, porém, achou que a menina poderia começar a chorar, o que alertaria os alemães sobre a presença das outras 24 pessoas que estavam lá escondidas. Hannah decidiu esperar.

\section{"Não vou ficar aqui esperando que me matem"}

Ao passar das horas, suspeitando que seu marido não voltaria e percebendo que o fim estava próximo, Hannah decidiu sair e negociar com um soldado que guardava as proximidades. Sua ideia era suborna-lo para que lhes facilitasse a fuga. Para isso, Blima lhe deu um pouco de ouro que tinha guardado junto ao corpo para um caso de emergência.

Hannah saiu e conseguiu subornar o guarda, mas a grande maioria das pessoas que estavam no bunker tiveram medo de serem capturadas e resolveram ficar. Somente Hannah, Mira e seu tio Yossef Wexler - irmão de seu pai - saíram do esconderijo.

O trio seguiu o guarda que os acompanhou até atravessarem a ponte. Junto com sua mãe e seu tio, Mira embrenhou-se na floresta. Fingindo persegui-los, o soldado deu três tiros para o alto como sinal para seu comando de que os havia assassinado.

No mesmo dia, as 23 pessoas que permaneceram no bunker e todos os demais moradores do gueto que estavam escondidos foram tirados de suas casas e levados em pequenos grupos até os limites da cidade. Após atravessaram a ponte sobre o rio Sluch, caminharam por aproximadamente $1 \mathrm{~km}$ até o local na floresta onde estavam as valas que haviam sido cavadas anteriormente. Lá, foram executados.

Dos aproximadamente 1.500 moradores do gueto de Ludvipol, 1.200 morreram naquele mesmo dia. Entre 200 e 300 conseguiram fugir para as florestas e cidades vizinhas. Para Hannah e Mira, iniciou-se um novo período de horror em busca de sua sobrevivência, desta vez nas florestas em torno a Stara Huta. 


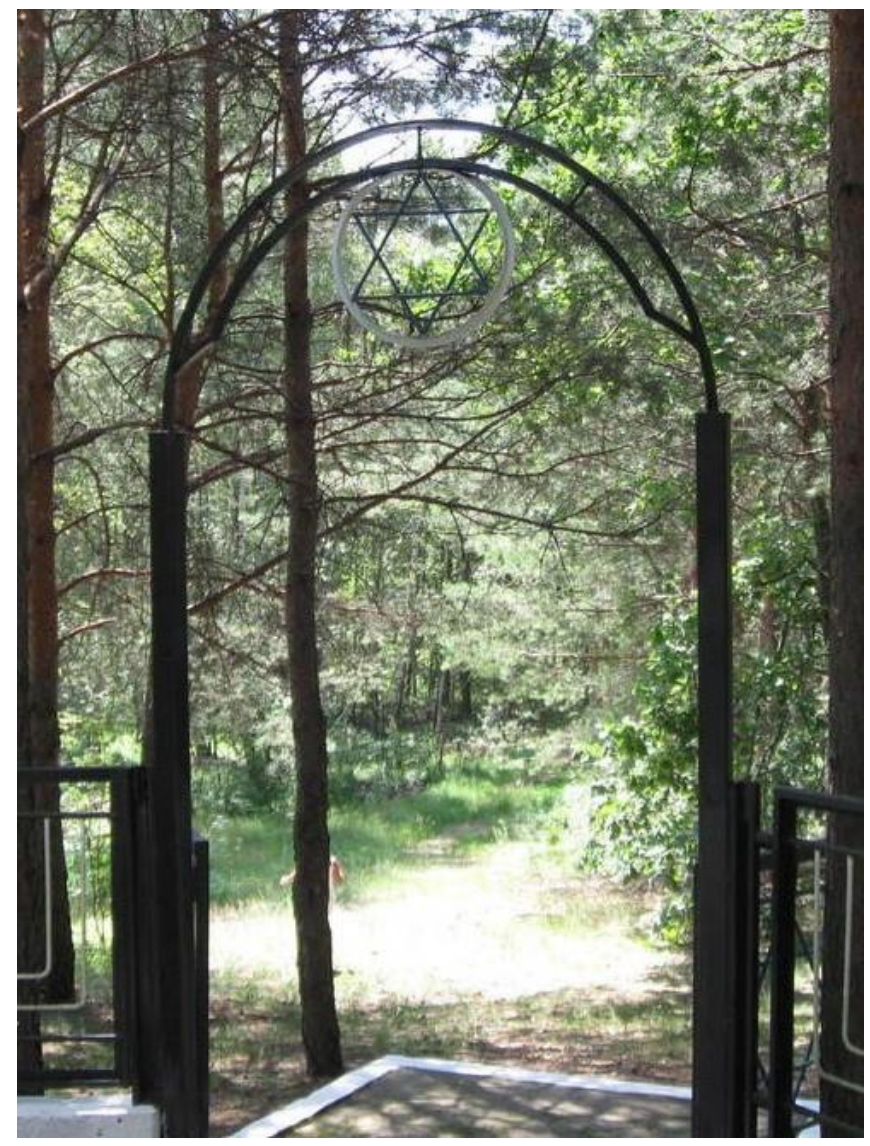

Acesso à floresta-memorial onde estão enterrados os corpos dos aproximadamente 1.200 judeus do gueto de Ludvipol http://www.sztetl.org.pl/en/city/ludwipol/

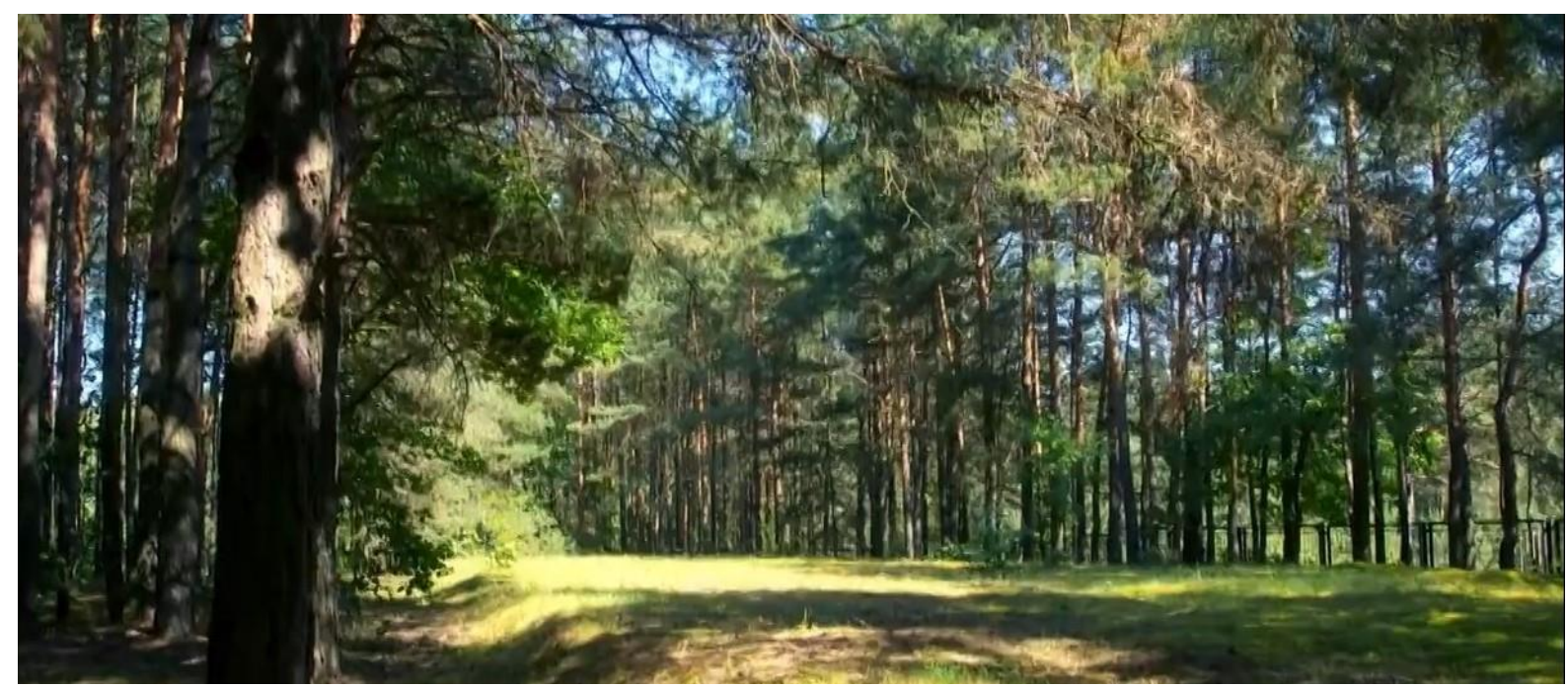

Vista do local onde estão enterrados os corpos dos aproximadamente 1.200 judeus do gueto de Ludvipol, onde há hoje um memorial. Captura de tela do documentário A House for Two Families (Uma casa para duas famílias), Jewish Federation for the Righteous, New York, 2014. 


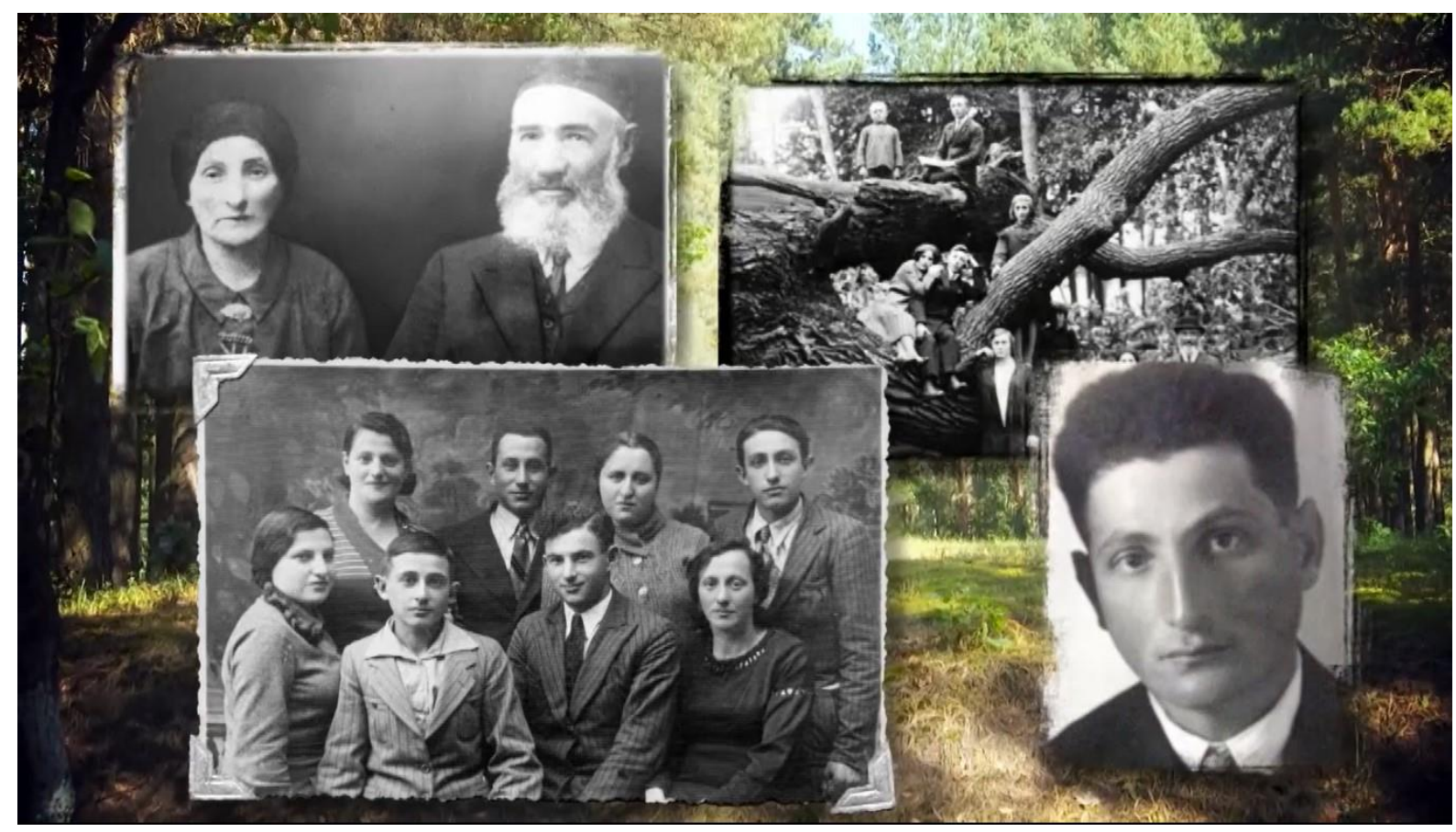

Familiares de Mira mortos no Holocausto.

Nas fotografias, à esquerda acima, seus avós; à esquerda (abaixo) e à direita (acima), seus primos; à direita (abaixo), Yankiel Wexler, pai de Mira. Captura de tela do documentário A House for Two Families (Uma casa para duas famílias), Jewish Federation for the Righteous, New York, 2014.

\section{A sobrevivência nas florestas}

As florestas da região em que Mira e sua mãe sobreviveram por dois anos, foram testemunhas silenciosas de anos em que horror e coragem se misturavam. Elas, assim como os 200 a 300 judeus de Ludvipol, encontrariam refúgio nesse cenário.

Muitos, porém, não sobreviveriam à falta de comida, ao frio, às perseguições dos Einsatzgruppen e de seus colaboradores que continuariam incessantemente até 1944, ano em que os alemães, derrotados pelo exército soviético, abandonaram a região.

A sobrevivência naquele lugar, onde as temperaturas no inverno chegam a $-40^{\circ} \mathrm{C}$ (quarenta graus abaixo de zero!), somente era possível graças à firme e contínua ajuda de pessoas que, apesar do risco, se encarregavam de fazer chegar a eles alimentos e roupas.

Dois fatores que contribuíram também para a sobrevivência dos judeus refugiados nas florestas foram, por um lado, o profundo conhecimento que tinham da geografia da região e por outro, os laços comunitários com famílias não-judias em quem podiam confiar. Naquele momento, era fundamental saber em que porta bater para não ser delatado aos alemães. 


\section{De volta a Stara Huta}

Logo que escaparam do bunker, Mira seguiu sua mãe em uma longa caminhada pela floresta até chegarem, primeiro, à casa de quem havia sido a babá de Mira, Tofília e depois à fazenda dos Weglowski, onde os Wexler haviam morado antes da chegada dos alemães.

Yossef, o tio de Mira que havia fugido com elas do gueto, seguiu em outra direção, indo reunir-se com sua esposa, Rachel, que havia conseguido escapar algum tempo antes e estava abrigada na residência do casal Stanislawa e Franciszek Weglowski, irmão de Florian. Lá se encontravam também os primos de Mira, Sylvia e Shaia, que durante as perseguições dos alemães, viram seu pai sendo assassinado e sua mãe sendo arrastada para longe.

Permanecer na casa dos Weglowski por muito tempo, no entanto, era muito arriscado, tanto para Hannah e Mira, quanto para os próprios Weglowski. Todos nas redondezas sabiam sobre a amizade das duas famílias, o que os colocava em sério risco.

Os dois anos seguintes seriam, para Hannah e Mira, um constante ir e vir entre a floresta e a fazenda. Quando não podiam ficar na casa, o próprio Florian Weglowski, ou algum de seus filhos, levavam comida e leite para Hannah, sua pequena filha e também para outros que, como elas, se refugiavam naquele lugar.

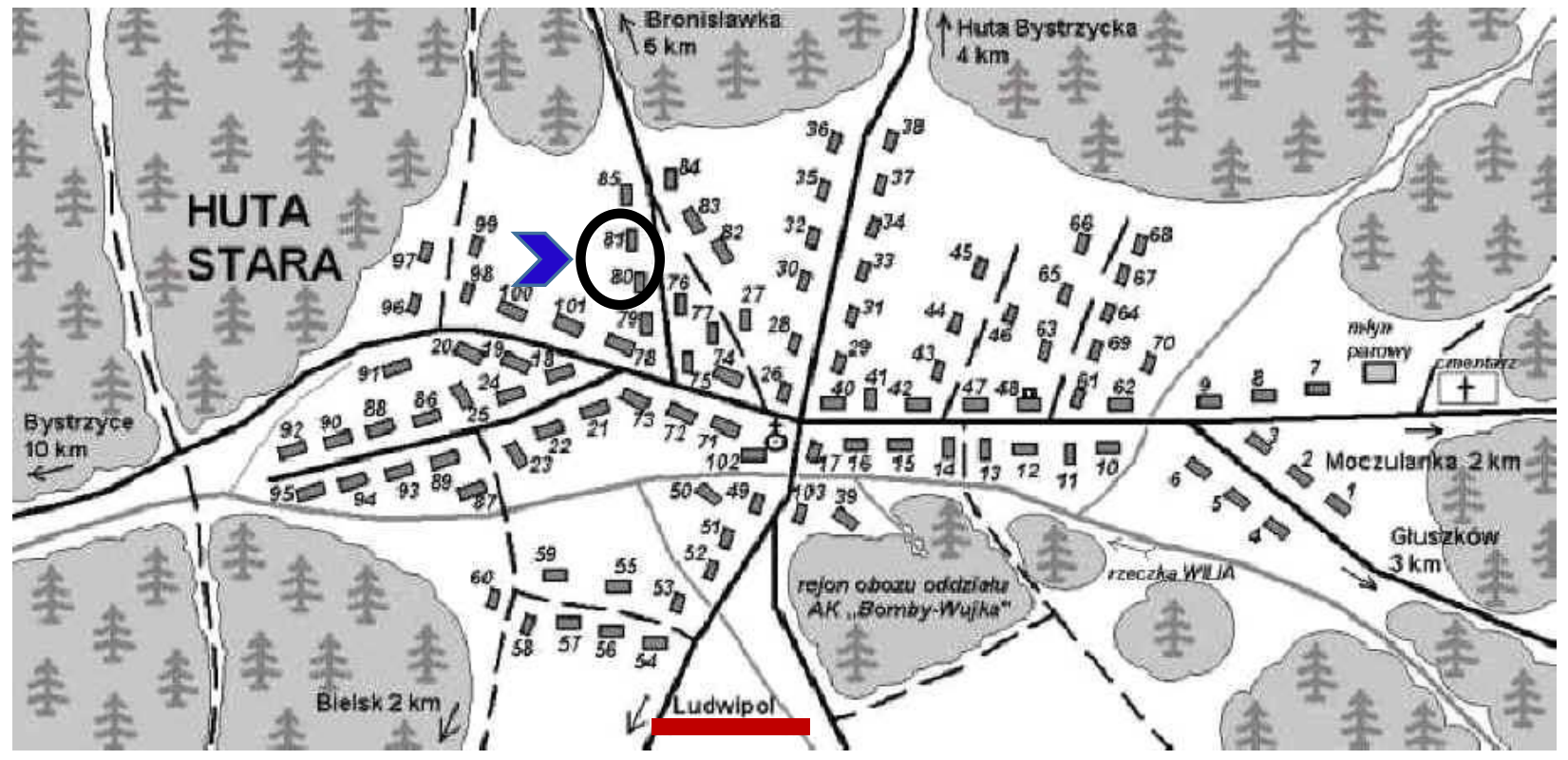

Croqui da cidade de Stara Huta (1939). A seta aponta para o ponto onde se localizava a propriedade dos Weglowski. No número 80, a fazenda de Florian; no número 81, a de Franciszek. Em destaque (ao centro, sublinhado), a estrada que ligava Stara Huta a Ludvipol. 

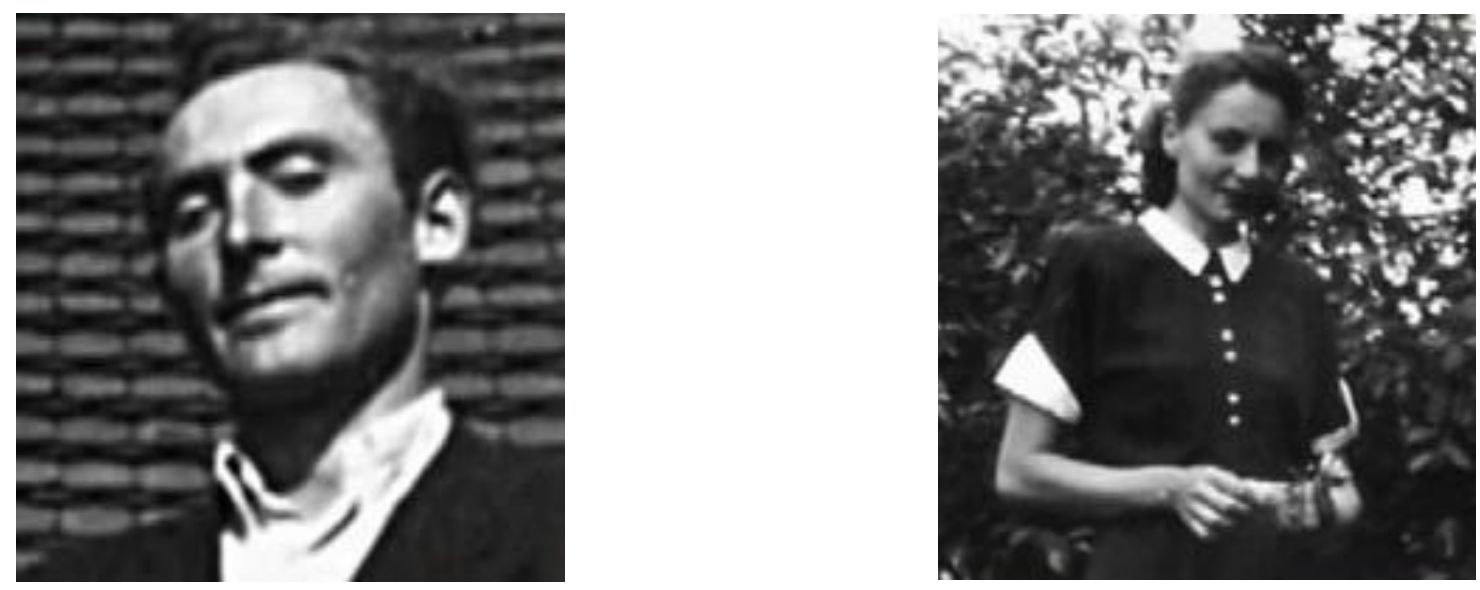

Dois dos irmãos Weglowski: Stanislaw e Helena.

Assim como seus pais, eles também se encarregavam de levar alimentos e abrigo àqueles que, como Hannah e Mira, buscavam refúgio nas florestas próximas à sua fazenda. Os nomes de Stanislaw e de seus pais, Florian e Maria, foram reconhecidos Memorial Yad Vashem de Israel; o Museu da História dos Judeus da Polônia (Polin) em Varsóvia, Polônia também incluiu o nome de Helena Weglowski.

Suportar aquelas temperaturas à intempérie era em si um ato de resistência. Para abrigarse, as pessoas se escondiam em porões, em valas, casebres abandonados, ou seja, qualquer lugar que servisse de cobertura. Além disso, nem todos os dias era possível ter acesso a comida já que as buscas dos alemães por judeus escondidos nas casas e fazendas eram constantes. Quando os rumores de sua aproximação se espalhavam, não era possível aproximar-se de casas como as dos Weglowski. Também não havia como levar alimentos - escassos para os próprios fazendeiros da região - ou roupas para os refugiados. Tudo era controlado e a tensão, permanente.

Mira relembra em seu relato, um episódio particularmente perigoso. Ela teve uma forte infecção no ouvido que Maria Weglowski, com muito cuidado e técnicas caseiras acabou curando. No entanto, isso fez com que elas tivessem que permanecer na fazenda por um período um pouco mais prolongado que o de costume.

Um dia Florian chegou muito nervoso, avisando que os alemães haviam cercado a fazenda. As duas deveriam sair. Aproveitando um momento em que os soldados estavam dormindo, Hannah pegou sua filha e saiu correndo rumo à floresta. Porém, ao passar perto deles, Hannah tropeçou no pé de um dos guardas e ele acordou. Ela ouviu os gritos: - Halt!, ordenando que parassem. Hannah fez de conta que não ouviu e seguiu em frente, embrenhou-se na floresta e assim, mais uma vez, conseguiu salvar sua vida e a de sua filha. 


\section{Quando as vozes se cruzam}

Ao debruçar-nos sobre histórias como as de Hannah e Mira, são muitas as vozes que nos falam; muitas as vozes que se cruzam. Nessa trama de testemunhos e fatos históricos, conseguimos perceber, através de cada pincelada, ao menos um pouco do que foi por eles vivido. Elas nos trazem as impressões de um tempo em que a razão e a humanidade foram viradas ao avesso.

A memória das comunidades judaicas da Europa Central e Oriental destruídas durante o Holocausto pôde ser mantida somente através do relato. Para elas, o "lugar da memória" é a palavra.

Assim, após a guerra, muitos sobreviventes daquelas localidades iniciaram um esforço coletivo de lembrar e preservar aquilo que foi destruído. Criaram assim verdadeiros livrosmemoriais, conhecidos como Yizkor (memorial em hebraico) que contêm relatos em primeira pessoa descrevendo como era a vida naquelas comunidades, seus costumes, sua cultura. Falam também sobre seu processo de destruição.

Em 1965, foi publicado em Israel, o Yizkor de Ludvipol ${ }^{145}$. Nele podemos encontrar testemunhos de vários de seus ex-moradores, como por exemplo Baruch Gutman, que em seu relato, nos conduz ao seu próprio cruzamento com a história de Mira e Hannah:

Aquela noite havia 'entretenimento' ${ }^{146}$ em Romizia e o tráfego na estrada estava pesado. Fui obrigado a rastejar por todo o caminho. Passei pela casa de Abraham-Isaac Gutterman e atravessei os campos em direção à praia até chegar ao [rio] Sluch. A noite estava fria. Entrei na floresta e me cobri com galhos de árvores. Quando acordei, depois de várias horas, fui à casa de um gentio ${ }^{147}$ que eu conhecia em Stara Huta. Ele me deu comida e surpreendeu-se ao ouvir que eu havia retornado aos vilarejos da Ucrânia depois de já ter passado o Sluch. Lá encontrei Hannah Wexler e sua filha, que não estavam longe dali [na floresta]. ${ }^{148}$

\footnotetext{
145 Alguns capítulos da tradução em inglês do Yizkor de Ludvipol estão disponíveis no em www.jewishgen.org/yizkor/ludvipol/ludvipol.html

${ }^{146}$ Nota de rodapé que consta do Yizkor: "aparentemente referindo-se sarcasticamente às buscas realizadas pelos alemães".

${ }^{147}$ Um não-judeu. Provavelmente trata-se da família Weglowski.

148 Extraído do relato de Baruch Gutman "Dias de Assassinato" que é parte integrante do Yizkor de Ludvipol. O texto em inglês pode ser consultado em www.jewishgen.org/yizkor/ludvipol/ludo78.html
} 


\section{Uma nova etapa rumo à "Solução Final"}

Durante o tempo em que Mira e sua mãe estiveram refugiadas na floresta, os Einsatzgruppen continuaram operando ativamente, penetrando o território soviético em direção a outras comunidades, destruindo tudo e todos. Até o início de 1943, ou seja, menos de dois anos após entrarem em operação, os Einsatzgruppen já haviam matado aproximadamente 1.250.000 judeus.

Seu trabalho, porém, começou a ser considerado pelas autoridades da Alemanha nazistas como muito "manual", com um alto desgaste do pessoal alemão envolvido. Era necessário encontrar novos métodos de execução, mais simples e rápidos, para levar a cabo a "Solução Final", ou seja, a aniquilação total do povo judeu.

O comandante do Einsatzgruppe $B$, Artur Nebe, que já havia tido experiência com assassinatos a gás na Alemanha ${ }^{149}$, propôs que, nos territórios de operação dos Einsatzgruppen, fosse introduzido o uso de vans de gás, ou seja, veículos cujo escapamento era direcionado para dentro da cabine hermeticamente fechada onde prisioneiros eram conduzidos, levando-os à asfixia por monóxido de carbono.

A experiência, como tal, também não foi "satisfatória", mas derivou na proposta de estabelecer instalações permanentes usando essa modalidade de extermínio: os campos de concentração equipados com câmaras de gás.
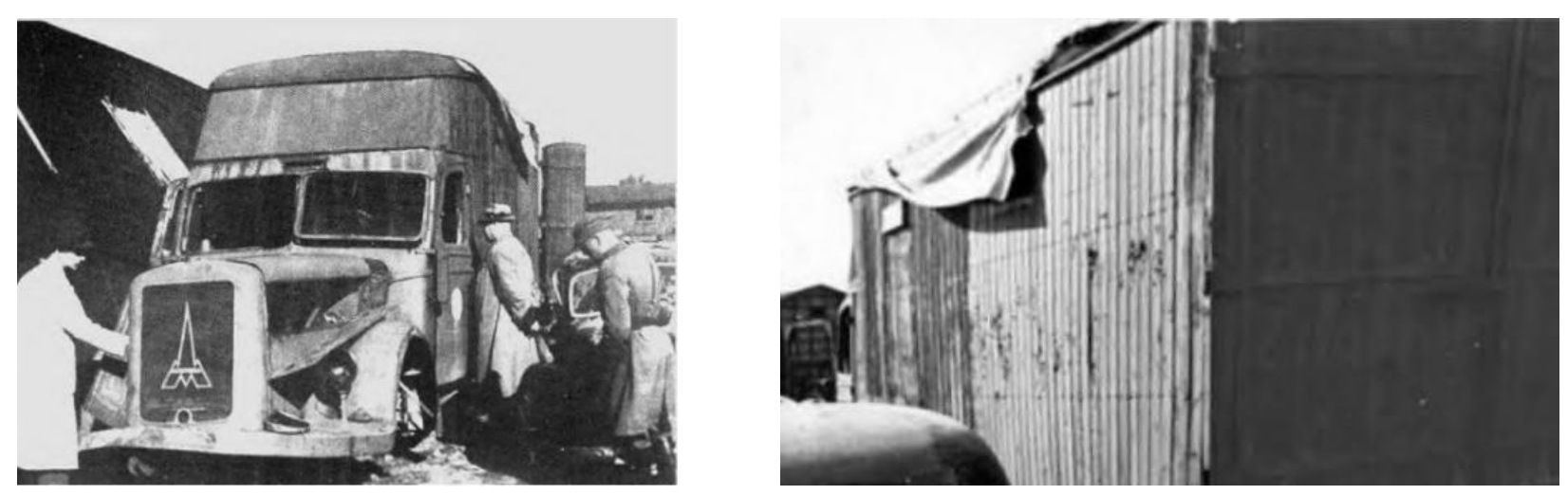

Este veículo encontrado nas proximidades de Chelmno é, segundo testemunhos, semelhante ao modelo utilizado para funcionar como vans de gás. Alguns modelos podiam carregar até 150 pessoas.

149 Programa iniciado em 1939 para assassinar pessoas com deficiência física e mental, chamado Aktion T4 (ou Programa de Eutanásia). Foi o primeiro programa de extermínio em massa criado pela Alemanha Nazista foi interrompido devido a uma forte pressão de igrejas cristãs e da sociedade alemã. Esses protestos não ocorreram em relação às ações contra outras minorias, principalmente os judeus. 


\section{O fim de Ludvipol}

Entre fevereiro e maio de 1944, teve lugar a ofensiva das forças soviéticas no norte da Ucrânia, que resultariam na liberação do território da Volínia das mãos dos alemães. A região ficou completamente devastada por bombardeios. De Ludvipol nada restou. Dos judeus da Volínia, somente $1,5 \%$ sobreviveram.

Hannah, Mira e sua prima Sylvia, que havia sido protegida pela família de Fransizcek Weglowski, permaneceram ainda por um tempo na floresta. Hannah, que durante seu refúgio havia se casado novamente, começou a trabalhar na cidade vizinha de Matchulanka, a $12 \mathrm{~km}$ de Ludvipol. Lá os soviéticos haviam formado um centro para administrar a área e onde muitos sobreviventes de Ludvipol começaram a residir à medida que iam saindo das florestas.

A "trégua" na vida daqueles sobreviventes, porém, durou menos de um ano: em 1945, um decreto do governo soviético obrigava que todos os antigos cidadãos da Polônia saíssem da região. Tanto os Wexler quanto os Weglowski deveriam partir.

\section{Recomeços}

Hannah, seu marido e Mira, foram para a Polônia, instalando-se inicialmente em Bytom, uma antiga cidade da região da Silésia, no sul da Polônia. Lá, Mira começou a frequentar à escola pela primeira vez.

O fim da guerra, porém, não significou o fim da violência. As matanças eram constantes e a própria Mira, embora com pouca idade, cansada de viver aquele cotidiano, forçou sua mãe e o padrasto a saírem da Polônia.

Em 1946 começaria uma travessia, que passou pela Tchecoslováquia, diversas cidades da Áustria incluindo a capital, Viena e França, antes de chegar ao Brasil.

Em recomeços como o da família de Mira, foi fundamental o papel das instituições de assistência da comunidade judaica existentes em diversos países e que cumpriam diversas funções: prover alojamento para os refugiados, assistência médica, trâmites de vistos, entre outros. Foi com a ajuda dessas instituições, como a financiada pelos Rothschild e a HIAS (Hebrew Immigrant Aid Society) que Mira, Hannah e seu padrasto puderam, aos poucos, começar a reconstruir suas vidas. 
Em Paris, Hannah recebeu uma carta de familiares que moravam para o Brasil chamando a pequena família a morar no país. A espera pelo visto do governo brasileiro, porém, demorou mais de um ano, já que o governo de Getúlio Vargas, tinha uma severa política de restrição à entrada de imigrantes judeus.

Tio Yossef Wexler, sua esposa Rachel, e os primos Sylvia e Shaia, imigrariam para o Canadá. Os Weglowski permaneceriam na Polônia. Mira e sua família seguiriam para o Brasil, chegando finalmente ao Rio de Janeiro em 15 de julho de 1948.

\section{O reencontro com sua salvadora}

Em novembro de 2014, 70 anos depois daqueles anos de horror, a Jewish Foundation for the Righteous (Fundação Judaica para os Justos) que presta ajuda àqueles que salvaram judeus durante o Holocausto, organizou o reencontro entre entre Mira e Helena, que, junto com o irmão Stanislaw são os únicos representantes anda vivos daquele núcleo da família Weglowski, cujo papel significou a sobrevivência de ao menos 6 judeus.

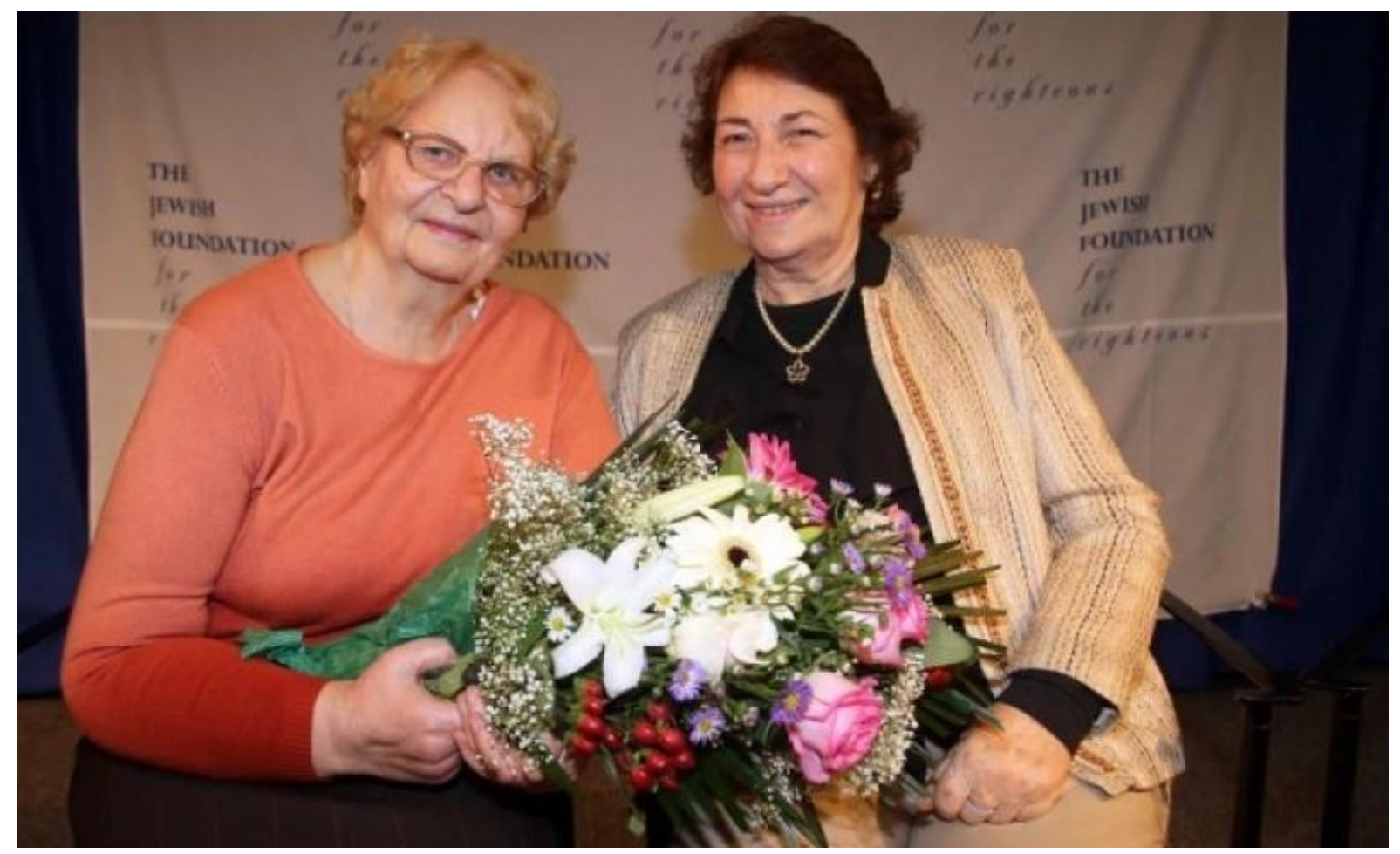

Helena Weglowski (à esquerda) e Mira Wexler (à direita) no evento organizado em Nova York pela Jewish Foundation for the Righteous, novembro, 2014.

Fonte: New York Post, 26 de novembro de 2014. 


\title{
4.2.2. Ze'ev Litwak: a resistência dos partisans judeus durante a guerra
}

\author{
Introduzindo a história de Ze'ev
}

A história de Ze'ev Litwak nos ajuda a aproximar o estudante de um dos aspectos talvez menos explorados tanto pelos professores quanto nos materiais didáticos utilizados em sala de aula: o das operações de resistência judaica.

De maneira geral, ao tratar do Holocausto, os materiais disponíveis aos estudantes do sistema escolar brasileiro -que na maioria das vezes se resumem exclusivamente aos livros didáticos- confirmam o que a cultura geral sobre o evento difunde em imagens como estas:
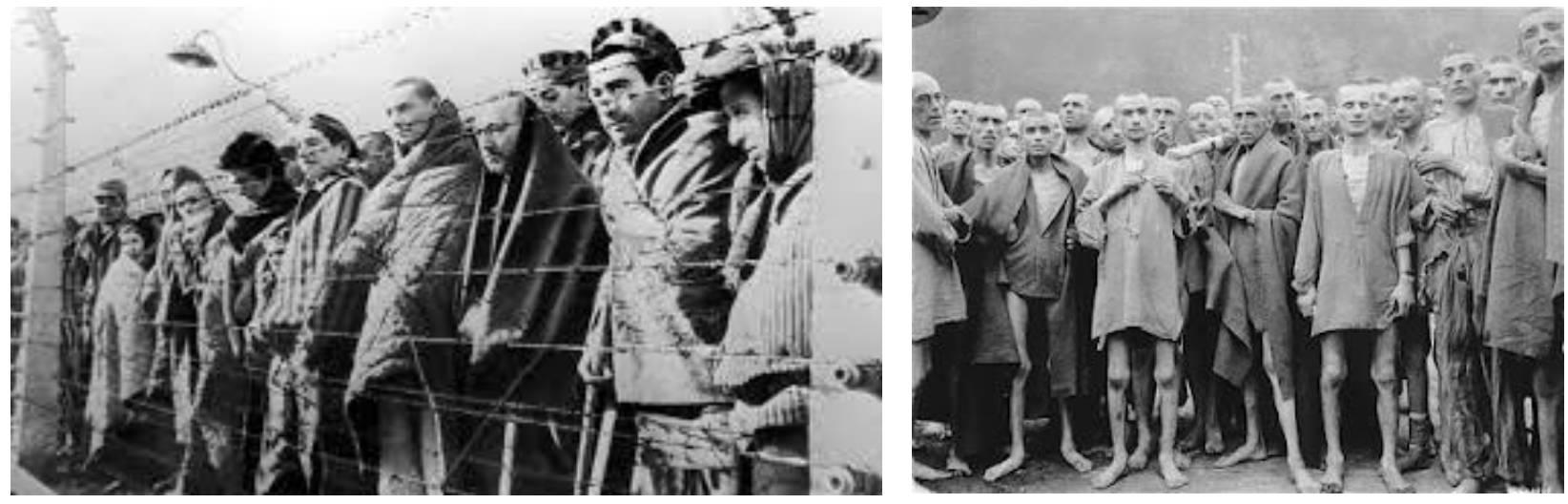

Nunca estas:
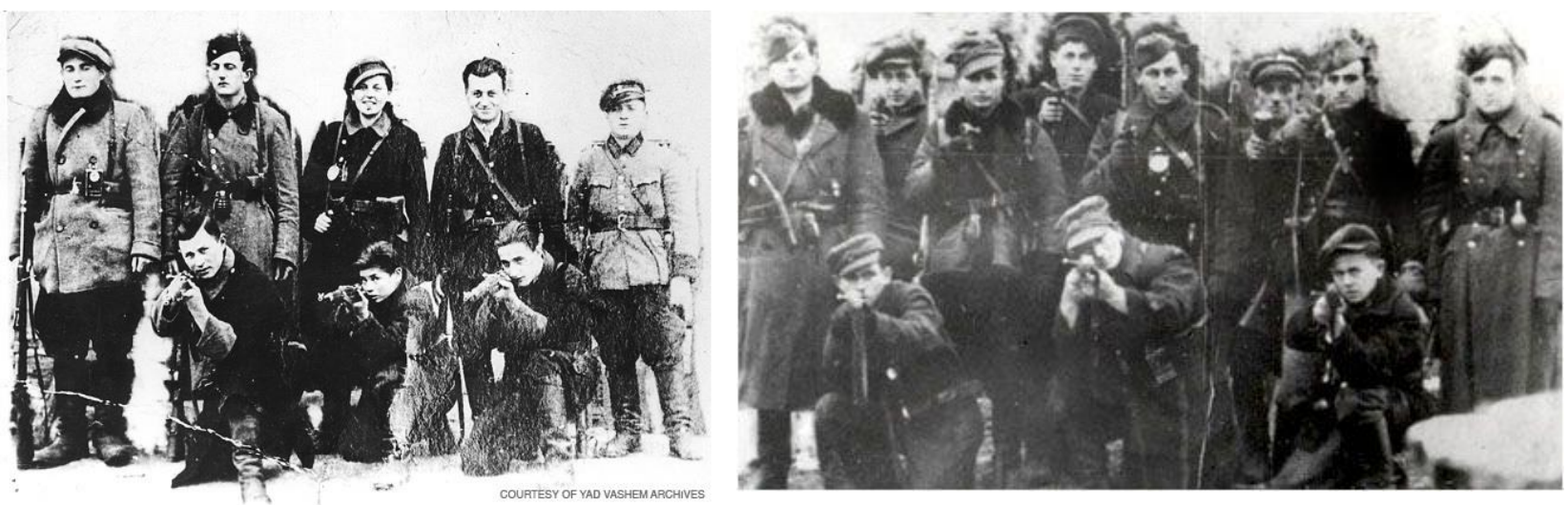
Discussões sobre as atividades de resistência dos judeus durante o Holocausto, não fazem parte nem dos materiais nem dos currículos escolares. É, portanto, uma tarefa crucial tentar, ao menos em parte, reparar essa ausência.

Quando nos debruçamos sobre a história do Holocausto o que surpreende, na verdade, é o quanto, apesar das incríveis dificuldades e do horror vivido, os judeus conseguiram resistir. Ter sobrevivido ao Holocausto constitui em si mesmo um ato de resistência, muitas vezes construído a partir de diversos blocos: resistência espiritual, artística, política e, como os estudantes e o público interessado em geral poderá conhecer através da história de Ze’ev, a resistência armada.

Assim, ajudar aos estudantes a descobrirem as diversas iniciativas, atividades e operações levadas a cabo nesse sentido, é de extrema importância para poder estabelecer um quadro mais exato da História do evento e ao mesmo tempo desfazer os mitos sobre a passividade da população judaica durante a catástrofe.

A história que trata a próxima proposta é a de Ze'ev Litwak. Nascido na cidade de Wlodava, Polônia, ao ver a situação que já se prefigurava para os judeus após a invasão pela Alemanha, decidiu, com apenas 16 anos, unir-se a um grupo de partisans que lutava nas florestas de Parczew, não muito longe de sua cidade, nas proximidades de Lublin.

Os partisans eram lutadores da resistência armada que lutavam atrás de linhas inimigas. Os primeiros grupos a formar-se na região onde Ze'ev lutou foram os partisans soviéticos, forças compostas por soldados do Exército Vermelho que haviam conseguido fugir do ataque alemão logo após a invasão nazista à região da Polônia anexada pela União Soviética.

Quanto aos judeus, a maioria dos partisans eram fugitivos de guetos (alguns inclusive de campos de concentração), que conseguiam chegar às florestas e unir-se aos grupos armados soviéticos. O forte antissemitismo tornava impossível para eles, unir-se aos grupos de resistência armada poloneses. Alguns partisans judeus, porém, chegaram a formar suas próprias unidades. Estima-se que entre 20.000 e 30.000 judeus tenham lutado em grupos de partisans durante os anos da guerra.

A área onde o grupo de Ze'ev operava, foi um dos principais campos de batalha desses movimentos. Além de lutar contra o inimigo principalmente através da destruição de alvos militares estratégicos (sabotagem de linhas férreas, trens, locais de suprimentos) ajudavam a garantir a segurança de mulheres, crianças e homens judeus que haviam buscado refúgio nas florestas. 
A situação desses partisans judeus era muito particular e em nada se assemelhava, por exemplo, à situação dos partisans soviéticos. Estes últimos, podiam às vezes voltar para casa e ver suas famílias. Os partisans judeus não tinham para onde ir. Eles lutavam para defender os judeus da aniquilação. Muitos deles, como Ze'ev, haviam perdido toda a sua família. Lutavam com pouco cuidado pelas próprias vidas, motivados pela manutenção do legado de seu povo ou para vingar a destruição causada pela ira do inimigo alemão. 


\section{LIVRO 2 - Zeev Wolf Litwak ${ }^{150}$}

"Nós estamos aqui"

Hino dos partisans judeus

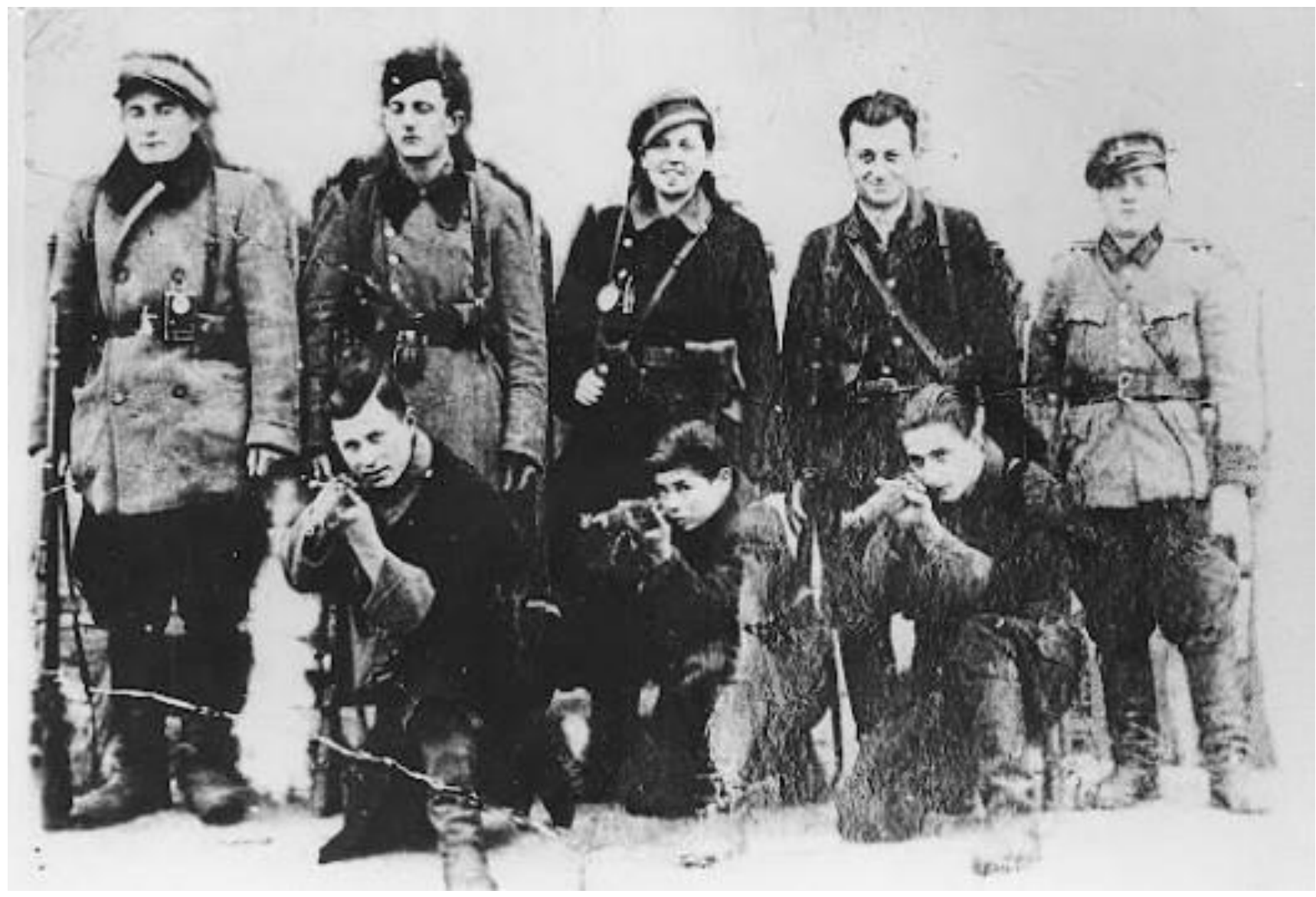

\section{Os partisans de Grynszpan}

Ao fundo (da esquerda para a direita: Harold Werner, Symcha Barbanel, Dora Grynszpan, Abram Grynszpan, Zeev Litwak; à frente (da esquerda para a direita): Chanina Henry Barbanel, Abram o Partisan, Shienka de Wlodawa. Como veremos, vários desses heróis refugiaram-se no Brasil após a Segunda Guerra. Fonte: Arquivo do Memorial Yad Vashem.

O repertório de imagens sobre judeus no Holocausto raramente é feito de fotografias como a que abre estas páginas: rostos de homens e mulheres confiantes, destemidos, armados.

150 Testemunho de Ze'ev Wolf Litwak ao Projeto Vozes do Holocausto (Arqshoah/LEER), Rio de Janeiro, 08 de julho de 2015. Ficha Técnica: Entrevistadora, Maria Luiza Tucci Carneiro; Câmera, Laís Rigatto Cardillo; Transcrição, Laura Lemmi di Natale. 
A ausência de histórias como as dos jovens que aqui vemos, são em boa parte responsáveis tanto pela crença sobre a passividade dos judeus perante a Alemanha nazista quanto por uma pergunta que se repete: por quê os judeus não lutaram contra seu próprio extermínio?

Tanto a crença quanto a pergunta têm uma resposta: eles resistiram. Resistiram de diversas formas, com variados meios e em todo o território onde foram perseguidos. Resistiram com seu espírito, com sua cultura, com sua arte. Resistiram educando as crianças nos guetos e esconderijos. Resistiram espionando ou transportando documentos e mensagens. Resistiram sabotando a infraestrutura do inimigo.

Zeev Litwak (na foto ao lado), foi um dos até 30.000 jovens judeus europeus que lutaram por sua sobrevivência e pela sobrevivência de tantos outros. Eram os chamados partisans, combatentes da resistência armada que operavam atrás das linhas inimigas.

Os partisans judeus eram, em sua maioria, jovens que conseguiram fugir de guetos ou campos de concentração e extermínio nazistas, principalmente a partir de 1942, quando as deportações para campos de extermínio se intensificaram. Muitos se uniam a grupos de partisans não-judeus -a maioria soviéticos- mas outros formaram suas próprias unidades. Entre elas, uma das mais combativas foi a de Yechiel (Chil) Grynszpan que atuou nas florestas de Parczew, na Polônia.

Esses jovens combatentes, em sua maioria adolescentes, não lutaram por ambição ou glória, mas sim para sobreviver, vingar o extermínio de suas famílias e proteger o maior número possível de judeus que, como eles, eram vítimas da mais terrível perseguição. Lutaram por um legado capturado em um trecho da letra do hino que os partisans judeus cantavam nas florestas: "Nós estamos aqui".

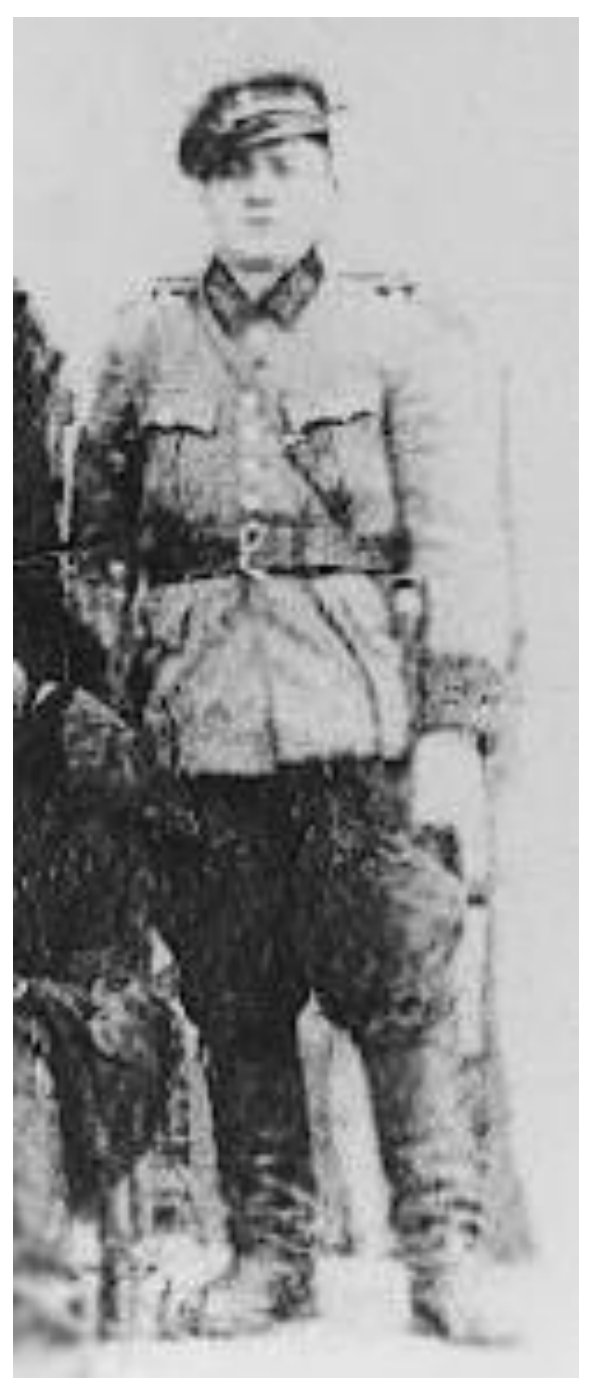




\section{Os primeiros anos na Polônia}

Quando nasceu, Zeev não se chamava assim. Seu nome era Herzel. Porém, muitas outras mudanças ainda estavam por acontecer na vida daquele menino que anos depois, ainda na adolescência e sem que quisesse, se transformaria em herói.

Naqueles primeiros anos de vida, entre meados da década de 1920 e 1930 seu lar era a Polônia e não o Brasil, para onde se mudaria anos mais tarde. Sua cidade, a pequena Sosnowica, distrito de Lublin na Polônia.

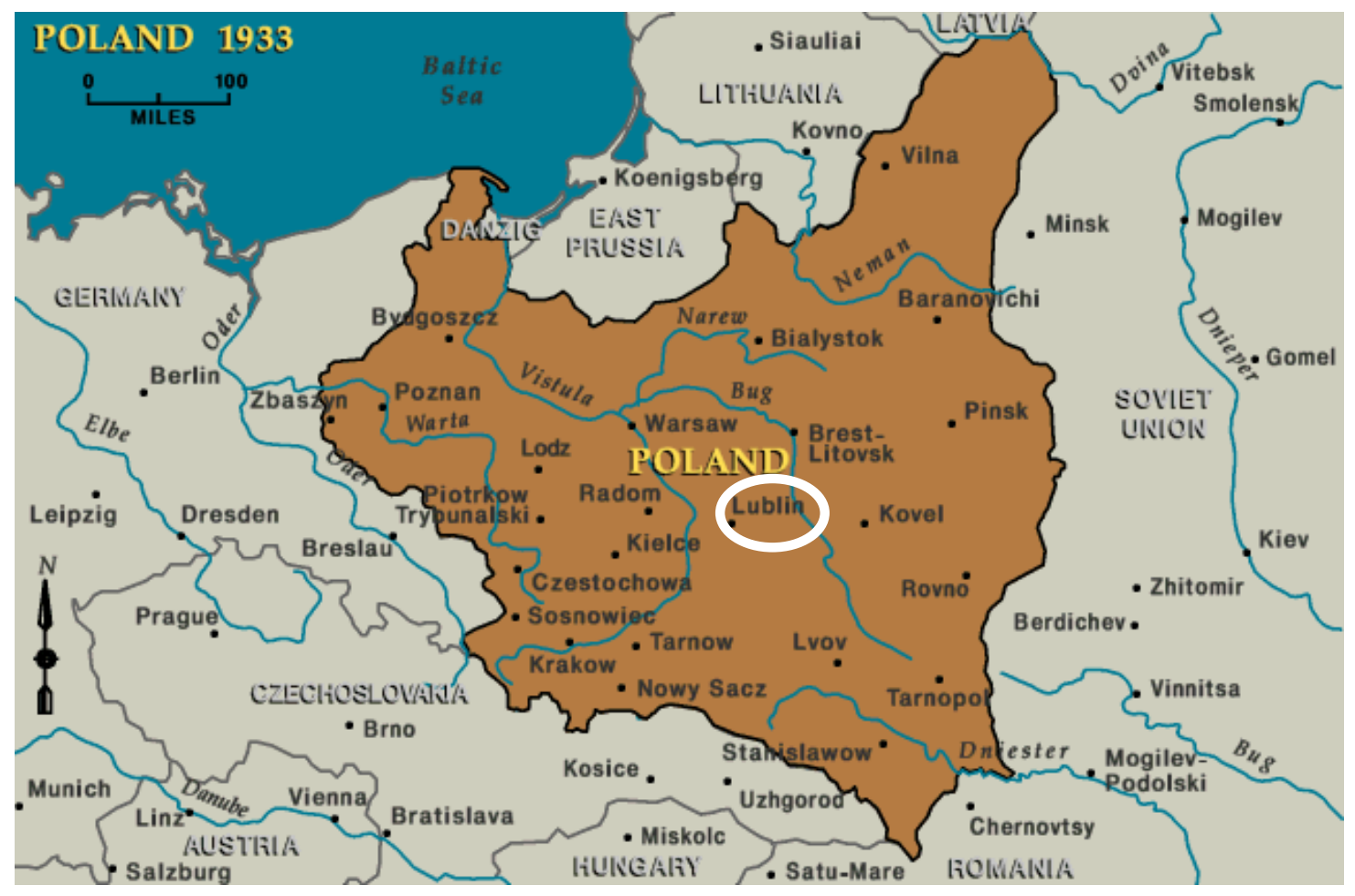

Polônia, 1933.

Em destaque (elipse vermelha), o distrito de Lublin, onde se localiza a cidade de Sosnowica. Fonte: United States Holucaust Memorial Museum (USHMM)

A comunidade judaica de Sosnowica totalizava cerca de metade da população local, isto é, dos aproximadamente 1.000 habitantes da cidade, pouco mais de 400 eram judeus. Seus pais, Hersh e Zipora, respeitavam o judaísmo e suas tradições, mas mesmo assim, decidiram matricular Zeev e seus seis irmãos na escola pública da cidade. 
Embora o antissemitismo estivesse muito presente na Polônia, inclusive nas escolas, a vida transcorria em relativa calma para Zeev, sua família e os judeus de Sosnowica.

Outubro de 1939, os alemães chegam a Sosnowica

Em $1^{\circ}$ de setembro de 1939, a Alemanha de Hitler, invadiu a Polônia lançando mão de uma cláusula secreta existente em um documento assinado entre a Alemanha e a União Soviética: o Pacto de Não Agressão Germano-Soviético (ou Ribbentrop-Molotov). Através desse pacto, os dois países dividiram a Polônia em duas partes: a Oeste, o território polonês seria anexado à Alemanha e a Leste, à União Soviética.

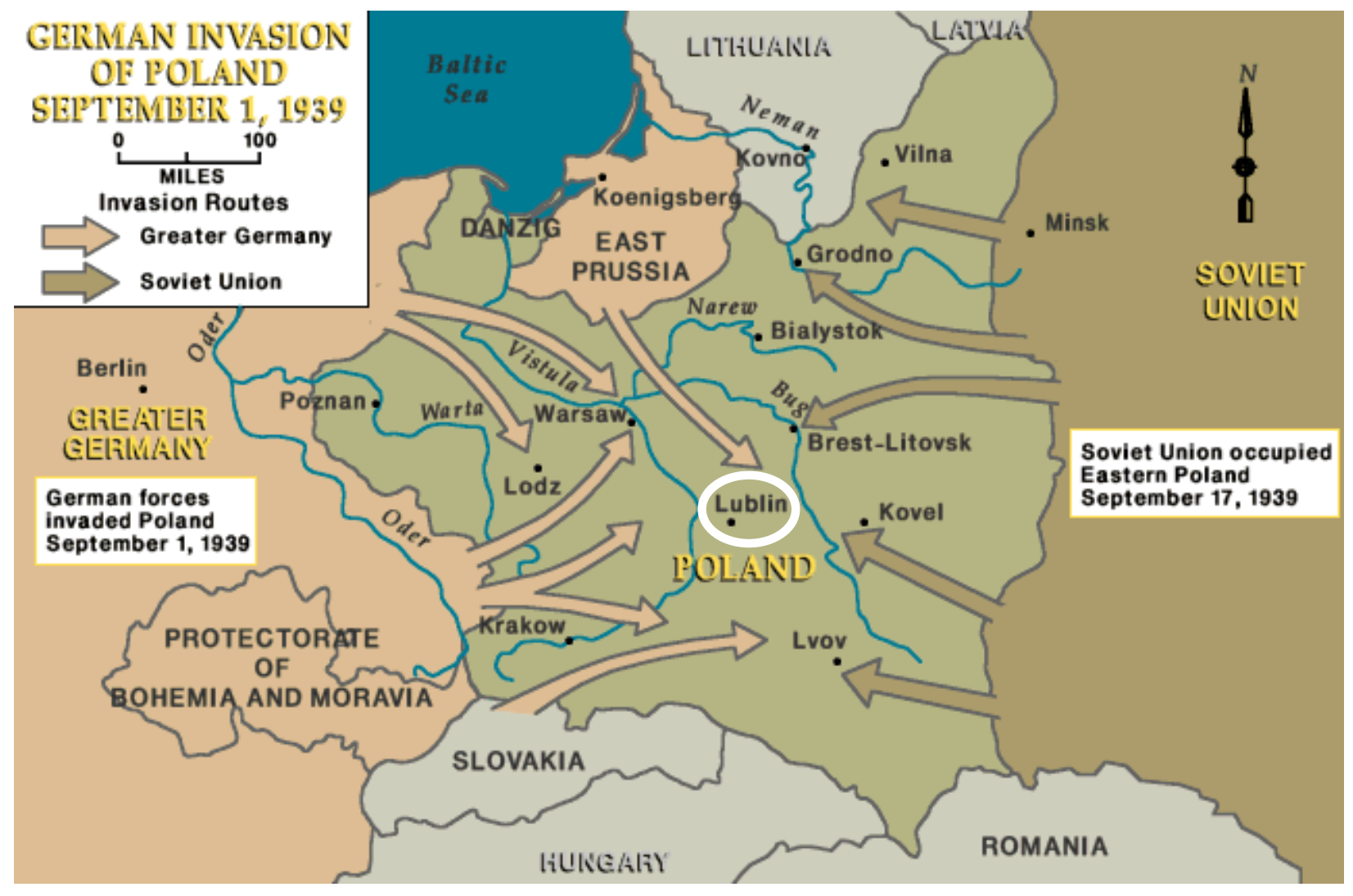

A invasão da Polônia

Fazendo uso de uma cláusula secreta presente no Pacto de Não-Agressão, as forças alemãs invadiram a Polônia em $1^{\circ}$ de setembro de 1939 (lado esquerdo do mapa); a União Soviética ocuparia o Leste em 17 de setembro de 1939. A elipse indica o distrito de Lublin ao qual pertencia Sosnowica. Fonte do Mapa: United States Memorial Museum (USHMM). 
Tal como aconteceu no restante da Polônia, a aproximação dos invasores a Sosnowica resultou imediatamente no aumento do antissemitismo entre os próprios habitantes poloneses que passaram a atacar fisicamente os judeus da cidade, assim como suas lojas e casas. A chegada dos alemães, por outro lado, resultou na prática de várias ordens restritivas aos judeus e a instituição de um sistema de trabalhos forçados.

Porém, até o início 1941, a vida para Zeev em Sosnowica transcorria em aparente "normalidade". Ele trabalhava em uma unidade da cavalaria da SA - unidades de assalto alemãs-, estacionada na cidade vizinha de Laski. Limpava os cavalos. Maus tratos e insultos antissemitas não eram realmente uma novidade na Polônia até o final dos anos 1930. A presença dos alemães, a princípio, parecia tratar-se de uma continuidade daquele cotidiano.

No entanto, por toda a Europa, as engrenagens da destruição já estavam em movimento. As notícias, porém, não se espalhavam rapidamente naquela Europa dos anos 1940.

\section{O estabelecimento do sistema de guetos na Polônia}

A invasão da Polônia pela Alemanha nazista marcou mais uma etapa na escalada rumo ao objetivo de tornar a Europa Judenfrei (livre de judeus). Uma das primeiras medidas que as autoridades invasoras tomaram em relação aos judeus, foi o estabelecimento de guetos. A decisão, tomada pelo governo central alemão, visava segregá-los e isolá-los dentro das cidades, conforme documentado em uma ordem expedida por Reinhard Heydrich em 21 de setembro de $1939^{151}$.

O documento de Heydrich determinava, entre outras disposições, que as áreas em questão fossem completamente liberadas de judeus e o estabelecimento de algumas cidades de concentração localizadas de modo "facilitar medidas subsequentes".

O momento da delimitação do gueto variaou de cidade para cidade e eram as autoridades alemãs locais que tomavam essa decisão. No entanto, um aspecto comum a todos os guetos era a formação de um Judenrat, conselho judeu, cujas características foram descritas por Heydrich no mesmo documento.

\footnotetext{
${ }^{151}$ Chefe da Agência Central de Segurança do Reich (RHSA), entre outros cargos de alto escalão, foi um dos principais executores da chamada "Solução Final". Em 1942, membros da resistência tcheca montaram uma emboscada que resultou na morte do comandante nazista. Cinco dias depois, Hitler ordenou uma retaliação exemplar, que resultou na completa destruição do vilarejo de Lídice, Tchecoslováquia e no assassinato de todos os homens acima de 15 anos. Fotografia: Arquivo do Memorial Yad Vashem.
} 
Aí ele determinava que os membros do Judenrat fossem os responsáveis por implementar todas as diretrizes expedidas pelos alemães, além de lidar com questões relativas ao dia-a-dia do gueto: alimentação, moradia, saúde, higiene e organização do trabalho. Seus membros seriam rabinos ou outras autoridades influentes dentro de cada comunidade.

Dois itens no documento de Heydrich, em relação ao Judenrat, deixam claro o difícil papel designado a esse conselho:

1) O Conselho será totalmente responsável, no sentido literal da palavra, pela implementação exata e rápida de todas as diretrizes expedidas ou a serem expedidas no futuro.

2) Em caso de sabotagem dessas instruções, os Conselhos serão advertidos de que as mais severas medidas serão tomadas. ${ }^{152}$

\section{O gueto de Wlodawa}

A aproximadamente $40 \mathrm{~km}$ de Sosnowica, onde Zeev vivia com sua família, encontra-se a cidade de Wlodawa. Centro de uma próspera comunidade judaica desde a Idade Média, sua população, no final dos anos 1930, era de aproximadamente 9.000 habitantes. Quase $70 \%$ deles eram judeus ocupados nas mais variadas atividades: médicos e joalheiros, açougueiros e alfaiates, comerciantes e proprietários de moinhos, professores e músicos.

Wlodawa recebeu sua primeira sinagoga no final do século XVII e entre 1764 e 1774, foi construído um imponente edifício para essa finalidade.

Entre outubro e novembro de 1939, Wlodawa passou a ter uma autoridade militar. Em novembro, porém, a SS tomou o controle da cidade e começaram a ser implementadas as determinações feitas por Heydrich: delimitação do gueto, transferência dos judeus para o gueto, estabelecimento do Judenrat.

Entre as primeiras ordens para este conselho, estavam a de conseguir suprimentos para os homens da SS, polícia e outros colaboradores, além de “doações” em dinheiro. Todos os dias,

\footnotetext{
152 Instruções de Heydrich sobre políticas e operações relativas aos judeus aos judeus nos territórios ocupados. Ordem de 21 de setembro de 1939. Fontes: Arquivos Yad vashem. Uma versão em inglês desse documento pode ser encontrada em: www.yadvashem.org/odot.pdf/microsoft\%20word\%20-\%1984.pdf. Negrito e sublinhado nosso.
} 
membros do Judenrat deviam apresentar-se aos homens da Gestapo para receber as instruções e demandas para o dia seguinte, as quais eram cada vez mais severas.

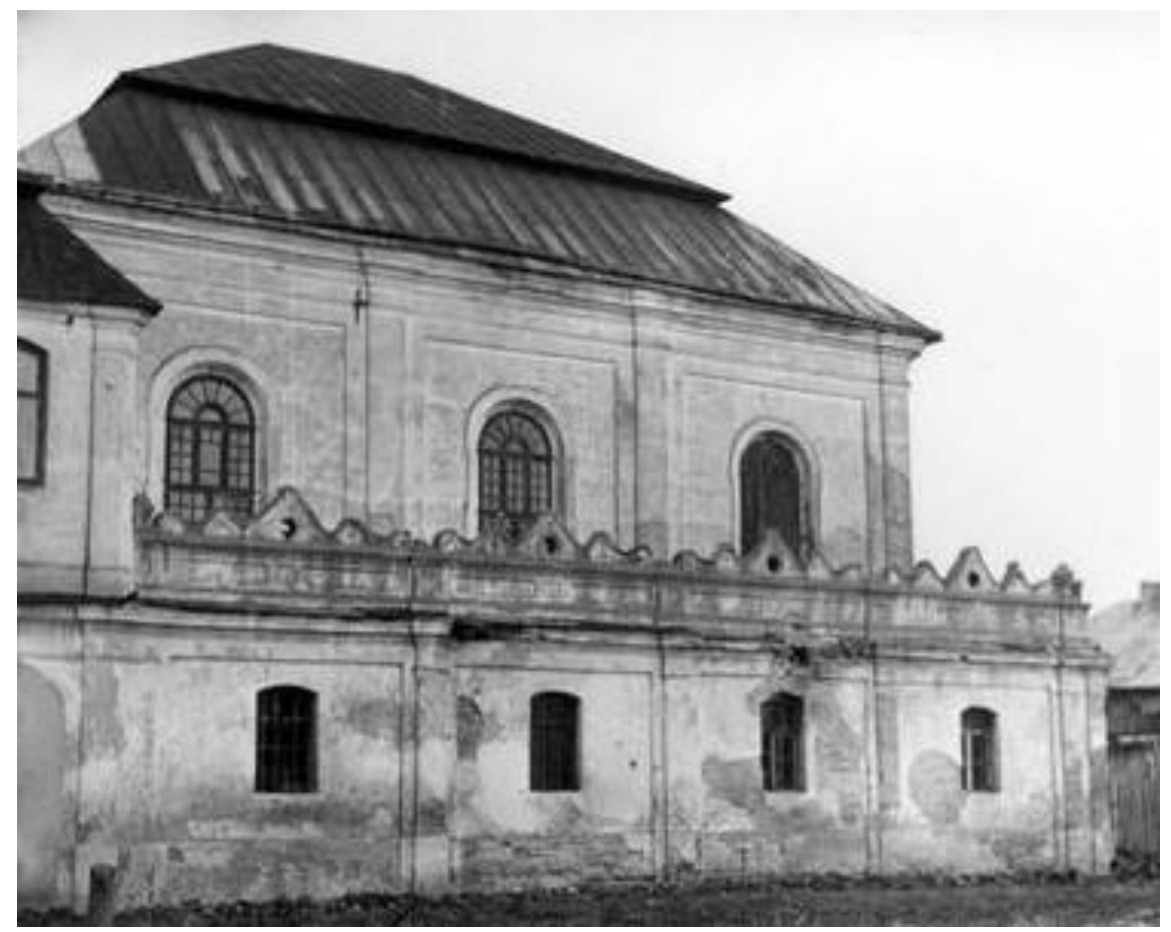

A Sinagoga de Wlodawa antes de guerra

Fonte: Arquivo do Memorial Yad Vashem, Jerusalém, Israel

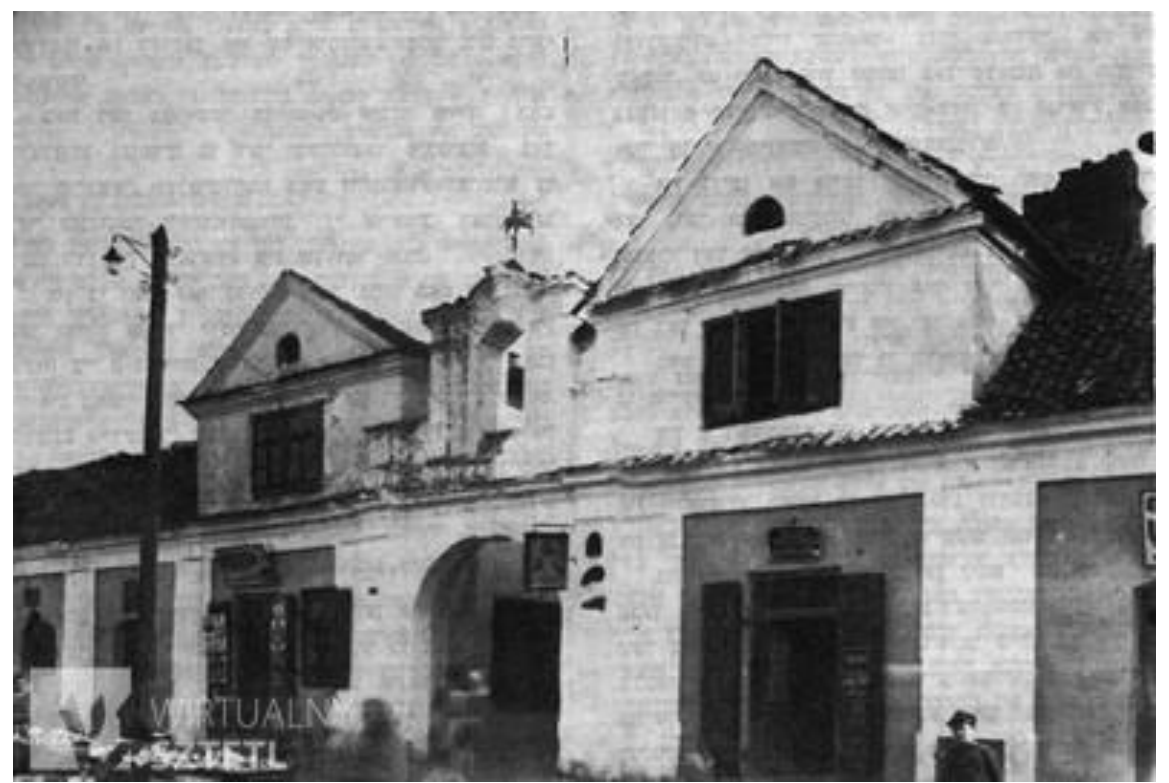

Mercado de Wlodawa antes de guerra

Fonte: Virtual Sztetl

www.sztetl.org.pl 
Os comandantes das autoridades invasoras, instalaram-se em prédios e casas da cidade cujos proprietários haviam sido forçados a morar no gueto. A ocupação incluiu a "pequena sinagoga", que passou a ser utilizada para estocagem de grãos.

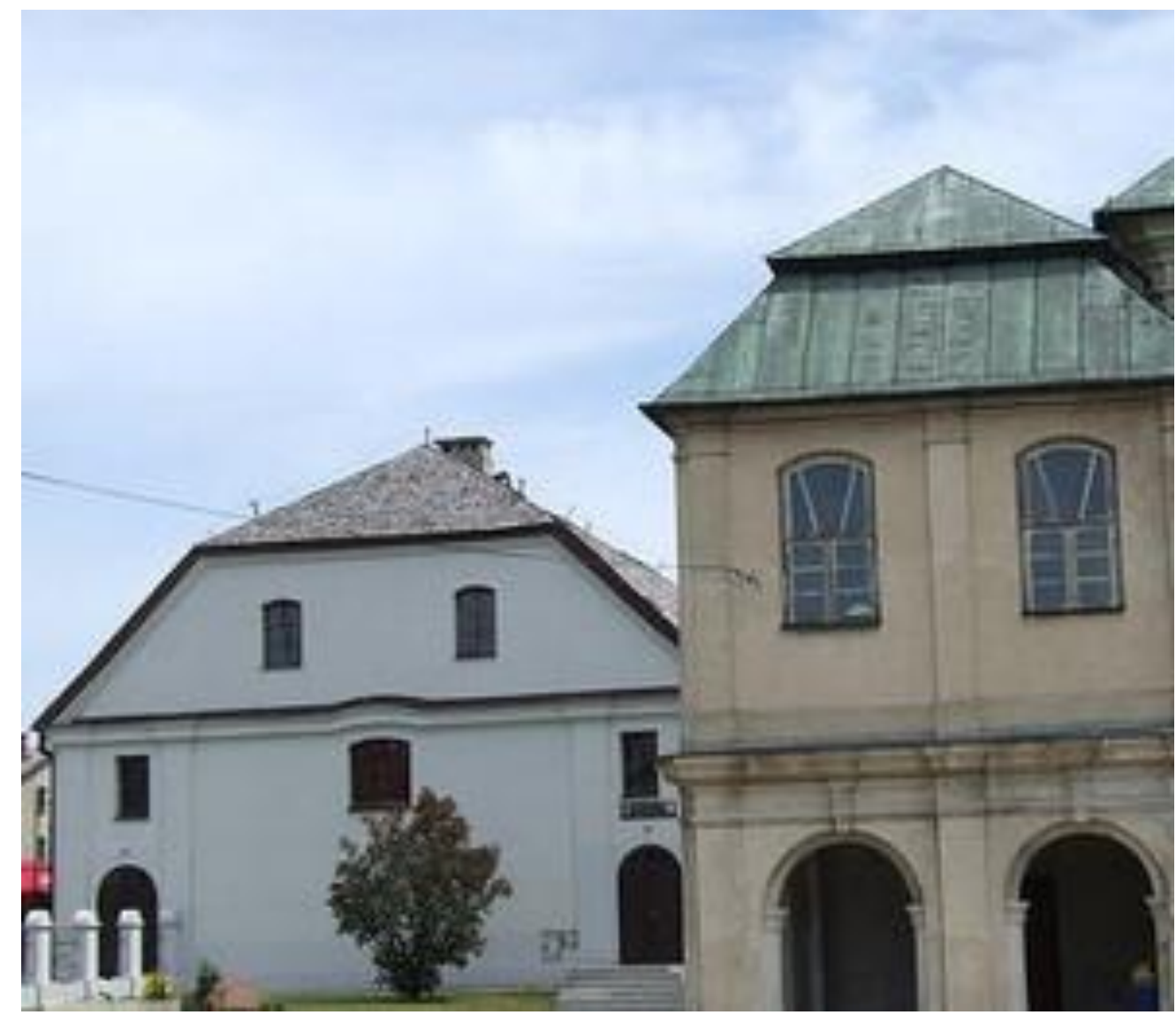

A Pequena Sinagoga de Wladowa (à esq.)

A construção foi restaurada entre 1983 e 1998. Hoje ela é parte do complexo do Museu Judaico de Wladowa e está localizada ao lado da Grande Sinagoga.

Fonte: Virtual Shtetl

Ainda em relação ao documento de 21 de setembro de 1939, Heydrich estabeleceu: "as comunidades judaicas com menos de 500 pessoas deverão ser dissolvidas e transferidas ao centro de concentração mais próximas" 153

Essa determinação foi sendo cumprida gradualmente a partir da invasão da Polônia por todo o território ocupado pela Alemanha. Em alguns casos, como em Sosnowica, onde Zeev e sua família ainda moravam, a ordem de transferência viria somente em 1942.

${ }^{153}$ Idem. 
Durante esses processos de transferência de prisioneiros, os guetos iam ficando cada vez mais superlotados e as condições de vida tornavam-se cada vez mais insuportáveis: escassez de alimentos, doenças, em meio a uma rotina de trabalhos forçados e constantes torturas e mautratos. Muitos perderam lá suas vidas.
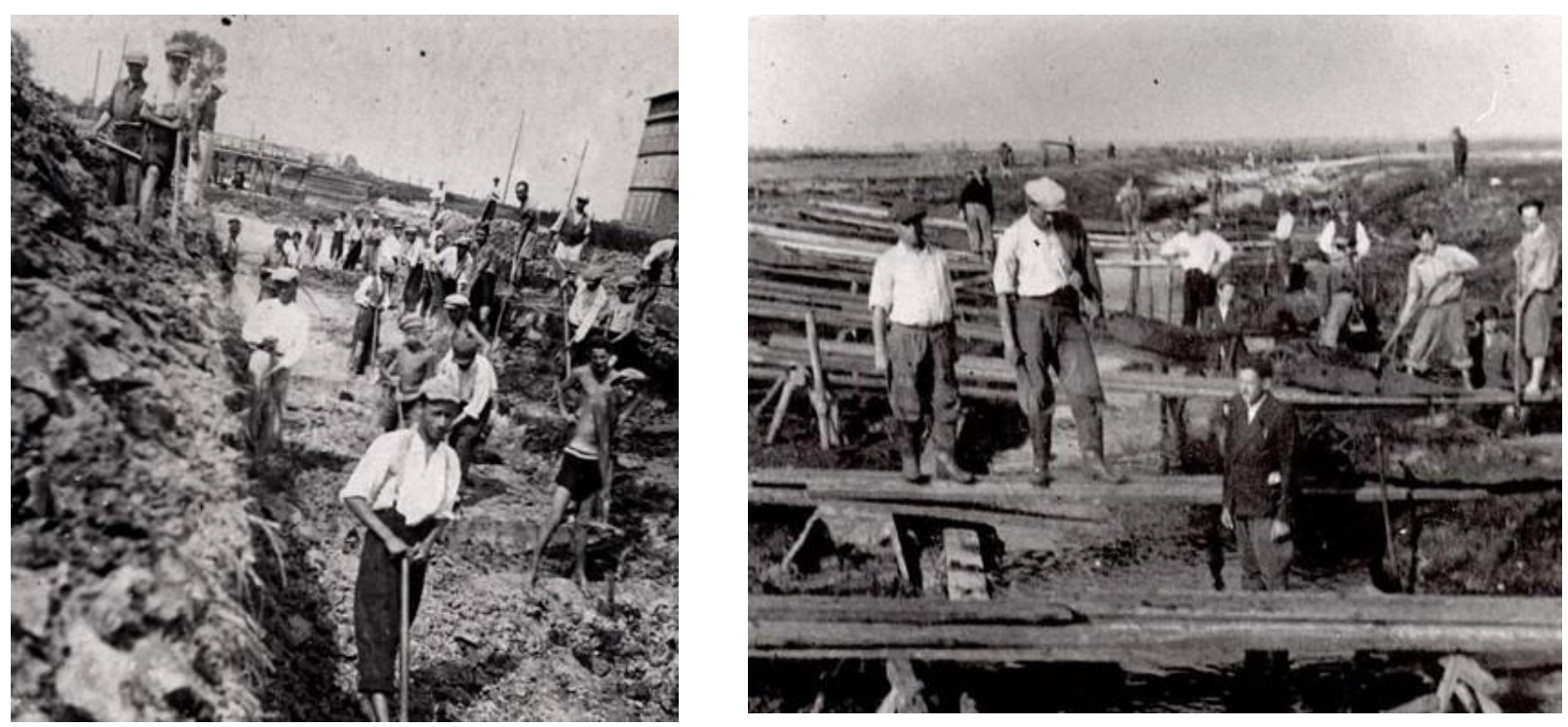

Trabalhos forçados nas proximidades do gueto de Wlodawa

Fonte: http://chelm.freeyellow.com/wlodawa.html

\section{A "Solução Final da Questão Judaica"}

Entre 1939 e 1941, como sabemos pelo testemunho de Zeev, a vida em Sosnowica ainda mantinha alguma estabilidade. Embora os alemães tivessem instituído um regime de trabalhos forçados além de inúmeras restrições, muitas famílias, inclusive a de Zeev, permaneciam intactas.

O que mudou para os judeus em 1941?

Em 22 de junho de 1941, a Alemanha invadiu União Soviética, dando início à chamada Operação Barbarossa. Embora os alemães já fossem responsáveis pela morte de judeus em todos os territórios ocupados, a aniquilação física da totalidade do povo judeu, foi decidida durante os preparativos para a invasão da União Soviética. 
Mas por que a guerra contra a União Soviética está relacionada à "Solução Final"?

Os dois elementos mais importantes que ligam a invasão da União Soviética à "solução final" encontram-se na própria visão de mundo deturpada de Hitler. Para ele, os judeus "controlavam" não só o capitalismo internacional quanto - ao mesmo tempo!- o bolchevismo na União Soviética. Erradicar o judeu era, para Hitler, erradicar o comunismo (e o capitalismo...).

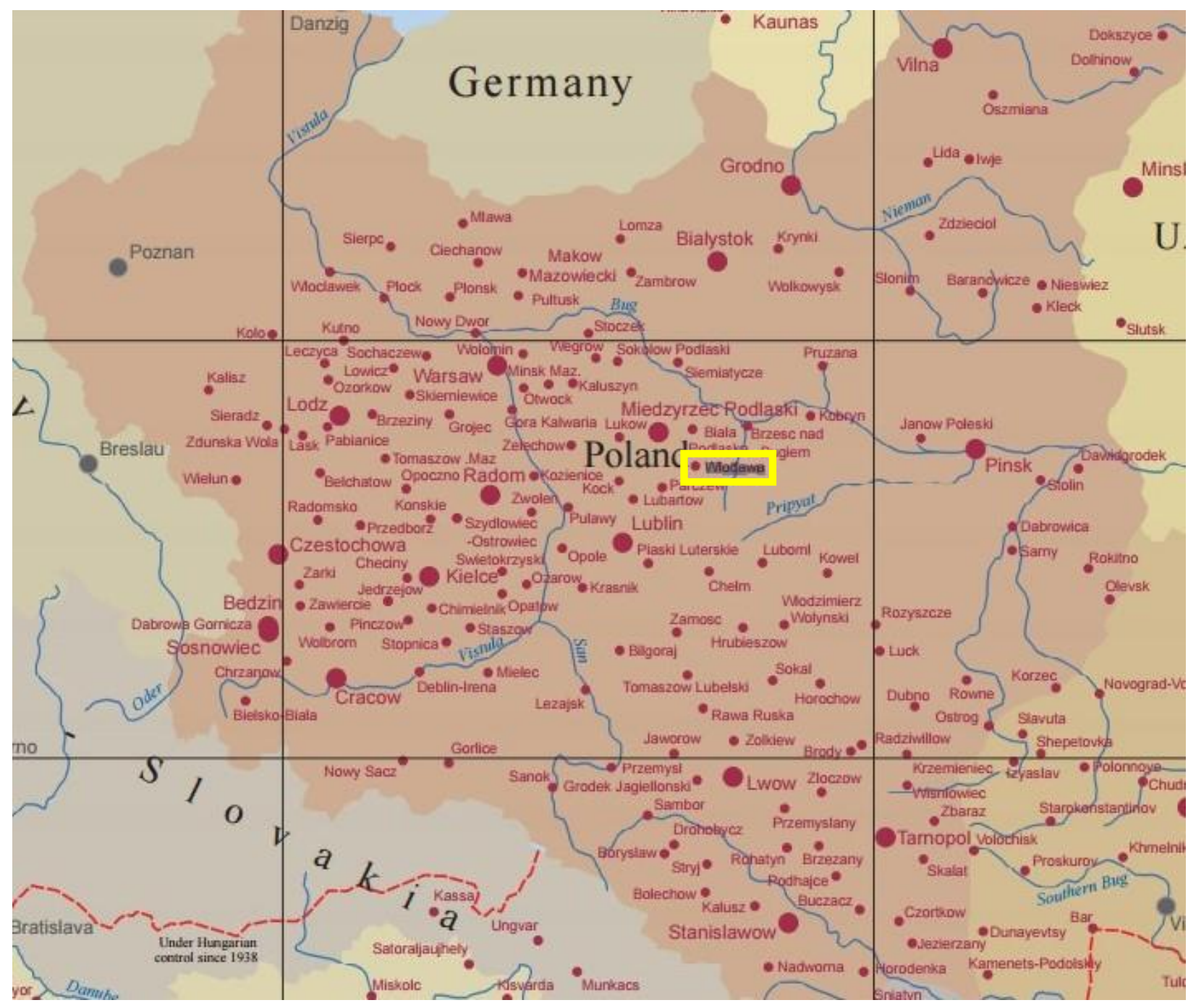

Principais guetos na Polônia

Este mapa mostra exclusivamente o território da Polônia. Porém, em outros países do Leste europeu ocupados pela Alemanha nazista também foram estabelecidos guetos, como pode ser observado pela presença de alguns pontos fora das fronteiras do território polonês.

Guetos maiores;• Outros guetos ; $\quad$ Gueto de Wlodawa

Fonte: Arquivo Yad Vashem, Jerusalém, Israel

https://www.yadvashem.org/yv/he/research/ghettos_encyclopedia/maps.pdf 
A aliança entre a Grã-Bretanha e a União Soviética e, posteriormente, a entrada dos Estados Unidos na Guerra no fim de 1941, eram para Hitler a "confirmação" de que os "judeus controlavam o mundo". Ele enxergava essa aliança como uma conspiração dos judeus contra a Alemanha quando na verdade se tratava de uma resposta a suas ambições expansionistas e segregacionistas.

É importante ter em mente neste ponto, o caráter profundamente contraditório - por não dizer absurdo - de uma visão que atribuía o controle dos dois maiores sistemas de organização social e econômico - o capitalismo e o comunismo - a um único (e proporcionalmente muito pequeno) grupo de pessoas. Um importante alerta quanto ao perigo das teorias da conspiração que ainda hoje circulam livremente.

De qualquer maneira, o período que começou em setembro de 1939 com a invasão de Polônia e os primeiros meses de 1941 representou a transição em direção ao último degrau na radicalização do projeto de extermínio do povo judeu: a criação de uma "linha de produção" da morte.

Por outro lado, à radicalização ideológica somou-se um fator de ordem prática: considerando os territórios ocupados da Polônia e União Soviética, os alemães passaram a controlar o local onde residia grande parte dos judeus da Europa. Aproximadamente mais 5,5 milhões de judeus entrariam então na órbita do Reich. Isolá-los em guetos e organizar sua deportação para algum lugar distante, já não parecia uma "solução" viável.

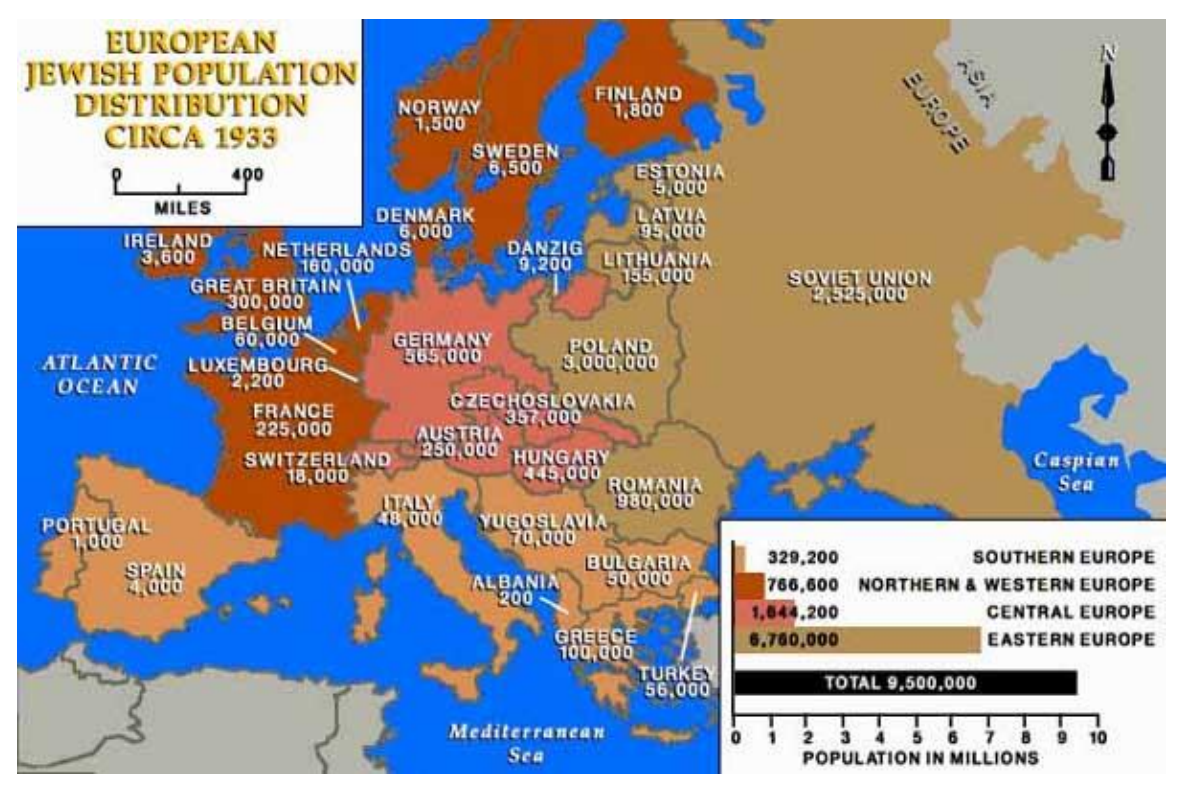

Distribuição da população judaica na Europa por volta de 1933

Fonte: United States Holocaust Memorial Museum (USHMM)

Washington, DC. Estados Unidos, www.ushmm.org 
Os líderes nazistas passaram então a planejar métodos mais extremos e rápidos. Reinhard Heydrich, homem de total confiança de Hitler, foi quem recebeu a missão de organizar o projeto genocida. A primeira ideia que pôs em prática foi a criação dos Einsatzgruppen, ou seja, unidades móveis de extermínio que avançavam "nos calcanhares" do exército alemão penetrando os territórios que iam sendo invadidos.

Cada grupo era composto por 500 a 900 homens, totalizando 3.000 subdivididos internamente -os chamados Sonderkommandos ou Einsatzkommandos. Contavam ainda com a ajuda de outros milhares de colaboradores locais e foram responsáveis pelo assassinato de mais de 1.500.000 de judeus.

Os Einsatzgruppen eliminavam suas vítimas mediante fuzilamentos em massa, próximo às localidades onde habitavam. Em geral, as pessoas eram reunidas à beira de barrancos, minas ou valas cavadas, na maioria das vezes, pelas próprias vítimas.

Seu trabalho, porém, começou a ser considerado pelas autoridades da Alemanha nazista como muito "manual", com um alto desgaste do pessoal alemão envolvido. Começaram então a procurar novos métodos de execução, mais simples e rápidos, para levar a cabo a "Solução Final", ou seja, a aniquilação total do povo judeu. Seria então proposto o estabelecimento de instalações permanentes usando a asfixia como modalidade de extermínio, e que resultou no estabelecimento de campos de concentração equipados com câmaras de gás.

As discussões em torno a essas questões foram feitas em reuniões e comunicados que tiveram lugar no segundo semestre de 1941 entre as autoridades do governo alemão diretamente envolvidas em sua implementação. Em 20 de janeiro de 1942, essas autoridades se encontrariam para dar um encaminhamento comum a essas questões. A reunião ficaria conhecida como a Conferência de Wannsee.

\section{A reunião de Wannsee}

O historiador britânico Martin Gilbert refere-se a Wannsee como o lugar onde a "Solução Final" recebeu seu endosso burocrático.

Embora essa reunião seja geralmente conhecida com o pomposo nome de Conferência de Wannsee, sua importância está muito mais próxima da definição de Gilbert.

A reunião, convocada por Heydrich, teve lugar em uma residência localizada a sudoeste de Berlim, Alemanha, à beira do lago de Wannsee. O objetivo era comunicar às autoridades 
presentes, a decisão de Hitler de levar a cabo a "solução final" -embora ela já estivesse em andamento-, e discutir os aspectos organizacionais e políticos da implementação.

A minuta da reunião revela que entre os temas discutidos estiveram a eficiência de métodos de extermínio que já vinham sendo implementados. Outra questão longamente analisada foi quanto à definição de "judeu", ou seja, quem era judeu, o que fazer com os judeus casados com arianos, ou com aqueles que tivessem pai ou mãe ariano, tudo baseado em classificações raciais pseudo-científicas.

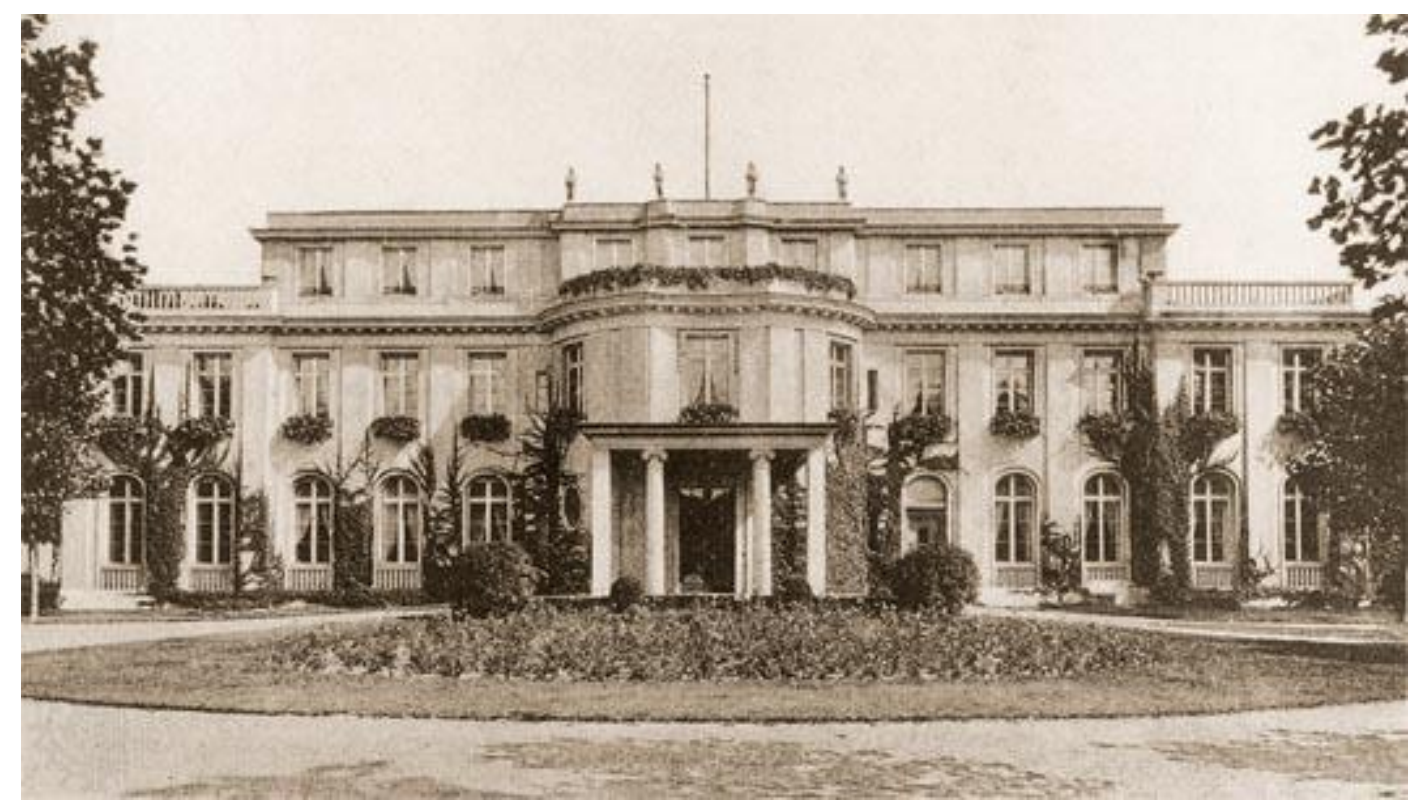

Residência onde foi realizada a reunião de Wannsee

\section{Os campos de extermínio nazistas}

Na segunda metade de 1941, a comunidade judaica de Sosnowica, embora ainda não estivesse ciente dos planos das autoridades do governo central alemão, sentia que a situação começava a mudar - para pior.

Zeev lembra que já nos primeiros meses de 1942, o Judenrat de Wlodawa, recebeu ordens das autoridades alemãs para recrutar alguns jovens judeus de Sosnowica. A promessa era que eles voltariam em vinte dias: “- Mas eles nunca voltaram. Foram usados para construir o campo de Sobibor". 


\section{Sobibor}

Junto com outros três campos - Chelmno, Belzec e Treblinka - Sobibor foi um centro exclusivamente de extermínio, onde aproximadamente 250,000 judeus foram assassinados em pouco mais de um ano. Ele fazia parte do sistema posto em prática por Heydrich e aprofundado depois da reunião de Wannsee.

Sobibor começou a ser construído em $1^{\text {o }}$ de março de 1942 e logo entrou em operação. Como você pode ver no esquema, seu projeto limita-se a um retângulo demarcado por uma cerca de arame farpado e cercado de árvores que cobriam sua visão. Entre a cerca e as árvores, uma faixa minada. Era dividido basicamente em três áreas: administração, recepção e extermínio, esta última equipada com câmaras de gás que funcionavam com monóxido de carbono.

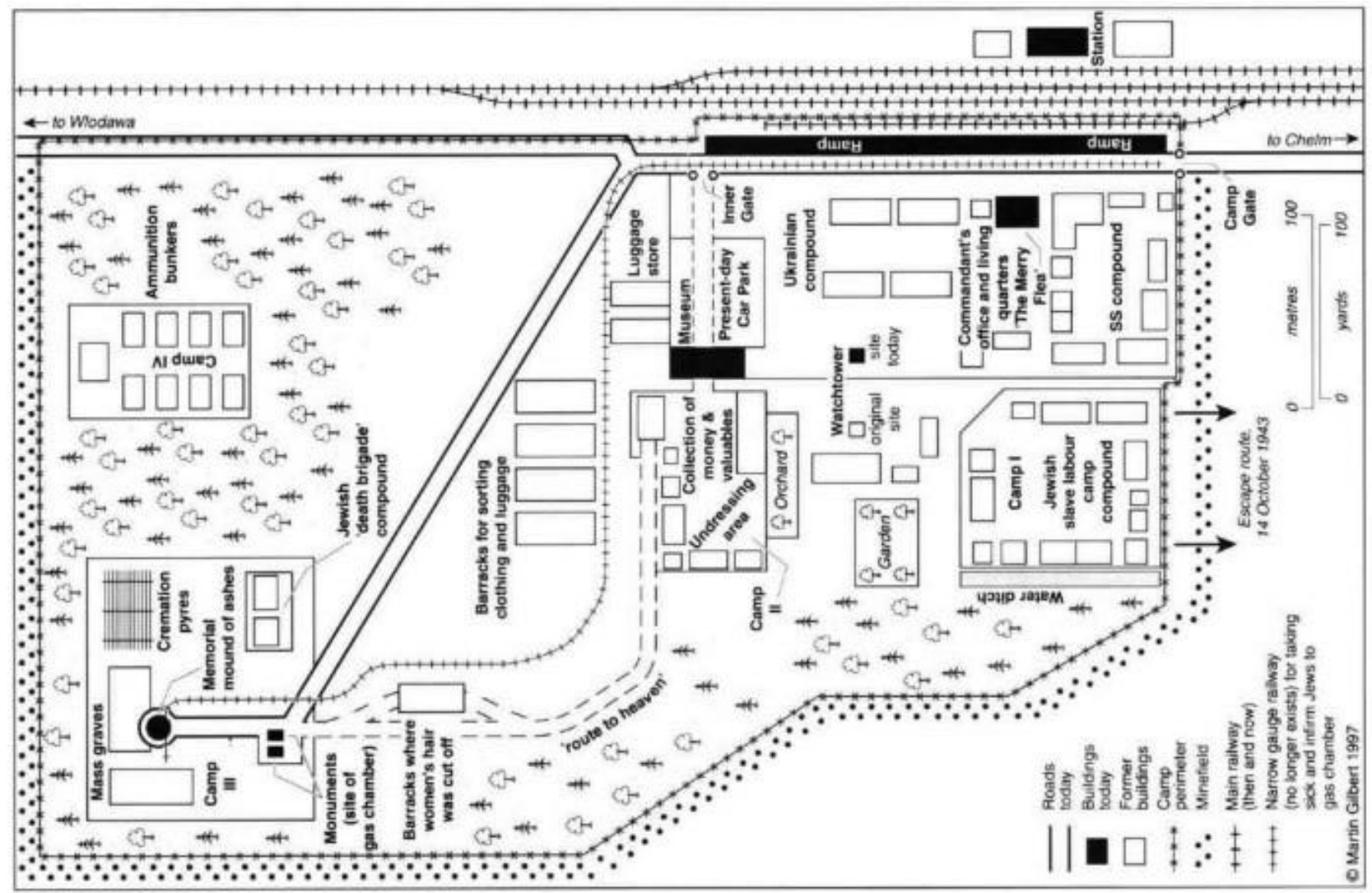

Esquema do campo de extermínio de Sobibor

Fonte: Martin Gilbert. Holocaust Journey. Travelling in Search of the Past.

New York: Rosetta Books, 2015

$\mathrm{Na}$ chegada a Sobibor eram selecionados os homens mais fortes que deviam trabalhar nas tarefas do dia-a-dia, os chamados Sonderkommando. Mas, não sendo um campo de trabalhos forçados, aqueles que não eram escolhidos, ou seja, idosos, mulheres, crianças, doentes, eram 
assassinados imediatamente $\mathrm{O}$ processo inteiro, desde a chegada até a morte, ocorria em no máximo 3 horas. Periodicamente, os próprios membros do Sonderkommando eram mortos e substituídos por outros homens recém deportados para o campo.

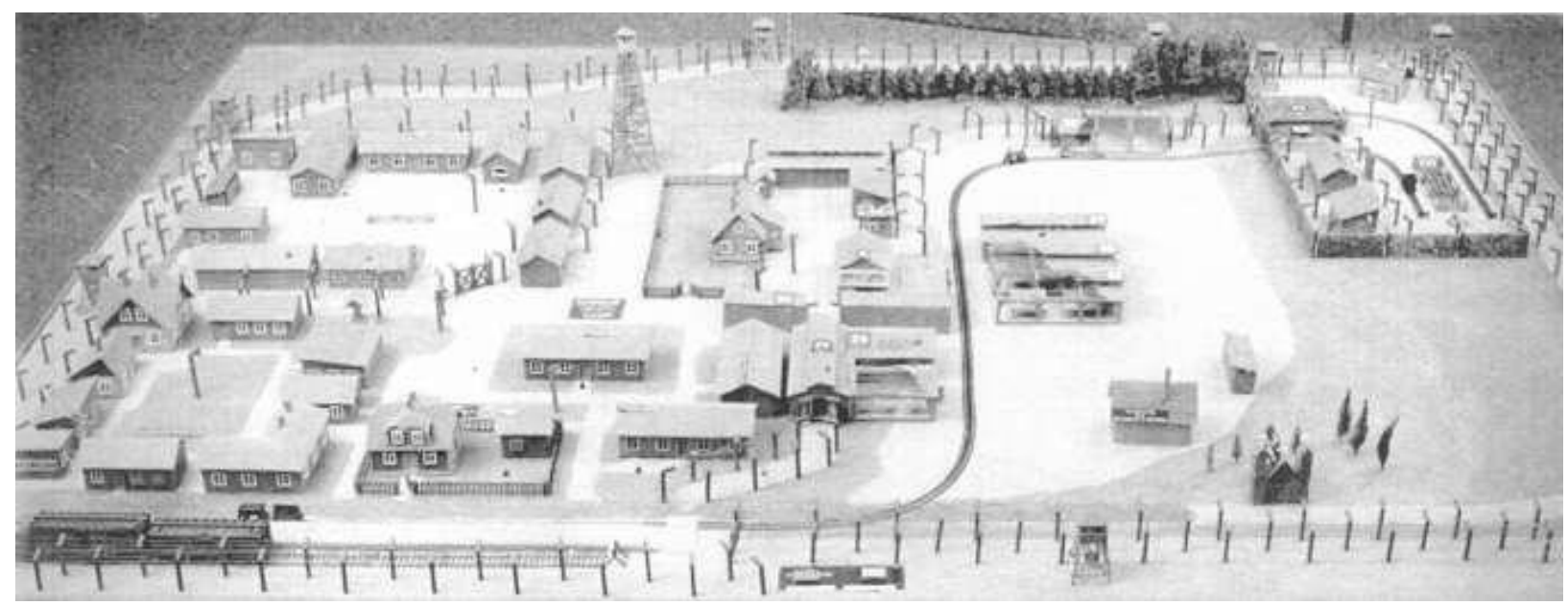

Maquete do campo de Sobibor

Esta maquete foi elaborada segundo o testemunho do sobrevivente Thomas "Toivi" Blatt e está em exposição no Martyrs Memorial Museum em Los Angeles. O campo foi desmantelado em novembro de 1943, após um levante, ocorrido em outubro, onde houve fuga de prisioneiros. Depois de arrasar todas as construções, os alemães plantaram árvores no lugar com o propósito de esconder as "atividades" que haviam sido levadas a cabo ali. Hoje, trabalhos de pesquisa arqueológica têm exposto com maior precisão a história desse centro.

Fonte da imagem: http://www.deathcamps.org/sobibor/blatt.html

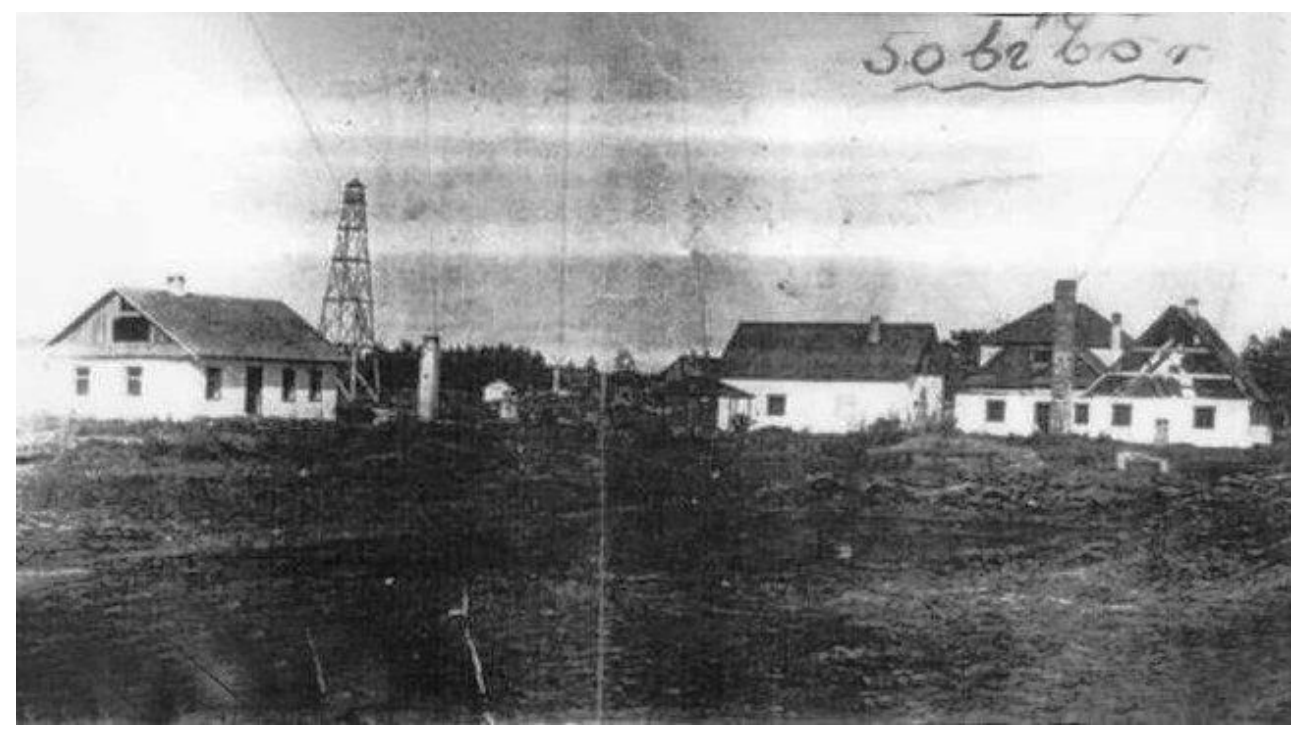

Campo de Sobibor, 1942. Vista externa.

Fonte: http://www.holocaustresearchproject.org/ar/sobibor.html 


\section{De Sosnowica, a Wlodawa, a Sobibor}

Em março de 1942, as autoridades alemãs ordenaram que todos os judeus de Sosnowica fossem transferidos para o gueto de Wlodawa que naquele momento, recebia judeus não somente das comunidades vizinhas, mas também de outros países da Europa, como Áustria e Holanda.

A cidade de Wlodawa, assim como a grande maioria das cidades nas quais foram construídos guetos, estava estrategicamente localizada próxima à via férrea que a conectava com a cidade de Chelmn.

Entre abril e maio de 1942, os judeus do gueto de Wlodawa começaram a ser reunidos em grupos e levados para Sobibor. A última dessas ações ocorreu em novembro do mesmo ano. $\mathrm{O}$ gueto estava praticamente liquidado e os 8.000 judeus que o habitavam, mortos.

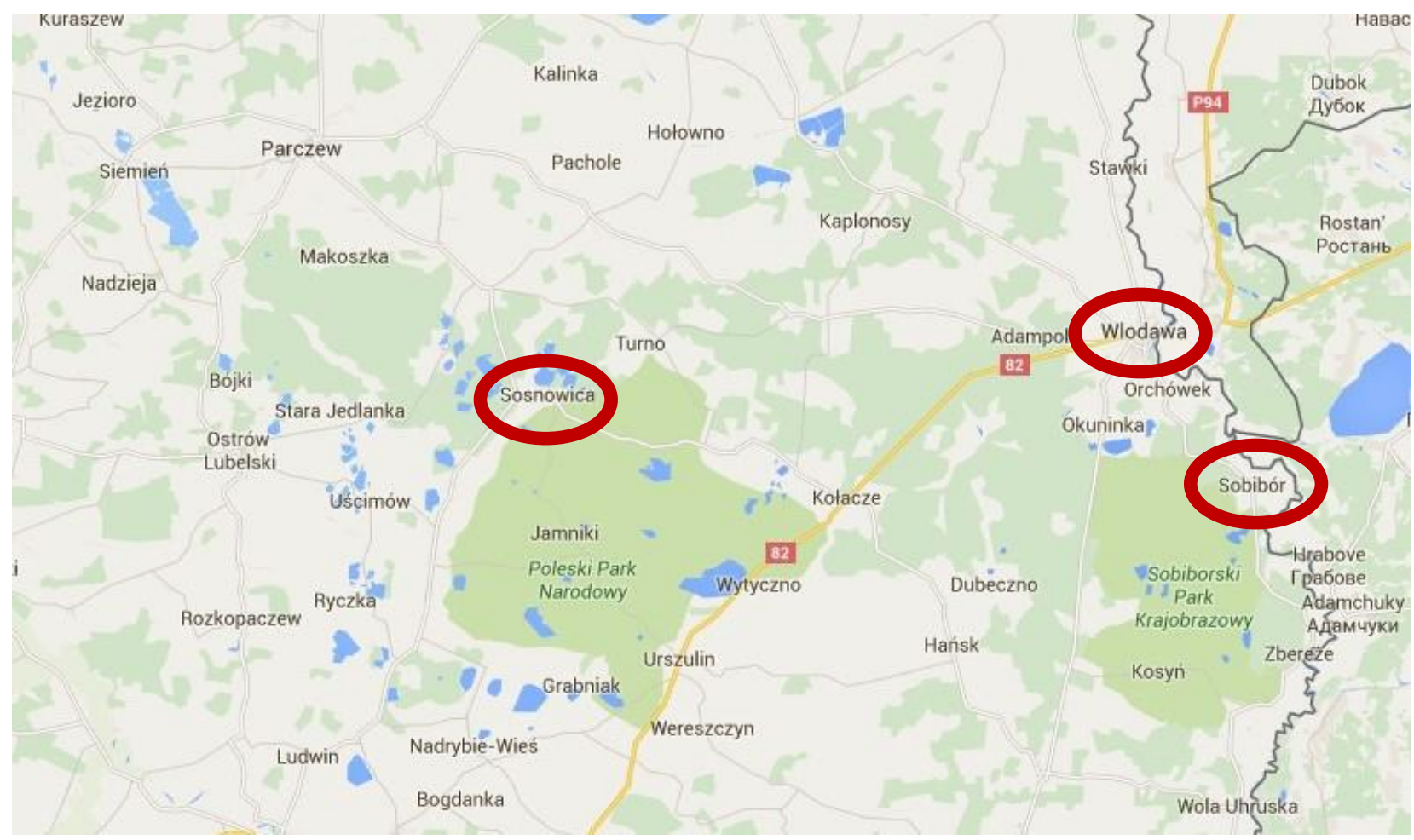

Geografia do extermínio no relato de Zeev.

Em destaque: Sosnowica, cidade onde Zeev Litwak e sua família viviam; Wlodawa, onde se localizava o gueto para onde todos os judeus de Sosnowica foram levados; Sobibor, onde foi construído o campo de extermínio com o mesmo nome. 


\section{Fuga e resistência}

Neste ponto, talvez você esteja se perguntando: - Mas ninguém resistiu? Ninguém tentou fugir? Ninguém tentou lutar? Sim, e Zeev seria um deles. Mas talvez você ainda continue perguntando: - Mas por que não os demais? Por que não todos?

Antes de passarmos a analisar como se deu a resistência, é importante ler as seguintes palavras de Aizik Rottenberg, um construtor que sobreviveu ao gueto de Wlodawa, provavelmente prevendo perguntas como as que talvez você esteja fazendo:

Você deve estar imaginando por que oito mil pessoas não lutaram contra os nazistas. Mas cem homens armados com metralhadoras são mais poderosos que uma multidão desarmada. Os jovens tentavam escapar, mas muitos se recusavam a abandonar seus pais; sabiam que isso significaria a morte dos mais velhos, e como era possível deixar para trás os irmãos e irmãs mais novos sem apoio ${ }^{154}$

Por outro lado, a maioria dos episódios de resistência provam que qualquer obstáculo ao projeto nazista de erradicar todo e qualquer judeu se traduzia numa contra-reação repressiva em grande escala. Retaliação era a palavra de ordem dos alemães a qualquer ato de resistir.

É por isso que o que deveria surpreender ao analisarmos os episódios de resistência ao nazismo não é a escassez, mas o fato de que tenham existido. É por isso também que tais atos devem ser valorizados tendo em conta não somente tudo o que estava em risco, mas também os poucos elementos disponíveis para a tomada de decisões.

\section{A decisão de Zeev}

A ordem de transferência de Sosnowica para o gueto de Wlodawa significava para a família de Zeev, assim como para todos os demais membros da comunidade judaica daquela localidade, que o pior estava por vir. Embora as informações que recebiam eram desencontradas, muitos pressentiam que o futuro era extremamente incerto. Porém, não havia saída. O prazo para cumprimento da ordem era de 48 horas.

154 Miriam Novitch. Sobibor, Martyrdom and revolt. Documents and testimonies. New York, Holocaust Library, 1980. In: GILBERT, Martin. The Holocaust: The Human Tragedy. New York, Rosetta Books, 2014 
Nessas horas decisivas, Zeev encontrou um amigo de escola, polonês católico, que conhecia um grupo de guerrilheiros russos que lutavam nas florestas da região. Para juntar-se a eles, Zeev precisava levar amigos e armas.

Nesse momento Zeev, então com apenas 16 anos ficou cara a cara com o que provavelmente foi a decisão mais difícil de sua vida: deixar sua família e fugir para a floresta. Conversou antes com sua família e apesar de sua dor e a de todos, estava claro que era a única maneira de ao menos algum deles escapar.

Antes da despedida, sua mãe preparou um embrulho com algumas coisas: em um saquinho, duas camisas; em outro, um pouquinho de açúcar e um pedaço de pão. Zeev e seus amigos partiram então para a floresta.

Aquela seria a última vez que ele veria a sua família. Também seria o único sobrevivente: seu pai morreu fuzilado em Wlodawa aos 42 anos de idade; sua mãe, cinco irmãs, um irmão mais novo e mais 75 pessoas entre avós, tios, primos, morreram em Sobibor.

\section{O encontro com os partisans na floresta}

Depois da despedida, Zeev e alguns amigos, entre eles Simcha Levinson, David Friedman, Eliezar Blumenkranz e os irmãos Yechiel e Abram Grynszpan, entre outros, saíram em direção à floresta ao encontro dos russos. Quando chegaram era de noite. Estava muito frio e chovia. Sem comer e bebendo água da chuva, continuaram andando. De madrugada ouviram um tiro. Correram na direção do som e lá encontraram dois guerrilheiros russos bem armados que a princípio ficaram desconfiados de que Zeev e seus amigos fossem alemães disfarçados.

Depois de superar a desconfiança inicial, levaram o grupo para onde estavam os demais partisans. Lá puderam comer e secar suas roupas enquanto aguardavam o comandante da unidade, um russo chamado Fioder.

O grupo de Zeev não havia ido ao encontro dos partisans de mãos vazias: ele e seus amigos estavam muito bem armados, o que facilitava -e muito- a aceitação de judeus em unidades de partisans não-judeus. Até aquele momento, no final de 1942, era muito difícil obter armas. Por isso, levar o próprio equipamento era uma porta de entrada importantíssima e que, como conta Zeev, foi reconhecido e elogiado pelo próprio comandante russo. Mas antes de 
prosseguir com o relato histórico, vamos explorar algumas particularidades sobre o dia-a-dia desses homens e mulheres, assim como de sua luta.

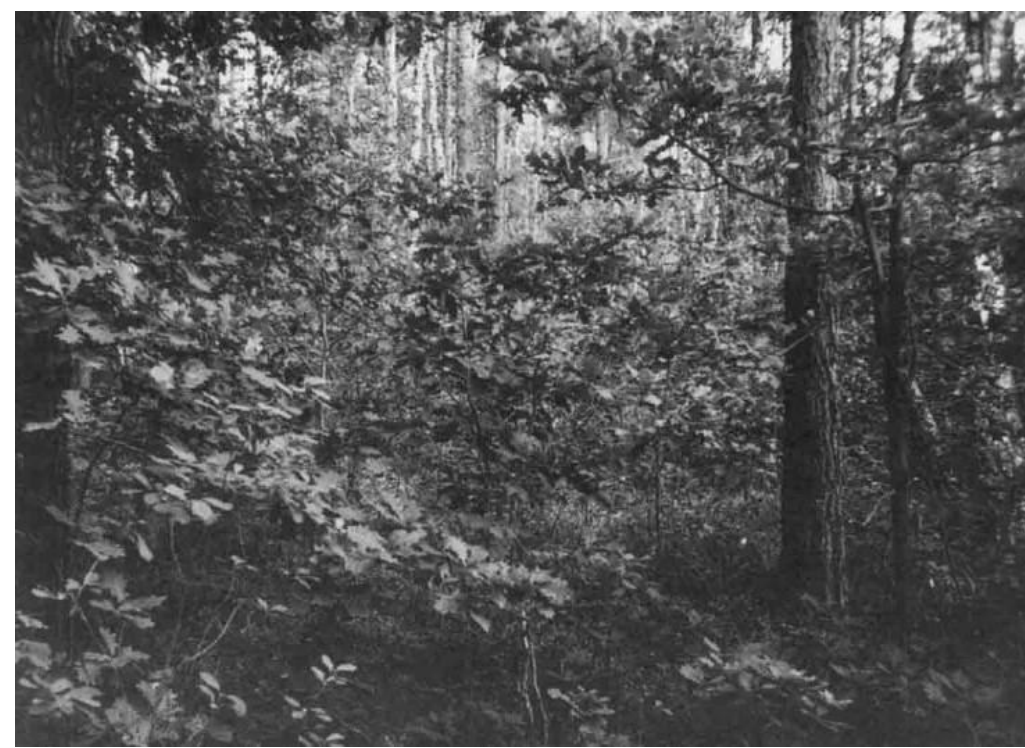

A floresta de Parczew, onde Zeev e seu grupo se reuniram

Fonte: Martin Gilbert. Holocaust Journey. Travelling in Search of the Past.

New York: Rosetta Books, 2015

O grupo de Zeev não havia ido ao encontro dos partisans de mãos vazias: ele e seus amigos estavam muito bem armados, o que facilitava - e muito- a aceitação de judeus em unidades de partisans não-judeus. Até aquele momento, no final de 1942, era muito difícil obter armas. Por isso, levar o próprio equipamento era uma porta de entrada importantíssima e que, como conta Zeev, foi reconhecido e elogiado pelo próprio comandante russo. Mas antes de prosseguir com o relato histórico, vamos explorar algumas particularidades sobre o dia-a-dia desses homens e mulheres, assim como de sua luta.

Quem eram os partisans?

Os partisans eram membros de grupos de combatentes organizados que lutavam contra um inimigo invasor - no caso, a Alemanha- principalmente dentro de um território ocupado. ${ }^{155}$

Com a invasão da União Soviética pela Alemanha, em 1941, soldados do Exército Vermelho, fugitivos dos campos de prisioneiros de guerra alemães, formaram unidades para lutar

${ }^{155}$ Definição de acordo com a Jewish Partisan Educational Foundation. 
contra o invasor alemão nas florestas. Muitos judeus uniram-se a esses grupos de partisans soviéticos.

Nos mesmos territórios, atuavam grupos de combatentes nacionalistas poloneses, mas, embora tenha havido judeus que lutaram junto a esses grupos, seu antissemitismo dificultava a entrada e a própria permanência. Mas, embora o antissemitismo estivesse menos presente entre os partisans soviéticos, ele não era de todo ausente. Por isso, muitos judeus acabaram formando seus próprios grupos de partisans.

Além do antissemitismo, havia também diferenças quanto aos objetivos dos diferentes grupos. Para os partisans judeus, lutar era uma questão de sobrevivência. Muitos dos combatentes lutavam com menos preocupação pelas suas próprias vidas, já que como Zeev, haviam perdido suas famílias inteiras -ou boa parte delas- tornando vazio de significado qualquer propósito que não fosse contribuir para acabar com a guerra, vingar a morte de seus familiares ou deixar um legado ao povo judeu. Quando o objetivo do inimigo é exterminar todo um povo, sobreviver e ajudar outros a sobreviverem é resistir.

Nesse sentido, os grupos de partisans judeus incumbiam-se de ajudar outros judeus que não estivessem em condições de engajar-se eles mesmos na luta armada. Para tal fim, estabeleciam acampamentos familiares nas florestas, dando-lhes proteção e conseguindo suprimentos.

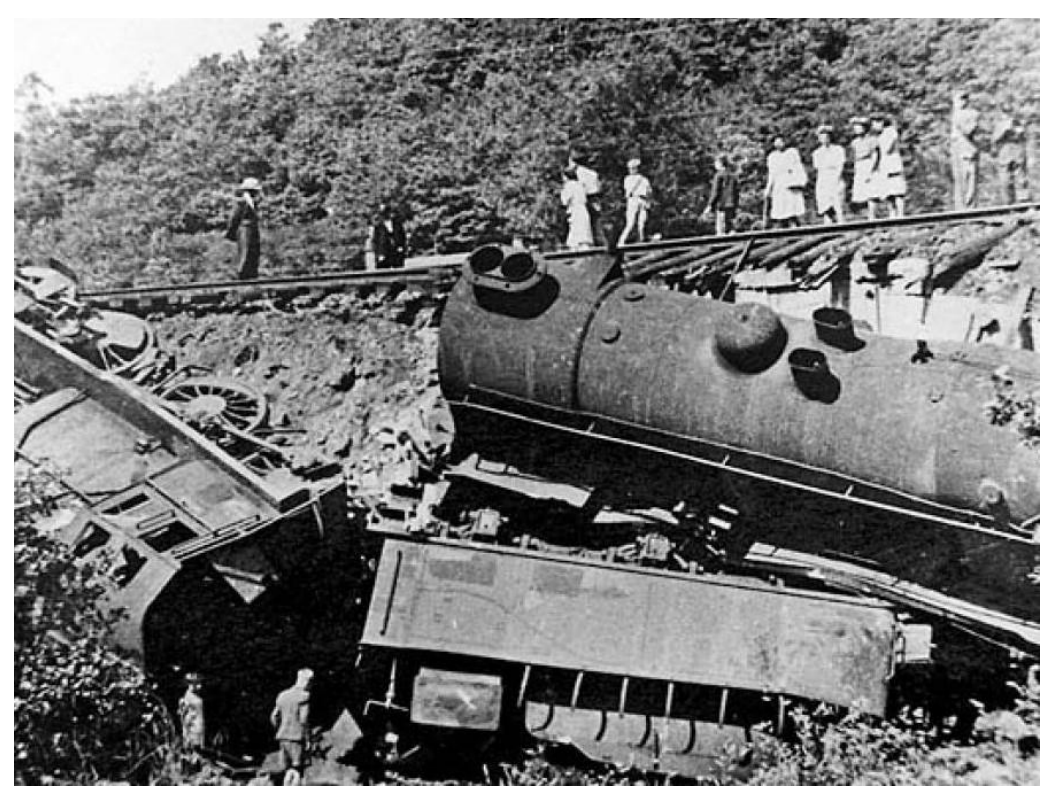

Trem descarrilado por partisans

Fonte: Jewish Partisan Educational Foundation 
Como os partisans agiam?

Devido à desproporção entre a disponibilidade de armamento dos alemães e dos partisans, estes tinham que ser ágeis e evitar o confronto direto. A ação concentrava-se então principalmente em atingir alvos militares do inimigo, sabotar sua infra-estrutura, conseguir armas e suprimentos.

\section{Como era a sobrevivência na floresta?}

Sobreviver como partisan era uma tarefa extremamente árdua e incessante, não somente devido a constante presença do inimigo como também pela hostilidade de um ambiente com um inverno extremo e escasso de recursos. Além disso, os partisans judeus, tinham que conviver com o antissemitismo tanto de civis camponeses quanto de outros grupos de partisans, principalmente os nacionalistas poloneses. O grupo Armia Krajowa em particular, cujos membros eram fortemente antissemitas, perseguia ativamente os judeus que se refugiavam na floresta.

Um grande desafio no dia-a-dia dos partisans era conseguir alimentos. Numa época de escassez generalizada essa era uma preocupação diária. O produto mais consumido por sua disponibilidade, era a batata. Carne, raramente.

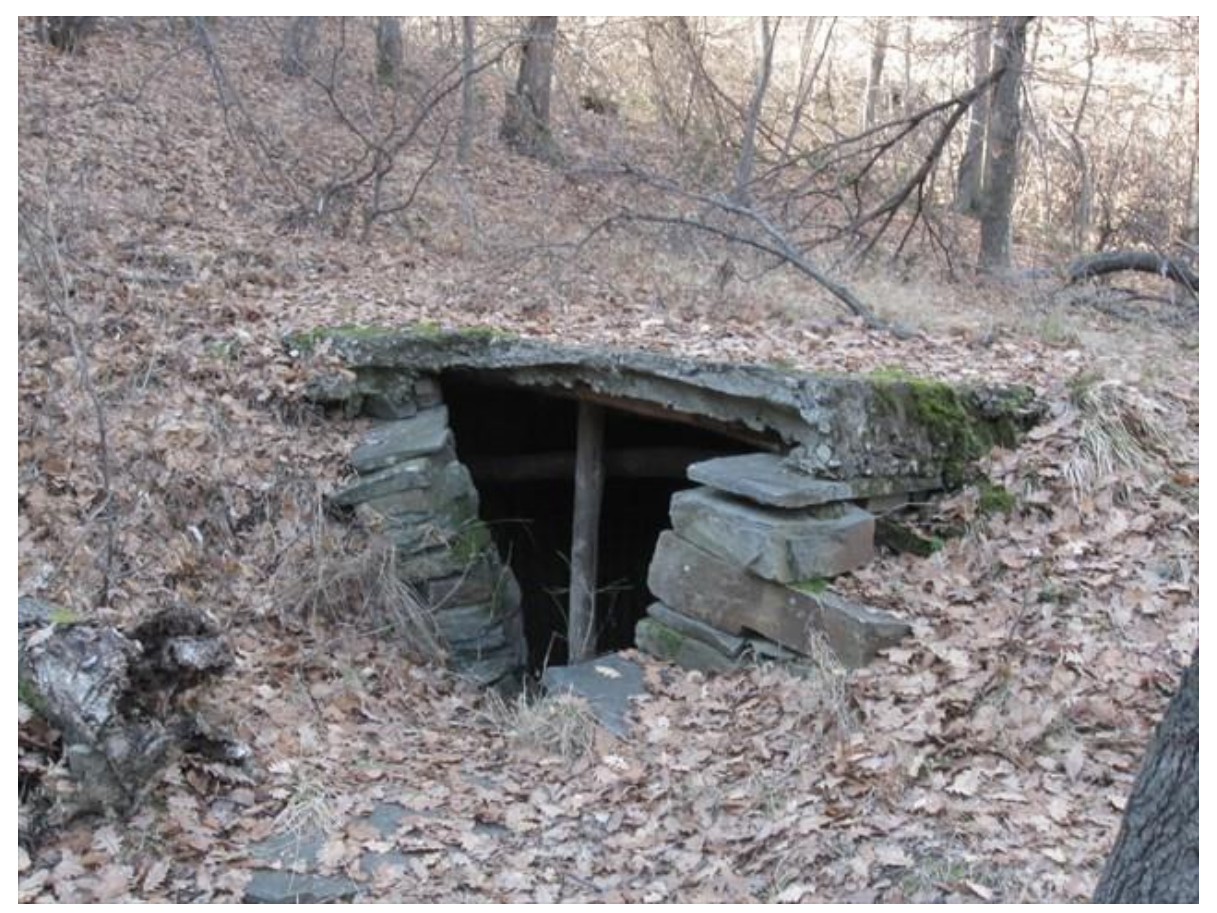

Modelo de Zemlyanka usados por partisans

Fonte: www.geocaching.com 
Quanto à habitação, devido à necessidade de estarem em constante movimento para não serem pegos de surpresa pelo inimigo, os partisans nas florestas do Leste europeu, tinham que utilizar qualquer proteção que a própria floresta oferecesse, ou construir abrigos temporários rudimentares quando as condições assim o permitiam. Uma das modalidades mais utilizadas nesses casos eram os chamados Zemlyankas, pequenas construções cavadas na terra, metade subterrânea e metade na superfície.

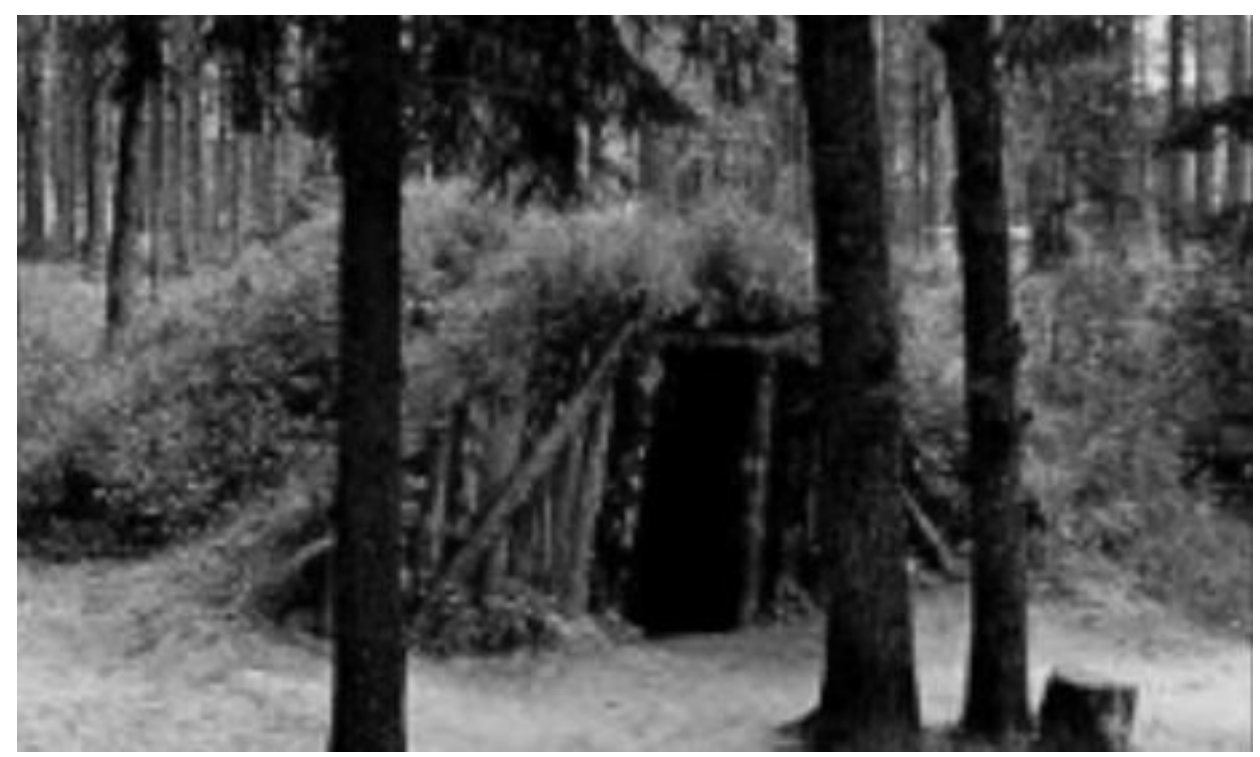

Modelo de Zemlyanka usados por partisans

Fonte: Jewish Partisan Educational Foundation

www.jewishpartisans.org

Conseguir medicamentos também era um desafio. Muitas vezes, dependendo da doença, sabia-se que não havia mais nada a fazer já que as opções com que contavam eram escassas e improvisadas. O pouco que conseguiam no início, era o que ficava abandonado por alemães em retirada. Posteriormente, o próprio exército soviético começou a jogar suprimentos de aviões que sobrevoavam a região.

Quanto às roupas, elas tinham o problema de desgastar-se rapidamente pelo uso constante das mesmas peças. Os uniformes de soldados alemães mortos em combate eram particularmente disputados entre os grupos de partisans já que além de quentes, serviam também como disfarce. Os sapatos, por sua vez, eram uma mercadoria também muito valiosa já que a necessidade de estar em constante movimento e de agir rapidamente dependiam de pés que de alguma forma 
isolassem o frio e que não machucassem. Um combatente que não conseguisse andar ao ritmo dos demais podia pôr o grupo inteiro em perigo.
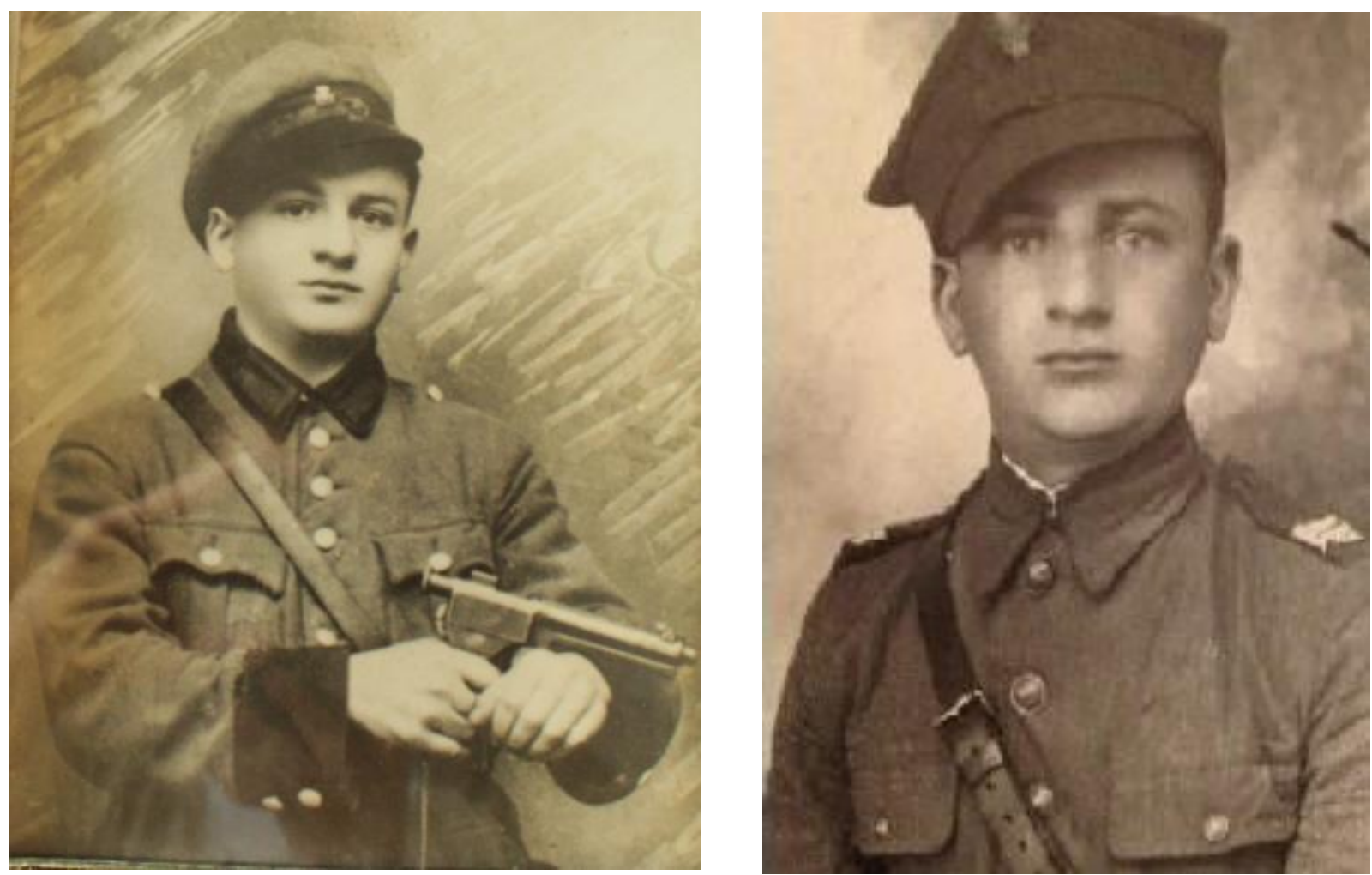

Zeev em seus uniformes de partisan

Fonte: http://chelm.freeyellow.com/partisans.html

Os partisans nas florestas de Parczew

O distrito de Lublin, onde se localizavam Sosnowica - cidade de Zeev - Wlodawa -onde estava o gueto para onde foram os judeus de Sosnowica- e Sobibor -o campo de extermínio onde a família de Zeev foi assassinada, era todo cercado de florestas. Foi em uma grande área dessas florestas, que Zeev e seus amigos lutaram durante aqueles anos da guerra. A localidade é conhecida como Parczew.

À medida que se intensificava o processo de extermínio no Leste europeu, alguns judeus -às vezes famílias inteiras- conseguiam fugir para as florestas. Nem todos sabiam sobre a existência de grupos de partisans e acabavam encontrando-os -ou sendo encontrados- por acaso. 
Assim, passavam a ficar sob a proteção desses combatentes que montavam acampamentos para essas famílias dando a eles segurança e comida.

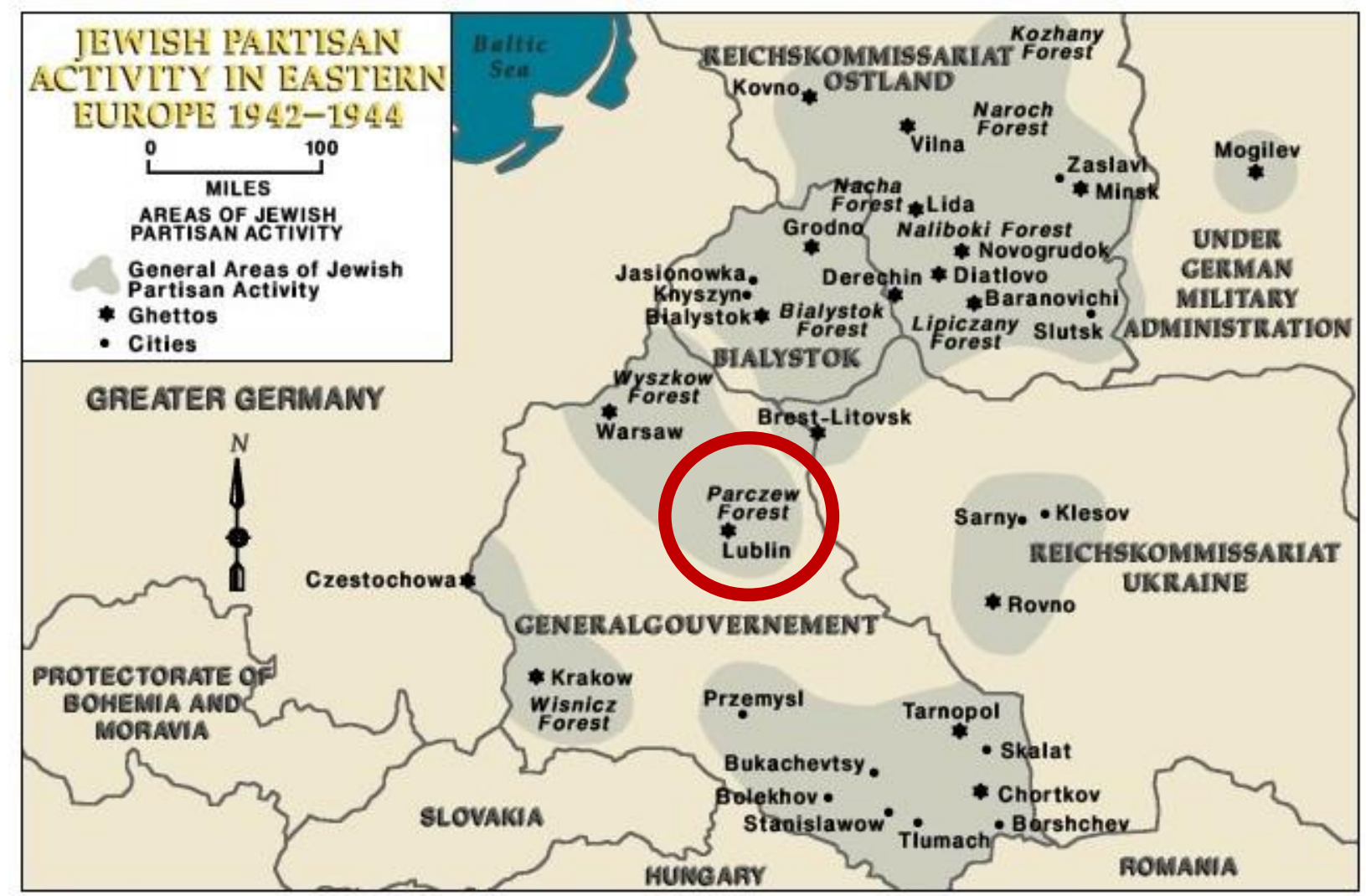

Áreas de atividade de partisans judeus no Leste da Europa, 1942-1944

No círculo, a floresta de Parczew, distrito de Lublin, onde Zeev e seus amigos combateram. Fonte: United States Holocaust Memorial Museum (USHMM).

www.ushmm.org

Em dezembro de 1942, os alemães atacaram o acampamento em que Zeev e seus amigos estavam instalados, junto com a unidade de partisans russos de Fioder e várias famílias de refugiados. Sob seu o comando, os partisans conseguiram contra-atacar causando aos alemães muitas baixas entre policiais e militares.

Após conduzirem vários ataques, nos meses seguintes, Fioder decide dividir seus combatentes em cinco grupos para facilitar a sobrevivência. Zeev e seus amigos formariam a partir daí uma unidade exclusiva de partisans judeus. Yechiel Grynszpan foi escolhido como comandante. 


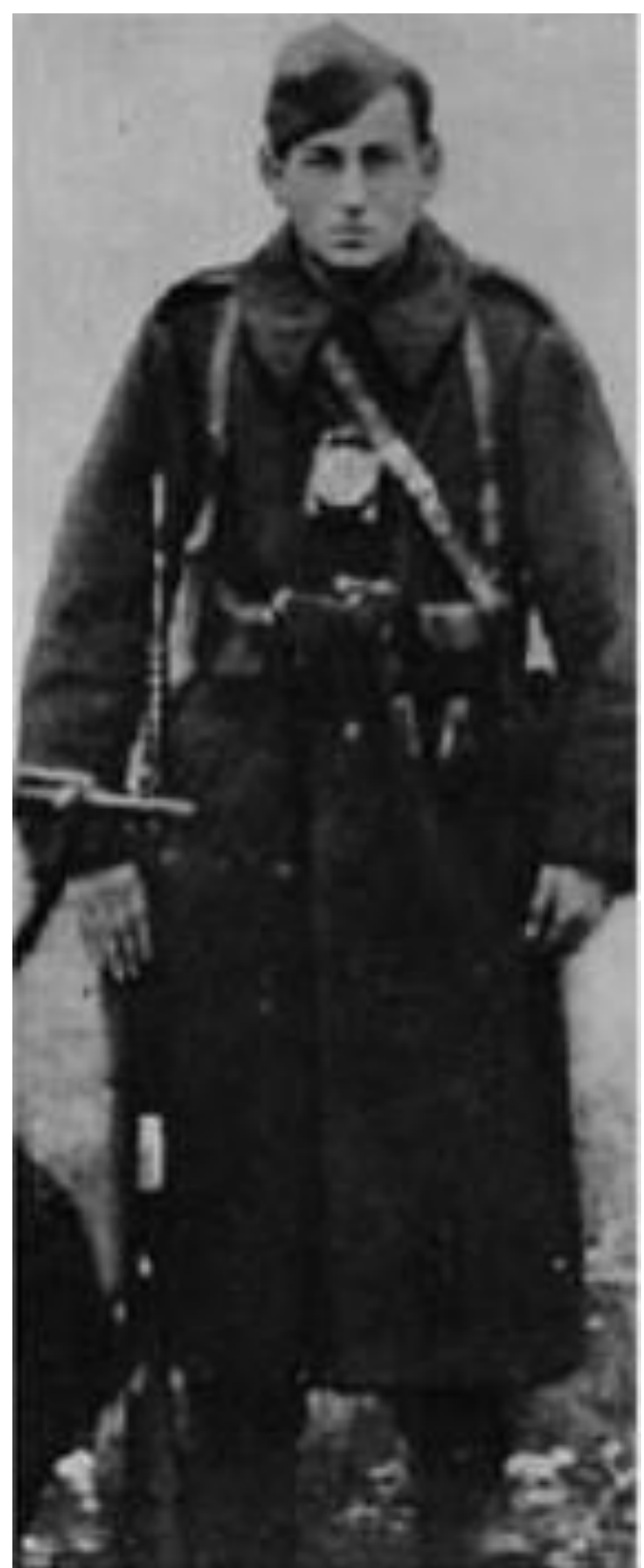

Yechiel Grynszpan, c. 1944

Arquivo Memorial Yad Vashem
Grynszpan - ou Chil, como era conhecido comandou um dos grupos de partisans judeus mais notáveis dentre aqueles que operaram no leste europeu entre 1942-1944. Ele pertencia a uma família de negociantes de cavalos e conhecia profundamente o território onde operava. Além disso, tinha treinamento militar. Como lembra Zeev, Yechiel implementou no grupo uma disciplina militar forte que, dependendo da infração, podia ser punida até mesmo com a pena de morte. Motivava seus combatentes dizendo: - Você nasce só uma vez; você morre só uma vez.

Quando começou, o grupo tinha 50 homens, e poucas armas. Aos poucos, adquiriram uma grande habilidade para conseguir armas, muitas delas descobertas escondidas na floresta, remanescentes de outras batalhas. Além disso, participaram com êxito em combates contra o inimigo alemão atraindo mais combatentes. A unidade chegou a contar com mais de 200 homens. Em julho de 1944, o Exército Vermelho Soviético avançou pelo Leste, entrando na floresta de Parczew. O fim da guerra estava próximo e esses homens e mulheres partiriam para os mais diversos destinos, procurando reconstruir suas vidas.

\section{Os partisans no Brasil}

Depois da guerra, Zeev deixaria a Europa em direção à então Palestina. Em 1948, testemunhou o nascimento do Estado de Israel. Nesse mesmo ano, seu amigo Yechiel Grynszpan 
chegaria ao Brasil. Anos mais tarde, os dois amigos retomariam o contato e, a convite do antigo comandante, Zeev decidiu imigrar para o Brasil. Chegou ao Rio de Janeiro em 1953.

Em 1957, mais dois ex-combatentes viriam a unir-se a eles: Abram Grynszpan -irmão de Yechiel- e sua esposa, Dora.

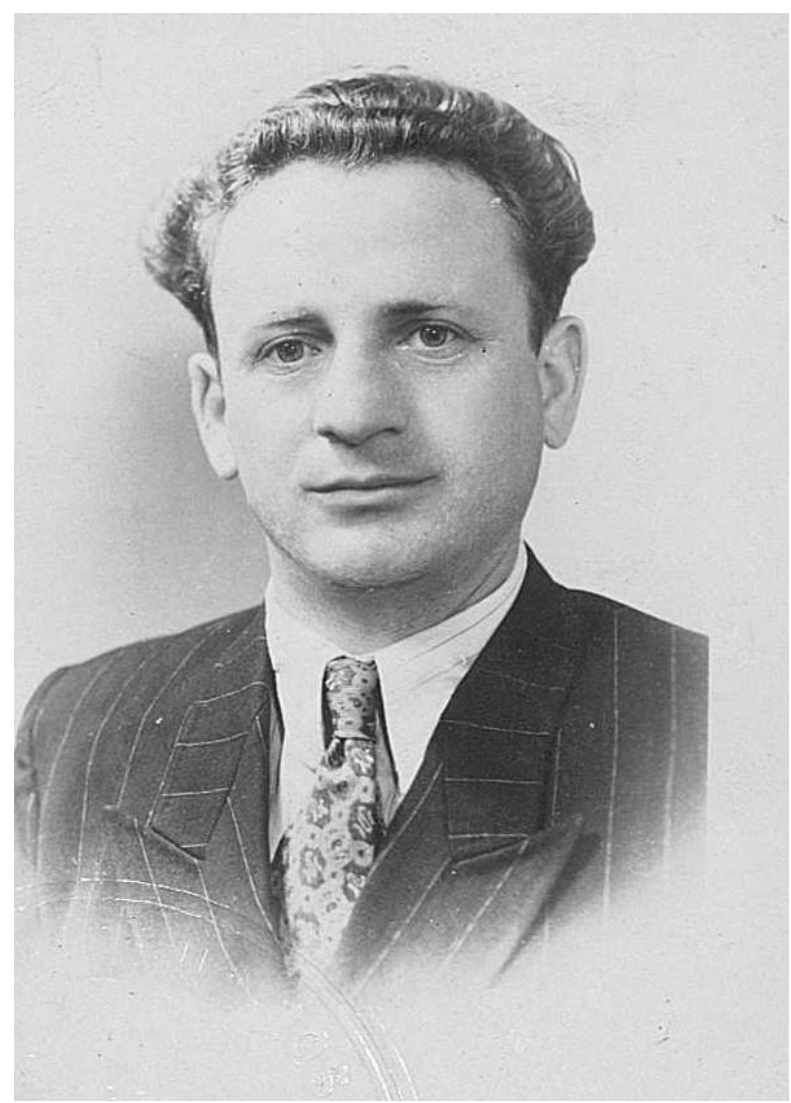

Zeev Litwak, 1953

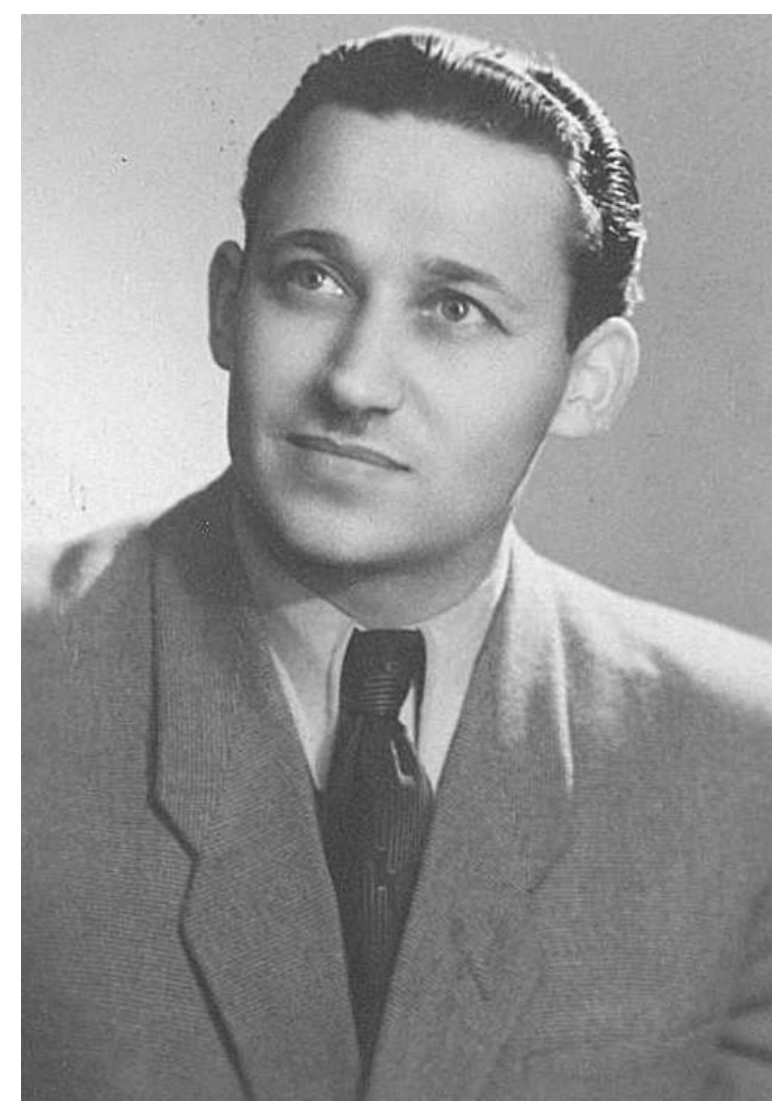

Yechiel Grynszpan, 1948

Os dois amigos heróis na época da chegada ao Rio de Janeiro, Brasil

Fonte: Fichas de Imigração, Brasil www.familysearch.org 


\subsubsection{Cecília Gewertz: resiliência, resgate e ... depois?}

\section{Introduzindo a história de Cecília}

Ao assistirmos os testemunhos dos sobreviventes -mesmo para os que estamos imersos no tema- temos muitas vezes uma falsa impressão de "naturalidade" ou de "simplicidade" nos relatos. Isso se deve em grande parte a um aspecto que tanto a historiografia quanto a teoria literária vêm abordando há décadas: o caráter indizível ou inexpressável não só do Holocausto como evento em si, mas também das vivências daqueles que estiveram no meio ao furacão; dito de outro modo, refiro-me aqui aos onipresentes limites da representação.

Transplantar essas experiências para a sala de aula representa, nesse sentido, um desafio enorme já que, além das limitações na transmissão próprias do tema, outros fatores conspiram para que essa fissura seja ainda mais profunda: escassez de tempo e recursos, formação dos professores, bagagem cultural dos alunos, vieses ideológicos, entre outros.

Um dos objetivos da produção de materiais didáticos vinculados aos testemunhos é tentar aproximar-nos ao âmago de alguns dos aspectos profundos contidos nas narrativas de modo a desnudar e exibir, dentro do possível, parte de sua complexidade. Mas repito, é uma tentativa dentro do possível.

O depoimento de Cecília é paradigmático nesse sentido. Ela mesma, em toda sua doçura nos alerta: "Eu me pinto, eu me arrumo, mas ninguém sabe o que tem dentro". Realmente. Não sabemos e nunca teremos como saber. Mas será que pelo menos sabemos ouvi-la? Eis aí o outro lado do espelho no que tange aos limites da representação: a nossa capacidade de escutar. Quando Cecília nos confidencia seu "medo de falar" é porque ela percebe, sabe, que nossos ouvidos e nossa mente não são capazes de processar "o que ela tem dentro de si".

Como entender o que é perder toda a família ainda adolescente, ser a única sobrevivente de um pelotão de fuzilamento, habitar o universo concentracionário de Auschwitz-BirkenauMonowitz-Ravensbrück - nele incluídos os experimentos de Mengele - ser parte de uma gigantesca operação de resgate rumo à Suécia em meio a bombardeios.

Do ponto de vista histórico e pedagógico, nossa tentativa é afastar a lente da Shoá individual do relato de Cecília, mantendo como fundo sua história, e proporcionar elementos que permitam ao aluno vislumbrar algo do que esteve em jogo em meio àquela monstruosa orgia genocida que marcou para sempre a história da humanidade. 
Toda narrativa parte da sistematização das fontes valorizadas por sua complexidade e detalhes. Assim, nesta etapa do nosso trabalho, o foco estará direcionado principalmente -mas não exclusivamente- para dois momentos marcantes na história de vida de Cecília: sua passagem pelo campo de mulheres de Ravensbrück - o campo onde Olga Benário esteve antes de ser assassinada - e o seu resgate junto com outras aproximadamente 15.000 mulheres (3.000 delas judias) levado a cabo pela Cruz Vermelha sueca na última semana de abril de 1945, semana esta em que Hitler cometeu suicídio em seu bunker. 


\section{Livro 3 - Cecília (Cesia) Rybitwer Gewertz ${ }^{156}$}

Eu me pinto, me arrumo, mas ninguém sabe o que tem dentro...

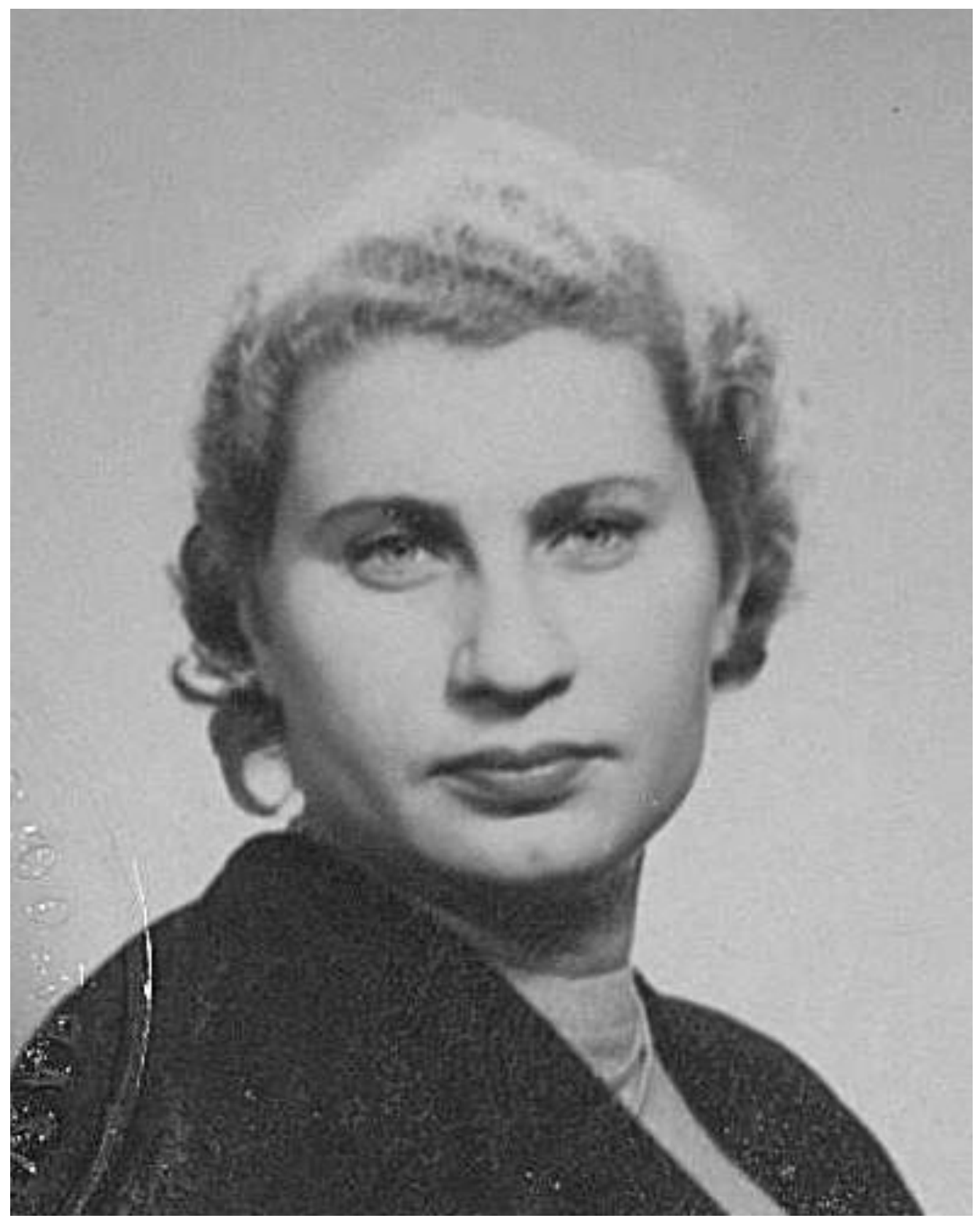

Cecília em sua chegada ao Brasil, 1952

Fonte: www.familysearch.org

Ficha de Imigração, Rio de Janeiro

156 Testemunho de Cecília Gewertz ao Projeto Vozes do Holocausto (Arqshoah/LEER), São Paulo, 17 de abril de 2013. Ficha Técnica: Entrevistadoras, Profa. Rachel Mizrahi e Profa. Sarita Saruê; Câmera, Lilian Ferreira de Souza; Transcrição, Laís Rigatto Cardillo. 
Os testemunhos dos judeus sobreviventes do Holocausto materializam em palavras suas múltiplas sobrevivências. São em si mesmas um universo feito de diversos fatores que contribuíram para que o resultado não fosse o destino que as autoridades da Alemanha nazista tinham traçado para todos os judeus da Europa: a morte.

Entre esses fatores estavam: conhecer a pessoa certa, obter a informação certa, estar no lugar certo; em outras palavras, contar com a sorte. Internamente, em cada um desses indivíduos o principal ingrediente foi a resiliência. Mas tudo isso teve um alto preço que deixou marcas profundas e inalteráveis para os que viveram o horror dos campos; algo quase inacessível para quem se aproxima às suas histórias.

As múltiplas sobrevivências de Cecília ocorreram ao longo de um período de 6 anos, de 1939 a 1945, durante os quais presenciou e vivenciou os mais profundos horrores: a perda da família, o pelotão de fuzilamento nazista, as tentativas de fuga, as deportações para diferentes campos de concentração - Auschwitz-Birkenau, Ravenbrück, Buna-Werk - os experimentos do carrasco Mengele.

Depois daqueles anos seus medos foram transformando-se, mas um deles, segundo seu testemunho, permaneceu com força: o de que, ao contar sua história, ao abrir os portões do "que tem dentro", ninguém acredite. Mas sabemos que o inferno que ela e milhares de outros sobreviventes nos contam existiu. E é para evitar que ele se repita que devemos continuar ouvindo.

\section{A vida de Cecília antes da Segunda Guerra}

Cecília Rybitwer - Cesia, ou ainda Tsirla, seu nome em ídiche - nasceu em 1922 na cidade polonesa de Sandomierz. Seus pais, Yossef e Eva, eram donos de um moinho. O casal comprava trigo dos colonos; eles mesmos o moíam e vendiam a farinha nas padarias e mercados. Eles tinham cinco filhos -Moshke e Chaim- e três filhas - Chana, Chaia e Cecília, a caçulinha mimada da família. 


\section{A cidade de Sandomierz}

Sandomierz é uma cidade localizada às margens do rio Vístula a sudeste da Polônia. Até o século XVIII teve um papel importante como centro comercial na rota fluvial que conduzia à cidade portuária de Gdansk, e também como entreposto entre as cidades de Cracóvia e Vilna, na Lituânia.

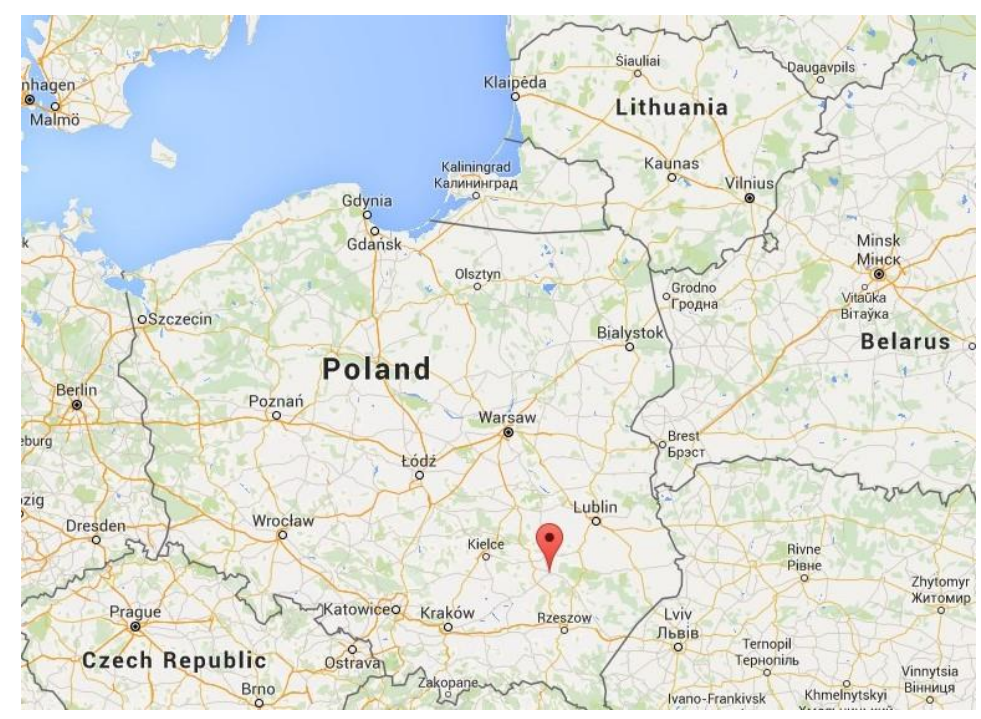

Mapa da Polônia. Em destaque, a localização de Sandomierz. Fonte: Google Maps

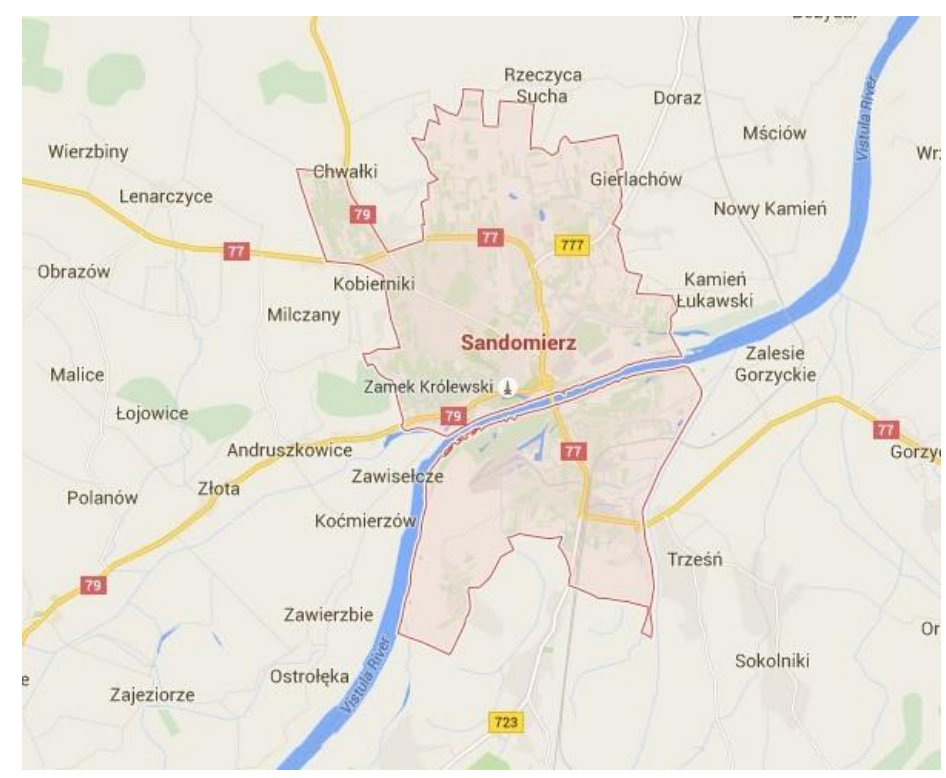

Sandomierz, cortada pelo Rio Vístula

Fonte: Google Maps 


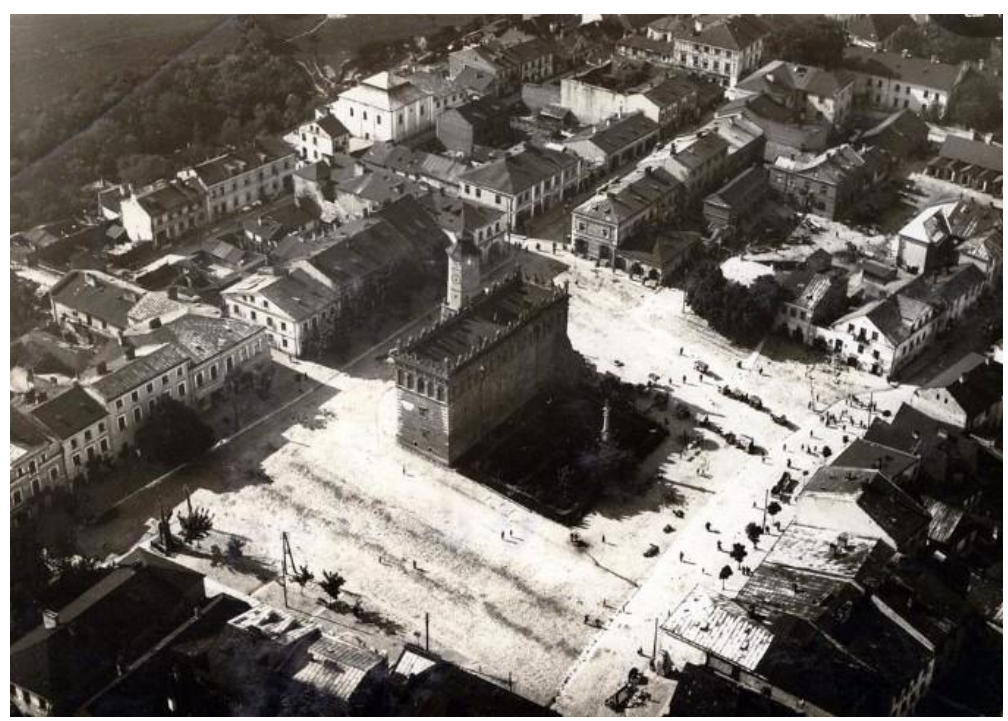

Vista aérea de Sandomierz, 1930

Fonte: Tomasz Wisniewski

www.yivoencyclopedia.org

\section{A comunidade judaica de Sandomierz}

Os primeiros judeus de Sandomierz chegaram à cidade em meados do século XIV. Registros de cobranças de impostos do início do século XVI indicam que Sandomierz era uma das maiores comunidades judaicas da Polônia. Lá desempenhavam atividades ligadas ao comércio e a trabalhos manuais, principalmente no ramo de vestimentas.

Mas assim como ocorreu em diferentes ocasiões ao longo dos séculos na maior parte do território europeu, ações por parte de governos locais ou centrais contra os judeus eram uma constante em Sandomierz. Uma dessas ações, por exemplo, foi a resolução de 1559 que proibia os judeus de participarem do comércio de varejo. Motivadas por questões religiosas ou econômicas, essas ações se materializavam não somente em leis, mas também em ataques físicos, expulsões ou acusações caluniosas.

Entre essas acusações caluniosas contra os judeus, a mais recorrente, principalmente na Idade Média, estava o chamado libelo de sangue, ou seja, a alegação de que os judeus matavam crianças não-judias, principalmente cristãs, para obter sangue para a Páscoa judaica e outros rituais. Esta crença partia de um total desconhecimento de que o judaísmo, através da Torah, condena terminantemente os sacrifícios de sangue, comuns em algumas religiões pagãs. No 
entanto, era uma crença "útil” para perpetuar a acusação de que os judeus foram responsáveis pela paixão e crucificação de Cristo.

Em Sandomierz, as tensões entre cristãos e judeus levaram a quatro casos de libelos de sangue entre os séculos XVII e XVIII, que terminaram em julgamento e condenação dos judeus. A sentença: execução. ${ }^{157}$

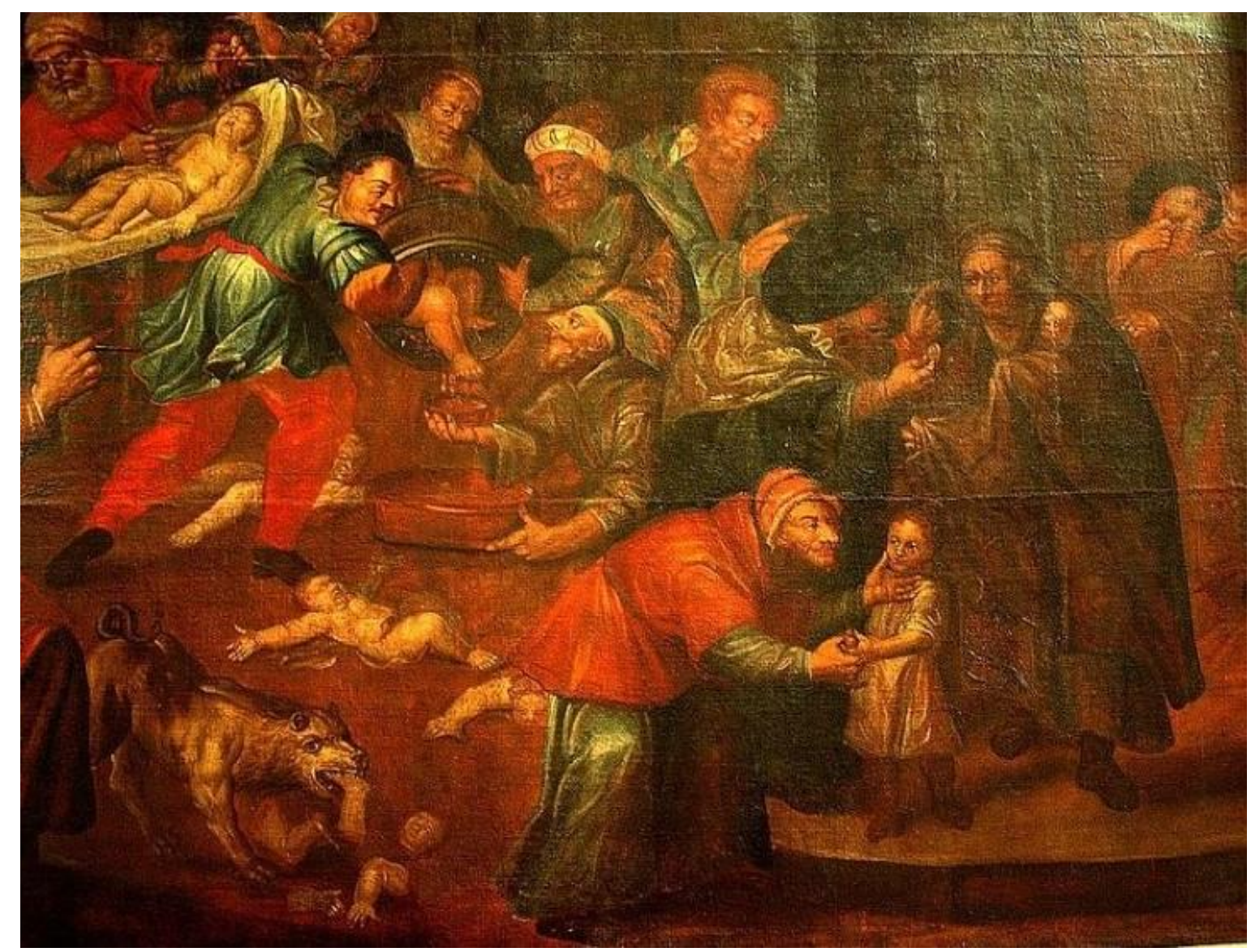

Catedral de S. Paulo, Sandomierz, Polônia

Pintura que representa o mito do libelo de sangue, Karol de Prevot, Sec. XVIII.

Óleo sobre madeira

Fonte: www.commons.wikimedia.org

\begin{abstract}
${ }^{157}$ Ainda hoje, quem visita a Igreja de S. Paulo, em Sandomierz podem ficar frente a frente com uma pintura que retrata o libelo de sangue. Feita no século XVIII pelo artista Karol de Prevot, ela reforça vários dos mitos e estereótipos que cercam os judeus. A importância de analisarmos obras como essa contribui para percebermos o ambiente que cercou por séculos os judeus da Europa reforçado por diversas crenças que ainda estão presentes em muitas mentes. Este quadro esteve durante séculos exposto sem nenhuma referência a seu caráter calunioso. Foi somente em 2006 que passou a ser acompanhado de uma placa na qual se lê: "Este evento não é historicamente preciso. Os judeus não podiam perpetrar e não perpetraram assassinato ritual". Gordon Haber, "A Personal History of Blood Libel in Poland", Forward, Março de 2014.
\end{abstract}


Apesar do antissemitismo e dos eventos muitas vezes brutais aos quais estavam expostos, a população judaica de Sandomierz continuou crescendo e prosperando nos séculos seguintes. O censo realizado em 1938, portanto pouco antes da invasão da Polônia pela Alemanha nazista, contava 10.316 habitantes na cidade, sendo 2.437 judeus. ${ }^{158}$

Para Cecília, até aquele momento, a vida transcorria com relativa calma entre estudos e família. Em 1939, com apenas 17 anos, sua adolescência se encerraria definitivamente.

\section{A invasão da Polônia. Os nazistas em Sandomierz}

Somente duas semanas após a invasão da Polônia, os alemães chegaram a Sandomierz, fato que produziu consequências imediatas para toda a comunidade judaica da cidade, nela incluída Cecília e sua família.

Como em todas as cidades da Polônia ocupadas pelos nazistas, foi imediatamente estabelecido um Judenrat -conselho judaico-, responsável por implementar as ordens das autoridades de ocupação. Já em 1940, porém, alguns dos judeus mais proeminentes da cidade foram capturados e enviados para campos de concentração. Os demais, foram convocados para a realização de trabalhos forçados. Cecília estava entre eles.

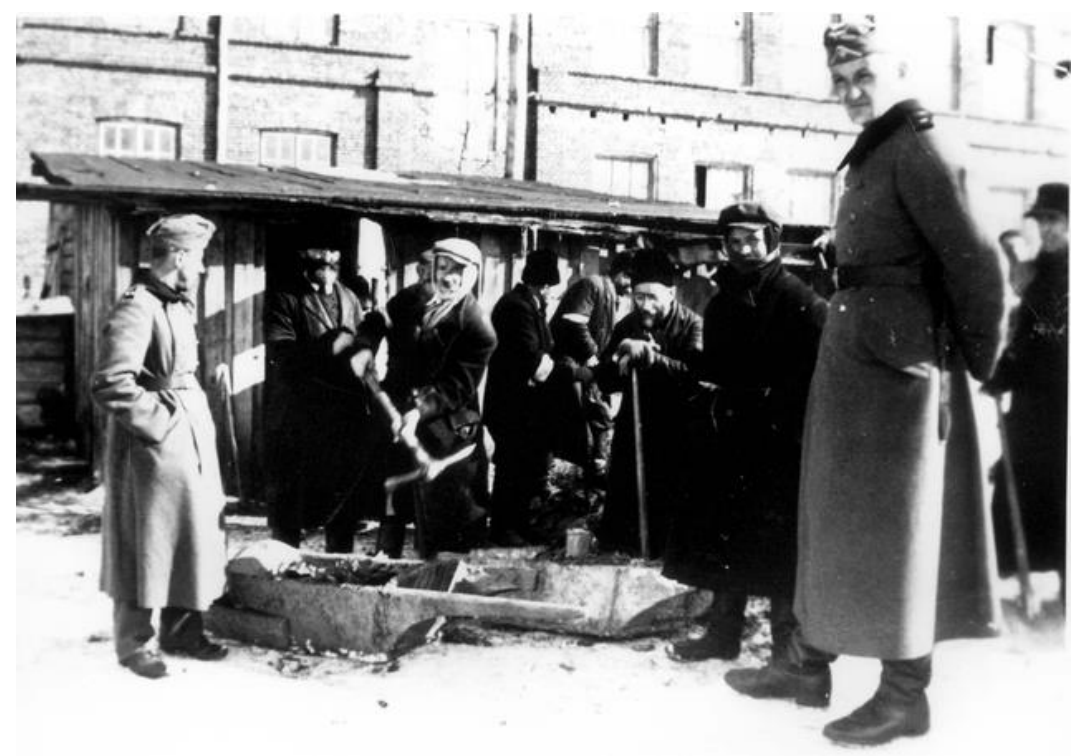

Trabalhos forçados em Sandomierz, inverno de 1941

Fonte: Arquivo Yad Vashem/Ghetto Fighter's House

158 Yivo Encyclopedia, www.yivoencyclopedia.org/articleaspx/sandomierz 
A rotina desses trabalhos fazia-se sob permanentes maus tratos e constante ameaça de punição. Qualquer atitude podia ser pretexto para o assassinato. Os tipos de trabalho eram variados: construção de estradas, limpeza, trabalhos em fábricas nas proximidades da região. Essa situação durou de 1939 até 1942, quando as deportações para campos de concentração e extermínio começaram para todos os judeus da Europa.

\section{O gueto de Sandomierz: estabelecimento e liquidação}

Assim como ocorreu em algumas cidades da Polônia ocupada, o gueto de Sandomierz teve curta duração: de junho de 1942 a janeiro de 1943. Na prática, as restrições aplicadas aos judeus em Sandomierz desde 1939 reproduziam condições de vida semelhantes às de um gueto. A demarcação, portanto, devia-se principalmente a razões relacionadas à organização e controle das deportações por parte das autoridades nazistas.

No decorrer desses seis meses, o gueto de Sandomierz passou a receber judeus de outras cidades do distrito de Radom, ao qual pertencia, piorando a situação de superlotação.

Em novembro de 1942, com a intensificação das deportações que ocorriam desde junho de 1942, os alemães anunciaram que na região Radom, todos os guetos seriam liquidados exceto quatro, entre eles Sandomierz. Temendo a deportação, muitos judeus fugiram para lá na esperança de conseguir sobreviver.

A hostilidade dos poloneses na região custou inúmeras vidas de judeus já que aqueles que tentavam fugir eram assassinados pelos próprios poloneses ou entregues aos alemães, o que

também resultava em morte. Por essa razão, às vezes permanecer no gueto parecia mais “seguro". Lá os habitantes construíam bunkers onde se escondiam, tentando escapar das chamadas Aktions dos alemães.

A família de Cecília permaneceu na cidade. Somente seu irmão, Moshke, fugiu para as florestas, unindo-se aos partisans, mas foi assassinado.

\section{As sobrevivências de Cecília}

\section{As unidades de fuzilamento}

Foi em uma das Aktions perpetradas pelos alemães no gueto de Sandomierz em 1942, que a família de Cecília foi capturada. Estavam todos escondidos em um dos bunkers que os próprios 
moradores haviam construído. Porém, devido ao cheiro de comida, um cachorro indicou o local permitindo que os alemães chegassem a eles.

Os pais, irmãos e as demais pessoas com as quais dividiam aquele espaço foram deportadas diretamente para o campo de extermínio de Treblinka, onde foram assassinadas. No entanto, Cecília e mais 106 pessoas foram levadas do gueto caminhando. Ninguém sabia para onde.

De repente chegaram a um cemitério próximo e veio a ordem do comandante alemão: “Atirar". Cecília caiu e encima dela, uma pilha de corpos. Todos haviam sido mortos menos ela. Por alguma razão, as balas não a atingiram. Ela nos conta:

"Fiquei em silêncio não sei por quanto tempo. Meu coração batia... Só ouvi que os alemães disseram: "Vamos deixar eles aqui. Depois a gente volta para jogar na vala."

Cecília ficou em silêncio por mais algum tempo até ter certeza que os soldados não estavam mais no local. Quando não ouviu mais nada, saiu arrastando-se para não ser vista. Foi até um rio para lavar o sangue que tinha ficado em seu corpo. Lá mesmo passou a noite, dentro de uma caixa que encontrou na floresta. Completamente confusa e sem saber o que fazer, de dia foi até a casa de uma mulher católica conhecida de sua mãe que a escondeu em um curral. Mas Cecília não ficaria lá por muito tempo. Tentou encontrar algum outro refúgio, mas foi novamente capturada. A próxima etapa: Auschwitz.

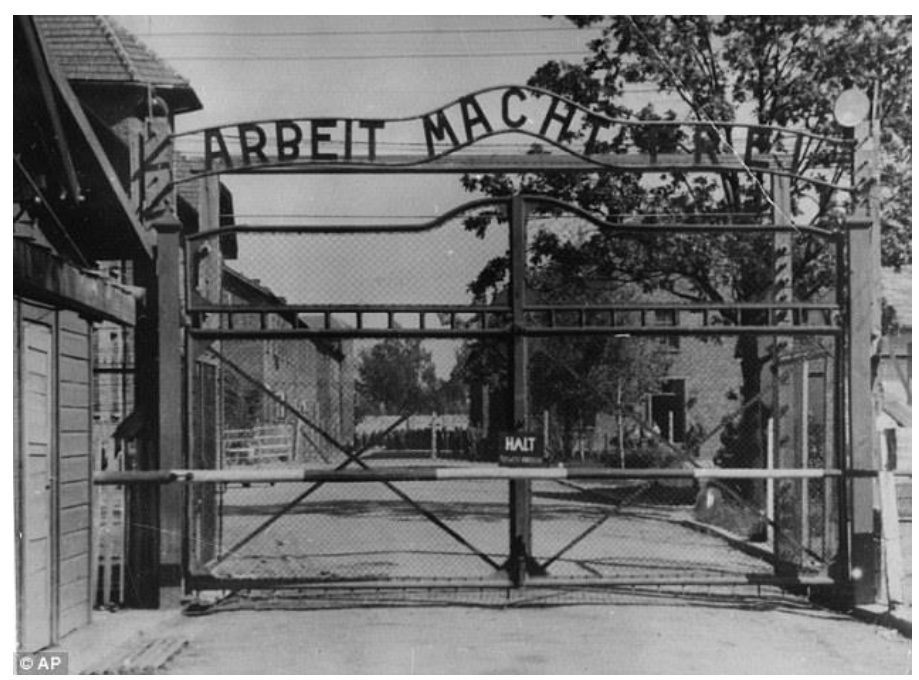

Portão principal de Auschwitz I, Janeiro de 1945

Fonte: Associated Press 


\section{O complexo Auschwitz-Birkenau-Monowitz/Buna}

Depois de ser capturada, começaria para Cecília um longo período nas entranhas da máquina de morte nazista: Auschwitz-Birkenau-Monowitz/Buna. Instalado em solo polonês, Auschwitz é sem dúvida o mais conhecido complexo do sistema de aniquilação montado pelos alemães. Foi ao mesmo tempo campo de concentração, de trabalhos forçados e de extermínio.

O primeiro campo do complexo foi construído em 1940 próximo à localidade de Oswiecim, a uns 60 quilômetros de Cracóvia na fronteira da Polônia com a Alemanha. Seus primeiros prisioneiros foram poloneses capturados após a invasão e anexação de parte do país.

Esse primeiro campo passou a ser chamado de Auschwitz I (o campo principal) em outubro de 1941, quando foi construído um segundo campo conhecido como Birkenau (ou Auschwitz II). Um ano depois, em outubro de 1942, foi acrescentado um terceiro campo ao complexo: Monowitz (Auschwitz III), também conhecido por Buna, já que lá se encontravam as instalações da fábrica de borracha Bunawerk, do complexo químico I. G. Farben.

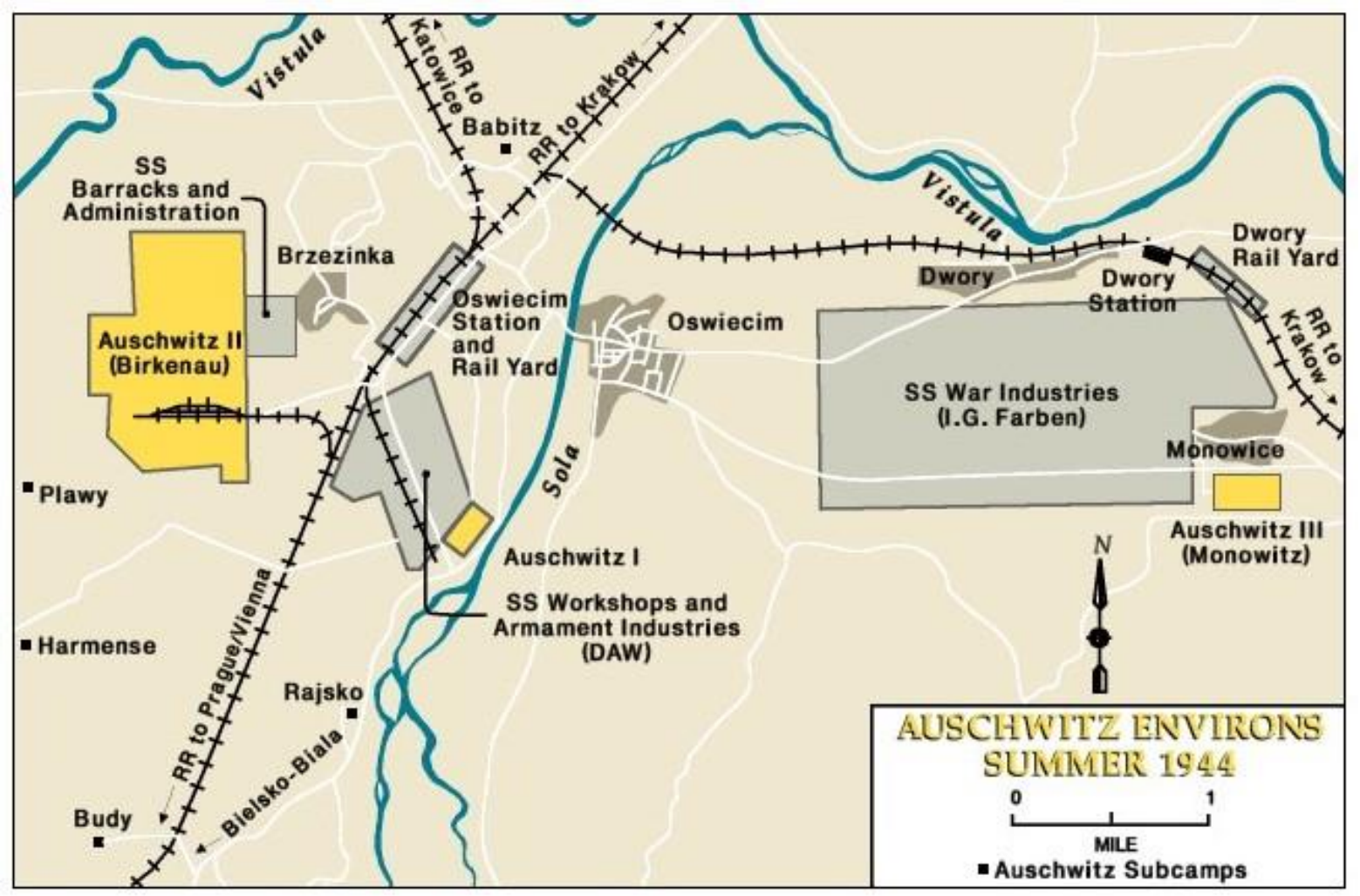

Esquema do complexo de Auschwitz indicando os três campos.

Fonte: United States Memorial Museum (USHMM)

www.ushmm.org 


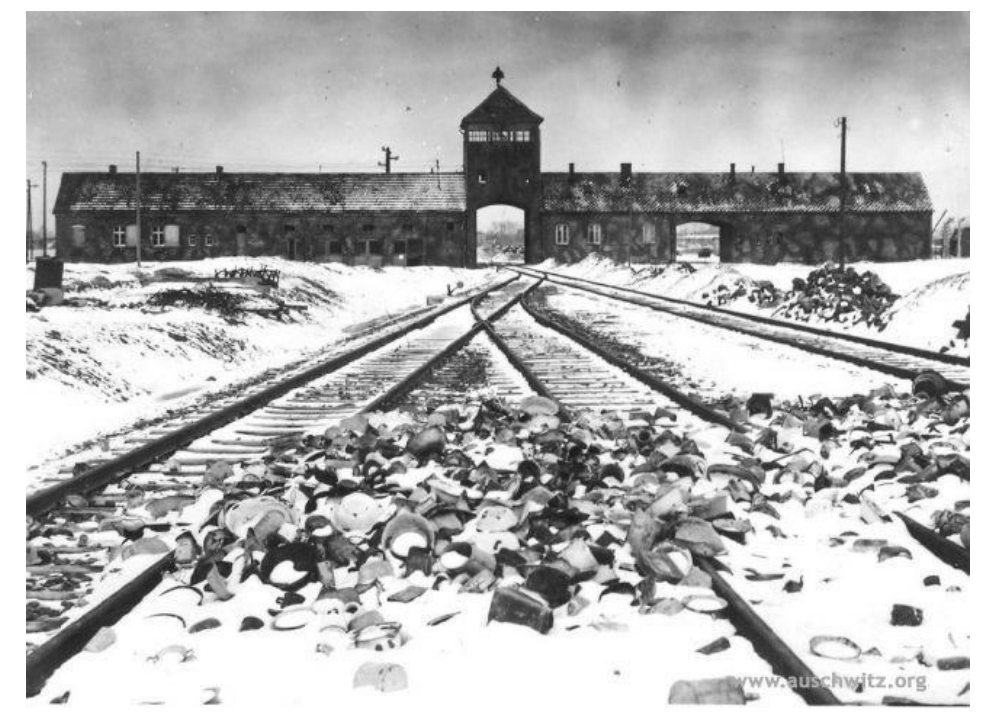

Plataforma de chegada dos trens e entrada a Auschwitz II-Birkenau.

Fonte: Memorial e Museu Auschwitz-Birkenau

www.auschwitz.org

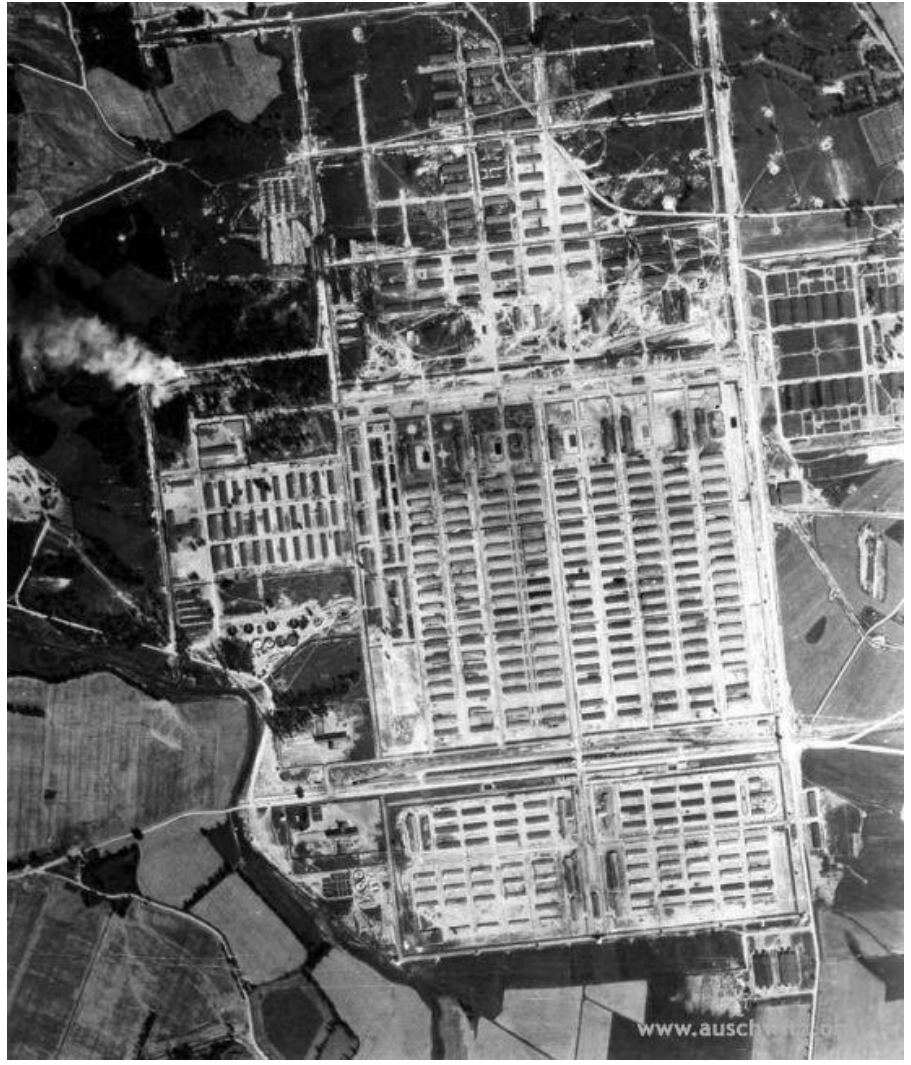

Vista aérea de Auschwitz II-Birkenau.

Fotografia tirada por aviadores das forças aliadas em 1944.

Na parte superior, à esquerda, é possível ver fumaça dos crematórios em funcionamento. Fonte: www.auschwitz.org 


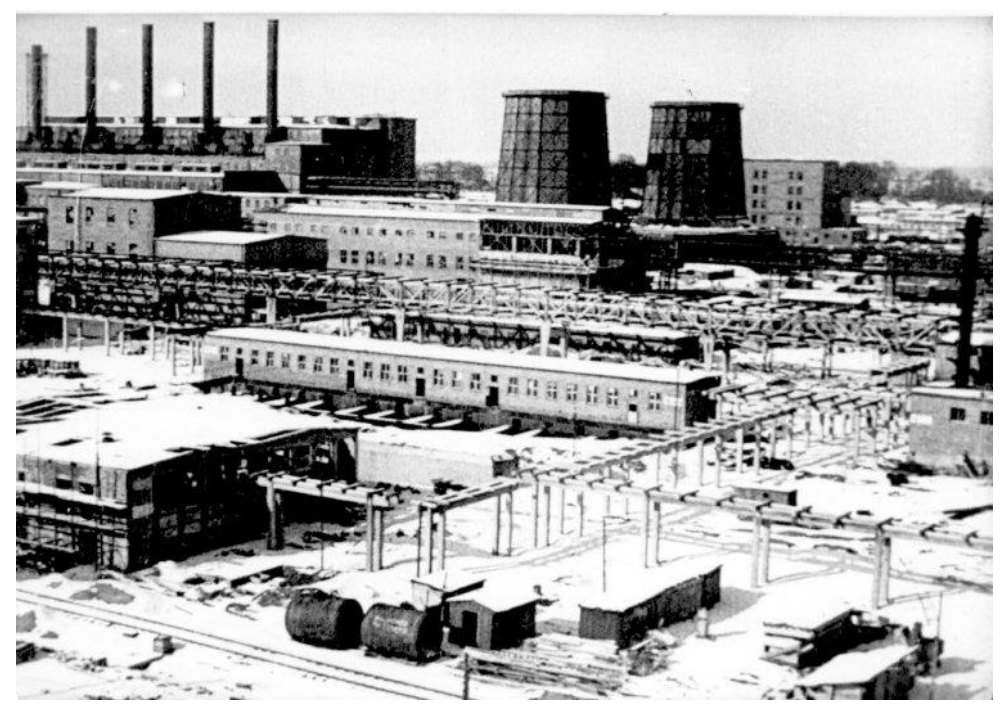

Buna Werk, e o complexo químico IG Farben

Fonte: www.holocaustresearchproject.org

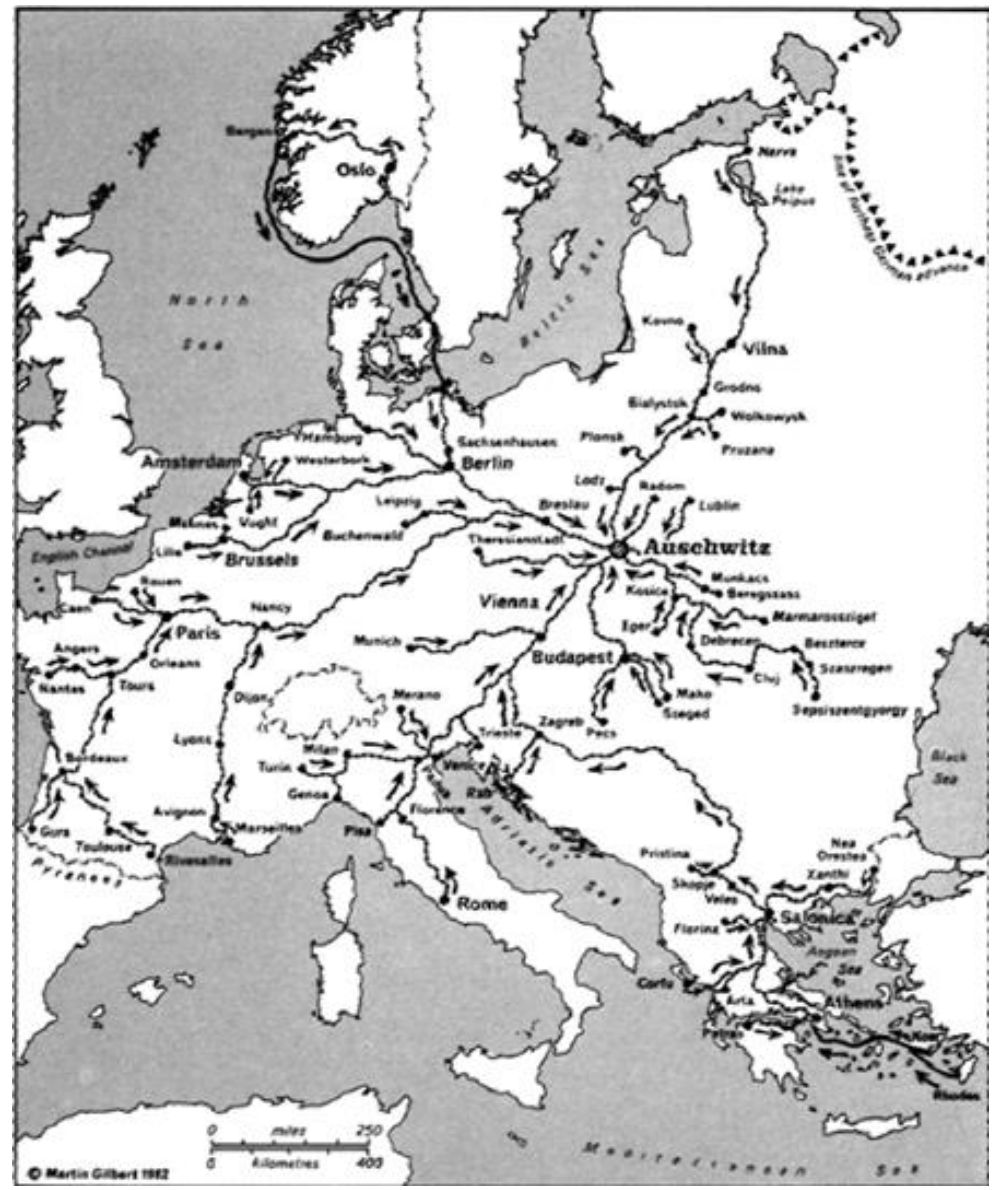

Mapa da Europa indicando as deportações para Auschwitz. Martin Gilbert. The Dent Atlas of the Holocaust.

London: Taylor \& Francis e-Library, 2005 (Electronic Edition) 
Estima-se que durante o período durante o qual esteve em funcionamento (1940-1945), a SS e a polícia alemã deportaram para o complexo aproximadamente 1.300 .000 pessoas de toda a Europa. Desses, 1.100.000 foram assassinados. A grande maioria eram judeus: dos 1.095.000 de judeus deportados para Auschwitz, aproximadamente 960.000 morreram.

Os demais grupos eram de: poloneses (dos 147.000 deportados, 74.000 morreram); ciganos (dos 23.000 deportados, 21.000 morreram); prisioneiros de guerra soviéticos (dos 15.000 deportados, quase todos morreram); outros civis (dos 25.000 deportados, 12.000 morreram) ${ }^{159}$.

Como prisioneira nas diversas unidades que utilizavam mão-de-obra escrava em Auschwitz, Cecília viu e viveu todos os horrores dos três campos do complexo. Esses horrores não eram só feitos das dificuldades do trabalho extenuante, mas também do permanente processo de desumanização ao qual eram submetidos os prisioneiros.

Logo na chegada Cecília, junto com aqueles que não eram imediatamente enviados às câmaras de gás passavam pelo mesmo ritual: tinham o cabelo raspado, eram "desinfectados" e recebiam o conhecido uniforme listrado. Ao mesmo tempo perdiam seus nomes e recebiam um número que era tatuado no braço. No "planeta Auschwitz"160, as raras vezes em que um alemão se dirigia a um prisioneiro, era através do número. A identidade do prisioneiro era assim apagada. Somavam-se a tudo isso a falta de alimentação, de higiene, de privacidade. Mas havia muito mais.

\section{Os experimentos do "Doutor" Mengele}

Josef Mengele era um médico alemão pertencente à SS e que ficou conhecido pelos terríveis experimentos que praticou no campo de concentração de Auschwitz. Chegou ao complexo em maio de 1943. Não era, porém, o único médico em Auschwitz nem tinha o cargo mais alto. Talvez pelo fato de ser uma presença constante na plataforma de Auschwitz onde os prisioneiros desembarcavam e como muitas vezes era ele mesmo que decidia quem era

\footnotetext{
${ }^{159}$ Dados publicados pelo United States Holocaust Memorial Museum - USHMM (Museu Memorial do Holocausto dos Estados Unidos, Washington, DC: https://www.ushmm.org/wlc/en/article.php?ModuleId=10005189. Consultado em 4 de outubro de 2016.

160 Assim chamado pelo autor israelense Yehiel Dinur (1909-2001), cujo nome de nascimento era Yehiel Feiner, mas que ficou conhecido pelo nome de Ka-Tzenik 135633 (Ka-Tzet em referência ao termo em alemão para campo de concentração - Konzentrationlager; o número foi o que foi estampado em seu braço durante os dois anos que foi prisioneiro em Auschwitz). Entre seus livros publicados estão Salamandra (1946) e Casa de Bonecas (1953), ambos publicados em Israel. Ele também ficou conhecido por seu dramático depoimento durante o julgamento de Eichmann em 1961.
} 
"selecionado" para viver ou morrer, referências a seu nome aparecem em muitos relatos de sobreviventes.

Cecília foi também vítima de um de seus notórios experimentos. Ela nos conta que um dia Mengele reuniu cinco meninas. Ordenou que tirassem as roupas e que entrassem numa banheira com a água extremamente quente, dizendo: "Vai entrando aí inteirinha senão você vai morrer”. Era insuportável. Mas como nos diz Cecília: “Para viver, aguentei”. Depois de algum tempo, ele ordenou que passassem para banheiras com água gelada. Cecília e as outras meninas gritavam. No dia seguinte, ela viu que uma daquelas meninas, uma judia grega, foi tirada morta.

Cecília passou ainda por muitos outros castigos e sofrimentos em Auschwitz. Mas ainda iria vivenciar outros infernos.

\section{O campo de mulheres de Ravensbrück}

As transferências de prisioneiros para diversos campos eram constantes e dependiam das necessidades de mão-de-obra escrava das empresas associadas ao sistema concentracionário ou as do próprio governo alemão, ou seja, se houvesse alguma atividade industrial, de manutenção ou mineração que demandasse mais prisioneiros, eles eram remanejados para aqueles locais.

Com a aproximação do exército soviético dos campos localizados no Leste europeu e a iminência da derrota da Alemanha na guerra, o motivo do remanejo era evacuar os campos de concentração nazista naquele território e transferir os prisioneiros para outros campos dentro da própria Alemanha. Cecília foi então levada para Ravensbrück.

Ravensbrück tinha uma particularidade: era um campo exclusivamente de mulheres. Como diz em seu livro a autora Rochelle G. Saidel, era "um inferno especial para mulheres”.

Localizado a menos de 80 quilômetros de Berlim, capital da Alemanha, sua construção começou em 1938 com o objetivo de abrigar prisioneiras políticas, dissidentes, membros da resistência ou ainda, aquelas classificadas como “indesejáveis” pelos alemães.

As primeiras mulheres chegaram em maio de 1939. Calcula-se que nos seis anos de seu funcionamento, passaram por lá aproximadamente 132.000 mulheres e dentre elas, por volta de 
117.000 não sobreviveram. ${ }^{161}$ Elas morreram de fome, de frio, asfixiadas nas câmaras de gás ou fuziladas.

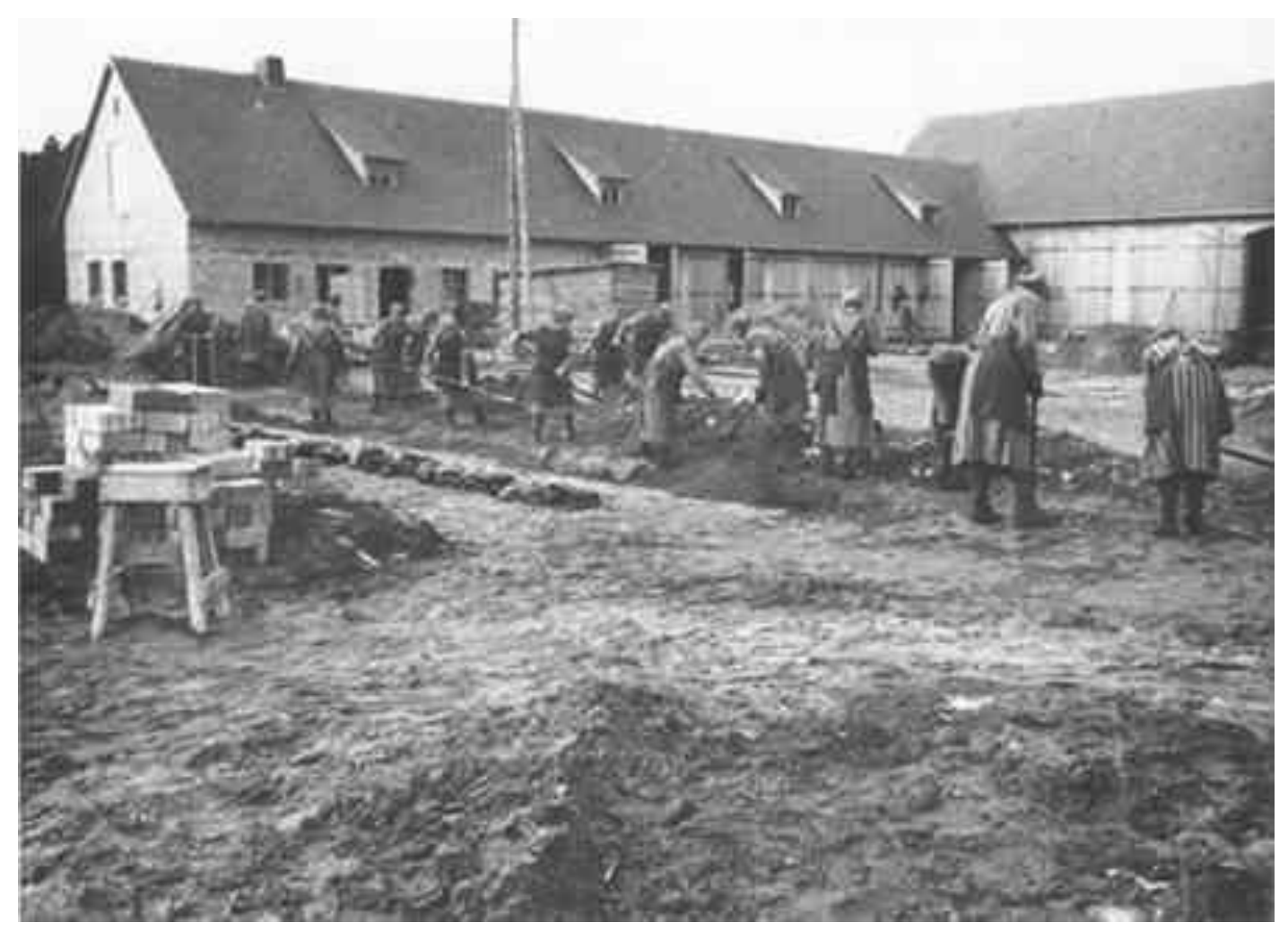

Prisioneiras trabalhando em Ravensbrück

Fonte: www.jewishvirtuallibrary.org

Uma das prisioneiras e vítimas de Ravensbrück mais conhecidas no Brasil é Olga Benário. Comunista judia alemã, ela vivia no Brasil em companhia do líder Luis Carlos Prestes. Juntos organizaram um movimento revolucionário em novembro de 1935 que acabou derrotado. Olga foi presa e em 1936, grávida, foi deportada para a Alemanha de Hitler pelo governo de Getúlio Vargas. Lá esteve presa primeiro Lichtenberg e em 1939 foi transferida para Ravensbrück onde permaneceu até sua morte na câmara de gás de Bernburg, ocorrida em abril de 1942.

${ }^{161}$ SAIDEL, Rochelle G. As Judias do Campo de Concentração de Ravensbrück. São Paulo: EDUSP, 2009. 


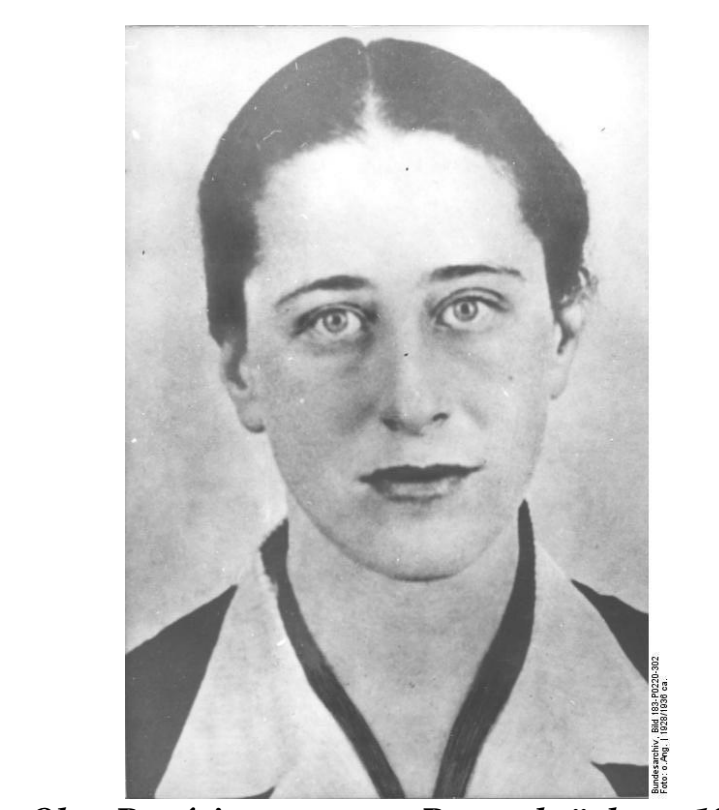

Olga Benário, morta em Ravensbrück em 1942

Fonte: www.commons.wikimedia.org

Dentre as mulheres prisioneiras que passaram por Ravensbrück por volta de $20 \%$ eram judias. No entanto, se para todas as mulheres que lá estiveram, a vida no campo era insuportável, as maiores dificuldades eram enfrentadas pelas judias.

Vários eram os motivos. Em primeiro lugar, a perspectiva certa de extermínio, sem distinção de gênero ou idade para os judeus. Segundo -e de certa forma relacionado ao primeiro aspecto- a pouca solidariedade das mulheres de outros grupos em relação às prisioneiras judias: como estas eram mais visadas pelos alemães, atividades de resistência organizadas por prisioneiras de outras origens quase nunca incluíam mulheres judias. Terceiro, as diversas origens geográficas, graus de religiosidade, barreiras linguísticas, das prisioneiras judias, dificultavam muito a possibilidade de estabelecer laços entre elas. Estes existiam, mas não no mesmo grau que entre, por exemplo, prisioneiras comunistas russas, resistentes francesas ou dissidentes alemãs.

Em seus seis anos de atividade, Ravensbrück, que havia sido originalmente projetado para 3.000 mulheres, recebia ano a ano um número crescente de prisioneiras. Isso se traduzia uma deterioração permanente nas condições de vida do lugar o que, somado aos maus tratos praticados desde o início, à má alimentação e às rotinas de trabalho escravo extenuantes, eram proporcionalmente responsáveis pelo aumento no número de mortes no local.

Muitas mulheres, judias e não-judias, deram seu testemunho sobre a vida naquele lugar. Uma delas, Violette Lecoq, enfermeira e resistente francesa, desenhou a realidade daquele 
campo em seus dois anos de permanência de outubro de 1943 a abril de 1945. É um trabalho de arte clandestino, cuja execução implicava enormes riscos; uma forma de resistência e também uma forma de testemunho.

Os desenhos de Violette registram temas recorrentes do cotidiano do campo: o trabalho, os castigos, as doenças, a crueldade das guardas alemãs; também a morte, sempre presente. A informação que esses desenhos nos transmitem é urgente e imediata e poderia se resumir em uma só frase: "Foi isto que eu vi".

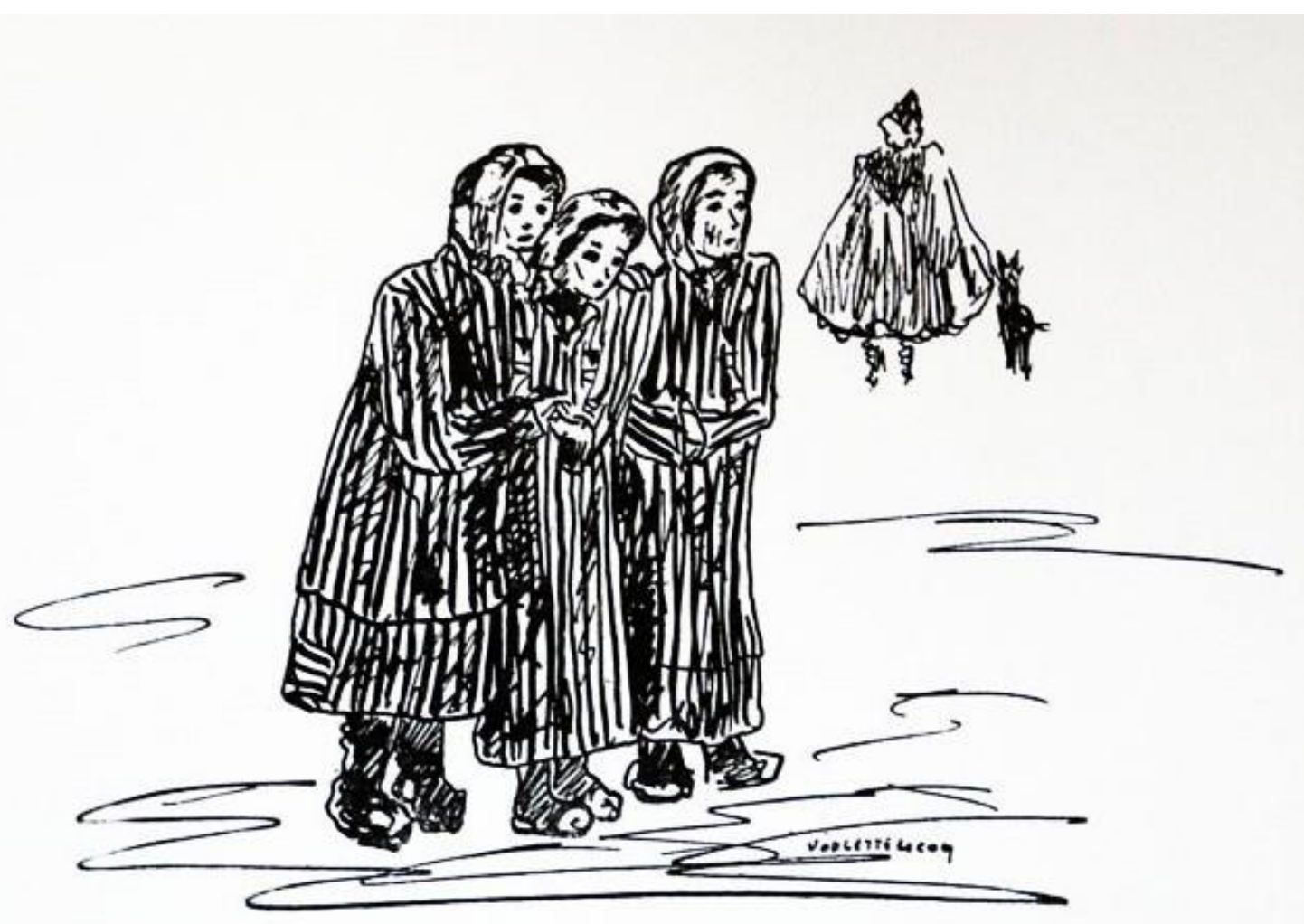

Violette Lecoq, As válidas

Desenho a lápis, 1943 


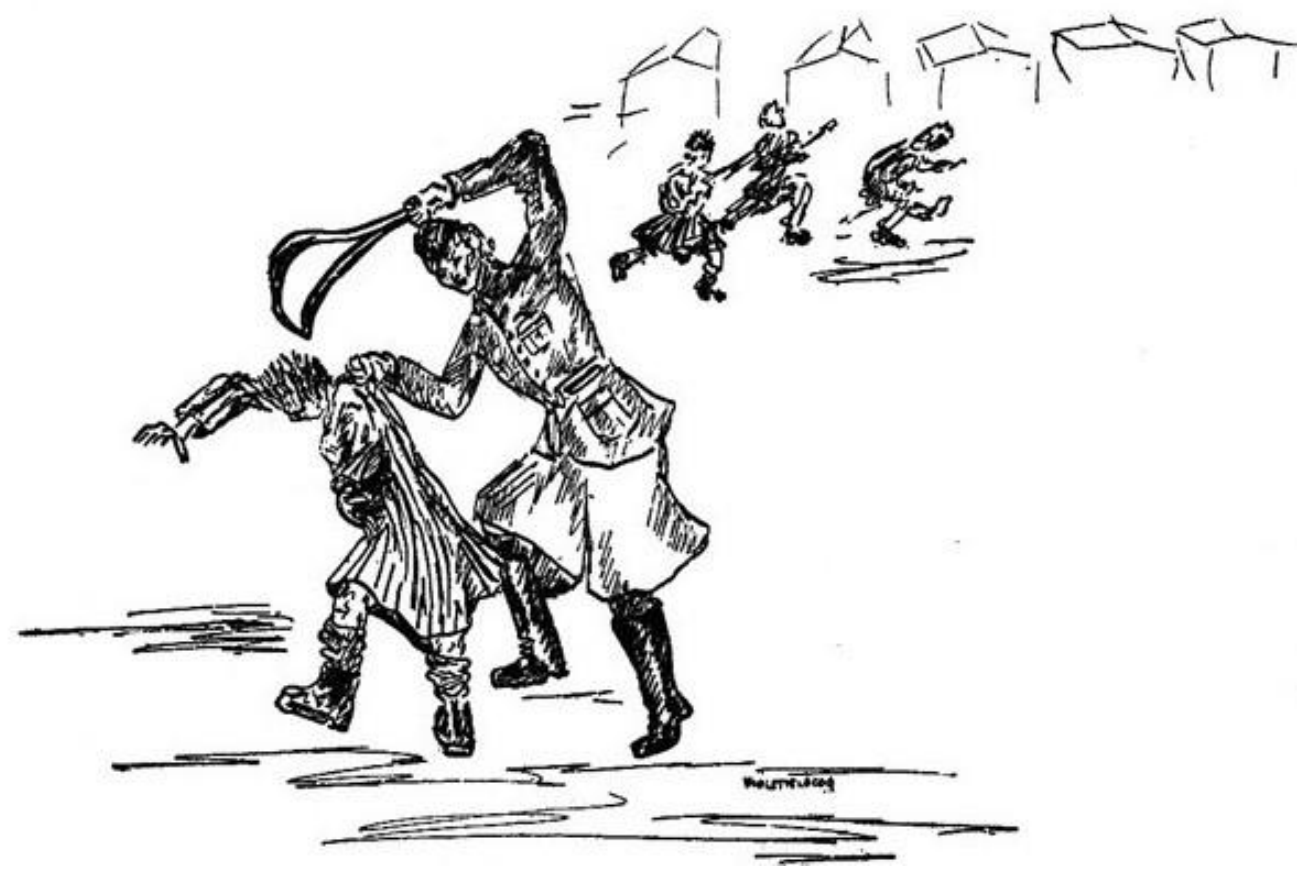

Violette Lecoq, A lei do mais forte

Desenho a lápis, 1943

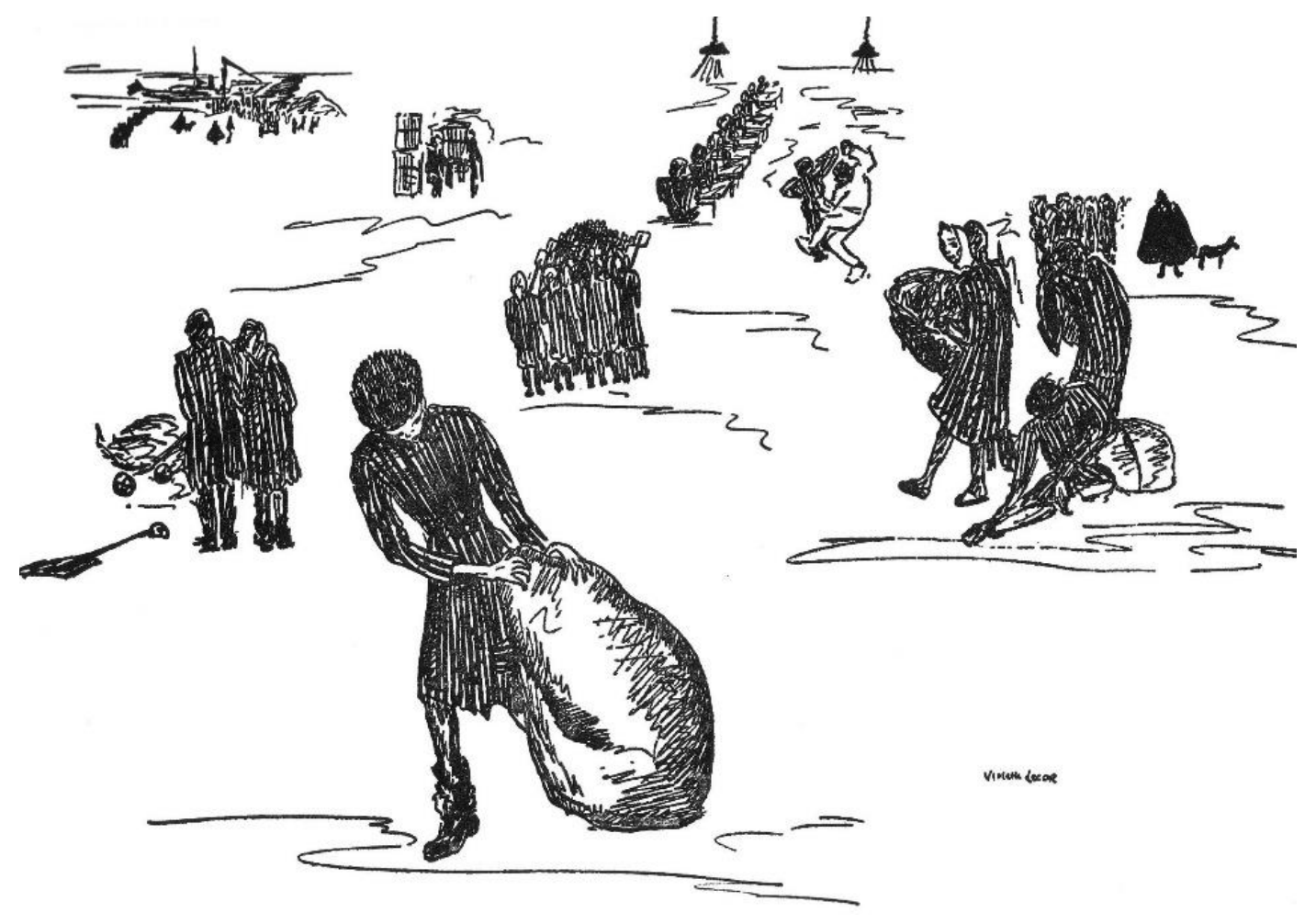

Violette Lecoq, Trabalhos

Desenho a lápis, 1943 
Na série de três desenhos a seguir, Violette retrata o rápido processo de desumanização das recém-chegadas a Ravensbrück. Na primeira imagem, intitulada ironicamente pela artista "Boas vindas", vemos as prisioneiras com seus pertences chegando ao campo. A seguir, a prancha denominada "Higiene", mostra as prisioneiras já sem roupa passando pelo processo de desinfecção. A última delas ou "Duas horas depois..." mostra a completa transformação dessas mulheres: sem cabelo, sem suas roupas, vestindo apenas seus pijamas listrados. Seus bens estão ao fundo, prontos para serem apropriados pelos alemães.

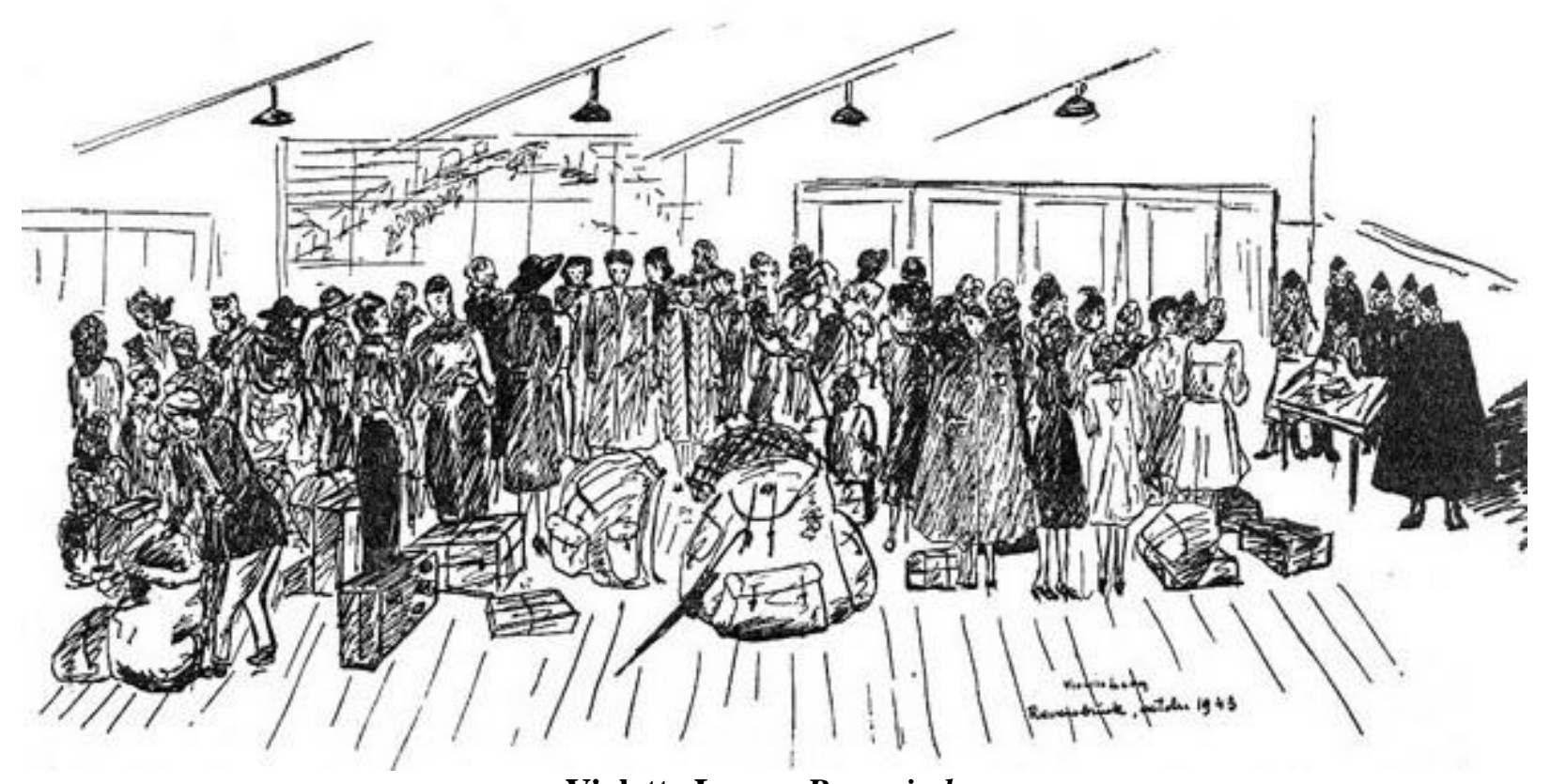

Violette Lecoq, Boas vindas

Desenho a lápis, 1943 


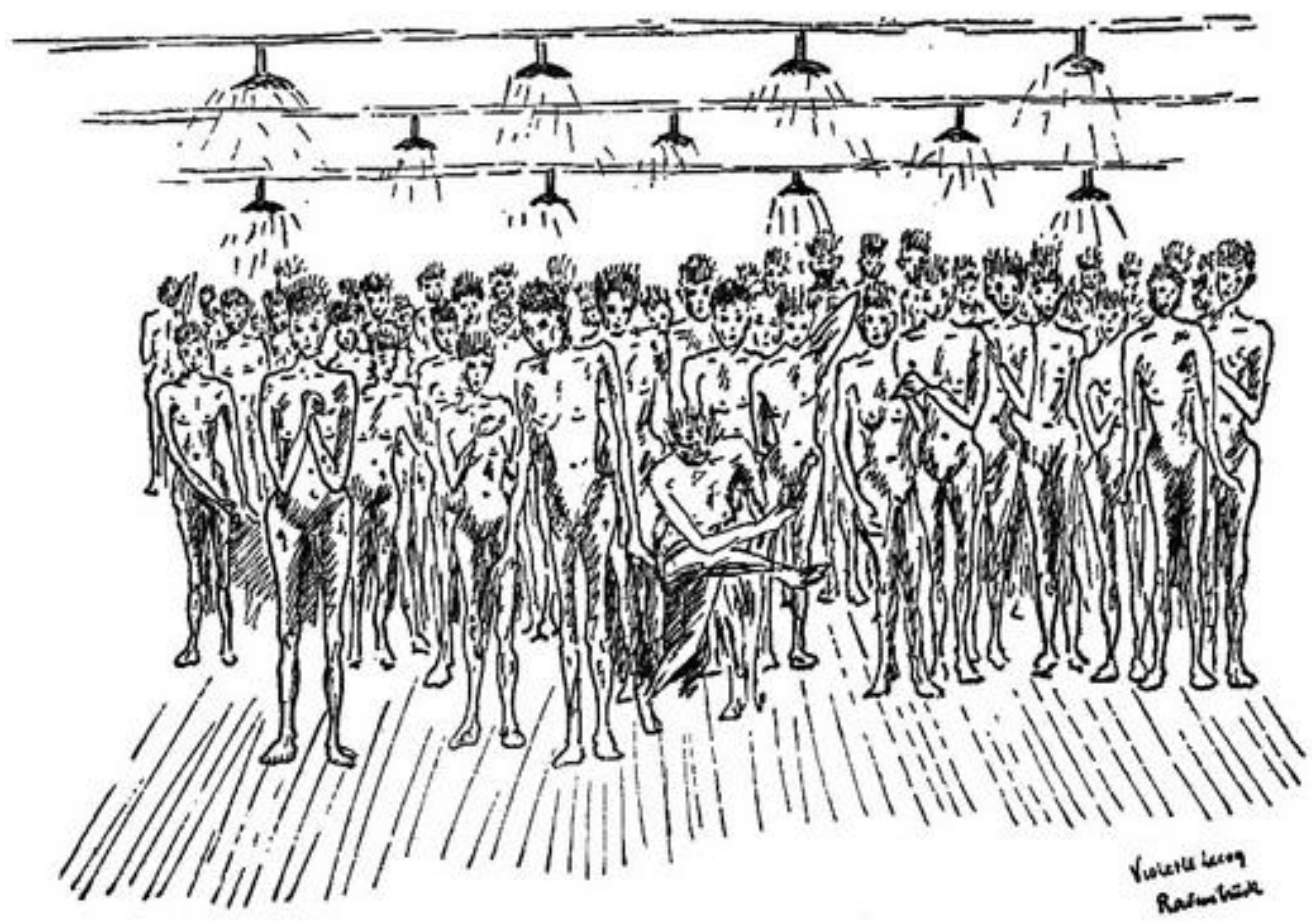

Violette Lecoq, Higiene

Desenho a lápis, 1943

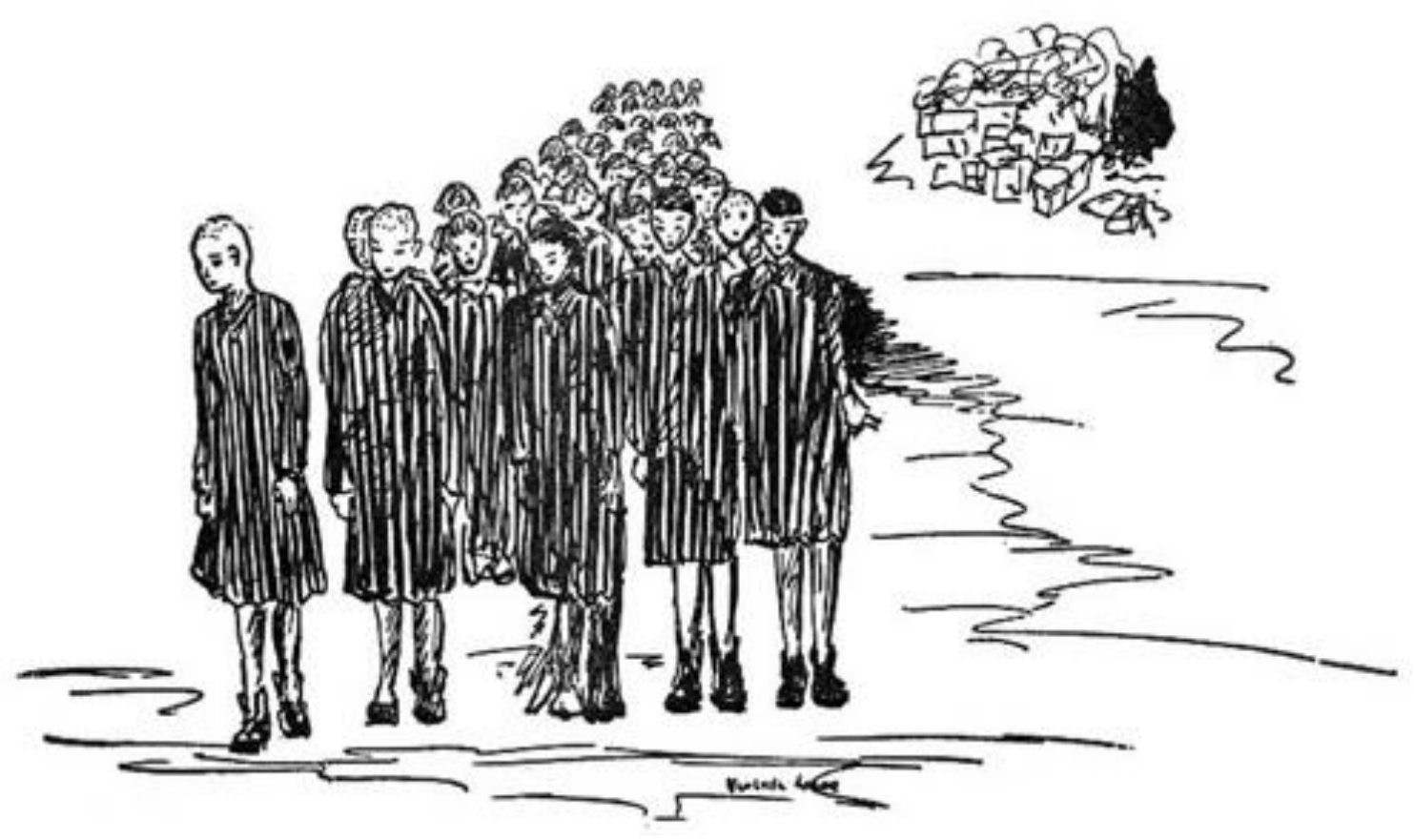

Violette Lecoq, Duas horas depois

Desenho a lápis, 1943 
Ao chegar a Ravensbrück, Cecília já havia passado por todo esse processo em Auschwitz. Porém ninguém se acostuma a esse horror. O novo campo seria mais de suas tantas sobrevivências; não a última, nem a mais fácil.

Os últimos meses de Ravensbrück, de janeiro a abril de 1945, viram a chegada de milhares de prisioneiras de vários campos do leste europeu que iam sendo libertados pelo exército russo. As condições de vida pioravam dia a dia devido à superlotação. Nem Cecília nem as outras prisioneiras sabiam que o fim daquele inferno estava próximo. Milhares delas não conseguiriam chegar ao fim do túnel: sobreviver era uma tarefa que exigia um esforço sobrehumano diário.

\section{As difíceis negociações para um resgate improvável}

Em fevereiro de 1945, dois jornais suíços publicaram notícias sobre negociações para o resgate de prisioneiros de campos de concentração que estavam ocorrendo entre o governo daquele país e Heinrich Himmler -se não o único, um dos maiores carrascos responsáveis pela execução da Solução Final e homem de absoluta confiança de Hitler. Ao ficar sabendo, Hitler reagiu com fúria e proibiu terminantemente que essas negociações continuassem.

A Cruz Vermelha Sueca, porém, aproveitou a oportunidade e retomou a iniciativa através de seu vice-presidente, o Conde Folke Bernadotte. O objetivo era negociar o resgate de prisioneiros escandinavos que se encontravam em campos em território alemão, entre eles Ravensbrück. Os encontros foram mediados por dois representantes próximos a Himmler: Walter Schellenberg e Felix Kersten. Este último, curiosamente o massagista de Himmler, junto com o diretor do Congresso Judaico Mundial na Suécia, Hillel Storch, desenharam um plano de resgate para apresentar a Himmler. Foi graças aos esforços de Storch que prisioneiros judeus foram incluídos no plano. ${ }^{162}$

\footnotetext{
${ }^{162}$ FLEMING, Gerald. Hitler and the Final Solution. Los Angeles: University of California Press, 1987.
} 


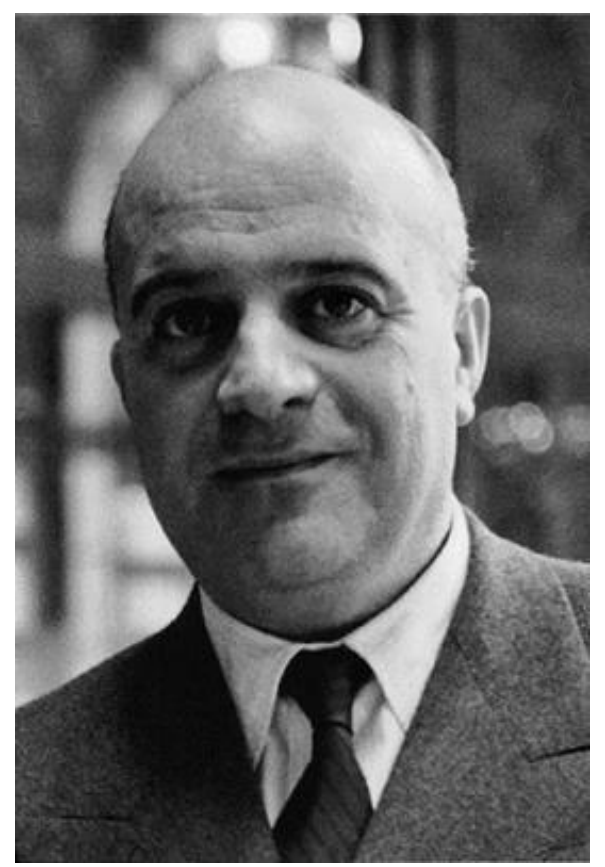

Hillel Storch, diretor do Congresso Judaico Mundial, Suécia

Fonte: Pinterest

As dificuldades das negociações eram enormes, principalmente devido à ordem expressa de Hitler de que, à medida que os exércitos se aproximassem, os campos de concentração fossem explodidos. Himmler, embora quisesse salvar sua pele, ainda não estava preparado para romper com o Führer. Em março, porém, Kersten conseguiu ao menos o compromisso de manter os campos intactos com os prisioneiros dentro. ${ }^{163}$

Em 20 de abril, Kersten e um enviado de Storch, Norbert Masur, reuniram-se em Berlim com Himmler que, como dissemos, procurava uma saída pessoal para a inevitável queda dada a derrota iminente dos alemães. Como resultado, Kersten e Masur conseguiram de Himmler a liberação de 1.000 prisioneiras de Ravensbrück.

Masur escreveria mais tarde: “... um judeu livre esteve sozinho com o temido e impiedoso Chefe da Gestapo que tinha as vidas de cinco milhões de judeus em sua consciência". 164

Após inúmeras idas e vindas e das ameaças de outros comandantes nazistas de interromper quaisquer planos de resgate, o mesmo começou a ser posto em prática.

${ }^{163}$ Idem.

${ }^{164}$ FOX, Frank. A Jew Talks to Himmler, http://www.zwoje-scrolls.com/zwoje38/text18p.htm 


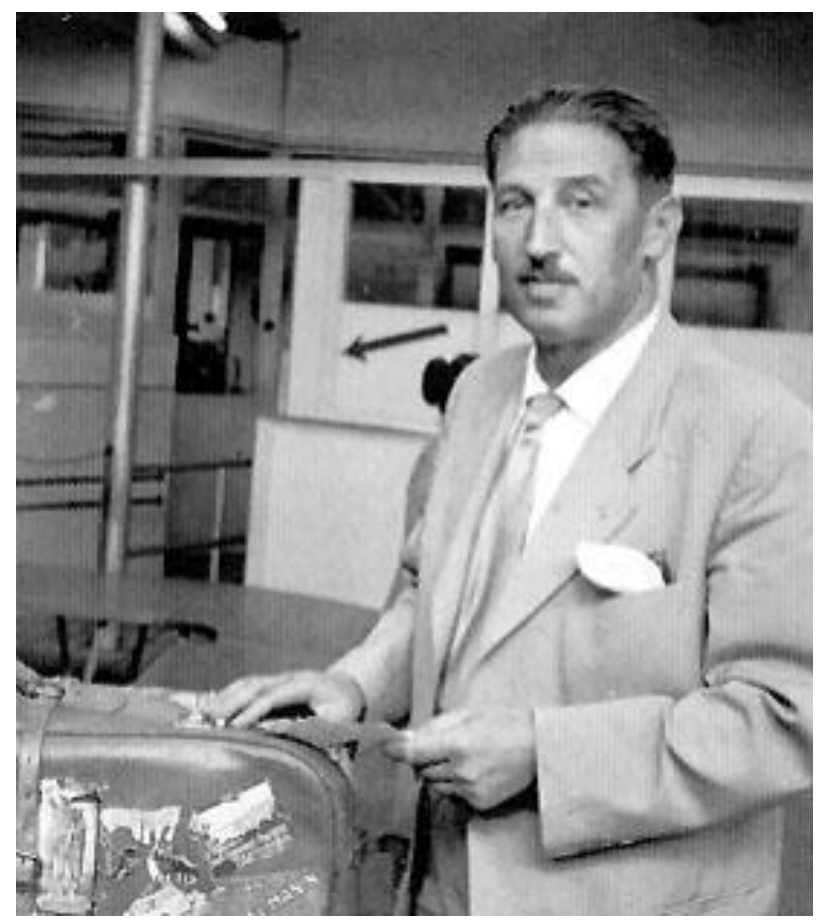

\section{Norbert Masur, emissário do Congresso Judaico Mundial, Suécia}

Fonte: www.zwoje-scrolls.com

\section{A saída de Ravensbrïck}

Ao tempo que aconteciam aquelas negociações, a aproximação dos exércitos aliados aos campos de concentração fez com que os comandantes recebessem a ordem de evacuá-los. Prisioneiros de vários campos foram forçados a empreender marchas a pé rumo a outros campos; sem alimentos, sem roupas nem sapatos adequados.

Em Ravensbrück não foi diferente. Antes que chegasse a ordem de liberação, milhares de mulheres foram tiradas de lá, ainda como prisioneiras, e forçadas a marchar. Algumas delas, como Cecília, foram conduzidas ao campo de Malchow, outras seguiram para outros campos; outras ainda morreram de fraqueza no caminho ou foram executadas pelos guardas da SS que as acompanhavam. A guerra estava acabando tarde demais para elas.

No dia 22 de abril, chegou a Ravensbrïck a ordem de liberar todas as mulheres do campo e sub-campos, inclusive Malchow onde Cecília havia chegado. Mas ainda não havia muito o que comemorar. As feridas eram muito profundas, as perdas inúmeras e irreparáveis, o futuro extremamente incerto. 


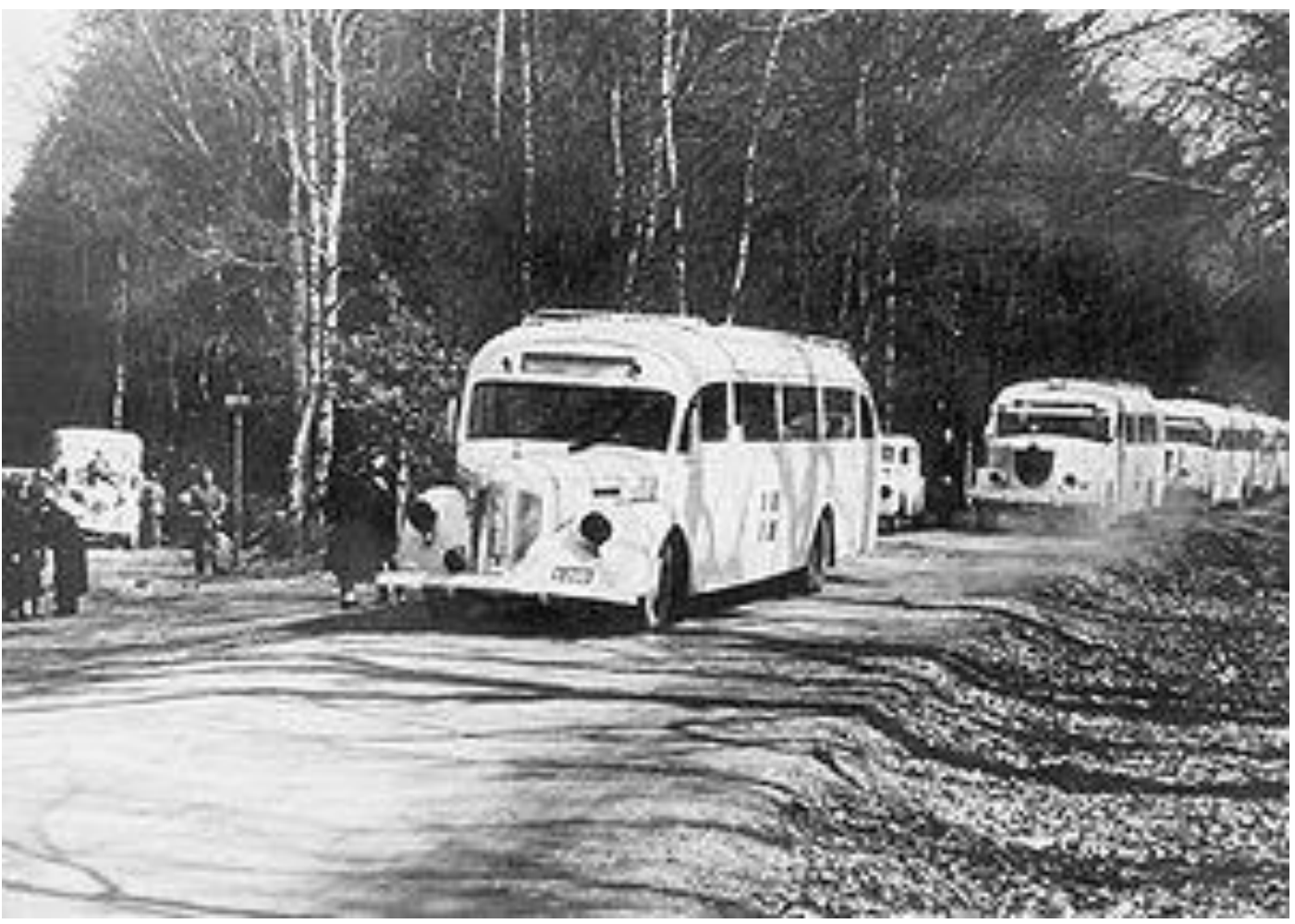

O comboio de ônibus brancos da Cruz, Vermelha sueca, 1945

Imediações de Friedrichsruh

Fotógrafo desconhecido

Fonte: www.commons.wikimedia.org

O resgate das mulheres de Ravensbrück começou efetivamente na última semana de abril. Como resultado das negociações do dia 20 do mesmo mês, a filial sueca da Cruz Vermelha e o governo da Dinamarca conseguiram organizar comboios que ficaram conhecidos como "os ônibus brancos”. Foi em um desses comboios que Cecília embarcou no dia 24 de abril de 1945 rumo à Suécia.

O trajeto era, porém, muito perigoso. A Europa ainda estava em guerra e o transporte tinha que ser feito por um corredor muito estreito entre o front soviético a Leste e o front britânico a Oeste. ${ }^{165}$ Como a própria Cecília relembra, um dos ônibus em seu comboio foi bombardeado e várias das ocupantes morreram.

165 CESARANI, David ; LEVINE, Paul. Bystanders to the Holocaust: A Re-Evaluation. New York: Routledge, 2002. 


\section{A chegada à Suécia}

A operação da Cruz Vermelha sueca foi o maior esforço de resgate de prisioneiros de campos de concentração na Segunda Guerra Mundial. É difícil estimar quantos prisioneiros foram levados para a Suécia nos comboios dos "ônibus brancos". Os números variam entre 20.000 e 30.000 pessoas, incluindo aqueles que foram resgatados em maio de 1945, quando a guerra já havia terminado. ${ }^{166}$

Cecília, lembra-se bem de quando seu comboio chegou à fronteira da Suécia. Lá havia comida. Ironicamente, devido ao seu estado físico, muitas mulheres morreram ao voltarem a se alimentar. Como todo o resto, acostumar o corpo novamente aos hábitos mais básicos também era um processo lento.

Na Suécia, Cecília e os demais prisioneiros eram levados para locais de quarentena para iniciar sua recuperação física. Foi lá também que começaram as buscas por familiares. Cecília lembra que no barracão onde estava alojada, havia instalados quatro alto-falantes que anunciavam nomes de pessoas que estavam sendo procuradas por parentes.

A alegria era enorme para aqueles que eram chamados já que isso significava que não estavam totalmente sozinhos. Mas Cecília nunca era chamada. Um dia, no entanto, ela conheceu um professor chamado Hugo Valentin que a convidou para morar com sua família. ${ }^{167}$

Durante sua estadia com os Valentin, o professor encontrou no jornal um anúncio de alguém procurando por Cecília Rybitwer. A surpresa foi enorme: era seu irmão Chaim. Foram ao encontro um do outro, mas quase não se reconheceram, tal era o estado físico que todos aqueles anos de sofrimento haviam imposto sobre eles.

Algum tempo depois Chaim foi para Frankfurt, na Alemanha, mas Cecília ficou na Suécia onde estava estudando graças a uma bolsa oferecida pelo Professor Valentin. Primeiro estudou enfermagem e mais tarde fez o curso da IBM.

\footnotetext{
166 Idem.

167 O Professor Hugo Valentin foi um respeitado historiador judeu sueco conhecido por seus estudos sobre o antissemitismo e sobre a história dos judeus em curso na Europa o Centro Hugo Valentin da Universidade de Upsala, na Suécia, é dedicado a estudos relacionados aos direitos humanos, genocídios e o Holocausto.
} 


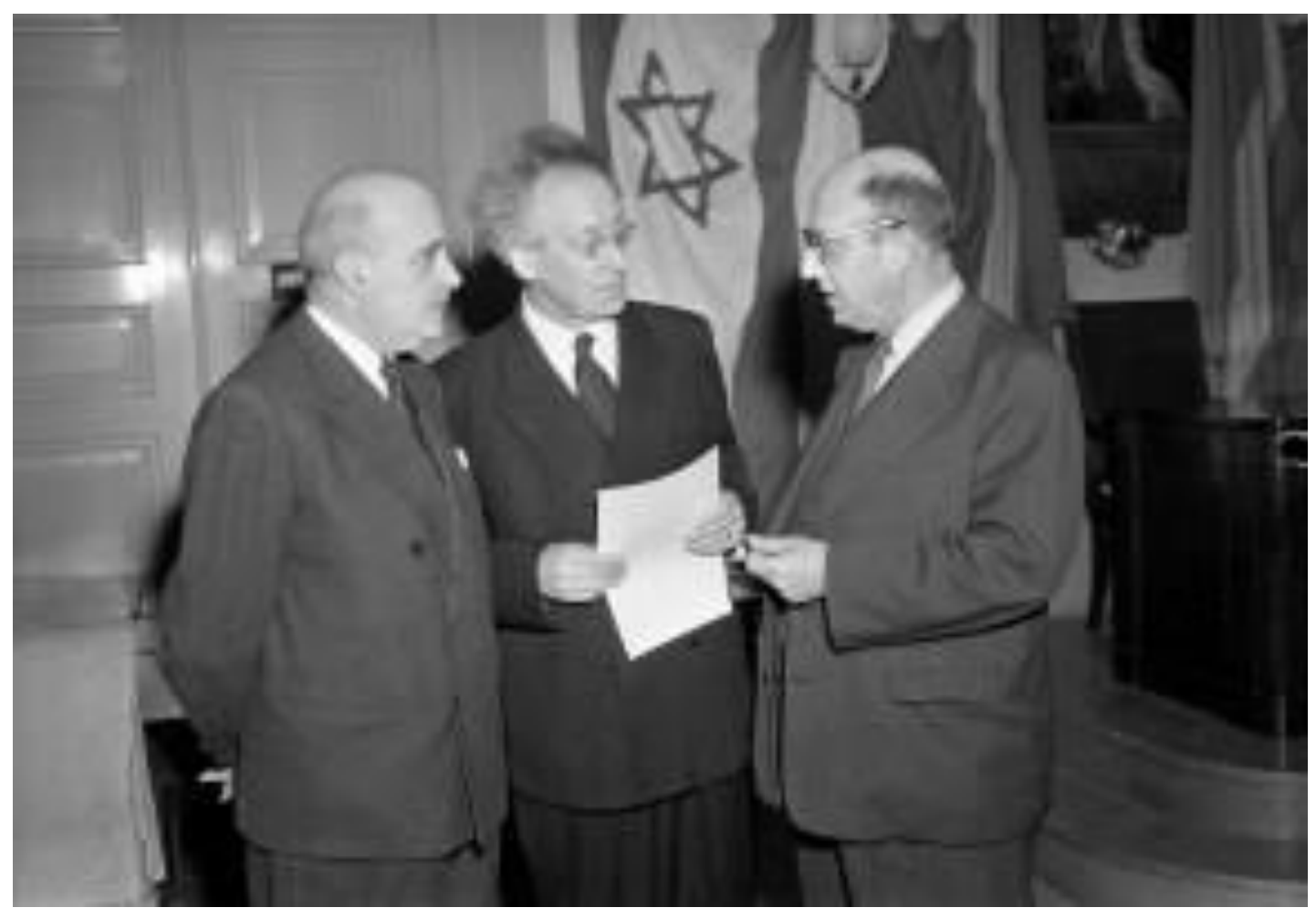

Hillel Storch, Prof. Hugo Valentin e o Rabino Kurt Wilhelm, 1953, Katthavet, Suécia

[Da esquerda para a direita]

Fotógrafo: Tore Burnäs

Cecília viveu na Suécia por sete anos. Lá se casou com Simon Gewertz. Como seu marido tinha familiares no Brasil, ele decidiu emigrar. Cecília o acompanhou. Ambos chegaram a São Paulo em 1952.

Eu me pinto, me arrumo, mas ninguém sabe o que tem dentro...

Reiteramos aqui a frase que abre estas páginas, e que foi pronunciada por Cecília em seu testemunho registrado em vídeo pela equipe Arqshoah. Ela traduz a nossa dificuldade de aproximar-nos de tudo aquilo que ela e tantos outros, naquela Europa ensandecida de ódio, vivenciaram. É o que também nos transmitem as palavras de outra sobrevivente de Auschwitz e Ravensbrück, a francesa Charlotte Delbo, através de sua poesia: 
Esteja você voltando da guerra ou de outro

lugar

quando é de um outro lugar

inimaginável para os outros

é difícil voltar

Esteja você voltando da guerra ou de outro

lugar

quando é de um outro lugar

que não é lugar algum

é difícil voltar

tudo em casa

se tornou estranho

enquanto estava em outro lugar

Esteja você voltando da guerra ou de outro

lugar

quando se trata de um outro lugar

onde se fala com a morte

é difícil voltar

e falar novamente com os vivos.

Esteja você voltando da guerra ou de outro

lugar

quando se volta de lá

e é necessário reaprender

é difícil voltar

quando se olhou a morte

com as pupilas nuas

é difícil reaprender

a olhar os vivos

de pupilas opacas. ${ }^{168}$

Charlotte Delbo

${ }^{168}$ DELBO, Charlotte. Auschwitz et atrès. Mesure de nos jours. Paris, Minuit, 1971 (Tradução nossa) 


\title{
4.2.4 Ariella Segre: a persistência do antissemitismo
}

\author{
Introduzindo a vida de Ariella
}

Em 1938, o governo fascista de Benito Mussolini implementou uma brutal política de exclusão “em defesa da raça italiana". Para os judeus da Itália, essas leis tiveram um forte impacto, principalmente por tratar-se de uma comunidade profundamente enraizada e integrada à vida do país.

A protagonista desta história, Ariella Pardo Segre, ainda não havia nascido quando estas leis foram promulgadas. Sua família, composta por professores e intelectuais, foi duramente atingida já que dentre as inúmeras determinações contidas nas leis uma das principais era a imediata retirada de todos os judeus de cargos em funções públicas, inclusive a educação.

O impedimento de judeus na educação, porém, não se limitava aos professores: atingia também todos os alunos judeus que, de um momento a outro, ficaram impedidos de prosseguir seus estudos, não importando o nível em curso. A preocupação com esses milhares de jovens fez com que a comunidade se organizasse rapidamente para suprir essa falta, atividade na qual os Pardo, como educadores conceituados, engajaram-se desde o início.

As dificuldades da vida na Itália entre os anos 1938 a 1943 transformaram-se em real perigo quando, após a queda de Mussolini, em setembro de 1943, as forças alemãs ocuparam a Itália. Imediatamente os judeus italianos começaram a ser persrguidos e deportados para campos de concentração no leste europeu. A captura e deportação dos milhares que ainda estavam em território italiano era de altíssima prioridade para os alemães. Somente uma centena deles conseguiu fugir para a Suiça através das montanhas - entre eles Ariella e sua família. 


\section{LIVRO 4 - Ariella Pardo Segre ${ }^{169}$}

Entre as cartas mudas de arquivo encontravas tragédias escondidas, e de atrozes calúnias as vítimas te falavam, pedindo uma voz, mesmo que fosse uma só, que pedisse por eles: JUSTIÇA!

Fragmento de poema a Gemma Volli Lucio Pardo, maio de 1971

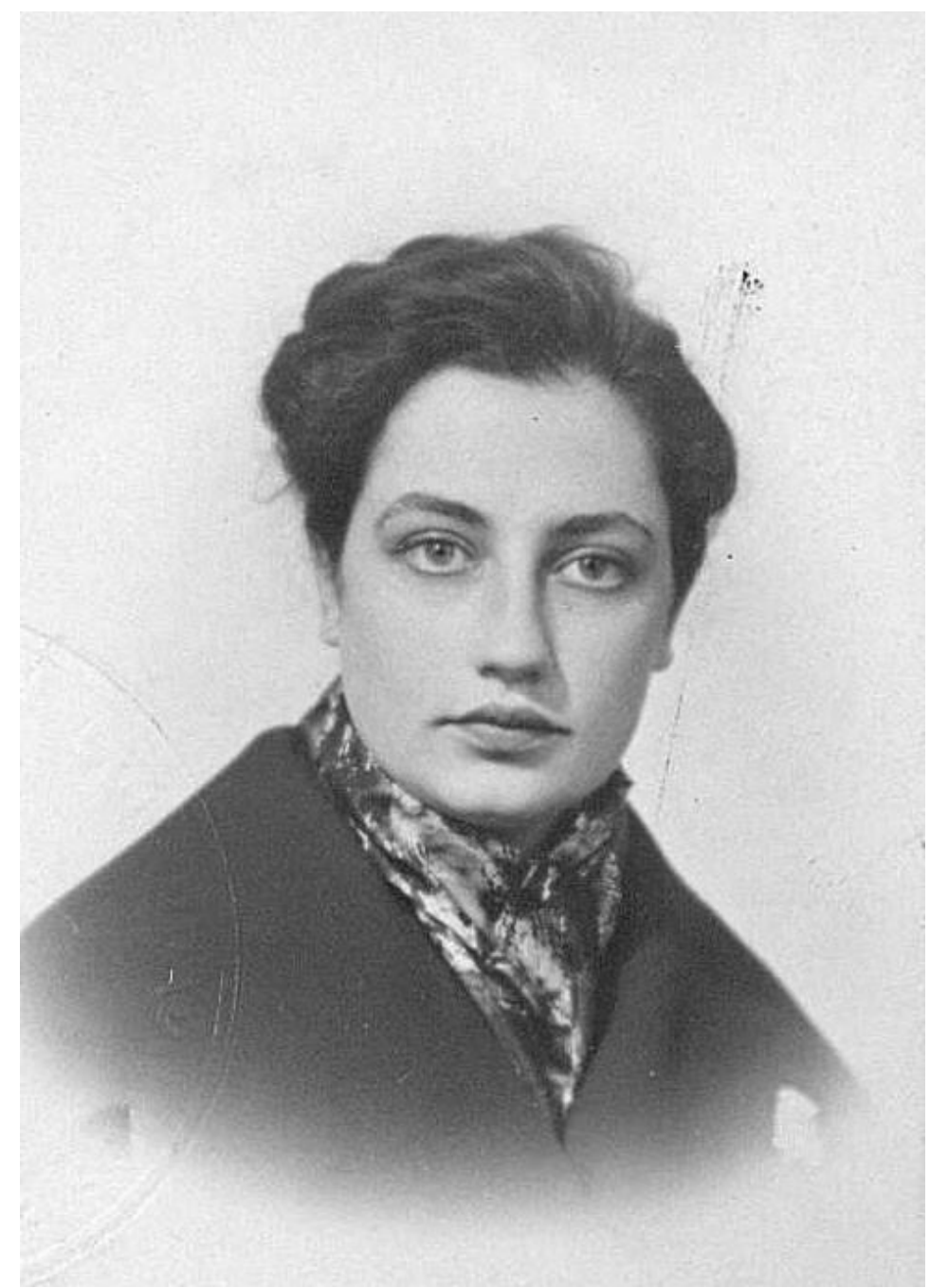

Ariella quando de sua chegada ao Brasil, 1960

Fonte: www.familysearch.org

169 Testemunho de Ariella Segre ao projeto Vozes do Holocausto. São Paulo, 15 e 29 de julho de 2015 . Ficha Técnica: Entrevistadora, Profa. Sarita Saruê; Câmera, Raíssa Alonso; Transcrição, Samara Konno. 
Estas páginas são fruto de múltiplas vozes. Seguindo a faísca acesa pelo testemunho de Ariella, seguiremos alguns dos inúmeros caminhos percorridos pelos judeus durante os mais de 2.000 anos de sua presença na Itália que, como ela mesma nos conta, é "a mais antiga fora de Israel".

O testemunho de Ariella, porém, evoca também a voz de outros protagonistas e de suas vivências: seu pai, o eminente professor Ferruccio Pardo, que deixou registrada, entre seus inúmeros escritos, sua experiência como judeu alvo das Leis Raciais impostas por Mussolini; sua mãe, Iris Volli Pardo, também professora, que em suas memórias relatou o gradual processo de perseguição sofrido por sua família; sua tia, Gemma Volli, historiadora, intelectual e ativista, que corajosamente guiou os seus numa arriscada fuga rumo à Suíça; seu irmão, Lucio Pardo, que incansavelmente trabalha ainda por proteger e manter viva a memória não somente dos membros de sua família, mas também da comunidade judaica de Bolonha.

Ao mesmo tempo, a história de Ariella também nos move à reflexão sobre o profundo enraizamento do antissemitismo, que, mesmo quando não se traduz em políticas de Estados - das quais ela foi vítima direta em seus primeiros anos de vida - permanece nas sombras, sempre à espreita, situação que até hoje a leva a afirmar: "Se alguém me disser que o antissemitismo não existe mais, eu não acredito".

\section{Breve relato sobre a longa história da comunidade judaica na Itália}

Embora nada possa generalizar-se a respeito da complexa experiência dos judeus na Itália, sua história, repleta de altos e baixos, é marcada pelo predomínio da tolerância.

Embora tenha sido em Roma que os judeus foram obrigados pela primeira vez a usar sinais distintivos, como insígnias ou chapéus, as quais tinham como objetivo diferenciá-los dos demais membros da sociedade, foi também em Roma onde eles conquistaram o respeito de vários de seus imperadores.

No entanto, quando a Cristandade foi reconhecida como religião oficial pelo império romano em 380 a.e.c., essa atitude começou a oscilar; por séculos, o pêndulo balançou entre exclusão e inclusão, com os Papas desempenhando um papel crucial para bem ou para mal.

Os Conselhos de Latrão - séculos XI e XII - instauraram medidas para impedir o crescimento "ameaçador" da heresia. Porém, a diferença de outras partes da Europa ou mesmo do sul da Itália, em Roma, esses decretos não foram realmente implementados. Isso permitiu que 
a cidade se tornasse abrigo para os judeus que fugiam das perseguições, especialmente após 1492, quando estes foram expulsos da Espanha.

No entanto, a partir do o século XVI, porém, leis anti-judaicas cada vez mais restritivas começaram a ser postas em prática na Itália e se materializaram, entre outras disposições, através do confinamento dos judeus em espaços delimitados dentro das cidades.

\section{A política de guetos}

É difícil pensar hoje na palavra gueto, sem que venham à mente as imagens dos guetos da Europa Oriental estabelecidos pela Alemanha nazista; por exemplo o gueto de Varsóvia.

No entanto, este termo, na verdade, originou-se na Itália aparentemente a partir do dialeto veneziano "ghèto" que significa jogar, derramar, verter e aludiria à atividade originalmente praticada na área destinada ao primeiro gueto, em Veneza. Esse local abrigou originalmente fundições (ghetti) da artilharia, daí o nome.

A decisão de implantar guetos para os judeus na Itália não surgiu de um momento a outro, e em termos práticos também não era uma novidade já que existiam bairros majoritariamente judeus em várias cidades.

No entanto, como política, o estabelecimento do gueto de Veneza em 1516, é tida como

um marco, já que inaugurou uma nova era nas relações entre judeus e cristãos na Itália e inspirou, outras cidades italianas e europeias a adotarem a mesma prática que duraria até o final do século XVIII e no caso de Roma, até o século XIX.

\section{O gueto de Veneza}

A partir de 1516, todos os judeus de Veneza foram obrigados a habitar na parte demarcada e destinada ao gueto. Embora fosse um espaço de restrição, o gueto veneziano era também um espaço de proteção contra eventuais ataques contra os judeus. Durante o dia, eles podiam sair desse espaço e retornar à noite, quando os portões eram trancados. 


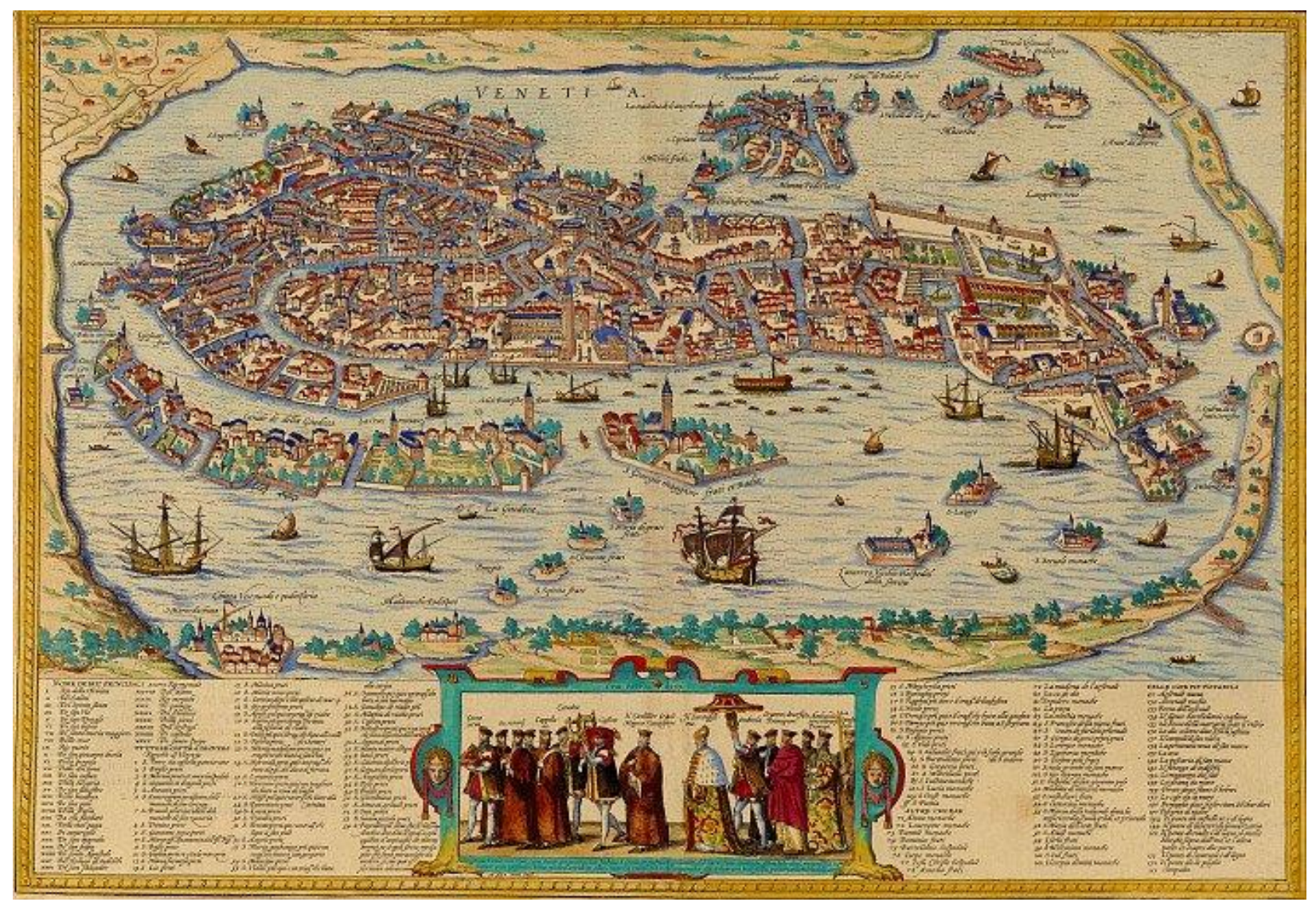

Mapa de Veneza

Bolognino Zaltieri

Gravura em cobre, colorido à mão, $1565(33,9$ x 47,9 cm)

Este mapa foi feito em meados do século XVI e indica a localização do ghetto.

Ampliando a imagem é possível ver que no guia, sob o número 144, aparece a palavra "ghetto".

Civitas Orbis Terrarum, Vol, 1, Köln, Coleção Peter von Brach

Fonte: www.commons.wikimedia.org

Alguns sinais adotados para diferenciar os judeus dos cristãos, adotados anteriormente à implantação do gueto, continuaram sendo exigidos aos judeus durante o dia para circular na cidade: um círculo amarelo preso às roupas do lado esquerdo, próximo ao ombro para os homens; uma echarpe amarela para as mulheres. Posteriormente o círculo no ombro foi substituído por um chapeuzinho amarelo e mais tarde por um vermelho.

Ao longo dos séculos, a parte original do gueto (Ghetto Nuovo) foi recebendo ampliações e novas construções. Entre elas, duas sinagogas: em 1528/29 a Scuola Grande Tedesca e em 1531/32, a Scuola Canton. 
Em 1541, judeus oriundos da região do Levante, no Oriente Médio, instalaram-se numa extensão do gueto que ficou conhecida como "Ghetto Vecchio" (Gueto Velho), onde mais tarde foi construída a Sinagoga Levantina. Em 1633, haveria ainda mais uma expansão chamada de "Ghetto Novíssimo".

A ordem em que os nomes foram dados (Novo, Velho e Novíssimo) parece confusa, mas na verdade refere-se ao fato de que o núcleo inicial do gueto ocupava a área onde originalmente se encontrava a fundição "nova". Em meados do século XVII, o gueto de Veneza chegou a abrigar mais de 4.000 habitantes. ${ }^{170}$

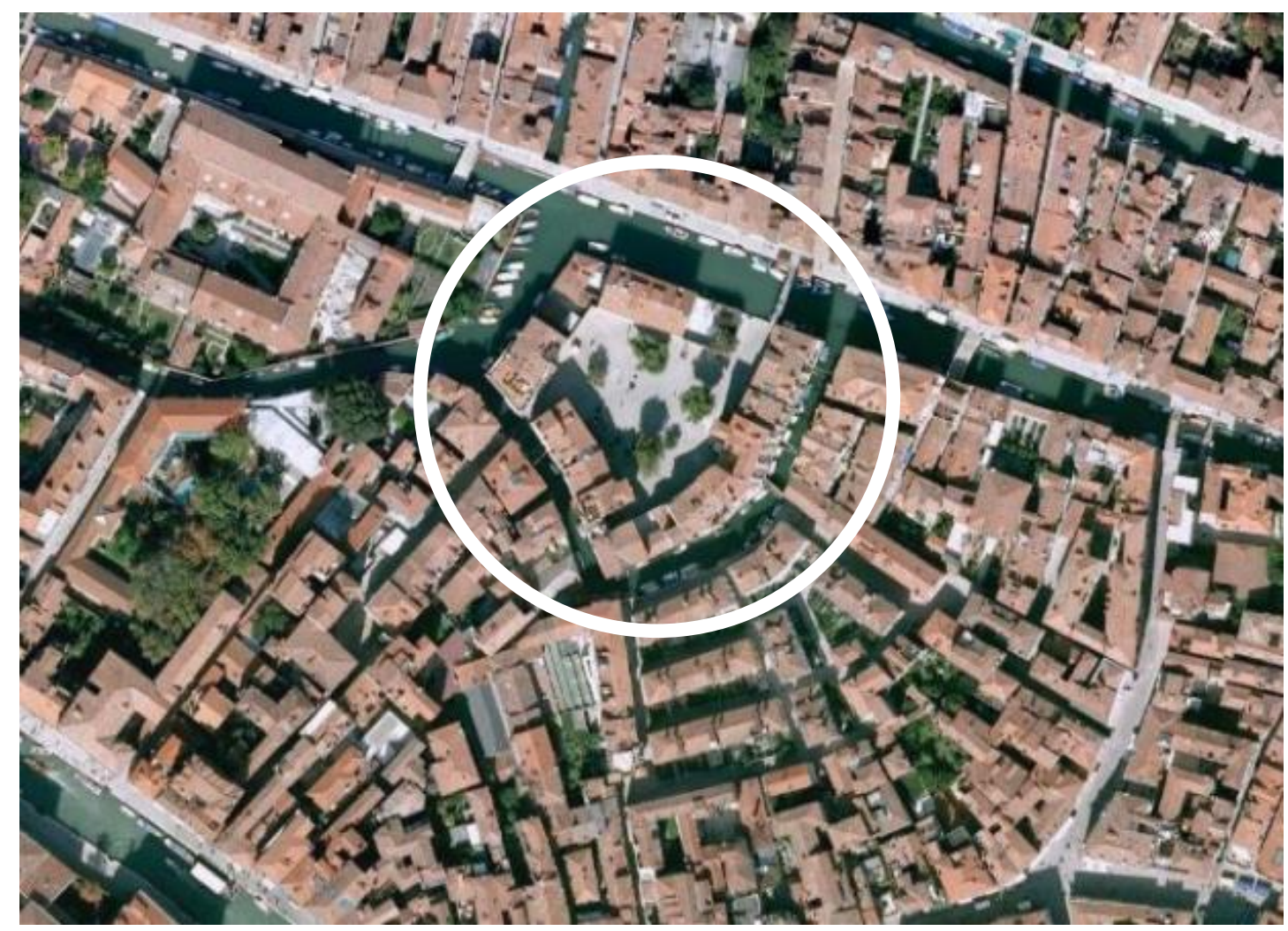

Vista aérea do Gueto de Veneza

Ao centro, dentro do círculo branco, a parte original do gueto.

Fonte: Université Numérique Européenne des Études Juives (UNEEJ)

"Histoire du Peuple Juif dans l'Occident Médieval"

Fiche Support (Captura de tela), 2016

www.uneej.com

170 Número extraído do site J-Italy, um projeto do Centro Primo Levi, New York, http://www.jitaly.org/jewish-ghetto-of-venice/ Consultado em 24 de setembro de 2016. 


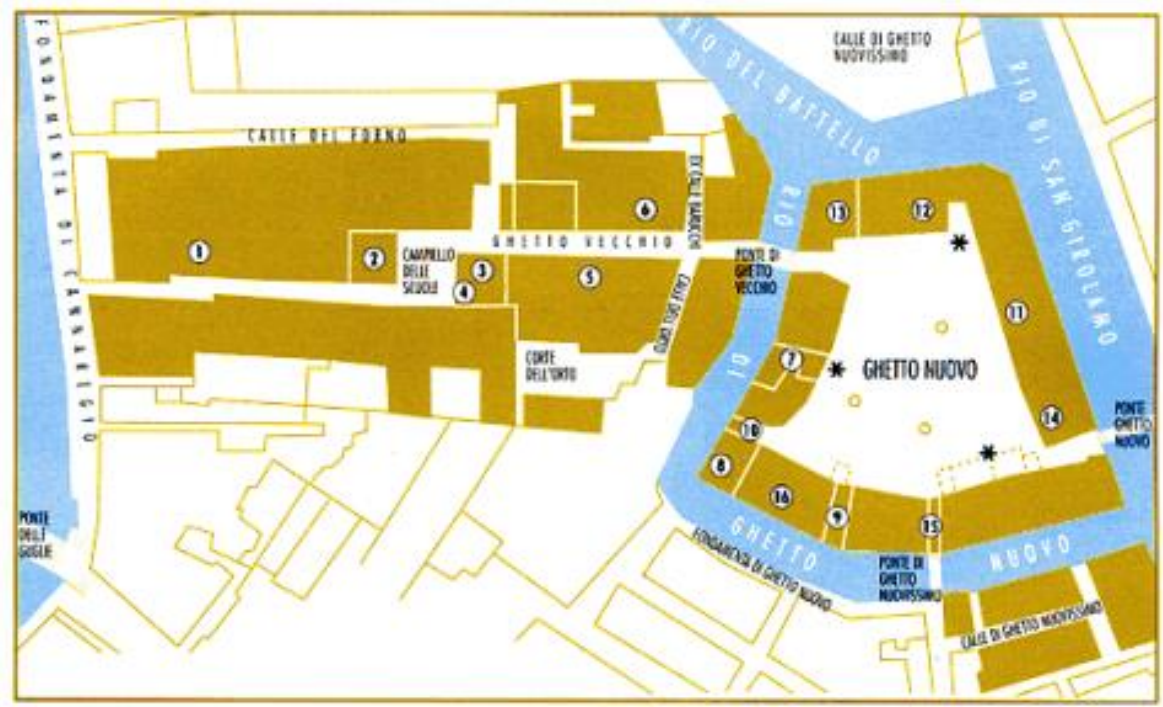

Plano do Gueto de Veneza e suas ampliações

À direita, a parte original, chamada "Ghetto Nuovo", à esquerda, o chamado "Ghetto Vecchio".

Também à direita, mas na parte superior, o "Ghetto Nuovíssimo"

Fonte: Université Numérique Européenne des Études Juives (UNEEJ)

"Histoire du Peuple Juif dans l'Occident Médieval"

Fiche Support (Captura de tela), 2016

\section{www.uneej.com}

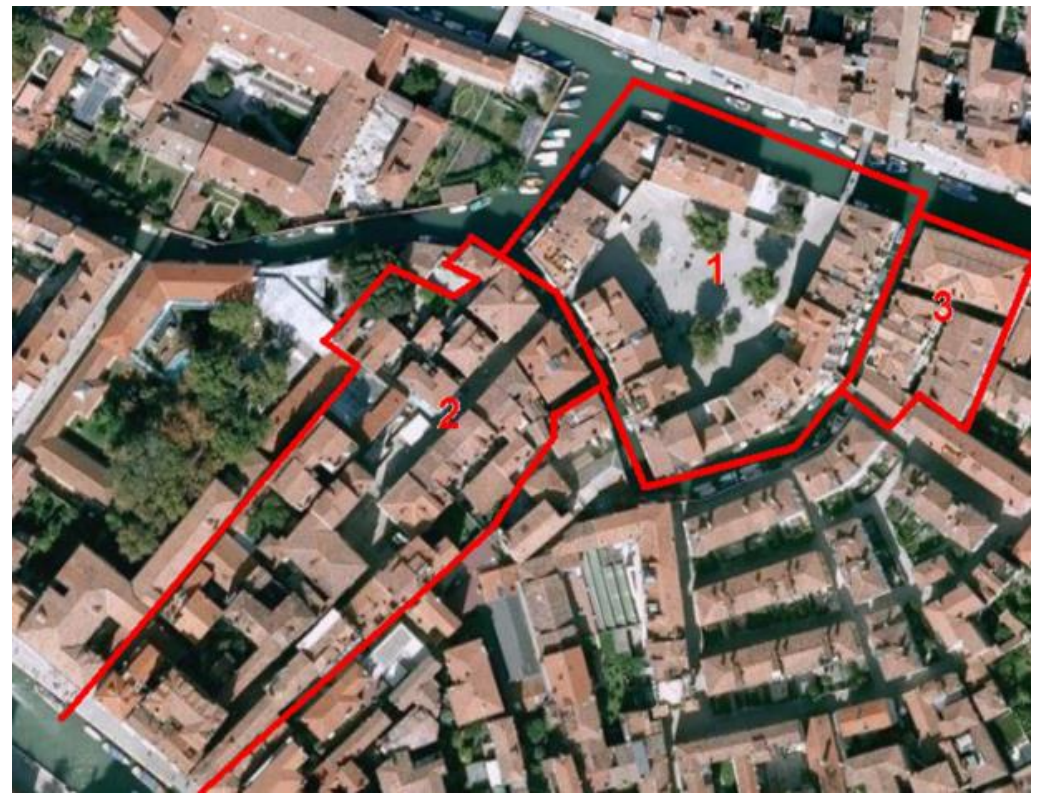

Vista aérea do Gueto de Veneza

No número 1, a área original ou "Ghetto Nuovo"; o número 2 indica o "Ghetto Vecchio";

o número 3, o "Ghetto Nuovíssimo"

Fonte: Université Numérique Européenne des Études Juives (UNEEJ)

"Histoire du Peuple Juif dans l'Occident Médieval"

Fiche Support (Captura de tela), 2016

www.uneej.com 


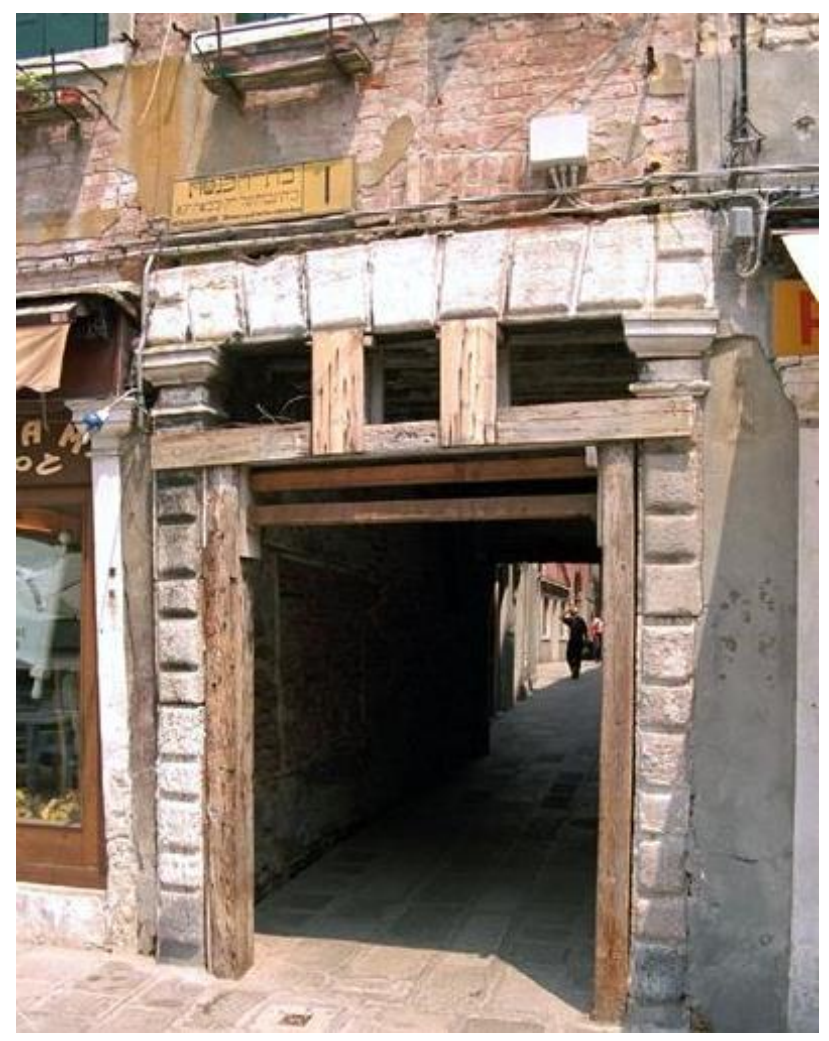

Entrada ao bairro judeu de Veneza

Aqui foi estabelecido, em 1516, o gueto da cidade

Crédito da imagem: Florida Center for Instructional Technology www.fcit.usf.edu

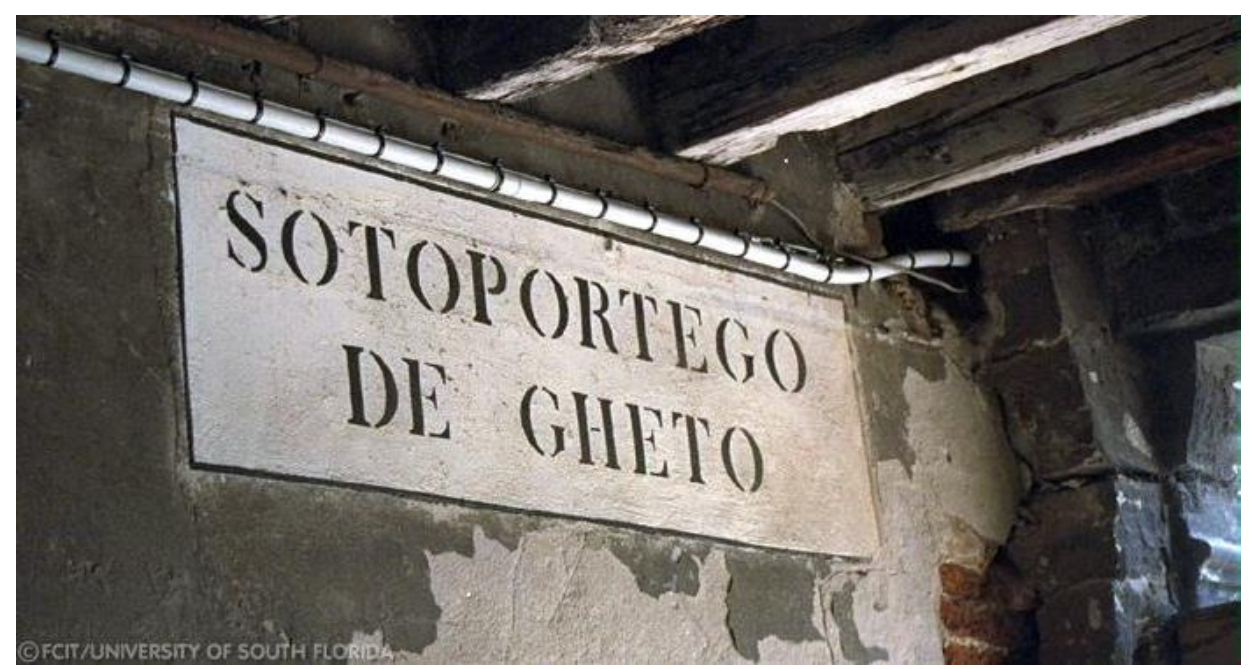

Placa na entrada do bairro judeu de Veneza

Crédito da imagem: Florida Center for Instructional Technology www.fcit.usf.edu 


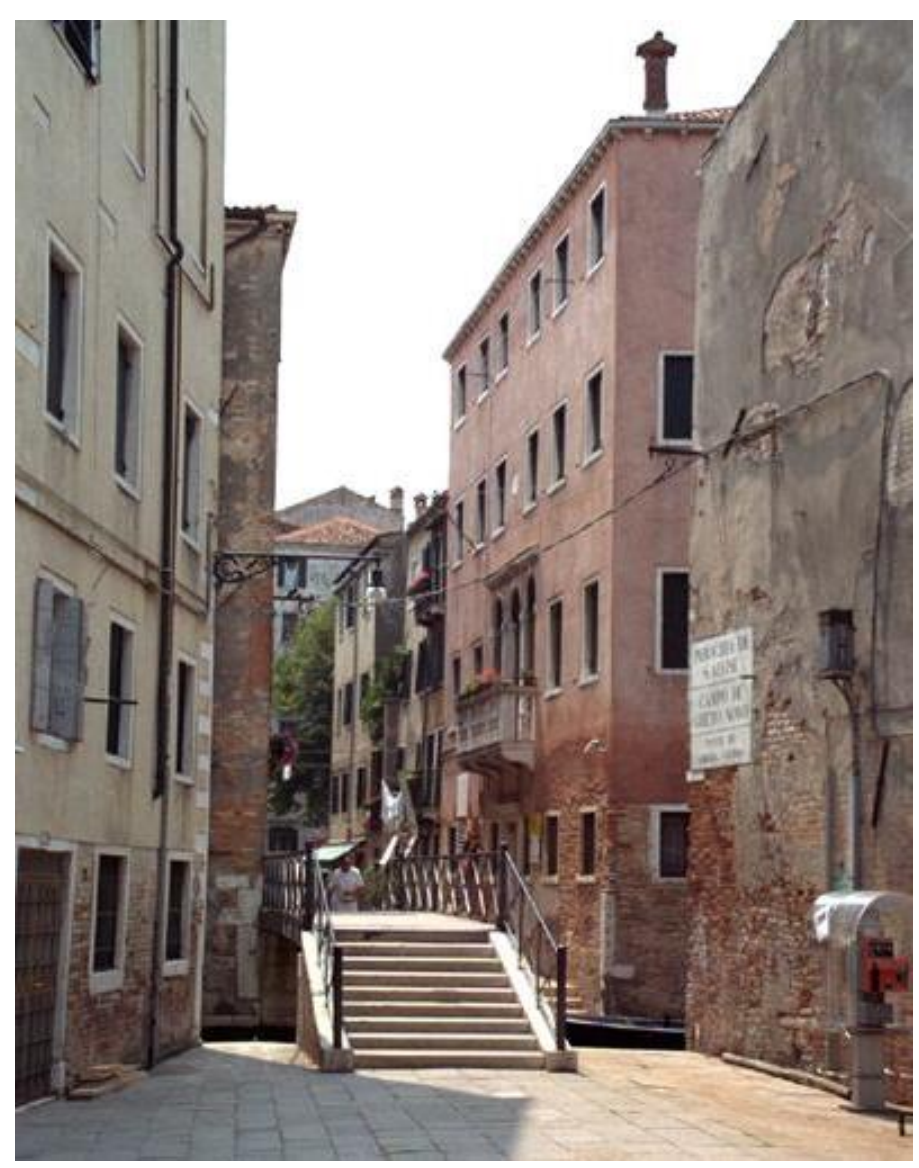

Ponte do Ghetto Vecchio conectando ao Ghetto Nuovo Crédito da imagem: Florida Center for Instructional Technology www.fcit.usf.edu

\section{O gueto de Roma}

Em 1555, o Papa Paulo IV, muito hostil aos judeus, determinou que, em Roma, eles passassem a habitar um espaço da cidade determinado para tal finalidade. Essa área, onde já habitavam boa parte dos judeus da cidade, foi cercada por muralhas e seus portões passaram a ser trancados à noite, tal como ocorria em Veneza. Outras cidades italianas adotaram posteriormente a mesma prática, entre elas Bolonha (1556), Florença e Siena (1571), Verona (1599), Pádua (1603). 


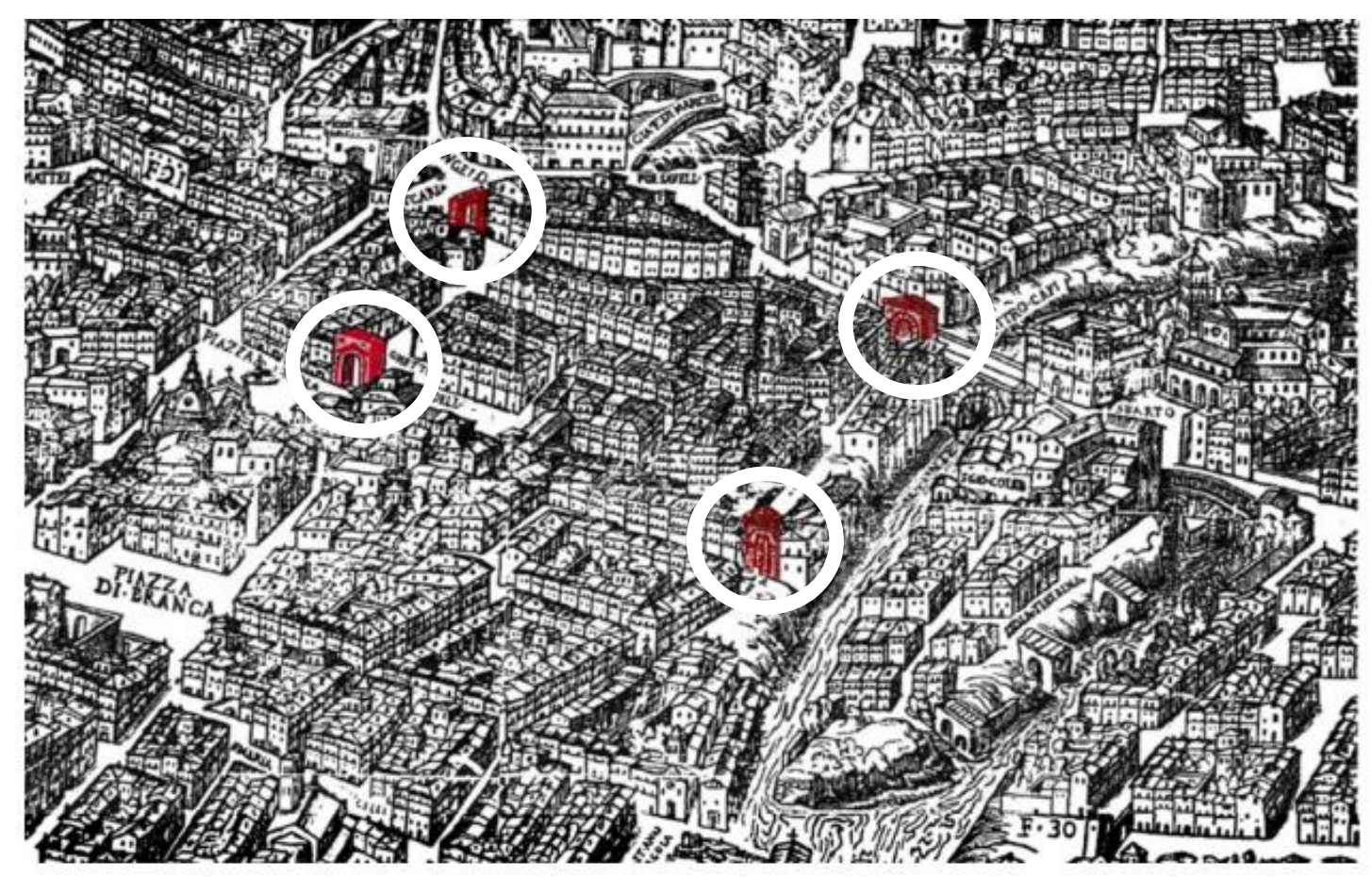

Vista de Roma, 1625

Desenho de Giovanni Maggi

Os quatro círculos brancos indicam a localização dos portões do gueto.

Fonte: Université Numérique Européenne des Études Juives (UNEEJ)

"Histoire du Peuple Juif dans l'Occident Médieval"

Fiche Support (Captura de tela), 2016

www.uneej.com

Somente a partir do final do século XVIII, a restrição de manter os judeus em guetos na Itália começou a ser gradualmente abandonada, como também as demais determinações que visavam diferenciá-los como grupo. Em 1870, o último gueto, o de Roma, deixou de existir.

\section{A ascensão do fascismo, os judeus da Itália e a promulgação das leis raciais}

O ano 1938 significou um momento de ruptura no intenso processo de integração social da sociedade judaica à sociedade em geral. Nesse ano, Mussolini promulgava as leis raciais dando início a um período de profundas mudanças para os judeus da Itália. Em muitos casos, significou um caminho sem volta. 


\section{Os judeus da Itália e a chegada de Mussolini ao poder}

A relação entre os judeus e a chegada ao poder de Benito Mussolini é cheia de ambiguidades e paradoxos, fruto principalmente da longa história da comunidade judaica na Itália que oscilou entre períodos de tolerância e exclusão no lugar que era - e ainda é - o coração do cristianismo.

No entanto, apesar das diferenças que podem ser estabelecidas entre o nazismo (genocida) e o fascismo (excludente), podemos afirmar hoje, graças ao estudo de documentos da época revelados nas últimas décadas e dos tantos testemunhos prestados por protagonistas como Ariella, que a Itália fascista foi, por sua própria iniciativa, fortemente destrutiva em relação aos judeus.

Diferente da Alemanha, porém, a perseguição de Mussolini aos judeus não se deu imediatamente após sua chegada ao poder em 1922. Desde esse ano, até aproximadamente 1930, apesar de algumas mudanças, é possível afirmar que não houve assédio à comunidade judaica. De maneira geral, eles continuaram sendo tratados como iguais.

Porém, esse tratamento aparentemente igualitário não significava que não houvesse antissemitismo. Estudos feitos por historiadores determinaram que em 29-30 novembro de 1928, por exemplo, Mussolini escreveu um artigo, publicado anonimamente no jornal Il Popolo di Roma, questionando a assimilação dos judeus à sociedade italiana. Em outra carta publicada anonimamente pelo jornal em 15 de dezembro do mesmo ano, Mussolini exagera o número de judeus residentes na Itália, dando a entender uma suposta "ameaça" por parte dessa minoria. ${ }^{171}$

Esses artigos geravam debates e serviam para envolver a opinião pública em direção a uma mudança de atitude em relação aos judeus através da propaganda, o que ajudou a preparar o terreno para as políticas anti-judaicas implementadas mais tarde, algumas delas já em 1930.

Devemos estar atentos neste momento para um aspecto importante: muitos estudos feitos nas primeiras décadas após a Segunda Guerra, apontam que o antissemitismo de Mussolini foi na verdade influenciado por Hitler. Contudo, é preciso lembrar que neste ponto do relato ainda estamos no início da década de '30. O nazismo, portanto, ainda não havia subido ao poder na Alemanha e os documentos italianos demonstram uma clara decisão de Mussolini rumo a uma política antissemita.

171 TALBOT, G. Censorship in Fascist Italy, 1922-1943: Policies, Procedures and Protagonists. New York: Palgrave Macmillan, 2007. 
Nesse sentido, é importante ter em conta como a cronologia é um aspecto que deve ser sempre considerado não somente para organizar a sequência de fatos no tempo, mas também para evitar que se incorra em generalizações ou que se tirem conclusões que muitas vezes induzem a visões deturpadas da História.

\section{A comunidade judaica italiana nos anos 1930}

Mas como se compunha essa comunidade que pouco a pouco estava sendo conduzida a um processo de destruição econômica, social -e em milhares de casos física- pelo governo fascista de Mussolini?

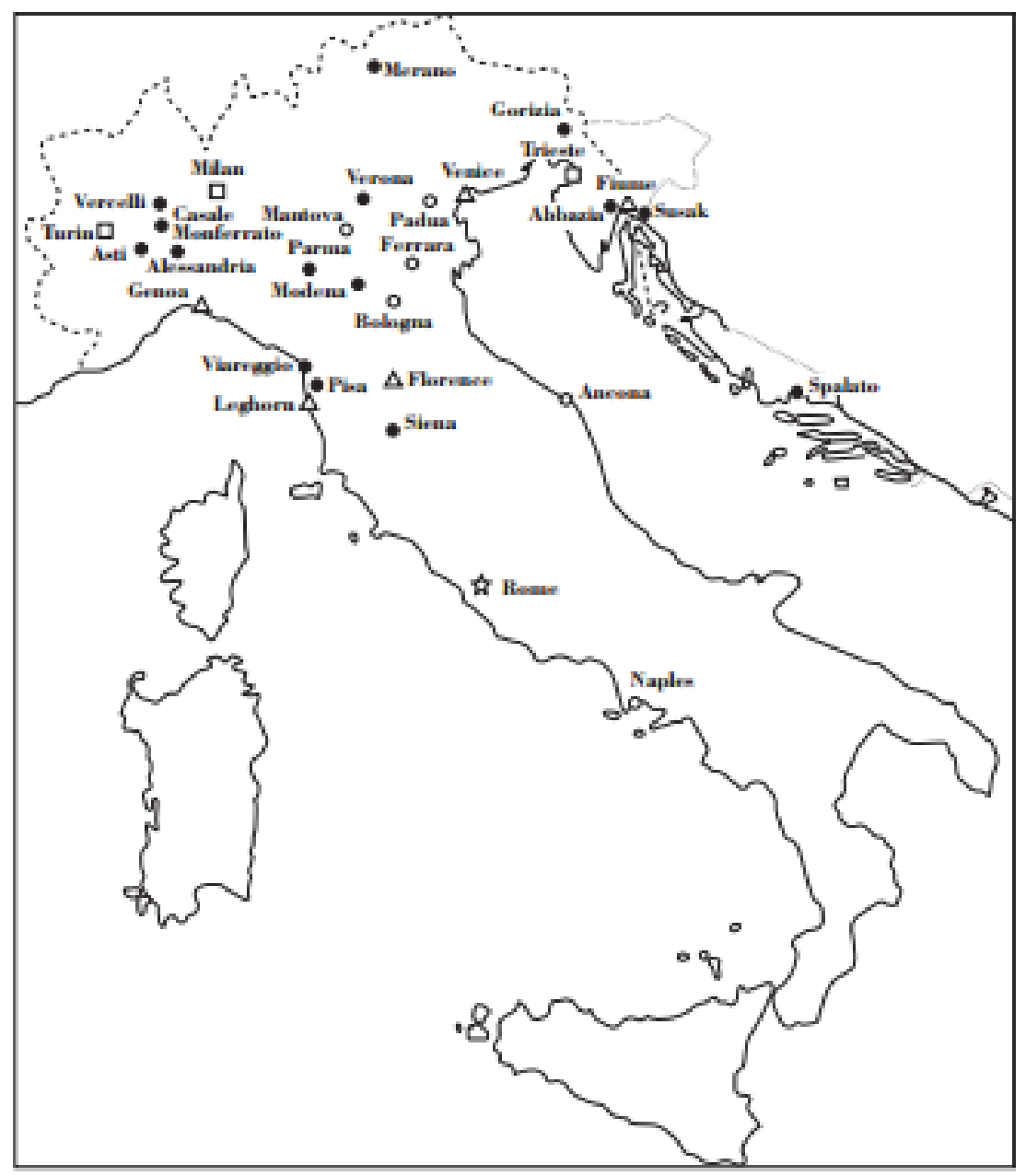

Mapa 1. Principais centros de residência da comunidade judaica na Itália

População em números absolutos:

动 12.000-13.000; $\square 4.000-6.000 ; \triangle 1.000-2.500 ; \bigcirc 500-1.000 ; \bigcirc 100-500$

Fonte: ZIMMERMAN, Joshua D. (Ed.). Jews in Italy under Fascist and Nazi Rule, 1922-1945.

New York: Cambridge University Press, 2005. 
A população judaica na Itália até 1938 era de aproximadamente 46.500 habitantes, em sua grande maioria urbana e pertencente à classe média. Dentre eles, aproximadamente $44 \%$ trabalhavam no comércio, $22 \%$ na indústria, $12 \%$ eram funcionários públicos e $9 \%$ ocupavam profissões liberais. Os demais dividiam-se entre o setor de transportes, comunicações, seguros. Somente $1,5 \%$ dedicavam-se à agricultura. ${ }^{172}$

\section{As Leis Anti-Raciais}

Após anos de preparação burocrática e da opinião pública, em 6 de outubro de 1938, o Grande Conselho do Fascismo aprovou o documento "Declarações sobre a Raça", que deu origem às chamadas Leis Raciais promulgadas em novembro e dezembro do mesmo ano

Essas leis significaram um duríssimo golpe para a comunidade judaica da Itália, já que entre as suas disposições, no que se refere aos judeus, determinava sua imediata exclusão do serviço público, do serviço militar, dos bancos e de todas as instituições públicas de ensino. Essa exclusão valia não somente para os professores, também os alunos não podiam frequentar escolas públicas.

Ao mesmo tempo, intensificou-se a atividade de propaganda lançada pelo fascismo contra os judeus, levada a cabo de maneira constante até quase o final de 1943, momento em que a Alemanha invadiu a Itália inaugurando uma nova etapa, ainda de maior violência, para os judeus italianos.

Um dos veículos mais intensos na propagação das ideias raciais do fascismo foi a imprensa, fundamentalmente através da publicação e distribuição de uma revista quinzenal chamada La Diffesa della Razza (A Defesa da Raça) que teve um papel crucial na campanha antissemita do governo de Mussolini.

Seus artigos, escritos por cientistas, antropólogos, médicos, biólogos, entre outros, tinham como objetivo dar um caráter "científico" à questão racial de modo a criar uma falsa "consciência" sobre a "raça italiana".

172 ZIMMERMAN, Joshua D. (Ed.). Jews in Italy under Fascist and Nazi Rule, 1922-1945. New York: Cambridge University Press, 2005, p. 9. 
Esse caráter pseudocientífico que atribuía um caráter biológico à questão judaica foi o elemento central da revista, que estampou na primeira página de seu primeiro número o chamado "Manifesto dos Cientistas Racistas".

O "Manifesto" incluía 10 pontos que estabeleciam uma plataforma racista e antissemita. O título referente ao ponto número 9 , mostra toda a violência dessa ideologia que jogava por terra tanto a rica experiência de mais de dois mil anos da comunidade judaica na Itália como o total processo de integração em que estava imersa no século XX. Nele se lê:

\section{Os judeus não pertencem à raça italiana}

(...)

Os judeus representam a única população que nunca se assimilou à Itália porque ela é constituída de elementos raciais não europeus, e que são totalmente diferentes dos elementos que deram origem aos italianos.

Manifesto dos Cientistas Racistas

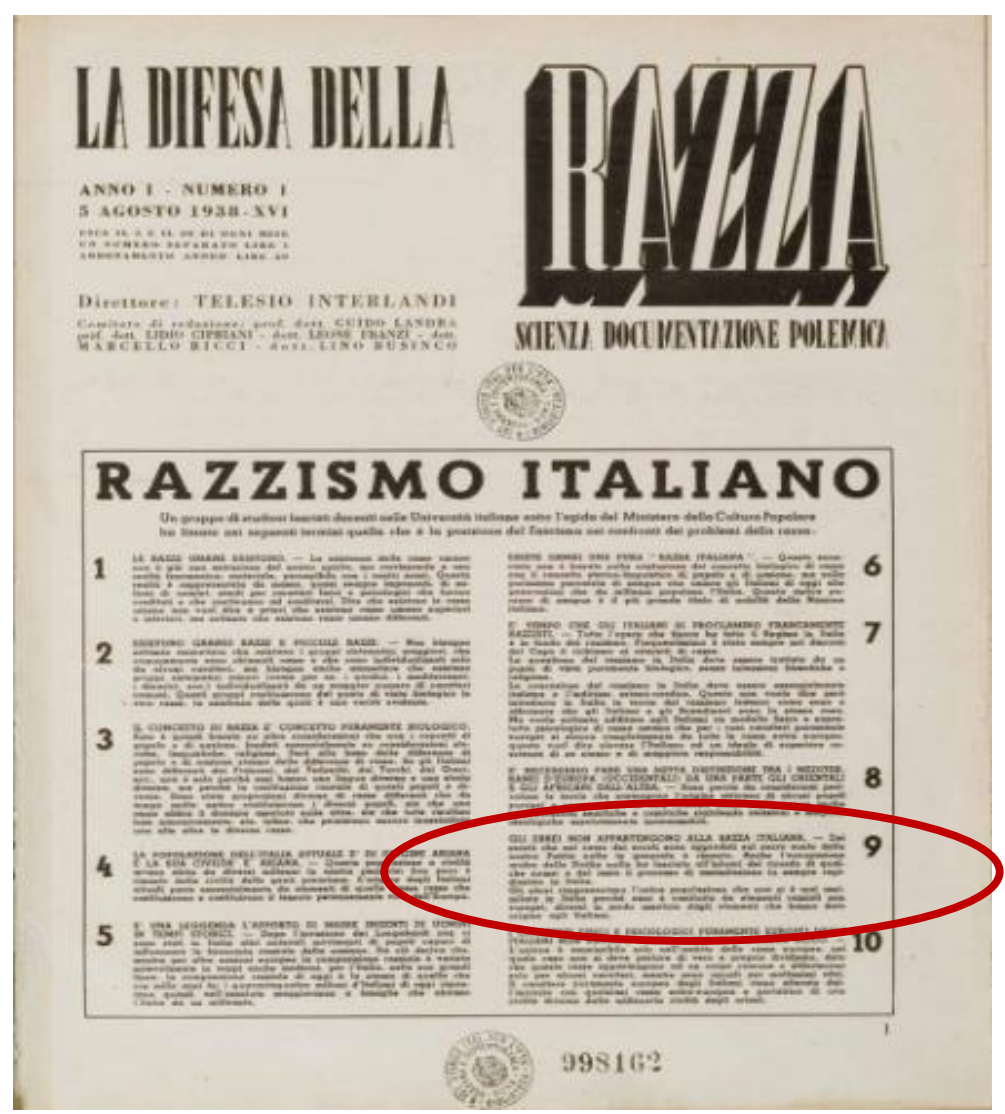

O Manifesto dos Cientistas Racistas

Revista La Difesa dela Razza, Ano I, N. 1 (Agosto, 1938)

Em destaque, na elipse, o ponto relativo aos judeus.

Fonte: www.digiteca.bsmc.it 
Nas capas da revista, eram constantemente retomados os temas que discutiam a "questão judaica" na Itália, reproduzidos não somente no conteúdo fortemente antissemita dos artigos, mas também nas capas dos diferentes números.

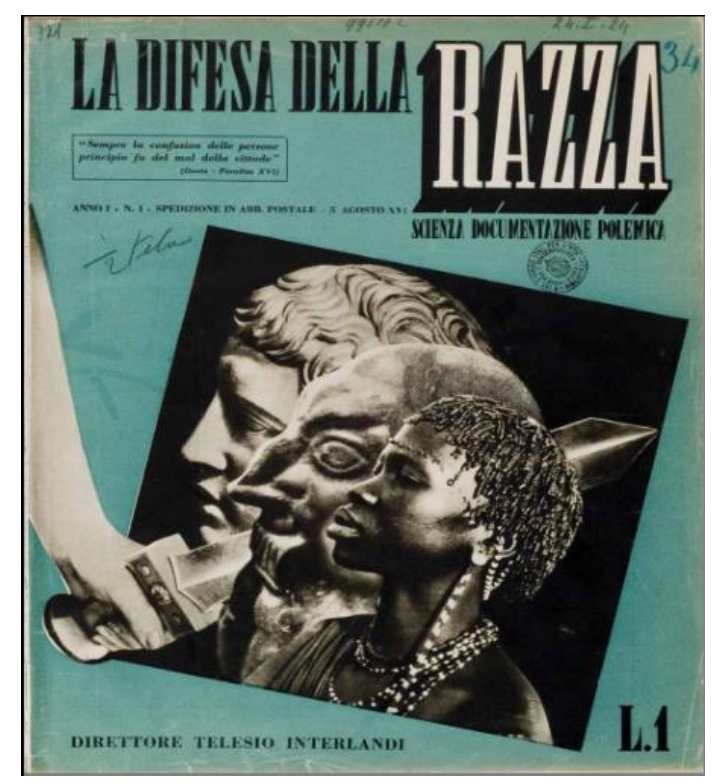

1938 (n. 1)

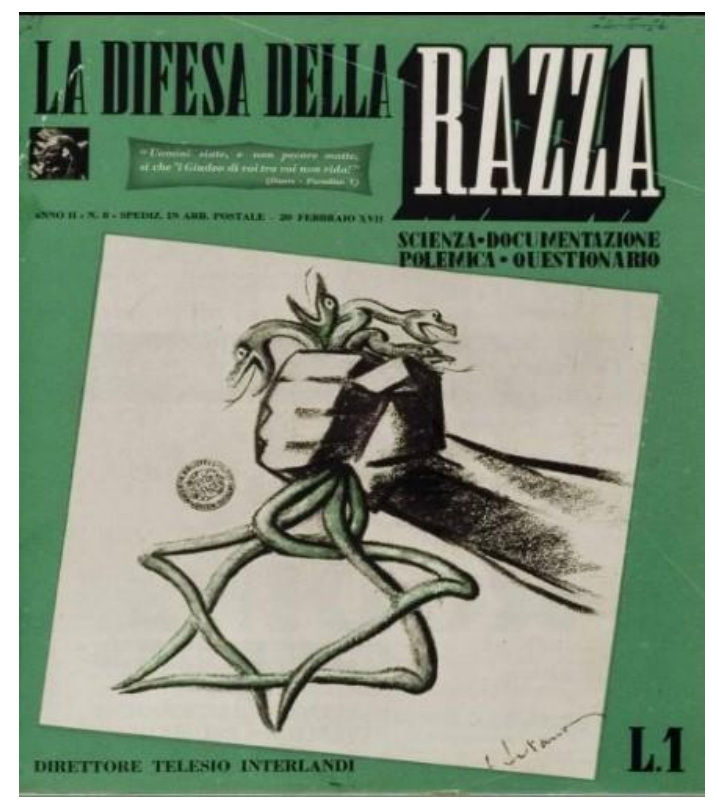

1939 (n. 8)

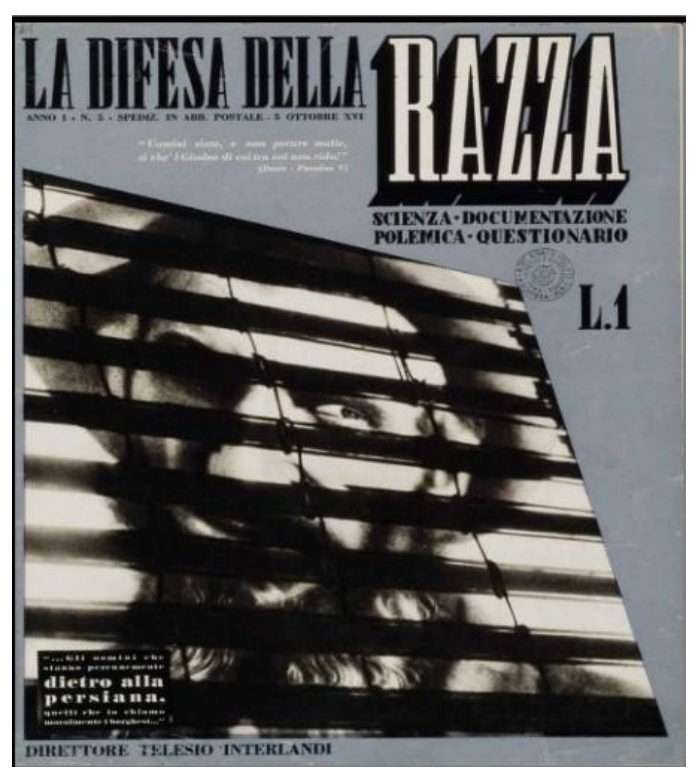

1938 (n. 5)

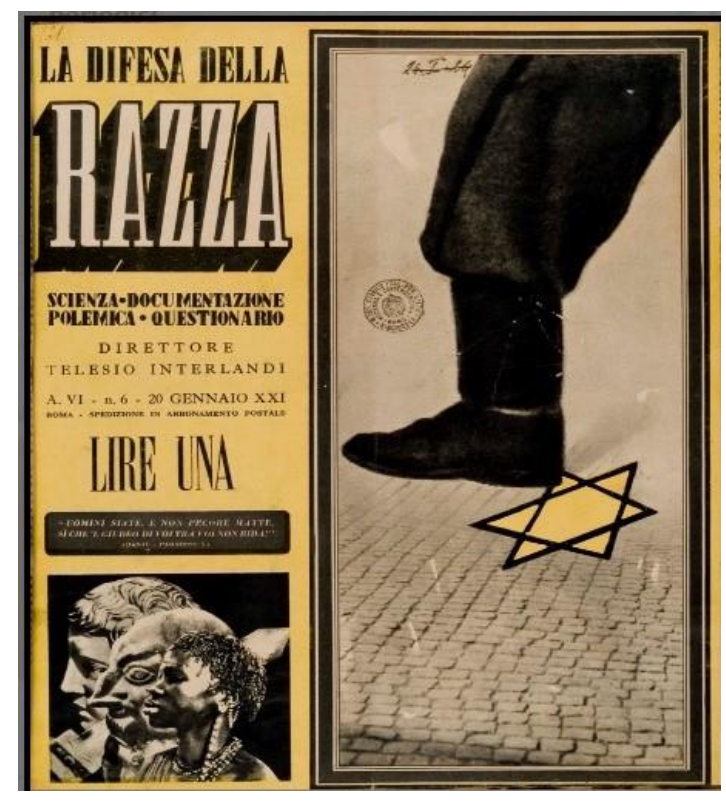

1943 (n. 6)

Capas da revista fascista La Difesa dela Razza (1938-1943)

Fonte: www.digiteca.bsmc.it 


\section{A família Pardo-Volli: entre ruptura e continuidade}

Ariella ainda não era nascida quando Mussolini decidiu, mediante o uso de leis racistas, expulsar os judeus italianos da sociedade. Ela chegaria quase dois anos mais tarde, em 9 de julho de 1940, entre os anos sombrios do fascismo e o início do período de fúria genocida nazista na Itália.

Um decreto promulgado em 5 de setembro daquele ano, foi de particular importância para uma família que era composta, em grande parte, por intelectuais e professores. Esse documento tratava dos "provimentos para a defesa da raça na escola fascista":

Art. 1

Ao cargo de professor em escolas estatais ou paraestatais de qualquer ordem ou grau (...) não poderão ser admitidas pessoas de raça judaica (...).

Art. 2

Nas escolas de qualquer ordem ou grau, (...), não poderão ser inscritos alunos de raça judaica.

Art. 3

A partir de 16 de outubro de 1938, todos os professores de raça judaica que pertençam ao cargo em escolas conforme o artigo 1, serão suspensos do serviço; para tal finalidade, equiparam-se aos professores os presidentes e diretores das escolas mencionadas, os ajudantes e assistentes universitários, o pessoal de vigilância nas escolas básicas. (...) $)^{173}$

As consequências do provimento fizeram-se sentir imediatamente. Naquele momento, o Professor Ferrucio Pardo, pai de Ariella, matemático, físico e filósofo, presidia uma prestigiosa escola secundária o Istituto Magistrale di Emilio Reggia, cargo ao qual chegara havia apenas um ano.

Sua reputação como intelectual e autor de teses e livros, alguns deles já publicados, estava então bem consolidada. Também eram comprovadas sua competência na direção de outros colégios como o Laura Bassi, de Bolonha e o Liceo Italiano no Cairo, Egito.

No plano pessoal, alguns anos antes, em 1934, em visita à sua cidade natal, Trieste, norte da Itália, seu grande amigo, Carlo Morpurgo, apresentou a Ferruccio uma jovem professora,

\footnotetext{
${ }^{173}$ Fondazione Centro di Documentazione Ebraica Contemporanea. http://www.cdec.it/home2_2.asp?idtesto $=185 \&$ idtesto $1=643 \&$ son $=1 \&$ figlio $=558 \&$ level $=6$ Consultado em 27 de setembro de 2016.
} 
muito ativa na comunidade judaica local com que se casou logo enseguida: Iris Volli. Em julho de 1936 nascia o primeiro filho do casal: Lucio.

Iris também pertencia a uma família de intelectuais judeus italianos. Sua irmã, Gemma, era tradutora, historiadora, autora e professora. Em 1938, pouco antes da promulgação das leis raciais, Gemma havia escrito um livro, Le Escluse (As Excluídas), que tratava da questão feminina. Apesar de já publicado, sua distribuição foi imediatamente proibida não pelo seu conteúdo, mas pelo fato de que sua autora era judia.

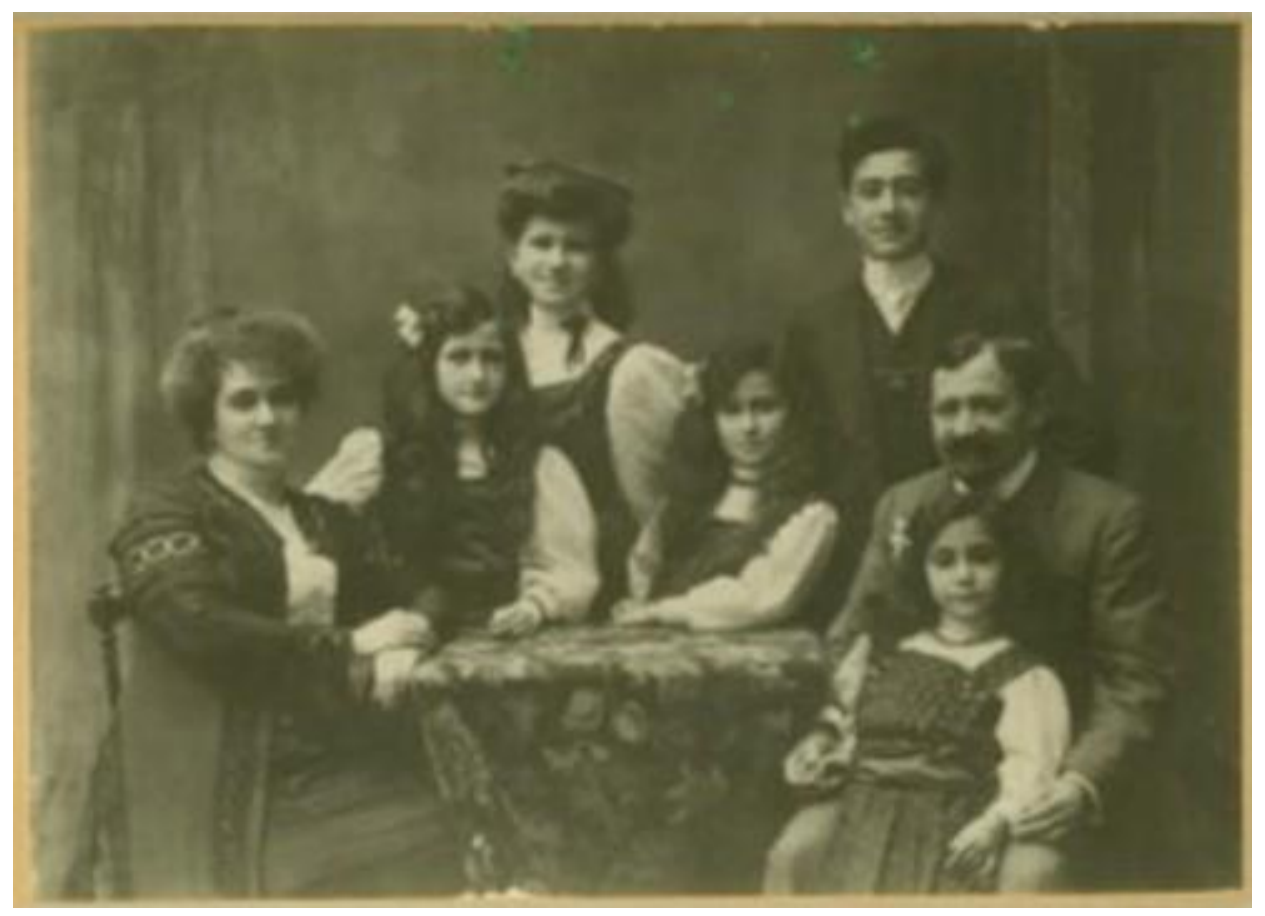

\section{A família Volli}

Da esquerda para a direita, Elvira, avó de Ariella, suas tias Alma, Flora e Gemma, seu tio Ugo, seu avô Ignacio e sua mãe Iris.

Fonte: GOLFERA, Silvia. Una donna del secolo scorso: Gemma Volli www.storiamemoria.it

No dia 16 de outubro de 1938, tal como exigia o decreto-lei, o Professor Pardo despediuse dos professores e funcionários do Istituto Magistrale ${ }^{174}$, já que a partir daquele momento, por determinação do governo, como judeu, ele não poderia continuar à frente da escola.

\footnotetext{
${ }^{174} \mathrm{Na}$ Itália, assim como na maior parte dos países do Hemisfério Norte, o ano letivo tem início no mês de setembro, quando terminam as férias de verão.
} 
Ferruccio Pardo deixou então o prédio e foi caminhando, sozinho, até a estação da cidade. Ao chegar lá, um pequeno grupo de professores, entre os quais a professora Lina Cecchini e a secretária Vera Bergomi o esperavam para uma pequena homenagem. ${ }^{175}$

A partir de então, também Iris e Gemma Volli, junto com aproximadamente 100 diretores de escola fundamental, 279 professores de escola média e diretores, centenas de professores universitários, 114 autores de livros escolares, foram impedidos de continuar exercendo suas atividades, fossem eles nascidos ou não na Itália. ${ }^{176}$

A princípio, muitos professores, inclusive Ferruccio Pardo, passaram a ministrar aulas particulares como forma de continuar mantendo suas vidas e as de suas famílias.

Além do efeito imediato em termos econômicos para todos os membros da comunidade judaica, havia uma preocupação adicional já que o decreto de 5 de setembro implicava a interrupção dos estudos para aproximadamente 1.500 estudantes universitários e 6.500 crianças dos níveis primário e secundário. ${ }^{177}$

Por outro lado, havia ainda o efeito psicológico nos jovens, já que eles se viram afastados não somente de seus estudos, mas também de seu círculo social, de suas amizades, de sua vida cotidiana, tudo isso somado ao medo sobre o futuro.

A historiadora Iael Nidam-Orvieto, estudiosa dos diários de judeus italianos que viveram à época das leis raciais, cita em um de seus trabalhos o relato de uma mãe judia no dia da volta às aulas após a proibição dos judeus nas escolas públicas italianas:

"Você viu a Lilly? Vá e veja, por favor. Ela esteve trancada em seu quarto a manhã toda. Não quer comer nada... Sabe, é o primeiro dia de aula... talvez ela se solte um pouco com você..." O primeiro dia de aula - o recomeço da vida no mundo das crianças, mas não para você, minha menina. Fui ao seu quarto com o coração na garganta. As lágrimas dos jovens são tão difíceis de secar... O quarto estava silencioso, parecia vazio. Então eu a vi, atravessada na cama, adormecida. Suas bochechas ainda estavam molhadas e em sua mão você ainda segurava o lenço, e seu "por que?" ainda ecoava no quarto silencioso. ${ }^{178}$

\footnotetext{
${ }^{175}$ Extraído do testemunho de uma das professoras do Istituto, Lina Cecchini,. PETRUCCI, Antonio. "Ferruccio Pardo e l'Istituto Magistrale di Reggio Emilia", In, FONTANESI, A., MUSSINI, L., PETRUCCI, A. Per le Recenti Disposizioni sulla Razza. Storia di Ferruccio Pardo e di altri reggianni ebrei. Reggio Emilia: Istituto Statale "Matilde di Canossa", 2009. Além de professora, Lina Cecchini, era também ativista do movimento antifascista católico, In, LAMA, Luisa. NILDE IOTTI 1945-1946. Alle Origini di uma Storia Politica al Femminile, http://www.fondazionenildeiotti.it/docs/documento3896177.pdf. Consultado em 28 de setembro de 2016.

${ }^{176}$ ZIMMERMAN, J. op. cit.

177 Ibidem.

${ }^{178}$ NIDAM-ORVIETO, Iael. "The Impact of Anti-Jewish legislation on Everyday Life and the Response of Italian Jews, 1938-1943. In, ZIMMERMAN, J, op. cit., p. 162.
} 
Em novembro de 1938, outro decreto foi promulgado restringindo ainda mais a situação dos judeus na Itália. Através dele, no que diz respeito exclusivamente ao plano da educação, ordenava-se a proibição em qualquer sala de aula, de qualquer texto que fosse de autor judeu, além de várias outras disposições que tornaram a vida da comunidade extremamente difícil.

Outras ordens, ainda mais restritivas, seriam ainda expedidas em junho de 1939. Isso provocou a saída de milhares de judeus da Itália, alterando definitivamente o perfil da comunidade no país.

\section{As escolas judaicas na Itália durante a vigência das leis raciais}

Para aqueles que permaneceram, como foi o caso da família Pardo, uma disposição na lei de novembro de 1938 relativa "à defesa da raça na escola italiana", em seu Artigo 6, determinava:

Escolas de instrução média para alunos da raça judaica poderão ser instituídas pela comunidade israelita ou por pessoas de raça judaica. (...) Nas escolas de instrução média às que se refere este artigo, o pessoal poderá ser de raça judaica e poderão ser adotados livros de autores de raça judaica. ${ }^{179}$

A comunidade judaica organizou-se então, para dar uma solução ao problema utilizando algumas escolas pertencentes à comunidade já existentes em diversas cidades e também criando outros núcleos. Professores judeus reuniram-se em torno a eles de modo a dar continuidade ao processo de educação dos jovens judeus italianos.

Em Bolonha, a família de Ariella teve um papel preponderante nesse sentido: o professor Ferruccio Pardo, desdobrava-se entre a direção da Escola Judaica de Bolonha, e o ensino de Matemática e Física. O Professor Pardo também lecionava na Escola Judaica Manzoni de Milão, ministrava aulas de matemática e física para os estudantes secundários e de análise matemática para o nível universitário. ${ }^{180}$

${ }^{179}$ REGIO DECRETO - LEGGE 15 novembre 1938 - XVII, n. 1779. Integrazione e coordinamento in unico testo delle norme già emanate per la difesa della razza nella Scuola Italiana. http://www.morasha.it/antisemitismo/razza_scuole2.html. Consultado em 28 de setembro de 2016. ${ }_{180}$ PARDO, Lucio. "La Communitá Ebraica di Bologna dal 1938 al 1943". In, Le Scuole Ebraiche di Bologna, dopo le legge razziali. http://www.comunitaebraicabologna.it/it/bologna-ebraica/comunita/5-lescuole-ebraiche-di-bologna-dopo-le-leggi-razziali. Consultado em 28 de setembro de 2016. 


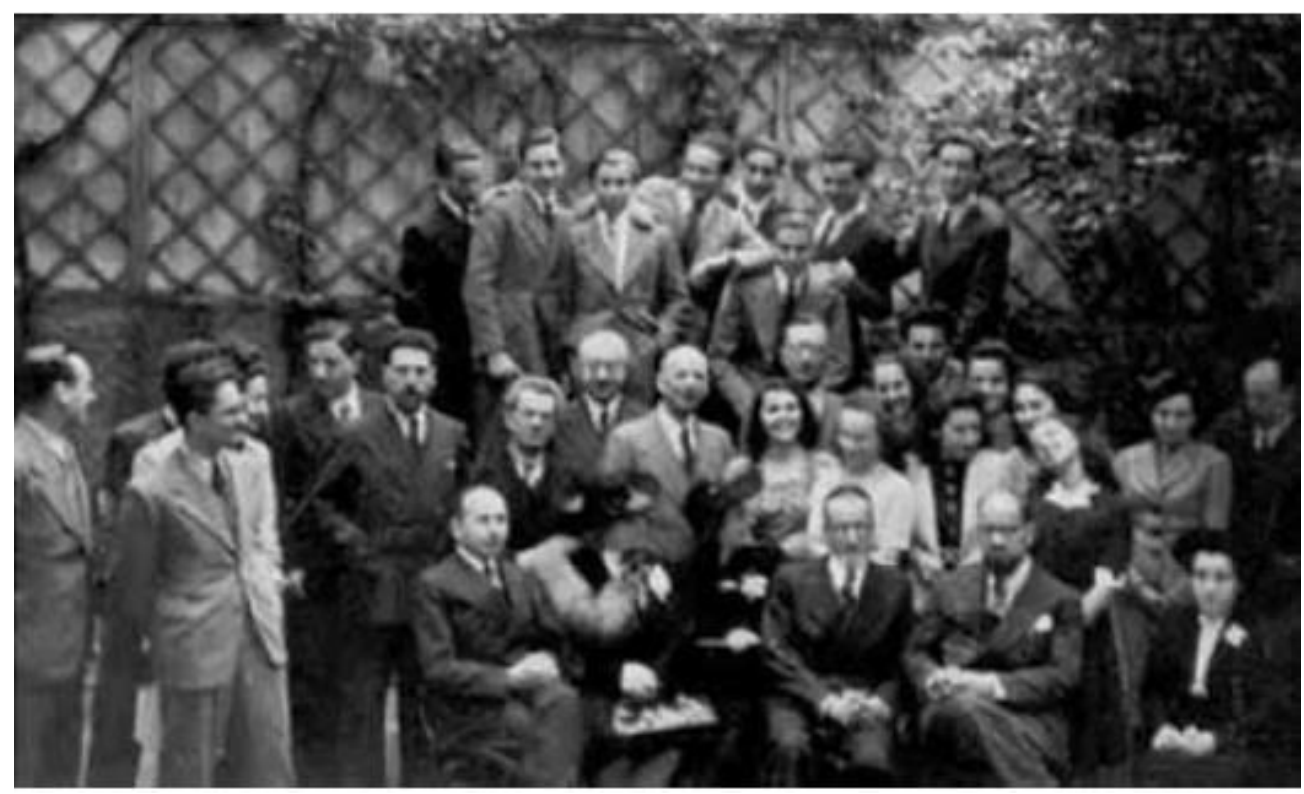

Professores e alunos no Jardim da Escola Judaica Manzoni, na via Eupili, Milão. Final do ano escolar 1940-1941.

Fonte: Oltre la memoria. Gli studenti ebrei del "Manzoni" al tempo dele legge razziali www.brianzapopolare.it/sezioni/storia/gani/20030127_om_album_via_eupili.htm

Ao mesmo tempo, Iris Volli Pardo participou ativamente na organização e no ensino para duas classes de Ensino Fundamental exclusivas para judeus. Chamada de scuoletta (escolinha) devido ao pequeno número de alunos, Iris, junto com o professor Giorgio Formiggini, encarregaram-se da educação formal de 15 meninas e 18 meninos. Até 1940, a pequena escola judaica funcionou num prédio da Via Pietralata, 60, em Bolonha.

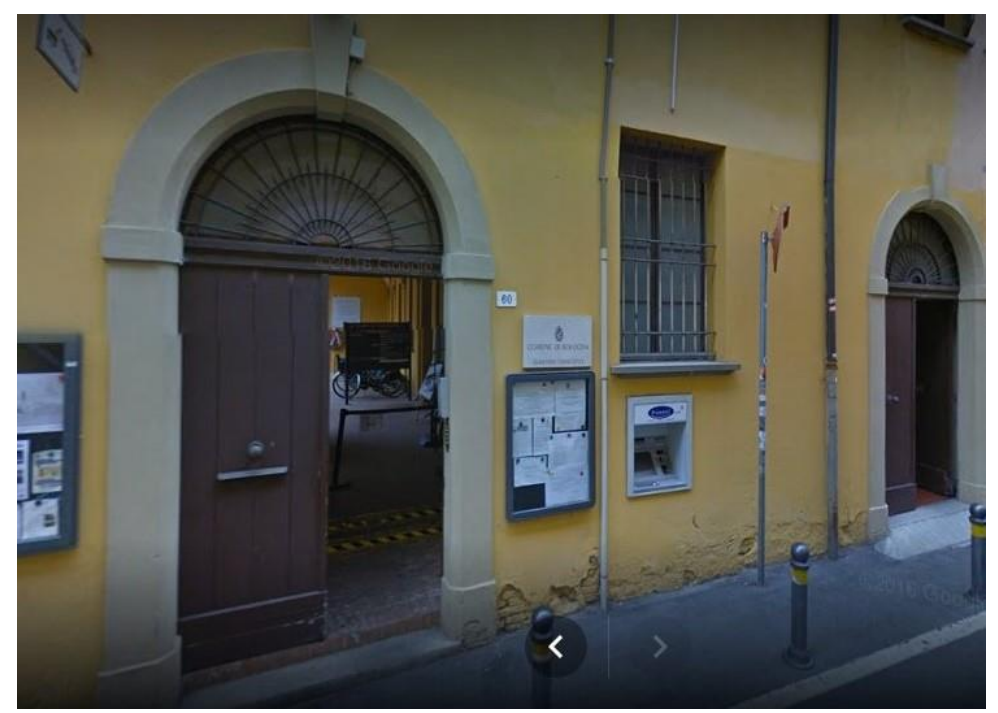

Via Pietralata 60, local onde de 1938 a 1940 funcionou a Scuoletta Ebraica di Bologna Fonte: Google Street View, 2016 
No entanto, o aprofundamento cada vez maior das políticas de restrição aos judeus italianos fez com que gradualmente a comunidade fosse diminuindo, assim como o número de alunos da scuoletta.

A partir de 1940 o prédio da Via Pietralata ficou muito pequena para os apenas 18 alunos remanescentes e, a partir de então, Iris e seu reduzido grupo de alunos mudaram-se para o prédio da Via Zamboni, 2, coincidentemente ao lado de onde era o antigo gueto de Bolonha, estabelecido em 1556.

A família Pardo, então um pouco maior com a chegada da pequena Ariella em julho de 1940, passou a morar no mesmo prédio onde funcionava a escola de Iris. As aulas eram ministradas ao mesmo tempo para alunos do $1^{\circ}$ ao $5^{\circ}$ ano. Foi ali que Lucio Pardo, irmão de Ariella, iniciou sua vida escolar, com sua mãe como professora. ${ }^{181}$

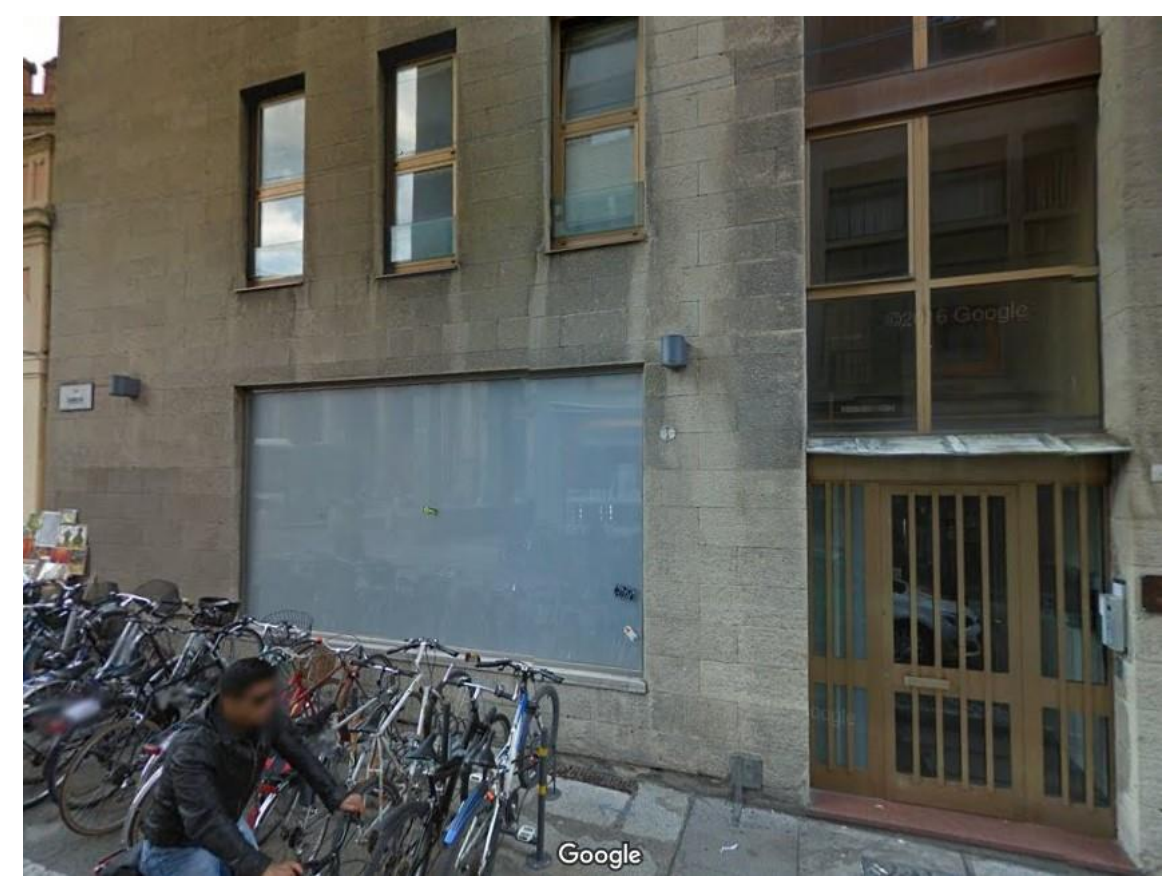

Via Zamboni 2, local da segunda sede da Scuoletta Ebraica di Bologna.

Foi em um dos andares deste prédio que Ariella e sua família viveram até 1943. Fonte: Google Street View, 2016.

${ }^{181}$ Entrevista com Lucio Pardo, por ocasião da homenagem aos alunos da escolinha judaica de Bolonha no Dia da Memória das vítimas do Holocausto. Bolonha, 27 de janeiro de 2015. Radio Cittá del Capo, https://soundcloud.com/radiocittadelcapo/lucio-pardo-sulla-scuoletta-ebraica-di-bologna\#c=280\&t=0:39 
É importante lembrar que as restrições econômicas atingiram severamente toda a comunidade judaica italiana, portanto, os pais pagavam aos professores aquilo que podiam. Era, portanto, um esforço coletivo para garantir a educação que o governo racista de Mussolini tentava negar-lhes.

O esforço de professores como Ferruccio e Iris Pardo, no entanto, não passou despercebido. Até hoje eles são lembrados e homenageados por ter-se dedicado à tarefa de possibilitar que aqueles jovens judeus italianos, vítimas inocentes de um sistema excludente, pudessem viver, apesar de tudo, na normalidade.

A placa que vemos a seguir é um exemplo desse reconhecimento e das inúmeras homenagens a esses professores. Ela foi inaugurada em Bolonha, no local ocupado pela scuoleta, em 27 de janeiro de 2006, dia em que se rememoram as vítimas do Holocausto.

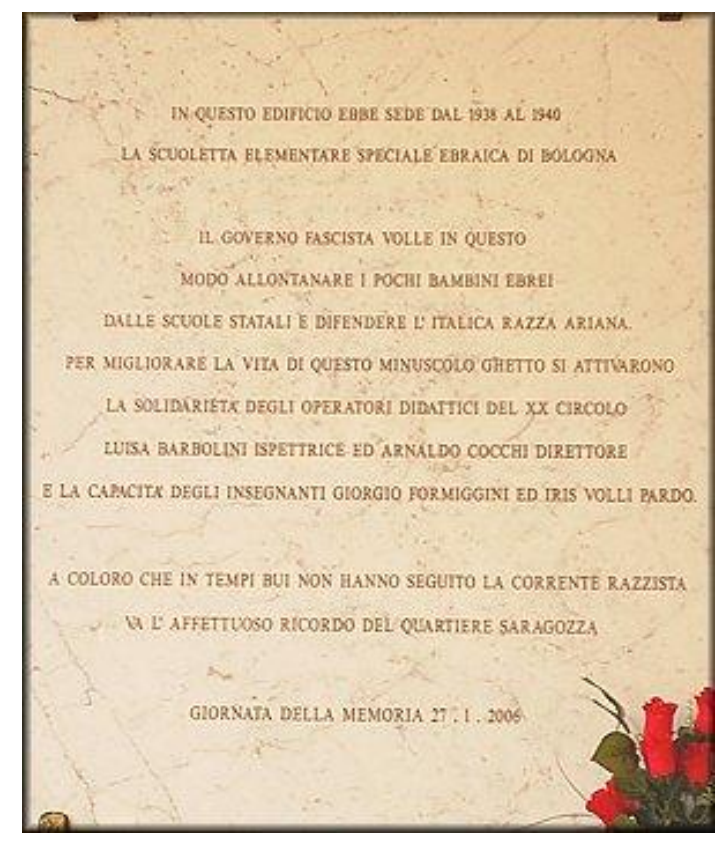

Placa em homenagem aos docentes que construíram e mantiveram em funcionamento a Scuoletta Ebraica di Bologna ${ }^{182}$

\footnotetext{
${ }^{182}$ Na placa, escrita em italiano, podemos ler: Este edifício foi sede de 1938 a 1940 da Scuoletta Elementar Especial Judaica de Bolonha / O governo fascista quis afastar desta maneira as poucas crianças judaicas da escola estatal e defender a raça ariana itálica / Para melhorar a vida deste minúsculo gueto estiveram ativas a solidariedade dos operadores didáticos do círculo XX, Luisa Bartolini, inspetora e Arnaldo Cocchi, diretor e a capacidade dos professores Giorgio Formiggini e Iris Volli Pardo / Àqueles que em tempos sombrios não seguiram a corrente racista vai dirigida a afetuosa lembrança do bairro Saragoza / Dia da Memória, 27.01.2006
} 


\section{O golpe de estado e a invasão nazista à Itália}

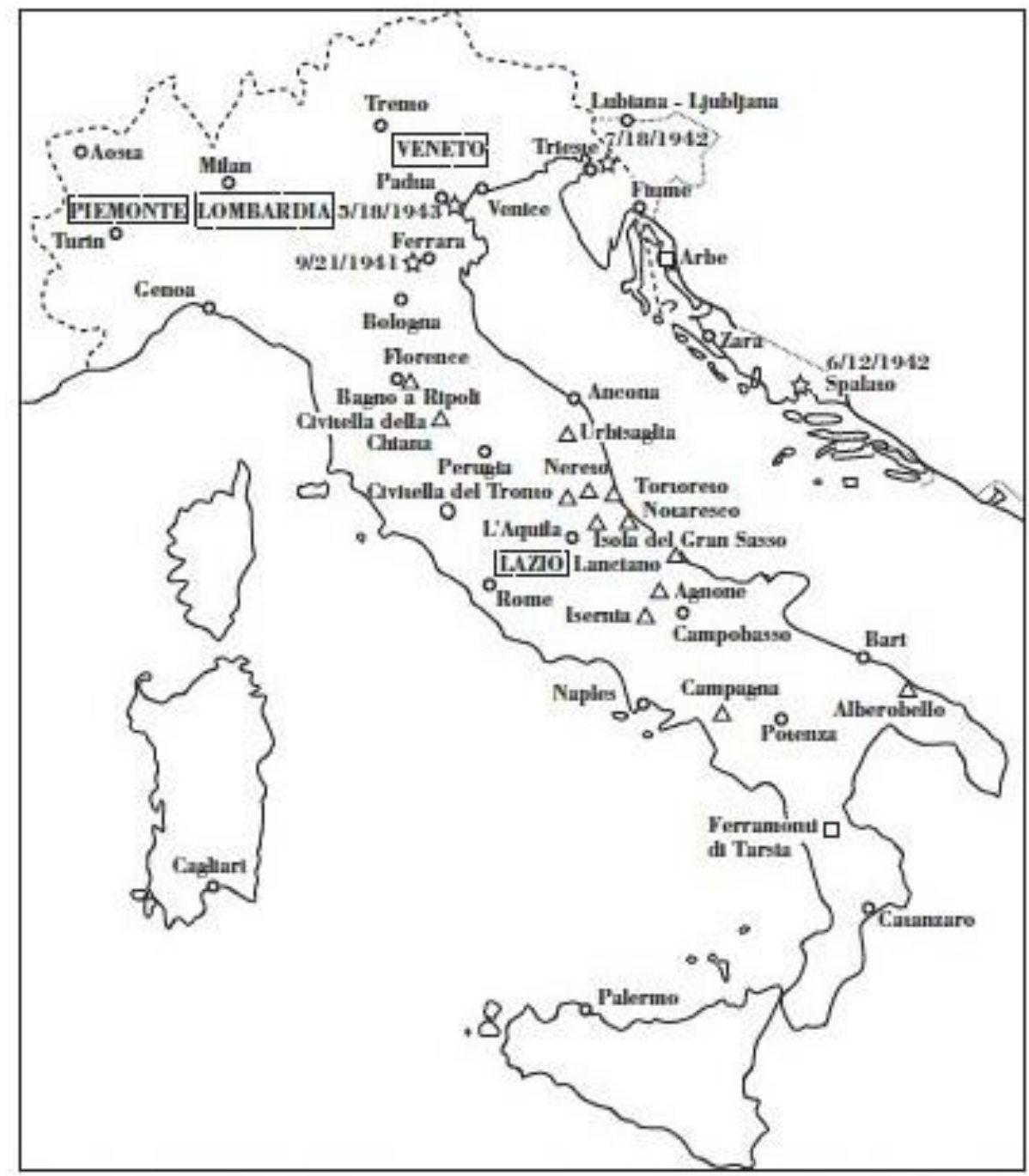

Mapa 2. Principais centros de perseguição contra judeus na Itália

$\triangle$ Campos de concentração com 50 a 300 judeus (1940-1943)

Campos de concentração com ao menos 1600 judeus (1940-1943)

^rincipais locais de destruição de sinagogas (1938-1943)

Fonte: ZIMMERMAN, Joshua D. The Jews in Italy under Fascist and Nazi Rule, 1922-1945

New York: Cambridge University Press, 2005

Em 25 de julho de 1943, um golpe de estado que retirou Mussolini do poder, ao menos temporariamente, resultou numa grave deterioração na situação da comunidade judaica na Itália já que a ele seguiu-se a invasão do país pela Alemanha nazista. Embora naquele momento, 
aproximadamente $20 \%$ dos judeus tivesse deixado o país devido à perseguição e à política de exclusão fascista, 39.907 ainda permaneciam em seu território. ${ }^{183}$

O cenário geral atingiu um alto nível de complexidade, com as forças aliadas avançando ao sul liberando território e campos de concentração, enquanto nas regiões central e norte, a Itália ia sendo rapidamente invadida pelas forças de Hitler. Nessa região ocupada formou-se, alguns meses mais tarde, um novo estado fascista, cuja capital era a cidade de Salò. Em referência a ela foi que o período ficou conhecido como a República de Salò.

Para os judeus que ficaram confinados dentro dessa área, o cenário passou a ser desesperador já que imediatamente começaram o confisco de bens, as prisões e deportações para os campos de concentração e extermínio nazistas localizados na Europa Central e Oriental.

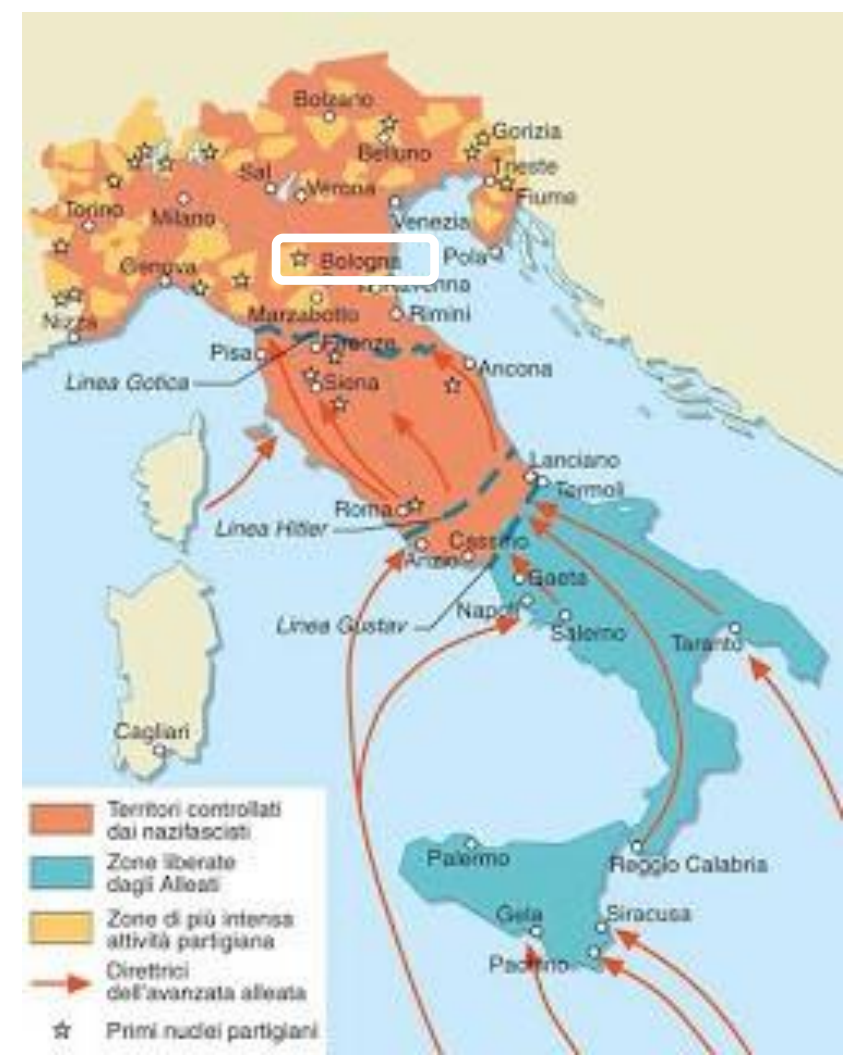

Mapa 3. A República Social Italiana (Repubblica di Salò, 1943-1945)

Ao sul (em azul), a zona liberada pelas forças aliadas. Ao norte e centro (laranja), o território controlado pelos nazistas. Nos pontos mais claros, as áreas de atividade dos partisans. As flechas em vermelho indicam o avanço das forças aliadas. As estrelas mostram os primeiros núcleos de partisans.

Em destaque, no retângulo branco, Bolonha, onde vivia a família Pardo Fonte: ESABAC Premiere

${ }^{183}$ PICCIOTTO, Liliana. "The Shoah in Italy: Its History and Characteristics". In, ZIMMERMAN, J. D. op. cit. 
A rapidez com que os comandos nazistas chegavam aos judeus dentro das cidades foi amplamente favorecida pela vasta burocracia montada até então pelo fascismo que, junto com a ativa participação da polícia italiana, permitiu que rapidamente fosse identificado o local de moradia dessa população, alvo de uma nova etapa de perseguição, desta vez genocida.

As contradições desse quadro são inúmeras e mostram como a sorte jogou um papel primordial no destino de milhares de pessoas. Como mostram os dois mapas a seguir, para aqueles que foram surpreendidos pela invasão alemã do "lado errado" do território, as chances de sobrevivência eram escassas. Fugir era a única saída. Em alguns casos, poucos quilômetros de distância faziam a diferença entre a vida e a morte.

No Mapa 4, é possível observar que, ao sul da Itália, há uma grande área em que não há pontos pretos nem quadrados amarelos que indicam centros de detenção ou internação. Essa área coincide com o avanço da zona liberada pelas forças aliadas.

Ao compararmos este mapa ao Mapa 1, que indica os centros existentes entre 1938 e 1943 -portanto antes da liberação do sul da Itália pelas forças aliadas- vemos que o cenário é bem diferente.

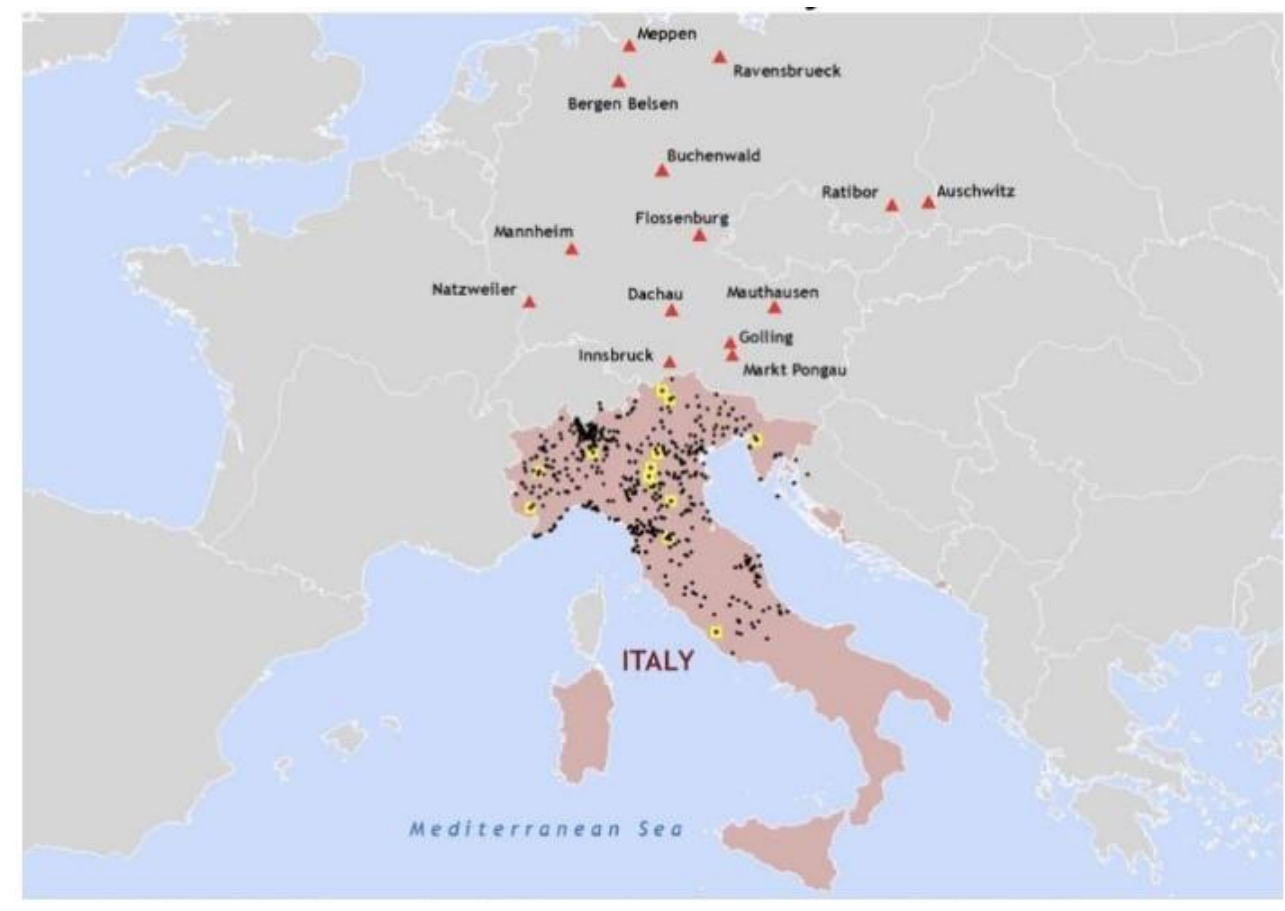

Mapa 4. O Holocausto na Itália.

Os locais de detenção estão indicados com pontos em preto; os locais de concentração são representados com quadrados amarelos; os campos de destino estão marcados com triângulos vermelhos.

Créditos: Alberto Giordano e Anna Holian, Geographies of the Holocaust Project Fonte: United States Holocaust Memorial Museum 
A perseguição organizada pelas forças nazistas contra os judeus na Itália, começou a ser posta sistematicamente em prática quando, em outubro de 1943, uma unidade especial chegou de Berlim e instalou seu quartel general na cidade de Verona. Essa unidade, que operou apenas dois meses, até dezembro de 1943, perpetrou uma de suas ações mais atrozes no dia 16 de outubro, quando em Roma 1.015 dos 6.730 judeus de Roma foram capturados "debaixo das janelas do Vaticano, por assim dizer" 184 e deportados para Auschwitz-Birkenau sem que isso gerasse praticamente nenhum protesto por parte do Vaticano. ${ }^{185}$

Nos dois meses seguintes, outros 7.345 judeus foram presos por todo o norte da Itália dos quais 6.746 foram para as câmaras de gás de Auschwitz logo após sua chegada, ou morreram devido às terríveis condições do campo. ${ }^{186}$ Entre os prisioneiros levados naqueles meses, estava o químico italiano Primo Levi, que se tornaria um dos maiores autores da chamada literatura do Holocausto, autor do clássico É Isto um Homem?, entre outros títulos. ${ }^{187}$

Em Trieste, cidade de nascimento de Ariella, os alemães encarregaram-se de matar 630 judeus no tristemente célebre campo de concentração La Risiera di San Sabba. ${ }^{188}$ Este campo foi o único em território italiano equipado com fornos crematórios. Alguns carrascos alemães responsáveis pelo assassinato de milhares judeus nos campos de Sobibor, Belzec ou Treblinka, foram transferidos a Trieste para lá continuar lá suas brutais atividades.

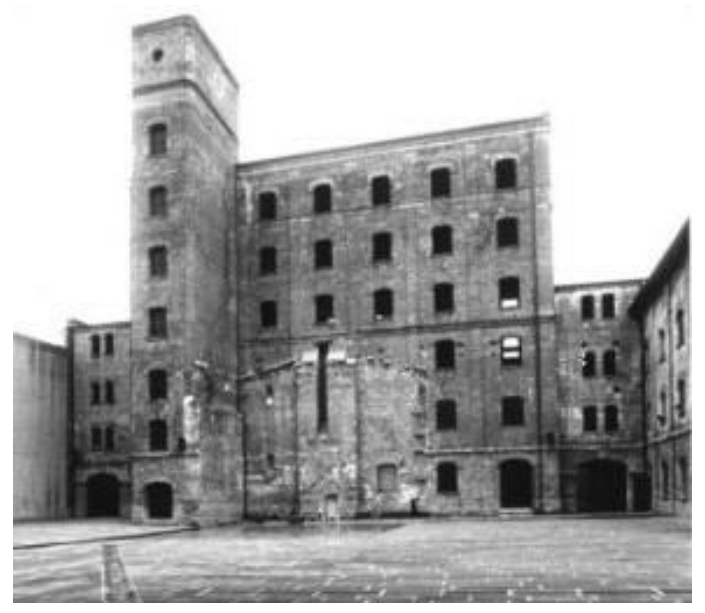

\section{O campo de concentração Risiera di San Sabba, em Trieste, Itália}

Fonte: www.ilfattoquotidiano.it

184 WISTRICH, Robert. Hitler and the Holocaust. New York: Modern Library, 2001.

185 ZUCOTTI, Susan. Under His Very Windows. New Haven: Yale University Press, 2000.

186 GILBERT, Martin. The Holocaust: The Human Tragedy. New York: RosettaBooks, 2014 (Edição Eletrônica)

187 Além de É Isto um Homem?, publicado pela Editor Rocco, há vários títulos de Primo Levi disponíveis em português: Os Afogados e os Sobreviventes (Editora Paz e Terra); A Assimetria e a Vida. Artigos e Ensaios 1955-1987. (Editora Unesp)

${ }^{188}$ GILBERT, Martin. Ibidem. 
Em novembro de 1943, numa tentativa de ressuscitar o Partido Fascista, foi promulgado o chamado Manifesto de Verona. Em um de seus 18 pontos este documento declarava os judeus como "inimigos da nação". Naqueles últimos meses de 1943, a situação dos judeus na Itália tornou-se insustentável. Para a família Pardo, isso também já havia ficado evidente.

\section{Perseguição e fuga: a saga da família Pardo}

Devido aos constantes bombardeios em Bolonha, Ferruccio e Iris haviam alugado um pequeno apartamento em Budrio, uma cidade a $20 \mathrm{~km}$ de distância. O professor Pardo, porém, ia regularmente a Bolonha para suas aulas. Um dia perdeu o trem e não conseguiu ir para a cidade, conseguindo chegar lá somente dois dias mais tarde.

Ao colocar a chave na fechadura do apartamento da Via Zamboni 2, que ficava no andar de cima da escola onde Iris tinha a sua escolinha, o Professor Pardo ouviu uma voz. Era seu vizinho do quarto andar, Alfredo Giommi, que estava esperando na escada havia três dias para advertir o professor sobre o perigo.

Alfredo convidou o professor para dar uma volta com ele no quarteirão e assim poder contar-lhe que dois dias antes -ou seja, no exato dia em que ele perdeu o trem, não conseguindo chegar a Bolonha- policiais nazistas e "carabinieri" italianos haviam estado procurando por ele. Era evidente que voltariam.

O professor Pardo soube então que não era possível continuar morando no país. Assim, despediu-se do amigo que lhe disse: "Quando você voltar festejaremos juntos". ${ }^{189}$ E assim fariam. Mas antes, uma longa, e perigosa jornada aguardava a família Pardo.

\section{A jornada rumo à Suíça}

Depois desse encontro em Bolonha, o professor voltou então para Budrio e comunicou a Iris que deveriam partir. Procuraram às pressas um carro ou algum transporte que os levasse embora dali. Embalaram algumas coisas e de madrugada, ainda escuro, partiram para Bolonha a

189 Transcriado a partir das memórias escritas de Iris Pardo, em trecho publicado por seu filho Lucio Pardo em "Il Segreto di Don Carlo Banfi". In, Don Carlo Banfi: Un Eroe Sconosciuto. Solidaritá e Impegno Civile a Sormano, 1943-1945. Documenti e Testimonianze. Comune di Sormano, 2013. 
fim de pegar um trem para Milão. O objetivo da família, porém, era a fronteira com a Suíça, onde buscariam refúgio.

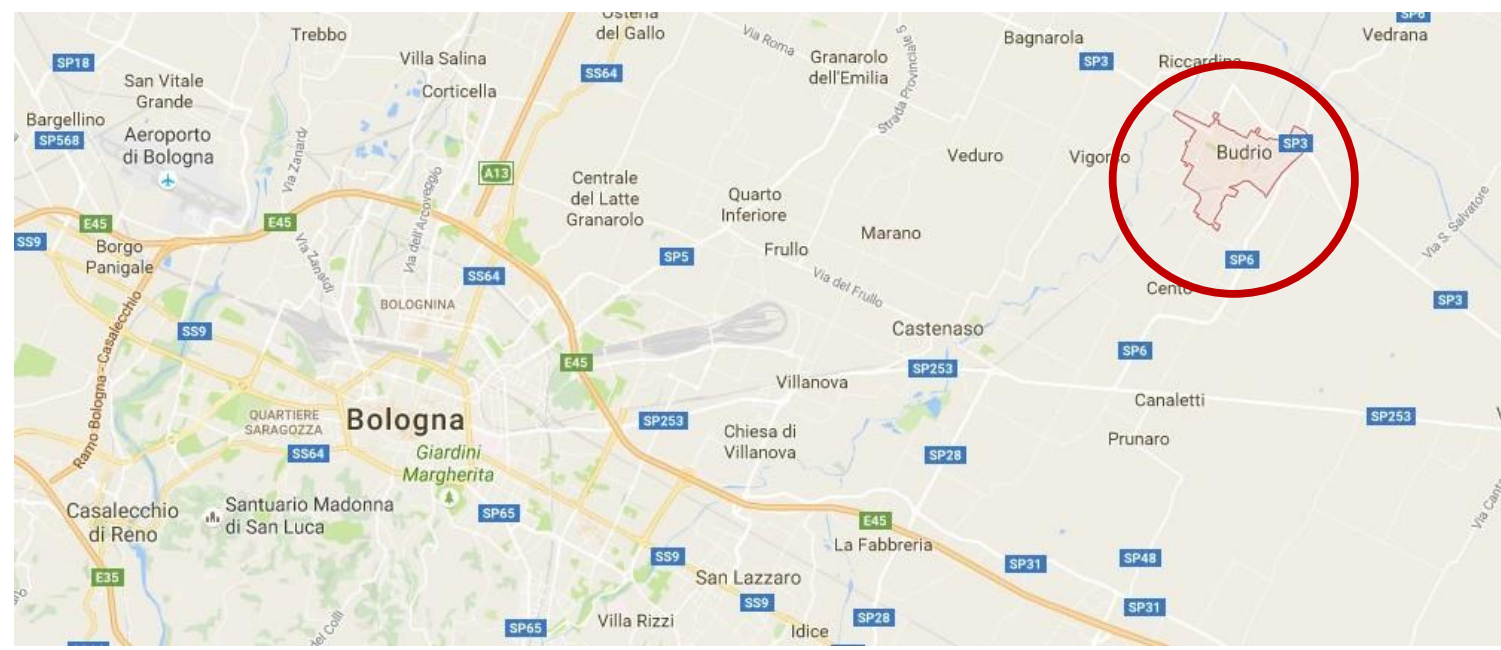

Mapa mostrando Budrio (à direita), cidade pertencente à Região Metropolitana de Bolonha Fonte: Google Maps

A estação de Bolonha havia sido bombardeada, mas mesmo assim conseguiram chegar a Milão. Daí a família seguiu para a cidade de Solzago, na região do Lago di Como, ainda na Itália, próximo à fronteira entre Itália e Suíça. Ali moravam a irmã de Iris, Flora, e seu cunhado Ernesto Raffa. Em seguida, encontrariam também ali a tia Gemma.

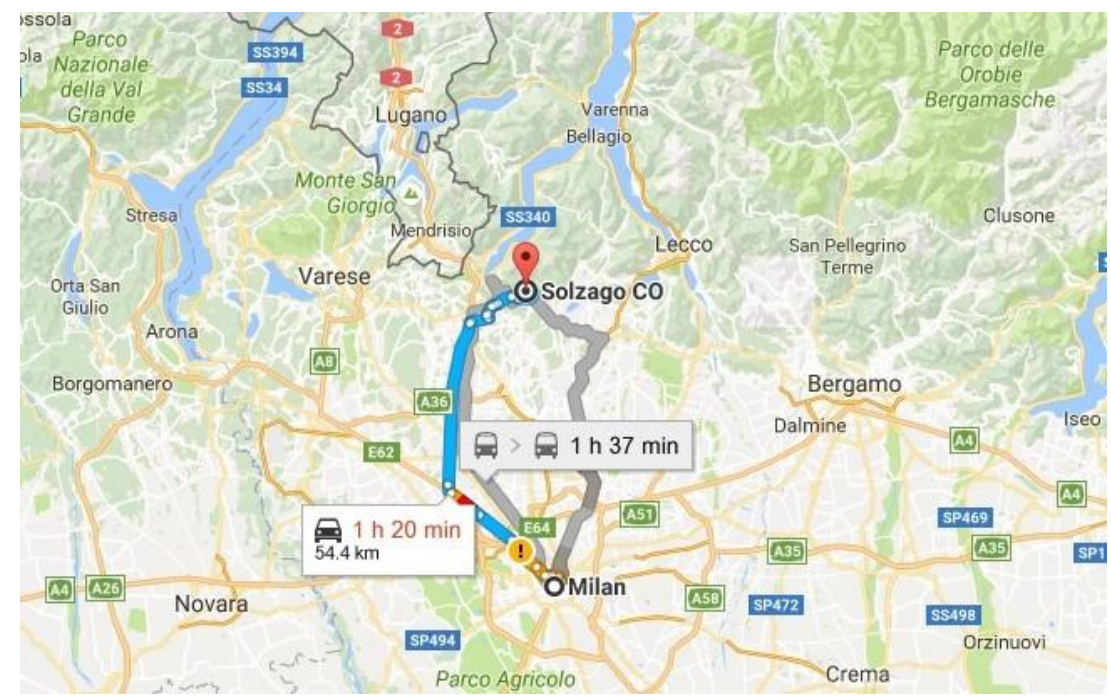

Trajeto entre Milão e Solzago

Fonte: Google Maps 
Ao saber dos planos da família de fugir para a Suíça, Gemma disse: "Querem ir para a Suíça? Iremos juntos. Deixem comigo". ${ }^{190}$ A partir daí, Gemma encarregou-se de organizar os preparativos e liderar o grupo naquela difícil travessia.

Além de uma intelectual, como foi mencionado anteriormente, Gemma Volli era também uma humanista. Mulher sensível que, ainda morando em sua cidade natal, Trieste, quando começou a perseguição dos judeus da Alemanha, em meados dos anos 1939, colaborou para a fuga de muitos dos que passavam pelo porto de sua cidade, rumo à Palestina, inclusive acompanhando alguns deles.

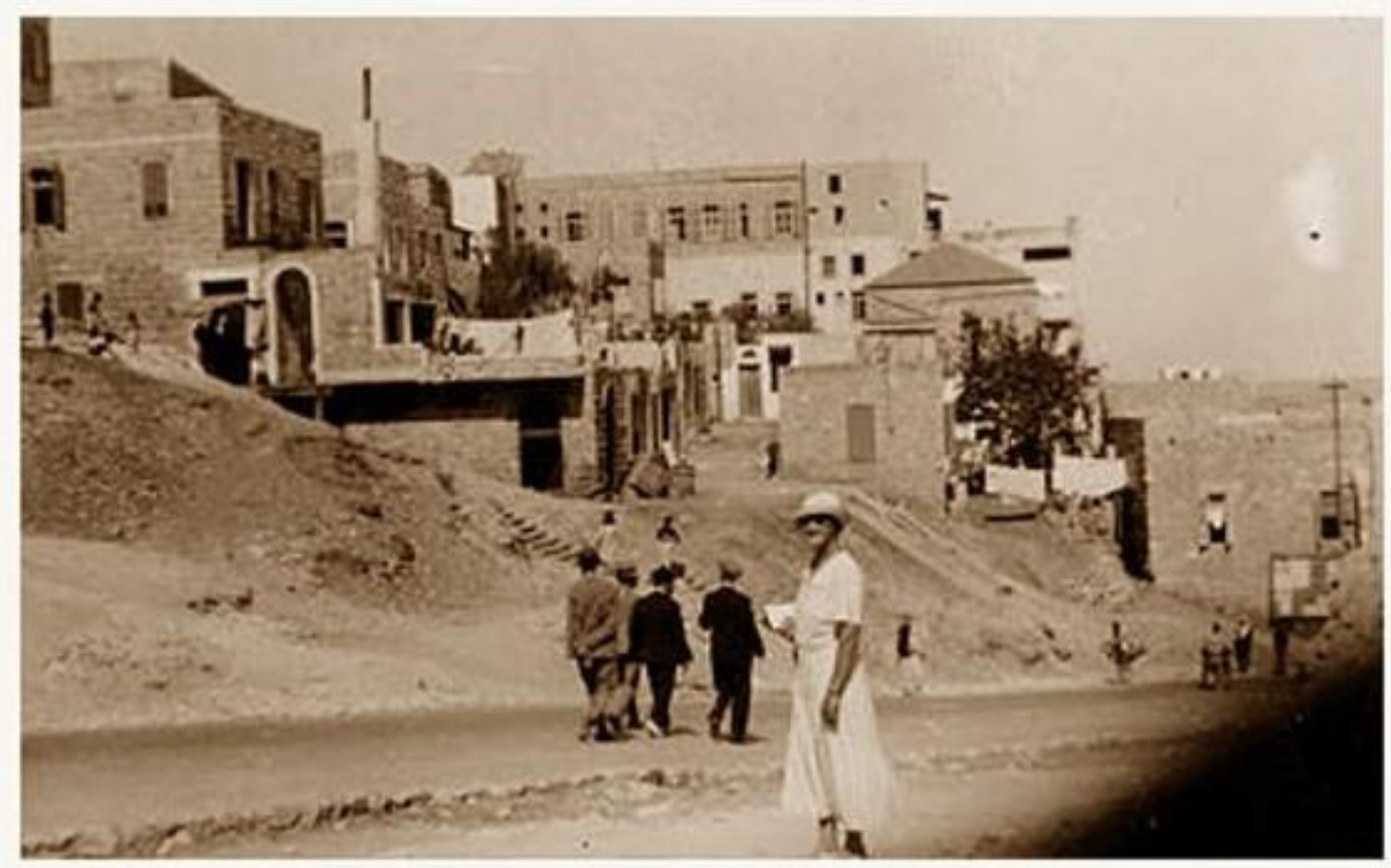

Gemma Volli, Palestina, anos 1930.

Fonte: GOLFERA, Silvia. Una donna del secolo scorso: Gemma Volli www.storiamemoria.it

${ }^{190}$ Ibidem. 


\section{A travessia dos Alpes}

Em suas memórias, Iris nos conta como somente um dia depois do encontro com Gemma, sua irmã já tinha um plano definido:

Agora a fronteira está aberta. Fiz contato com contrabandistas que nos levarão até lá. É necessário levar roupas pesadas, sapatos adaptados porque a estradinha que devemos percorrer pode estar congelada. Nevou um pouco no [Monte] Bisbino e temos que ultrapassá-lo. Me garantiram que vão conseguir duas mulas. Podem levar uma mochila por pessoa, nada além disso! Malas? Nada de malas! Haverá ainda um carregador para levar a menina [Ariella] até a fronteira. ${ }^{191}$

Após os preparativos, o grupo deixou Solzago em direção a Laglio. Desse ponto, uma pequena estrada conduzia ao Monte Bisbino por onde iniciariam a subida para atravessar a fronteira e chegar à Suíça. Outras pessoas juntaram-se ao grupo, entre eles o casal Caffaz, também de Bolonha.

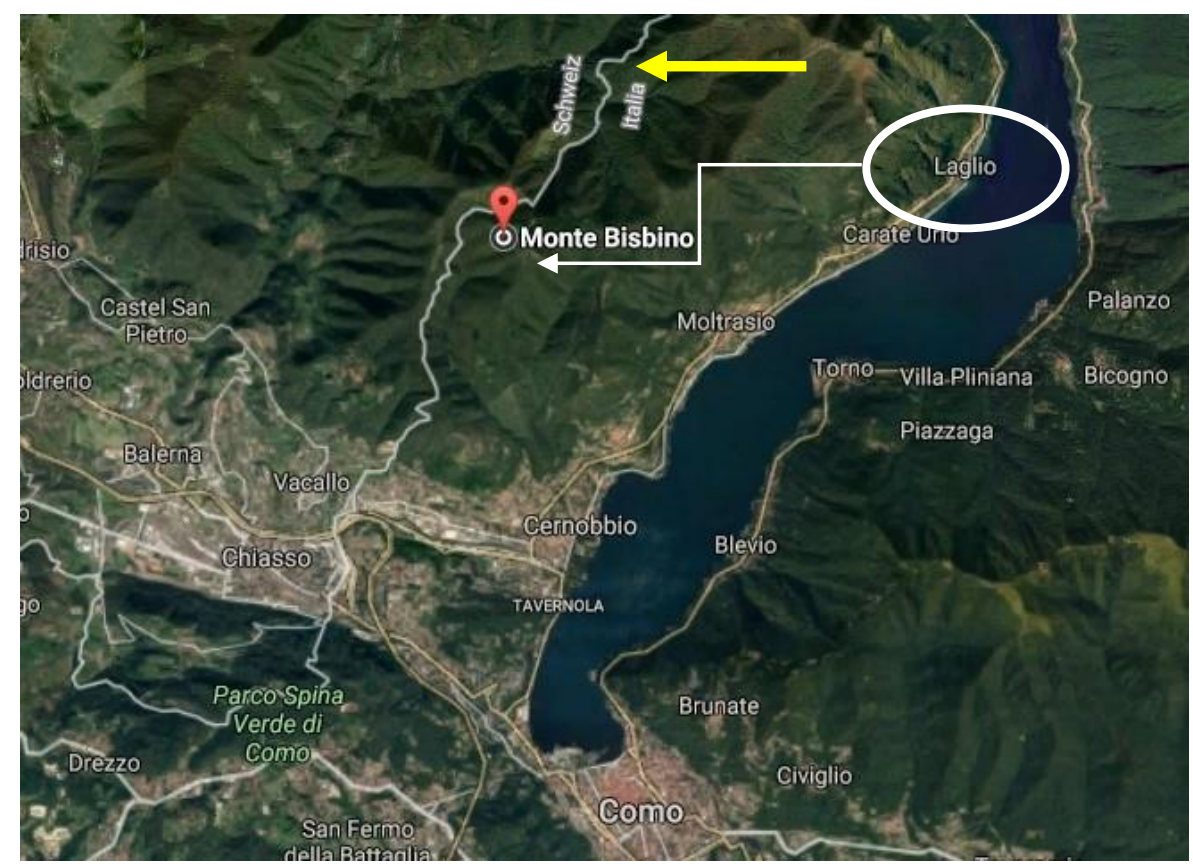

Mapa indicando a localização de Laglio (indicado pela elipse), de onde a família de Ariella partiu para atravessar a fronteira pelo Monte Bisbino. A seta aponta para a linha que demarca a fronteira entre Itália e Suíça.

Fonte: Google Maps

191 Transcrito das memórias de Iris Pardo. PARDO, Lucio. "Il Segreto di Don Carlo Banfi". In, Don Carlo Banfi: Un Eroe Sconosciuto. Solidaritá e Impegno Civile a Sormano, 1943-1945. Documenti e Testimonianze. Comune di Sormano, 2013 
A estradinha era muito estreita, portanto todos seguiam em fila indiana em absoluto silêncio. À frente de Iris ia uma das mulas que carregava as mochilas. Devido ao cansaço, ela decidiu segurar no rabo da mula para ajudar na subida, mas em determinado ponto, o animal fez um movimento brusco e derrubou Iris.

Apesar de que na época tinha apenas três anos e meio, esta imagem nunca saiu da memória de Ariella. O pavor de ver sua mãe caindo fez com que ela soltasse um grito que todos se apressaram a inibir para não atrair a atenção de alguém que pudesse delatá-los. Devido à escuridão, todos pensaram que Iris estava morta, mas ela se recuperou da queda e uniu-se ao grupo novamente.

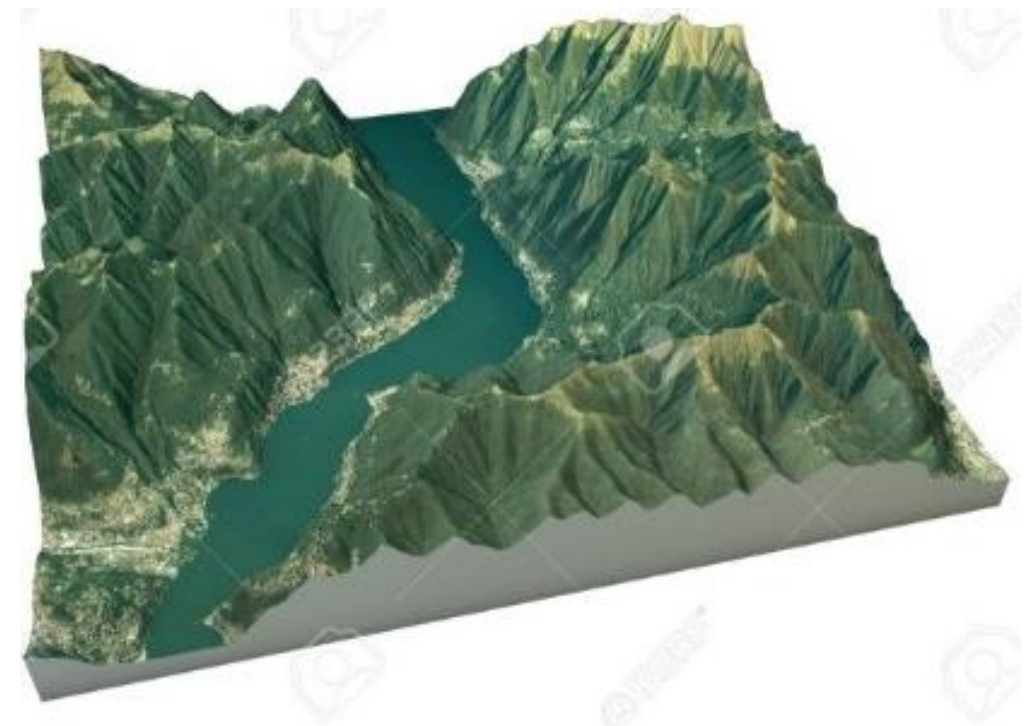

Topografia do Lago di Como, fronteira Itália-Suíça

Por estas montanhas, a família Pardo empreendeu sua fuga Fonte: www.123rf.com

$\mathrm{Na}$ fronteira, porém, um dos guardas encarregados avisou que eles não poderiam ficar. Teriam que voltar para a Itália, ao que a pequena Ariella respondeu: "Mas ali tem os alemães que querem prender e matar a gente!". O guarda, sensibilizado, pegou Ariella nos braços e os acompanhou até o posto regional.

De lá seguiram para Chiasso, onde foram aceitos. Receberam ali documentos de refugiados o que lhes dava direito a abrigo e comida. 


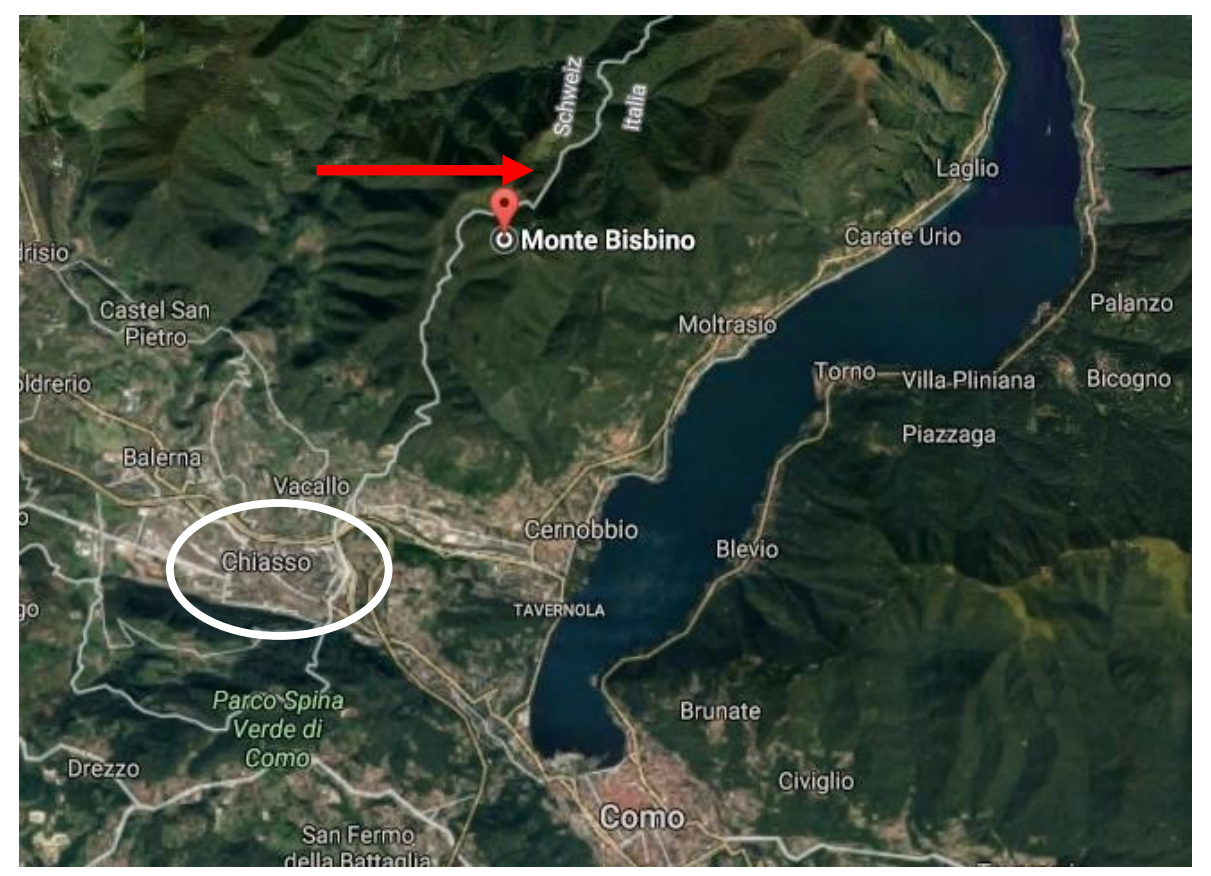

Mapa indicando a localização de Chiasso (elipse), em território suíço.

Para ali, o grupo foi levado junto com outros refugiados.

A seta vermelha aponta para a linha que demarca a fronteira entre Itália e Suíça.

Fonte: Google Maps

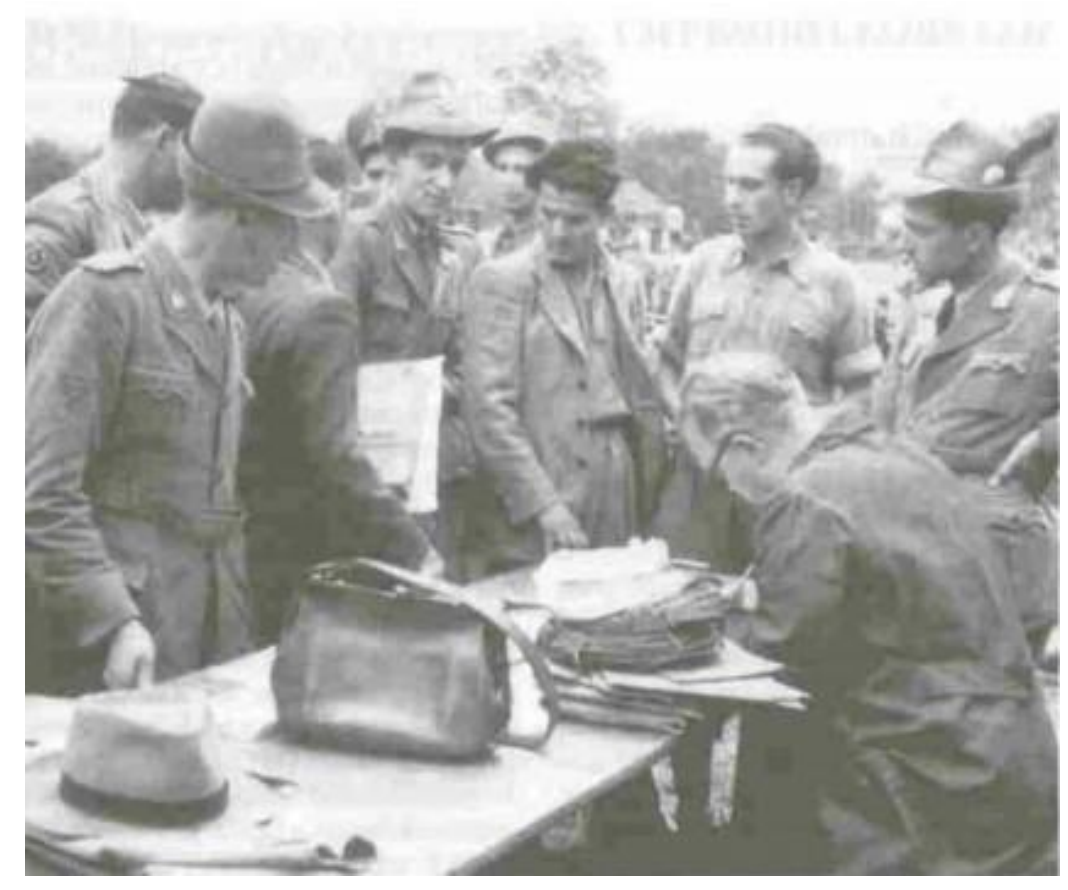

Funcionários suíços registram os refugiados

Fonte: BROGGINI, Renata. Terra d'asilo. I rifugiati italiani nella svizzera, 1943-1945.

Bologna: Il Mulino, 1993 


\section{Aguardando o retorno à Itália}

Durante o período entre 1944 e 1945, enquanto permaneciam na Suíça, Ferruccio, Iris e Gemma engajaram-se em atividades educacionais que visavam contribuir a que crianças e jovens refugiados pudessem recuperar o tempo de estudo perdido.

Em Lugano, por iniciativa do governo regional, funcionou uma escola num local chamado Castello di Trevano, destinada aos jovens de famílias italianas refugiadas, cujo trabalho foi organizado pelo Professor Pardo. Iris dava aulas para as crianças pequenas. Foi ali onde Ariella começou sua vida escolar.

Gemma, por sua vez, organizaria um grupo de alunos na cidade de Weggis com o objetivo de prepará-los para o retorno à vida escolar quando a guerra acabasse.

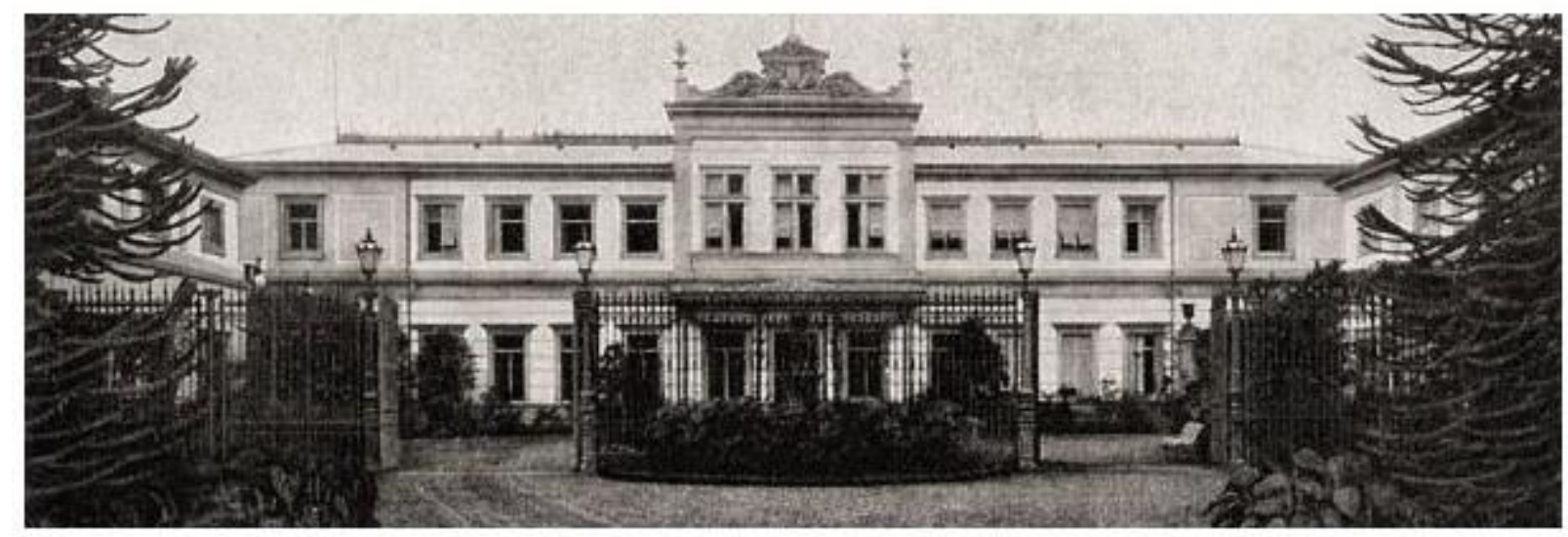

\section{Castello di Trevano, Lugano, Suíça}

Neste local funcionou uma escola para refugiados italianos entre 1944 e 1945.

Fonte: www.geocaching.com

\section{O regresso a Bolonha}

Com o fim da guerra, em julho de 1945 veio a notícia: os refugiados poderiam voltar para casa. As famílias foram então levadas em caminhões do Exército americano para a Itália. Três dias depois da chegada a Como a família Pardo estava de volta a Bolonha.

Porém, nem tudo estava como antes. Ao chegar à Via Zamboni, 2, descobriram que o apartamento da família estava ocupado. O governo fascista havia confiscado as casas que 
anteriormente pertenciam aos judeus, outorgando-as a outros habitantes. Os livros da família pardo haviam sido queimados para alimentar fogões instalados no terraço do prédio. Alguns bens, inclusive um livro que o Professor Pardo estava escrevendo antes da guerra e que havia deixado no cofre do banco, também haviam desaparecidos.

A única opção, ao menos imediatamente, era morar nas tendas que haviam sido montadas numa praça da cidade. Foi nesse acampamento que um dia, o velho amigo da família, Alfredo Giommi, ao passar pelo local das tendas reconheceu a pequena Ariella. Emocionado, imediatamente ofereceu o pouco espaço que tinha em sua casa para a família Pardo. A partir de então, a vida começava a ser lentamente reconstruída.

Em 1946, uma revista destinada à comunidade judaica propôs a seus leitores a seguinte pergunta: “Apesar do que aconteceu na Europa, você permanece judeu. Por que?” O professor Pardo escreveu uma carta-resposta à revista na qual elaborou a seguinte reflexão:

Permaneço judeu por Fé; por imperativo absoluto do dever; pela indissolubilidade moral do vínculo. ${ }^{192}$

Para Pardo, negar o judaísmo significava negar sua própria história, unindo-se dessa maneira àqueles que haviam tentado destruir seu povo. Além disso, estaria ensinando aos seus filhos a serem algo que eles não são, a viverem falsamente. Nesse caso, prossegue o professor:

(...) cometeria uma ação totalmente reprovável a ponto de ter que reconhecer não ter merecido a graça (e a imensa responsabilidade) de abrir os olhos à luz do sol nem a de poder ainda ver e meditar e operar depois que a recente barbárie afogou grande parte de nossos melhores irmãos, em cujo nome, mais do que no nosso próprio, devemos defender o sagrado patrimônio que nos restou. ${ }^{193}$

É esse patrimônio que Ariella e Lucio continuam defendendo.

192 Citado por Antonio Petrucci in, "Ferruccio Pardo..." op. cit.

${ }^{193}$ Idem. 
O fim da guerra, como nos conta Ariella, não significou o fim do antissemitismo na Europa. Nos anos 1950 seu pai foi novamente vítima de uma injustiça: a perda de seu cargo de presidente no Istituto Magistrale Laura Bassi e a transferência para uma pequena escola na cidade de Lodi. O episódio, último de uma série de tantos, levou-o a um infarto.

Para Ariella foi o ponto final. Ela, que já queria deixar seu país, havia chegado a hora. Primeiro pensou em imigrar para Israel, mas em 1958 conheceu quem viria a ser seu marido, Marco Vittorio Segre, médico italiano que vivia no Brasil desde o final dos anos 1930. Aqui ela teve quatro filhos.

Lucio permaneceu na Itália, em Bolonha, onde é engenheiro civil e nuclear além de ter exercido por vários anos o papel de dirigente da Comunidade Judaica de Bolonha.

Gemma Volli, após sua volta para Itália continuou sua atividade como intelectual e professora, até sua morte em Bolonha, no dia 4 de maio de 1971. Publicou diversos livros, entre os quais Il Caso Mortara, trabalho pioneiro no qual analisa a história do menino judeu raptado pelo Vaticano. A história de Edgardo Mortara será em breve levada às telas pelo cineasta Steven Spielberg.

Íris Volli Pardo também permaneceu na Itália até sua morte aos 73 anos.

O Professor Ferruccio Pardo continuou sua atividade intelectual à qual, após aposentar-se da docência no final dos anos 1960, dedicou-se integralmente até sua morte em 1976.
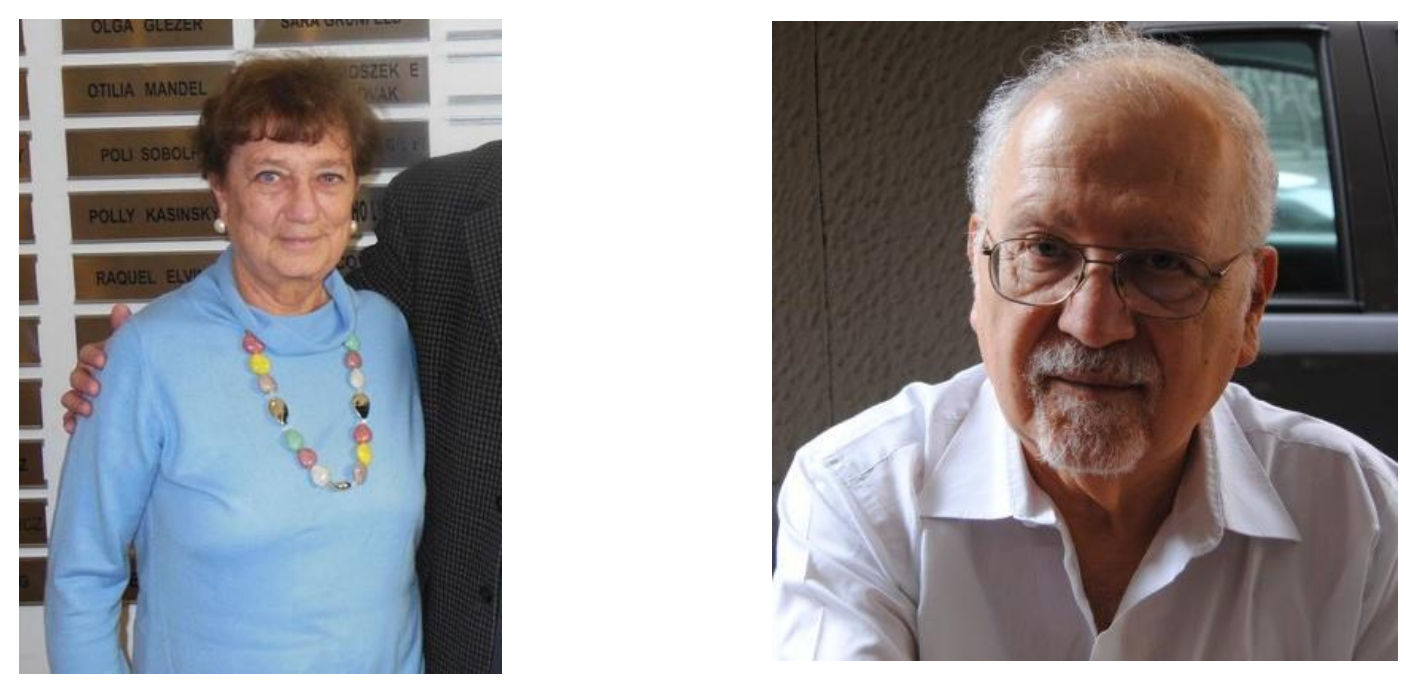

Os irmãos Ariella e Lucio Pardo 


\title{
4.2.5. Helena Blankfeld: geografias, dilemas e ideais na história de uma vida
}

\author{
Introduzindo a vida de Helena
}

O testemunho de Helena poderia ser resumido, segundo sua própria definição e parafraseando o título da obra de Charles Dickens como "Um Conto de Seis Cidades". Os vaivéns geográficos de Helena e de sua família naquele cenário da Polônia (região hoje pertencente à Polônia), invadida primeiro pela União Soviética e posteriormente pela Alemanha nazista, é um retrato riquíssimo não só do caleidoscópio de fatos ocorridos, mas também da complexa trama de reações e tomada de decisões na qual se viram envolvidos os membros das comunidades judaicas de uma Europa descontrolada. Essas decisões não se limitavam simplesmente a ficar ou ir embora; envolviam verdadeiros dilemas, tais como: ficar ou abandonar tudo o que várias gerações antes de mim construíram?; fugir com a família ou deixar as crianças com alguém para que estejam protegidos?; entregar meu patrimônio inteiro para salvar minha família ou preservar algo para poder usá-lo durante a fuga ou para conseguir esconder-me?; renunciar à minha identidade e tentar 'passar' como algo que não sou ou morrer?; fugir ou esconder-me debaixo da terra, quem sabe até quando, até que a tempestade passe? A família de Helena, como ela mesma nos mostra, deparou-se com todos esses dilemas. Nesse sentido, sua história nos convida, de maneira profunda, a diversas reflexões sobre a vida durante o Holocausto.

No entanto, dentro daquilo que considero o tripé que suporta a narrativa de Helena -as Geografias, os Dilemas e os Ideais- este último elemento é de extrema importância para as propostas de educação sobre o Holocausto, já que estabelece um forte laço com aspectos geralmente negligenciados dentro do tratamento do tema, tanto nas salas de aula quanto nos livros didáticos de História: o movimento sionista no pré-guerra na Europa, o papel das organizações clandestinas judaicas da Palestina Mandatária quanto ao resgate de judeus europeus (a Brihah, por exemplo), e os anos entre o pós-catástrofe e a pré-formação de uma nova nação.

Mas, por que esses elementos são tão importantes? As razões são várias, mas apontamos aqui duas delas: primeiro, pelo próprio interesse histórico na busca por conhecer que a história do Holocausto não terminou com a liberação dos campos pelas potências ocidentais; segundo, pela necessidade de incorporar à narrativa histórica os enormes esforços de resgate dos sobreviventes do Holocausto por parte dos judeus da Palestina Mandatária. 
Há, porém um terceiro elemento subjacente a todas essas razões e que, na verdade, vem em resposta a uma situação cada vez mais presente: o ressurgimento do antissemitismo -sob novo rótulo de antissionismo-, principalmente voltado ao que Léon Poliakov denominou, já no final dos anos 1960, de "o judeu entra as nações"194, ou seja, o Estado de Israel.

Na pesquisa sobre os livros didáticos de História evidencia-se em muitos títulos que a narrativa sobre o Holocausto está sendo afetada sobremaneira por questões ideológicas ligadas à visão das equipes editoriais das obras quanto à formação e realidade atual do Estado de Israel. Trata-se de textos que permitem entrever de maneira clara, indícios de conceitos presentes na narrativa de autores como Edward Said e seu Orientalismo, Ilan Papen, entre outros, e que colocam a história de Israel como fruto de um projeto colonialista ou até mesmo imperialista.

Dito de outro modo, ao abrirmos um livro didático procurando saber como é tratado o tema do Holocausto, percebemos características tais como a "desjudaização" do evento, a desproporcional prevalência de outros grupos -mesmo que também tenham sido vítimas da Alemanha nazista, como por exemplo ciganos, ou homossexuais- ou até mesmo propostas de discussão sobre o impacto da bomba de Hiroshima sendo tratados no mesmo capítulo. Nesses casos, é possível afirmar com pouca margem de erro, que algumas páginas adiante, quando do tratamento da história do Estado de Israel, os indícios citados no parágrafo anterior estarão materializados, resultando em deturpações grosseiras não somente dos eventos tratados, mas de todo o processo histórico.

A necessidade de atenção a esses temas, dentro do continuum de assuntos relacionados à história do povo judaico, torna-se ainda mais relevante quando analisamos as propostas em curso para a educação. Por exemplo, no atual documento da Base Nacional Comum Curricular proposto pelo Ministério da Educação nos deparamos com o fato de que nas suas 652 páginas, não há uma única menção ao Holocausto; no entanto, propõe-se o estudo do processo de formação do Estado de Israel. De que modo? Ainda é uma incógnita. Portanto, propostas que não só incluam, mas que conectem esses temas -obviamente com o devido rigor histórico- em projetos que engajem os estudantes através de reflexões de qualidade, tornam-se prementes.

O trabalho de planejamento deste livreto paradidático baseado na história de Helena Blanksfeld, inclui, de derta forma, essa interconexão de aspectos, e tentar fazer jus, dentro dele,

194 POLIAKOV, Léon. De l'antisionisme à l'antisemitisme. Paris: Calmann-Lévy, 1969. 
ao orgulho que Helena expressa, nas palavras finais de seu testemunho, por sua Mediná Israel, o Estado de Israel. 


\section{LIVRO 5 - Helena (Halina) Kuper Blankfeld ${ }^{195}$}

Isso tudo nunca vai me marcar; para marcar, é preciso entender, e eu nunca entendi.

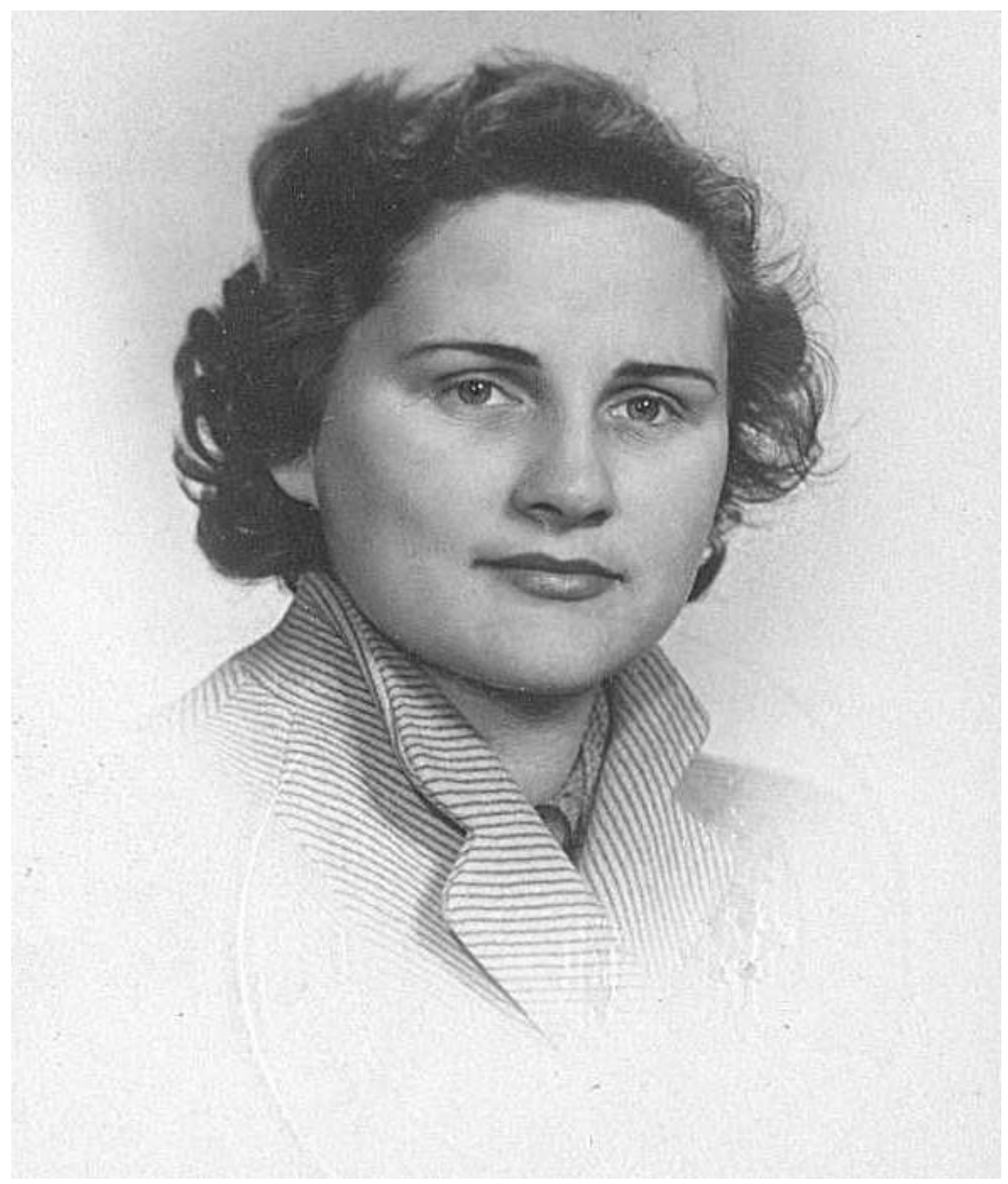

Helena quando de sua chegada ao Brasil, 1954

Fonte: www.familysearch.org

Ficha de Imigração, Rio de Janeiro

195 Testemunho de Helena Blankfeld ao Projeto Vozes do Holocausto (Arqshoah/LEER), São Paulo, 22 de abril e 09 de maio de 2014. Ficha Técnica: Entrevistadoras, Profa. Rachel Mizrahi e Profa. Sarita Saruê; Câmera, Laís Rigatto Cardillo; Transcrição, Daniel Loeb 
A história de Helena poderia ser resumida, segundo ela mesma, pelo título "Um Conto de Cinco ou Seis Cidades"196. Os vaivéns geográficos de sua história na Polônia (hoje Bielorússia), invadida primeiro pela União Soviética e posteriormente pela Alemanha nazista, é um retrato riquíssimo não só do caleidoscópio de fatos ocorridos, mas também da complexa trama de reações e tomada de decisões na qual se viram envolvidos os membros das comunidades judaicas daquela Europa embrutecida.

Essas decisões não se limitavam simplesmente a ficar ou ir embora; envolviam verdadeiros dilemas pessoais que incluíam perguntas como: devo abandonar tudo o que várias gerações antes de mim construíram?; devo fugir com a minha família ou deixar as crianças com alguém para que pelo menos elas estejam protegidas?; devo entregar meu patrimônio inteiro para salvar minha família ou preservar algo para usar durante a fuga; devo tentar esconder-me e escondê-los?; devo renunciar à minha identidade e tentar 'passar' como algo que não sou ou arriscar a minha vida?; devo fugir ou esconder-me debaixo da terra até que a tempestade passe? A família de Helena, como ela mesma nos mostra, deparou-se com todos esses dilemas. Nesse sentido, sua história nos convida, de maneira profunda, a diversas reflexões sobre o cotidiano de milhões de judeus durante o Holocausto.

O testemunho de Helena apoia-se, portanto, sobre um tripé composto pelas Geografias das idas e vindas, os Dilemas que sua família vivenciou, e os Ideais do povo judeu que, em meio aos embates que levaram à formação de seu próprio Estado, teve que enfrentar ainda a dura tarefa de resgatar milhares dos seus, das entranhas de um continente que tinha como objetivo devorá-los. Mas antes disso, Helena nos conta como esses Ideais estavam sendo estabelecidos naquele Leste europeu do pré-guerra, tanto através de atividades culturais como políticas.

Conheceremos assim um pouco sobre o que é o sionismo, sobre a efervescência das atividades educacionais implementadas pelo movimento dos jovens sionistas e sobre como trabalhavam, entre outros objetivos, em favor do ressurgimento da língua hebraica. Veremos também como muitos desses mesmos jovens cumpririam posteriormente um importante papel no resgate de milhares de judeus durante e imediatamente após o Holocausto, tanto a partir da Palestina ainda controlada pelos britânicos -o Estado de Israel seria fundado somente em 1948-, quanto na própria Europa através da formação de organizações de resistência e que

\footnotetext{
${ }^{196}$ Helena faz aqui uma paráfrase ao título do célebre livro do autor britânico Charles Dickens, Um Conto de Duas Cidades.
} 
possibilitaram que milhares de refugiados reconstruíssem suas vidas ao tempo em que construíam um novo país.

\section{Os anos anteriores à guerra}

A primeira cidade na história de Helena, é Pinsk, na Polônia. Foi ali que a pequena Haia (seu nome em ídiche) nasceu em 12 de dezembro de 1930. Seus pais Abraham e Basia a chamavam de Hayale, uma forma carinhosa de referir-se à bebê.

Antes da Segunda Guerra, Pinsk situava-se em território polonês. Com as mudanças políticas ocorridas depois da Segunda Guerra e, posteriormente, com o fim da União Soviética, a cidade hoje localiza-se ao sul da Bielorússia, país que declarou sua soberania em 1990.

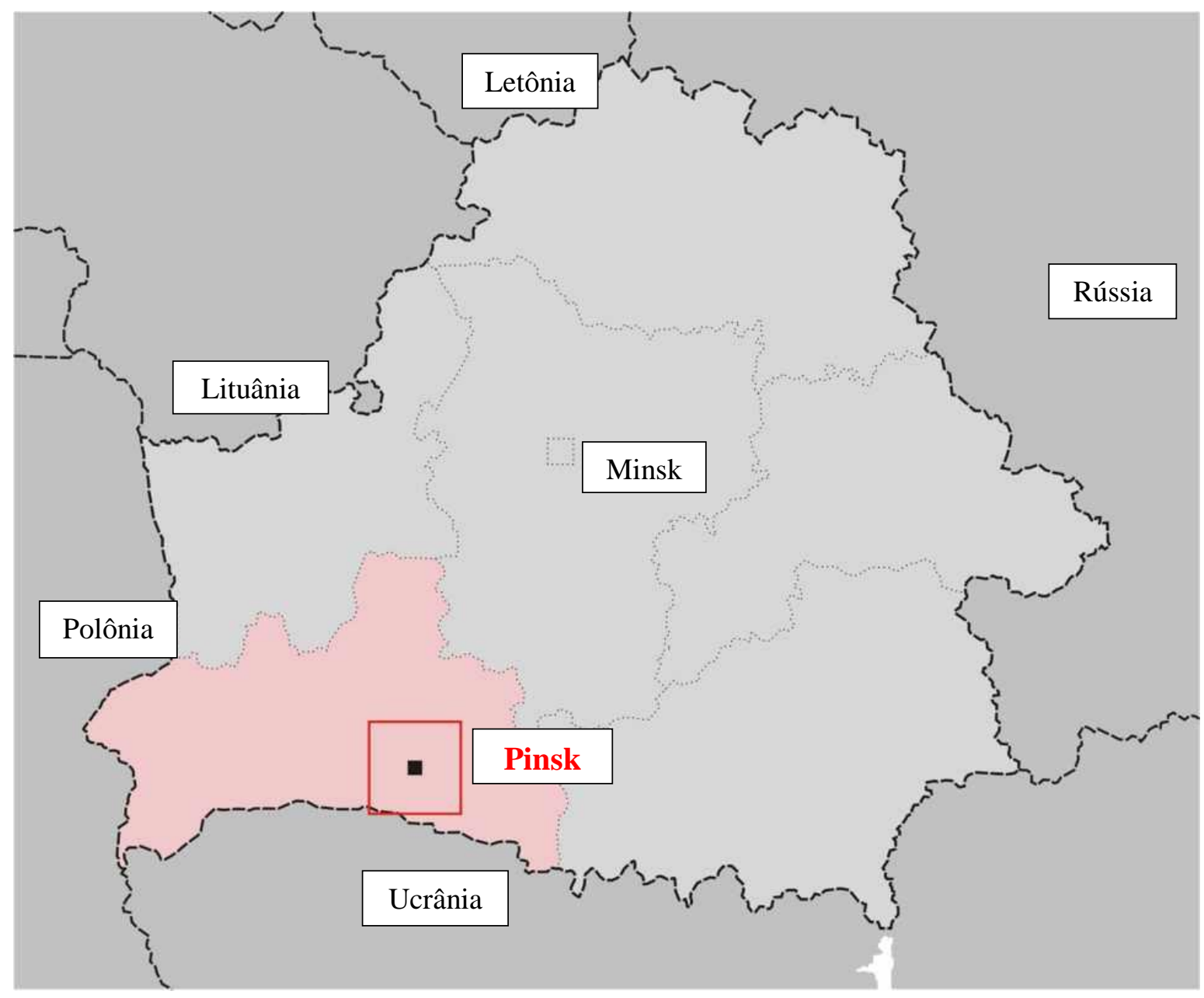

Bielorússia. Em destaque, Pinsk.

Fonte: www.commons.wikimedia.org 


\section{A comunidade judaica de Pinsk}

Por volta de 1500, as primeiras famílias judias começaram a instalar-se em Pinsk. Ao longo dos séculos, mais e mais judeus chegaram à cidade, oriundos de outras localidades da região. Dedicavam-se às mais diversas atividades, principalmente aquelas voltadas ao comércio e à pequena indústria. No século XIX, Pinsk já constituía um importante centro comercial situado na convergência de rios que a conectavam com o Mar Báltico a norte e o Mar Negro ao sul. Chegou a ser a cidade com maior proporção de judeus em toda a Europa.

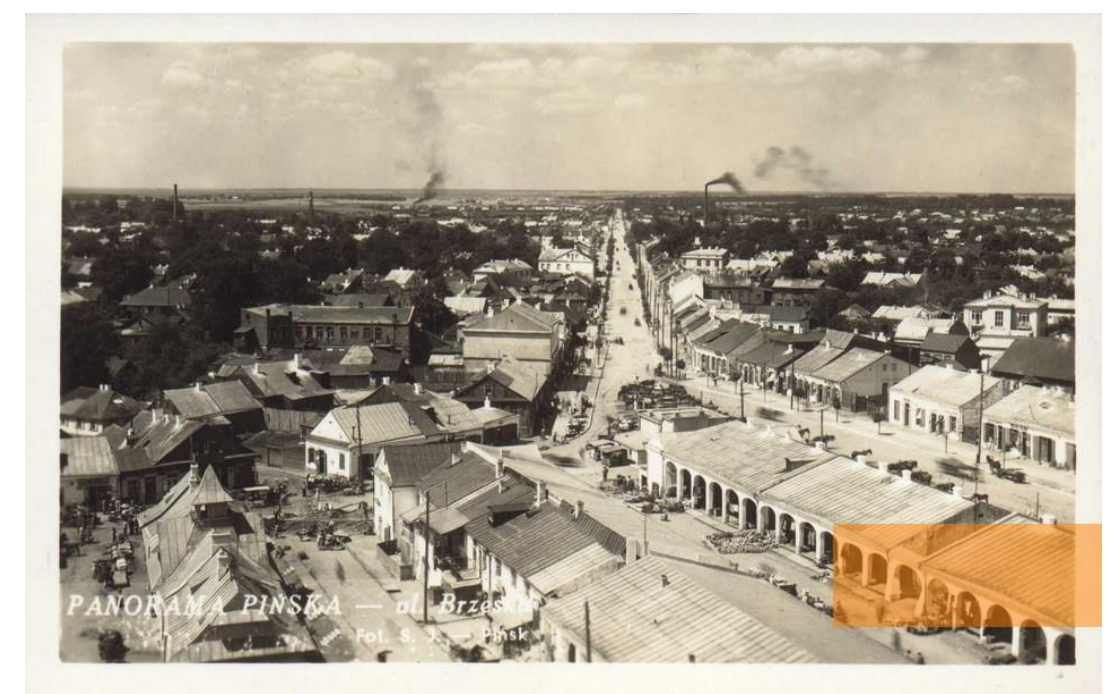

Pinsk, panorama da cidade antes de 1939

Fonte: Stiftung Denkmal für die ermordeten Juden Europas

(Fundação Memorial para os Judeus Assassinados da Europa) www.memorialmuseums.org

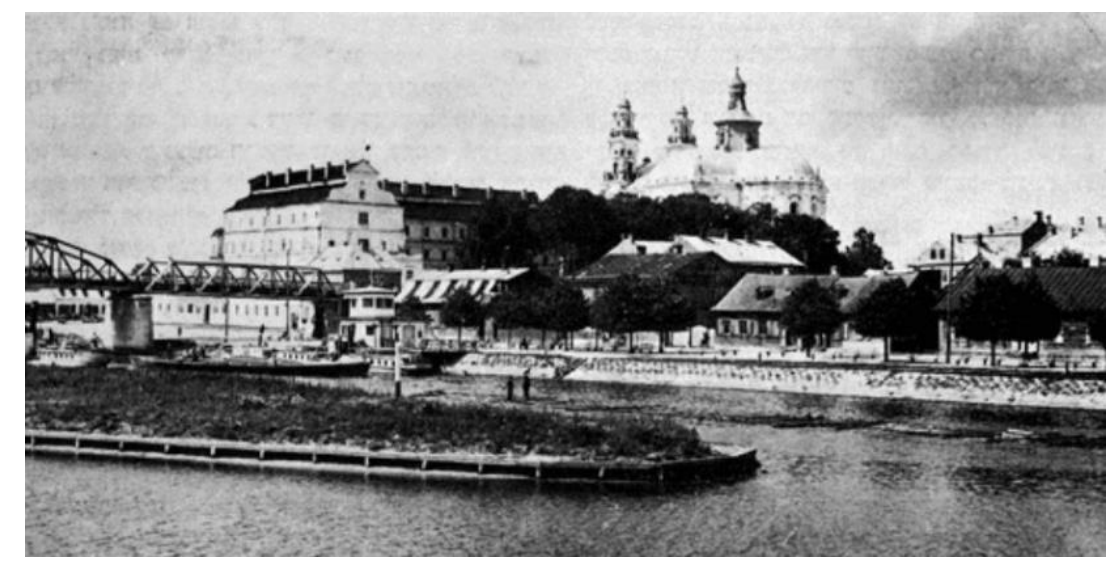

Pinsk, vista da cidade a partir do rio Pina

Fonte: Shtetl Routes

www.shtetlroutes.eu 


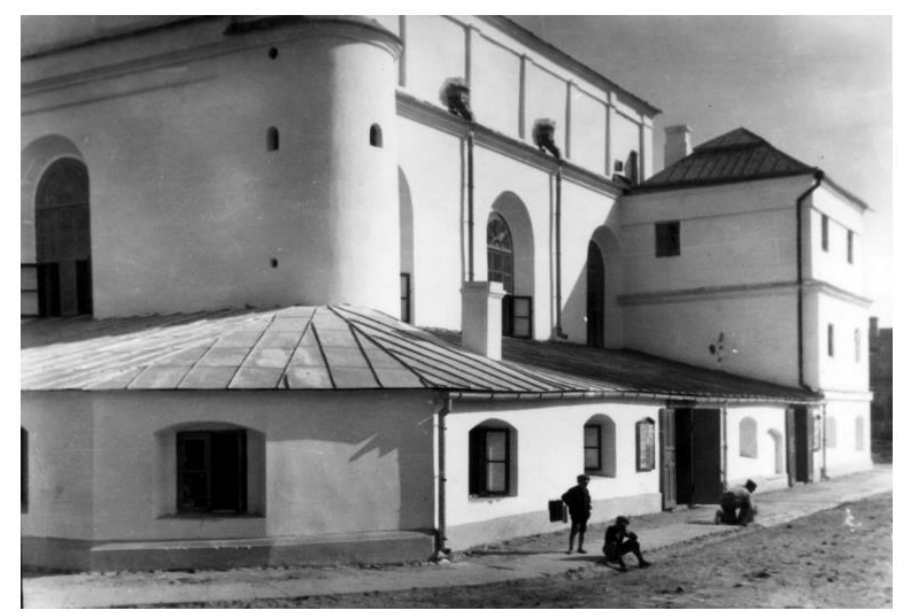

Exterior de sinagoga, Pinsk, primeiras décadas do século $\mathrm{XX}$. Fonte: Arquivo do Memorial Yad Vashem, Jerusalém, Israel www.yadvashem.org

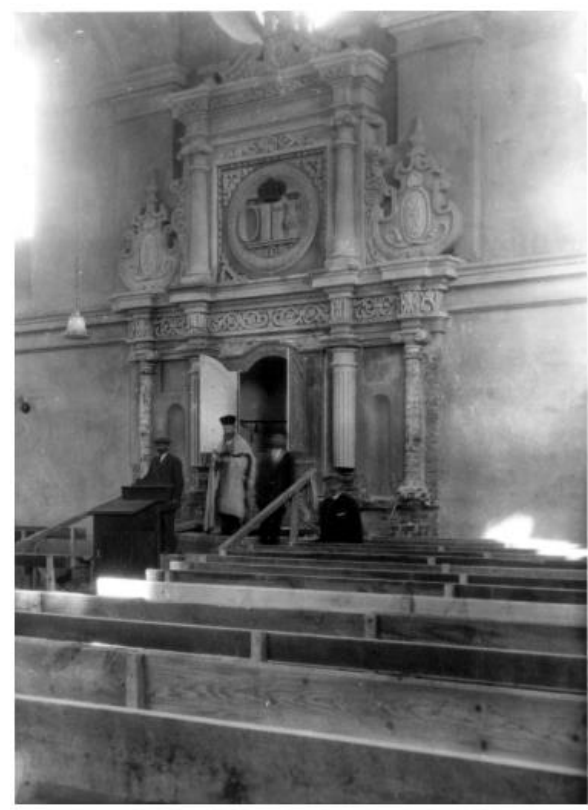

Interior de sinagoga, Pinsk, primeiras décadas do século XX. Fonte: Arquivo do Memorial Yad Vashem, Jerusalém, Israel www.yadvashem.org

No início dos anos 1930, -ou seja, quando Helena nasceu- a população judaica de Pinsk era de aproximadamente 20.000 habitantes, ou 70\% do total da cidade. Lá Abraham e Basia, os pais de Helena, eram proprietários de uma padaria que fazia pães para o Exército da Polônia. A finalidade estava no próprio nome da padaria: Padaria do Exército (Piekarnia Wojska em polonês). 
Mas a população judaica de Pinsk, assim como ocorria na maior parte das cidades do Leste europeu, não se dedicava somente às atividades comerciais ou industriais. Do ponto de vista político, por exemplo, principalmente a partir do século XIX, os membros da comunidade, sobretudo os jovens, começaram a organizar-se crescentemente em torno a alguns movimentos que visavam o retorno à Terra de Israel, tais como o socialismo judaico do Bund (Aliança ou União em ídiche), o partido religioso ortodoxo Agudath Israel e o sionismo.

\section{As escolas Tarbut e o movimento sionista}

Durante sua infância, Helena frequentou a escola Tarbut. Esta escola, cujo nome em hebraico significa cultura, era na verdade uma rede de instituições educacionais de caráter secular (não religioso) cuja língua de instrução era o hebraico. Seu público incluía não somente estudantes da pré-escola ao ensino secundário, mas também adultos aos quais eram oferecidas aulas noturnas, seminários para professores e escolas agrícolas. Contavam também com um sistema de bibliotecas além de publicarem jornais pedagógicos e livros didáticos.

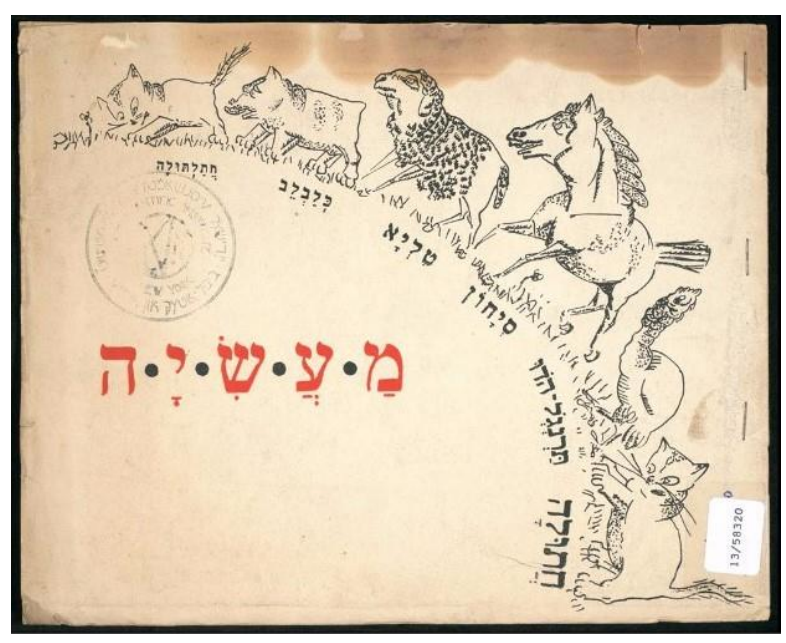

Capa do livro infantil Hataltulah she-shakhahah ekh tesh'al okhel (O Gatinho que Esqueceu como Pedir Comida), de Ben-Tsiyon Raskin. Escola Tarbut, Polônia, 1923. Fonte: The Yivo Encyclopedia of Jews in Eastern Europe: www.yivoencyclopedia.org

A ideia de uma educação secular em hebraico originou-se na Rússia no final do século XIX por iniciativa de membros do movimento Hibat Tsiyon (Amantes de Sião). Mantendo os princípios tradicionais da educação das crianças judaicas em prática desde a Idade Média (heder), incorporava as mudanças pedagógicas de essência europeia e disseminava os princípios do Iluminismo Judaico no contexto de um projeto que tinha como objetivo a independência política do povo judeu. 


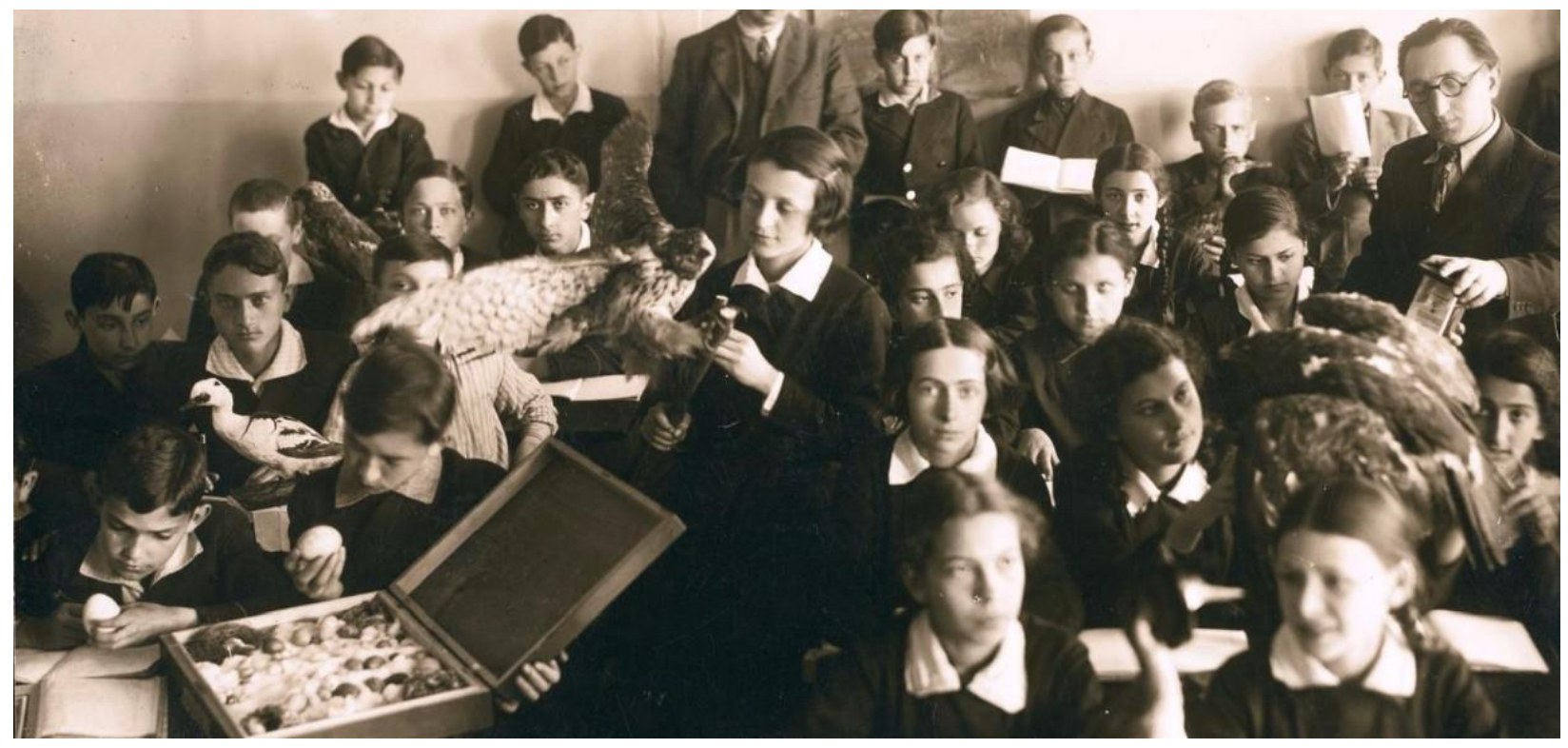

Escola Tarbut em Pinsk, 1936. Uma aula de ciências naturais.

Fonte: The Yivo Encyclopedia of Jews in Eastern Europe http://www.yivoencyclopedia.org/article.aspx/Tarbut

$\mathrm{Na}$ imagem anterior podemos ver estudantes numa aula de ciências naturais, analisando animais e ovos verdadeiros. Trata-se de uma típica sala de aula de escola Tarbut cuja pedagogia consistia em aproximar o aluno da vida em vez de uma educação baseada somente nos livros. $\mathrm{O}$ estudo da natureza tinha um papel muito importante, assim como a agricultura e os esportes. Quanto ao ensino da língua hebraica, o método era o chamado "hebraico pelo hebraico", ou seja, toda a educação se fazia sem tradução para outras línguas. A questão da língua era central para o movimento sionista, já que o retorno à terra de Israel passava pela retomada da língua hebraica, havia séculos adormecida.

Na Rússia, o governo comunista que resultou da vitória da Revolução Bolchevique decidiu em 1919 que a língua dos judeus fosse somente o ídiche, proibindo a partir daí a educação em língua hebraica. Deu-se assim o fechamento das escolas Tarbut na União Soviética.

Na Polônia, porém, desde sua independência em 1918, as escolas Tarbut estiveram ativas e no momento imediatamente anterior à Segunda Guerra, atendia a 45.000 alunos em 270 instituições localizadas principalmente ao leste do país, nos territórios que anteriormente pertenciam à União Soviética. Era o caso de Pinsk. 


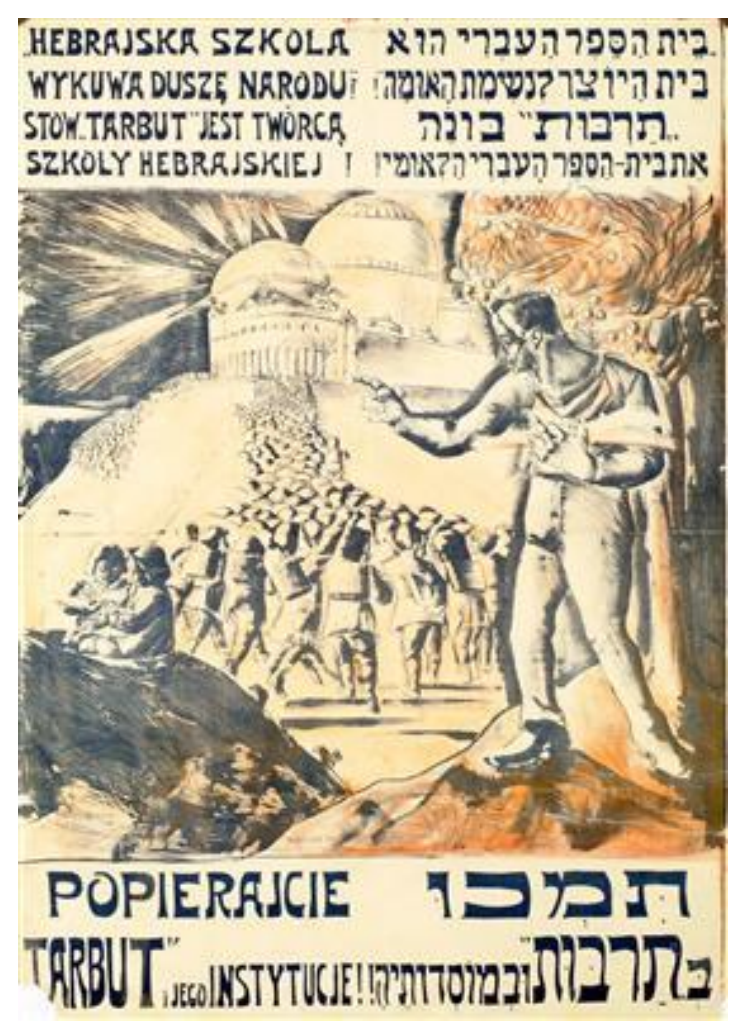

Cartaz da rede Tarbut onde se lê em polonês e hebraico:

"Apoie a Tarbut e suas Instituições. A escola hebraica é a forja da alma da nação! Tarbut constrói a escola hebraica nacional!

Fonte: The Yivo Encyclopedia of Jews in Eastern Europe www.yivoencyclopedia.org

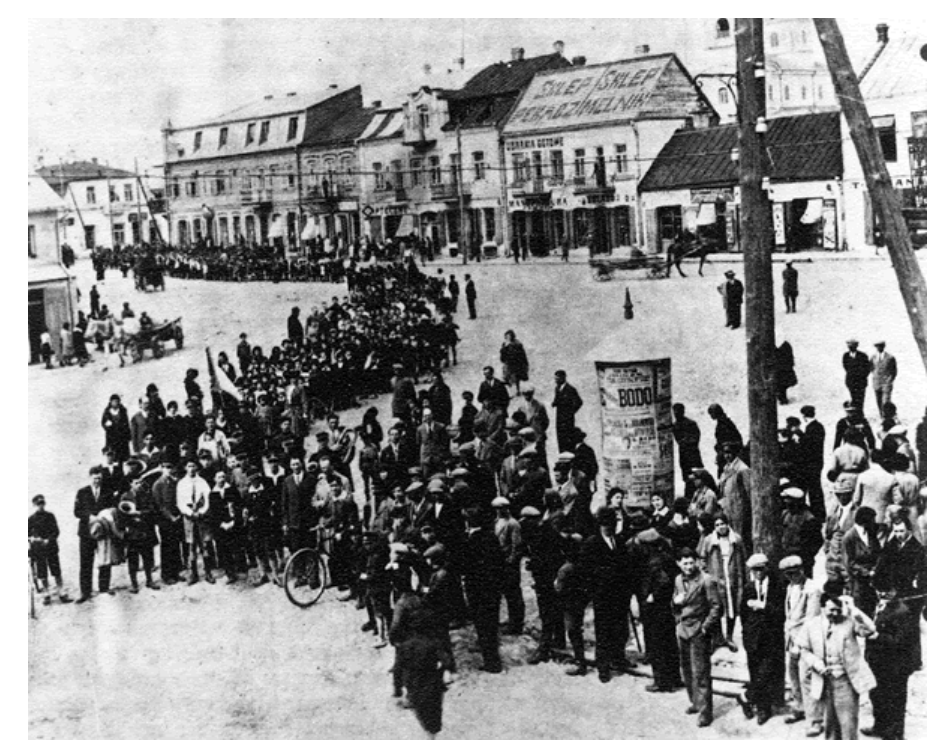

Parada de membros do movimento jovem sionista Hanoar Hatzioni.

Pinsk, primeiras décadas do século $X X$

Fonte: www.eilatgordinlevitan.com/pinsk/pinsk.html 
Como movimento político, o sionismo visava a independência política do povo judeu na Terra Santa. O maior impulso deu-se devido aos pogroms de 1881-1882 na Rússia que custou a vida de muitos judeus. Foi a partir de então que várias organizações Hibat Tsiyon iniciaram o estabelecimento de colônias judaicas na então Palestina Otomana.

Do ponto de vista intelectual, a inspiração para essas ações originou-se em parte pelos escritos do médico e ativista Leon Pinsker, especialmente em seu livro Autoemancipação ${ }^{197}$ no qual argumentava:

Não importa o quanto as nações discordem umas com as outras, quão diversos sejam seus instintos e objetivos, em relação a seu ódio contra os judeus elas dão as mãos; nessa matéria todos concordam.

Pinsker, portanto, propunha:

(...) a solução reside em encontrar meios de reajustar este elemento exclusivo à família das nações onde habitam; assim, a base da questão judaica será permanentemente removida.

Em outras palavras, os judeus deveriam ter uma nação para si mesmos.

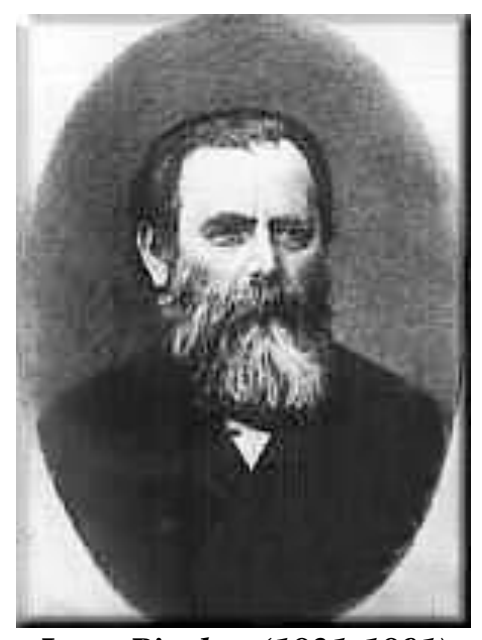

Leon Pinsker (1821-1891)

Fonte: Jewish Virtual Library www.jewishvirtuallibrary.org

${ }^{197}$ PINSKER, Leon. Auto-Emancipation. www.jewishvirtuallibrary.org/jsource/Zionism/pinsker.html, Jewish Virtual Library. 
Poucos anos depois, já no final do século XIX, a proposta sionista ganharia um maior impulso através de Theodor Herzl, jornalista austro-húngaro que em 1894 foi enviado a Paris para cobrir o caso do capitão judeu francês, Alfred Dreyfus, injustamente acusado de traição. Durante esse período Herzl testemunhou a hostilidade das massas que aos gritos de "morte aos judeus" revelavam como o antissemitismo latente na França era propagado a viva voz. Ao mesmo tempo via como em sua cidade, Viena, Karl Lüger ${ }^{198}$, político dono de um discurso fortemente antissemita o qual, entre outras ideias, pregava a proibição da imigração judaica para a Áustria, era eleito prefeito.

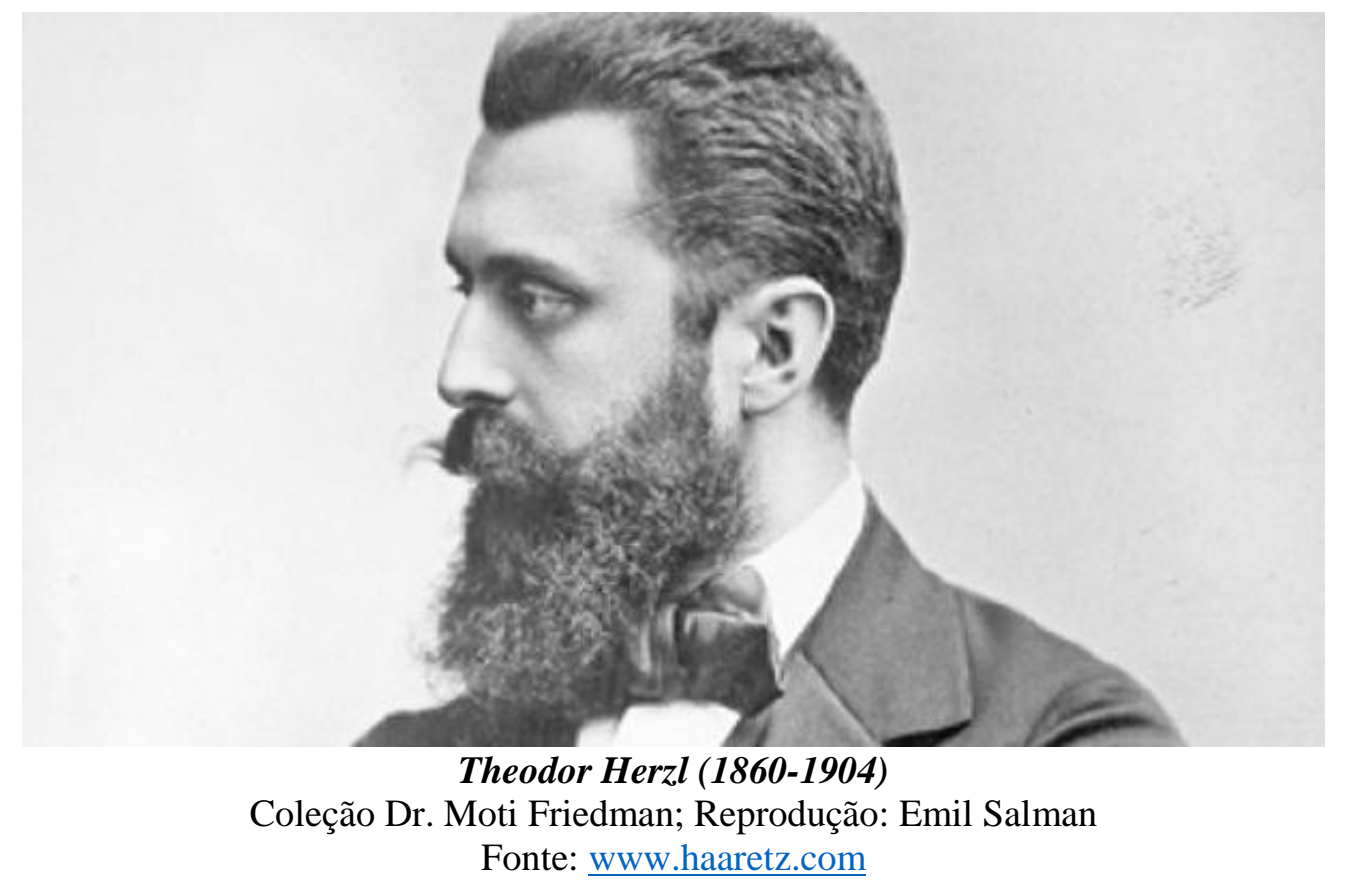

Nesse panorama, ficou claro para Herzl que o antissemitismo era uma característica imutável da sociedade europeia e através de seu livro, O Estado Judeu, apresentou suas ideias para um estado nacional.

Em 1897 conseguiu organizar na Basileia, Suíça, o primeiro Congresso Sionista e nesse âmbito fundou a Organização Sionista cujo programa declarava:

O sionismo busca para o povo judeu uma pátria legal e publicamente reconhecida na Palestina.

198 Os discursos e posteriormente as práticas antissemitas de Karl Lüger, quando chegou ao governo, tiveram uma forte influência no então jovem Adolf Hitler. 
As iniciativas de Herzl deram ao movimento sionista um caráter mais coeso do que as ações do movimento Amantes de Sião. Começou então um processo baseado em uma série de ações concretas e de um trabalho voltado tanto à atividade política quanto à conquista das comunidades judaicas ao redor do mundo para a causa. O sucesso do Primeiro Congresso motivou Herzl a escrever em seu diário:

Se eu tivesse que resumir o Congresso da Basileia em uma frase, esta seria: na Basileia eu fundei o Estado Judeu.

\section{Pinsk, do sionismo ao stalinismo}

O ambiente cultural e político impulsionado pelo movimento sionista e as escolas Tarbut no qual Helena estava se formando, viu-se interrompido em 17 de setembro de 1939, com a invasão soviética à parte oriental da Polônia, onde Pinsk estava localizada.

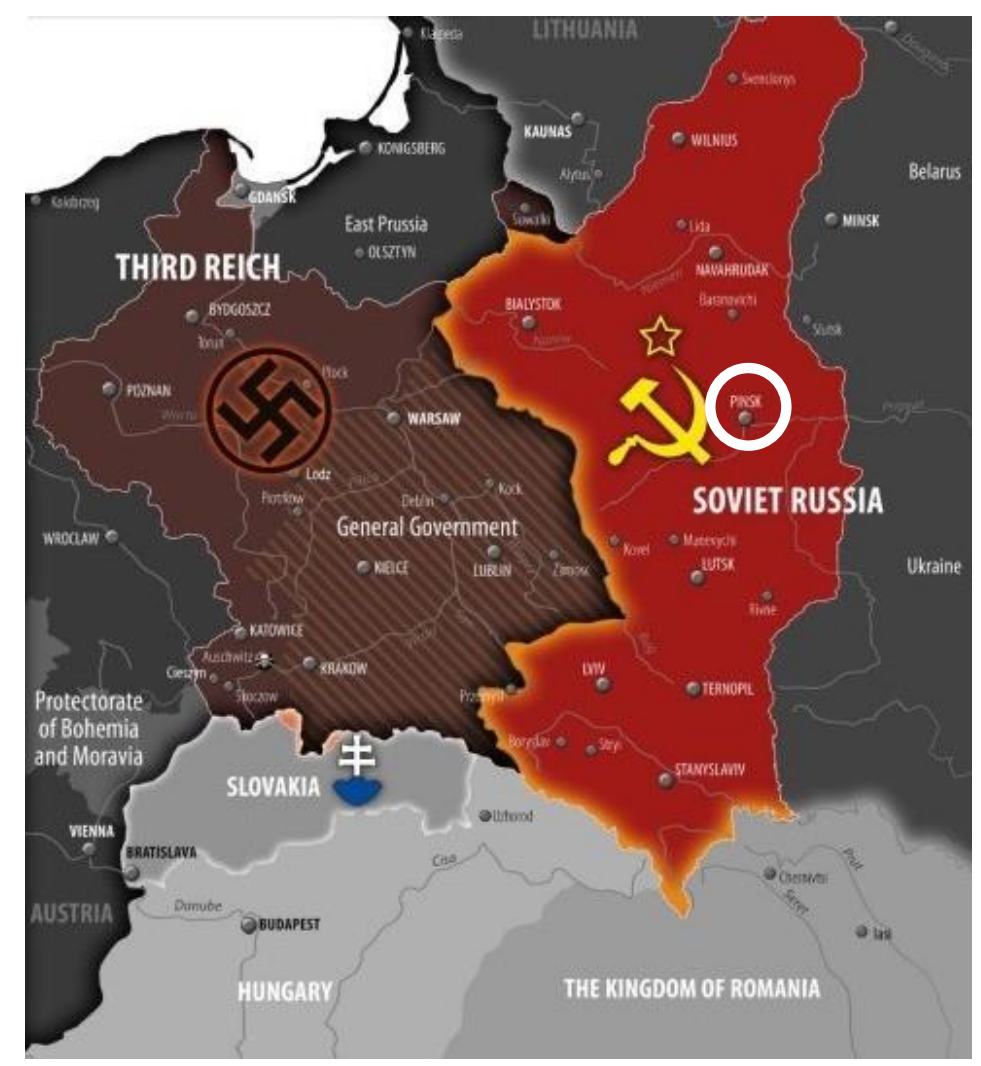

A invasão nazista e soviética da Polônia

Em destaque, dentro do círculo branco, a cidade de Pinsk

Fonte: www.mapsontheweb.zoom-maps.com 
Pouco mais de duas semanas antes, em 1 de setembro, a Alemanha havia invadido a parte ocidental do país. Esse "compartilhamento" da Polônia pelas duas grandes potências era resultado do Pacto Ribentropp-Molotov assinado entre os dois países.

No caso específico da comunidade judaica, todas suas instituições e organizações políticas e culturais foram desmanteladas. $\mathrm{O}$ ensino da língua hebraica nas escolas foi proibido e o ídiche foi declarado a língua de instrução para os judeus. Os autores hebraicos e mesmo o estudo da Bíblia foram banidos. O currículo escolar foi reformado e os livros didáticos foram substituídos com exemplares soviéticos. Nas bibliotecas, todos os volumes deveriam ser em russo, retirando-se todos os demais.

A atividade política judaica também foi proibida e seus partidos e movimentos passaram para a ilegalidade. Ao mesmo tempo, propagou-se uma intensa propaganda antirreligiosa.

Foi então através da língua que Helena, então somente com 9 anos, começou a sentir que alguma coisa havia mudado. Mas como ela mesma conta, as crianças foram adaptando-se já que o ídiche era para todos a língua falada em casa com a família.

Nos meses seguintes, porém, as escolas foram rapidamente entrando no que Helena chama de "atmosfera soviética": as paredes das salas de aula tinham retratos de Stalin, Lenin, Marx e Engels, o currículo escolar foi modificado e mais tarde, mesmo nas escolas judaicas, a língua de instrução passou a ser o russo.

A partir daí as perseguições passaram a ser constantes sob o mando soviético, assim como as acusações e prisões dos chamados "inimigos do povo". Helena lembra também o intenso trabalho de doutrinação de crianças e jovens; sem perceber, como ela mesma comenta, foi ficando fascinada pelo líder tal como era retratado pela escola e ao tomar algumas decisões pensava, "o Stálin vai adorar!".

Em 1941, quando chegaram as férias, Helena foi para um acampamento da escola. Sua mãe a levou para a estação e ao despedir-se lhe disse: "Hayale, se estourar uma guerra, não corra para Pinsk. Vá para a casa de seu tio Srulik". Helena achou que a mãe estava exagerando, afinal ainda menina, não entendia nada de política e obviamente, uma guerra não estava no seu horizonte. 


\section{De Pinsk a Kamenets-Podolski}

Iniciava-se então um período de intensas mudanças na vida de Helena. Em questão de dias, seu destino oscilava de uma cidade para outra, de um grupo de familiares para outro. Apesar do pânico e da incerteza, porém, foram esses vaivéns que garantiram sua sobrevivência.

A onda de nacionalizações e desapropriações ordenadas pelos soviéticos já havia provocado a partir de setembro de 1939 um forte impacto para vários familiares de Helena. Seu tio paterno, Srulik Kuper, assim como muitos outros empresários e proprietários de imóveis, foi forçado a abandonar Pinsk. Junto com sua família Srulik reinstalou-se na cidade de KamenetsPodolski, próximo a Lvov, na região de Volyn, na Polônia.

Durante o ano entre a partida e o início da guerra, tio Srulik manteve contato por carta regularmente com os pais de Helena. Aos poucos as famílias iam analisando as possibilidades caso a guerra acontecesse.

Quando Helena voltou do acampamento, ainda de férias, a menina ficou sabendo da decisão tomada por seus pais: iria morar com seus tios e sua prima Sonia, apenas um ano mais velha, para ficar em maior segurança. Além disso, as duas meninas fariam companhia uma para a outra.

Assim, Helena partiu rumo a Kamenets-Podolski acompanhada por uma vizinha, Lea Dolinko e sua filhinha. Ela era muito conhecida de ambas famílias e uma pessoa de total confiança.

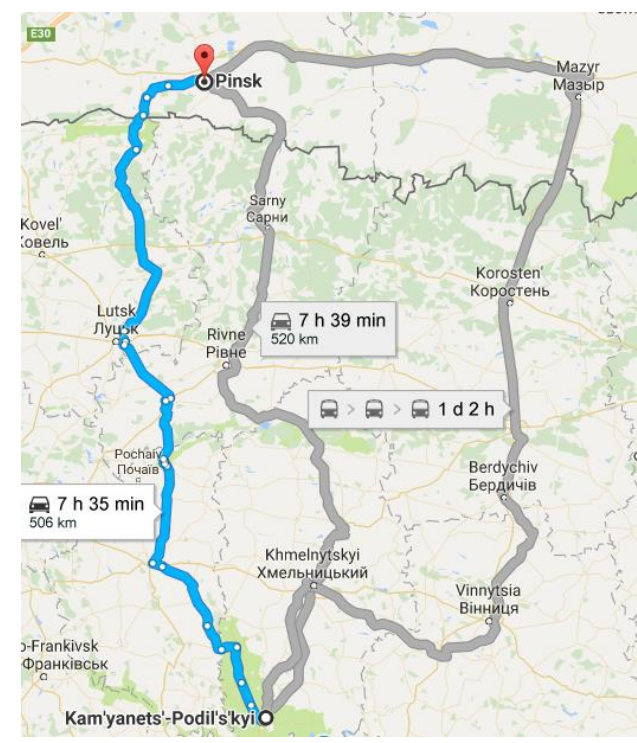

Mapa que mostra o trajeto entre Pinsk e Kamenets-Podolski

Fonte: Google Maps 
Já em Kamenets-Podolski, alguns dias depois de sua chegada, Helena lembra que na manhã do dia 22 de junho de 1941, toda a população da cidade foi acordada por alto-falantes que pediam aos moradores que ligassem seus rádios para ouvir o pronunciamento do Ministro de Relações Exteriores Vyacheslav Molotov, o mesmo que havia assinado o Pacto de Não Agressão em nome da União Soviética. Na transmissão, ele anunciava:

Cidadãos da União Soviética,

O Governo Soviético e seu chefe, o Camarada Stálin, autorizaram-me a fazer a seguinte declaração.

Hoje às 4:00 da manhã, sem apresentar qualquer reivindicação à União Soviética, sem uma declaração de guerra, tropas alemãs atacaram nosso país, atacaram nossas fronteiras em vários pontos e bombardearam pelo ar nossas cidades (...).

Este ataque inaudito sobre nosso país é uma traição sem paralelo na história das nações civilizadas. $\mathrm{O}$ ataque ao nosso país foi perpetrado apesar do fato de haver um pacto de não-agressão entre a União Soviética e a Alemanha e de que o governo soviético seguiu todas as estipulações do tratado. ${ }^{199}$

\section{Nova mudança}

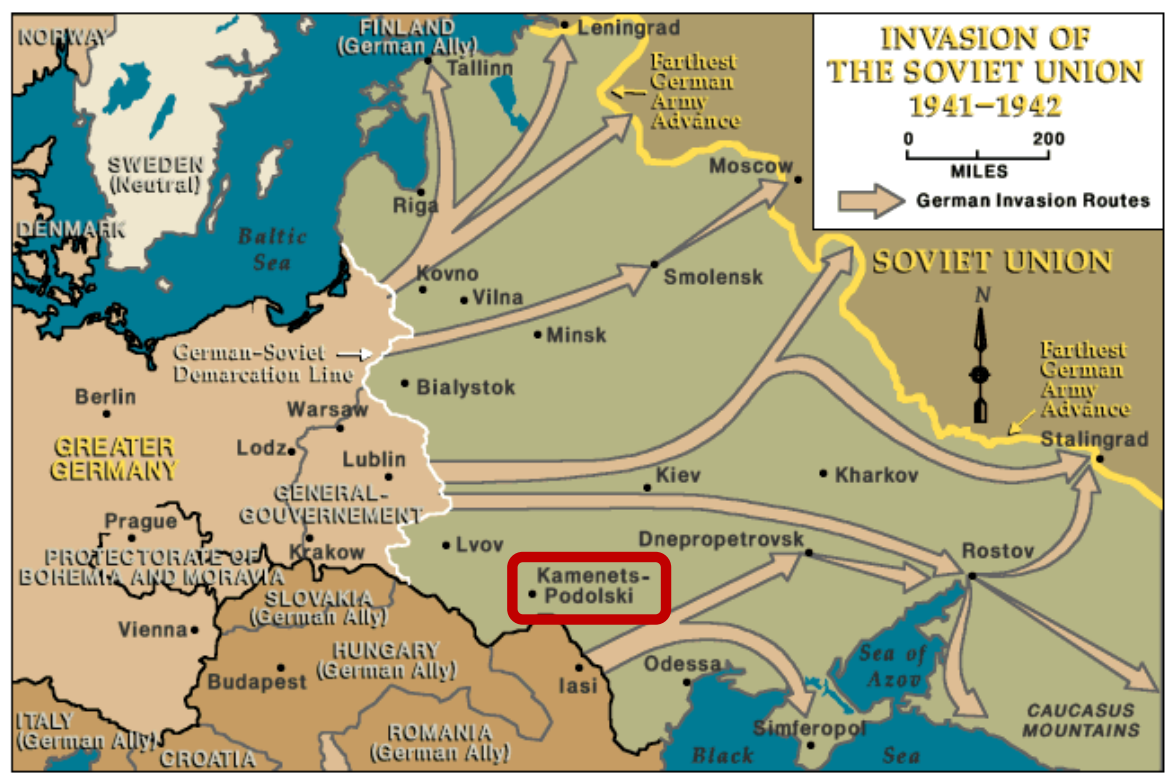

Rotas da Invasão da Alemanha à União Soviética

Em destaque, Kamenets-Podolski, cidade onde Helena morava com seus tios. Fonte: United States Holocaust Memorial Museum (USHMM)

${ }^{199}$ Mesmo que você não entenda russo, é interessante sentir a gravidade do momento na voz de Molotov e nos rostos dos habitantes de diferentes localidades no seguinte vídeo: https://www.youtube.com/watch?v=69uNxX04y44 
A guerra que a mãe de Helena temia havia chegado até eles. Com a invasão alemã, porém, tio Srulik e sua esposa Chava, ficaram numa terrível dúvida: o que era mais adequado para Helena? Mandá-la de volta para Pinsk ou mantê-la com eles em casa? Kamenets-Podolski estava muito próximo à fronteira por onde a Alemanha estava invadindo. Helena também não sabia o que fazer já que a mãe tinha pedido que ela não voltasse porque achava que estaria mais segura com os tios. Mas estava decidido: menina voltaria novamente para seus pais.

Helena, Lea Dolinko e a sua filhinha, foram para a estação para iniciar a viagem de trem de volta para Pinsk. O trem estava cheio; todo o mundo parecia estar correndo de algum lugar para algum lugar. Mesmo assim, elas conseguiram entrar. Logo depois da primeira parada, souberam que os trilhos haviam sido bombardeados mais adiante e não era possível continuar. No entanto, foram informadas que ainda havia um trem saindo para Stolin, cidade não muito distante de Pinsk.

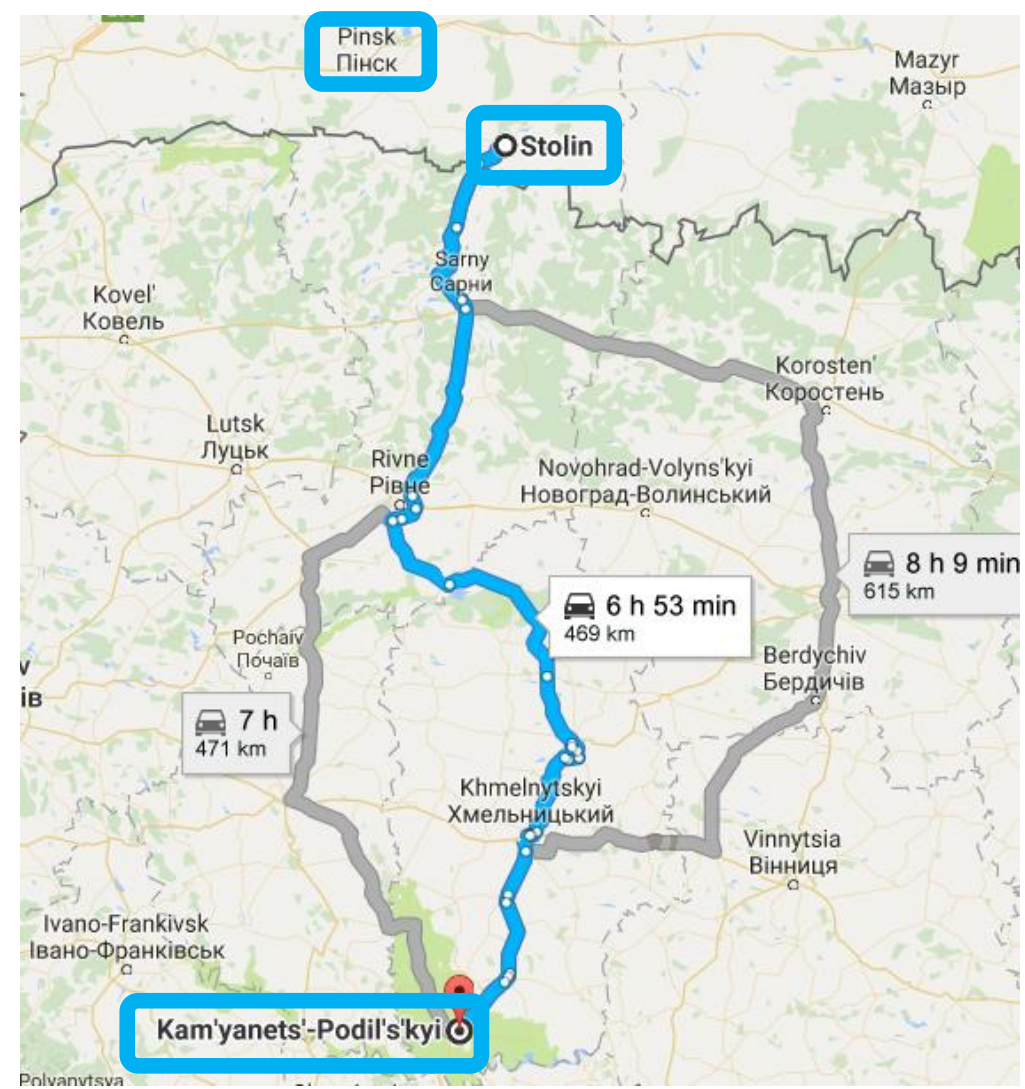

Mapa que mostra o novo trajeto de Helena em busca de sua sobrevivência.

Em destaque nos retângulos, Pinsk, Stolin e Kamenets-Podolski

Fonte: Google Maps 
Em Stolin, a comunidade judaica local, através de sua Kehilah (congregação) estava muito bem organizada e recebia a todos aqueles que estavam fugindo em direção à fronteira com a União Soviética. Helena e suas acompanhantes foram acolhidas na sinagoga com comida e abrigo.

As pessoas que buscavam refúgio em Stolin, muitas delas provenientes de Pinsk, informavam sobre a situação na cidade natal de Helena. Foi através deles que ela soube estava, por assim dizer, correndo na direção contrária à do restante dos refugiados. Decidiram então ficar por mais tempo em Stolin.

\section{A chegada dos alemães a Pinsk}

Enquanto Helena estava em Stolin, nos primeiros dias de julho de 1941, membros das forças invasoras da Alemanha nazista chegavam a Pinsk. Eles ocuparam a maioria dos prédios públicos, inclusive escolas, e os transformaram em quartéis e barracões para seus oficiais e soldados.

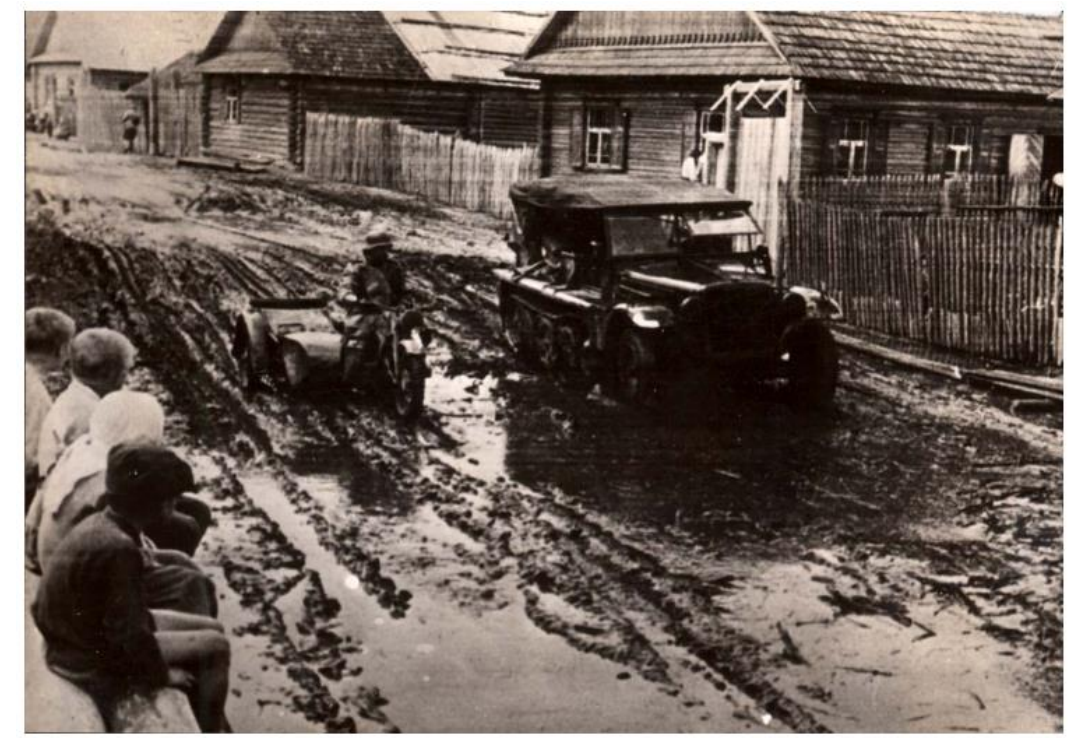

Soldado alemão em motocicleta em uma rua de Pinsk, julho de 1941 Fonte: Lester Hajenina, Coleção Yad Vashem www.yadvashem.org

A perseguição aos judeus de Pinsk também começou imediatamente. Já no dia 5 de julho, 16 judeus foram capturados e executados na floresta de Leszcze, próxima à cidade. No dia 30 de julho de 1941 foi dada a ordem para o estabelecimento de um Judenrat (conselho judaico) que 
faria a intermediação entre a comunidade judaica e as autoridades alemãs. O diretor da escola Tarbut de Pinsk, David Alper foi nomeado chefe do Judenrat, mas dois dias mais tarde renunciou ao perceber que seu papel não seria o de negociar com os alemães mas apenas ode obedecer suas ordens.

Entre os dias 5 e 7 de agosto, portanto apenas um mês após sua chegada à cidade, os soldados e policiais alemães Einsatzgruppen em uma ação totalmente planejada, como mostram decretos e documentos emitidos pelas próprias autoridades alemães encarregadas da região, assassinaram aproximadamente 8.000 judeus da cidade, entre eles David Alper e mais 20 membros do Judenrat.

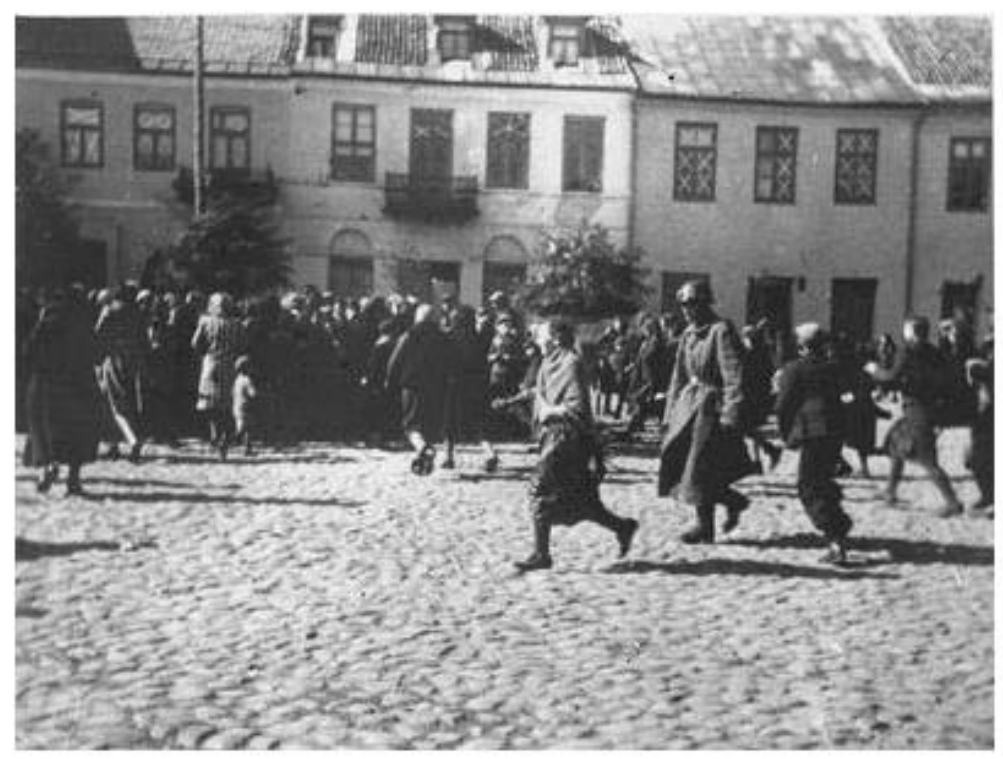

Perseguição a judeus por soldados alemães (Aktion), Pinsk

Fonte: Lester Hajenina, Coleção Yad Vashem www.yadvashem.org

\section{Notícias da família em Pinsk}

Em Stolin, Helena, então com onze anos, encontrou uma vizinha e colega da Escola Tarbut quem lhe deu uma péssima notícia: seus pais haviam sido capturados pelos soviéticos alguns dias antes da invasão alemã e enviados no último comboio de trens para a Sibéria. Ela havia sabia, porém, que essa última caravana havia sido bombardeada e que ninguém sobreviveu. O mundo de Helena caiu. De repente ela se viu sozinha e sem um lugar para onde ir. 
Dias depois, chegou ao seu abrigo um camponês com uma carta para Helena vinda de uma localidade próxima chamada David Gorodok (Dawigrodek em polonês). Era d irmão de sua mãe, Avraham Neiman, que morava naquela cidade. A Kehilah que estava tomando conta dela em Stolin havia feito o contato e seu tio mandou buscá-la. Helena seguiu para mais uma etapa em busca de refúgio, desta vez em David Haradok.

Devemos lembrar que estamos no início da década de 1940, portanto as comunicações eram lentas e feitas principalmente por carta ou mensageiros. Os telefones eram raros. Portanto, é de se destacar o papel das congregações judaicas em organizar a busca por familiares e o contato entre essas pessoas, principalmente crianças, que como Helena, muitas vezes ficavam perdidas em meio à perseguição e ao conflito.

\section{De Stolin a Davyd Haradok}

Davyd Haradok é uma cidade pertencente ao distrito de Stolin, na Polônia -hoje Biolerússia- próxima à fronteira com a União Soviética. Desde 1523, residia ali uma ativa comunidade judaica. Na década de 1930, a localidade abrigava aproximadamente 4.500 judeus dedicados a várias atividades. O tio de Helena, por exemplo, era um atacadista de grãos. A família de sua esposa, Dvora, tinha uma grande loja de tecidos e aviamentos.

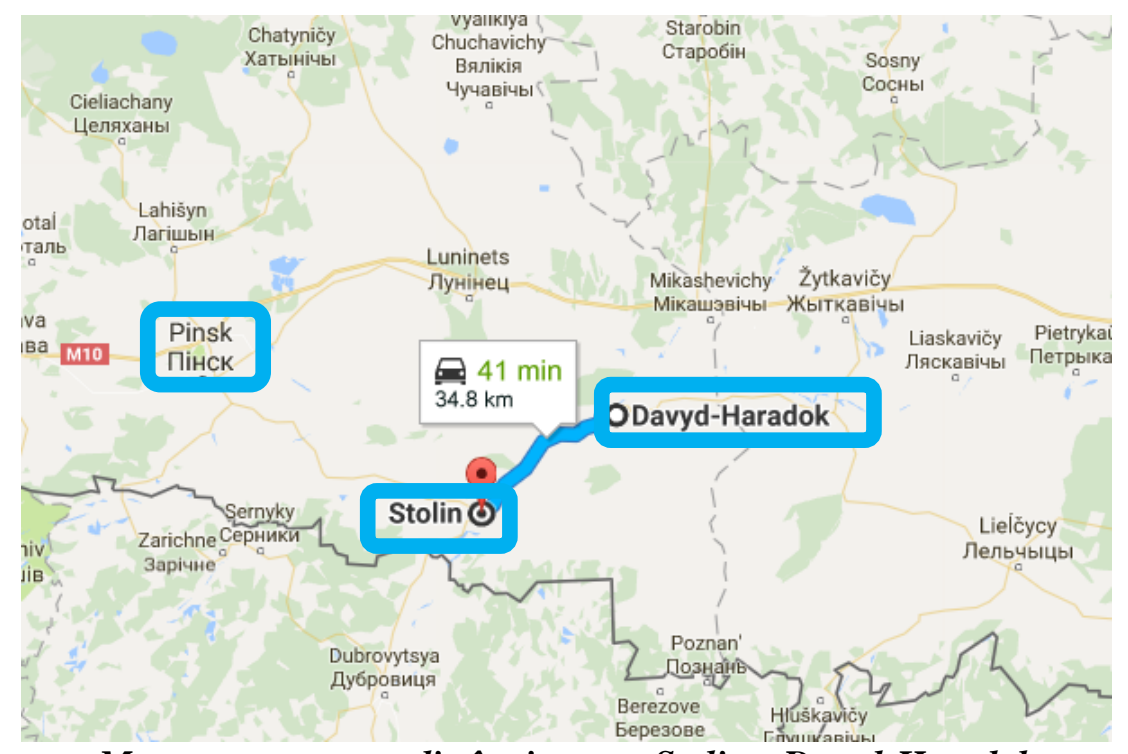

Mapa que mostra a distância entre Stolin e Davyd-Haradok

Em destaque, além das duas cidades, vemos Pinsk.

Fonte: Google Maps 
A menos de uma semana da chegada de Helena a David Haradok, as Aktions (ações) de perseguição aos judeus por parte dos Einsatzgruppen começaram também naquela cidade. Não era coincidência nem falta de sorte de Helena. A perseguição aos judeus por parte dos invasores alemães era constante, rápida, indiscriminada e estendia-se a todo e qualquer canto da Europa onde eles estivessem.

No dia 10 de agosto de 1941, alto-falantes chamavam todos os homens acima de 14 anos para que se dirigissem à praça da cidade. Helena lembra que tio Avraham, sem conhecer o propósito do chamado foi para lá. Naquele mesmo dia, com a ajuda de policiais locais, todos os homens que compareceram à praça foram executados.

Helena, tia Dvora, suas duas filhas e seu irmão -que não atendeu ao chamado dos alemães- passaram a noite escondidos atrás de uma parede falsa que a família havia construído no setor de estoque da loja. De lá eles ouviram os tiros.

Pouco depois veio o aviso para que todas as mulheres e crianças judias saíssem da cidade. Todas suas posses foram tomadas, mas a preocupação de tia Dvora era seu irmão, que não havia se apresentado na praça no dia anterior. Se ele fosse descoberto seria morto imediatamente. A solução encontrada foi vesti-lo de mulher.

Assim, junto com um grande grupo de mulheres e crianças começaram então a caminhada pela estrada que conduziria Helena de volta para Stolin. Mesmo não sendo muito distante, descalças e com fome, levaram dias para chegar ao destino. Algumas pessoas davam água e comida no caminho. Outros os abrigavam em suas casas ou estábulos -como foi o caso de Helena- para que lá passassem a noite.

Ao chegarem a Stolin, a mesma congregação que havia ajudado Helena, veio ao auxílio do grupo. Através de outros testemunhos de sobreviventes sabemos que foram os próprios membros da congregação que se organizaram para subornar os alemães e assim poder levar as mulheres sobreviventes de Davyd Haradok para Stolin:

Tentamos acomodar as pobres mulheres e crianças. Compartilhamos com eles nossas casas, escolas, sinagogas, todo lugar público. Todos os celeiros estavam repletos. O maior problema era a comida. Todos tentavam preparar o máximo de comida que 
podiam para os dias horríveis que esperavam por nós. Não havia tempo para pensar nisso.

Dividimos com elas tudo o que tínhamos. ${ }^{200}$

Em poucos meses também os judeus de Stolin entrariam na rota de destruição da Alemanha nazista. Em maio de 1942 foi criado na cidade um gueto, onde passaram a morar 7.000 judeus cercados por arame farpado por todos os lados. Em 10 de setembro do mesmo ano, todos os membros do Judenrat de Stolin foram capturados e executados. Ao pôr do sol, o gueto foi cercado e aqueles que fossem vistos tentando fugir eram mortos ali mesmo. Ao amanhecer, os moradores do gueto foram sendo levados em grupos de 500 para uma floresta próxima onde havia uma grande vala. Lá mesmo, à beira da vala, eram assassinados a tiros. As execuções continuaram até o fim da noite. ${ }^{201}$

\section{Helena volta a Pinsk}

Ainda em 1941, Helena recebeu outra carta, desta vez de seu tio Srulik com quem ela havia ido morar logo depois de deixar a casa de seus pais. Ele estava voltando para Pinsk. Ao saber que Helena estava em Stolin, pagou a um mensageiro para ir buscá-la. Porém, enquanto tio Srulik não chegava a Pinsk, Helena ficaria com a família de outro irmão de sua mãe, Herschel Neiman.

Quando Helena chegou a Pinsk, Herschel já não estava em casa. Havia sido levado junto com os demais homens judeus de Pinsk para serem executados. No entanto, ele conseguiu escapar dos tiros e uma noite voltou para casa.

Em 1 de maio de 1942, os alemães estabeleceram o gueto onde os aproximadamente 10.000 judeus da cidade que haviam sobrevivido à massacre de agosto de 1941 passaram a morar.

A essa altura, tio Srulik e sua família estavam de volta em Pinsk e Helena foi novamente morar com eles no quarto que lhes foi atribuído no gueto. Cada quarto da casa onde ficaram era para uma família e a cozinha era comum.

\footnotetext{
${ }^{200}$ Carta do sobrevivente Michael Nosanchuk a Boris Nosanchuk escrita em 11 de janeiro de 1946 na qual são relatados os detalhes das perseguições nas cidades de Stolin, Rubele e David Haradok. In, Stolin, Belarus. The Shtetl and Its People. http://kehilalinks.jewishgen.org/stolin/account nosanchuk letter.php

${ }^{201}$ Memórias de Shammai Tokel, The Last Days of the Ghetto in Stolin (Os últimos dias do gueto em Stolin) http://www.jewishgen.org/yizkor/Stolin/sto208.html
} 
Mesmo naquela precária situação e como não havia escola, tio Srulik contratou uma professora para dar aulas para Helena e sua prima Sônia. Elas tinham aulas de Hebraico e de Geografia, entre outras.

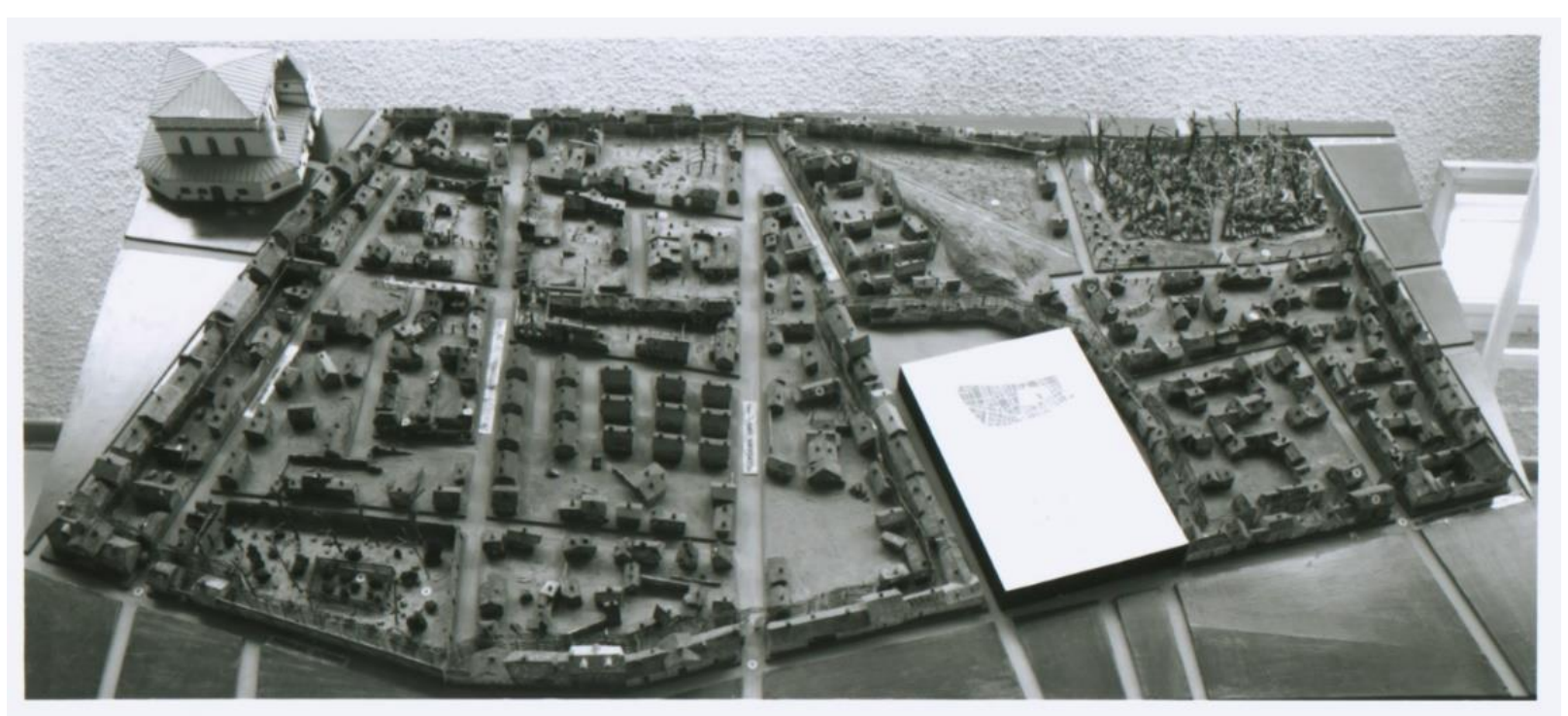

Maquete do gueto de Pinsk

Em exibição no museu Lochame Hagetaot, Haifa, Israel

Fonte: The Jewish Community of Pinsk www.pinskjews.org.il

Nos cinco meses em que Helena esteve no gueto, havia as chamadas Ratzie (razias) nas quais os alemães procuravam idosos e crianças. Helena e sua prima permaneciam então parte do tempo escondidas. Durante o dia, todos trabalhavam, inclusive crianças como Helena. Ela estava encarregada de várias atividades como cozinhar e carregar água de uma bomba que havia a alguns quarteirões de casa. Era nessas idas para a bomba que Helena conheceu Yossele Kolodny, um dos maiores músicos do teatro ídiche que, como ela, era de Pinsk. Ele a ajudava a carregar água.

Periodicamente, na casa de Helena havia reuniões secretas onde moradores do gueto combinavam ações de resistência. Nessas reuniões havia vários membros do movimento sionista que chegaram inclusive a preparar algumas bombas caseiras que ficavam escondidas em uma espécie de bunker, cavado pelos próprios moradores, dentro da casa. 


\section{A fuga do gueto}

Um dia, cinco meses depois do estabelecimento do gueto, o tio Srulik chegou do trabalho mais cedo. Ele pediu para sua esposa ajudar Helena e Sônia a se vestirem e informou a todas sobre um endereço. Elas deveriam sair separadamente, como se fosse para trabalhar, e ir até lá. O endereço era na última casa da rua. Essa era a casa de uma mulher católica polonesa, Theodora Fiodorchenko, com quem o tio de Helena havia negociado a permanência em troca de joias e relógios de ouro que ele ainda guardava. Como a liquidação do gueto era iminente, a mulher concordou em tê-los em sua casa por uma ou duas semanas.

No dia 27 de outubro de 1942 Himmler ordenou diretamente ao comandante da SS e polícia local Hans-Adolf Prützman que liquidasse o gueto:

Instruo a liquidar e destruir o gueto em Pinsk completamente, embora haja considerações econômicas contra essa decisão. Se a Aktion permitir separe [entre a população do gueto] uma força de 1.000 trabalhadores homens e disponibilize-os ao exército para a construção de abrigos de madeira. Contudo, esses 1.000 trabalhadores devem ser colocados para trabalhar somente em um campo fechado e cuidadosamente guardado. Se tal vigilância não puder ser garantida, eles também devem ser exterminados. ${ }^{202}$

Como a liquidação vinha sendo planejada, na verdade, desde setembro, as autoridades alemãs na cidade tiveram tempo de fazer os preparativos necessários. Foi assim que ordenaram que sete grandes valas fossem cavadas no terreno de um aeroporto abandonado a aproximadamente três quilômetros de Pinsk.

Na manhã de 29 de outubro de 1942, às 6:30 da manhã, ordenou-se a todos os judeus do gueto que se reunissem num local próximo ao cemitério judaico. Lá mesmo, por volta de 400 foram separados para trabalhar posteriormente em várias tarefas. Os demais tiveram que entregar

202 Ordem emitida e assinada por Himmler a Hans-Adolf Prützman. Relatórios de investigação, acusações e vereditos nos julgamentos de membros do Batalhão de Polícia 306, 1963, Arquivo Yad Vashem, YVA, TR- 10/790, p. 126. In, Tikva Fatal-Knaani, "The Jews of Pinsk through the Prism of New Documentation", Yad Vashem, http://www.yadvashem.org/download/about_holocaust/studies/FatalENGPRINT.pdf 
seus pertences e seguirem em fileira para um lugar determinado. Cerca de 10.000 judeus foram assassinados naquele mesmo dia. ${ }^{203}$

Foi das janelas da casa da Sra. Fiodorchenko que Helena e os demais viram como todos os judeus do gueto de Pinsk eram levados para a morte.

\section{A vida no esconderijo}

Ao ver os judeus sendo levados, o desespero tomou conta da Sra. Fiodorchenko já que percebeu que seus "hóspedes" não tinham para onde ir e, portanto, teria que ficar com eles em sua casa. $\mathrm{Na}$ verdade, o risco para ela era também considerável, porque se os alemães descobrissem que ela abrigava -mesmo que fosse por dinheiro- judeus em casa, a punição seria muito séria.

O tio de Helena teve então a ideia de que a família, que contava com seis pessoas, fosse temporariamente para o porão. Porém, o que era para ser um refúgio de uma semana acabou tornando-se uma estadia de 21 meses.

À medida que o tempo passava, como o grupo estava impossibilitado de deixar o esconderijo, o nervosismo de Theodora ia aumentando e se tornava muito perigoso; a ameaça de que ela entregasse o grupo era muito grande, mesmo depois que o tio de Helena entregou a ela tudo o que tinha. Graças ao padre da igreja que Theodora frequentava, a situação pôde ir sendo contornada.

Em 1944, com a aproximação do exército soviético a Pinsk, Theodora começou a mudar de ideia. Ela percebeu que seria útil ter como provar que havia ajudado alguém durante a guerra. No dia 14 de julho do mesmo ano, as forças soviéticas tomaram Pinsk. Após 630 dias num pequeno quarto com mais cinco pessoas, Helena finalmente estava livre. Porém, as comunidades

judaicas de Pinsk, Stolin e David-Haradok, assim como milhares de outras espalhadas por todo o leste europeu não mais existiam.

${ }^{203}$ Idem. 


\section{Reencontros e recomeços}

Um dos momentos mais comoventes para Helena foi o reencontro com seus pais. Se bem era verdade a informação de que eles haviam sido deportados para a Sibéria pela polícia secreta soviética, a NKVD, antes da invasão de Pinsk pela Alemanha nazista, o que a menina não sabia era que seus pais e seu irmão haviam sobrevivido.

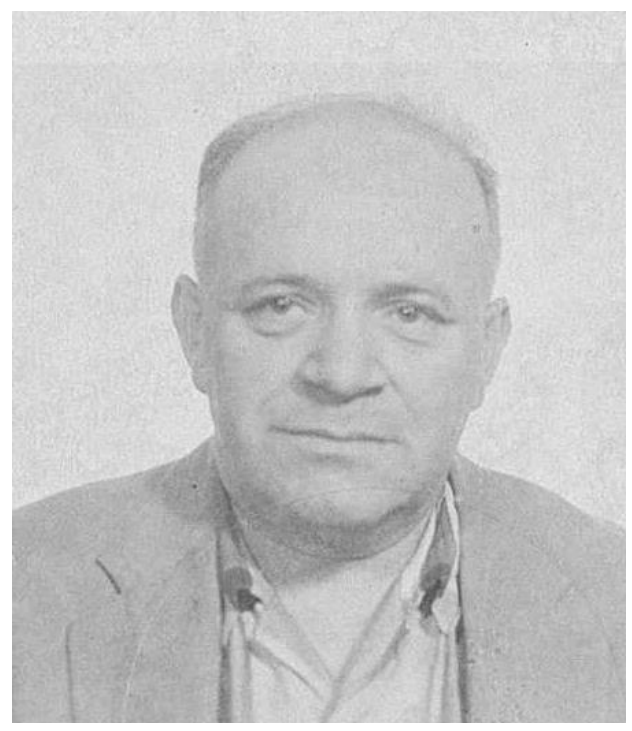

Abraham Kuper

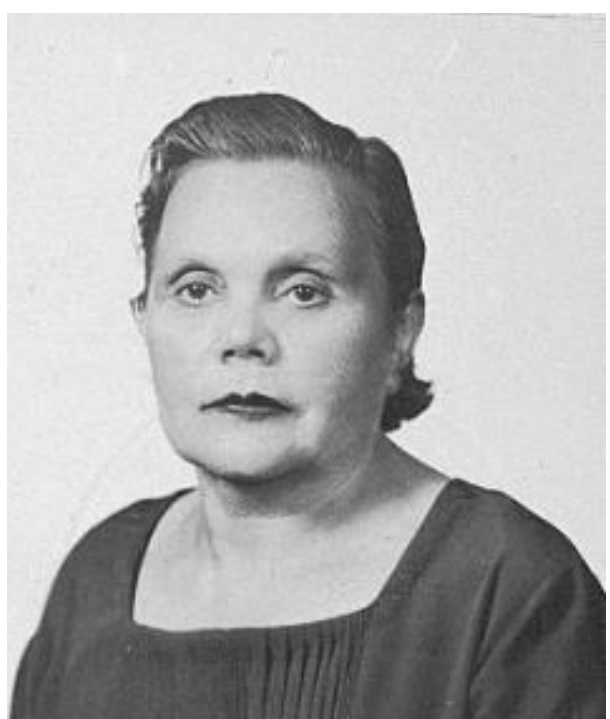

Basia Kuper

Fotografias reproduzidas das Fichas Consulares de Imigração, Brasil, 1956

Fonte: www.familysearch.org

Essas deportações -embora não fosse esse o objetivo de Stalin dado seu forte antissemitismo- acabaram salvando a vida de muitos judeus poloneses, ao menos aqueles que conseguiram resistir às terríveis condições dos gulags $^{204}$ e à rotina de trabalhos forçados imposta pelas autoridades soviéticas, já que milhares sucumbiram ao frio, à fome e aos maus-tratos.

${ }^{204}$ Gulag: Sistema de campos de trabalho mantidos pela União Soviética e usado principalmente para prisioneiros políticos ou aqueles que eram considerados "inimigos do regime". 


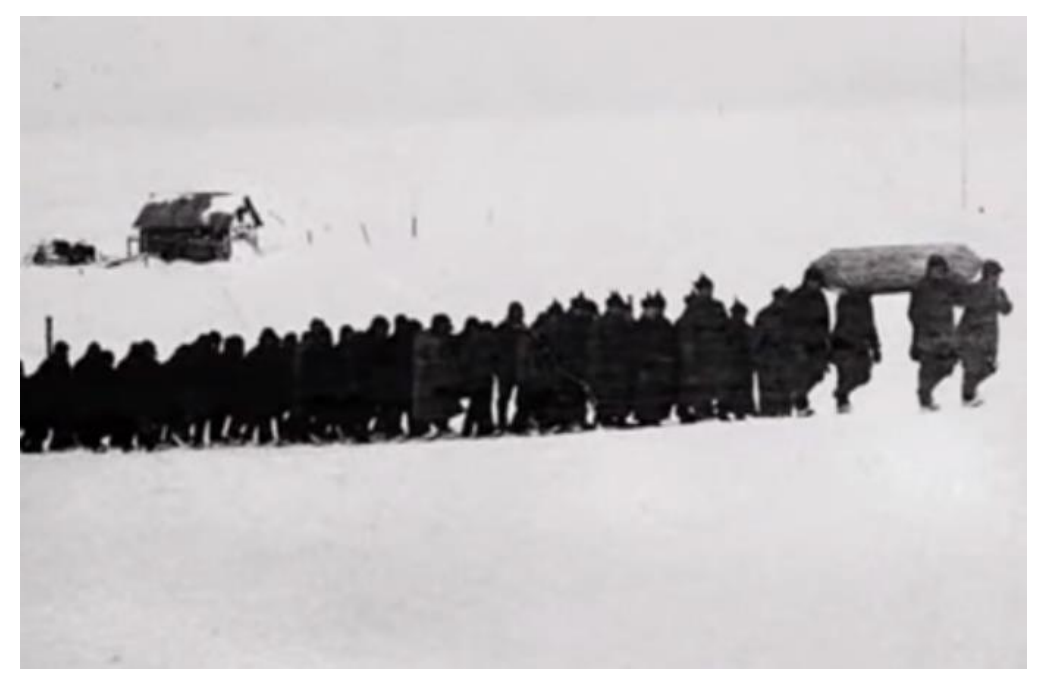

Trabalhos forçados no rigoroso inverno da Sibéria.

Fonte: Captura de tela do documentário "Saved by Deportation" Slawomir Grunberg e Robert Podgursky, 2007

Estima-se que, sob as ordens de Stalin, aproximadamente 300.000 judeus foram deportados dos territórios do leste da Polônia ocupados pelas forças do governo comunista, para as profundezas da União Soviética.

Entre eles estava o filósofo e autor judeu Julius Margolin. Nascido em Pinsk, como Helena, e deportado a Sibéria, Margolin escreveu suas memórias que resultaram numa importante obra até hoje considerada por críticos como a mais profunda análise sociológica do gulag $^{205}$. Ele também fez profundas reflexões sobre o antissemitismo ao qual chamava de o "paradoxo do ódio" que identificou nos "antissemitas que não podem viver sem os judeus". Sionista convicto, Margolin viveu em Tel-Aviv, Israel até sua morte, aos 70 anos de idade.

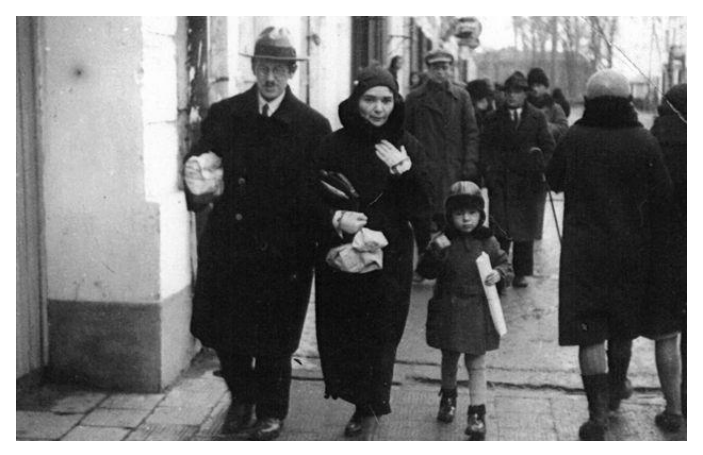

O filósofo Julius Margolin e sua família antes da guerra.

Fonte: $\underline{w w w . f o r w a r d . c o m}$

${ }^{205}$ Seu livro foi relançado em 2011 em vários países com o título A Journey to the Land of the Ze-Ka (Uma Viagem à Terra dos Ze-Ka). Ze-Ka era o nome dado aos prisioneiros dos Gulag. 
Com o fim da guerra, aos poucos, a vida de Helena e de sua família, agora novamente reunida, foi tomando forma. Os 630 dias no pequeno porão, contudo, tinham cobrado um preço e Helena não conseguia se movimentar com naturalidade. Foi necessário fazer aulas para ensiná-la novamente a andar e correr.

A princípio a família passou a morar numa casa abandonada que as novas autoridades lhes atribuíram. Tinham até uma vaca! Ela foi chamada de Murca. Helena passou também a frequentar a escola. Mas o pai de Helena sabia que para os judeus, viver sob o governo de Stalin não era seguro. Por outro lado, havia sempre o risco iminente de pogroms. A família começou então a procurar alternativas.

\section{O Brihah e a organização do resgate dos judeus da Polônia}

Uma das alternativas para a família de Helena veio através de um movimento organizado por jovens sionistas que desde 1944 operavam com o fim de resgatar sobreviventes judeus e, através das fronteiras da Polônia Tchecoslováquia e Hungria enviá-los, primeiro para campos de deslocados na Alemanha, Áustria e Itália e posteriormente para a Palestina do Mandato Britânico. Esse movimento era o Brihah.

O movimento, cujo nome significa escape em hebraico, surgiu em 1944 por iniciativa de partisans e membros das Brigadas Judaicas que lutaram junto ao exército britânico durante a Segunda Guerra.

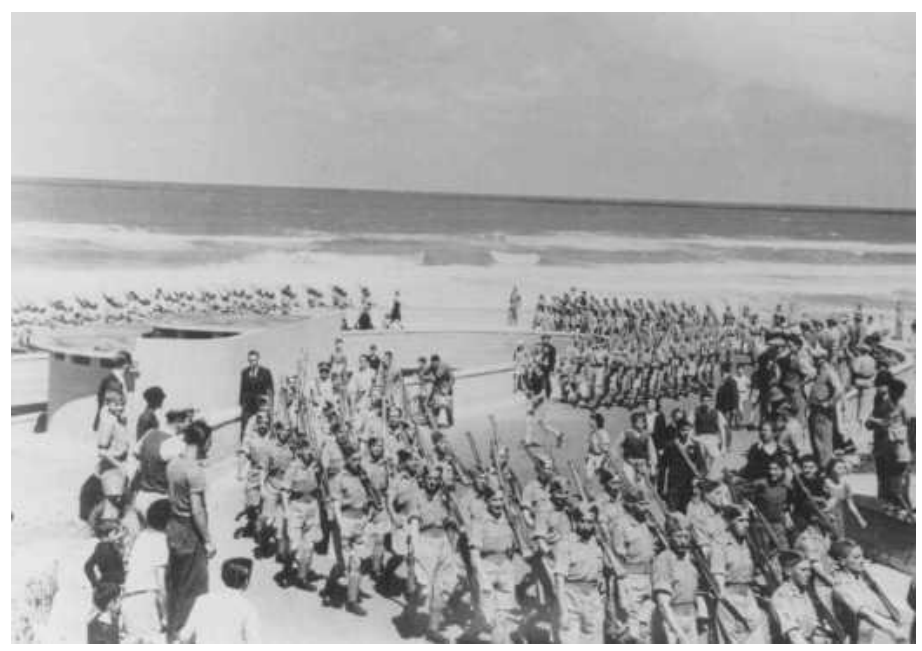

Membros da Brigada Judaica. Tel-Aviv, Palestina, 1944

Fonte: Arquivo Sionista Central

United States Holocaust Memorial Museum (USHMM) 
O grupo visava possibilitar o resgate dos milhares de sobreviventes judeus da Europa, legalmente ou ilegalmente, já que para a maioria deles o fim da guerra não representou um período de livre circulação ou de opções de locais de residência: vistos eram difíceis de obter, fronteiras fechavam-se constantemente e assim a entrada na maioria dos países do mundo tornava-se quase impossível.

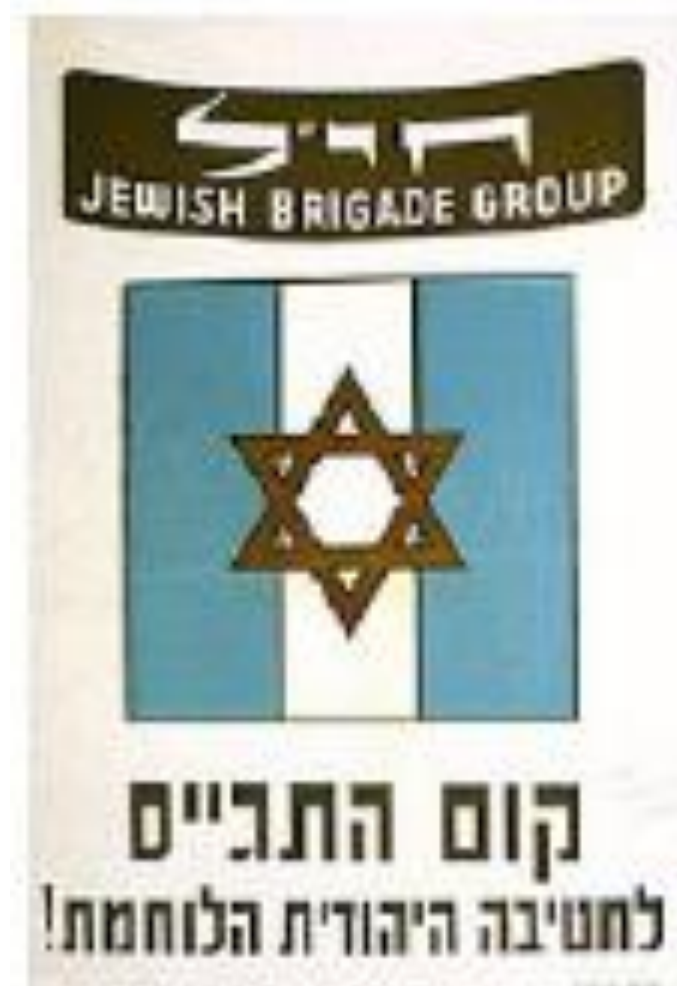

Pôster convocando jovens judeus na Palestina a alistar-se na Brigada Judaica, 1944

Fonte: Arquivo Sionista Central

United States Holocaust Memorial Museum (USHMM)

www.ushmm.org

Uma das principais figuras do movimento, no início da formação do Brihah, foi Abba Kovner, poeta judeu nascido em Sebastopol, Ucrânia, e criado em Vilna, Lituânia. Durante o Holocausto Kovner tornou-se um importante líder no movimento de resistência. Com o fim da guerra, ele assumiu a tarefa de procurar um lar para os milhares de judeus sobreviventes do massacre. 


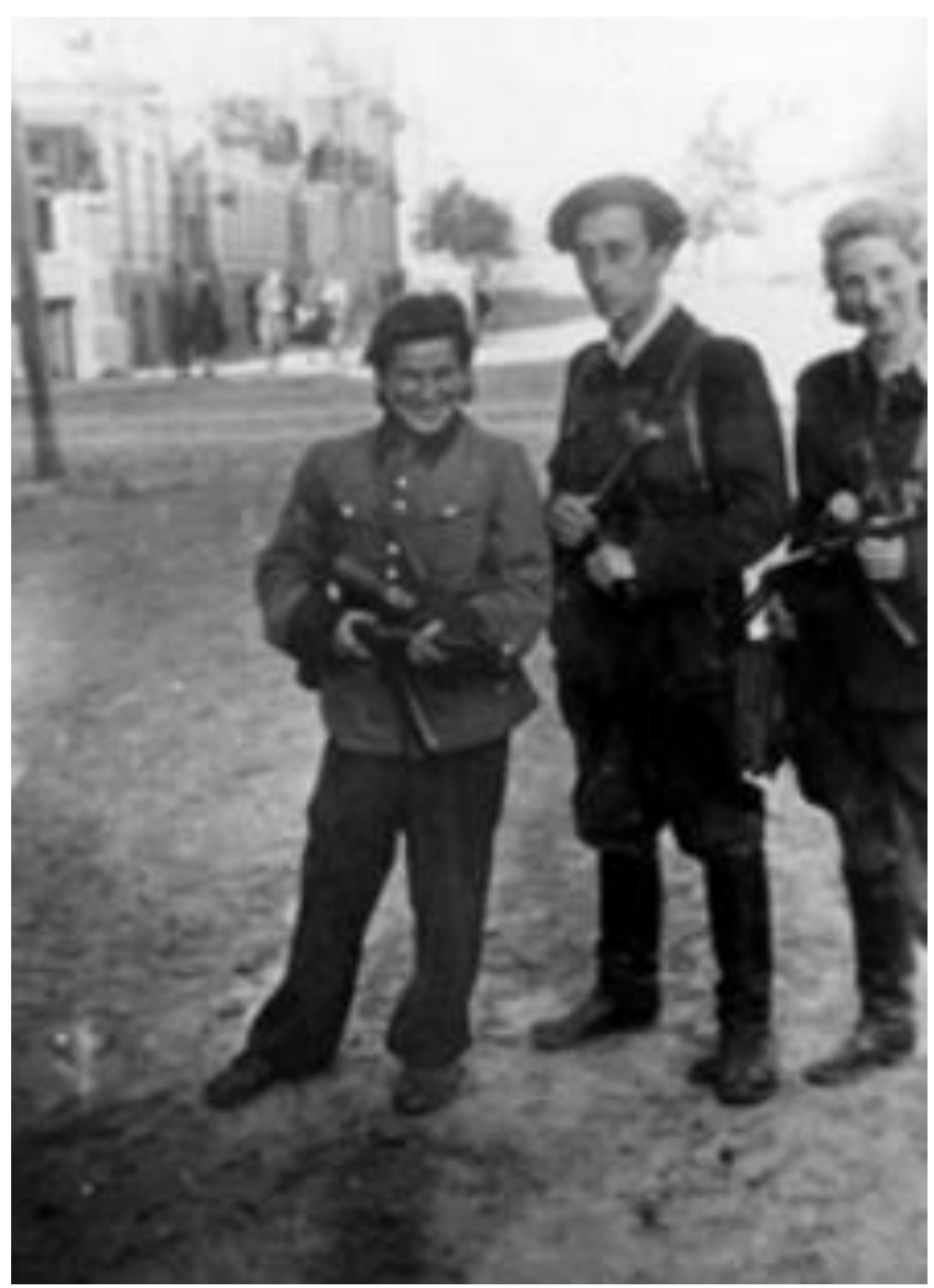

Abba Kovner (ao centro) com duas combatentes após a liberação de Vilna Ruzka Korczak e Vita Kempner, com quem Kovner se casou mais tarde. Vilna, Lituânia, 14 de julho, 1944. Fotógrafo não identificado. Fonte: Yad Vashem/Jewish Partisans Organization www.jewishpartisans.org

Na complexa logística que possibilitou o resgate de aproximadamente 150.000 judeus da Polônia até 1946, o Brihah contou com o apoio financeiro da American Jewish Joint Distribution Committee and Refuge Aid, instituição fundada em 1914 nos Estados Unidos encarregada de angariar e distribuir fundos para ajudar as populações de judeus do Leste europeu durante a Primeira Guerra Mundial. 


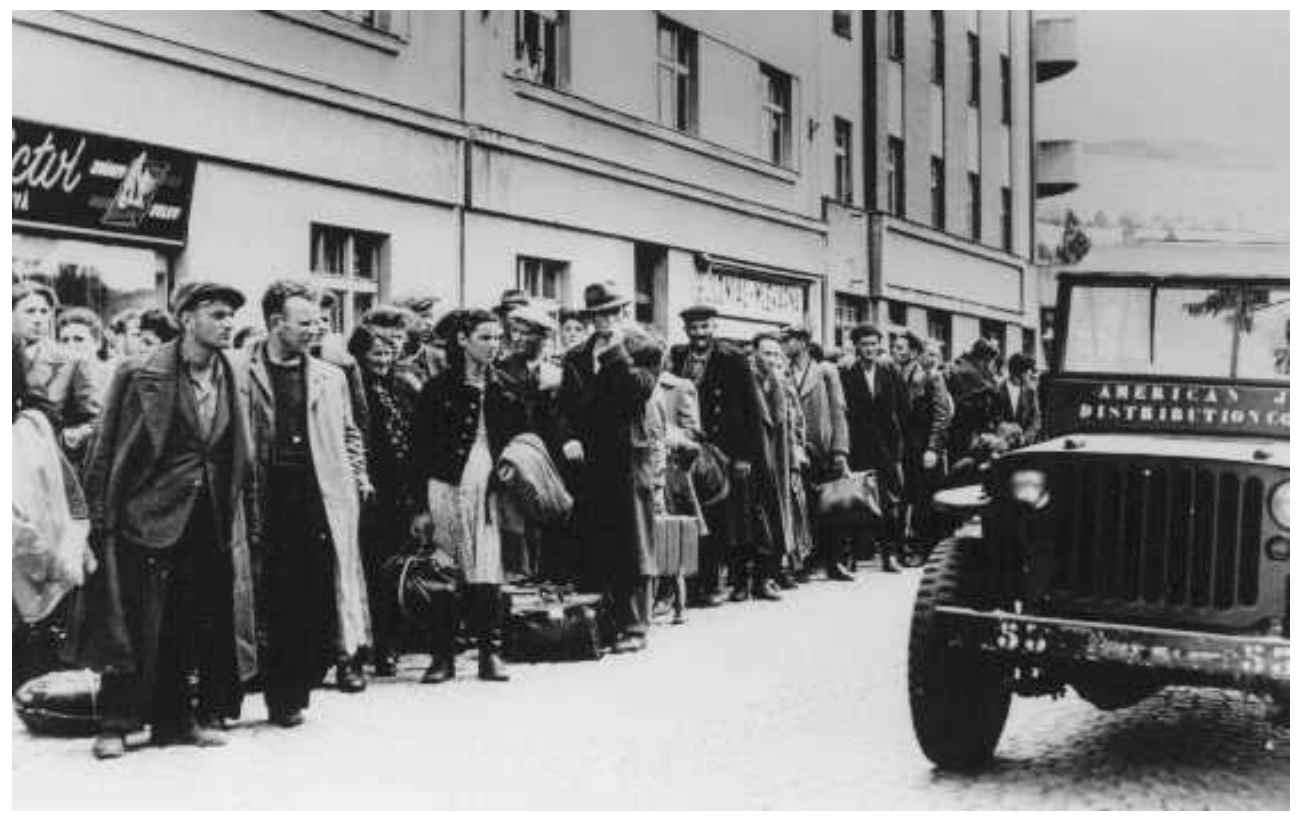

Fila de refugiados judeus que deixavam a Polônia em centro de recepção na Tchecoslováquia. À direita, carro do American Joint Distribution Committee. Fonte: Wide World Photo. United States Holocaust Memorial Museum (USHMM). www.ushmm.org

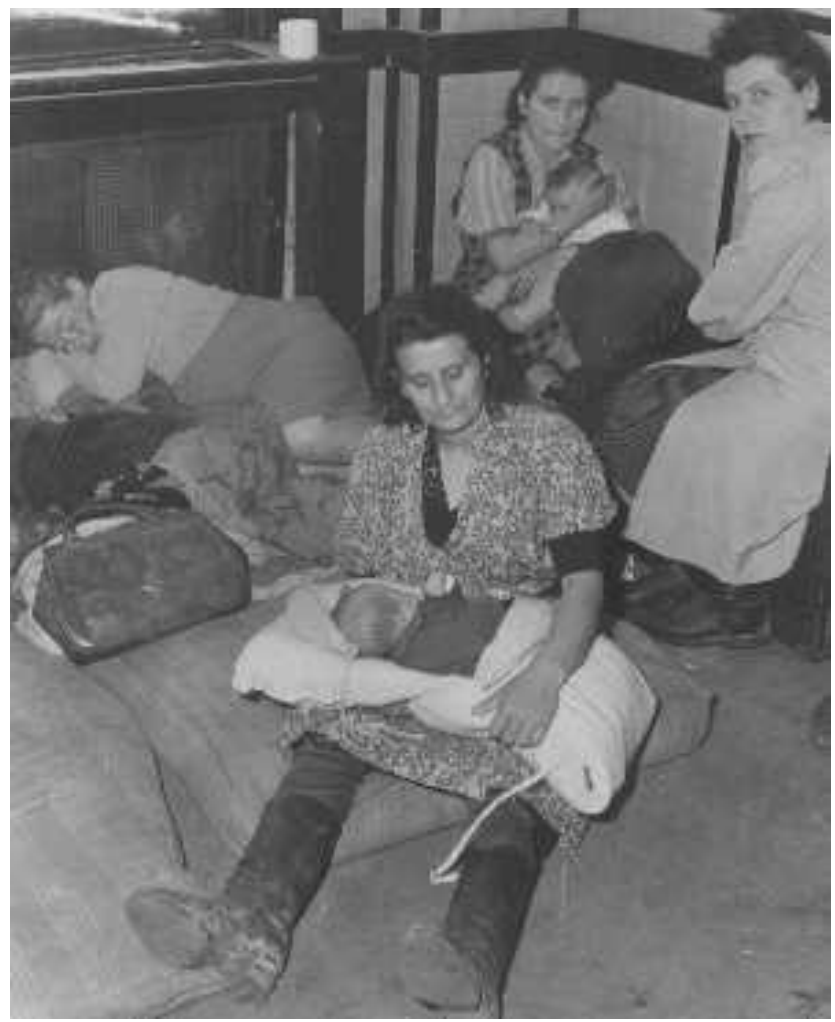

Mulheres e crianças judias deixando a Polônia como parte da Brihah. Nachod, Tchecoslováquia, 1946.

Fonte: American Joint Distribution Committee United States Holocaust Memorial Museum (USHMM) www.ushmm.org 
Com a ajuda do Brihah, Helena e sua família seguiram então para a Alemanha, onde foram encaminhados para um campo para deslocados de guerra em Berlim, sempre juntos. Lá, Helena retomou seus estudos. Quando começaram os conflitos que deram início à Guerra Fria, os refugiados de Berlim foram transferidos para o setor americano em Munique. Foi nessa cidade que Helena conheceu Elias Blankfeld, jornalista nascido em Riga na Lituânia, com quem se casou.

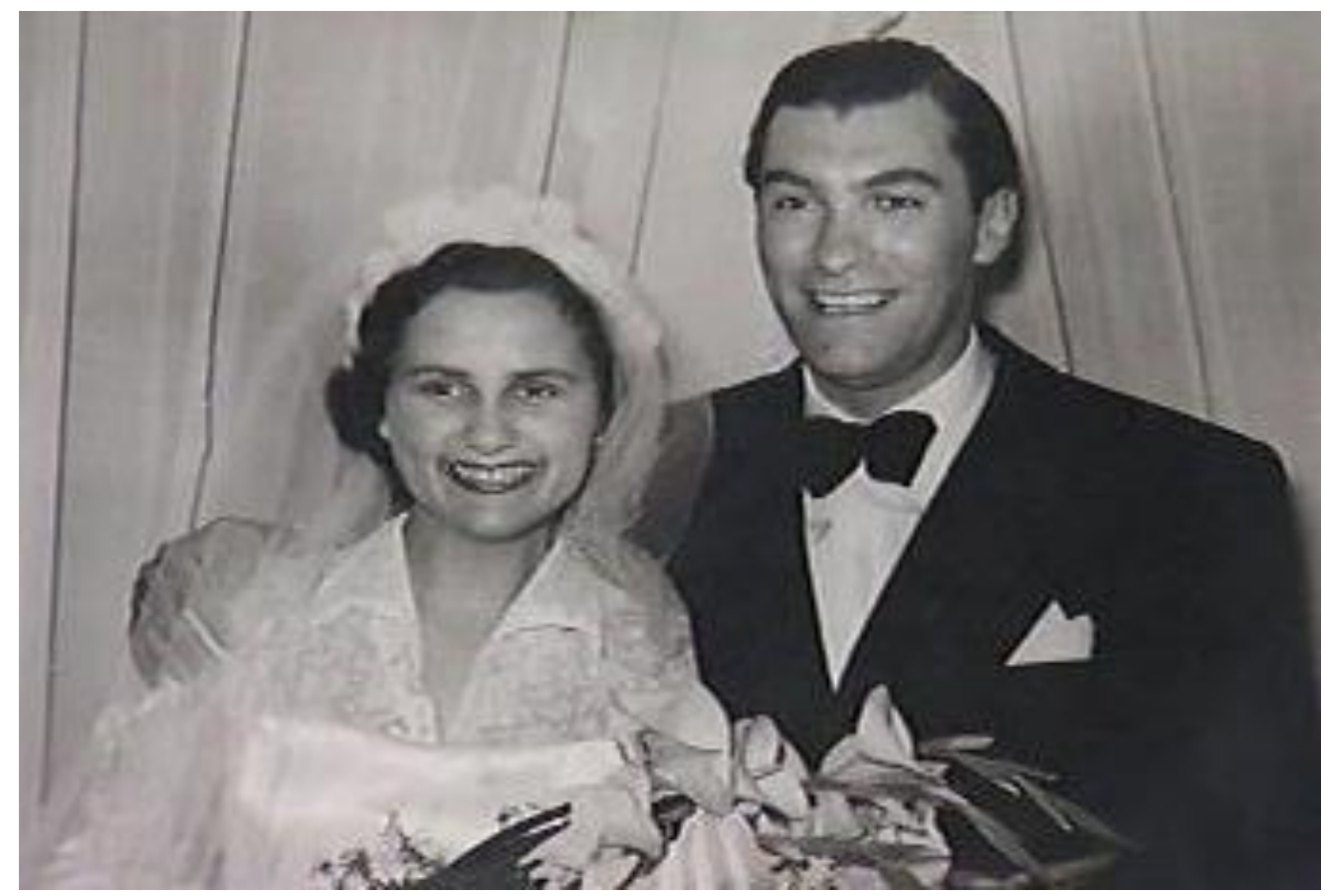

Helena e Elias Blankfeld, Alemanha

Fonte: Visual History Archive Online

USC Shoah Foundation

http://vhaonline.usc.edu/

Os pais de Helena, Abraham e Basia conseguiram visto para os Estados Unidos e se mudaram para o país. A ideia de Helena e de seu marido era seguir para Israel. O nascimento de seu primeiro filho Mordechai, porém, provocou uma mudança de planos: todos, inclusive os pais de Helena, viriam para o Brasil onde tinham um tio. Foi aqui que Helena criou sua família, orgulhosa, como ela mesma diz, de que hoje exista uma Medinah (Estado) para cuidar de todos os judeus: Israel. 


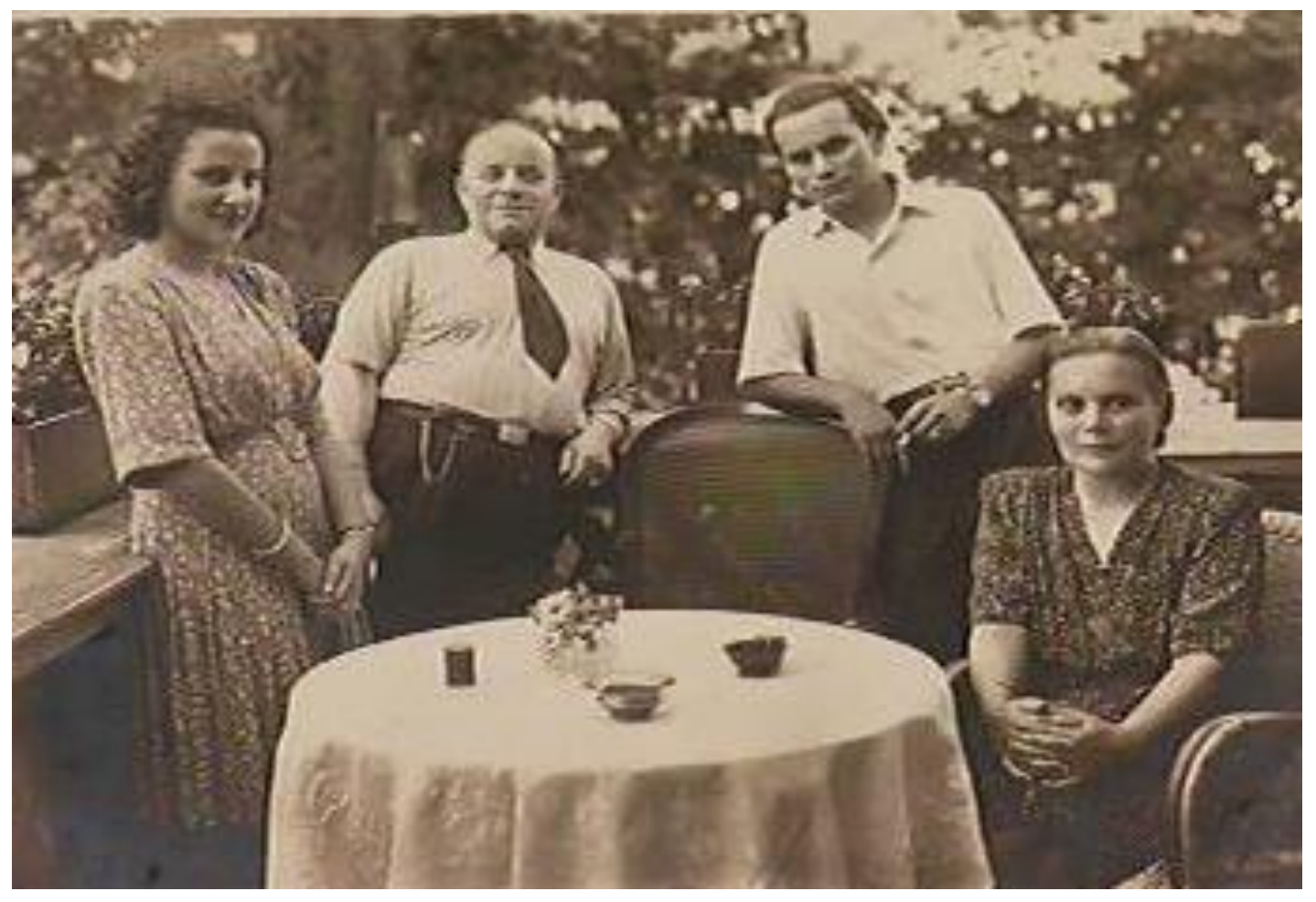

Reencontros. Helena e sua família

Fonte: Visual History Archive Online USC Shoah Foundation

http://vhaonline.usc.edu/ 


\section{CONCLUSÃO}

Inauguramos este estudo referindo-nos à tendência recente a uma fundamental ausência em discursos que têm circulado na data oficial de rememoração às vítimas do Holocausto: os judeus. Procuramos demonstrar a maneira como esse fenômeno vem ocorrendo através de um processo que denominamos de fagocitose da história do Holocausto, o qual em geral tenta manter alguns aspectos do evento, convertendo-os gradualmente em tema para consumo geral. No entanto, não somente nos discursos, mas também em produções escritas, muitas vezes voltadas à educação sobre o tema, têm-se deixado de lado seu elemento central, ou seja, o principal alvo da política genocida do Terceiro Reich.

Empenhamo-nos em mostrar também que esse processo, na verdade, é em parte fruto da persistência de uma mentalidade antissemita que - emprestando o conceito de Leon Poliakov hoje percebe o Estado de Israel como o "judeu entre as nações", ou seja, o inimigo a ser deslegitimado. Mas, o que ocorre quando esse inimigo, o judeu, foi reconhecidamente vítima de um dos piores crimes perpetrados na história da humanidade? Paradoxalmente, mira-se contra ele.

Em um artigo publicado em $2013^{206}$, o escritor britânico Howard Jacobson, referindo-se a esse fenômeno cita o historiador romano Tácito quem afirmava: "É parte da natureza humana odiar o homem que feriste". Seguindo essa premissa, Jacobson pergunta: "Quando os judeus serão perdoados pelo Holocausto?"207 Ao tempo que responde: "Nunca".

Nesse sentido, a memória do Holocausto passa a ser, ela mesma, alvo de uma nova etapa no contexto do que podemos denominar antissemitismo contemporâneo - embora outros prefiram o termo antissionismo - com o negacionismo em um de seus extremos. Porém, a ocultação da centralidade do judeu dentro da narrativa histórica do evento, também traduz uma forma de negação. Ela constitui, nesse sentido, uma ameaça real não somente à memória, mas também ao enorme legado deixado por estudiosos, pelos sobreviventes através de seus testemunhos registrados em vídeos, diários e livros. Uma memória refletida que, apesar de nossas próprias limitações cognitivas - e muitas vezes morais - podem nos ajudar a compreender a dimensão do

\footnotetext{
${ }^{206}$ JACOBSON, Howard. "Will We Ever Be Forgiven for the Holocaust?", Forward, New York, 20 de outubro de 2013, http://forward.com/culture/books/185720/will-we-ever-be-forgiven-for-the-holocaust/

${ }^{207}$ Em seu artigo, Jacobson estende à humanidade a frase "os alemães nunca perdoarão os judeus por Auschwitz". Esta frase, de autoria controversa, foi atribuída ao psiquiatra israelense Zvi Rex. Ela foi citada pela primeira vez por Henryk Border em seu livro Der ewige Antisemit (O Eterno Antisemita), onde desenvolve a análise de Adorno sobre o que este denominou "antissemitismo secundário", ou seja, a recusa em rememorar os crimes cometidos pelo nazismo contra o povo judeu.
} 
ocorrido, assim como enxergar o ser humano para além dos registros oficiais deixados pelos perpetradores. Ao mesmo tempo, despertamos para a importância de valorizarmos, ainda mais, a ética, a responsabilidade e o respeito, tão fragilizados neste século XXI.

Este mesmo fenômeno deve ser estendido ao âmbito da educação que, "mesmo após Auschwitz", merece todo o nosso crédito. Nã devemos nos descuidar deste investimento formador das atuais e novas gerações. Daí a nossa proposta de avaliar o tema do Holocausto enquanto conteúdo nos livros didáticos; daí a nossa preocupação de elaborar uma análise crítica acompanhada de um projeto-piloto que coloque algo mais neste espaço vazio gerado pelo desconhecimento e, se quisermos ir um pouco mais adiante, pela ideologia do apagamento.

Retomamos aqui o último discurso proferido durante o V Fórum Global sobre o Antissemitismo ${ }^{208}$, realizado em Jerusalém poucos dias antes de sua morte em maio de 2015, onde Wistrich apontou a necessidade de se rever o modo de abordar a educação sobre o Holocausto como antídoto contra o antissemitismo. Segundo o autor, estamos em meio a outro processo que identificou como "efeito bumerangue", evidenciado pela crescente instrumentalização da memória sobre o Holocausto, direcionada contra Israel em particular e contra os judeus em geral.

Robert Wistrich, que além de seu valioso trabalho historiográfico sobre o Antissemitismo, esteve profundamente envolvido nos trabalhos pioneiros em prol do ensino sobre o Holocausto, não sugere de nenhuma maneira o fim dos programas de educação sobre o tema, mas alerta para a necessidade atual de modificar seu curso. Infelizmente, ele não está mais entre nós para guiar-nos no sentido de desenhar novas fórmulas. Cabe assim à comunidade de estudiosos sobre o tema, tentar buscá-las e determinar nossas próprias respostas aos novos desafios. O antissemita de hoje, arvorado em sua nova veste de antissionista, não facilitará a tarefa, mas justamente por isso ela é particularmente encorajadora.

Essas respostas, porém, não podem de nenhuma maneira ser reducionistas. Programas que tentem facilitar a abordagem do Holocausto e do Antissemitismo, tal como procuramos demonstrar neste trabalho, podem dar espaço a interpretações ambíguas que deixam abertas avenidas para a propagação de velhos ódios.

\footnotetext{
${ }^{208}$ ISRAEL MINISTRY OF FOREIGN AFFAIRS, $5^{\text {th }}$ Global Forum for Combating Antisemitism, 12 - 15 de Maio, Jerusalém, Israel. A palestra do Professor Robert Wistrich pode ser vista na íntegra em: https://ukmediawatch.org/2015/05/24/robert-s-wistrichs-last-major-speech-on-antisemitism/ Consultado em 4 de outubro de 2016.
} 
Acreditamos firmemente que a educação é a única arma capaz de intervir em prol de uma conscientização sobre os deveres de cada ser humano na construção de um mundo em que direitos sejam a consequência natural de posturas éticas e que prosseguir no estudo de fenômenos como o Antissemitismo, como ódio singular, e do Holocausto, como evento singular, podem nos ajudar sobremaneira a obter parte das respostas.

Não podemos, porém, iludir-nos. Milênios de discussões e ensinamentos filosóficos não impediram que atos de injustiça extrema fossem perpetrados por Estados, grupos ou indivíduos ao longo da História. A tendência a visitar periodicamente o abismo parece ser parte intrínseca da natureza humana, embora também o seja a tendência a refletir sobre erros cometidos. Até os anos 1930 não era possível imaginar que um Holocausto pudesse acontecer. No início dos anos 1940 o mundo não acreditava que na verdade ele estivesse, de fato, acontecendo. Porém, uma vez que, naquele momento, o mal de plantão foi derrotado, ao olharmos mais de perto, não somente foi possível ver o que havia sido feito, mas também sentir o que se permitiu que fosse feito.

É principalmente sobre este último aspecto, o das consequências de se fechar os olhos à injustiça, que a educação deve intervir. Neste trabalho, a partir da análise do estado da arte da educação sobre o Holocausto nos materiais didáticos, buscamos desenhar propostas que, tendo como ponto de partida os testemunhos das pessoas que vivenciaram a catástrofe, possa servir para aproximar os jovens aos protagonistas dessas histórias de modo a sensibilizá-los em relação ao fato de que o processo histórico não ocorre num palco imaginário. Ele afeta indivíduos, laços familiares e sociais com consequências muitas vezes trágicas que reverberam por várias gerações.

Ao mesmo tempo, através das propostas apresentadas no projeto-piloto, procuramos que o pano de fundo contido nessas histórias servisse para mostrar não somente os aspectos alusivos à tragédia que se abateu sobre os judeus na Europa dos anos 1930 e 1940. Propusemos também vislumbrar uma imagem de como era a vida desses protagonistas, tanto do ponto de vista histórico e geográfico das diversas comunidades, quanto do ponto de vista pessoal, tentando incluir o antes, o durante e o depois o que, nos casos das testemunhas protagonistas deste trabalho, resultou na reconstrução de suas vidas aqui mesmo no Brasil, perto de nós.

Nesse sentido, se a educação não puder intervir para impedir completamente que o mal absoluto tente incursionar em meio a nós de tempos em tempos, que ao menos ela possa formar 
uma parcela de indivíduos atentos para os deveres e responsabilidades de cada um para prevenir esses episódios ou, caso consumados, reduzir suas consequências.

Os testemunhos dos sobreviventes do Holocausto mostram permanentemente que o resultado de suas histórias dependeu de escolhas não somente próprias, mas também de outros atores, muitas vezes alheios ao processo, que tomaram para si a responsabilidade de agir. Esses atores, porém, não foram uma maioria. Ao contrário. O Holocausto não foi somente o ápice do mal; foi também o ápice da cegueira, do descaso e, fundamentalmente, da irresponsabilidade, sendo esta tomada na origem etimológica do verbo em latim sponsare, ou seja, comprometer-se com o outro, assim como do subsequente significado de respondere, responder, oferecer uma resposta. A atitude da maior parte daqueles que observavam o Holocausto e "nada viram" - ou nada quiseram saber - oscilou entre essas duas ausências: a do compromisso e a da resposta.

A importância da educação sobre o Holocausto reside, portanto, entre outros aspectos, em seu enorme potencial de resgatar - sempre que devidamente contextualizadas - questões como ética, compromisso e dever, todos eles inseridos no conceito de reponsabilidade.

Cabe, porém, a pergunta: a educação não deveria ter como propósito formar indivíduos livres, com pensamento crítico e conscientes de seus direitos? Sem dúvida, mas se os fundamentos da educação estiverem apoiados somente em liberdade e direitos poderemos acabar obtendo como resultado gerações cujos indivíduos que tendam mais ao narcisismo, pouco preocupados pelo bem-estar comum; em outras palavras, gerações cuja posição perante o universo seja: "Você me deve".

Estamos cientes de que qualquer proposta que se debruça sobre questões relacionadas à Educação depende certamente de um ativo envolvimento do Estado, no sentido de favorecer políticas públicas que incluam ao menos parte das preocupações aqui colocadas. O momento no Brasil, desse ponto de vista, não poderia ser mais promissor. Encontramo-nos em meio às discussões sobre o documento que propõe estabelecer uma Base Nacional Comum Curricular assim como da pauta para uma reforma do Ensino Médio.

Esperamos que este trabalho possa de alguma forma contribuir para aprofundar o diálogo sobre as melhores práticas para enfrentar os desafios futuros de uma educação para a ética, que tenha como meta formar cidadãos intelectualmente capazes de pensar o processo histórico e que optem por engajar-se na sociedade de maneira responsável. O horizonte se move, mas não temos o direito de desistir de seguir em frente, tentando alcançá-lo. 
Gostaria de encerrar citando o psiquiatra Viktor Frankl, ele mesmo sobrevivente dos campos de concentração nazistas e autor de vários livros, entre eles Man’s Search for Meaning, do qual extraio a seguinte citação:

Liberdade não é a última palavra. Liberdade é somente parte da história e metade da verdade. A liberdade nada mais é do que o aspecto negativo do fenômeno como um todo cujo aspecto positivo é a responsabilidade. Na verdade, a liberdade está em perigo de degenerar em mera arbitrariedade a não ser que seja vivida em termos de responsabilidade. ${ }^{209}$

${ }^{209}$ FRANKL, Viktor E. Man's Search for Meaning. Boston: Beacon Press, 1992 (4ª ed.), p. 134. 


\section{FONTES}

\section{Artigos}

BITTENCOURT, Circe Maria Fernandes. "Produção Didática de História: Trajetória de Pesquisas." In, Revista de História.São Paulo, n. 164, jan/jun 2011, p. 487-516

CARNEIRO, Maria Luiza Tucci. Por uma cultura de tolerância. In, Revista do Instituto Cultural Marc Chagall. V. 3, No. 1. Jan/Jun 2011. (Edição Eletrônica WebMosaica).

Rompendo o Silêncio: a Historiografia sobre o Antissemitismo no

Brasil. In, Cadernos de História, Belo Horizonte, v. 13, n. 18, $1^{\circ}$ sem., 2012;

CHOPPIN, Alain. "História dos livros e das edições didáticas: sobre o estado da arte." In, Educação e Pesquisa, São Paulo, v. 30, n.3, set/dez. 2004, p. 549-566

FOX, Frank. A Jew Talks to Himmler, http://www.zwoje-scrolls.com/zwoje38/text18p.htm

FREUD, S. "O interesse científico da psicanálise", In: FREUD, S. Sigmund Freud: Obra Completa. Edição Standard. Vol. XIII, p. 169-192. Rio de Janeiro: Imago, 1996.

FRIEDLANDER, Henry. "Toward a methodology of teaching the Holocaust." Teachers College Record, 80(3), 519-542, 1979.

FRIEDLÄNDER, Saul. "The 'Final Solution": On the Unease in Historical Interpretation”. In, History \& Memory, Vol. 1, No. 2 (Fall-Winter, 1989), pp. 61-76.

GAULUPEAU, Yves. "Les manuels par l'image: pour une approche sérielle des contenus." In, Chopin, Alain (org.). Manuels scolaires, États et societies. XIXe - XXe siècles.Histoire de l'éducation. No. 58. Paris: Institut National de Recherché Pédagogique, Mai 1993.

GOMBRICH, Ernst Hans. "Mito y realidade em las emisiones de radioalemanas durante la guerra" In: Ideales e ídolos: ensayos sobre los valores em la historia del arte. Barcelona: Gustavo Gili, 1981.

HABER, Gordon ,“A Personal History of Blood Libel in Poland”, Forward, Março de 2014.

HENI, Clemens. "Secondary Anti-Semitism: From Hard-Core to Soft-Core Denial of the Shoah", In, Jerusalem Center for Public Affairs. Jerusalem, 2 de novembro de 2008. http://jcpa.org/article/secondaryanti-semitism-from-hard-core-to-soft-core-denial-of-the-shoah/

HOWE, Irving. "A Escrita e o Holocausto", In: Cadernos de Língua e Literatura Hebraica, Faculdade de Filosofia, Letras e Ciências Humanas/USP - n. 2 (1999) - São Paulo: Humanitas FFLCH/USP, 1998.

KATZ, Dovid. "Understanding Double Genocide". In, JHC Centre News, Jewish Holocaust Centre, Victoria, Australia, September 2011.

http://defendinghistory.com/wp-content/uploads/2013/06/Dovid-Katz-on-Double-Genocide-20111.pdf 
LAJOLO, Marisa. “Livro didático: um (quase) manual de usuário.” In, Em Aberto, Brasília, ano 16, n.69, jan./mar. 1996.

LAMA, Luisa. NILDE IOTTI 1945-1946. Alle Origini di uma Storia Politica al Femminile, http://www.fondazionenildeiotti.it/docs/documento3896177.pdf

LEVIN, Judith \& UZIEL, Daniel. "Ordinary Men, Extraordinary Photos”. Yad Vashem Studies, Vol. XXI, 1998, pp. 280-293

LINDQUIST, David H. "Instructional Approaches in Teaching the Holocaust". American Secondary Education (39), 117+, 1997. (Questia)

Education, 21-36, 2007.

. "A Necessary Holocaust Pedagogy: Teaching the Teachers". Issues in Teacher

. "The Coverage of the Holocaust in High School History Textbooks." In, Social Education 73(6), pp 298-304. National Council for Social Studies (NCSS), 2009.

. "Textbook Coverage of the Destruction of the Armenians." In, Journal of International Social Studies. Volume 2. Number 1. Spring/Summer 2012, pp 26-37

MIRANDA, Sonia R. \& DE LUCA, Tania R. "O livro didático de história hoje: um panorama a partir do PNLD” In, Revista Brasileira de História. Vol. 24, No. 48, São Paulo, 2004.

MUNAKATA, Kazumi. "O livro didático: alguns temas de pesquisa". Revista Brasileira de História da Educação, Campinas/SP, v.12, n. 3 (30), set/dez. 2012, p. 179-197

OZICK, Cynthia. "Who Owns Anne Frank?”, In: Quarrel \& Quandary. Essays by Cynthia Ozick. New York: Alfred A. Knopf, 2000. Publicado originalmente na revista The New Yorker, edição de 6 de outubro de 1997.

PARDO, Lucio. "La Communitá Ebraica di Bologna dal 1938 al 1943". In, Le Scuole Ebraiche di Bologna, dopo le legge razziali. http://www.comunitaebraicabologna.it/it/bologna-ebraica/comunita/5-lescuole-ebraiche-di-bologna-dopo-le-leggi-razziali

PASSONE, Eric F. K. "Notas psicanalíticas: os discursos contemporâneos acerca da avaliação educacional no Brasil”, In: Revista Educação e Pesquisa. São Paulo, v. 41, n. 1, jan-mar, 2015, p. 185201,

REICHSTADT, Rudy. "Conspirationnisme: un état des lieux", In: Note $n^{o}$ 11, Fondation Jean-Jaurés. Observatoire des radicalités politiques, 24 de fevereiro de 2015 (tradução nossa):

https://jean-jaures.org/sites/default/files/note-radic-pop-ndeg11.pdf

REPOUSSI, Maria \&TUTIAUX-GUILLON, Nicole. "New Trends in History Textbook Research: Issues and Methodologies toward a School Historiography." In, Journal of Educational Media, Memory and Society. GEI. Volume 2, Issue 1, Spring 2010. 
SANDKÜHLER, Thomas. "Nach Stockholm: Holocaust-Geschichte und historische Erinnerung im neueren Schulgeschichtsbuch für die Sekundarstufen I und II." In, Zeitschrift für Geschichtsdidaktik, Jg. 11 (2012), 50-76.

. Der Holocaust im aktuellen Geschichtslehrbuch der Sekundarstufen I und II.

Kontextualisierung, fachliche Qualität, Erinnerung. Berlin: Humboldt-Universität, Institut für Geschichtwissenschaften, 2012.

SHAPIRA, A.; KEYNAN, I. The Survivors of the Holocaust. Jerusalem: Yad Vashem, 2016.

STEINER, George. "El milagro hueco", In: Lenguaje y Silencio. Ensayos sobre la Literatura, el Lenguaje y lo Inhumano. Barcelona: 2003.

UNESCO-Georg Eckert Institut. International Status of Education on the Holocaust. A Global Mapping of Textbooks and Curricula. Braunschweig/Paris: UNESCO - GEI, 2015. O documento pode ser consultado no endereço:

http://unesdoc.unesco.org/images/0022/002287/228776e.pdf

\section{Cartografia}

(por ordem de aparecimento)

Dois mil Anos de Vida Judaica na Europa por volta de 1933. Fonte: GILBERT, Martin. The Dent Atlas of the Holocaust. The complete history. Londres: Orion House, 1993, 2 ed., p. 8.

Judeus marcados para a morte, 1942. Fonte: Martin Gilbert. Atlas of the Holocaust. London, Taylor \& Francis e-Library, 2005

Deportações para Auschwitz. Fonte: Martin Gilbert. Atlas of the Holocaust. London: Taylor \& Francis eLibrary, 2005

Área de operação das quatro unidades de Einzatsgruppen. Fonte: Pinterest.

Locais de massacres perpetrados pelos Einsatzgruppen. Fonte: Arquivo Fotográfico do United States Holocaust Memorial Museum (USHMM), Washington DC, Estados Unidos.

Ludvipol e região por volta de 1940. Captura de tela do documentário A House for Two Families (Uma casa para duas famílias). Jewish Federation for the Righteous, New York, 2014.

Mapa da rua principal de Ludvipol. Captura de tela do documentário A House for Two Families (Uma casa para duas famílias). Jewish Federation for the Righteous, New York, 2014.

Polônia, 1933. Em destaque (elipse vermelha), o distrito de Lublin, onde se localiza a cidade de Sosnowica. Fonte: United States Holucaust Memorial Museum (USHMM)

A invasão da Polônia. Fonte do Mapa: United States Memorial Museum (USHMM).

Principais guetos na Polônia. Fonte: Arquivo Yad Vashem, Jerusalém, Israel https://www.yadvashem.org/yv/he/research/ghettos encyclopedia/maps.pdf 
Distribuição da população judaica na Europa por volta de 1933. Fonte: United States Holocaust Memorial Museum (USHMM). Washington, DC. Estados Unidos, www.ushmm.org

Geografia do extermínio no relato de Zeev. Em destaque: Sosnowica. Fonte: Google Maps.

Áreas de atividade de partisans judeus no Leste da Europa, 1942-1944. Fonte: United States Holocaust Memorial Museum (USHMM), www.ushmm.org

Mapa da Polônia. Em destaque, a localização de Sandomierz. Fonte: Google Maps

Sandomierz, cortada pelo Rio Vístula. Fonte: Google Maps

Mapa da Europa indicando as deportações para Auschwitz. Fonte: Martin Gilbert. The Dent Atlas of the Holocaust. London: Taylor \& Francis e-Library, 2005 (Electronic Edition)

Principais centros de residência da comunidade judaica na Itália. New York: Cambridge University Press, 2005.

Principais centros de perseguição contra judeus na Itália. Fonte: ZIMMERMAN, Joshua D. The Jews in Italy under Fascist and Nazi Rule, 1922-1945. New York: Cambridge University Press, 2005

A República Social Italiana (Repubblica di Salò, 1943-1945). Fonte: ESABAC Premiere

O Holocausto na Itália. Créditos: Alberto Giordano e Anna Holian, Geographies of the Holocaust Project Fonte: United States Holocaust Memorial Museum, www.ushmm.org

Budrio, cidade pertencente à Região Metropolitana de Bolonha. Fonte: Google Maps

Trajeto entre Milão e Solzago. Fonte: Google Maps

Mapa indicando a localização de Laglio e fronteira entre Itália e Suíça. Fonte: Google Maps

Mapa indicando a localização de Chiasso em território suíço. Fonte: Google Maps

Bielorússia. Em destaque, Pinsk. Fonte: www.commons.wikimedia.org

A invasão nazista e soviética da Polônia. Fonte: www.mapsontheweb.zoom-maps.com

Mapa que mostra o trajeto entre Pinsk e Kamenets-Podolski. Fonte: Google Maps

Rotas da Invasão da Alemanha à União Soviética. Fonte: United States Holocaust Memorial Museum (USHMM)

Mapa que mostra o novo trajeto de Helena em busca de sua sobrevivência. Fonte: Google Maps

Mapa que mostra a distância entre Stolin e Davyd-Haradok. Fonte: Google Maps 


\section{Comunicados}

BRASIL. Ministério das Relações Exteriores, Brasília, 27 de janeiro de 2016.

http://www.itamaraty.gov.br/index.php?option=com_content $\&$ view=article\&id=13008\&catid=42\&Itemid $=280 \&$ lang $=$ pt-BR

\section{Discursos}

Chaim Weizmann, Jerusalém em 25 de abril de 1936.

Justin Trudeau, Primeiro Ministro do Canadá, Ottawa, Ontário, 27 de janeiro de 2016

http://pm.gc.ca/eng/news/2016/01/27/statement-prime-minister-canada-holocaust-remembrance-day

François Hollande, Presidente da França, 27 de janeiro de 2015.

http://www.elysee.fr/declarations/article/discours-au-memorial-de-la-shoah-2/

\section{Documentos}

BRASIL. Ministério da Educação. Secretaria de Educação Básica. Diretrizes Curriculares Nacionais da Educação Básica. Brasília, 2013.

BRASIL. Ministério da Educação. Fundo Nacional de Desenvolvimento da Educação. Secretaria de Educação Básica. Edital de Convocação para o Processos de Inscrição e Avaliação de Obras Didáticas para o Programa Nacional do Livro Didático PNLD 2017. Brasília, 2015.

BRASIL. Ministério da Educação. Fundo Nacional de Desenvolvimento da Educação. Secretaria de Educação Básica. Edital de Convocação para o Processos de Inscrição e Avaliação de Obras Didáticas para o Programa Nacional do Livro Didático PNLD 2017. Brasília, 2015. http://www.fnde.gov.br/programas/livro-didatico/livro-didatico-editais/item/6228-edital-pnld-2017

Carta do sobrevivente Michael Nosanchuk a Boris Nosanchuk escrita em 11 de janeiro de 1946 na qual são relatados os detalhes das perseguições nas cidades de Stolin, Rubele e David Haradok. In, Stolin, Belarus. The Shtetl and Its People. http://kehilalinks.jewishgen.org/stolin/account nosanchuk letter.php

Fondazione Centro di Documentazione Ebraica Contemporanea. http://www.cdec.it/home2_2.asp?idtesto=185\&idtesto1=643\&son=1\&figlio=558\&level=6

Instruções de Heydrich sobre políticas e operações relativas aos judeus aos judeus nos territórios ocupados. Ordem de 21 de setembro de 1939. Fontes: Arquivos Yad Vashem. www.yadvashem.org/odot.pdf/microsoft\%20word\%20-\%1984.pdf.

Ordem emitida e assinada por Himmler a Hans-Adolf Prützman. Relatórios de investigação, acusações e vereditos nos julgamentos de membros do Batalhão de Polícia 306, 1963, Arquivo Yad Vashem, YVA, TR- 10/790, p. 126. In, Tikva Fatal-Knaani, "The Jews of Pinsk through the Prism of New Documentation", Yad Vashem.

http://www.yadvashem.org/download/about_holocaust/studies/FatalENGPRINT.pdf 
PNLD. Programa Nacional do Livro Didático. Dados Estatísticos, 2014:

http://www.fnde.gov.br/programas/livro-didatico/livro-didatico-dados-estatisticos

Guia de livros didáticos PNLD 2015. Ensino Médio.

REGIO DECRETO - LEGGE 15 novembre 1938 - XVII, n. 1779. Integrazione e coordinamento in unico testo delle norme già emanate per la difesa della razza nella Scuola Italiana.

http://www.morasha.it/antisemitismo/razza_scuole2.html.

Stroop Album. Facsímile: http://pamiec.pl/ftp/ilustracje/Raport_STROOPA.pdf.

\section{Filmografia}

Culpa é das Estrelas, A. Diretor: Jos Boone, 2014.

Lista de Schindler, A. Diretor: Steven Spielberg, Estados Unidos, 1993.

Shoah. Diretor: Claude Lanzmann, 1985

Tale of Two Families, Jewish Foundation for the Righteous, 2014, https://jfr.org/video-library/reunion2014/

\section{Iconografia}

(por ordem de aparecimento)

Charge de Feras Haggag, Jornal Al-Arab, Qatar, 17 de novembro, 2015. Fonte: Blog da ADL (Liga AntiDifamação)

http://blog.adl.org/international/anti-semitic-conspiracy-theories-crop-up-in-wake-of-paris-attacks

Charge de autor não identificado. Divulgado por Mary Hughes Thompson, 14 de novembro, 2015 (via Twitter). Blog da ADL (Liga Anti-Difamação)

http://blog.adl.org/international/anti-semitic-conspiracy-theories-crop-up-in-wake-of-paris-attacks

Charge de Peter Schrank publicada (posteriormente removida) na revista The Economist, Edição Oriente Médio e África, Janeiro, 2014. Fonte: Times of Israel, Jerusalém.

http://www.timesofisrael.com/economist-removes-anti-semitic-cartoon-after-uproar/

Charge do cartunista francês Zéon, vencedora da edição de 2016 do concurso de charges sobre o Holocausto organizado pela revista iraniana Hamshahri. Fonte: Blog da ADL (Liga Anti-Difamação), 2016. http://blog.adl.org/international/winners-of-irans-holocaust-cartoon-contest-announced

Liquidação do Gueto de Varsóvia. Relatório Stroop. Fotógrafo desconhecido. Fonte: www.yadvashem.org 
Sobreviventes do barracão 56 de Auschwitz, 16 de abril de 1945. Fotógrafo: Soldado H. Miller (Exército dos Estados Unidos). Fonte: United States Holocaust Memorial Museum (USHMM), Washington, EUA

Mira Wexler aos três anos de idade

O rio Sluch hoje, www.commons.wikimedia.org

Yankiel e Hannah Wexler. Fonte: Documentário A Tale of Two Families. Jewish Foundation for the Righteous, 2015. Captura de tela

Florian e Maria Weglowski. Fonte: Documentário A Tale of Two Families. Jewish Foundation for the Righteous, 2015. Captura de tela

Execução de judeus por membros dos Einsatzgruppen. Fonte: Arquivo Fotográfico do United States Holocaust Memorial Museum (USHMM). Washington DC, Estados Unidos

Prisioneiros judeus cavam suas valas observados por soldados alemães. Fonte: Arquivo da coleção de fotos do Memorial Yad Vashem, Jerusalém, Israel

Família sendo perseguida por soldado alemão. Fonte: Arquivo Fotográfico do United States Holocaust Memorial Museum (USHMM). Washington DC, Estados Unidos

Mulher protege seu filho enquanto soldado mira para atirar. À esquerda é possível ver também a ponta das armas de outros soldados e abaixo, um corpo no chão. Fonte: Arquivo Fotográfico do United States Holocaust Memorial Museum (USHMM). Washington DC, Estados Unidos

Velvele Valentine Pinkert, c. 1939. Cidade e fotógrafo não identificado. Fonte: Arquivo da coleção de fotos do Memorial Yad Vashem.

Acesso à floresta-memorial onde estão enterrados os corpos dos aproximadamente 1.200 judeus do gueto de Ludvipol, http://www.sztetl.org.pl/en/city/ludwipol/

Vista do local onde estão enterrados os corpos dos aproximadamente 1.200 judeus do gueto de Ludvipol, onde há hoje um memorial. Captura de tela do documentário A House for Two Families (Uma casa para duas famílias), Jewish Federation for the Righteous, New York, 2014.

Familiares de Mira mortos no Holocausto. Nas fotografias, à esquerda acima, seus avós; à esquerda (abaixo) e à direita (acima), seus primos; à direita (abaixo), Yankiel Wexler, pai de Mira. Captura de tela do documentário A House for Two Families (Uma casa para duas famílias), Jewish Federation for the Righteous, New York, 2014.

Croqui da cidade de Stara Huta (1939). A seta aponta para o ponto onde se localizava a propriedade dos Weglowski. No número 80, a fazenda de Florian; no número 81, a de Franciszek. Em destaque (sublinhado), a estrada que ligava Stara Huta a Ludvipol.

Extraído de: http://wolyn.ovh.org/opisy/huta stara-03.html

Dois dos irmãos Weglowski: Stanislaw e Helena. Captura de tela do documentário A House for Two Families (Uma casa para duas famílias), Jewish Federation for the Righteous, New York, 2014. 
Helena Weglowski (à esquerda) e Mira Wexler (à direita) no evento organizado em Nova York pela Jewish Foundation for the Righteous, novembro, 2014. Fonte: New York Post, 26 de novembro de 2014.

Os partisans de Grynszpan. Ao fundo (da esquerda para a direita: Harold Werner, Symcha Barbanel, Dora Grynszpan, Abram Grynszpan, Zeev Litwak; à frente (da esquerda para a direita): Chanina Henry Barbanel, Abram o Partisan, Shienka de Wlodawa. Como veremos, vários desses heróis refugiaram-se no Brasil após a Segunda Guerra. Fonte: Arquivo do Memorial Yad Vashem.

A Sinagoga de Wlodawa antes de guerra. Fonte: Arquivo do Memorial Yad Vashem, Jerusalém, Israel

Mercado de Wlodawa antes de guerra. Fonte: Virtual Sztetl, www.sztetl.org.pl

A Pequena Sinagoga de Wladowa (à esq.). A construção foi restaurada entre 1983 e 1998. Hoje ela é parte do complexo do Museu Judaico de Wladowa e está localizada ao lado da Grande Sinagoga. Fonte: Virtual Shtetl

Trabalhos forçados nas proximidades do gueto de Wlodawa. Fonte: http://chelm.freeyellow.com/wlodawa.html

A floresta de Parczew, onde Zeev e seu grupo se reuniram. Fonte: Martin Gilbert. Holocaust Journey. Travelling in Search of the Past. New York: Rosetta Books, 2015

Trem descarrilado por partisans. Fonte: Jewish Partisan Educational Foundation

Residência onde foi realizada a reunião de Wannsee. Fonte: www.commons.wikimedia.org

Esquema do campo de extermínio de Sobibor. Fonte: Martin Gilbert. Holocaust Journey. Travelling in Search of the Past. New York: Rosetta Books, 2015

Maquete do campo de Sobibor. Fonte da imagem: http://www.deathcamps.org/sobibor/blatt.html

Campo de Sobibor, 1942. Vista externa. Fonte: http://www.holocaustresearchproject.org/ar/sobibor.html

Modelo de Zemlyanka usados por partisans. Fonte: www.geocaching.com

Modelo de Zemlyanka usados por partisans. Fonte: Jewish Partisan Educational Foundation www.jewishpartisans.org

Zeev em seus uniformes de partisan. Fonte: http://chelm.freeyellow.com/partisans.html

Yechiel Grynszpan, c. 1944. Fotógrafo desconhecido. Arquivo Memorial Yad Vashem

Os dois amigos heróis na época da chegada ao Rio de Janeiro, Brasil. Fonte: Fichas de Imigração, Brasil www.familysearch.org

Cecília em sua chegada ao Brasil, 1952. Fonte: www.familysearch.org. Ficha de Imigração, Rio de Janeiro.

Vista aérea de Sandomierz, 1930. Fonte: Tomasz Wisniewski. www.yivoencyclopedia.org

Catedral de S. Paulo, Sandomierz, Polônia. Pintura que representa o mito do libelo de sangue, Karol de Prevot, Sec. XVIII.. Óleo sobre madeira. Fonte: www.commons.wikimedia.org 
Trabalhos forçados em Sandomierz, inverno de 1941. Fonte: Arquivo Yad Vashem/Ghetto Fighter's House.

Portão principal de Auschwitz I, Janeiro de 1945. Fonte: Associated Press

Esquema do complexo de Auschwitz indicando os três campos. Fonte: United States Memorial Museum (USHMM). www.ushmm.org

Plataforma de chegada dos trens e entrada a Auschwitz II-Birkenau. Fonte: Memorial e Museu Auschwitz-Birkenau. www.auschwitz.org

Vista aérea de Auschwitz II-Birkenau. Fotografia tirada por aviadores das forças aliadas em 1944. $\mathrm{Na}$ parte superior, à esquerda, é possível ver fumaça dos crematórios em funcionamento. Fonte: www.auschwitz.org

Buna Werk, e o complexo químico IG Farben. Fonte: www.holocaustresearchproject.org

Prisioneiras trabalhando em Ravensbrück. Fonte: www.jewishvirtuallibrary.org

Olga Benário, morta em Ravensbrück em 1942. Fonte: www.commons.wikimedia.org

Violette Lecoq, As válidas. Desenho a lápis, 1943.

Violette Lecoq, A lei do mais forte. Desenho a lápis, 1943.

Violette Lecoq, Trabalhos. Desenho a lápis, 1943.

Violette Lecoq, Boas vindas. Desenho a lápis, 1943.

Violette Lecoq, Higiene. Desenho a lápis, 1943.

Violette Lecoq, Duas horas depois. Desenho a lápis, 1943.

Hillel Storch, diretor do Congresso Judaico Mundial, Suécia. Fonte: Pinterest.

Norbert Masur, emissário do Congresso Judaico Mundial, Suécia. Fonte: $\underline{\text { www.zwoje-scrolls.com }}$

O comboio de ônibus brancos da Cruz Vermelha sueca, 1945. Imediações de Friedrichsruh. Fotógrafo desconhecido. Fonte: www.commons.wikimedia.org

Hillel Storch, Prof. Hugo Valentin e o Rabino Kurt Wilhelm, 1953, Katthavet, Suécia. [Da esquerda para a direita]. Fotógrafo: Tore Burnäs

Ariella quando de sua chegada ao Brasil, 1960. Exraído da Ficha de Imigração. Fonte: www.familysearch.org

Mapa de Veneza. Bolognino Zaltieri. Gravura em cobre, colorido à mão, 1565 (33,9 x 47,9 cm). Este mapa foi feito em meados do século XVI e indica a localização do ghetto. Ampliando a imagem é possível ver que no guia, sob o número 144, aparece a palavra "ghetto". Civitas Orbis Terrarum, Vol, 1, Köln, Coleção Peter von Brach. Fonte: www.commons.wikimedia.org 
Vista aérea do Gueto de Veneza. Ao centro, dentro do círculo branco, a parte original do gueto. Fonte: Université Numérique Européenne des Études Juives (UNEEJ), "Histoire du Peuple Juif dans 1'Occident Médieval", Fiche Support (Captura de tela), 2016, www.uneej.com

Plano do Gueto de Veneza e suas ampliações. Fonte: Université Numérique Européenne des Études Juives (UNEEJ), "Histoire du Peuple Juif dans l'Occident Médieval”, Fiche Support (Captura de tela), 2016. www.uneej.com

Vista aérea do Gueto de Veneza, Fonte: Université Numérique Européenne des Études Juives (UNEEJ)

"Histoire du Peuple Juif dans l'Occident Médieval", Fiche Support (Captura de tela), 2016, www.uneej.com

Entrada ao bairro judeu de Veneza. Crédito da imagem: Florida Center for Instructional Technology www.fcit.usf.edu

Placa na entrada do bairro judeu de Veneza. Crédito da imagem: Florida Center for Instructional Technology, www.fcit.usf.edu

Ponte do Ghetto Vecchio conectando ao Ghetto Nuovo. Crédito da imagem: Florida Center for Instructional Technology, www.fcit.usf.edu

Vista de Roma, 1625. Desenho de Giovanni Maggi. Fonte: Université Numérique Européenne des Études Juives (UNEEJ), "Histoire du Peuple Juif dans l'Occident Médieval”, Fiche Support (Captura de tela), 2016, www.uneej.com

O Manifesto dos Cientistas Racistas. Revista La Difesa dela Razza, Ano I, N. 1 (Agosto, 1938). Em destaque, na elipse, o ponto relativo aos judeus. Fonte: www.digiteca.bsmc.it

Capas da revista fascista La Difesa dela Razza (1938-1943). Fonte: www.digiteca.bsmc.it

A família Volli. Da esquerda para a direita, Elvira, avó de Ariella, suas tias Alma, Flora e Gemma, seu tio Ugo, seu avô Ignacio e sua mãe Iris. Fonte: GOLFERA, Silvia. Una donna del secolo scorso: Gemma Volli, www.storiamemoria.it

Professores e alunos no Jardim da Escola Judaica Manzoni, na via Eupili, Milão. Final do ano escolar 1940-1941. Fonte: Oltre la memoria. Gli studenti ebrei del "Manzoni" al tempo delle legge razziali, www.brianzapopolare.it/sezioni/storia/gani/20030127 om album via eupili.htm

Via Pietralata 60, local onde de 1938 a 1940 funcionou a Scuoletta Ebraica di Bologna. Fonte: Google Street View, 2016.

Via Zamboni 2, local da segunda sede da Scuoletta Ebraica di Bologna. Fonte: Google Street View, 2016.

Placa em homenagem aos docentes que construíram e mantiveram em funcionamento a Scuoletta Ebraica di Bologna.

O campo de concentração Risiera di San Sabba, em Trieste, Itália. Fonte: www.ilfattoquotidiano.it

Gemma Volli, Palestina, anos 1930. Fonte: GOLFERA, Silvia. Una donna del secolo scorso: Gemma Volli, www.storiamemoria.it 
Topografia do Lago di Como, fronteira Itália-Suíça. Fonte: www.123rf.com

Funcionários suíços registram os refugiados. Fonte: BROGGINI, Renata. Terra d'asilo. I rifugiati italiani nella svizzera, 1943-1945. Bologna: Il Mulino, 1993

Castello di Trevano, Lugano, Suíça. Neste local funcionou uma escola para refugiados italianos entre 1944 e 1945. Fonte: www.geocaching.com

Os irmãos Ariella e Lucio Pardo

Helena quando de sua chegada ao Brasil, 1954. Ficha de Imigração, Rio de Janeiro, Fonte: www.familysearch.org

Pinsk, panorama da cidade antes de 1939. Fonte: Stiftung Denkmal für die ermordeten Juden Europas (Fundação Memorial para os Judeus Assassinados da Europa), www.memorialmuseums.org

Pinsk, vista da cidade a partir do rio Pina. Fonte: Shtetl Routes, www.shtetlroutes.eu

Exterior de sinagoga, Pinsk, primeiras décadas do século XX. Fonte: Arquivo do Memorial Yad Vashem, Jerusalém, Israel, www.yadvashem.org

Interior de sinagoga, Pinsk, primeiras décadas do século XX. Fonte: Arquivo do Memorial Yad Vashem, Jerusalém, Israel, www.yadvashem.org

Capa do livro infantil Ḥataltulah she-shakhahah ekh tesh'al okhel (O Gatinho que Esqueceu como Pedir Comida), de Ben-Tsiyon Raskin. Escola Tarbut, Polônia, 1923. Fonte: The Yivo Encyclopedia of Jews in Eastern Europe: www.yivoencyclopedia.org

Escola Tarbut em Pinsk, 1936. Uma aula de ciências naturais. Fonte: The Yivo Encyclopedia of Jews in Eastern Europe, http://www.yivoencyclopedia.org/article.aspx/Tarbut

Cartaz da rede Tarbut onde se lê em polonês e hebraico: "Apoie a Tarbut e suas Instituições. A escola hebraica é a forja da alma da nação! Tarbut constrói a escola hebraica nacional! Fonte: The Yivo Encyclopedia of Jews in Eastern Europe www.yivoencyclopedia.org

Parada de membros do movimento jovem sionista Hanoar Hatzioni. Pinsk, primeiras décadas do século XX. Fonte: www.eilatgordinlevitan.com/pinsk/pinsk.html

Leon Pinsker (1821-1891). Fonte: Jewish Virtual Library www.jewishvirtuallibrary.org

Theodor Herzl (1860-1904). Coleção Dr. Moti Friedman; Reprodução: Emil Salman. Fonte: www.haaretz.com

Soldado alemão em motocicleta em uma rua de Pinsk, julho de 1941. Fonte: Lester Hajenina, Coleção Yad Vashem, www.yadvashem.org

Perseguição a judeus por soldados alemães (Aktion), Pinsk. Fonte: Lester Hajenina, Coleção Yad Vashem www.yadvashem.org 
Maquete do gueto de PinskEm exibição no museu Lochame Hagetaot, Haifa, Israel. Fonte: The Jewish Community of Pinsk, www.pinskjews.org.il

Abraham e Basia Kuper, Fichas de Imigração, www.familysearch.org

Trabalhos forçados no rigoroso inverno da Sibéria. Fonte: Captura de tela do documentário "Saved by Deportation”, Slawomir Grunberg e Robert Podgursky, 2007.

O filósofo Julius Margolin e sua família antes da guerra. Fonte: www.forward.com

Membros da Brigada Judaica. Tel-Aviv, Palestina, 1944. Fonte: Arquivo Sionista Central. United States Holocaust Memorial Museum (USHMM). Pôster convocando jovens judeus na Palestina a alistar-se na Brigada Judaica, 1944. Fonte: Arquivo Sionista Central. United States Holocaust Memorial Museum (USHMM), www.ushmm.org

Abba Kovner (ao centro) com duas combatentes após a liberação de Vilna. Ruzka Korczak e Vita Kempner, com quem Kovner se casou mais tarde. Vilna, Lituânia, 14 de julho, 1944. Fotógrafo não identificado. Fonte: Yad Vashem/Jewish Partisans Organization. www.jewishpartisans.org

Fila de refugiados judeus que deixavam a Polônia em centro de recepção na Tchecoslováquia. À direita, carro do American Joint Distribution Committee. Fonte: Wide World Photo. United States Holocaust Memorial Museum (USHMM), www.ushmm.org

Mulheres e crianças judias deixando a Polônia como parte da Brihah. Nachod, Tchecoslováquia, 1946. Fonte: American Joint Distribution Committee. United States Holocaust Memorial Museum (USHMM) www.ushmm.org

Helena e Elias Blankfeld, Alemanha. Fonte: Visual History Archive Online. USC Shoah Foundation http://vhaonline.usc.edu/

Reencontros. Helena e sua família. Fonte: Visual History Archive Online. USC Shoah Foundation http://vhaonline.usc.edu/

\section{Livros Didáticos}

BOULOS Jr, Alfredo. História, Sociedade \& Cidadania, 9ª ano. São Paulo: FTD, 2012.

Catelli, Roberto. Conexão História. São Paulo: AJS, 2013.

Projeto Araribá. História. 9a ano. Obra coletiva organizada pela Editora Moderna e coordenada por Maria Raquel Apolinário. São Paulo: Editora Moderna, 2013.

\section{Sites}

ADL. Anti-Defamation League

www.adl.org 
Arquivo Virtual sobre o Holocausto e o Antissemitismo

www.arqshoah.com

Fortunoff Archive

http://web.library.yale.edu/testimonies

GEI. Georg-Eckert-Institut für International Schulbuchforschung.

www.gei.de

Jewish Genalogy (Yizkor Project)

www.jewishgen.org

Jewish Virtual Library

http://www.jewishvirtuallibrary.org/jsource/Holocaust/terezin.html

Jewish Women's Archive

http://jwa.org/encyclopedia/article/bergmann-gretel

Journée d'Études: Réagir Face aux Théories du Complot, 9 de fevereiro de 2016:

http://www.education.gouv.fr/cid98418/journee-d-etude-reagir-face-aux-theories-du-complot.html

Portal do MEC. Programa Nacional do Livro Didático.

www.portal.mec.gov.br/pnld/apresentacao.

United States Holocaust Memorial Museum:

https://www.ushmm.org/wlc/en/article.php?ModuleId=10007941

USC Shoah Foundation

https://sfi.usc.edu/

Yad Vashem

www.yadvashem.org

\section{Teses}

BIGAZZI, Anna Rosa. "In Diffesa della Razza”. Os judeus italianos refugiados do fascismo e o antisemitismo do Governo Vargas. Tese de Doutorado. Universidade de São Paulo, São Paulo, 2008.

BITTENCOURT, Circe. Livro Didático e Conhecimento Histórico: Uma História do Saber Escolar. Tese de Doutorado em História Social. São Paulo: FFLCH. Universidade de São Paulo, 1993. 


\section{Testemunhos Orais}

Testemunho de Mira Gutfilen ao Projeto Vozes do Holocausto (Arqshoah/LEER), Rio de Janeiro, 08 de julho de 2015. Ficha Técnica: Entrevistadoras, Profa. Maria Luiza Tucci Carneiro; Câmera, Laís Rigatto Cardillo; Transcrição, Samara Konno.

Testemunho de Ze'ev Wolf Litwak ao Projeto Vozes do Holocausto (Arqshoah/LEER), Rio de Janeiro, 08 de julho de 2015. Ficha Técnica: Entrevistadora, Maria Luiza Tucci Carneiro; Câmera, Laís Rigatto Cardillo; Transcrição, Laura Lemmi di Natale.

Testemunho de Cecília Gewertz ao Projeto Vozes do Holocausto (Arqshoah/LEER), São Paulo, 17 de abril de 2013. Ficha Técnica: Entrevistadoras, Profa. Rachel Mizrahi e Profa. Sarita Saruê; Câmera, Lilian Ferreira de Souza; Transcrição, Laís Rigatto Cardillo.

Testemunho de Ariella Segre ao Projeto Vozes do Holocausto (Arqshoah/LEER), São Paulo, 15 e 29 de julho de 2015. Ficha Técnica: Entrevistadora, Profa. Sarita Saruê; Câmera, Raíssa Alonso; Transcrição, Samara Konno.

Testemunho de Helena Blankfeld ao Projeto Vozes do Holocausto (Arqshoah/LEER), São Paulo, 22 de abril e 09 de maio de 2014. Ficha Técnica: Entrevistadoras, Profa. Rachel Mizrahi e Profa. Sarita Saruê; Câmera, Laís Rigatto Cardillo; Transcrição, Daniel Loeb 


\section{BIBLIOGRAFIA}

\section{Obras}

ABELLA, Irving \& TROPER, Harold. None Is Too Many. Canada and the Jews of Europe. 1933-1948. Toronto: University of Toronto Pres, 2012.

ADORNO, Theodor W. Minima Moralia. Lisboa: Edições 70, 1951.

. Cultural Industry. New York: Routledge, 1991.

. Educación para la Emancipación. Conferencias y conversaciones com Helmut

Becker (1959-1969). Madrid: Ediciones Morata, 1998.

APPELFELD, Aharon. The Story of a Life. New York: Schocken Books, 2004.

ARENDT, Hannah. The Origins of Totalitarianism. New York: Harvest, 1976. (1a ed. 1958).

BARTHES, Roland. La Chambre Claire: Notes sur la Photographie.Paris: Gallimard Seuil, 1980.

BARTOV, Omer (ed.). The Holocaust. Origins, Implementation, Aftermath. New York: Routledge, 2000.

BAUER, Yehuda. A History of the Holocaust. Connecticut: Franklin Watts, 1982.

Rethinking the Holocaust. New Haven: Yale University Press, 2002.

BELLER, Steven. Antisemitism. A Very Short Introduction. New York: Oxford University Press, 2007.

BITTENCOURT, Circe Maria Fernandes. "Livros didáticos entre textos e imagens". In, O Saber

Histórico na Sala de Aula. São Paulo: Editora Contexto, 2004.

BLATMAN, Daniel. The Death Marches. The Final Phase of Nazi Genocide. Cambridge, Massachusetts: The Belknap Press of Harvard University Press, 2011.

BORGES, Jorge Luis. Funes, el memorioso. Publicado em Buenos Aires em 1944.

BOYNE, John. O Menino do Pijama Listrado. São Paulo: Editora Seguinte, 2007.

BREITMAN, Richard. Official Secrets: What the Nazis Planned, What the British and Americans Knew. New York: Hill \& Wang, 1998.

BROMLEY, Patrícia \& RUSSELL, Susan G. The Holocaust as History and Human Rights: A CrossNational Analysis of Holocaust Education in Social Science Textbooks, 1970-2008. UNESCO IBE, 2010.

BROWNING, Christopher R. Ordinary Men: Reserve Battalion 101 and the Final Solution in Poland. New York: Harper Perennial 1993.

University Press. 2000. . Nazi Policy, Jewish Workers, German Killers. New York: Cambridge 
. The Origins of the Final Solution. The Evolution of Nazi Jewish Policy, September 1939 - March 1942. Jerusalem: Yad Vashem, 2004.

BRUNER, Jerome. Actual Minds, Possible Worlds. The Jerusalem-Harvard Lectures. Cambridge: Harvard University Press, 1987. . Making Stories: Law, Literature, Life. Cambridge: Harvard University Press, 2002.

BURDIN, A.; DRUCKER, J.; LUNENFELD, P.; PRESNER, T.; SCHNAPP, J. Digital_Humanities. Cambridge: The MIT Press, 2012.

CARNEIRO, Maria Luiza Tucci. O Anti-semitismo na Era Vargas. Fantasmas de uma geração (19301945). São Paulo: Perspectiva, 2001.

São Paulo: Perspectiva, 2003.

O Veneno da Serpente. Reflexões sobre o anti-semitismo no Brasil.

Cidadão do Mundo. O Brasil diante do holocausto e dos judeus refugiados do nazifascismo (1933-1948). São Paulo: Perspectiva, 2010. Holocausto, Crime contra a Humanidade. São Paulo: Ática, 2010. . Dez Mitos sobre os Judeus. São Paulo: Ateliê Editorial, 2014.

CARNEIRO, Maria Luiza Tucci (org.). O Anti-semitismo nas Américas. Memória e história. São Paulo: Edusp, 2008.

CESARANI, David \& LEVINE, Paul. Bystanders to the Holocaust: A Re-Evaluation. New York: Routledge, 2002.

CHALK, F. \& JONASSOHN, K. The History and Sociology of Genocide: Analyses and Case Studies. New Haven: Yale University Press, 1990, p. 8.

CHARLOT, Bernard. La Relación con el Saber, formación de maestros y profesores, educación y globalización. Montevideo: Ediciones Trilce. 2008.

CONFINO, Alon. A World Without Jews. The Nazi Imagination from Persecution to Genocide. New Haven: Yale University Press, 2014.

CROCCI, Federico; CARNEIRO, Maria Luiza Tucci (org.). Tempos de Fascismos. Ideologia, intolerância, imaginário. São Paulo: EDUSP, 2010.

DAVIES, Ian. Teaching the Holocaust. Educational Dimensions, Principles, and Practice. London: Continuum, 2000.

DAWIDOWICZ, Lucy S. The War Against the Jews. 1933-1945. New York: Open Road Integrated Media, 2010.

DELBO, Charlotte. Auschwitz et Après. Mesure de nos Jours. Paris, Minuit, 1971.

EVANS, Richard J. The Coming of the Third Reich. New York: Penguin Books, 2003. 
. The Third Reich in Power. New York: Penguin Books, 2005.

The Third Reich at War. New York: Penguin Books, 2009.

FALLACE, Thomas D. The Emergence of Holocaust Education in American Schools. New York: Palgrave Macmillan, 2008.

FERRO, Marc. Os Tabus da História. Rio de Janeiro: Ediouro, 2002.

FERRO, Marc. The Use and Abuse of History. Or how the past is taught to children. London: Routledge Classics, 2003.

FEYNMAN, Richard. Surely You're Joking, Mr. Feynman! Adventures of a Curious Character. New York: W. W. Norton \& Company, 1985.

FLEMING, Gerald. Hitler and the Final Solution. Los Angeles: University of California Press, 1987,

FLUSSER, Vilém. Ser Judeu. São Paulo: Annablume Editora, 2014, p. 79.

FRANK, Anne. The Diary of a Young Girl. London: Penguin, 2001, p. 261-262

FRIEDLÄNDER, Saul. Memory, History and the Extermination of the Jews of Europe. Bloomington: Indiana University Press, 1993.

Nazi Germany and the Jews. The Years of Persecution, 1933-1939. Volume 1.

New York: HarperCollins, 1993.

. Nazi Germany and the Jews. Volume 2: The Years of Extermination, 1939-1945.

New York: Harper Collins, 2007.

GEORG ECKERT INSTITUT. GEI. International Status of Education on the Holocaust. A Global Mapping of Textbooks and Curricula.

GILBERT, Martin. The Holocaust: The Human Tragedy. New York, Rosetta Books, 2014

GILBERT, Martin. The Dent Atlas of the Holocaust. London: Taylor \& Francis e-Library, 2005 (Electronic Edition)

GINZBURG, Carlo. Clues, Myths, and the Historical Method. Baltimore: The Johns Hopkins University Press,

GIRARDET, Raoul. Mitos e Mitologias Políticas. São Paulo: Companhia das Letras, 1987.

GREEN, John. A Culpa é das Estrelas. São Paulo: Intrínseca, 2012.

GROSS, Jan T. Fear: Anti-Semitism in Poland After Auschwitz: An Essay in Historical Interpretation. New York: Random House, 2006.

GRUBER, Ruth. Exodus 1947: The Ship that Launched a Nation. New York: Sterling USA, 2007. 
HADAS-LEBEL, Mireille. L'Hébreu: 3000 ans d'histoire. Paris: Albin Michel, 1992.

HERF, Jeffrey. Reactionary Modernism. Technology, culture, and politics in Weimar and the Third Reich. Cambridge: Cambridge University Press, 2003.

HERF, Jeffrey. The Jewish Enemy. Nazi Propaganda During World War II. Cambridge, Massachusetts: The Belknap Harvard University Press: 2008.

HILBERG, Raul. The Destruction of European Jews. Volumes I, II \& III. New York: Holmes \& Meier, 1985.

Perpetrators, Victims, Bystanders. The Jewish Catastrophe. 1933-1945. New York:

Harper Collins Publishers, 1993.

KAPLAN, Chaim A. Scroll of Agony. The Warsaw Diary of Chaim A. Kaplan. Indiana: Indiana University Press, 1999.

KERSHAW, Ian. Fateful Choices: Ten Decisions That Changed the World, 1940-1941. New York: The Penguin Press, 2007.

KLEMPERER, Victor. LTI, la Langue du IIIe Reich. Paris: Éditions Albin Michel, 1996

KLIPPENDORF, Klaus. Content Analysis: An Introduction to its Methodology. New York: SAGE Publications, 2012.

KLUGER, Ruth. Landscapes of Memory. A Holocaust Girlhood Remembered. London: Bloomsbury, 2010.

KOIFMAN, Fábio. O Imigrante Ideal. São Paulo: Civilização Brasileira, 2012;

KOLB, Eberhard. The Weimar Republic. New York: Routledge, 1988.

KOSELLECK, Reinhart. The Practice of Conceptual History. Timing History, Spacing Concepts. Stanford: Stanford University Press, 2002

KOSSOY, Boris. Fotografia e História. São Paulo: Atica, 2003 (2ed.).

LAQUEUR, Walter (ed.). The Holocaust Encyclopedia. New Haven: 2001.

LESSER, Jeffrey. Immigration, Ethnicity and National Identity in Brazil. Cambridge: Cambridge UK, 2013;

LEVI, Primo. Se questo è um uomo. Torino: Einaudi, 2005 (1ed. 1947).

LEVI, Primo. I sommersi e i salvati. Torino: Einaudi Tascabili, 1986.

LEWY, Guenter. Harmful and Undesirable. Book Censorship in Nazi Germany. New York: Oxford University Press, 2016.

LUCA, Tania Regina. O debate em torno aos livros didáticos de história. Assis: UNESP, 2001. 
MACHADO, N. J. Epistemologia e didática. São Paulo: Cortez, 1995.

. Educação: Projetos e Valores. São Paulo: Escrituras, 2000.

Conhecimento e Valor. São Paulo: Moderna, 2004.

MARCUS, Kenneth. The Definition of Antisemitism. New York: Oxford University Press, 2015.

MAYER, Arno J. Why Did the Heavens Not Darken? The "Final Solution" in History. New York: Pantheon Books, 1988.

MAZET, Sophie. Manuel d'Auto-défense Intellectuelle. Paris: Robert Laffont, 2015.

MELVILLE, Herman. Bartleby, the Scrivener. A story of Wall Street. Publicado em Nova York em 1853.

MICHMAN, Dan \& SCHRAMM, Lenn J. The Emergence of Jewish Ghettos During the Holocaust. New York: Cambridge University Press: 2011.

OZ, A. \& OZ-SALZBERGER, F. Os Judeus e as Palavras. São Paulo: Companhia das Letras, 2015.

PERRY, Marvin \& SCHWEITZER, Frederick M. Antisemitism. Myth and Hate from Antiquity to the Present. New York: Palgrave Macmillan, 2002.

PINGEL, Falk. UNESCO Guidebook on Textbook Research and Textbook Revision. $2^{\text {nd }}$ revised and updated edition. Paris/Braunschweig, 2010.

POLANYI, Karl. The Tacit Dimension. Chicago: The University of Chicago Press, 2009.

POLIAKOV, Leon. Do Anti-sionismo ao Anti-semitismo. São Paulo: Perspectiva, 2000.

POLIAKOV, Leon. The History of Anti-Semitism. Philadelphia: University of Pennsylvania Press, 2003 (Vols. I, II e III);

POPPER, K. Objective Knowledge. Oxford: Oxford University Press, 1972.

POPPER, Karl R. "Prediction and Prophecy in the Social Sciences", In: GARDINER, Patrck (ed.).

Theories of History. Illinois: The Free Press, 1959.

ROSENFELD, Alvin. The End of the Holocaust. Bloomington: Indiana University Press, 2011.

ROSENFELD, Gavriel. Hi Hitler: How the Nazi Past is Being Normalized in Contemporary Culture. Cambridge: Cambridge University Press, 2015.

SAIDEL, Rochelle G. As Judias do Campo de Concentração de Ravensbrück. São Paulo: EDUSP, 2009.

SHIRER, William L. Berlin Diary. The Journal of a Foreign Correspondent, 1934-1941. New York: Alfred A. Knopf, 1942,

SONTAG, Susan. On Photography. New York: RosettaBooks LLC, 2005. 
STEINWEIS, Alan. Studying the Jew. Scholarly Antisemitism in Nazi Germany. Cambridge: Harvard University Press, 2006.

STONE, Dan (Ed.). The Historiography of the Holocaust. London: Palgrave Macmillan, 2004.

TAGUIEFF, Pierre-André. The Force of Prejudice. On Racism and Its Doubles. Minneapolis: University of Minnesota Press, 2001.

Éditions Mille et une Nuits, 2005

La Foire aux Illuminés. Ésotérisme, théorie du complot, extrémisme. Paris: . L'Imaginaire du Complot Mondial. Aspects d'un mythemoderne. Paris:

Éditions Mille et une Nuits, 2006.

TAGUIEFF, Pierre-André. Court Traité de Complotologie. Paris: Mille et une nuits, 2013

TALBOT, G. Censorship in Fascist Italy, 1922-1943: Policies, Procedures and Protagonists. New York: Palgrave Macmillan, 2007.

TOTTEN, Samuel \& FEINBERG, Stephen. Teaching and Studying the Holocaust. Boston: Allyn \& Bacon, 2000.

TOTTEN, Samuel, BARTROP Paul R., JACOBS, Steven L. Teaching about the Holocaust. Essays by College and University Teachers. Connecticut: Praeger, 2004.

VIDAL-NAQUET, Pierre. The Assassins of Memory: Essays on the Denial of the Holocaust. New York: Columbia University Press, 1992.

VOLKOV, Shulamit. Antisemitismus als kultereller Code. München: Verlag C.H. Beck, 1990.

University Press. 2006.

German, Jews and Antisemites. Trials in Emancipation. New York: Cambridge

WIESE, Christian \& BETTS, Paul (Org.). Years of Persecution, Years of Extermination. Saul Friedländer and The Future of Holocaust Studies. London: Continuum, 2010.

WIESEL, Elie. La Nuit. Paris: Les Éditions du Minuit, 1958/2007.

WIEVIORKA, Annette. The Era of the Witness. Ithaca: Cornell University, 2006.

WINTER, Jay. Sites of Memory, Sites of Mourning: The Great War in European Cultural History. Cambridge: Cambridge University Press, 1995.

WISTRICH, Robert S. Antisemitism: The Longest Hatred. London: Schocken, 1994

Hitler and the Holocaust. New York: Modern Library, 2001.

Random House, 2010.

. A Lethal Obsession: Anti-Semitism from Antiquity to Global Jihad. New York: 
ZIMMERMAN, Joshua D. (Ed.). Jews in Italy under Fascist and Nazi Rule, 1922-1945. New York: Cambridge University Press, 2005, p. 9.

ZUCOTTI, Susan. Under His Very Windows. New Haven: Yale University Press, 2000. 